THE UNITED ARAB EMIRATES : A STUDY IN SURVIVAL

\author{
Christopher M. Davidson
}

A Thesis Submitted for the Degree of PhD

at the

University of St Andrews

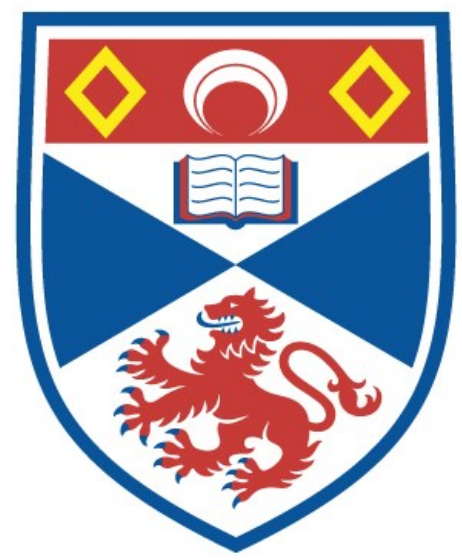

2003

Full metadata for this item is available in

St Andrews Research Repository

at:

$\underline{\text { http://research-repository.st-andrews.ac.uk/ }}$

Please use this identifier to cite or link to this item:

http://hdl.handle.net/10023/13898

This item is protected by original copyright 


\section{THE UNITED ARAB EMIRATES: A STUDY IN SURVIVAL}

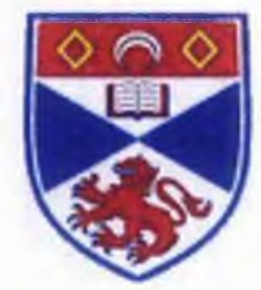

Christopher Davidson

Thesis submitted for the degree of DOCTOR OF PHILOSOPHY

In the Department of International Relations, UNIVERSITY OF ST. ANDREWS

May, 2003 
ProQuest Number: 10170771

All rights reserved

INFORMATION TO ALL USERS

The quality of this reproduction is dependent upon the quality of the copy submitted.

In the unlikely event that the author did not send a complete manuscript and there are missing pages, these will be noted. Also, if material had to be removed, a note will indicate the deletion.

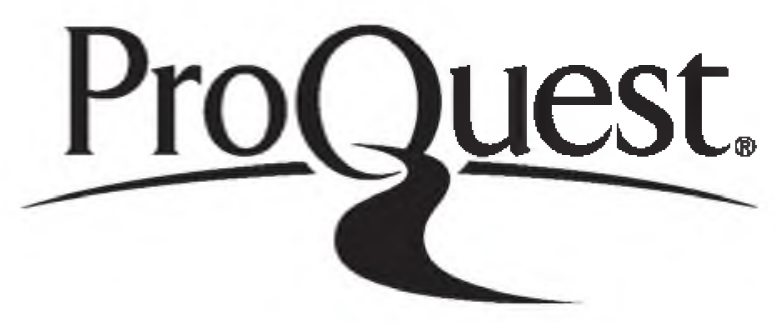

ProQuest 10170771

Published by Proquest LLC (2017). Copyright of the Dissertation is held by the Author.

All rights reserved.

This work is protected against unauthorized copying under Title 17, United States Code Microform Edition (C) ProQuest LLC.

ProQuest LLC.

789 East Eisenhower Parkway

P.O. Box 1346

Ann Arbor, Ml 48106 - 1346 
ruterte 


\title{
THE UNITED ARAB EMIRATES: A STUDY IN SURVIVAL
}

\begin{abstract}
This present thesis seeks to account for the UAE's remarkable socio-economic development path while also attempting to explain the survival of the state's seemingly anachronistic political structures. In doing so, the thesis proceeds to set up a multilayered framework drawing upon and reconciling elements of the two major schools of development theory. Specifically, a dependency analysis is used to demonstrate the UAE's inherited situation, including the region's historic peripheralisation, its early rentier structures, and the external reinforcement of a client elite; while a combination of rentier-dependency models and revised modernisation theories are used to illustrate the way in which the UAE's contemporary monarchies have managed to consolidate their position and secure considerable political stability, which is itself an important prerequisite of the modernisation process. With regard to the recent attempts of these 'modernising monarchies' to improve the more negative aspects of their dependency situation, it is shown that while there have been successes there have also been serious development pathologies, and in many ways these must be regarded as the hidden costs of escaping the inevitability of early modernisation predictions and the demise of tradition. Essentially, viewed within a Weberian variant of modemisation theory, the strengthening of the structures which allowed for the stability in the first place can in many cases be seen to have gone too far and has now made legal-rational objectives difficult to achieve. Finally, however, it is suggested that greater modernisation, especially in the form of positive globalising forces, may still provide solutions for these problems. Indeed, while the first wave of globalisation may have reinforced entrenched dependency structures, there are nevertheless clear indications that something of a second wave may well lead to liberalising reforms, a more diversified economy, and a stronger civil society.
\end{abstract}




\section{THE UNITED ARAB EMIRATES: A STUDY IN SURVIVAL}

\section{Declarations}

I, Christopher Davidson, hereby certify that this thesis, which is approximately 100,000 words in length, has been written by me, that it is the record of work carried out by me and that it has not been submitted in any previous application for a higher degree.

date ..7/.5/.03.. signature of candidate .

I was admitted as a research student in September, 1999 and as a candidate for the degree of $\mathrm{PhD}$ in September, 1999; the higher study for which this is a record was carried out in the University of St Andrews between 1999 and 2003.

date ...7. $5 \% 03 .$. signature of candidate .....

I hereby certify that the candidate has fulfilled the conditions of the Resolution and Regulations appropriate for the degree of PhD in the University of St Andrews and that the candidate is qualified to submit this thesis in application for that degree.

date $\ldots .7 / 5 / .03$. signature of supervisor

In submitting this thesis to the University of St Andrews I understand that I am giving permission for it to be made available for use in accordance with the regulations of the University Library for the time being in force, subject to any copyright vested in the work not being affected thereby. I also understand that the title and abstract will be published, and that a copy of the work may be made and supplied to any bona fide library or research worker.

date ..7. $/ 5 . / 03 \ldots$ signature of candidate . 


\section{Table of Contents}

Introduction 1

$\begin{array}{ll}\text { 1.0 An Historical Background } & 10\end{array}$

1.1 - The traditional economic structure $\quad 11$

$\begin{array}{ll}1.2 \text { - The traditional social structure } & 17\end{array}$

$\begin{array}{ll}1.3 \text { - The traditional political structure } & 22\end{array}$

1.4 - External influences and the 'Trucial States' 30

1.4.1 - Greater British political and economic involvement 39

1.4.2 - Greater peripheralisation and the emergence of rentier 45 structures

1.4.3 - Local resistance and the suppression of the Dubai reform 49 movement

1.4.4 - Britain and the path to federation 53

$\begin{array}{ll}1.5 \text { - The federation of Emirates } & 58\end{array}$

1.6-Conclusion 64

2.0 The Survival of Monarchy - An Overview

2.1 - The Sheikh's dilemma $\quad 74$

2.1.1 - Voluntary transformation $\quad 76$

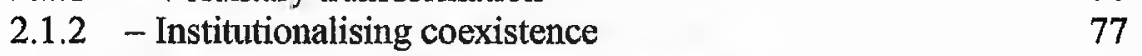

2.1.3 - Maintaining the polity / resisting reform 79

2.2 - The legitimacy formula $\quad 80$

$\begin{array}{lll}2.2 .1 & \text { - Personal resources } & 81\end{array}$

2.2 .2 - Patrimonial networks 83

2.2.3 - Cultural and religious resources $\quad 89$

\begin{tabular}{ll}
2.2 .4 & - Ideological resources \\
\hline
\end{tabular}

2.2.5 - The two-level Emirati identity 94

2.2.6 - Structural resources and 'neo-patrimonialism' 98

$\begin{array}{ll}2.3 \text { - Rentierism } & 102\end{array}$

2.3.1 - Rentier wealth and ruling coalitions 105

2.3.2 - Rentier wealth and favourable international relations $\quad 107$

2.4 - Dynastic monarchy and the evolution of traditional polity 110

$\begin{array}{ll}2.5 \text { - Conclusion } & 117\end{array}$

$\begin{array}{ll}\text { 3.0 - Socio-economic Development and the Diversification Effort } & 127\end{array}$

$\begin{array}{ll}3.1 \text { - Modifying dependent development } & 128\end{array}$

3.2 - Diversification through industrialisation 131

3.2.1 - Fostering technology linkages with foreign firms $\quad 136$

$\begin{array}{ll}3.3 \text { - Diversification through agriculture } & 138\end{array}$

3.4 - Diversification through commerce and tourism 141

3.5 - The physical infrastructure for diversification 147

$\begin{array}{ll}3.6 \text { - Social growth } & 150\end{array}$

$\begin{array}{ll}3.7 \text { - Emiratisation } & 156\end{array}$

3.7 .1 - Emiratisation strategies 163

3.8 - Sub-strategies: Abu Dhabi and Dubai, a comparative analysis 169 
$\begin{array}{ll}3.9 \text { - Development problems } & 178\end{array}$

3.10 - Conclusion 186

$\begin{array}{ll}\text { 4.0 Domestic Pathologies and the Political Process } & 198\end{array}$

4.1 - Domestic pathologies 199

4.2 - The decision-making structure $\quad 202$

4.2.1 - The Federal National Council: a paralysed legislature $\quad 210$

4.3 - The emirate level decision-making structure $\quad 212$

4.3.1 - The relationship between federal and emirate level 214

4.4 - Other institutions, parastatals and bureaucracies $\quad 226$

4.4.1 - Chambers of commerce and industry 227

4.4.2 - The judiciary and related institutions 230

4.4.3 - The UAE's banking sector and the Central Bank 231

$\begin{array}{ll}4.4 .4 & - \text { The BCCI scandal } \\ & 237\end{array}$

4.4.5 - The drive for greater transparency 244

4.5 - Elite interest groups: old rentiers versus new rentiers 248

4.5.1 - Foreign property ownership 253

4.5.2 - Commercial ventures and free zones 257

4.5.3 - The foreign investment debate 261

$\begin{array}{ll}4.6-\text { Conclusion } & 265\end{array}$

5.0 - Globalisation and the prospects for Civil Society 275

5.1 - The globalisation dilemma $\quad 275$

5.2 - The historical antecedents of globalisation 278

5.3 - The impact of globalising forces on the contemporary economy 281

5.4 - The impact of globalising forces on contemporary society and 289

culture

5.5 - Civil society and globalisation 293

5.5.1 - Preconditions for the emergence of civil society 294

5.5.2 - The co-option and patronage of civil society 298

5.5.3 - Globalising forces and external motivation 320

5.6 - Conclusion $\quad 324$

$\begin{array}{lr}\text { Summary of Conclusions } & 332\end{array}$

$\begin{array}{ll}\text { Appendices } & 344\end{array}$

Glossary of Terms, Abbreviations and Acronyms 353

$\begin{array}{ll}\text { Selected Sources } & 358\end{array}$ 


\section{List of Figures}

Figure (i) "The United Arab Emirates: a theoretical framework" 3

Figure (ii) "The Hukūma" $\quad 25$

Figure (iii) "Layers of control and dependency" 48

Figure (iv) "A History of economic rent in the lower Gulf" 49

Figure (v), "The United Arab Emirates: a historical background" 65

Figure (vi) "The Survival and evolution of traditional polity" 117

Figure (vii) "Abu Dhabi and Dubai, a comparative analysis" 177

Figure (viii) "Socio-economic development strategies in the United Arab 186 Emirates"

Figure (ix) "The decision-making structure" 209 


\section{List of Charts}

Breakdown of Abu Dhabi government employees by nationality - 1995

Breakdown of Dubai households -1998

Citibank loans

Comparison of oil and non-oil sector contributions to Dubai's GDP

Contributions to UAE GDP in 1975 (by Emirate)

Contributions to UAE GDP in 1995 (by Emirate)

Davidson identity survey response (2002)

Distribution of FNC members

Distribution offoreign direct investment in the UAE

Distribution of ministerial portfolios in the UAE

Dubai Hotels

Dubai: Major non-oil trading partners - imports

Dubai: Major non-oil trade partners - exports

Dubai's manufacturing sector: value added to domestic manufactures (2000 prices)

Dubai's non-oil foreign trade - 1975

Dubai's non-oil foreign trade -2001

Dubai's non-oil foreign trade - quantity

Dubai's non-oil foreign trade - value (1995 prices)

Dubai population breakdown - by gender

Dubai re-exports - quantity

Dubai re-exports - value (1995 prices)

Dubai re-exports (as a percentage of the value of total trade at 1995 prices)

Dubai Tourists (per annum) 
Findlow identity survey response (1999)

Graduates of the UAE University in Al-Ayn - by gender

Healthcare improvements in Dubai

Jebel Ali Free Zone Companies 2000: regional distribution

Labour productivity scores - Dubai compared with the UAE average

List of attempts to promote liberalising reforms

List of attempts to block liberalising reforms and augment existing restrictions

List of cultural / educational / environmental organisations

List of expatriate community organisations

List of Islamic / charity organisations

List of media / press related organisations

List of recreational organisations

List of welfare organisations

List of women's groups 306

List of workers / professional organisations

Net enrolment ratios (primary, secondary and tertiary sectors)

Student/teacher ratios in Dubai schools

The UAE Council of Ministers 2002

Total area under agriculture in Dubai

Total manufacturing plants in the UAE (all sizes)

UAE secondary school graduates (per annum)

UAE students' language preferences 1999

UAE population breakdown - by gender 


\section{Introduction}

In one of history's great ironies, the past thirty years have witnessed the transformation of the shaykhdoms of the lower Gulf from sleepy, undeveloped backwaters of the British Empire into some of the world's wealthiest oil producers, with socio-economic conditions comparable, and in some cases superior to those of many western states. Furthermore, following the withdrawal of their superpower protector and in defiance of the critics, the federation of these shaykhdoms, the United Arab Emirates, has remained a mainstay of stability in an increasingly volatile Middle East and, crucially, has managed to maintain and even consolidate an essentially traditional polity despite rapid modernisation and the often intrusive forces of globalisation. Underneath these layers of success and stability, the UAE's development path has, however, been far from smooth and a number of problems, many of which would appear deeply ingrained, continue to surface. As such, it is the purpose of this thesis to consider not only the UAE's significant socio-economic achievements and the survival of its seemingly anachronistic political structures, but also to provide a greater understanding of some of the key pathologies which have persistently undermined the development objectives of this nascent state.

In doing so, this study will on one level serve to build upon and update the empirical picture of the UAE offered by the small number of existing surveys on the subject, including those of Donald Hawley, ${ }^{1}$ Kevin Fenelon, ${ }^{2}$ Malcolm Peck, ${ }^{3}$ Muhammad Morsy Abdullah, ${ }^{4}$ and most notably Frauke Heard-Bey's From Trucial States to United Arab Emirates. ${ }^{5}$ Alongside these works, this study will also attempt to locate and synthesise the arguments and writings of a number of indigenous Emirati and Gulf Arab scholars on the development of the region, including those of Fatma AlSayegh, ${ }^{6}$ Ibrahim Al-Abed, ${ }^{7}$ Fatima al-Shamsi, ${ }^{8}$ and Shaykha Shamma Al-Nuhayyān. ${ }^{9}$ Crucially, and on a more theoretical level, the thesis will attempt to go beyond these primarily historical and socio-economic analyses by placing the UAE example within the broader academic discipline of Middle East development studies. In particular, the 
UAE's socio-economic and political development will be assessed within the context of the plethora of recent research conducted on some of the region's other surviving traditional monarchies and oil-rich 'rentier states'. As such, this volume will consider, among many others, the dependency theories applied by Jacqueline Ismael to the Kuwaiti example, ${ }^{10}$ the rentier models of Jill Crystal and Gregory Gause, ${ }^{11}$ the civil society approaches of Sheila Carapico and Mehran Kamrava, ${ }^{12}$ and the fascinating investigation of evolving 'dynastic monarchy' structures outlined in Michael Herb's All in the Family: Absolutism, Revolution, and Democracy in the Middle Eastern Monarchies. $^{13}$ Indeed, by testing the applicability of such varied arguments and findings to the UAE case study, and by attempting to reconcile these with existing and often competing theoretical frameworks, this work will demonstrate the need for a very specific and multi-layered conceptual model in order to fully understand and appreciate the survival and development path of this highly distinctive Gulf state.

In particular, by drawing upon elements of the two major schools of thought, it will be shown on the one hand how dependency theories can be used to provide an excellent starting point for explaining the remarkable stability of the many structures which remain in place and continue to shape the UAE's development, whereas on the other hand the tools of modernisation theory and its variants can be employed to provide not only a better understanding of the UAE's equally significant attempts to adapt within this 'dependent development', but also to underscore the importance of some of the development problems which are now being faced and, under the guise of benign globalisation, to highlight also the potential for future change. Specifically, a dependency framework will be used to demonstrate the UAE's inherited situation, including the historic peripheralisation of the region's economy, the emergence of early rentier structures, and the external reinforcement of a client elite capable of blocking both participation and indigenous reform. Secondly, in an effort to account for the inaccuracies of early modernisation theory and to explain why these pre-capitalist traditional structures were not swept away during the oil era, a combination of rentierdependency models and 'modernisation revisionism' (emphasising how certain traditional forces can be adapted and made functional $)^{14}$ will be used to illustrate the 
way in which the UAE's monarchies have managed to secure considerable political stability, which of course is itself an important prerequisite of the modernisation process. Thirdly, however, with regard to the recent attempts of these 'selective modernising' monarchies to reduce some of the most obvious weaknesses of their dependent economies and thereby improve their situation, it will be demonstrated that while there have been some successes there have also been serious development pathologies, and in many ways these must be regarded as the hidden costs of escaping the inevitability of early modernisation predictions and the demise of tradition. Essentially, viewed within a Weberian variant of modernisation theory, the freezing and reinforcement of the structures which allowed for the stability in the first place can in many cases be seen to have gone too far, as neo-patrimonial / clientalist networks, nonparticipatory structures, a lack of transparency, and retarded civil society have all made legal-rational objectives difficult to achieve. Finally though, with regard to the future, it will be suggested that greater modernisation, especially in the form of positive globalising forces, may still provide solutions for these pathologies. Indeed, while the first wave of globalisation may have reinforced dependency structures and problems, and while there still remains great uncertainty, there are nevertheless clear indications that something of a second wave may well lead to liberalising reforms, a more diversified economy, and a stronger civil society. See figure (i).

Working within this framework, the first chapter, an historical background, will therefore highlight the lower Gulf's many antecedents to the same socio-economic and political structures later recognised by dependency theorists such as André Gunder Frank (with reference to Latin America) and Samir Amin (with reference to the Arab world). ${ }^{15}$ Indeed, it will be shown that by the beginning of the twentieth century the region was already heavily reliant on foreign labour, foreign technology, and, critically, the export of a single primary product. Indeed, in much the same way as the oil exports later in the century, the export of pearls also suffered from the vagaries of the international market, and when demand fell, the peripheral economy of the lower Gulf suffered the consequences. Even more significantly, however, it will be shown how an indigenous economic power was effectively displaced and its rulers incorporated as 


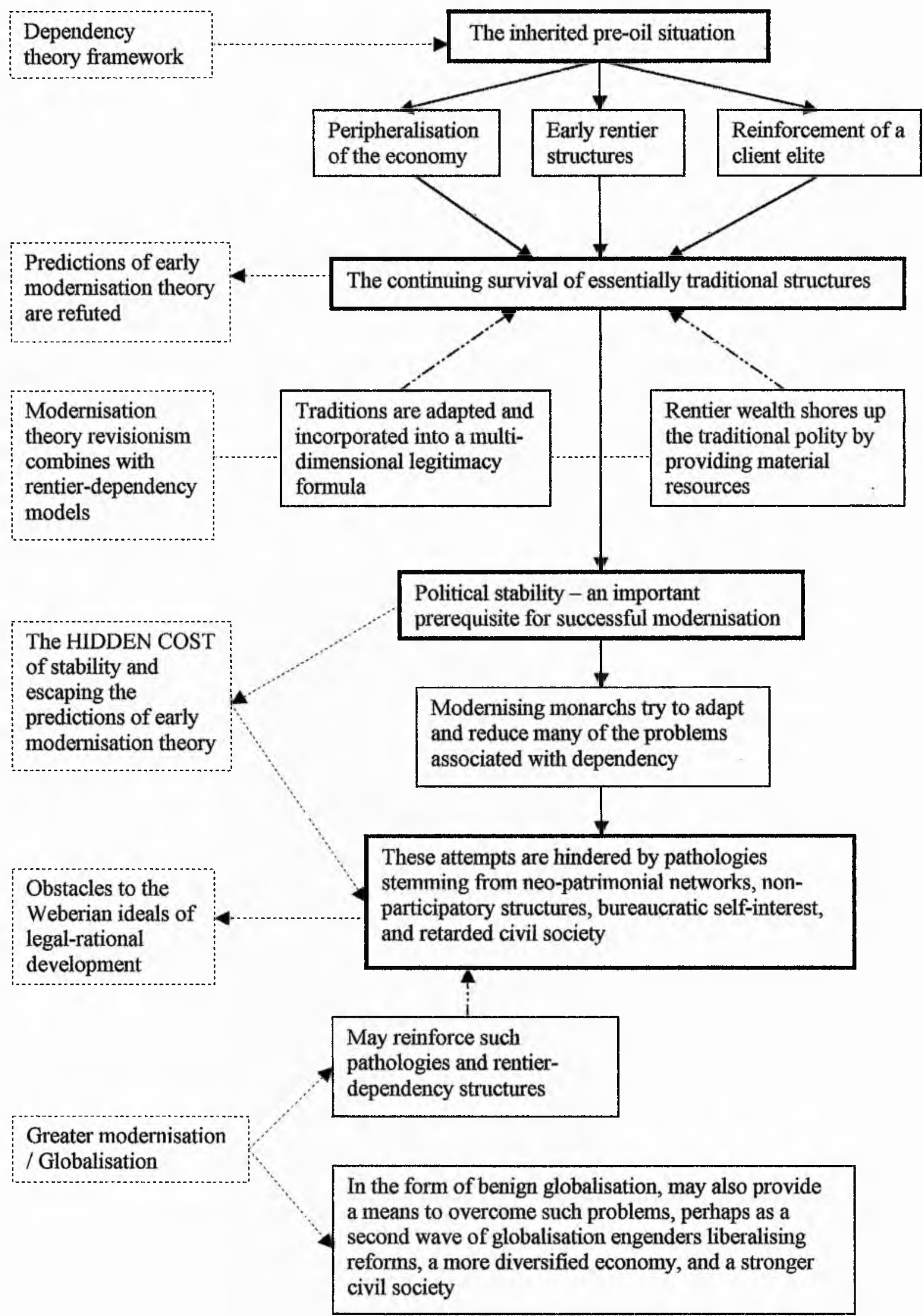


clients into a greater British-Indian network. Certainly, although this period remains a subject of great dispute with local revisionist scholars such as Shaykh Sultān al-Qāsimī challenging the well-established 'Arab piracy' explanations expounded by JG Lorimer, Jolnn Kelly, Charles Belgrave and other British historians, ${ }^{16}$ there is nevertheless little doubt that the outcome resulted in overwhelming British dominance and a fundamental reshaping of the region's structures. As this chapter will demonstrate, Ismael's comparable argument for Kuwait which focuses on the detachment of the coastal towns from the hinterland and the external reinforcement of the local rulers would seem highly applicable to the lower Gulf given the multitude of treaties and 'exclusivity agreements' which were signed between Britain and the ruling shaykhs of the main ports. ${ }^{17}$ In effect these new relations froze the centuries-old $\mathrm{ebb}$ and flow of tribal powers and suppressed attempts to revitalise autonomous development by local merchants, thus confirming both the rulers' predominance and their increasing reliance on British support. Furthermore, it will also be revealed how the subsidies, air landing fees, and exploration concessions paid out by British companies during this period led to considerable unearned wealth and relative financial autonomy for these rulers, at least from their own people, thus providing important early evidence for the rentier development models now being applied by Crystal and Gause to the oil-era Gulf states. ${ }^{18}$

In the following chapter it will be observed how these strengthened traditional political structures, essentially by-products of the lower Gulf's historically dependent relations, have continued to survive long after British withdrawal as the ruling families have carefully developed multi-dimensional 'ruling bargains' between themselves and their populations. Indeed, it will be shown how the UAE has continued to refute the predictions of early modernisation theories, including those of Daniel Lerner and Karl Deutsch, ${ }^{19}$ as the demise of traditional monarchy remains far from inevitable, despite the furious pace of the region's socio-economic development. Similarly, it would seem that the hypotheses of Samuel Huntington, writing shortly before the region's independence, have also remained inapplicable to the UAE, as the polity has thus far managed to circumvent any form of 'Shaykh's dilemma' in which traditional rulers are expected to accommodate new groups created by modernising forces and thereby cede 
some or all of their former power. ${ }^{20}$ Secondly, this chapter will demonstrate how the modernisation theory revisions of Michael Hudson and others who argued that merged sources of personal, patrimonial, and structural legitimacy may delay such a predicament, ${ }^{21}$ along with the rentier-dependency arguments of Hazem Beblawi and Giacomo Luciani, ${ }^{22}$ have offered much greater optimism and, when combined, can provide something of a pragmatic explanation for the survival of such polities. Certainly, in the case of the UAE it will be shown how rentier theories can find much purchase as, with massive levels of oil-related economic rent accruing directly to the rulers and their governments, the rulers have been able to placate almost all segments of society with distributed wealth, employment, free education, a welfare state, and a host of other privileges. Complementing this body of rentier theory, the applicability of Crystal's concept of rentier coalitions will also be considered. ${ }^{23}$ Specifically, it will be noted how the merchants of the lower Gulf, unlike those of Kuwait, were weakened by the collapse of their economic base long before the oil era and were therefore more easily absorbed into a new ruling coalition in which the shaykhs' incomes could be used to guarantee political acquiescence. Moreover, also related to rentierism, it will be argued that although external support from the major oil purchasing states has at times compromised the polity's legitimacy, Gause's favourable superpower relations explanation must nevertheless be regarded as another important element of the rentier survival model. ${ }^{24}$ Finally, by building upon the neo-patrimonial legitimacy formula and these rentier theories, this chapter will also attempt to incorporate the study of 'dynastic monarchy' into the UAE example. In particular, it will be shown how Herb's recent attempts to explain the survival of traditional monarchies through their development of self-regulating mechanisms are highly relevant to the seven shaykhdoms of the lower Gulf. $^{25}$ Crucially it will be demonstrated how these continuously evolving and expanding monarchies, many of which are vast in membership, are now acting as surrogates for large political parties, thus allowing for an alternative means of expanding power and therefore yet another means of circumventing, at least semipermanently, Huntington's dilemma. 
The focus of the third chapter will be the UAE's remarkable socio-economic development and it will be shown how this, or at least the various development strategies employed in the two principal emirates of Abu Dhabi and Dubai, ${ }^{26}$ can be best explained within the context of the UAE's rentier wealth and the attempts of the modernising monarchs and their planners to alter and remove some of the less desirable aspects of dependent relations. Indeed, it will be revealed that from a relatively early stage there was already an acute awareness of the shortcomings of the neo-classical and economic nationalism models employed elsewhere in the developing world, ${ }^{27}$ and instead a recognition of the more urgent need to address many of the long-term dangers of dependency to the UAE's economy and society, including the state's considerable over-reliance on oil exports, foreign technology, and foreign labour. Thus, by diversifying the economy and building up the non-oil sectors, by encouraging greater technology transfers, and by attempting to 'emiratise' the workforce, it will be demonstrated how the development planners began to tackle many of the features of economic disintegration resulting from core-periphery relations, including many of those later summarised by Amin in The Arab Economy Today. ${ }^{28}$ While many of these plans have been moderately successful, this chapter will, however, also underscore some of the more serious and seemingly insolvable problems which continue to distort the UAE's development, including chronic over-consumption and trade imbalances, the wasteful duplication of investments, and the substantial disequilibrium between the constituent emirates. In particular, it will be shown how these are the kind of pathologies which have not been easily overcome by injections of wealth and instead indicate much deeper dependency-related concerns.

As such, the purpose of the fourth chapter will be to explore further some of these under-the-surface pathologies and to demonstrate how seemingly domestic problems must also be taken into account in explaining the path of socio-economic development. Crucially, it will be shown how the arguments of Todaro, Toye, and other economic neo-liberals who have sought to place a greater emphasis on such internal problems ${ }^{29}$ can be easily reconciled with dependency theory, at least with the UAE example, given that the region's historic rentier-dependent relations are actually 
responsible for the existence and resilience of many of the contemporary domestic structures. Indeed, this chapter will demonstrate how many of the structures which allowed for monarchical survival and political stability have persisted and in some cases have been reinvigorated to such an extent that they now undermine the UAE's development objectives. Moreover, explaining more clearly how such internal structures may lead to a lag in development and inhibit any evolution towards Weberian legal-rational ideals, it will be shown how neo-patrimonial networks, bureaucratic self interests, and complex client elite orientations remain clearly identifiable in the UAE's internal political process and in the interactions of its key interest groups. Indeed, with regard to the latter, it will be demonstrated how the seemingly liberal reforms of the emerging technocratic interest groups can also be seen as the products of rentierdependency structures. Essentially these new groups, in much the same way as those conservative groups reliant on oil-related economic rent, are also aiming to secure rentier wealth, albeit from new sources such as real estate and business parks. As such they must be viewed as part of the same client elite seeking to perpetuate rather than inhibit certain existing rent-channelling structures.

The aim of the fifth chapter will be to assess the recent and future impact of globalising forces and the 'new economy' on what would seem to be this dependent development. Specifically, the anti-globalisation arguments, many of which concentrate on the predatory nature of intrusive external forces and thereby reinforce the earlier underdevelopment theories, ${ }^{30}$ will be considered alongside the more pro-globalisation literature of David Held and others who assert that greater global integration will provide substantial long-term socio-economic and political benefits for developing states. ${ }^{31}$ With regard to the UAE's socio-economic development it will be shown, or at least indicated how, thus far, there is considerable evidence to back each viewpoint, with globalising forces seemingly capable of both reinforcing and overcoming existing development pathologies. With regard to globalisation and political development, the second section of this chapter will demonstrate how most of the preconditions for the successful emergence of civil society suggested by Weigle and Butterfield, Kamrava, and Carapico ${ }^{32}$ are currently absent from the UAE given the high levels of financial and 
organisational co-option and the absence of any real cultural milieu (problems which can be seen as the rentier-dependency products of persisting patrimonial networks and a continuing reliance on vast quantities of expatriate labour). However, it will also be suggested that certain external forces, including improved communications and the increasing presence and influence of international NGOs, may be increasingly capable of surmounting such obstacles and strengthening indigenous civil society. Thus, this chapter will seek to illustrate the twin effects of globalising forces on the UAE's development, emphasising how the same international forces which created the dependent structures in the first place may now, perhaps in a second wave of globalisation, be the forces most likely to engender liberalising reforms.

\footnotetext{
'See HAWLEY, Donald (1970), "The Trucial States", London, George Allen \& Unwin

${ }^{2}$ See FENELON, Kevin (1973), "The United Arab Emirates: An Economic and Social Survey", London, Longman

${ }^{3}$ See PECK, Malcolm C (1986), "The United Arab Emirates: A Venture in Unity", Boulder Colorado, Westview Press

"See ABDULLAH, Muhammad Morsy (1978), "The United Arab Emirates: A Modern History", London, Croom Helm

5 See HEARD-BEY, Frauke (1996), "From Trucial States to United Arab Emirates - new edition", London, Longman

${ }^{6}$ See (in Arabic) AL-SAYEGH, Fatma (1997), "The UAE; from tribe to state", Al-Khalij Books, Dubai; AL-SAYEGH, Fatma (1998), "Merchants' role in a changing society: the case of Dubai, 1900-1990", in MIDDLE EASTERN STUDIES, Volume 34 Number 1, January 1998; and AL-SAYEGH, Fatma (1999), "Symposium on Shaykh Zäyid" taken from a conference convened by the Middle East Policy Council on $20^{\text {th }}$ April 1999, in MIDDLE EAST POLICY, Volume 6 Number 4, June 1999

${ }^{7}$ See AI-ABED, Ibrahim (2001), "The Historical Background and Constitutional Basis of the Federation" in AL-ABED, lbrahim (ed.) (2001), "The United Arab Emirates: A New Perspective", Abu Dhabi, Trident

${ }^{8}$ See AL-SHAMSI, Fatima S (1999), "Industrial Strategies and Change in the UAE during the 1980s", in ABDEKARIM, Abbas (1999), "Change and Development in the Gulf", London, Macmillan; and ALSHAMSI, Fatima S (2001), "Symposium on Shaykh Zāyid", in MIDDLE EAST POLICY, Volume 6 Number 4, June 1999

'See AL-NUHAYYAN, Shaykha Shamma bint Muhammad bin Khalid (2000), "Political and Social Security in the UAE", Dubai; and AL-NUHAYYAN, Shaykha Shamma bint Muhammad bin Khalid (2000), "Political and Social Security in the Arabian Gulf region and United Arab Emirates after the Second Gulf War: External and Internal Challenges", Research Centre of Slovak Foreign Policy Association, Studies on International Issues, Volume B05

${ }^{10}$ See ISMAEL, Jacqueline S (1993), "Kuwait: Dependency and Class in a Rentier State", University Press of Florida

${ }^{11}$ See CRYSTAL, Jill (1990,1995), "Oil and Politics in the Gulf: Rulers and Merchants in Kuwait and Qatar", New York, Cambridge University Press; GAUSE, F Gregory (1994), "Oil monarchies: domestic and security challenges in the Arab Gulf states", New York, Council on Foreign Relations Press; and GAUSE, F Gregory (1999), "The persistence of monarchy in the Arabian Peninsula: a comparative analysis", in KOSTINER, Joseph (ed.) (2000), "Middle East monarchies: the challenge of modernity", Colorado, Rienner

${ }^{12}$ See CARAPICO, Sheila (1998), "Civil society in Yemen: the political economy of activism in modern Arabia", Cambridge, Cambridge University Press; KAMRAVA, Mehran (2000), "Politics and society in the developing world", London, Routledge; and KAMRAVA, Mehran (2002), "Civil Society and Political Democratisation in Comparative Perspective: Lessons from Latin America and the Middle East", presented to the University of Warwick in February 2002
} 
${ }^{13}$ See HERB, Michael (1999), "All in the Family: Absolutism, Revolution, and Democracy in the Middle Eastern Monarchies", New York, State University Press

${ }^{14}$ For a discussion of modernisation revisionism or 'revised modernisation theory' see RANDALL, V and THEOBALD, R (1998), "Political change and underdevelopment", London, Macmillan, pp.45-48, modernisation revisionist studies have demonstrated that not only may traditional institutions adapt and co-exist with modern institutions, but, in addition, the process of modernisation may actually revitalise dormant traditional institutions and practices.

${ }^{15}$ See FRANK, André Gunder (1971), "Capitalism and Underdevelopment in Latin America: Historical studies of Chile and Brazil", New York, Monthly Review Press; and AMIN, Samir (1982) "The Arab Economy Today", New York

${ }^{16}$ See AL-QASIMI, Shaykh Sultān bin Muhammad (1986), "The Myth of Arab Piracy in the Gulf", London, Croom Helm; LORIMER, JG (1915), "Gazetteer of the Persian Gulf, Oman and Central Arabia" Volumes 1 and 2, Calcutta. Superintendent Government Printing [republished 1970 by Gregg International Publishers; KELLY, John B (1968), "Britain and the Persian Gulf", London; and BELGRAVE, Charles (1966), "The Pirate Coast", London, G. Bell and Sons

${ }^{17}$ ISMAEL (1993), pp.152

${ }_{18}^{18}$ CRYSTAL (1990, 1995), pp. 10-11; and see GAUSE (1994)

${ }^{19}$ LERNER, Daniel $(1958,1964)$, "The Passing of Traditional Society: Modernising the Middle East", Toronto, Free Press, pp.399; and DEUTSCH, Karl W (1961), "Social mobilisation and political development", in AMERICAN POLITICAL SCIENCE REVIEW, Volume 55 Number 3, September 1961

${ }^{20}$ HUNTINGTON, Samuel P (1968), "Political Order in Changing Societies", New Haven, Yale University Press, pp.140-142, 169, and 179-191

${ }^{21}$ HUDSON, Michael C (1977), "Arab Politics: the Search for Legitimacy", New Haven, Yale University Press, pp.1-2 and 7-11; and EASTON, David (1965), "A systems analysis of political life", New York, Wiley, pp.287-303

${ }^{22}$ BEBLAWI, Hazem (1987), "The rentier state in the Arab world" in BEBLAWI, Hazem, and LUCIANI, Giacomo (eds.) (1987), "The rentier state", New York, Croom Helm, pp.50-52; and LUCIANI, Giacomo (1987), "Allocation versus production states: a theoretical framework", pp.63-82 in the same volume

${ }^{23}$ CRYSTAL (1990,1995), pp. 1, 10-11, and 196

${ }^{24}$ See GAUSE (1999)

${ }^{25}$ HERB (1999), pp. 3, 9, 36-37, 136-137, 141-144, and 237-239

${ }^{26}$ As section 3.8 will demonstrate, although Abu Dhabi and Dubai have pursued very different development strategies in many ways these can be seen as increasingly complementary for the UAE's overall growth

${ }^{27}$ For a discussion of orthodox economic development theories see ARNDT, HW (1987), "Economic development: The History of an Idea", Chicago, Chicago University Press; for a discussion of economic nationalism see HARRIS, N (1987), "The End of the Third World", London, Penguin

${ }^{28}$ AMIN (1982), pp.56-78, summarised by SHARABI, Hisham (1988), "Neopatriarchy: A Theory of Distorted Change in Arab Society", New York, Oxford University press, pp. 133-135

${ }^{29}$ See TODARO, M (1994), "Economic Development in the Third World", London, Longman; and TOYE, J (1987), "Dilemmas of Development", Oxford, Blackwell

${ }^{30}$ See AMIN, Samir (1997), "Capitalism in the age of globalisation: the management of contemporary society", London; and AMIN (1982)

${ }^{31}$ Held, who although warning of the dangers of predatory globalisation, concludes that globalisation is not beyond regulation and can be harnessed as a civilising and democratising force, see HELD, David, MCGREW, Anthony, GLODBLATT, David, and PERRATON, Jonathan (1999), "Global transformations: politics, economics and culture", Oxford, Polity Press, pp.444-452

${ }^{32}$ See WEIGLE, MA and BUTTERFIELD, J (1992) "Civil society in reforming Communist regimes: the logic of emergence", in COMPARATIVE POLITICS, Volume 25 Number 1, October 1992, pp.122, cited by RANDALL and THEOBALD (1997), pp.203-204; KAMRAVA (2000), pp.195; and CARAPICO (1998), pp.15 


\section{An Historical Background}

"In the name of God, the merciful, the compassionate. Praise be to God, who hath ordained peace to be a blessing to His creatures. There is established a lasting peace between the British Government and the Arab tribes, who are parties to this contract."

Under the federal banner of the 'United Arab Emirates', the shaykhdoms of the lower Gulf were transformed by the massive oil booms of the 1970s. A development miracle was born and, remarkably, these once impoverished territories suddenly found themselves guardians of the modern world's richest resource. There is no doubt that this great and rapid wealth, more than any other factor, has been the driving force behind almost all aspects of change and development in the region. Certainly, as the later chapters of this thesis will demonstrate, oil and its politics can rarely be separated from any study of the Gulf States, and the UAE is no exception. Nevertheless, it is the purpose of this chapter to establish that the oil era cannot be used as the sole starting point for any comprehensive study of the lower Gulf. Nor, for that matter, can one focus exclusively on the time of independence and the subsequent creation of the federal state. Instead, one must also consider the region's traditional structures, its preoil dynamic, and its historical relations with other powers. Indeed, while some of these features have now faded from memory, there are however a significant number which have survived and evolved, and, as important antecedents of the current order, many of these have continued to form the cornerstones of the contemporary state.

Firstly, an historical background will examine the main characteristics of the traditional economic, social and political structures. The second section of this chapter will detail the increasing external influences in the region, most notably from the British, and will explain how some of these early structures were reinforced while others were modified and in some cases even removed. Crucially, this chapter will view British involvement not only in the context of regional security and institution 
building, but also as part of a broader struggle for control over local economic networks. Moreover, the argument will be made that Britain's attempts to displace and later incorporate these indigenous networks effectively created a client elite dependent on British guarantees of sovereignty and the core economies of Britain and India. In addition, with cash payments, concessionary agreements, and a host of other subsidies, it will also be shown how the local elite's reliance on non-earned, 'rentier' income was sealed long before the first shipments of oil began. Finally, this chapter will consider the important period of transition when, faced with the imminent withdrawal of Britain from the Gulf, the reluctant shaykhdoms were spurred on to seek greater unity and collective security on the eve of their independence. The agreements and accommodations reached during this vital episode not only ensured the short-term survival of the region from both external threats and internal fragmentation but, as this thesis will demonstrate, have also continued to provide the backdrop against which Emirati politics take place.

\section{I - The traditional economic structure}

The first postage stamps to be issued in the region depicted a string of pearls, local sailing craft, and date palms. ${ }^{2}$ Together with animal husbandry, hunting, and fishing (and of course periodic desert raiding ${ }^{3}$ ), these activities formed the basis of the lower Gulf's traditional economy for much of the nineteenth and early twentieth centuries. Although agriculture was severely constrained by the harsh climate, date farming did provide some sustenance in the vast interior, especially for those near to the many oases which stretched across the Rub' al-Khāin, and for those working the 'falaj' irrigated lands in the shadow of the Hajar mountains. ${ }^{4}$ Animal husbandry, especially of camels and sheep, ${ }^{5}$ provided a similarly limited source of wealth and nutrition, as did the hunting of gazelles ${ }^{6}$ and the fishing grounds close to the northern coastlines. ${ }^{7}$ Pearl diving, however, provided a much higher but more seasonal source of income for those who travelled to the seashores or to the many tiny islands of the lower Gulf, and in turn numerous other associated activities and industries such as pearl trading and boat building were also able to flourish in the small coastal towns. 
Indeed, pearl diving soon became the region's primary economic activity during the pre-oil era given the lower Gulf's abundance of oysters and the shallowness of its seas. Over time, however, it is important to note that the intensity of the activity did vary as a function of both international demand and regional security. ${ }^{8}$ The industry reached its zenith in the late 1890s; a period when wealthy merchants from Bombay and even as far a field as East Africa would frequent the Gulf during the pearling season and buy up all of the best specimens for export to their affluent foreign clients.' Furthermore, many of these merchants began to settle in the growing ports, and many of their descendants remain based there today, even if their present-day economic activities are very different to those of their ancestors. JG Lorimer provides a good insight to the scale of this boom, reporting in his Gazetteer of the Persian Gulf that in one year alone (1896-1897) pearls valued in excess of 100 lakhs were exported (approximately threequarters of a million pounds sterling), this compared with just 10 lakhs per year in the 1870 s. $^{10}$

Moreover, as by-products of the pearling industry and the pearling trade, a number of other economic activities began to emerge in these towns. Indeed, while there were some small-scale cottage industries producing pottery and items of metal and woodwork, most of the manufacturing that did exist was in direct response to the needs of the pearling community. Most obviously, pearling led to a boom in the local boat building industry with Umm al-Qawain and Dubai establishing themselves as the main centres for the assembly of a wide variety of craft built from imported African ropes and sails. ${ }^{11}$ Furthermore, as pearling brought greater wealth to the region, other activities geared towards more luxury items were also able to develop, a good example being tailoring and weaving. ${ }^{12}$ Although weaving was already a well-established activity in the region, with many travelling great distances to buy from the many renowned tailors in Buraimī, the greater purchasing power during the pearling boom undoubtedly catalysed their growth in the coastal communities. Indeed, as a testament to this period one can walk the older quarters of Ra's al-Khaimalı today and still see row after row of professional tailors. 
However, by the early 1930 s the pearling industry and these associated coastal activities had already begun to decline due to a combination of worldwide depression and increasing competition from Japanese 'cultured' pearls. ${ }^{13}$ This rapid downswing illustrates how, even in pre-oil times, the lower Gulf's economy was already heavily reliant on the export of a single primary product and was therefore extremely vulnerable to external market forces. Indeed, as Lorimer noted:

\begin{abstract}
"Were the supply of pearls to fail... the ports of Trucial Oman, which have no other resources, would practically cease to exist; in other words, the purchasing power of the inhabitants of the eastern coast of Arabia depends very largely upon the pearl fisheries. ${ }^{114}$
\end{abstract}

Similarly, as Abu Jaml, the son of a wealthy Dubai 'pearl king', emphasises, pearling had led to an early form of dependency in the region, thus creating many dilemmas for his father's generation:

"Pearl prices were governed by the dynamics of supply and demand, as is the case with oil today, and there were times when the catch of a whole season did not fetch enough money to cover the cost of the meals consumed by the divers and sailors. At one stage things got so bad that the British government decided to give pearl traders access to markets in Ceylon. But in return for this the traders had to forfeit two-thirds of their earnings to the British and Ceylonese governments to be shared equally between them."15

Clearly, as the operations of these pearl kings expanded they became increasingly susceptible to the fluctuations of the international economy, and as this example describes, in some cases they even had to forego most of their profits simply to survive. Furthermore, and even more ruinously, many of these men were also resistant to the concept of diversifying their interests. Indeed, as Jaml explains, pearling and pearl trading had come to represent not only a source of income but also a way of life, and as such the pearlers were overly cautious when it came to considering any other activity: 
"...even though some pearl merchants went bankrupt as a result of the slumps that hit the pearl markets from time to time, most of them would not explore new areas of business. I was with my father in Bombay when he sold pearls worth more than one million mpees and was advised by a Bahraini merchant to buy Madinat Hotel that was offered for sale at 70,000 mupees. My father told the man that he was out of his senses to advise him to freeze so much money... that hotel is still in business in Bombay while the pearl era eclipsed more than 40 years ago!"16

As will be demonstrated later in the study, this is entirely the fate that the contemporary UAE, specifically Dubai, has been trying to avoid. Hotels, commerce, light industry and all manner of activities are being explored as part of an unceasing attempt to diversify the narrow base of the oil dependent economy. ${ }^{17}$

Although clearly not self-sustaining, another important aspect of the Gulf's pearling economy was that it was beginning to exhibit signs of indigenous capitalist development. Indeed, while the region has often been associated with non-capitalist relations of production in which capital and labour were rarely separated (the farmers would own their land, the Bedu would own their camels, the fishermen would own their boats, etc.), the growth of the pearling industry nevertheless led to an evolution of capitalism not too dissimilar to that found in feudalist-capitalist Europe. The key to this change was the matter of ownership of the pearling boats. In the early years of pearling, the well-practised ikhluwi was a communal system in which the crew would jointly own a boat and would share all of the season's profits, distributed according to the type of work each individual performed. However, as the size of boats increased and the period of expeditions lengthened, it became less easy for the crew to afford to maintain and equip such boats. This was further exacerbated by the influx of expatriate pearling crewnen who were present for only a short period and required a more tangible wage. As such, the 'Amil system became more prevalent. Under this system the boats were owned and fitted out by wealthier individuals who possessed the necessary capital outlay, and in return would receive a large part of the take at the end of the season, 
leaving the rest to be divided among the crew. Inevitably, this arrangement led to the emergence of two distinct groups: those who were unable to jointly equip a boat and therefore had to offer themselves as salaried crewmen, and those who were able to invest in pearling boats and thereby claim a share of the profits without even having to participate in the expedition. ${ }^{18}$ Furthermore, this system of financial interdependence was being continually reinforced by the captains, many of whom doubled up as brokers (musaqqam) and were often relied upon by their crewmen to obtain the necessary outlay from the entrepreneurs. These intermediaries charged high rates of interest (between 10 and $25 \%$ ) and also claimed a further share of the profits for themselves. ${ }^{19}$ Thus, in many ways a clearly identifiable 'pearling proletariat', the 'ghāsa', was beginning to emerge underneath an early form of capitalist / entrepreneurial class. ${ }^{20}$

Lastly, alongside these pearling-related activities and their mode of organisation, it is also worth noting some of the other forms of commerce which were practised in the area, as before the nineteenth century overseas and regional trading had provided another important means of livelihood for those in the coastal towns and for those based near the major sougs of the interior. Indeed, the lower Gulf maintained trade links with many foreign ports, including Manama, Basra, Muscat, and even Zanzibar. Similarly there were many well-established land routes for caravans from Oman and other parts of Arabia. Many of the old trading posts, such as the camel market north of Buraimi oasis, still function today, and continue to help support the local economy while also boosting the tourist appeal. Simple commodities formed the bulk of the goods, but two especially lucrative activities are worthy of mention: slaves and gold. The lower Gulf has long been associated with the slave trade and, as will be discussed later, at one point its towns served as entry points for close to 12,000 African slaves a year, many of whom were then transported by land into the Arabian interior or across the Gulf to Persia. $^{21}$ The gold trade was another important component of the pre-oil economy, and continued to grow in volume well into the twentieth century. Indeed it is believed that in the $1960 \mathrm{~s}$, on the eve of the creation of the federation, no less than one-tenth of all of the non-Communist world's gold passed through the region's ports. ${ }^{22}$ 
With the exception of Dubai, which continued to position itself as the commercial hub of the lower Gulf, ${ }^{23}$ overseas trade did however begin to fall into longterm decline with many of the towns' commercial activities only beginning to pick up in more recent times as a result of the oil boom and the resulting improvements in infrastructure and ports. Britain's controversial military actions in the early nineteenth century and its anti-slavery treaties, both of which will be considered later in this chapter, effectively capped the region's trading potential and in many ways terminated what used to be a prosperous Arabian monopoly. Furthermore, with the development of more advanced ships requiring deeper berths the costal towns found themselves unable to accommodate many of the larger European vessels. As Frauke Heard-Bey describes:

"... a great number of coral reefs and sandbanks, together with the numerous low lying islands make navigation extremely difficult and hazardous. Due to the extreme difficulty of approach and the lack of any sizable natural harbours there was comparatively little long distance shipping undertaken during the last few centuries from the ports of this coast... and overseas trading has consequently not been a very important feature of its economy until recently."24

In summary, most of the lower Gulf's traditional economic activities were centred around the scant geographical resources of the desert. The camels and gazelles of the hinterland allowed for some limited animal husbandry and hunting, while the oases and mountainous areas provided the opportunity for some small-scale agriculture. The exception to this scarcity was the richness of the Gulf itself, which provided both plentiful fish and, more importantly, an abundance of pearls. Indeed, pearling was especially significant given that it provided a lucrative source of income capable of fuelling other associated economic activities in the coastal towns. Nevertheless, pearling was unstable, highly vulnerable to the vagaries of overseas markets, and its eventual collapse had damaging repercussions for the entire economy. Thus, given the general impoverishment of the region and its over reliance on the export of single primary product, the lower Gulf was in many ways doomed to be a periphery of the 
international economy long before the oil era. Finally, however, with the emerging capitalist mode of production clearly evident in the pearling industry, and with the trading links forged between the Gulf and other Asian economies, it also remains important to underscore the significant level of indigenous economic organisation and regional integration which was taking place; developments which were to be later blocked and reversed during the years of British control.

\section{2 - The traditional social structure}

Alongside the development of these economic activities, a distinct social structure was forming as a result of both the lower Gulf's natural resources and the circumstances surrounding their exploitation. Important social groupings and divisions have been evident in the region since nomadic times, and many of these were further stratified as a result of the shift of activity towards the coasts in pursuit of pearling. Moreover, the influx of foreigners and the described relations of production led to additional layers, as expatriate workers and pearling merchants gradually became a part of the new social fabric. Further related to these changing economic conditions, the increasing urbanisation of the population became another important feature of this period as the region's communities were permanently transformed and its people began to adapt to a more sedentary life.

In the years preceding British intervention and the pearling boom, the desert and the nomadic lifestyle were still the greatest influences on society. The well-established Bedu tribes, many of which still exist today, at least in name, can be seen as having spawned the first set of distinct classes in the lower Gulf. As shown, many of these nomads survived simply by hunting or through animal husbandry. These activities afforded only a subsistence living given the meagre resources, but the importance of the latter cannot be understated as it reveals an important early difference between the region's various tribes. Animal husbandry normally took two forms: sheep herding and camel herding. Of these, camel herding was a far more mobile pursuit given the greater range and resilience of the camels, and as such the sharif or camel herding tribes were 
slowly able to achieve something close to hegemony over their sheep herding counterparts, many of whom were reduced to tending sharif flocks and maintaining sharif pastoral lands. ${ }^{25}$ Moreover, this distinction was reinforced by means of social exclusivity and selective inter-marriage, allowing the members of the sharif tribes to assume an almost aristocratic status over the less mobile tribes. Thus, in an almost tributary system, these weaker tribes were left to evolve as a dependent class of producers and forced to accept a subservient role in exchange for economic and military security from their more powerful fellow tribes.

The origins of the lower Gulf's social structure can therefore be traced back far further than the relatively recent move towards the town life of the ports. Indeed, the desert hierarchy provides the first real example of social stratification in the region as well as underscoring the early significance of descent lineages, many of which are of course still carefully maintained today. Essentially, these lineages reinforced exclusivity and formed a key pillar of Bedu society, allowing tribesmen to claim authority and status based solely on their descent from esteemed ancestors, whether real or fictional. In practice, these lineages were inevitably subdivided given the large number of disparate tribes and the vast geographical area of the desert, but, as Ibn Khaldûn foresaw, they continued to provide a strong sense of security and allowed for several economic advantages which were normally beyond the capabilities of individual families. Indeed, group endeavours were often only possible with the support of a tribe given the large membership and the mutual trust resulting from their shared ancestry. ${ }^{26}$ As such, co-operative social labour often became the norm within a greater kinship organisation, or 'ashīra, as competition over herds or pasturelands could be moderated, and as large-scale agricultural projects could be undertaken and shared for the benefit of the whole group.

The second major feature of the region's early social structure developed out of the need to diversify and escape from the subsistence living afforded by the desert's extremely limited wealth. Clearly, the climatic limits on all of the region's traditional pursuits, coupled with the high population density relative to the available resources, 
prevented not only the expansion of any one activity but also the emergence of any distinct occupational groups such as fishermen or farmers. Indeed, unlike many of the neighbouring Omani and Yemeni tribes, ${ }^{27}$ a shortage of fertile land prevented most from leading any form of settled existence (the hadhr people), and, as the move to the coasts was a very gradual process, there was a long period in which many Bedu would engage in different activities at different times of the year. As such, a semi-nomadic pattern emerged, and led to a great deal of versatility among the tribes. In the winter tribesmen would tend to their herds in the desert, while in the summer they would move to the cooler coastlines to fish or, as later became the case, dive for pearls; and at various other times some would harvest dates or even harvest millet high in the Hajar mountains. ${ }^{28}$ As one might expect, this level of versatility seems to have been particularly evident along the Indian Ocean coastline (Fujairah, Khor Fakkān, Kalbā, etc.) where both the sea and the palm groves were within easy reach of the villages, therefore discouraging any occupational specialisation. ${ }^{29}$ Moreover, in general very few of the region's tribes were ever tied to one geographic location or to one specific activity as eventually circumstances would change and they would be forced to either diversify or relocate. Indeed, severe droughts could push agriculturalists out into the desert to take up animal husbandry once more, and equally the nomadic tribes could plunder and assume control of agricultural lands, they themselves switching their primary occupation. ${ }^{30}$

Significantly, the pearling boom and the subsequent growth of the ports exercised major changes on this traditional society as the growing foreign demand for Gulf pearls meant that many of the previously semi-nomadic Bedu who had occasionally participated in the aforementioned ikhluwi co-operatives finally had enough money to purchase more than the basic necessities, and, crucially, were also able to build houses in the expanding coastal towns. ${ }^{31}$ However, despite this greater urbanisation, in many ways the existing social stratification remained in place as a number of the sharif tribesmen, who were often the only pearlers possessing sufficient surplus capital, chose to re-invest in the pearling industry under the new 'âmil system, thereby becoming part of the new merchant / entrepreneurial class, and effectively transferring the old hierarchy of the desert to the pearling industry. Prominent figures in 
this emerging group included Khalaf Al-Utaibah of Abu Dhabi and Salim bin Misabbah of Dubai, both of whose families remain prominent in Emirati society today. Over the years, many of these wealthy notables came to exercise great political power behind the scenes, and, as Abdullah has shown, in the case of Sharjah they were even able to replace one ruler with another as they saw fit. ${ }^{32}$ Furthermore, given that their capitalist ventures were frequently more lucrative than the ruler's sources of income, it was often they who were the main financiers of any local projects, or indeed any local wars. ${ }^{33}$

The relatively rewarding nature of the pearling industry and the ability to make substantial profits from successful ventures also attracted many foreigners to the lower Gulf for the first time. Many believe that it was only when the oil boom began that large numbers of expatriates moved to the area, but in fact this process had begun far earlier and the region was no stranger to such a phenomenon. Although the bulk of these expatriates were temporary crewmen, attracted by the high demand and high wages associated with pearl diving, there were, however, a large number of merchants who also began to arrive and take up semi-permanent residence. Interestingly, in much the same way as the skilled expatriates working in the UAE today, these Hindu and Khojah merchants would often bring their families with them to Dubai or Abu Dhabi and would spend most of the year living and working in the town, but would always take their annual leave (and presumably their savings) back in India and did not consider their place of work to be their home. ${ }^{34}$ Moreover, the interests of these foreigners soon began to expand beyond pearling, with many being equally attracted to the other economic activities that the boom had given rise to. Indeed, given that most of the local Arabs tended to limit themselves to dhow trading or pearling, which were considered to be honourable activities, this left plenty of opportunity for foreign entrepreneurs to monopolise shop-keeping and other retail activities. ${ }^{35}$

As such, the region's foreign population continued to grow as new socioeconomic groups began to form around countries of origin. Certainly, in a study presented to the Political Resident in 1901 there were already believed to be 500 Persians and 52 Banians (British-Indian subjects) in Dubai, and 96 Persians and 39 
Banians resident in Abu Dhabi. ${ }^{36}$ Given their similarities in cultural background, many of the expatriate Muslim Arabs and Persians were easily assimilated by the existing society, and as time passed some of these were even offered citizenship. The Indian Hindus, with their religious and cultural differences were, however, less easily absorbed and remained a more distinct social group. Indeed, as Lorimer describes, the result was an almost alien cluster within society, but given their usefulness and the high demand for their labour and skills, they were tolerated and accepted; the parallels with the contemporary UAE's reliance on Indian labour being very clear. There was though one complication at this time which is not an issue today: during the pearling era many of the wealthier Indian merchants held British-Indian passports which guaranteed them some degree of diplomatic immunity, and, crucially, exempted them from taxation. ${ }^{37}$ In the UAE most undesirable expatriates can simply be relieved of their visas and deported, but in earlier times the rulers did not possess the same level of control over their sizeable British-Indian population. ${ }^{38}$ A good example would be Heard-Bey's account of the Banian Bin Lutah family. On leaving Dubai for 'Ajman, the family decided to take their pearl divers with them, without first settling their debts in Dubai. The ruler of 'Ajman, bound by an earlier British agreement to hand over fraudulent absconders, attempted to return these unwanted divers to Dubai, but the British Political Resident in Bushire intervened, sending a Royal Navy vessel to 'Ajman to enforce his decision in favour of the Bin Lutahs. ${ }^{39}$ Indeed, there were many examples where Britain ended up supporting absconding subjects, especially if they were indebted to British creditors who would stand to lose upon their death. ${ }^{40}$

Following the pearling booms, the aforementioned decline of the industry in the 1930s also had major ramifications for the region's social structure, as most of the more able foreigners began to drift away, leaving something of a void in local society. Indeed, many of the activities formerly run by the expatriates began to peter out, including, most notably, the running of the schools. Furthermore, it is worth noting that those foreigners who did remain during this time of hardship were far less easily integrated into society than during the boom time. The wealth and prosperity which had previously gelled the region's heterogeneous society together had declined and tensions 
began to surface, the situation almost certainly being exacerbated by the many foreign moneylenders who had begun to gain something of a stranglehold over the locals given their earlier financing of pearling expeditions. These predominantly non-Muslim brokers, many of whom had been able to practise usury, ${ }^{41}$ were either attempting to call in their debts during a time of uncertainty or were simply capitalising on the situation by charging high rates of interest for bridging loans. ${ }^{42}$

In summary, the pearling booms transformed the region's traditional social structure as large numbers of foreigners were attracted to the region for the first time, and in many ways this massive influx of expatriates can be seen as a clear antecedent to the contemporary UAE's labour market. More importantly, however, a number of these new foreign contingents, especially the wealthy Banian merchants, can also be seen as having further reinforced the early peripheral nature of the lower Gulf's economy as many of these British-Indian subjects operated autonomously of the local rulers, ${ }^{43}$ were exempt from taxation, and remained only semi-permanent residents, regularly returning to India, and thereby transferring the bulk of their accumulated capital from the region to a core economy. Nevertheless, alongside these foreign expropriators it is also important to note that there existed an extremely wealthy indigenous class which had emerged as the stronger sharif tribes (often possessing surplus capital from their camel herding activities) were able to invest heavily in new pearling ventures. Moreover, many of these Arab merchants were also capable of funding local development projects and, on occasion, even checking the ruler's power. However, as the remainder of this chapter will demonstrate, by the early twentieth century indirect British intervention and new sources of wealth had effectively restrained the expansion of this entrepreneurial class, thus shifting the crucial merchant-ruler balance, and thereby permanently altering the course of the region's socio-economic development.

\section{3 - The traditional political structure}

In much the same way as the region's traditional economic and social structures the geographical context, the great distances, the harsh conditions, and the tribal 
hierarchy primarily defined the traditional political structures of the lower Gulf. As such, in terms of authority, the modern territorial concept of statehood was largely alien to the region's traditional polity given the vagueness of the desert and the tribal way of life. Certainly, as Kevin Fenelon notes:

"The desert was like an ocean highway across" which the nomadic tribes could move at will. Their organisation was tribal, and the ruler was not so much a territorial overlord as one who held the allegiance of several tribes or tribal groups. In times of emergency the tribes might rally round a shaykh of the strongest tribe, but the concept that the authority of a ruling shaykh had a territorial extent as well as a personal one was only brought in when the British gave the name of 'state' to the sum of political influence that one of the undersigning shaykhs could muster among the tribes. "44

Thus, in the period prior to British involvement, the political structure revolved primarily around the tribe and authority over people, rather than vast tracts of mostly worthless sand. Indeed, as Heard-Bey argues, even by the mid-twentieth century the establishment of a territorial state with distinct physical boundaries was still very much "... out of tune with the traditional conduct of local politics given that sovereignty over people was far from permanently binding, let alone sovereignty over territory." ${ }^{.45}$

Two clear examples of this need for authority over people would be the longrunning struggles for mastery over the tribes of Buraimī and Ra's al-Jibāl. Buraimī, as explained, was a strategically important oasis and trading post, with many of the local rulers believing that hegemony over tribes in this area would soon lead to great power over influential groups needing to visit the oasis. As such, control over the population of Buraimĩ has long been a source of conflict for the rulers of Abu Dhabi, Oman, and Saudi Arabia. Indeed, as will be described later in this chapter, the contest reached its most acute point only as recently as 1952 , with the central argument still surrounding the allegiance of the local independent tribes. This aspect of the dispute was only resolved in 1959 when Abu Dhabi and Oman finally agreed to delineate boundaries 
through the area, thus dividing it into the present day towns of Buraimī (in Oman) and Al-'Ayn (in Abu Dhabi emirate). This physical demarcation was seen as the only way of preventing the local tribes from continuously attempting to play off one regional power against another. Similarly, the Ra's al-Jibāl example highlights the attempts of another major power, Ra's al-Khaimah, to dominate an area in order to gain influence over local tribes. Certainly, given the Ra's al-Jibāl tribesmen's preference for the distant and rather ineffective authority of the Sultan of Oman, Ra's al-Khaimah needed to demonstrate its ability to exert control over nearby populations. For many years, however, Ra's al-Jibāl remained loyal to far-away Muscat, frustrating Ra's al-Khaimah and thereby illustrating how tenuous the concept of political power was at this time. Certainly, with different tribes in close proximity to each other, and with many accepting the sovereignty of different rulers, it was exceedingly difficult for any one power to form a coherent political entity. ${ }^{46}$ Indeed, even a close inspection of a map of the present day UAE will still reveal many pockets of territory which continue to exist many miles inside the territorial boundaries of neighbouring states; obvious examples being the Omani controlled Musandam Peninsula and the village of Madha close to the Wādi al-Hatta. This complex patchwork of enclaves serves as a reminder of the continuing relevance of tribal allegiances and the contemporary rulers' desire to maintain control over certain groups even if there are considerable logistical difficulties in enforcing such authority.

Despite this rather vague sense of political control, the region's traditional governments, or huküma, did, however, possess certain key institutions which were deemed necessary for administering the ruling shaykh's authority. Perhaps the most important of these institutions were the dīwān and the majlis. The semi-formal dĩwăn consisted of the shaykh's appointed advisers, each of whom represented an important segment of society. The tribal nature of the political system was clearly present in the dīwân given that the ruler's family tended to dominate, as they were always the largest tribe in the area (the one exception being the ruling tribe of Ra's al-Khaimah). ${ }^{47}$ On a more informal level the majlis (pl. majālis) provided a forum for the people to air their grievances, often in the presence of the shaykh himself. Thus, in many ways this early 
form of government left room for a kind of consultation-based grass roots democracy, as in theory any member of a town's population could find a channel of communication leading directly to their ruler. ${ }^{48}$ This may not seem a very democratic system in the western sense, but given the described nature of the region's loosely defined constituencies, the majālis nevertheless allowed for a form of 'mobile democracy'. Indeed, any tribesman who raised an issue with a ruler and was left unsatisfied could simply move to another village or town under a different administration, thus 'voting with his feet'. ${ }^{49}$

Underneath the ruler and these rudimentary institutions there were of course many other manifestations of administrative authority, and as society gradually became more sedentary a greater number of institutions and official positions were required to protect, supervise and govern the various towns and activities of the region: See figure (ii).

- Ruler - the principal shaykh assumed responsibility of all institutions and made himself available to hear any grievances from his population

- Dīwãn - the ruler's court of advisers

- Majlis / majälis - informal consultation chambers, often in the presence of the ruler or his representatives

- Ruler's personal secretary - normally an educated expatriate Arab responsible for administration and communication between the ruler and other authorities

- $Q \vec{a} d \bar{\imath}$ - an important position for a religious man, responsible for dispensing justice according to Islamic law

- Qādī court / Pearling courts - tribunals presided over by either a qădī or representatives of the pearling committee to resolve disputes and dispense justice. As described, the complex system of financing employed by the pearling industry involved both creditors and debtors and as such was frequently the cause of dispute. As a result, pearling courts or sālifa alghaus were set up by the ruler or wâlī and presided over by captains and 


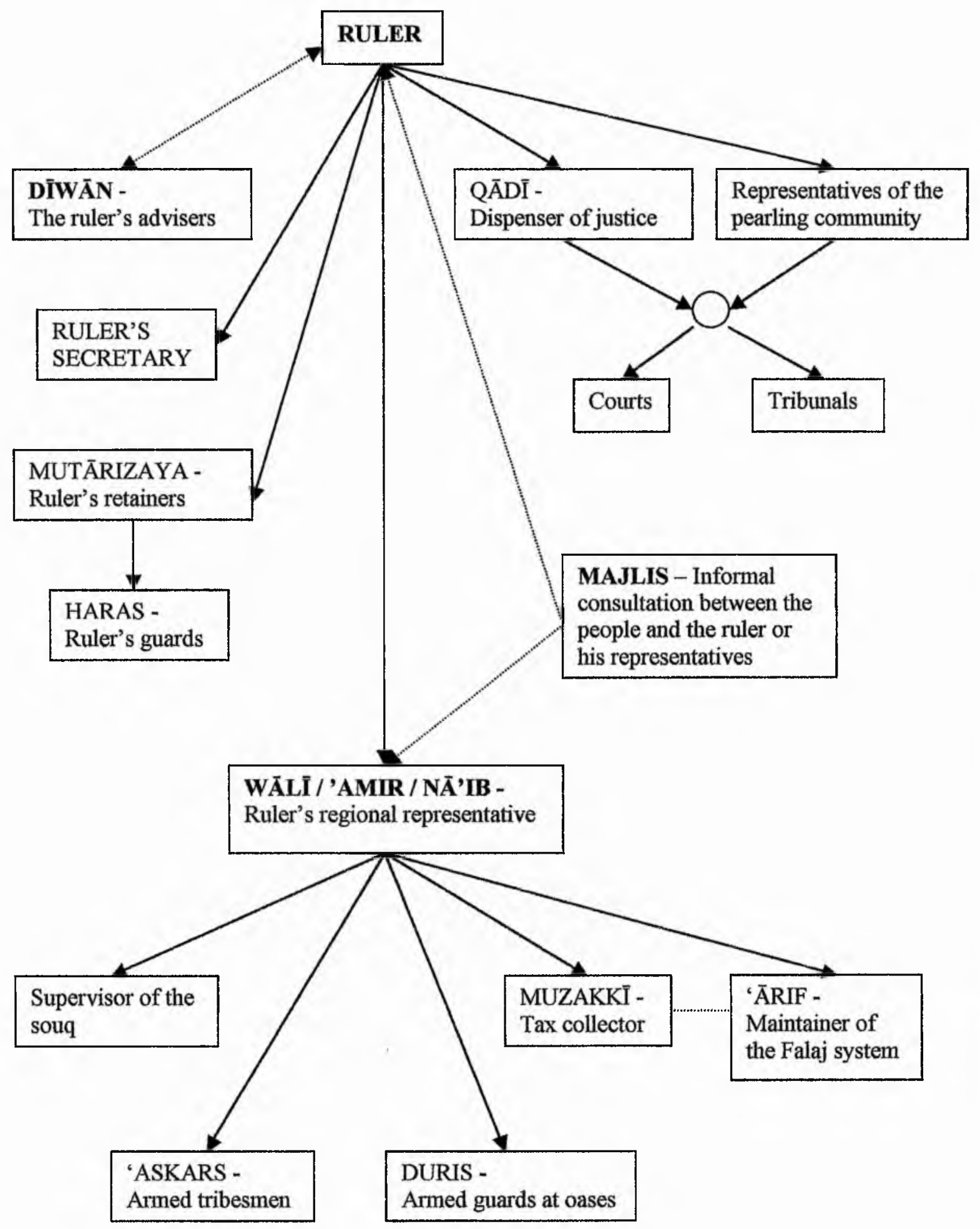


other members of the pearling community who 'had a reputation for faimess and good judgement' 50

- Wälī / 'Amir (in Dalmā) / Nâa'ib (in Al-'Ayn) - the ruler's representative in an outlying region

- Muzakki - an official responsible for the collection of taxes and customs

- 'Arif - an official responsible for the maintenance of the falaj channels in agricultural towns such as Hatta and Al-'Ayn. These men collected a fixed sum of money (the māshā) from the owners of date gardens in exchange for diverting the flow of water from one channel to another as necessary. ${ }^{51}$

- Mutārizaya - the ruler's armed retainers

- Haras - armed guards at the ruler's fort in the main town

- 'Askars - armed tribesmen paid a salary to enforce the ruler's authority in outlying regions

- Duris - armed guards in the oasis towns and outlying regions responsible for protecting camels and other livestock from raiders

- Supervisor of the souq - an official responsible for ensuring the smooth functioning of the town's marketplaces. ${ }^{52}$

Of these other hukūma positions perhaps the most useful in contributing to a further understanding of the traditional political structure would be the ruler's representatives, who were usually placed in charge of outlying territories, often beyond the range of the ruler's personal authority. Broadly speaking, this system of delegation was practised throughout the region, albeit with different titles and slightly different responsibilities. In the northern shaykhdoms, for example, the rulers appointed wälis to collect taxes from their more remote towns, and also to organise the defence of any outposts against raiders or attacks from rival shaykhs. Moreover, the wālīs were also expected to serve as the rulers' de facto governors in these towns, holding local majālis, arbitrating disputes, and dispensing justice with the assistance of qādīs and pearling courts. ${ }^{53}$ Similarly, Abu Dhabi employed 'amirs who would live and work on the many scattered islands belonging to the ruler. Their task, like that of the wălī, was to collect pearling taxes and settle disputes with the assistance of the muzakki and various other 
customs officials. ${ }^{54}$ The crucial difference being that the 'amirs received a fixed payment from the ruler rather than a share of the local taxes, thus making them the region's earliest form of salaried bureaucrat.

Significantly, and again illustrating the de-centralised and fluid nature of politics during this period, in many cases these representatives grew autonomous of the ruler as their control over local taxes and populations invariably allowed them to develop personal fiefdoms. Indeed, as Heard-Bey describes, very often the further away a wāln was from the ruler's town, the greater became his political weight. ${ }^{55}$ Certainly, there have been many examples in the region's history of such representatives seceding and in some cases even returning to usurp the ruler's control over the main town. A good example of such a struggle being how, in 1948, the nephew of the ruler of Sharjah used his position as a wāli to gain immense local popularity and power by supporting those who wanted a reduction in the pearling tax imposed by the ruler. By successfully defying his uncle he managed to build sufficient support to enable him to take over as ruler of nearby $\mathrm{Ra}^{2} \mathrm{~S}$ al-Khaimah. ${ }^{56}$ of course a more recent example would be the events surrounding the accession of Shaykh Zāyid Al-Nulhayyān during the 1960s. As governor or $n \bar{a} ' i b$ of the large agricultural town and the nearby villages of Al-'Ayn, Zāyid had proved himself a capable ruler in his own right and had amassed considerable popular support. Thus, as will be discussed in the following chapter, when the time came for pressure to be placed upon his older and more conservative brother in the capital, Zãyid was seen as the natural successor and, given his existing power base, the transition was both straightforward and popularly accepted. ${ }^{57}$

Another crucial aspect of the traditional administrative structure was its ability to subsidise the population. This was an important manifestation of the ruler's authority and in many ways a precursor to the system of wealth distribution practised during the oil era. Indeed, during this period the rulers frequently used heavy subsidies to buy influence and protection from other tribes, thereby keeping the peace. ${ }^{58}$ Lorimer illustrates this point showing how the rulers were able to maintain control over Bedu groups simply by giving their chiefs a steady stream of gifts. ${ }^{59}$ Even more noteworthy 
than these subsidies, however, were the taxes imposed upon the population at this time. Although the taxes collected were never particularly high and never reached the same levels as the European states, they nevertheless required the hukuma to operate certain extractive institutions and allowed the ruler to raise funds for various projects: fiscal capabilities which have rarely been employed by the contemporary state.

By far the most important of these taxes were those levied on pearling and its associated activities, especially during the boom period. Tarâz taxes were collected to pay guards to protect towns during the height of the pearling season when many of the men were out at sea, and also to protect the many pearling boats which were left unattended along the coasts during the off-season. ${ }^{60}$ The tarăz was levied from each two-man pearling team (a diver and hauler partnership called a qalta), and the pearling crews had to pay collectively a naub tax on their boat in addition to royalties on any pearls valued at more than 1000 rupees. $^{61}$ Other lucrative forms of dues included the customs duties the ruler imposed on the ports, the ruler's collection of rent from shops in the souqs, and also the ruler's ability to issue fishing licences and charge a commensurate fee. ${ }^{62}$ As mentioned, a number of taxes were also levied by the walis in order to raise funds for the town's administration, the payment of its guards, and the upkeep of its forts and towers. Moreover, there were specific taxes collected by 'ärif' officials for the upkeep of community projects such as the operation of the falaj irrigation channels, in addition to taxes on some of the agricultural activities themselves. If a farmer produced more than the nisab, which was the tax-threshold quantity of dates, then it became necessary for him to pay between 5 and $10 \%$ of his income to the wālir. In practice however, many areas failed to meet the nisab or were simply left untaxed, and even if the wâli did begin to collect, it was usually just payment in kind in order to help feed his retainers. ${ }^{63}$ Similarly insignificant were the taxes on livestock, the zakät tax, which amounted to a mere 10 rupees per camel. ${ }^{64}$ Nevertheless the zakāt and nisab taxes, although small, still served as a symbol of authority over tribesmen and in some cases were the only reminder for many Bedu people of exactly who their distant overlord was; this being underscored during the 
aforementioned Buraimi disputes when the different sides began to claim sovereignty over the area based on a history of zakăt collection among particular tribes.

In order to understand better the impact of this taxation, a brief case study of one of the many pearling / fishing islands of Abu Dhabi clearly highlights the role of the tax collector, and provides something of an insight into the early extractive process. Dalmā, a small island off the coast of Abu Dhabi, is still a base for fishermen, and used to be a major centre of activity during the pearling boom. In 1955 the ruler's representative, the 'amir, gave a written description of the taxation system still in use on the island:

"(1) At the beginning of the pearling season a sack of rice, juniya, and four rupees tumān were collected from every boat; half of both amounts were taken from small boats. (2) A share equal to the season's income of one rope-puller, a saib, was collected as häsila. This amount was calculated. The remainder was shared between the divers and saibs at the proportion of three for the former and two for the latter, after adding an imaginary saib. The share of that saib was the tax due to the ruler of $A b u$ Dhabi. (3) At the end of a season a tax of two rupees was levied on every qalta (pair, a diver and a hauler). (4) On every pearl valued 2000 rupees or more a tax of 200 mupees was taken by the ruler. (5) Naub was at that time the term for the tax levied on every pearl merchant or other merchant in Dalmã or the islands and coastal tracts administered by the 'amir. The tax varied between 2 and 200 rupees a year for an individual, depending on the size of his business. (6) 'Azima was a voluntary contribution of the pearl merchants towards the cost of a feast traditionally given in honour of the ruler when he or a close relative came to Dalmā at the end of every diving season." 65 
Thus, no fewer than six specific forms of dues existed on the island. With Dalmā Island being a typical example of a pearling community, this demonstrates the way in which taxation was very much a part of life for the coastal region during the pre-oil period.

In summary, the lower Gulf's traditional political structures were in many ways products of the same factors which shaped the early economic and social structures; namely the region's geography and the tribal system. Certainly, with well spread out and distant settlements, and with the need to control tribal populations rather than physical territory, there evolved a de-centralised and extremely fluid political system in which the power of rulers and governors would vary according to their popular support, and in which the people could exercise considerable mobile democracy by moving from one constituency to another. Eventually, as society became more sedentary the traditional governments did expand as, in Weberian terms, the system evolved from one of family-based patriarchal authority to one of patrimonialism, ${ }^{66}$ requiring new positions and institutions to arbitrate, subsidise, and tax the population. While many of these features, including the hukūma's system of appointments and the early distribution of wealth, are certainly important antecedents of contemporary political structures, it is however quite apparent that other equally notable characteristics of the traditional polity have either faded or, in some cases, disappeared. Indeed, with well-established rulers, a more centralised state, and larger populations, much of the former flexibility of political control has gone, which of course has also reduced the effectiveness of the old system of mobile democracy. Furthermore, whereas in the past the traditional government was routinely able to tax its population and was therefore a relatively 'strong state' with well-defined extractive capabilities, ${ }^{67}$ much of this ability would now appear to have been lost.

\section{4 - External Influences and the 'Trucial States'}

To provide a better explanation of these important political changes and continuities in addition to the previously discussed socio-economic developments, this section will consider the substantial impact of external forces on the region, and their 
role in reinforcing certain traditional structures while removing and suppressing others. Although beginning with an assessment of the early Portuguese presence in the lower Gulf, the main focus will be the increasing influence of the British Empire and the expanding regional power of the British East India Company. In particular, it will be shown how Britain's relationship with the lower Gulf evolved from one of open conflict to one of maritime peace, and then to one of increasing economic and political control. Moreover, it will be demonstrated how Britain's intensifying efforts to dominate the region can be viewed as not only an attempt to preserve existing British economic networks, namely the trading route to India, but also as an attempt to incorporate and control indigenous Arab networks. Furthermore, it will be shown how this peripheralisation of the region also led to the creation of local client rulers, many of whom were reliant on the British core not only for their sovereignty but also for their economic livelihood and as a source of non-earned wealth.

Portuguese interests in the lower Gulf were essentially limited to trade. Specifically, it was the empire's intention to monopolise the trade route between Europe and its colonies in the East Indies by outflanking the traditional overland routes of Persia and the Mashriq. ${ }^{68}$ To this end, Portugal concentrated on developing the entirely maritime route around the African Cape of Good Hope which their navigators had successfully charted in the fifteenth century. By using such a route it was critical that the periphery of the Indian Ocean was secured, and many in Lisbon believed that the Straits of Hormuz were necessary for this control. ${ }^{69}$ As such, some form of Portuguese presence was required in Oman, and naval bases were also established in nearby Khor Fakkān (a present day container port on the UAE's Indian Ocean coastline) and in Ra's al-Khaimah. However, unlike the Asian Portuguese colonies of Macao and Goa, these Arab ports never became major bases due to their lack of natural harbours and the few watering places along the coast of the Gulf. Consequently, no real settlement took place in the region, and as such the period of Portuguese occupation had little effect on indigenous structures. Certainly, as Heard-Bey claims, the empire's only real impact on the region was to have reduced the lower Gulfs security as the imperial presence frequently endangered local Arab trade by bringing Ottoman, Dutch, and British rivals 
ever closer to the area. Furthermore, the well-documented Portuguese practice of putting to death entire communities if local harbours and fortifications were withheld may have imprinted lasting memories on the minds of the native population. ${ }^{70}$ As such, it has been argued that the longevity of these memories created an understandable sense of distrust and unease in the Arabs' future dealings with foreigners, and may therefore, as much as any other factor, have contributed to the initial clash with Britain, the second imperial power to take an interest in the region.

Indeed, Britain's first major contact with the lower Gulf was a trading dispute which soon escalated into warfare. In the early eighteenth century the Qawāsim (adj. Qāsimī) tribes of Ra's al-Khaimah and Sharjah had been growing in strength and prestige as their trading activities flourished. When Qāsimī power eventually extended to the island of Qishm ${ }^{71}$ they began to establish a third trading base, but this new entrepôt Arab port soon began to affect adversely the customs receipts which had previously been divided between the British and Persian empires. This loss of revenue prompted the British East India Company, a Bombay-based trading company, to send an armed expedition to the island to claim by force the Company's share of the customs from the Arab traders. ${ }^{72}$ Thus, an intense maritime struggle over local trading networks began; a struggle which was to last well into the nineteenth century, the events of which have been clouded in historical controversy with the Qawāsim being branded as fanatical pirates and the British as imperial aggressors.

With the benefit of hindsight, little is clear, although there appear to have been a number of different issues which contributed to this protracted and bloody conflict. Firstly, there is no doubt that with the growth of European competition along the Indian Ocean trading routes, the decline of the narrow maritime-oriented economic base of the Qawāsim was in many ways inevitable. As such, Heard-Bey argues that with so many Qāsimī boats and sailors out of action due to the decline in trade, it was foreseeable that at least some would turn their hand to something more lucrative. After all, nomadic desert raiding, or 'ghazu' was not uncommon in the hinterland and had always proved a popular alternative during times of austerity. Thus, piracy on the seas may have been 
viewed by some as simply an extension of such an activity, albeit with far higher rewards. ${ }^{73}$ Moreover, the power vacuum and the lawlessness following the concurrent decline of the Persian Empire may have compounded the economic downswing and provided even more conditions conducive to a serious conflict between the local power and the major foreign power. Indeed, Donald Hawley, a former British Political Agent in Dubai, supports such a view:

"... while the Gulf was far from peaceful during the eighteenth century, the blame did not lie entirely with the Qawāsim. Persia was in internal turmoil, and trade, which the Qawäsim shared with other Gulf Arabs, was carried on against a background of strife. Piracy was also endemic in the Gulf and had broken out periodically throughout history, when no strong government controlled the area."

Certainly, Hawley believes that if the region had not been so turbulent and that "if the Qawāsim had not crossed swords with the rising power of British India and been branded pirates by the secure Victorians," then their fame may have rested on more peaceful foundations. ${ }^{75}$

Regional politics may have also played a part, with the Qawāsim's traditional rivalry with neighbouring Oman and the increasing influence of the Arabian Wahhābi movement both acting as catalysts. By the early 1800 s the Omani fleet had grown to become a serious trading rival and, in 1804, the Sultan of Oman even began to claim the exclusive right to protect navigation in the Gulf, thus making Muscat the sole distribution centre for foreign goods. ${ }^{76}$ The Omanis had therefore placed the Qawāsim under considerable economic pressure, and, given Oman's historic alliance with Britain, a backlash may have been unavoidable. Furthermore, it is also believed that the increasingly popular Wahhābi religious reformers may have exacerbated the situation given their strengthened alliance with the Qawāsim, their expansionist ambitions over Omani territory, and their hostility towards Britain and Britain's polytheist and idolatrous Hindu Indian sailors and crewmen. Indeed, it is believed that the Wahhabism 
which had emerged from the heart of Arabia during the mid-eighteenth century eventually reached Buraimī and the Qawāsim by around 1800. Its namesake, Muhammad ibn Abdul-Wahhāb, launched the movement, and after his death it was led by its first Imãm, the Saudi shaykh. The Wahhābis preached a more purified brand of Islam, a doctrine of pure monotheism and a return to the fundamental tenets of Islam as laid down by the Koran. As such, they were unitarians, emphasising the "centrality of God's unqualified oneness in Sunni Islam'. ${ }^{77}$ Essentially, they sought to renew the Prophet's golden era of Islam, and all who stood in their way were to be swept aside, including other Islamic rulers who lived 'impure' lives such as the pro-British Sultan of Oman. As such, by the time of their contact with the Qawāsim, Hawley believes the movement had become something of a "religio-military confederacy under which the desert people, stirred by a great idea, embarked on a common action", ${ }^{78}$ and sought constant expansion in the manner of the original Islamic concept of dâr al-harb. Indeed, in his account of the period, Charles Belgrave notes how Abdul-Wahhāb "told his followers that it was their religious duty to convert their fellow men with fire and sword, and to plunder and destroy all those who professed to be Muslims but did not accept Wahhabism". He then draws the conclusion that it was this prospect of authorised and religious sanctioned plunder which "may have attracted the desert Bedu and the pirates of the coast to align themselves under the green standard of the Wahhābis", ${ }^{79}$ thus adding a tinge of religious fanaticism to an already serious conflict.

Wahhabism's role as a catalyst would, therefore, seem very clear, especially given the Qawāsim's inclination to form alliances with any power hostile to their traditional Omani rivals. Furthermore, the clear evidence of Wahhābi control over the region during this period, underscored by the imposing Wahhābi fort constructed in Buraimi to serve as a vantage point over the oasis and to sever trade routes into Oman, may even indicate that the Wahhābis were as much to blame for the ensuing struggle as the Qawāsim. ${ }^{80}$ Indeed, it is recorded that at one point the Wahhābis were able to claim one-fifth of all Qawāsim booty and to confine the Qāsimì shaykh's authority to just Ra's al-Khaimah itself. ${ }^{81}$ Moreover, in 1809 they were even temporarily able to depose the shaykh and appoint their favoured ruler, the Shaykh of Rams (a small town just 
north of Ra's al-Khaimah) in his place to be the Wahhābi governor and tax collector. ${ }^{82}$ These examples of control may hint at the true extent of Wahhābi involvement, especially given that in 1809 the so-called acts of Qãsimī piracy were at their peak even though Qāsimī power was restricted to just one coastal town.

However, as both Lorimer and Belgrave note, the lack of an adequate British response to the initial Qāsimī and Wahhābi-inspired attacks must also be seen as a layer of explanation, at least with regard to the longevity of the conflict. Indeed, as the author of the Gazetteer reported, the initial strikes on British-Indian shipping, including the assaults on the Viper cruiser and the Bassein dhow, failed to elicit any real response from Bombay. ${ }^{83}$ With "no reparation seeming to have been exacted for this insult to the British flag", it is argued that the Qāsim̄̄-Wahhābi alliance was left to grow bold and over-ambitious. Certainly, Belgrave supports Lorimer's view, believing that Bombay's lack of steps to punish those responsible led to the Arabs "finding they could attack British ships with impunity... with the pirates becoming more audacious". 85 Moreover, Belgrave sums up what might have been the frustration felt by the British following these attacks:

"... still the Bombay government took no action. Not only was it inactive, but commanders of the Bombay Navy were ordered not on any account to attack or molest 'these innocent natives of the Gulf', and were threatened with 'the displeasure of the Government' if they failed to carry out their orders. This policy was due to the Government's fear of becoming involved with the Wahhäbis, although it was known that they were supporting and encouraging the pirates, and receiving a portion of the spoil. The pirates, assuming that there would be no reprisals, became more daring. In 1805 they captured two brigs belonging to Mr. Manesty, the Resident at Basra. Many of the crews were murdered and the Captain of one of the brigs had his arm cut off because he was seen to fire a musket. He put his severed arm into some hot ghee, which saved his life. The two brigs were added to the pirate [Qāsimī] fleet. ${ }^{\prime 86}$ 
In 1809 an expedition was finally launched against the 'pirates' of Ra's al-Khaimah but this too was seen as an inadequate response and one which failed to gain any formal submission from the Qăsimi sailors, many of whom simply retreated inland. The British response in 1816 was regarded as similarly ineffective with Belgrave describing it as having been nothing more than a 'badly managed demonstration' $:{ }^{87}$

"The [British] ships then opened fire on some pirate dhows which were anchored near the shore, but the dhows were too far distant for the gunfire to be effective. Guns from the town replied with slightly more success, for one of the shots carried away part of the sail from a British ship. 'At least three hundred shots were discharged from the squadron, not one of them seemed to have done any execution'. The ships then set sail leaving the pirates performing jubilant war dances on the shore... "\$8

Thus, this second fiasco, much like the earlier mission, also portrayed the British as weak and ineffective, and was seen as prompting "...the Qawãsim to engage in piracy with new vigour. They had good reason to believe that the British, in spite of their superior ships and armaments, were incapable of resisting them. ${ }^{389}$

The final expedition did not come until $1819 / 1820$, but this time the British response was strong and well planned, with Ra's al-Khaimah becoming the scene of one of history's first major amphibious assaults. The Qāsimĩ stronghold had been able to rebuild its fortifications following the 1809 attacks, with Captain Loch of HMS Eden stating in his diary, "to say the least of it, $\mathrm{Ra}$ 's al-Khaimah was no mean or insignificant work of defence". ${ }^{90}$ Indeed, the well-defended port was seen as a very tough proposition for the Bombay landing party. The force, comprising both British officers and Indian infantry was the largest to have ever appeared in the Gulf with over 3000 soldiers, three battleships and nine cruisers. The plan was to assault simultaneously Ra's al-Khaimah and the nearby pirate base of Zaya, and then to sail further down the coast crushing each remaining Qãsimī redoubt one at a time. ${ }^{91}$ Loch's diary provides an understandably pro-British view of these events and although this view is unlikely to be 
shared by many today, Belgrave's highly controversial summary of its contents is nevertheless useful in capturing something of the British perception and mentality towards the Arabs of the lower Gulf at that time:

"Loch's diary makes the reader realise how many British lives were sacrificed in suppressing piracy... Britain achieved these objectives, not with any ambitions towards territorial conquests, but in order to make the seas safe for the ships of all nations and to put an end to the people of the Gulf carrying off their fellow creatures into slavery. Unfortunately very few of the present generation of Gulf Arabs realise the part which Britain played in the past." 92

An account of these events would, however, be incomplete without also considering the more recent Arab revisionist history of the Qawāsim. Indeed, Shaykh Sultān al-Qāsimī, the current ruler of Sharjah and a descendent of the Qawāsim, offers an entirely different perspective ${ }^{93}$ (which to some extent has now been corroborated by the work of the British historian Charles Davies ${ }^{94}$ ). Essentially, al-Qāsimī presents an alternative explanation of the events surrounding Britain's destruction of Ra's alKhaimah, or to be precise, the British East India Company's important role in the suppression of the Qawāsim. Central to his claim is that Lorimer, the author of the much-celebrated Gazetteer, was a civil servant of the British India government and as such his views were entirely pro-British and therefore need to be treated with caution in any impartial study of the region. Furthermore, al-Qāsimī emphasises that because Lorimer's study was the first of its kind, it was heavily relied upon by almost all subsequent scholars, including John Kelly's influential work on the Gulf. ${ }^{95}$ Al-Qāsimī has therefore sought to refute the generalisations and claims of Lorimer and these other historians that the Qawāsim were simply marauders and pirates. Instead he argues that the Qawāsim were instead accomplished maritime traders who were able to outcompete and undercut many of their rivals, including the British Indian merchants. 
Indeed, al-Qāsimī identifies the expansion of Imperial trade as the key issue behind the conflict, stating that the British East India Company, a firm with vast commercial interests in the region, was

"... determined to increase its share of the trade in the Gulf by all possible means. Any increase in the Company's share would be at the expense of the Arab natives of the Gulf... the Company's government of Bombay realised that any real opposition to their plans in the Gulf would come from the Qawāsim." 96

In order for the Company to achieve the destruction of their enemies, they needed to be able to persuade the decision-makers in both Bombay and London of the need to mobilise British naval forces against their principal trading rival, the Qawāsim. Accordingly, as al-Qāsimî describes:

\begin{abstract}
"A concerted campaign was mounted by Company officials to present, or rather misrepresent, the Qawāsim as pirates whose depredations posed a serious threat to all maritime activities in the Indian Ocean... ". 97
\end{abstract}

Thus, al-Qāsimī believes that any misfortune which fell upon any British ship in the area was immediately attributed to Qawāsim 'pirates', and as such a 'big lie' was contrived, a lie so readily accepted that the coast of the lower Gulf even became known as the 'Pirate Coast'. 98

As such, al-Qāsimī’s alternative history attempts to demonstrate how many of the accidents and unexplained incidents which occurred at sea during this period were always reported to the British Political Resident, and in turn London, as being the work of dangerous pirates. His study is well researched, drawing heavily from the Bombay archives. These, unlike the India Office records held in London, house the complete files of the British East India Company and therefore contain a far more substantial quantity of the correspondence between the Gulf, Bombay, and London at that time. ${ }^{99}$ 
Indeed, from this correspondence, al-Qāsimi reveals how the Company hoped that a sufficient body of anti-Arab evidence could be presented to the Bombay government, enough to persuade the government that the Royal Navy needed to be used to remove by force their commercial rivals. Certainly, al-Qāsimî̉'s argument would seem highly credible given that the British destruction of the 'pirates', their strongholds, and their means of livelihood led to a commensurate increase in the Company's share of trade in the Gulf. With their main opponents removed by military means, the Company"s imports to Bombay rose from nearly 1.7 million lakhs in 1801 (prior to the expeditions), to over 3.3 million lakhs by 1822 (following the final expeditions). Similarly, the Company's exports from Bombay rose from over 1.2 million lakhs to over 3.3 million lakhs over the same period. ${ }^{100}$ In this light, the early Anglo-Arab conflict can therefore be seen as being far from an accidental clash of interests and 'empire by absentmindedness', and instead as part of a long-term effort by the Bombay government and the Company to suppress and displace an indigenous Arab trading network.

\subsection{1 - Greater British political and economic involvement}

Regardless of these differing historical accounts surrounding the causes of the conflict, after the assault on Ra's al-Khaimah and the destruction of the other pirate strongholds the immediate threat to British Indian shipping and the Company's commercial interests had subsided and left many in Bombay with the dilemma of whether Britain should continue to involve herself in the region, or should simply maintain a watching brief. As Malcolm Peck describes, many believed that a permanent military establishment in the Gulf was undesirable unless the cost of the upkeep could be recovered from the Omanis or from other local sources. Furthermore, it was felt that any greater interference in internal Arab affairs would lead to unnecessary complications, especially as the Wahhābi threat had diminished and the reinstated Shaykh Saqr of $\mathrm{Ra}^{\prime}$ s al-Khaimah appeared to be a reliable and relatively pro-British ruler. However, a second, more hawkish camp intended to launch a full-scale sweep of the Gulf destroying any remaining pirate bases and removing local rulers as they saw fit. Crucially, this interventionist camp had much support given that shortly before the 
1819 expedition the Qawāsim had been blamed for a number of attacks just seventy miles from Bombay itself, ${ }^{101}$ and in 1816 had been held responsible for the plundering of three British Indian merchant ships in the Red Sea. ${ }^{102}$

Eventually something of a middle ground was taken with the Bombay government deciding to follow up their expeditions by seeking to retain influence over the tribes with periodic shows of force, while at the same time preparing the ground for greater co-operation between the British and the local Arab rulers. Captain Perronet Thompson, a former governor of Sierra Leone, was brought in to supervise and, ${ }^{103}$ one by one, individual treaties were signed between the Bombay government and the ruling shaykhs. The first of these was signed with the ruler of Sharjah in 1820 , requiring him to surrender all remaining pirate vessels, fortified towers, guns, and British prisoners. In exchange he was given assurances by the British that all pearling and fishing vessels would be restored to Sharjah, and, significantly, that all Sharjah trading vessels would be granted access to British ports. Thus, given the recent economic decline and war damage both of these guarantees were major non-military incentives for the Shaykh to honour the treaty, ${ }^{104}$

Consequently, as a result of these early accords between Britain and the participating 'Trucial States' maritime peace was finally achieved. Many amongst the Bombay elite were, however, distrustful of such a loose arrangement and pressed for stricter treaties with additional provisions such as the banning of armed Arab vessels, the limiting of Arab commercial vessels, and the banning of timber exports from India to the Gulf (presumably to limit Arab shipbuilding). ${ }^{105}$ Although few of these draconian measures were implemented, further annually renewed maritime truces were called for, in which the rulers had to guarantee that all hostilities at sea would be outlawed. These began to be signed from 1835 onwards and culminated in the 1853 Perpetual Treaty of Peace, an essentially self-enforcing truce given that the economic benefits of regional stability were enough to ensure co-operation from most parties. ${ }^{106}$ Indeed, following these treaties Britain was able to scale back her naval presence in the Gulf, retaining only a small squadron to police the region and signal the Imperial 
presence. ${ }^{107}$ Thus, without having to become directly involved in internal security or other expensive complications, by the mid-nineteenth century Britain had found a costeffective means of maintaining a strong influence over the area while containing indigenous power bases and trade networks.

Nevertheless, as an indirect result of these peace treaties Britain did begin to be drawn into a closer relationship with the rulers of the coastal towns. Indeed, as Britain's policing role inevitably expanded to include the arbitration of local disputes, many of the rulers and their courts became dependent on British support for their judgements. Moreover, given that only recognised rulers were selected to be signatories of the Perpetual Treaty, some even began to draw strength from their treaty agreements as rival shaykhs were effectively delegitimised by their non-signatory status. Furthermore, after a time, Britain also began to screen potential new rulers to check if they were likely to adhere to existing as well as future treaties. If a new ruler was deemed suitable he was then sent a fresh copy of the treaties, thus formalising his sovereignty in British eyes and often among his own people. Thus, British influence started to become paramount in approving rulers, and it often happened that if a Shaykh strayed from the terms of the treaties he would lose popular support from a community that preferred to tow the line and not endanger their pearling or trading operations. ${ }^{108}$

As such, even though Britain was not directly involved in internal politics, her distant authority nonetheless caused a massive change to the lower Gulf's balance of power. Most obviously, the treaties and their recognition of the region's current rulers effectively froze a snapshot of local power struggles and stabilised formerly elastic territorial boundaries, ${ }^{109}$ thus preventing any indigenous challenge to the status quo, and thereby bringing to an end the previously described ebb and flow of tribal powers. Indeed, the immediate aftermath of the expedition against the Qäsimī capital of Ra's alKhaimah provides such an example. Spurred on by the Qawāsim's decline in regional prestige and power, the nearby towns of Umm al-Qawain and Ajman seized the opportunity to claim independence, thus geographically splitting $\mathrm{Ra}^{\prime} \mathrm{s}$ al-Khaimah from Sharjah, the other main Qāsimī base. Moreover, revolts in Fujairah on the Indian Ocean 
coast had also weakened Qāsimî power in Ra's al-Khaimah, allowing Sharjah to emerge as the pre-eminent town of the lower Gulf. ${ }^{110}$ When the British treaties began to be introduced, all of these newly independent towns were well placed to sign, which effectively guaranteed their future sovereignty and prevented any reprisal from their former Ra's al-Khaimah overlords. ${ }^{111}$ Although perhaps less obvious, another important consequence of these maritime treaties for the balance of power was their effective formalisation of the supremacy of the coastal tribes and towns over those of the interior, thereby allowing the maritime rulers to absorb more easily large tracts of the hinterland into their 'Trucial States'. ${ }^{112}$ Indeed, if one follows Ismael's parallel argument for Kuwait, this superiority can be seen as adding another explanatory layer for the lower Gulf's increasing peripheralisation as the coastal towns' absorption of the weakened interior further imbalanced the regional economy thereby reducing the likelihood of future indigenous development. ${ }^{113}$

In addition to indirectly altering the local power structures, the presence of the British also began to have a major impact on some of the region's long-practised economic activities, especially the slave trade. As described, slaving had always been a highly profitable venture for many of the local Arabs, with even the ruler of Sharjah believed to have been levying a tax on each successfully imported slave. ${ }^{114}$ The slaves were shipped from the East coast of Africa to the lower Gulf's ports, most notably to 'Ajman and Umm al-Qawain, and from these they would be transported by land into the Arabian interior where they would finally be sold to wealthy patrons. Although many British individuals also prospered from slavery, ${ }^{115}$ there was nonetheless a growing moral consensus against slavery in the Empire, and by 1838 this had culminated in the outlawing of slavery in all British dominions. Given that the shaykhdoms of the lower Gulf were not actually British colonies, but simply in treaty relations with Britain, these developments did not immediately affect the region. Nevertheless, Britain did place increasing pressure on the rulers to abandon slavery voluntarily, ${ }^{116}$ and agreements were soon drawn up which allowed British cruisers to detain and search suspected slaving vessels, and which required all Somalis (who were British subjects) to be freed from slave labour in the Gulf. In 1847 a further treaty outlawed the export of slaves from 
Africa by Arab ships, ${ }^{117}$ and in 1856 the restrictions were further tightened, requiring all of the rulers to embargo and hand over any suspected vessels that arrived in their ports. ${ }^{118}$ These efforts gradually reduced slavery, but it took a long time and there were pockets of strong resistance to the policy of manumission even as late as the 1950s, especially in the interior, ${ }^{119}$ with some slaves even being employed by the oil companies. $^{120}$

Significantly, this persistence of slavery and Britain's continuing opposition to the lucrative activity created a window of opportunity for certain other powers, including the French and the Ottomans, to gain influence in the region. This attempted intervention, together with a number of other factors, led Britain to seek even greater control over its Trucial States in order to prevent future interference from external powers, and to discourage any 'playing off' between the local powers and Britain's rivals. Thus, by the latter part of the nineteenth century, the political relationship between Britain and the Trucial States expanded even further to include control over the region's foreign affairs. This time, however, the catalyst was neither the Qawâsim nor any other local maritime power, but instead the Bani Yas of Abu Dhabi; a powerful tribal agglomeration which controlled most of the slaving routes into the interior. Unlike the 'Qāsimī pirates', the Bani Yas had been relatively untroubled by earlier British involvement given that their other economic activities were centred around the date groves of Līwā and the pearl fisheries close to Dalmā island, both far away from the main trading routes of the Gulf. However, as the Bani Yas continued to prosper they also began to assume a position of supremacy over the weakened northern shaykhdoms, symbolised by their ruler's defeat of the Ra's al-Khaimah shaykh in single combat. ${ }^{121}$ Naturally this emergence of a new indigenous power bloc became a cause of concern for the British who were keen to maintain the detached nature of the Trucial system. Far more importantly, however, the British were also becoming increasingly distressed by Abu Dhabi's attempts to seek external support for their slaving activities from other regional and foreign powers. Indeed, Shaykh Zāyid bin Khalifa of Abu Dhabi had begun to form a close alliance with the Sultan of Muscat who, by this stage, was receiving overtures from the French. Indeed, by the 1880 s the French had already 
given their flag and citizenship to the slave-trading sailors of the port of Sur in Oman, ${ }^{122}$ with the clear intention of undermining the British anti-slavery agreements, stirring resentment amongst those in favour of slaving, and bolstering French support in the region. Furthermore, many of the region's more enterprising slave traders were beginning to sail into the Gulf under French flags from Djibouti, thus avoiding the British restrictions, ${ }^{123}$

By 1890 this encroachment had become an even more serious threat with French diplomats reportedly having begun to visit the ruler of Umm al-Qawain, who, by all accounts was receptive to their advances. ${ }^{124}$ Moreover, the ruler of Dubai was also believed to have been openly discussing the advantages of taking the French flag thereby "escaping the malice of the English", 125 or, as one local historian has described, "courting the French in an effort to evade the British protection grip". ${ }^{26}$ What is more, by the end of the nineteenth century Britain not only had to face possible interference from the French but also from the Ottomans. Indeed, Ottoman influence had already begun to reach as far as Qatar and, at one point, the official Baghdad Gazette even listed Bahrain and eight towns in the Trucial States as being part of the Turkish controlled province of Najd. ${ }^{127}$ Similarly disturbing for the British were the reports of Persian representatives attempting to gain a foothold in the region. These agents were thought to be stirring religious sentiments among the local Arabs and were reported to have met with the rulers of Abu Dhabi and Dubai in an effort to persuade them to denounce 'Christian influences' and allow for their towns to come under the Persian sphere of influence. $^{128}$

Inevitably, Britain regarded all such contact with foreign powers, including correspondence, as undermining both the Trucial system and Imperial authority. If French, Ottoman, or Persian agents were allowed to visit and gain influence with the local rulers, the British stood to lose some or all of the control they had carefully established over the region earlier in the century. Britain's low cost and almost selfenforcing maritime treaties would be undone and her crucial trade routes to India and the Far East would once again face competition and possible security threats. The 
solution was seen as being an 'Exclusivity Agreement' which would require all of the signatories of the earlier maritime truces to accept complete British management of their foreign policies. Consequently, in $\mathbf{1 8 9 2}$ and at the height of the Bani Yas 'violations', such an agreement was proposed, and although it was viewed by many of the locals as a "reinforcement of the eternal subordination of the shaykhdoms", ${ }^{129}$ it was nevertheless accepted by the rulers, many of whom remained wary of British naval power and the economic consequences of renewed instability. Essentially, this new contract bound the rulers and their future heirs not to

"... enter into any agreement or correspondence with any power other than the British Government... and they were not allowed to... cede, sell, mortgage or otherwise give for occupation any part of their territory except to the British Government... The exact international effect of these two agreements [referring to the 1892 agreement and the final maritime truce of 1853] is a matter for publicists to determine, but taken together they evidently create preferential and almost exclusive relations between the British Government and the Trucial Chiefs, - relations which might be held to imply the dependency of the Shaykhs on the British Government in foreign affairs and a moral obligation on the part of the British Government to protect the Shaykhs in so far as they be endangered, or disabled from defending themselves...." 130

\subsection{2-Greater peripheralisation and the emergence of rentier stmictures}

Although, as described, British Indian merchants had long been involved in the lower Gulf's pearling industry on an individual level, by the turn of the twentieth century the Bombay government had, however, also begun to take far more interest in the activity. Essentially, in much the same way as the fear of foreign intervention in the region's slave trade had prompted the British to assume control over the lower Gulf's foreign affairs, the attempts of European merchants and entrepreneurs to capitalise on the region's pearling boom and to develop technologically the local industry led the 
British to seek greater economic protection for its Trucial States. Specifically, a number of German and French entrepreneurs had decided that by co-operating with the local Arabs and by offering them more modern equipment and access to new markets, both parties could make considerable profits. Indeed, foreigners made several requests for pearling rights in the Gulf during this period, but Bombay's policy remained unchanged and Britain began to police strictly the pearl banks against any unauthorised foreign intrusion. Furthermore, the British Political Resident explicitly advised against any of the Arabs accepting foreign assistance, arguing that he needed to create an Anglo-Arab monopoly in order to protect the Arabs' primary source of income, ${ }^{131}$ because if the industry ever failed then many of the Arabs would be driven to gunrunning, piracy and slaving. ${ }^{132}$ Indeed, a later letter from the Resident to the government made his position quite clear, warning of the danger of granting pearling concessions to Britain's rivals and forbidding the use of any modern technology in what should remain a 'traditional activity'. ${ }^{133}$ Thus when this policy was eventually formalised in 1905 the following statement was issued:

"Within the three mile limit, and in any other water which might justly be considered territorial, the tribes of the Arabian Coast were entitled to the exclusive use of the pearl fisheries. As regards pearl banks outside territorial waters it was held that, as a matter of international law, such banks were capable of being the property of the tribes to the exclusion of all nations. "134

Moreover, in 1914 this decision was reinforced by a new agreement which prevented the rulers from giving any concessions for pearling or sponge fishing without first consulting the British Political Resident. ${ }^{135}$ Given that permission for such concessions was never granted, ${ }^{136}$ the Gulf had therefore been transformed into a 'British lake' under the total control of Bombay and effectively sealed off from all other economies. Significantly, this protection, by inhibiting domestic and externally assisted development and by restricting access to other markets, can be seen as having limited 
the opportunities of the aforementioned indigenous merchant class and thereby further strengthening the already peripheralised nature of the region's economy.

As the century progressed, this economic dependency on Britain and India continued to increase with many of the rulers beginning to receive and rely upon generous income from Imperial air landing rights. During the late 1920s refuelling facilities were required for military aircraft en route from Britain to India, and Sharjah was deemed an excellent refuelling point. An agreement with the ruler was duly signed, dictating that he would host a British airbase and in return would receive a personal income of 500 rupees per month and a further 5 rupees for every aircraft that landed in Sharjah. ${ }^{137}$ In 1932 another agreement was reached in which Sharjah would provide similar civilian landing facilities for Imperial Airways aircraft, ${ }^{138}$ also in exchange for generous remuneration. ${ }^{139}$ These air concessions were not restricted to Sharjah, and similar agreements were signed in 1937 with the ruler of Dubai allowing Imperial Airways to land flying boats on the Dubai Creek. ${ }^{140}$ Even Kalbā, a small town on the Indian Ocean coast, was temporarily granted independence from Sharjah and declared to be a Trucial State in its own right precisely so it could be used as a landing facility. ${ }^{141}$

Oil, or rather oil exploration concessions added another layer of dependence and of course another source of income for the rulers. In 1922, in a further example of increasing British protection and control over the region's foreign relations, all of the rulers undertook not to consider any oil concessions which were not supported by the British government. In other words the rulers were made to refuse any offers from the rival American oil companies which had already begun prospecting in other parts of Arabia. At this early stage there was no firm proof of oil in the lower Gulf, but given that Britain had already imposed similar agreements on the rulers of Kuwait and Bahrain, it seemed practical to lock the Trucial States into the same system. As such, in 1935 the London-based Iraqi Petroleum Company (IPC) formed a wholly owned subsidiary, Petroleum Concessions Ltd., which was to be the sole operator of concessions in the lower Gulf. ${ }^{142}$ Unsurprisingly the Political Resident soon issued an ultimatum binding the Trucial rulers to deal only with Petroleum Concessions. As Peck 
notes, this ultimatum, in much the same way as the 1922 agreement, should not necessarily be seen as a reflection of British interest in the discovery of oil deposits in the region (given that Britain already had a great supply at that time), but instead as an expression of the continuing British desire to exclude other foreign parties from the economic and political affairs of the Trucial States: "the oil agreements might thus be seen as symbolising the considerable degree of isolation that British protection imposed on the Trucial States." ${ }^{143}$ Crucially, these concessions also provided another high stream of income for the rulers, which, in some cases, even dwarfed the generous air landing fees. Indeed, the Dubai concession (signed in 1938) provides such an example as the ruler was to be given 60,000 rupees on signing; a substantial annual income of 30,000 rupees, and then the oil company would pay 200,000 rupees upon the discovery of any oil. ${ }^{144}$ See figure (iii).

In addition to increasing the rulers' dependency on Britain as a source of easy non-earned income, the very nature of this new wealth must also be seen as an important historical antecedent of more contemporary structures. Although this subject will be discussed in greater depth in the following chapter, ${ }^{145}$ it is nevertheless significant to note how much of the lower Gulf's pre-oil wealth was also derived from 'economic rent' (Economic rent being the difference between the return made by a factor of production and the return necessary to keep the factor in its current occupation $^{146}$ ). Indeed, upon closer inspection, it would appear that the region has experienced a long history of such 'rentier wealth', with some of the aforementioned activities such as the booty from Bedu raids and the issuing of fishing licences, ${ }^{147}$ together with examples of income from guano collecting concessions ${ }^{148}$ and red oxide mining authorisations ${ }^{149}$ all providing early indications of rent-gathering. With the generous air landing fees and oil exploration concessions this rentier wealth was, however, raised to a new level. Significantly, although now enormous, these payments continued to accrue directly to the ruler, with the bulk of the population remaining uninvolved in the wealth creation process. Indeed, Shaykh Sa'id Al-Maktūm, the ruler of Dubai at that time, believed, as did the other rulers receiving such vast incomes from concessions, that these guaranteed annual rents were to be his personal profit. ${ }^{150}$ 


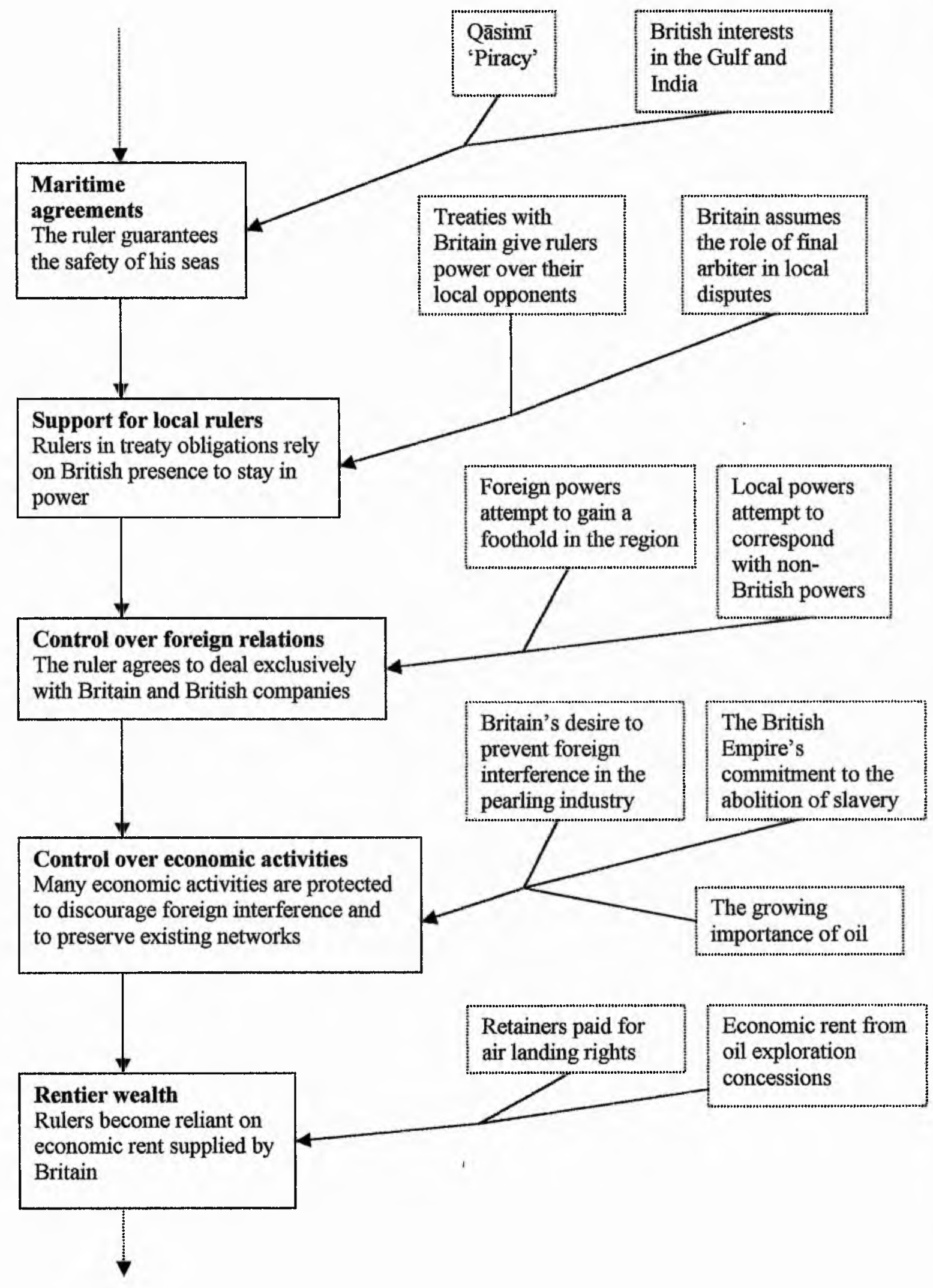


Consequently, the previously described power balance between the wealthy indigenous merchant class and the rulers began to shift, especially as the newly rich Shaykhs were able to reduce their reliance on taxation and instead distribute wealth to their people. As such, many of the traditional extractive institutions fell into decline and, eventually, a new 'rentier' relationship was born between the rulers and their populations, a relationship which is still in evidence today. See figure (iv).

\subsection{3 - Local resistance and the suppression of the Dubai reform movement}

Given that the early oil exploration concessions were all land-based, the IPC needed Britain to provide a more extensive security umbrella across the region, providing a secure environment for its personnel and better protection for the Company's interests. These concerns, together with the rise of Ibn Saud and the perceived threat to British airbases from resurgent Wahhabism, ${ }^{151}$ led to fresh calls for a greater British commitment to the region's internal stability. Quite simply the stakes were now higher than before. Although creating a full-blown protectorate was still deemed unnecessary, ${ }^{152}$ many in the British Indian government, including the Political Resident of the Gulf, argued that these new circumstances required Britain to assume greater responsibilities in the Trucial States: to ensure more directly the orderly succession from shaykh to shaykh, to maintain the shaykhs' individual powers, and to protect the Trucial States by land as well as sea. Thus, in light of these recommendations, together with Air Staff memoranda along similar lines, the British Prime Minister and the Foreign Secretary responded by setting up the Persian Gulf subcommittee of the Committee of Imperial Defence. ${ }^{153}$

The sub-committee's role was clarified when, in 1934, it was decided that for the first time Britain should openly intervene in a local struggle. As described earlier in this chapter, Dubai had emerged as one of the region's main ports and by this stage had become a key distribution point for the oil companies. Thus, when the ruler narrowly escaped an assassination attempt by two of his cousins, Britain immediately responded in an effort to secure the city. British armaments were overtly delivered to the surviving 


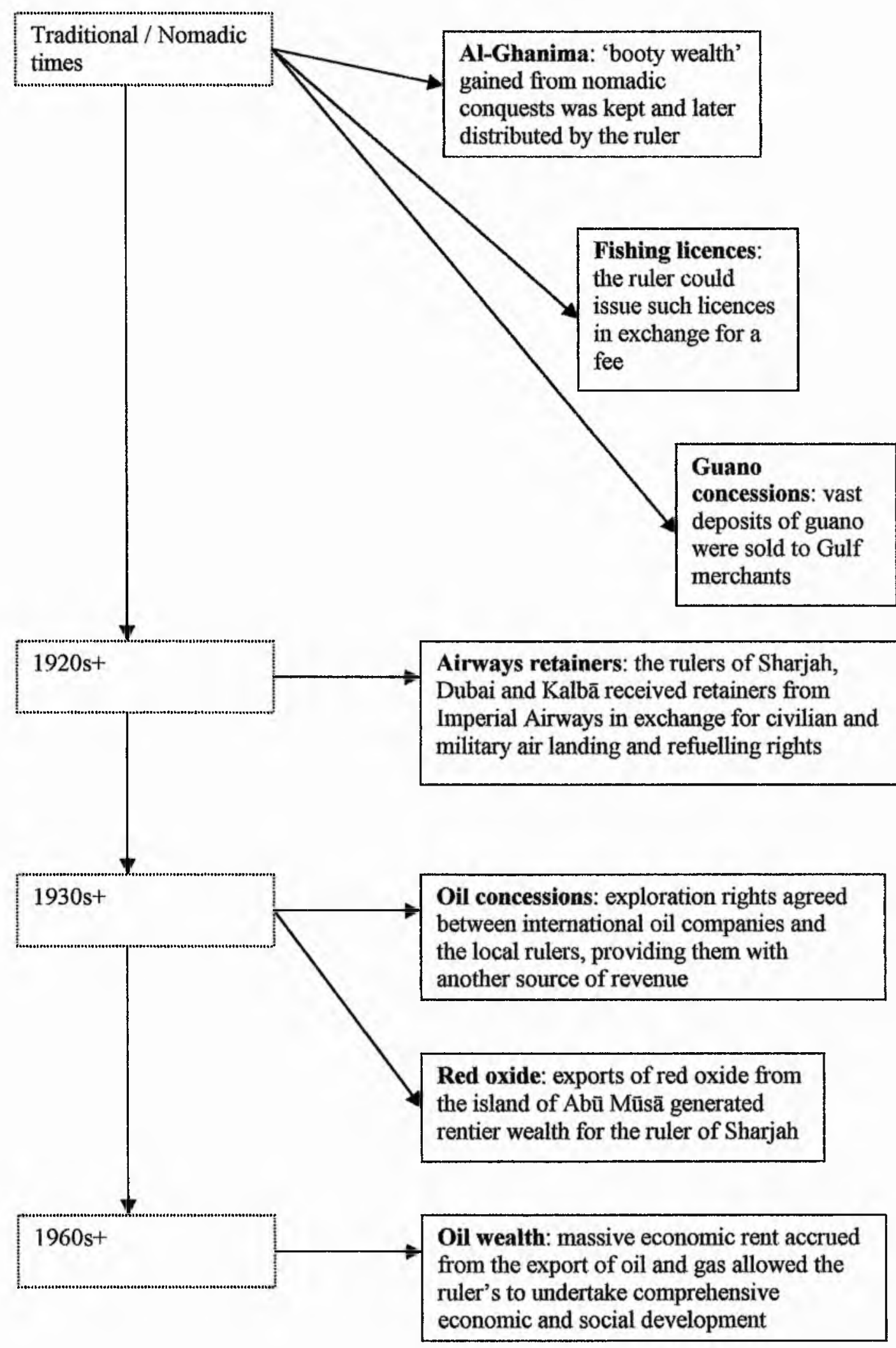


Shaykh Sai'd Al-Maktūm. Moreover a British message of support for the Āl-Maktūm was circulated throughout Dubai and backed up by Iraqi-based British aircraft which flew over the town several times. Following this armed response, the Shaykh's cousins immediately relinquished their claims. ${ }^{154}$

Even more significant than this succession dispute and Britain's early show of force were, however, the events surrounding the Dubai reform movement of 1938 , especially with regard to the reinforcement of the local rulers' client status and the continuing isolation and peripheralisation of the lower Gulfs economy. In much the same way as Ismael's example of the Kuwait commercial class which had tried to reestablish trading links with other parts of Arabia during the inter-war period, ${ }^{155}$ and the Bahraini merchants who had begun to demonstrate during at this time, ${ }^{156}$ Dubai's merchants also attempted to re-adjust existing structures by imposing reforms on their ruler. Essentially, faced with economic decline and marginalisation following the collapse of the pearling industry, they were trying to revitalise the lower Gulf's autonomous development but, as with the other Gulf merchant communities, their movement was suppressed by a ruler who had the clear support of the British.

Indeed, given that the decline in pearling was concurrent with the described rise in the rulers' rentier income; the increasing disparity prompted many of the merchants to request the rulers to share their wealth and to allow much more of it to be managed by the community in the interests of improving social conditions and boosting indigenous development. ${ }^{157}$ Crucially, however, unlike previous rulership contests, Dubai's merchants did not necessarily intend to depose their ruler. Instead the merchants and other notables decided to set up a new consultative majlis in which the ruler would be recognised as the president of a fifteen member chamber, but in exchange would have to share seven-eighths of Dubai's total revenue. The shared revenue was to be spent in the name of the state and only with the prior approval of the members of the new majlis. Although the merchants' majlis operated for only a very brief period, Heard-Bey nevertheless shows from the correspondence and minutes of their meetings how it is clear that they were not only concerned with practical economic 
reforms, but also intended to bring about key changes in the political and social structures. ${ }^{158}$ Indeed, the majlis quickly established a number of important institutions including a municipal council, in addition to planning for a social security system for the elderly, and electing new customs officials to be employed by the state, not the ruler. $^{159}$ Moreover, Abdullah highlights the movement's considerable financial contribution to Dubai's education system and its concerted efforts to re-open Dubai's schools. Indeed, the majlis established an education department, appointed a DirectorGeneral for Dubai schools, and, as noted in the majlis' documents, they even managed to recruit the majority of teachers from the local population (many of whom were older Dubai men who had been educated when schools had flourished during the pearling boom). ${ }^{160}$

Thus, in light of these efforts and their many other innovations and recommendations the majlis believed that their presence was welcomed by all of Dubai, and also felt that

"...their mandate carried a responsibility towards all groups and communities within the state, and that to reform certain aspects of government improved the lot of the common man and was therefore a national duty."

The ruler and those loyal to his regime were, however, far from defeated, and when in 1939 the majlis decided to add even more limitations to the ruler's income by allowing him to retain just 10,000 rupees of the state's revenue for his personal use, the ruler was forced to resort to military means. The majlis responded by blocking all access to Deira (the merchant-controlled northern half of the town) from Shaykh Sai'd's armed men in Bur Dubai, but a plan was drawn up when, in an apparent peace-offering, the ruler's younger brother Rāshid decided to marry a Deira inhabitant. The merchants made the mistake of relaxing their control to allow Rāshid's men to cross the creek to participate in a gun salute at the wedding. ${ }^{162}$ Thus, when this loyal contingent of Bedu was unleashed, the majlis and their members were attacked and quickly dispersed, thereby 
allowing Shaykh Sa'id to regain control over Dubai. ${ }^{163}$ Crucially, this collapse of the majlis would, in any event, have been inevitable given Britain's continuing support for the Āl-Maktūm. Given that Shaykh Sa'id and the other Trucial rulers remained the preferred clients of the Bombay government, the prospect of any potentially autonomous reform movement was unacceptable to British interests. ${ }^{164}$ Certainly, although the British publicly viewed the merchants' majlis and their reform attempts with indifference, British misgivings over the movement were nevertheless clearly in evidence. Indeed, in a revealing effort to bolster indigenous support for the beleaguered ruler following the dispersal of the movement, the British Political Resident's statement erroneously claimed that the majlis had collapsed due to mismanagement and a lack of popular support:

"Recently there has been democratic movement in the State of Dubai which is in special treaty relations with His Majesty's Government. This was an internal matter and HMG however advised the Shaykh to associate his people with himself in his government according to immemorial Arab custom by formation of a Council. The Shaykh did not take this advice and a Council was forced on him by the people which owing to maladministration later grew unpopular. At the end of March Shaykh Sai'd with his supporters dissolved the Council... "i65

Finally, despite the movement's collapse, it must also be noted how many of its actions and suggestions were not without some long-term achievenent, with many of them forming the blueprints for later initiatives undertaken by the rulers themselves. Indeed, in the 1940s and 1950s Shaykh Sa'id and his new 'Majlis al-tujjär' attempted to rejuvenate many of the merchants' planned improvements in an effort to boost the emirate's commercial prosperity. ${ }^{166}$ Furthermore, upon his succession in 1958, one of Shaykh Răshid's very first acts was to re-establish the Dubai Municipal Council, despite championing his brother's cause against it just twenty years previously. The Municipal Council, when founded, appointed councillors to represent different sections of the community for periods of two years. It was empowered to make the necessary orders 
for the administration of the town and to administer Dubai's first official development plans, all of which were commissioned by the ruler and prepared by British experts. ${ }^{167}$ The key difference between this council and the merchants' majlis was of course that it had to subject all of its decisions to the ruler's confirmation and had to seek its financial support from the ruler's office. Thus, the rulers of Dubai chose to reform only when they had complete control and the approval of British advisers, and when the previously powerful merchant elites had completely lost their ability to operate autonomously of the core-periphery relationship.

\subsection{4 - Britain and the path to Federation}

Shortly after the suppression of the merchants' movement another important step took place when, in 1940, Britain decided to land troops in the region for the first time since the 1820 landings in order to enforce peace attempts between the squabbling emirates of Dubai and Sharjah. As before, a visible and direct response was effective with the conflict soon subsiding and the security of the British airbases being maintained. ${ }^{168}$ The most extensive British intervention did not, however, take place until the 1950s. As described in the earlier discussion of the traditional political structure, the Buraimi Oasis and its surrounding villages had been a bone of contention between many of the local powers for hundreds of years, and once again the dispute had come to the fore, but this time becoming international news. Increasing friction between Britain and the United States had manifested itself in a major struggle between their respective oil companies. Thus, when ARAMCO, the American concession holder for Saudi Arabia, pressed its host country to stake a fresh claim on the area, conflict was inevitable. The aforementioned zakāt tax was used as a lever in the struggle and ARAMCO devoted all of its scholarly resources to proving the legitimacy of the Saudis' claim. ${ }^{169}$ In 1952, when a Saudi force was finally sent to secure the area, Britain responded by backing an armed Omani contingent and demanding the surrender of the ARAMCO / Saudi troops. This British force temporarily secured the area but, as a side note, this dispute was so difficult to resolve that it lingered on until 1974 when Shaykh Zāyid, the president of the UAE, reportedly had to offer Saudi Arabia the Zarāra oil 
fields and a strategic corridor of land to the Gulf in exchange for Saudi recognition of UAE sovereignty. ${ }^{170}$ Even then, this agreement remained informal until $1992 .{ }^{171}$

The severity of the Buraimi crisis therefore highlighted the need for the region's improved collective security, as the British had little desire to make repeated and expensive deployments. As such, believing that greater regional unity would better guarantee such security, by the mid-1950s Btitain began to become more directly involved in the region's institutional development. Thus, in addition to providing limited military support as and when required, Britain also started setting up a Trucial States Council with the aim of bringing the various Trucial rulers together in much the same way as the contemporary Supreme Council of Rulers. Although this early council was merely an advisory body and had no formal constitution, it nevertheless did engender some sense of unity between the previously disparate shaykhdoms and, as all decisions that were reached had to be implemented by the rulers themselves, ${ }^{172}$ it provided valuable experience for those involved. The British Political Agent in Sharjah presided over the Council up until 1965 when it was decided that the chairmanship should be rotated among the seven rulers, and that the task of examining and preparing proposals for the Council should be given to a Deliberative Committee comprising two delegates from each emirate. ${ }^{173}$

Even so, the British Agent still remained involved in the Council's affairs and sat in on all of its subsequent meetings. He also remained active in trying to put forward Britain's views on what should be the region's key development priorities. ${ }^{174}$ Indeed, as Heard-Bey describes, the Agent or his deputy continued to preside over many board meetings ranging from hospitals to trade schools, and over many other committees engaged in local development projects. ${ }^{175}$ The representatives of the British oil companies were also involved, and it became increasingly common for them to sit, with their Arabic interpreters, at the rulers' majālis and discuss matters of mutual interest such as local employment, training, and healthcare. ${ }^{176}$ Initially the budget for the Council was provided from a British administered Trucial States Development Fund which, as an earlier version of the federal budget, allowed for a Trucial States 
Development Office to assume responsibility for the implementation of various regionwide five year plans. ${ }^{177}$ Initially, Britain's contributions formed the bulk of the budget, but as the region's oil revenues began to increase, so too did the indigenous contributions, and by the time the office was transferred to a federal ministry Abu Dhabi was already contributing several million pounds per annum and over $70 \%$ of the total fund. ${ }^{178}$ However, as the remainder of the chapter will reveal, this greater financial independence in no way reduced the rulers' reliance on British tutelage and support.

As Britain had anticipated, the Council's first priority was to secure the hinterland and to allow for safe transport and communications between the shaykhdoms without the fear of raiders. To this end the Trucial Oman Levies (renamed the Trucial Oman Scouts in 1956) were formed as a British-officered standing army and were placed under the command of the Political Resident in Bahrain. As the first visible reflection of Britain's greater institutional involvement, the force was regarded as a great success given its important role in policing the Buraimī area, in mopping up the remnants of the slave trade, and in assisting the oil companies in their exploration of the desert. ${ }^{179}$ Indeed, with a more secure environment and a greater degree of regional cooperation, the Levies provided the necessary foundations for the Council to press ahead with its other objectives. Indeed, by the mid-1960s, many other institutions had already been established, and many other services were being provided under the auspices of the Development Office. Among others, these included:

- The provision of agricultural services ${ }^{180}$ See appendix (i).

- The operation of trade and technical schools in Sharjah and Dubai

- Offering scholarships abroad for talented subjects of the Trucial States

- Offering courses of instruction for Trucial States Council administrative staff

- Offering health services (centred in Dubai's Āl-Maktūm Hospital), in addition to providing a touring doctor service, several rural clinics and another hospital in Ra's al-Khaimah.

- Creating a department to survey and develop the fisheries resources 
- Creating a public works department to execute the capital works programme with overall responsibility for the development of water resources, buildings, road maintenance, and the supervision of public utilities. ${ }^{181}$

Moreover, in addition to the Development Office's efforts it is also worth noting that considerable aid and assistance began to flow into the region from some of the other British-backed Gulf States. By far the most significant of these benefactors was Kuwait, which, after attaining formal independence in 1961, chose to establish a Gulf Permanent Assistance Committee (GUPAC) to recommend and administer economic aid to the less developed areas of the Gulf. Soon after, a GUPAC office was set up in Dubai to co-ordinate Kuwaiti aid to the Trucial States, the bulk of which was concentrated in the education sector. Kuwait financed the salaries of most of the expatriate teachers, helped to train up local teachers, helped to construct schools, and contributed to the Development Office's overseas scholarships. On a smaller, but still notable scale, Qatar and Bahrain also contributed, not only to the Development Fund but also by assisting in the construction of highways and the provision of fresh water supplies. $^{182}$

However, despite these British and British-Gulf administered developments, many believed that London's long-term post-war retrenchment would soon lead to a British withdrawal from the region, and that the Trucial States were still inadequately prepared for such an eventuality. ${ }^{183}$ Without more improvements, new institutions, and new legislation, it was thought unlikely that the regional administration would be able to function smoothly and, given the ambitions of neighbouring Saudi Arabia and nearby Iran, it was feared that that the area would quickly be absorbed by a foreign power. As such, the mid-1960s witnessed even more rapid development, especially in the coordination of actions between the various Trucial States, with many of what were soon to become the UAE's federal institutions being set up. The announcement, however, came sooner than expected when in 1967 a Westminster white paper was published calling for the termination of Britain's bases east of Suez and a proposed withdrawal by 1971. Although there was a brief period of uncertainty following a surprise 
Conservative election victory in $1970,{ }^{184}$ no reversal of the Labour Party's policies took place, and all that happened was a long-drawn out delay before Edward Heath's government finally re-affirmed its predecessor's original departure date. ${ }^{185}$

The local reaction, at least from the ruling elite, was one of intense disappointment, as many felt that much of the recent development work would stall or be undone without further British support. Similarly, those Britons working in the Gulf believed that the couple of million pounds that London spent maintaining British forces and the administration in the Trucial States was a more than worthwhile insurance for the $£ 2$ billion in annual revenues from the oil companies operating there. ${ }^{186}$ Indeed, it is believed that Shaykh Zãyid Al-Nuhayyañn and the rulers of the other oil producing sheikdoms were so reluctant to lose British protection that they even offered to pay towards maintaining an Imperial presence in the lower Gulf. As a report to the British Cabinet described:

"... he [Z̄āyid] would be happy to contribute the funds himself from his oil revenues to secure the continuance of the benefits he and his fellow mlers derived from the British presence in the Gulf. His neighbour, Shaykh Rāshid of Dubai, made a like proposal a fortnight later. The four oilproducing Shaykhdoms under British protection - Dubai, Abu Dhabi, Bahrain and Qatar - would be perfectly willing, Räshid said, to meet, in proportion to their respective means, the anmual cost of retaining the British forces in the Gulf. "187

This willingness, more than anything else, points to the closeness of the relationship that Britain had built with her clients by the eve of the withdrawal. New wealth was on the horizon and without British support the rulers were actually disinclined to accept their 'independence'. 


\section{5 - The federation of Emirates}

Although scaling back her military presence in the Gulf in the late 1960s, Britain did, however, remain closely involved in the region. Besides continuing to help create many of the institutions which any new independent state would need to inherit, British advisers also continued to encourage plans for even greater unity and for some kind of federal framework of collective security between the various shaykhdoms. ${ }^{188}$ Indeed, as Fenelon contends, the British had long been aware of the possibility of such a union given that the Political Residency in Bahrain had been imposing some degree of uniformity on the seven 'emirates' for over a century. ${ }^{189}$ Furthermore, as Hawley explains, the British were also conscious of the historical effectiveness of inter-emirate co-operation, with the Residency having recorded examples of successful meetings between the Trucial shaykhs as far back as $1905 .{ }^{190}$ More significantly, in the 1930s there had also been a British-forwarded proposal for a ten-member association comprising of Bahrain, Qatar, Kuwait and the Trucial States. Among other things this had called for:

- The establishment of a council in which each emirate would field a representative

- The establishment of an assembly to propose regulations and ratify draft legislation

- The unification of the judiciary and legislative systems

- The creation of a common nationality, with the abolition of the necessity of passports for travel between the member emirates

- The establishment of a unified education system, with a central administrative headquarters in Bahrain

- The creation of a unified postal service ${ }^{191}$

Although the outbreak of the Second World War had temporarily distracted Britain from the Gulf and little further energy was given to implementing the proposal, its contents nevertheless became widely known throughout the region, with the subject 
sparking much discussion in educated circles, especially from the Manama-based magazine, 'Al-Bahrain', ${ }^{192}$ and with many of the proposal's elements later being incorporated into the institutions of the 1950s and 1960s.

Thus, many administrators, both British and Arab, viewed federation as a natural progression for the region, especially as the Trucial States Council and the Development Office had already allowed the rulers to perform jointly many of the functions which had previously been Britain's responsibility. ${ }^{193}$ Certainly, as a former Political Agent in Dubai has noted, while it still remained Britain's policy to protect the Trucial States right up until her departure, in these final years Britain did, however, become far more open to granting the rulers freedom to make collective decisions of their own. ${ }^{194}$ In fact, by this stage Britain was actively encouraging the rulers to gain as much administrative experience as possible, even in the previously restricted field of foreign relations. As such, the rulers were invited to attend international conferences, were allowed to create foreign trade offices in their towns, and were even allowed to participate in a number of the Arab League's committees. ${ }^{195}$ Moreover, during this curious period of transition between British rule and full independence, Abu Dhabi was also permitted to join the Organisation of Petroleum Exporting Countries (OPEC); the first of the Trucial States to do so, and in 1968 Shaykh Zâyid Al-Nuhayyān was even allowed to visit Jordan and establish relations with the Palestinian leader, Yasser Arafat, on behalf of Abu Dhabi and the other Trucial States. ${ }^{196}$

The first clear step towards a federation came in 1968 when Shaykh Zãyid met with Shaykh Rāshid Al-Maktūm, the ruler of Dubai, and formally agreed to merge the two emirates into a union capable of jointly conducting foreign affairs, defence, security, social services, and a common immigration policy. Shortly afterwards, with the added support of the British, the rulers of the five other Trucial States in addition to the rulers of Bahrain and Qatar met together in Dubai. These nine rulers held a constitutional conference to discuss the future of their states. The initial plan, as proposed by Qatar, called for the amalgamation of the five smallest Trucial States (Sharjah, Ra's al-Khaimah, 'Ajman, Fujairah and Umm al-Qawain), which was to be 
known as the 'United Arab Coastal Emirates'. This union would allow these emirates to be considered as one state, thereby guaranteeing them a collective voice and easing future federal negotiations with the larger emirates of Abu Dhabi, Dubai, Bahrain and Qatar. ${ }^{197}$ Later that same year, a second meeting was convened, this time in Abu Dhabi, where once again the nine rulers and their advisers met to discuss the region's postBritish future. Most importantly, all were agreed on the pressing need for some kind of federation, but already, even at this stage, deep divides were beginning to emerge over the exact nature of the association. Bahrain and $\mathrm{Ra}$ 's al-Khaimah demanded a popular referendum to decide upon the presidency, and some even saw the federation as being a vehicle for evolving towards democratic representation. The most important division, however, was the one emerging between the two principal Trucial States of Abu Dhabi and Dubai. Dubai wished for a president and a capital city to be decided upon as soon as possible whereas Abu Dhabi and some of the smaller emirates advocated proceeding more slowly to allow everyone to adjust to the new situation. ${ }^{198}$

Nevertheless, despite these disagreements the meetings continued, and in 1969 a conference was held in which Shaykh Zāyid was to be elected as president of the new federation, with Shaykh Rāshid as his vice-president, and with Shaykh Khalifa bin Hamad (the deputy ruler of Qatar) serving as the first prime minister. It was also hoped that the growing city of Abu Dhabi would be accepted as the federation's temporary capital until a new, permanent capital city could be built along the border of Abu Dhabi and Dubai. The name of the proposed site was the Wādī al-Mawt or 'Valley of Death', not exactly an encouraging omen, and for a multitude of reasons and differences of opinion the conference collapsed and the nine shaykhs never again met as a council. ${ }^{199}$ By this stage, Abu Dhabi and Dubai had to come to terms with the fact that any proposed federation would be smaller than originally anticipated, as it was becoming increasingly unlikely that the wishes of Bahrain and Qatar could be fully accommodated. One factor was Bahrain's determination that the federation's parliament or council needed to be based on a system of proportional representation, but given that Bahrain possessed the largest population, this was strongly rejected by the less populous Trucial States. Later, Bahrain did briefly agree to a system of equal 
representation in which each member state would supply four members, but by 1970 it had renewed its demands for representation based on population size. ${ }^{200}$ Secondly, as the British Ambassador to Bahrain explained, the emirate was also becoming reluctant to join any kind of union that the increasingly wealthy Abu Dhabi may come to dominate. $^{201}$ Another factor was the fear of the reaction of other regional powers to such a federation. In particular, Bahrain did not want to be caught up in Abu Dhabi's continuing dispute with Saudi Arabia (as Saudi Arabia continued to claim nearly fourfifths of Abu Dhabian territory), and equally Abu Dhabi and the other Trucial States did not wish to be involved with Iran, which had laid claim to Bahrain. Duly, for these reasons, Bahrain and Qatar decided to opt for independence, thus reducing the proposed federation to just seven potential members. However, as Zaki Nusseibeh, the Press Secretary to Shaykh Zāyid at that time stated, this withdrawal was of little real concenn to the Trucial States, and in many ways Abu Dhabi began to view Bahrain and Qatar as being the real losers:

\begin{abstract}
"Bahrain was the real loser because she had so much to gain because she is not a wealthy country and by joining she would have shared the UAE's wealth. The sophistication of her people and their educational level would have given Bahrain a natural leadership role in the federation. "202
\end{abstract}

Even so, as the date for British withdrawal drew closer, there was a great feeling of uncertainty, and for many a feeling of negativity given the troubled negotiations, the absence of the two most developed emirates, and the Trucial States' uneasy relations with the other regional powers. Even many of the British were pessimistic, with a number of commentators describing the lack of confidence felt at that time. In 1966 David Holden described a distinguished joumalist of the Middle East as having declared:

"There is no realistic possibility of the present Gulf rulers coming together of their own accord in any political grouping worth mentioning... and the prospects of the British pushing them into doing so are equally weak". ${ }^{203}$ 
Writing later, just a few months before the federation in 1971, Holden also reports it having been said that:

"Whatever happens, the Gulf has already entered a period of flux in which neither existing boundaries nor traditional regimes can be expected to prevail." 204

Even the British Political Resident of the Gulf at that time, Sir Geoffrey Arthur, reflected on the negativity of the period:

"The UAE looked loose and ramshackle, and it was born, so said the facile commentator of the day, under the ill star of British patronage... it [the UAE] has since acquired a host of fair weather friends, but I do not recollect that a single special correspondent of a major western newspaper, let alone a politician or a statesman, took the trouble to attend the ceremony of its formation." 205

Similarly, as Joseph Sisco, the US Undersecretary for Political Affairs announced to Congress in 1975, the USA had also expressed grave doubts about the UAE holding together back in $1971 .^{206}$ Thus, both the old and new superpowers in the Gulf had little confidence in the UAE surviving its infancy; with many believing it would soon succumb to either internal fragmentation or external threats.

The worst fears of many were confirmed when British forces finally left. Iran immediately and forcibly occupied the island of Abū Mūsā belonging to Sharjah, and seized two smaller islands belonging to Ra's al-Khaimah. ${ }^{207}$ Secondly, Saudi Arabia's territorial dispute with Abu Dhabi remained unresolved with the former deciding to withhold diplomatic recognition of the newly independent state. Thirdly, a Marxist-led rebellion was taking place in neighbouring Oman. ${ }^{208}$ Nevertheless, despite this unpleasant cloud of doubt a federation was officially proclaimed on the $2^{\text {nd }}$ December 1971, and the United Arab Emirates came into being with Shaykh Zāyid as its president 
and with Abu Dhabi as its temporary capital. Soon after, a Council of Ministers was formed; a federal government in which each emirate was given a proportionate number of portfolios, ${ }^{209}$ and within a few more days the new state had joined both the Arab League and the United Nations as a full member. As was expected, the transition was not entirely smooth given that certain institutions did not yet exist to take over all of the responsibilities previously fulfilled by the British; also the Trucial Oman Scouts required a new command structure and the judicial system still relied on British arbitration, but after a series of federal laws and with some further help from the British, the takeover was finally complete. ${ }^{210}$

There was, however, one internal security flaw which remained unresolved, and that was the absence of Ra's al-Khaimah from the federation. In much the same way as the early disputes between Abu Dhabi and Dubai, Ra's al-Khaimah's early stance is also worthy of attention as its relative independence also had an effect on the later evolution of federal politics. The emirate had initially refused to join given that it was not accorded equal status with the other larger emirates of Abu Dhabi, Dubai, Bahrain and Qatar. Indeed, as this chapter has shown, Ra's al-Khaimal had enjoyed a long history of regional dominance, at one point being the main stronghold of the Qãsimi traders, and as such felt that its proud past should have been better taken into account. ${ }^{211}$ Secondly, the emirate had strong hopes for oil strikes of its own, which, if wellfounded, would have transformed the emirate's economy and would have given it a far better bargaining position. Thirdly, the emirate refused to sign an agreement with Iran over its two occupied islands in the same way that Sharjah had negotiated with Iran over the loss of $A b \bar{u}$ Mūsā. Eventually, a year later, Ra's al-Khaimah was persuaded to join the UAE, but only after the other emirates first agreed to a number of conditions. They had to adopt the question of Iranian occupation as the main thrust of their foreign policy objectives, Ra's al-Khaimah was to receive generous federal aid for its development projects, and the emirate was to receive the same number of seats in the government as Sharjah. $^{212}$ 
Lastly, as another important product of these early federal negotiations, it is also worth noting the rulers' careful creation of a provisional federal constitution. Although the main body of the constitution was nothing remarkable, what did make it unusual was the large number of emirate-specific clauses, including those articles which permitted the individual emirates to retain control over their own oil revenues and local political institutions. Many of these were the result of long and complex debates, and were seen as necessary if a balanced compromise was to be reached. Indeed, as HeardBey noted:

\footnotetext{
"The realities of political life in the UAE did not encourage rapid unification in every aspect, and this helped to maintain the integrity of the various local systems. It was eventually realised that these systems still had a very valuable role to play because of their immediate proximity to the citizen." 213
}

This attitude may explain why the constitution remained temporary for so long (until 1996) and is also perhaps one of the reasons behind the federation's initial stability. Indeed, as Ali Muhammad Khalifa has indicated, the intention to preserve certain existing laws and traditional institutions may well have eased the transition and kept the channels of access open to the people, thus allowing a more gradual shift of power between local and central administration. ${ }^{214}$ Certainly, as will be explained in greater detail in the study of federal and emirate level politics later in this thesis, ${ }^{215}$ a more rigid and uncompromising constitution at this early stage would have probably unravelled within a few years with each emirate seeking to reassert its independence and quickly falling back on more parochial forms of government. ${ }^{216}$

\section{6 - Conclusion}

As the first section of this chapter described, in many ways the lower Gulf was doomed to a future of peripheralisation given the region's scant geographical resources and the local economy's early reliance on both foreign labour and the export of a single 
primary product. Nevertheless, despite these conditions there were important signs of indigenous sociomeconomic development. Indeed, with the pearling booms there began to evolve something of a capitalist mode of production and, significantly, a domestic merchant / entrepreneurial class began to emerge from the wealthier strata of the old desert hierarchy. Capable of funding local development projects and even checking the power of their rulers, these merchants were powerfill players in lucrative economic networks stretching from South Asia to East Africa. Moreover, alongside these formations there also existed remarkably flexible and relatively de-centralised political structures which allowed for direct channels of access to the rulers and highly effective systems of mobile and consultative democracy. Crucially these traditional polities were also comparatively strong given that they possessed efficient extractive institutions which were capable of both collecting taxes and financing a range of rudimentary government services.

Working within a dependency framework, the chapter demonstrated how this inherited situation was fundamentally altered as the lower Gulf's increasing contact with the core economy and Imperial power of Britain led to the elimination of certain traditional structures and the reinforcement of others. In particular, it was shown how Britain's initial conflict with the Qawāsim traders of Ra's al-Khaimah not only secured the British East India Company's trade routes but also displaced a major indigenous economic network and, through a system of maritime treaties, effectively transformed the remaining local rulers into a British client elite. Indeed, by guaranteeing lasting peace in exchange for recognition of their sovereignty, these externally strengthened Trucial rulers, many of whom would have otherwise held only precarious control over their rivals, effectively formalised their dependence on British support and thereby brought to an end the fluidity of the traditional tribal political structure. Moreover, as the region's strategic worth and the value of its resources increased, these clients were gradually persuaded by a combination of economic benefits and the implicit threat of renewed conflict to allow almost total British control over their foreign affairs and their local industries. Thus, by excluding all forms of outside intervention, Britain had for all intents and purposes turned the Gulf into a 'British lake' isolated from other economic 
Figure (v), "The United Arab Emirates: a historical background"

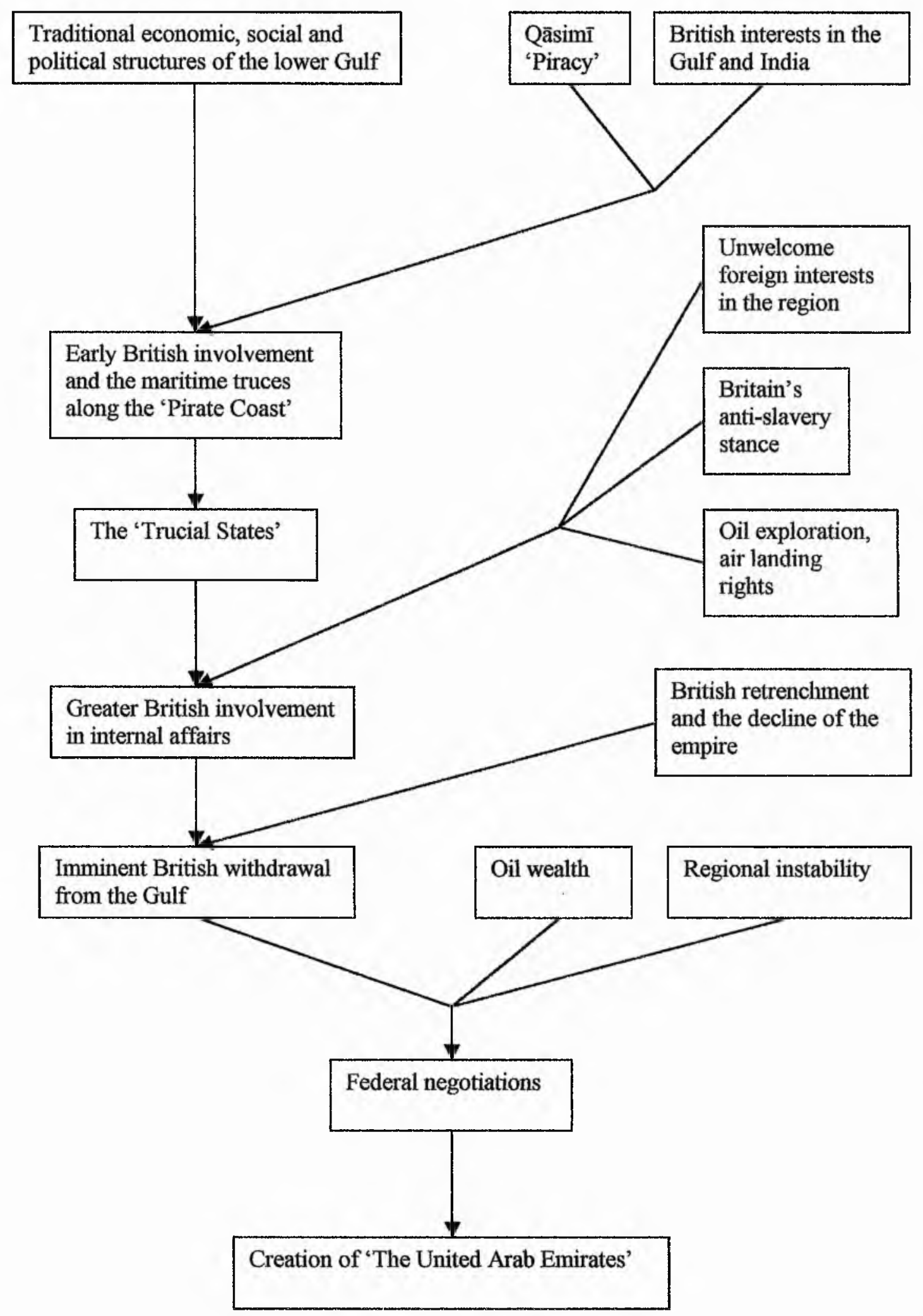


and political powers. Certainly, without such control and the detachment of the lower Gulf from the wider region it is highly likely that the Trucial States would have either fallen under French influence, or would have been absorbed into a Persian, Ottoman, or other indigenous economic bloc.

By the 1920 s the dependency and responsiveness of these clients to their core patron was further reinforced as the rulers began to receive substantial and often personal incomes from British air companies and British oil exploration firms. Although, as demonstrated, the lower Gulf has experienced a long history of rentgathering, these new sources of unearned rentier wealth were on a much greater scale and can be seen to have laid the foundations for many of the region's contemporary structures long before the first oil exports. Indeed, with access to such revenues the rulers were not only able to discontinue most of the existing extractive institutions and instead distribute wealth to their populations, but were also able to shift the traditional ruler-merchant balance of power. Certainly, with the rulers no longer reliant on their merchants for taxation, they were able to assume a new degree of autonomy over their people and, although there were attempts to reinvigorate indigenous development and share the rentier wealth (most notably the Dubai reform movement), these were easily suppressed by the British-backed clients.

Finally, even as the Empire began to withdraw in the late 1960s, the British went to great lengths to ensure the survival of their former clients and their future oil suppliers by helping to build up region-wide institutions such as the Trucial States Council and the Trucial States Development Office. Indeed, by encouraging greater regional unity and a federal framework it was hoped that the newly independent state could be guaranteed at least some measure of security from nearby powers and the threat of internal fragmentation. Significantly, many of the region's existing local systems and preferences, such as the emphasis on consultation and the direct channels of communication, were incorporated alongside these seemingly more central institutions, and as such the new state was able to ensure a relatively smooth transition without any significant break with the past. Thus, through careful negotiation and 
compromise the federation was able to steer its way through the initial complications, and in its early years, against the expectations of many, became one of the most stable and successful examples of Arab political union. See figure (v).

${ }^{1}$ FOREIGN OFFICE HISTORICAL SECTION (1920), "Persian Guff', London, HMSO, Issue 76, pp.78, this extract taken from the preamble to the 'General Treaty between Great Britain and the Arab Tribes of the Persian Gulf, $1820^{\circ}$

${ }^{2}$ HAWLEY, Donald (1970), "The Trucial States", London, George Allen \& Unwin, pp. 195

${ }^{3}$ For an account of the lawlessness of the region and the impact of Desert raiding or ghazu, see section 1.4 , also see section 1.4.2 with regard to the division of the booty from such raids

${ }^{4}$ LORIMER, JG (1915), "Gazetteer of the Persian Gulf, Oman and Central Arabia" Volume 1 Historical Part II, Calcutta. Superintendent Government Printing [republished 1970 by Gregg International Publishers], pp.2296 This 'falaj' system (pl. aflä) comprised of subterranean stone tunnels that were designed to bring water down to the level of the towns from the high water tables of the nearby mountains. When the tunnels reached the agricultural gardens they would become surface channels allowing the water to be regulated and re-directed to wherever it was most needed. See appendix (i). s HEARD-BEY, Frauke (1982), "From Trucial States to United Arab Emirates", London, Longman, pp.168-169

'Ibid. pp.171 Indeed, 'Abu Dhabi' translates as 'Father of the white gazelle'.

${ }^{7}$ Ibid. pp. 172

${ }^{8}$ HEARD-BEY (1982), pp.11

${ }^{9}$ FENELON, Kevin (1973), "The United Arab Emirates: An Economic and Social Survey", London, Longman, pp.56

${ }^{10}$ LORIMER (1915), Volume1 Historical Part II, pp.2252

${ }^{11}$ HEARD-BEY (1982), pp. 192-193

${ }^{12}$ Ibid. pp. 195

${ }^{13}$ FENELON (1973), pp.56 and HAWLEY (1970), pp.197, cultured pearls could be acquired at far less expense than the natural pearls of the Gulf

${ }^{14}$ LORIMER (1915), Volume 1 Historical Part II, pp.2220; also see AL-SAYEGH, Fatma (1998), "Merchants' role in a changing society: the case of Dubai, 1900-1990", in MIDDLE EASTERN STUDIES, Volume 34 Number 1, January 1998, pp.89

15 JAML, Abu (1985), "Of Pearls and Pearl Kings", in GULF NEWS, 5 th April 1985

${ }^{16}$ Ibid.

${ }^{17}$ See sections 3.2-3.5

${ }^{18}$ HEARD-BEY (1982), pp.208-209

19 LORIMER (1915), Volume 1 Historical Part II, pp.2227

${ }^{20}$ Ibid. pp. 2228

${ }^{21}$ GRAHAM, GS (1967), "Great Britain in the Indian Ocean, 1810-1850", Oxford, pp. 147; for a discussion of Britain's impact on the region's slave trade see section 1.4.1

${ }^{22}$ GREEN, Timothy (1968), "The World of Gold", London, Michael Joseph, pp. 171; and HAWLEY (1970), pp.205

${ }^{23}$ For a discussion of Dubai's commercial development strategy see section 3.8

${ }^{24}$ HEARD-BEY (1982), pp. 10-11

${ }^{25}$ Personal interviews, Abu Dhabi, March 2001; also see ISMAEL, Jacqueline S (1993), "Kuwait: Dependency and Class in a Rentier State", University Press of Florida, pp.17-18, Ismael provides a similar account of this hierarchy with reference to Kuwait

${ }^{26}$ KHALDÜN, "Abd-ar-Rahman Abu Zayd ibn Muhammad ibn Muhammad ibn (1377), "The

Muqaddimah: An Introduction to History", translated by ROSENTHAL, Franz [republished 1967 by Routledge and Kegan Paul, London], pp.102

${ }^{27}$ Those tribes able to enjoy more fertile conditions in neighbouring Oman were quicker to settle, and as such their communities gradually began to be organised along the lines of village neighbourhoods or in the form of occupational communities, see HEARD-BEY (1982), pp.24

${ }^{28}$ Ibid. pp. $25-26$

${ }^{29}$ Ibid. pp. 173-174

${ }^{30}$ KHALDÜN (1377), pp. 141-142

${ }^{31}$ HEARD-BEY (1982), pp.200, with specific reference to Abu Dhabi 
${ }^{32}$ ABDULLAH, Muhammad Morsy (1978), "The United Arab Emirates: A Modern History", London, Croom Helm, pp.104, This refers to 1884 when Shaykh Saqr bin Khalid al-Qāsimĩ was replaced by Shaykh Salim.

${ }_{33}$ Ibid. pp. 104

${ }^{34}$ HEARD-BEY (1982), pp. $189-190$

${ }^{35}$ LORIMER (1915), Volume 2A Geographical and Statistical, pp.411

${ }^{36}$ ABDULLAH (1978), pp.105

${ }^{37}$ LORIMER (1915), Volume 2B Geographical and Statistical, pp. 1451

${ }^{38}$ With regard to British Indian merchants and British Indian agents (especially in Bahrain), see for example ONLEY, James (2003), "Britain's native agents in Arabia and Persia, 1758-1958", in

COMPARATIVE STUDIES OF SOUTH ASIA, AFRICA AND THE MIDDLE EAST, Volume 33

${ }^{39}$ HEARD-BEY (1982), pp.212-213

${ }^{40}$ Ibid. pp.214-215

${ }^{41}$ AL-SA YEGH (1998), pp.88

42 ABDULLAH (1978), pp. 105

${ }^{43}$ For further information on British Indians during this period see ONLEY, James (2003), "Britain's native agents in Arabia and Persia, 1758-1958", in COMPARATIVE STUDIES OF SOUTH ASIA, AFRICA AND THE MIDDLE EAST, Volume 33; and also ONLEY, James (2003), "The politics of protection in the Gulf: the Arab rulers and the British Resident in the Nineteenth Century", in NEW

ARABIAN STUDIES, Volume 6

${ }^{44}$ FENELON (1973), pp.19

${ }^{45}$ HEARD-BEY (1982), pp. 56-57

${ }^{46}$ Ibid. pp. 80

${ }^{47}$ PECK, Malcolm C (1986), "The United Arab Emirates: A Venture in Unity", Boulder Colorado,

Westview Press, pp. 125

${ }^{48}$ HEARD-BEY, pp. 100

${ }^{49}$ Ibid. pp. 101

${ }^{50}$ Ibid. pp.217

${ }^{51}$ Ibid. pp.179-180

${ }^{52}$ Ibid. pp.124-125

${ }^{53}$ Ibid. pp.85-86

${ }^{54}$ Ibid. pp. 111

${ }^{55}$ Ibid. pp.81

${ }^{56}$ Personal interviews, Sharjah, October 2002

${ }^{57}$ HERB, Michael (1999), "All in the Family: Absolutism, Revolution, and Democracy in the Middle Eastern Monarchies", New York, State University Press, pp.136-137; also see section 2.4

${ }^{58}$ HEARD-BEY (1982), pp. 120-121

${ }^{59}$ LORIMER (1915), Volume 2A Geographical and Statistical, pp. 409

${ }^{60}$ LORIMER (1915), Volume 1 Historical Part II, pp.2284-2287; and HEARD-BEY (1982), pp.113

${ }^{61}$ HEARD-BEY (1982), pp. 114

${ }^{62}$ Ibid. pp. 118-119

${ }^{63}$ Ibid. pp. $115-117$

${ }^{64}$ Ibid. pp. 117

${ }^{65}$ Ibid. pp. 115

${ }^{66}$ For a discussion of patrimonial authority and Weberian groupings see HUDSON, Michael C (1977),

"Arab Politics: the Search for Legitimacy", New Haven, Yale University Press

${ }^{67}$ Tilly argues that the origins of a strong state must lie in its fiscal ability and tax-gathering structures, for a good discussion of Tilly's views see CRYSTAL, Jill (1990,1995), "Oil and Politics in the Gulf:

Rulers and Merchants in Kuwait and Qatar", New York, Cambridge University Press, pp.194; similarly Chaudhry argues that extractive structures are a crucial sign of state strength, see CHAUDHRY, Kiren Aziz (1997), "The price of wealth: economies and institutions in the Middle East", New York, Comell University Press

${ }^{68}$ As described in the earlier discussion of the traditional economic structure, Al-Mashriq (the eastern Arab world) was a major overland trading route, with many of the lower-Gulf's towns and ports serving as distribution points

${ }^{69}$ PECK (1986), pp.27

${ }^{70}$ HEARD-BEY (1982), pp. 282

${ }^{71}$ Qishm being a large island close to the Straits of Hormuz and the present day Iranian port of Bandar 'Abbās

${ }_{72}^{72}$ HEARD-BEY (1982), pp. 280

${ }^{73}$ Ibid. pp. 229-230

${ }^{74}$ HAWLEY (1970), pp.90 
${ }_{75}^{75}$ Ibid. pp. 90

${ }^{76}$ LORIMER (1915), Volume 1 Historical Part 1A, pp.436

${ }^{77}$ PECK (1986), pp.29-30

${ }^{78}$ HAWLEY (1970), pp.96-97

79 BELGRAVE, Charles (1966), "The Pirate Coast", London, G. Bell and Sons, pp.25

${ }^{80}$ PECK (1986), pp.29-30

${ }^{81}$ LORIMER (1915), Volume 1 Historical Part 1A, pp.635-636

82 HAWLEY (1970), pp. 101

${ }^{83}$ LORIMER (1915), Volume 1 Historical Part 1A, pp.634-636, these two attacks took place in the 1790 s, before the Wahhābis arrived in Buraimĩ, indicating an early pre-Wahhābi conflict between the Qawāsim and the British

${ }^{84}$ Ibid. pp. 634

${ }^{85}$ BELGRAVE (1966), pp.29

${ }^{86}$ Ibid. pp. 30

${ }^{87}$ Ibid. pp. 36

${ }^{88}$ Ibid. pp.37

89 Ibid. pp.37

${ }^{90}$ Ibid. pp.135-143, Captain Loch's diaries are held in the Scottish Records Office

${ }^{91}$ Ibid. pp.135-143

${ }^{92}$ Ibid. pp. 192

${ }^{93}$ See AL-QASIMI, Shaykh Sultân bin Muhammad (1986), "The Myth of Arab Piracy in the Gulf", London, Croom Helm

${ }^{94}$ See DAVIES, Charles E (1997), "The Blood Red Arab Flag: an investigation into Qāsim̄̄ piracy", Exeter, University of Exeter Press

${ }^{95}$ See KELLY, John B (1968), "Britain and the Persian Gulf", London; and KELLY, John B (1986), "Arabia, the Gulf and the West: A Critical View of the Arabs and their Oil Policy", New York

${ }^{96}$ AL-QĀSIMİ (1986), introduction xiii-xV

${ }^{97}$ Ibid.

${ }^{98}$ Ibid

${ }^{99}$ Ibid. introduction xvii

${ }^{100}$ Ibid. pp. 231

${ }^{101}$ PECK (1986), pp. 31

${ }^{102}$ HAWLEY (1970), pp.107

${ }^{103}$ Ibid. pp. 126-127

${ }^{104}$ HEARD-BEY (1982), pp. 284-285

${ }^{105}$ LORIMER (1915), Volume 1 Historical Part 1A, pp.673

${ }^{106}$ PECK (1986), pp.32

${ }^{107}$ HEARD-BEY (1982), pp. 286

${ }^{108}$ Personal interviews, Abu Dhabi , March 2001, with reference to the Trucial system and the reliance on British support

${ }^{109}$ PECK (1986), pp.62, Peck argues that the British treaties, as much as any other factor, led to the replacement of the traditional 'dira', the elastic concept of an area in which a tribe exercised sway, with something more akin to a territorially defined modern state

${ }^{110}$ ABDULLAH (1978), pp.90

${ }^{111}$ See PECK (1986), pp.34, Qãsimī power never recovered and continued to decline throughout the nineteenth century. Added to this, $\mathrm{Ra}^{\text {'S }} \mathrm{s}$ al-Khaimah had Jost the port of Lingah (on the Persian coast of the Gulf), and more importantly had lost its greatest patriarch, Shaykh Saqr. Upon Saqr's bequest, what remained of the once great Qåsimi federation was to be partitioned between his sons (with the senior ruling Sharjah, and the others ruling Ra's al-Khaimah, Dibba and Kalbā), thus formalising the geographical split between Ra's al-Khaimah and Sharjah.

112 HEARD-BEY (1982), pp. 290-291

${ }^{113}$ ISMAEL (1993), pp.152

${ }^{114}$ LORIMER (1915), Volume 1 Historical Part 1A, pp.725, Lorimer alleges that the ruler of Sharjah levied a tax on each imported slave during the 1850 s

${ }^{115}$ LORIMER (1915), Volume 1 Historical Part II, pp. 2475

${ }^{116}$ HEARD-BEX (1982), pp.288-289

${ }^{117}$ Ibid. pp.289-290

${ }^{118}$ LORIMER (1915), Volume 1 Historical Part 1A, pp.725

${ }^{119}$ THESIGER, Wilfred (1991), "Arabian Sands", London, Penguin, pp.284. Describing his visit to Buraimi in 1950, Thesiger remarks on the continuing demand for slaves, "At Lahamma Well we found many day-old tracks of men and camels. My companions said that they were made by Ali al-Murri and the caravan of forty-eight slaves which he was taking to Hasa. It seemed that the enormous wealth which 
was pouring into Saudi Arabia from the American oil companies had greatly increased both the demand for slaves and the price paid for them. They said Ali made a large profit not only from the slaves, but also from the camels which he bought in Buraimi." Also see pp. 272 where Thesiger describes the flourishing slave trade practised by Saudi merchants in the two Buraimi villages not controlled by Shaykh Zãyid.

${ }^{120}$ HAWLEY (1970), pp. 136

${ }^{121}$ Ibid. pp.146, referring to Shaykh Saqr's successor

122 ABDULLAH (1978), pp.25

123 HAWLEY (1970), pp.136

${ }^{124}$ ABDULLAH (1978), pp.25

${ }^{125}$ ABDULLAH (1978), pp.38, describing the letter written from the Political Agent in Sharjah to the Political Resident in Bahrain.

${ }^{126}$ (in Arabic) RĀSHID, Ali Muhammad (1989), "Political and Economic Agreements made between the Oman Coast Emirates and Britain (1806-1971)", UAE Writers' Union Publications, pp. 129

${ }^{127}$ KELLY (1968), pp.729

128 ABDULLAF (1978), pp. 24-25

129 AL-NUHAYYĀN, Shaykha Shamma bint Muhammad bin Khalid (2000), "Political and Social Security in the Arabian Gulf region and United Arab Emirates after the Second Gulf War: External and Internal Challenges", Research Centre of Slovak Foreign Policy Association, Studies on International Issues, Volume B05, pp.11; and see RASHID (1989), pp.131-132

${ }^{130}$ LORIMER (1915), Volume 2B Geographical and Statistical, pp.1450-145 1

${ }^{131}$ HEARD-BEY (1982), pp. 187

${ }^{132}$ ABDULLAH (1978), pp.103-104

${ }^{133}$ Ibid. pp. 104

${ }^{134}$ LORIMER (1915), Volume 1 Historical Part II, pp.2248

${ }^{135}$ HAWLEY (1970), pp. 140

${ }^{136}$ Personal interviews, Dubai, March 2001

137 ABDULLAH (1978), pp.56

138 Imperial Airways later became BOAC and is now British Airways. Footage of the first British landings in Sharjah can be seen in the ruler's old fort in Al-Hosn place, Rolla.

${ }^{139}$ ABDULLAH (1978), pp.56

140 FENELON (1973), pp.86

141 HEARD-BEY (1982), pp.298-299

${ }^{142}$ Ibid. pp.295

${ }^{143}$ PECK (1986), pp.37

144 ABDULLAH (1978), pp.70

${ }^{145}$ See section 2.3

${ }^{146}$ BANNOCK, Graham (1992), "The Penguin Dictionary of Economics", London, Penguin, pp. 129

${ }^{147}$ Four-fifths of this booty or 'Al-ghanima' would be divided amongst the tribesmen and one-fifth retained by the leader, Personal interviews, Abu Dhabi, March 2001; also see HITTI, PK (1964), "History of the Arabs" $8^{\text {th }}$ Edition, London, pp.25; and ISMAEL (1993), pp. 19, with reference to Kuwait ${ }^{148}$ HEARD-BEY (1982), pp.175-176, although seemingly an unpleasant and meagre existence, there were considerable guano deposits to be found on many of Abu Dhabi's islands such as Dăs and Dalmā. Indeed, at one time these deposits were believed so lucrative that concessions for their collection were signed between the ruler of Abu Dhabi and prominent merchants from both Dubai and Kuwait ${ }^{149}$ HAWLEY (1970), pp.203, red oxide was mined on the island of Abū Mūsā

${ }^{150}$ HEARD-BEY (1982), pp.253

151 ABDULLAH (1978), pp.41, In 1927 the Political Resident of the Gulf, Colonel Haworth, argued that "The rise of Ibn Saud and the security to which a chain of air stations along the Arab coast might be exposed by internal dissensions and the danger of Saudi interference in the petty shaykhdoms of the Trucial Coast."

${ }^{152}$ Ibid. pp.41-43, The idea of a protectorate was rejected on the grounds that such a move would needlessly antagonise the ruler of Saudi Arabia, Ibn Saud, and indeed the Trucial shaykhs themselves, in addition to overstretching British military resources.

${ }^{153}$ Ibid.

154 Ibid. pp.46-47

155 ISMAEL (1993), pp.152-153

${ }^{156}$ HEARD-BEY (1982), pp.255

${ }^{157}$ ABDULLAH (1978), pp. 126

${ }^{158}$ HEARD-BEY (1982), pp.256

${ }^{159}$ ABDULLAH (1978), pp.131

${ }^{160}$ Ibid. pp. 109 
${ }^{161}$ HEARD-BEY (1982), pp.256, Indeed, as a side note, the movement's sense of national duty can also be seen as a reflection of the changing political attitudes at this time, with terms such as 'country' and 'state' being reportedly used during the majlis' brief tenure; also see ABDULLAH (1978), pp.131

${ }^{162}$ Ibid. pp. 132

${ }^{163}$ HEARD-BEY (1982), pp.256

164 Ibid. pp.254-255

${ }^{165}$ ABDULLAH (1978), pp.132-133, this was part of a broadcast made by the Political Resident on $28^{\text {th }}$ April 1940 on the BBC

${ }^{166}$ AL-SAYEGH (1998), pp. 96

${ }^{167}$ ABDULLAH (1978), pp.134-136, the first development plan was commissioned in 1960

${ }^{168}$ HAWLEY (1970), pp. 171

${ }^{169}$ Ibid. pp. 188

${ }^{170}$ ANTHONY, John Duke (1975), "Arab States of the Lower Gulf: People, Politics, Petroleum", Washington DC, Middle East Institute, pp.148-149

${ }^{171}$ FOLEY, Sean (1998), "The United Arab Emirates: Political Issues and Security Dilemmas", Middle

East Review of International Affairs (MERIA), Volume 3 Number 1, March 1998, pp. 10

172 PECK (1986), pp.45

${ }^{173}$ HAWLEY (1970), pp. 177

${ }^{174}$ HEARD-BEY (1982), pp.324

${ }^{175}$ Ibid. pp.310-311

${ }^{176}$ Ibid. pp.306-307

177 FENELON (1973), pp.25-26, Two of these five year development plans were drawn up, one in 1955 and one in 1960

${ }^{178}$ Ibid. pp. 26

${ }^{179}$ HEARD-BEY (1982), pp.312

${ }^{180}$ FENELON (1973), pp.46-47 and 49-50, see appendix (i).

${ }^{181}$ HEARD-BEY (1982), pp.321

${ }^{182}$ FENELON (1973), pp.26-27

183 HEARD-BEY (1982), pp.317

${ }^{184}$ In opposition, Edward Heath's Conservative party had been critical of Harold Wilson's retrenchment policies. As such, when the Conservatives came to power many in the Gulf expected a reversal of Labour's policy, or at the very least a delay. See PECK (1986), pp.48

${ }^{185}$ See HEARD-BEY (1982), pp.336-340; and PECK (1986), pp.48

${ }^{186}$ PECK (1986), pp.48

${ }^{187}$ KELLY (1986), pp. 49 this quote is from Goronwy Roberts' report to the British Cabinet in 1968

${ }^{188}$ See BECK, Nelson R (1978), "Britain's withdrawal from the Persian Gulf and the formation of the United Arab Emirates, 1968-1971", in TOWSON STATE JOURNAL OF INTERNATIONAL

AFFAIRS, Volume 12 Number 2, Beck describes how Britain encouraged the UAE as a means of collective survival following the withdrawal of British military protection

${ }^{189}$ FENELON (1973), pp.21

${ }^{190}$ HAWLEY (1970), p.148, The 1905 meeting took place in Abu Dhabi with the ruler of Abu Dhabi acting as president and chairing a committee to discuss a border dispute concerning the villages of Masfut and Hajarain in the Hatta enclave

${ }^{191}$ See AL-ABED, Ibrahim (2001), "The Historical Background and Constitutional Basis of the Federation" in AL-ABED, Ibrahim (ed.) (2001), "The United Arab Emirates: A New Perspective", Abu Dhabi, Trident

${ }^{192}$ Ibid.

${ }^{193}$ For a general discussion of this period of transition see KHALWA, Ali Muhammad (1979), "The

United Arab Emirates: Unity in Fragmentation", Boulder, Westview Press

${ }^{194}$ HAWLEY (1970), pp.182-184

${ }^{195}$ Ibid. pp.182-184

${ }^{196}$ HELLYER, Peter (2001), "The Evolution of UAE Foreign Policy", in AL-ABED (ed.) (2001), pp. 166

${ }_{197}^{197}$ HEARD-BEY (1982), pp.343-344

${ }^{198}$ Tbid. pp.345-347

${ }^{199}$ PECK (1986), pp.50

${ }^{200}$ HEARD-BEY (1982), pp.351 and 357

${ }^{201}$ OVERTON, JL (1983), "Stability and change: Inter-Arab politics in the Arabian Peninsula and Gulf", $\mathrm{PhD}$ thesis, University of Maryland, taken from Overton's interview with EF Given, British Ambassador to Bahrain, in Manama, Bahrain on $3^{\text {rd }}$ June 1976, pp.173

${ }_{202}$ Ibid. taken from Overton's interview with Zaki Nusseibeh, Press Secretary to Shaykh Zāyid, in Abu Dhabi on $24^{\text {th }}$ May 1976, pp. 173 
${ }^{203}$ HOLDEN, David (1966), "Farewell to Arabia", New York, pp.159

${ }^{204}$ HOLDEN, David (1971), "The Persian Gulf after the British Raj", in FOREIGN AFFAIRS, Volume 49 Number 4, July, pp.729

${ }^{205}$ HEARD-BEY (1982), introduction xxiv, Sir Geoffrey Arthur former British Political Resident in the Gulf, writing the foreword to Heard-Bey's study

${ }^{206}$ UNITED STATES DEPARTMENT OF STATE (1975), "US policy in the area of the Persian Gulf', Bulletin 73, $14^{\text {th }}$ July 1975 , pp.74

${ }^{207}$ See (in Arabic) AI-AYDERŨS, Muhammad Hassan (1983), "Political Developments in the UAE",

Zat al-Salasil Publications, Kuwait, pp.164-165, the two smaller islands were the Greater and Lesser

Tunbs, or rather Tunb al-Kubrā and Tunb al-Sughrä.

${ }^{208}$ PECK (1986), pp. 120

${ }^{209}$ The federal government and its various institutions are considered in detail in sections 4.2 and 4.3

${ }^{210}$ HEARD-BEY (1982), pp.368, the Trucial Oman Scouts (formerly the Trucial Oman Levies) refers to the British-officered and trained soldiers tasked with policing the roads in the hinterland

${ }^{211}$ HEARD-BEY (1982), pp.369-370; also see ANTHONY (1975), pp.24, "Indeed, the branch of the Qawāsim family ruling Ra's al-Khaimah even considered thenselves to be of nobler descent than their counterparts in the other six shaykhdoms"

${ }^{212}$ MANN, Clarence (1969), "Abu Dhabi: birth of an oil shaykhdom", Beirut, Khayats, pp.33-50; also for a discussion of inter-emirate rivalry during this early period, see HEARD-BEY (1982), pp.369-370

${ }^{213}$ HEARD-BEY (1982), pp.372

${ }^{214}$ See KHALIFA (1979) for an overview of this period of transition

${ }^{215}$ See section 4.3.1

${ }^{216}$ OVERTON (1983), in his study of political stability in the Gulf in the early 1970s Overton singles out the UAE as the most impressive example of political union, "If one were to do a micro-analytical study of the Gulf region with the hope of projecting the chances for stability and growth in the future, the UAE would provide the perfect case study... it has not only survived but has grown stronger. If the UAE model continues to be successful, there is every reason to assume that a broader system of regionalism among the Arab states of the Arabian Peninsula is a practical goal for the future." 


\section{The Survival of Monarchy - An Overview}

As the historical background has shown, following the British withdrawal in 1971 the newly independent United Arab Emirates had little more to rely upon than its traditional political structures and a few hastily established federal institutions. Although, as demonstrated, careful negotiations and a spirit of compromise did allow the fledging state to survive its troubled inception, many observers believed that the lower Gulf's traditional monarchies and rudimentary institutions could never represent anything more than a transitional phase. Indeed, given the region's massive oil wealth and accelerating socio-economic development, such polities were seen as being both anachronistic and irreconcilable with any modernisation process. More than thirty years later the UAE continues to experience such rapid development and now boasts one of the highest GDPs per capita in the world, ${ }^{1}$ comparable with and in some cases higher than many of the western industrialised economies. ${ }^{2}$ At the same time, however, despite these massive changes the seven ruling families are still very much in place, and have retained, or at least appear to have retained much of their traditional authority. Indeed, of the world's eight remaining absolute monarchies, the UAE's autocratic structures and its lack of political freedom are consistently ranked second only to Saudi Arabia. ${ }^{3}$

The purpose of this chapter is, therefore, to provide an explanatory overview of the survival and continuing relevance of what were in effect the end-products of the region's history of dependent relations and its reinforced client elite formations. Essentially, by combining the tools of modernisation revisionism and rentierdependency theories this chapter will demonstrate how there has been a subtle evolution of these primarily traditional structures and the creation of a carefully managed 'ruling bargain' between the rulers and their population; a bargain which relies heavily on a number of key criteria. The first section will consider the UAE's cautious fusion of old and new sources of legitimacy, highlighting the rulers' astute balance of traditional sources of legitimacy alongside seemingly new institutions in their efforts to circumvent 
permanently the 'Shaykh's dilemma'. ${ }^{4}$ Secondly this chapter will assess the role of oil and material resources in continuing to build up a distributive 'rentier state' capable of further strengthening the rulers' authority, and capable of providing them with enough structural space to forge new and mutually beneficial ruling coalitions with their people. Also relating to oil wealth, the third section will consider the UAE's favourable international relations, and will determine the extent to which external support has strengthened the rulers' authority in one of the world's most volatile regions. Finally, this chapter will demonstrate how the UAE's monarchies have transformed over the years into powerful and resilient 'dynastic monarchies'. ${ }^{5}$ With far larger ruling families in control of far more unitary and resource-rich states, these evolving monarchical structures have allowed for improved collective security, more scope for internal bargaining, better stability mechanisms, and, in many ways can be seen to be functioning as surrogates for large-scale single political parties.

\section{1-The Shaykh's dilemma}

At the time of the Trucial States' independence, many political scientists maintained that most of the world's remaining traditional monarchies would soon collapse, as pressures for political reform would inevitably overload their 'weak' traditional polities. Early examples of such hypotheses included Daniel Lerner's 'passing of traditional society' theory and Karl Deutsch's 'social mobilisation' theory; both of which asserted that modernising forces and their consequences for society would soon render traditional monarchies anachronistic. Writing in the late 1950s, Lerner demonstrated in his studies that in every country where individuals could be classed as experiencing the effects of modernisation, they would be considerably 'happier' than those still living by traditional means. From his socio-scientific analysis he therefore drew the conclusion that traditional society was passing from the Middle East simply because "relatively few Arabs still wanted to live by its rules." In much the same way, Deutsch argued that modernising forces in such states would invariably expand the size of the educated and literary middle classes, thereby leading to increased social mobilisation, which would in turn outweigh the capabilities of the traditional 
polity and would eventually catalyse some kind of political development. ${ }^{7}$ Indeed, in many ways the newly rich oil monarchies of the Persian Gulf were seen by such theorists as providing perfect examples of future change given that their ambitious development programmes and their inevitably fast-paced modernisation were predicted to engender increasing levels of political consciousness and greater demands on the state.

Published just three years before the United Arab Emirates came into being, Samuel Huntington's influential Political Change in Traditional Polities was similarly pessimistic with regard to the survival of traditional monarchies. Indeed, central to one chapter's framework was the assumption that in order to cope successfully with modernising forces, traditional rulers would eventually be faced with an inescapable 'King's dilemma' or, in the case of Arabia, a 'Shaykh's dilemma'. Essentially, in much the same way as Deutsch and the other early modernisation theorists, it was reasoned that the modernisation process and the necessary innovation of economic and social development policies would invariably create new groups which the polity would have difficulty assimilating alongside existing traditional groups. ${ }^{8}$ As such, the traditional monarch would either have to resist modernisation in some way or would instead have to accommodate the new groups, a route which would invariably lead to the ceding of former powers. ${ }^{9}$ Thus, believing there was no adequate long-term solution to such a quandary, Huntington predicted the eventual demise of those traditional polities presiding over rapid modernisation by arguing that

"... a gap opens between the increasingly modern society and the traditional polity which gave it birth; able to transform the society, but unable to transform itself, the monarchical parent is eventually devoured by its modern progeny". ${ }^{10}$

However, for the purposes of this study it is also important to note that although Huntington claimed the key question for these monarchies would ultimately "concern simply the scope of the violence of their demise and who will wield the violence," 11 he 
nevertheless accepted that certain short-term strategies could temporarily postpone such a fate. Indeed, it was believed that under certain circumstances a traditional monarch could provisionally circumvent the assimilation predicament by either seizing the initiative and allowing for some degree of voluntary transformation of the polity (while still retaining some traditional power), by institutionalising coexistence within the polity, or by carefully maintaining the polity (resisting reform), and thereby limiting the effects of modernisation. ${ }^{12}$ To varying extents all of these strategies have been in evidence in the remaining Middle Eastern monarchies and, although only deemed to be temporary measures by western political scientists, they have nevertheless been recognised by the rulers as important ways in which to prolong traditional authority and sidestep the Shaykh's dilemma. Although the UAE has at times made limited attempts to follow such strategies, by discussing these three measures it will, however, be demonstrated how the UAE's survival and legitimacy has never had to rely heavily on such methods, and therefore how the remarkable longevity and resilience of traditional polity in the UAE must be seen as being distinct from the less assured survival of some of the other Middle Eastern monarchies, including even the neighbouring Gulf emirates of Bahrain and Kuwait.

\subsection{1 - Voluntary transformation}

Both Huntington and Manfred Halpern suggested that some kind of voluntary transformation of the polity might extend monarchical rule. Essentially the ruler himself could become the main modernising force by pre-empting demands for political reform and by instituting constitutional reforms on his own terms. In such a scenario it was felt that "the King may be able to reserve his power as a symbol of unity above particular parties by acting as a moderator, but never engaging himself as a final authority except in crises that party politicians cannot remedy".13 Certainly, as early as the 1930s there was evidence of such a strategy having been suggested to the rulers of the Trucial States when, during a brief period of instability, the British Political Resident in the Gulf actively encouraged the ruler of Dubai to voluntarily yield a portion of his authority: 
"You are a wise man, $O$ Shaykh! And must be aware that all over the world cases have occurred of demands which have been made on their Rulers by their people for reforms, and which demands have been refused. The result has often been that in the end the Rulers have had to give much more than if they had given a little in the beginning, and in some cases the Rulers have even lost their thrones. Briefly then, $O$ Shaykh!... I can as your friend advise you to look carefully to the future, and to profit by the experience of other countries where early and generous reforms have deprived those who wished to oppose the Rulers of the popular support on which they relied."14

Although no such development took place in Dubai or indeed any of the other Trucial States at this time, Shaykh 'Almmad Al-Sabāh of Kuwait was nevertheless coaxed by the British into devolving some of his powers to restless merchants. ${ }^{15}$ Moreover, when the subject of pre-emptive political reform was revived during the federal negotiations of the late $1960 \mathrm{~s}^{16}$ the Trucial rulers again shied away from such suggestions, whereas Bahrain chose to "modify its position in the light of the recent survey of public opinion conducted by the UN emissary and in response to the popular requests for more democratic institutions" ${ }^{17}$ Of course the more recent developments in Bahrain can also be seen as evidence of such willingness. ${ }^{18}$ Indeed, while the Bahraini Emir's encouragement of democratic elections and his creation of a national charter or ' $\mathrm{Al}$ mithaq, may still represent little more than political window-dressing, ${ }^{19}$ such a move nevertheless underscores how the strategy of voluntary transformation continues to be recognised, at least in the background, by the other Gulf monarchies.

\subsection{2 - Institutionalising coexistence}

An alternative strategy for a ruler attempting to escape the Shaykh's dilemma would be to try to combine his traditional rule with some form of representative government. In other words the ruler could choose to institutionalise coexistence within the polity. In the UAE this strategy has also remained extremely limited. Although, as demonstrated in the historical background, during the pre-oil and pre-urbanised era the 
traditional majālis and the easy access to the rulers' representatives did allow for a certain degree of consultative democracy and an opportunity for the people to air their grievances at the highest levels, ${ }^{20}$ no such direct representation really takes place in the contemporary UAE. Indeed, with rapidly expanding populations and a plethora of ministries and bureaucracies, the only representative government bodies are the Federal National Council and, at the emirate level, the Abu Dhabi National Consultative Council. Moreover, as will be described in greater depth later in this thesis, even these are extremely inadequate institutions, ${ }^{21}$ and in many ways it would appear that in real terms there has actually been a contraction of access in the UAE. Conversely however, in many of the other Middle Eastern monarchies there have been highly visible attempts to institutionalise at least some form of coexistence, although it remains important to note that in most cases these have lacked any genuine commitment. In Jordan for example, latent pressures for political participation from under-represented groups including the Palestinians led to national elections and the creation of a National Assembly comprising of a Senate appointed by the King and a popularly elected House of Representatives. $^{22}$ Similarly in Morocco a bicameral parliament exists, comprising of an appointed Chamber of Counsellors and a popularly elected Chamber of Representatives. $^{23}$ This multi-partyism or ta'addudiyya has, however, had little structural impact, with parliamentary discussion often limited to local and procedural issues, with the political parties functioning as little more than 'loyal opposition', and with the more radical parties being marginalised. ${ }^{24}$ Moreover, with the case of the Shah's Iran, while coexistence was certainly institutionalised, the strategy's inherent weaknesses soon became apparent as the government was fragmented by dual responsibilities to both the monarch (royal sovereignty) and the elected assembly (popular sovereignty). ${ }^{25}$ As such the traditional polity was seen to have provided insufficient structural space for adequate manoeuvre. This led to mutual frustration and repeated attempts by the monarch to limit the new authorities, most notably by suppressing the Prime Minister, Mussadiq. Indeed, as Dilip Hiro describes, Mussadiq's clash with the Shah over the subject of oil nationalisation led to the elected premier's dismissal, and when Mussadiq returned to power on a wave of popular support, the Shah had no option but to reassert his authority with what was essentially a military 
operation. $^{26}$ The Kuwaiti example is also important to note, not least due to its close proximity and its seemingly similar socio-economic structures to the UAE. In much the same way as these other monarchies, Kuwait's National Assembly was seen by the $\bar{A} l-$ Sabāh rulers as providing a necessary degree of coexistence within the polity in order to preserve stability and control the assimilation of new groups. In reality however, the level of representation was minimal with all candidates being restricted to individual platforms and with ail political parties being banned. ${ }^{27}$ Moreover, when electoral platforms finally did begin to emerge around blocs and groups in the 1970s, the Kuwaiti executive felt compelled to dissolve the assembly and place restrictions on the press. ${ }^{28}$ Only in the 1990 s, following the country's liberation from Iraq was a return finally made to the original constitution and the limited coexistence of the $1960 \mathrm{~s}^{29}$

\subsection{3 - Maintaining the polity / resisting reform}

Thirdly, a traditional monarch can attempt to circumvent the Shaykh's dilemma and seek to maintain his traditional authority simply by resisting reform and avoiding the assimilation of new groups, often by balancing modernisation alongside repression. ${ }^{30}$ To some extent, such maintenance has been evident in the UAE, but although there has undoubtedly been an appreciable increase in internal security, ${ }^{31}$ there has never been a heavy reliance on coercion, and at no stage has the country suffered from a particularly repressive atmosphere. ${ }^{32}$ Instead, there have been subtle controls placed on almost all civil society organisations, religious groups, media organisations and workers' associations. Though these restrictions will be analysed in more detail in the discussion of Emirati civil society later in this thesis, it is worth noting that these controls have usually been limited to financial co-option, ${ }^{33}$ government licensing, ${ }^{34}$ selfenforcing censorship ${ }^{35}$ and, in the case of the UAE's mosques, the supervision and approval of practising ulama ${ }^{3} .^{36}$ As with the two other monarchical survival strategies, there has, however, been far more evidence of strict maintenance in other Middle Eastern monarchies and potentates than in the UAE, perhaps most notably in the Imăm's Yemen. Indeed, as Muhammad Zabarah notes in his study of Yemeni state formation, although a maintenance strategy may have temporarily delayed the collapse 
of the traditional polity, the Imām's lack of responsiveness to demand for political and socio-economic reforms eventually reached such a level that the country became openly divided between traditionalists and modernists. ${ }^{37}$ Crucially this struggle soon extended to the army when, wary of the new officer class whose political notions were seen as running contrary to his own, the Imām chose to inhibit the development of a strong Yemeni army. ${ }^{38}$ Thus, driven by the need to keep modern ideas away from his domain, the ruler attempted to undermine his armed forces and instead began to rely upon the tribes in an effort to preserve traditional values, thereby irrecoverably compromising Yemeni national security and leading to a coup.

\section{2 - The Legitimacy Formula}

While voluntary transformation, the institutionalisation of coexistence, and often maintenance strategies have been used to varying degrees of success in many other Middle Eastern monarchies throughout the twentieth century, and even in some of the other Gulf monarchies, the UAE's reliance on such methods has clearly remained limited. Moreover, the Shaykh's dilemma and the problems of balancing traditional and modern forces appear to have been largely avoided without resorting to these temporary measures. Indeed, as political scientists began to argue in the late 1970s, certain monarchies were, if anything, more stable than ever before, even after experiencing great wealth and extensive socio-economic development programmes. Thus, given that these traditional monarchies were surviving despite considerable evidence of modernising forces in their countries, there was clearly a need for a re-examination of the belief in the inevitability of the passing of traditional political systems. Among these modernisation revisionists, Michael Hudson effectively began to contest the early assumption that monarchical legitimacy was necessarily anachronistic and reasoned that, in certain circumstances, a traditional polity could evolve towards more long-term legitimacy and stability. More specifically, it was argued that, within a Weberian framework, certain traditional sources of legitimacy could be utilised and adapted by monarchies as part of a more comprehensive survival strategy. ${ }^{39}$ By assessing the careful use of personal, patrimonial, cultural, and ideological legitimacy resources this 
section will attempt to underscore the evolution of the UAE's legitimacy formula over the past thirty years and, moreover, by considering the polity's far-sighted attempts to develop greater structural resources alongside these traditional resources it will also be shown how the UAE's traditional polity is now beginning to survive within a much broader 'neo-patrimonial' network. ${ }^{40}$

\subsection{1-Personal resources}

As demonstrated in the historical background, personal resources have always been a cornerstone of the traditional polity's legitimacy. Indeed, for centuries the lower Gulf's political structures were dominated by personalities and the need for personal authority over populations, even more so than over territorial or geographical resources. ${ }^{41}$ Central to such authority was the principle of bay'a:

"Bay' $a$ is the act by which a certain number of persons acting individually or collectively recognise the authority of another person. Thus, the bay'a of an emir/king/caliph is the act by which one person is proclaimed and recognised as the head of the Muslim state." 42

Certainly, prior to the oil era, many of the region's rulers drew considerable legitimacy from their citizens' public endorsement of their personal ability. Without the bay'a these rulers would have been unable to command sufficient respect for their traditional patriarchal governments or 'hukūma'. Moreover, for the purposes of this study it is important to note the continuing relevance of the bay'a mechanism and the efforts of the contemporary rulers' to shore up the old Bedu notions of citizenship. ${ }^{43}$ Indeed, although family and polity may no longer reach the point of absolute congruence, ${ }^{44}$ and although the personal competence of Emirati rulers may no longer be judged in terms of their ability to fight, ride camels, or arbitrate tribal disputes, there is nevertheless little doubt that personal authority remains most significant. The possession of sufficient charisma or 'baraka' together with the ability to personally mediate and supervise are still regarded as being essential functions of successful rulership, and as such it is 
widely believed among the local Emirati populations that new rulers must still be seen to have informally earned the bay'a from respected members of the community. ${ }^{45}$

Among the present-day rulers the clearest example of such personal authority has of course been that of Shaykh Zãyid Al-Nuhayyān, the ruler of Abu Dhabi and the UAE's long-serving president. Having secured considerable popular support throughout the emirate during his time in Al-'Ayn and Buraimī, Zãyid is widely credited as the 'Father of the UAE' and as the driving force behind much of the UAE's success. ${ }^{46}$ Indeed, as an Emirati minister claimed in a recent international conference, a significant portion of the UAE's political stability must be attributed to Zāyid's consensus rule and the enormous personal respect he continues to command from the people of all seven emirates:

\begin{abstract}
"Fortunately for us and our neighbours, we have developed without undermining the social, cultural and political fabric of our society. This has been due in large part to leadership. Shaykh Zāyid has served as president of the UAE since its inception in 1971. And his leadership is based on consensus among the seven emirates. In keeping with Islamic tradition, he is seen as first among equals, continuing to serve as president because he commands the respect of the nation's other leaders and the reverence of the people. ${ }^{47}$
\end{abstract}

Similarly at the emirate level, another good example of strong leadership would be the highly personal and very popular rule of Shaykh Rāshid Al-Maktīun, the 'Father of Dubai', who closely presided over an era of rapid socio-economic development in the emirate until his death in $1990 .{ }^{48}$ Indeed, in Hudson's study of monarchical legitimacy, Shaykh Råshid was singled out for his considerable input into the running of Dubai, his intensiveness, and his extraordinary level of individual commitment:

"In the early period Shaykh Rāshid's personal involvement in the day-today running of Dubai Emirate was extremely intense: "he rises every 
morning at 6am, before anybody else is up, and after prayers takes an inspection drive around the town. Then, after coffee he is off to the office for a morning of routine royal duties: receiving distinguished visitors and petitioners, checking the status of various projects and signing cheques. After lunch he turns his attention to new projects and planning... ",49

Thus, in these cases, and in Sharjah and the other smaller emirates where, from informal research, it would appear that the Qawāsim, the Sharqiyīn, and the other ruling families also continue to command considerable support from their local populations, it would therefore seem there are still strong indications of personal resources playing a key role in the rulers' legitimacy formulae. Indeed, spontaneous rallies and public displays of agreement with the ruler's decisions are a frequent spectacle in almost all of the emirates. $^{50}$ This of course contrasts markedly with the former monarchs of Iraq, Afghanistan, and Libya where, as will be demonstrated later in this chapter, for a multitude of reasons including their lack of public accessibility and their unpopular foreign relations, it would seem that the ruling families failed to foster any real admiration or respect from their subjects. ${ }^{51}$

\subsection{2-Patrimonial networks}

However, as described, even in the pre-oil era the region's political structures were already beginning to evolve from a total reliance on personal authority following the growth of the coastal towns, the increasing urbanisation, and the greater administrative demands being placed on the state. ${ }^{52}$ In more recent years, with rapidly expanding populations and a plethora of new bureaucracies the distance between the ruler and his people has continued to grow, and although personal resources have certainly remained an important legitimacy component, these have now been augmented by the development of extensive intermediary networks. Indeed, the rulers have actively encouraged and nurtured new and extended patterns of authority based on informal relations, kinship groups and long-standing traditional loyalties. The result has been an extension of the ruler's personal network to a much greater patrimonial 
network; one that filters down through all sections of society with the ruler at the very top of the pyramid and with all other echelons tied into the system at various strata beneath him. Patrimonialism therefore provides additional layers of legitimacy by reducing the traditional polity's total reliance on personalism and potentially unpredictable resources such as charisma and popular veneration, and in addition has created important vertical linkages between the ruler and his people which have helped to provide individual mobility within the polity while at the same time fostering some degree of loyalty at all levels.

Indeed, with regard to reducing the reliance on personal authority, patrimonial networks have been seen as an increasingly important method of ensuring ongoing support for the various ruling families. Shaykh Rāshid has now been succeeded by four sons and, as an old man, Shaykh Zāyid will soon be approaching the end of his long and illustrious reign. Despite his considerable administrative experience, few would doubt that Shaykh Khalifa Al-Nuhayyān, Zāyid's eldest son and Abu Dhabi's Crown Prince, could ever hope to draw upon the same level of personal legitimacy from his peers as his distinguished father. As such, for the long-term survival of the traditional polity it has become essential that the UAE's elites, both inside and outside of politics, are all in some way vertically connected to the ruler, and therefore 'clients' dependent on the ongoing stability of the polity for the preservation of their social status, economic advantages and whatever other privileges they have been accorded within the patrimonial-clientalist network.

At the political level, this incorporation has been largely based on 'consolation prizes' for powerful elites outside of the ruling family and for other aspiring individuals; an important feature of Emirati politics which will be returned to later in this chapter and throughout the remainder of this thesis. ${ }^{53}$ Indeed, evidence of this strategy was readily apparent even at the time of Shaykh Zãyid's succession as ruler of Abu Dhabi. As Abdullah describes: 
"From 1966 onwards, Shaykh Zāyid adopted the wise policy of sharing the responsibilities of his new government between members of the ruling family, notable local figures and certain graduates from the more prominent families... This was an example that was quickly followed in the other emirates. The trust the Shayk showed in the young educated generation won him their affection and in due course they proved their reliability." 54

Similarly in Sharjah, when Shaykh Khalid al-Qāsimĩ succeeded as ruler in 1965, one of his first actions was to give young Sharjah graduates a share in the local administration. ${ }^{55}$ Of course, as will also be demonstrated later in this thesis, the obvious weakness of such individual incorporation into the patrimonial network is that in future years the size of the UAE's graduate and educated 'technocratic' population may begin to exceed the polity's capacity for providing them with meaningful public sector employment. $^{56}$ Thus, as explained, the patrimonial network must also be much broader, providing other rewards and incentives to the Emirati elite.

Perhaps the strongest example of such rewards has been the polity's overt attempts to encourage and foster the emergence of a privileged 'local' class comprising of the UAE's entire indigenous population which of course has now become dwarfed by the UAE's massive expatriate populations. Given the small size of this national population the 'locals' form a natural elite group, easily identifiable by their adherence to traditional dress codes, ${ }^{57}$ and the majority openly receive a number of generous socioeconomic benefits from the state, thus making them reliant on the rulers' munificence and therefore more favourably disposed towards the survival of the traditional polity. Indeed, as Frauke Heard-Bey noted in her updated 1996 study of the UAE:

"Every UAE national, however humble his or her material and educational circumstances and status within this society, by virtue of not being part of the non-national majority, has a vested interest in the continued integrity of the traditional society with tribal shaykhs and rulers at its apex. Being part 
of this structure is the basic reason why a national family is able today to lead a life in which poverty has been left behind." 58

In recent years one of the clearest examples of such largesse has been Shaykh Zāyid's scheme to provide substantial 'marriage funds' for young locals. Ostensibly these funds were designed to tackle the problem of large dowries and extravagant weddings, but more importantly they are a means of ensuring the preservation of the local population by ensuring Emirati inter-marriage, and of course a means of providing large state-sponsored subsidies to young Emirati men:

"He [Zâyid] has been particularly critical of the growing habit of extravagant weddings and of the reluctance of some young people to contribute in a positive way towards society. 'Extremely high dowries, extravagance at wedding parties and everything else which burdens young people with debt when they are on the threshold of their lives as a family are matters for which there can be no justification, 'he said... To counteract this trend, Shaykh Zâyid ordered the creation of a special Marriage Fund to offer grants to young men wishing to marry, and also urged the country's tribes to take action to discourage expensive parties and large dowries. The response was immediate, both from tribal elders throughout the UAE, and from young nationals, who flocked to apply for help from the Marriage Fund. Unique of its kind in Arabia, the Fund seems set to make a major contribution to the stability of society and the preservation of local culture. ${ }^{59}$

Other important examples of such privileges would include the considerable business advantages conferred on the local population. Indeed, with reference to Abu Dhabi, an identifiable government aim has been to:

"... institutionalise a number of privileges for nationals so that they can earn income, for instance from trade agencies, renting property built with 
government provided loans on freely distributed land, renting vehicles to companies operating in the desert or competing on favourable terms for projects. Thus, the illiterate Bedu as well as the urbane chairmen of trading empires are well aware of the benefits of being one of the small number of Abu Dhabi nationals. "60

Chiefly, this financial assistance is provided by the 'Social Services and Commercial Buildings Committee' otherwise known as the 'Khalifa Committeee', which ensures that loans are available at low interest rates to all Abu Dhabian nationals. ${ }^{61}$ Furthermore, as figures from Citibank UAE indicate, these considerable advantages also extend to the private sector with different loans and terms being made available to different groups, clearly indicating those favoured by the broader patrimonial-clientalist network:

\begin{tabular}{|l|l|l|}
\hline Category of loan & UAE Nationals & Non-nationals \\
\hline $\begin{array}{l}\text { Start-up loans available on } \\
\text { first day of job: }\end{array}$ & 100,000 Dirhams & 60,000 Dirhams \\
\hline $\begin{array}{l}\text { Loans available on } \\
\text { completion of six months } \\
\text { employment: }\end{array}$ & 250,000 Dirhams & 120,000 Dirhams \\
\hline $\begin{array}{l}\text { Maximum repayment } \\
\text { period allowed: }\end{array}$ & 84 months & 48 months \\
\hline
\end{tabular}

[Source: Citibank UAE, 2002] $]^{62}$

Evidently, non-nationals, regardless of the strength of their connections with the UAE, do not have access to the same benefits as the nationals. Moreover, in some cases these differences in privileges have even been formalised in UAE legislation, as indicated by the Federal Commercial Companies Law which states:

"... Each company incorporated in the State shall hold its nationality but it shall not necessarily be entitled to privileges reserved only to U.A.E nationals. "63 
More specifically, Article 22 of the Companies Law provides an important advantage for UAE nationals. Certain commercial activities are restricted to UAE nationals, and in those areas that are not, all companies must be 'sponsored' by one or more UAE nationals

"... whose share shall not be less than 51\% of the company's capital. Therefore, any company's contract that does not incorporate such a provision shall be considered to be null and void. "64

Lastly, it is important to emphasise the extent to which such rewards and advantages have also been extended to the very poorest UAE nationals, with many houses and other amenities being provided free of charge to those in the lowest income brackets and with many fully equipped farms being provided for those closer to the main agricultural areas. ${ }^{65}$ Indeed, as Kevin Fenelon observed in his survey of the region, even in the early 1970s the lives of many of the most impoverished Emirati citizens were being dramatically improved as the governments began to construct thousands of new free homes and public facilities:

"... for lower income families, a considerable number of one-storey low cost houses were erected by the governments, including those of 'Ajman and Umm al-Qawain. These two towns in consequence began to look far less picturesque, but in compensation, the inhabitants were far better housed and were better provided for by modern amenities such as piped water and electricity. In Abu Dhabi more than 3000 low cost homes were erected and were freely distributed to Abu Dhabi nationals with limited incomes. Other Abu Dhabi nationals were given building plots on which to build houses of their own." 


\subsubsection{Cultural and religious resources}

Alongside the continuing use of personal legitimacy resources and the development of a patrimonial network of socio-economic privileges and loyalties, it is important to note how the role, or rather the revitalised role of cultural resources ('turāth') has also formed a key component of the traditional polity's legitimacy formula. Essentially, by preserving and restoring memories of the region's rich history of traditional activities, the ruler's position at the head of a contemporary patriarchal and patrimonial society can be further reinforced. Indeed, as Davis explains in his study of oil and historical memory, a state's ability to draw upon cultural resources and revive traditional experiences can in many cases greatly enhance the legitimacy of its polity:

"... [the state has] an ability to reconstruct, synthesise and even invent symbols that will touch a psychological nerve in the populace at large. A strong state is one that can exercise this craft and that continues to forge emotive links with the populace over which it rules. "67

Certainly, many of the lower Gulf's traditional customs and practices are still in evidence today, and in some cases these are now being reintroduced and formalised as 'living memories' for the increasingly urbanised and modern population. Indeed, in her recent study of Emirati society, Sally Findlow supported this view by concluding that

$$
\begin{aligned}
& \text { "...this modern Muslim Gulf Arab nation-state retains strong elements of } \\
& \text { traditional conservatism while endeavouring simultaneously to preserve } \\
& \text { indigenous cultural authenticity." } 68
\end{aligned}
$$

Although the UAE's cultural revival and the state's massive investment in new museums, cultural foundations, and various other heritage centres will be discussed in greater detail later in this thesis, ${ }^{69}$ at this stage it is worth noting how certain cultural 
symbols have been used (or in some cases even invented) with the specific intention of augmenting the ruler's traditional legitimacy.

A good example of such symbolism would be camel racing in the UAE which, in recent years, has evolved into a highly lucrative and widely televised sport. In an attempt to preserve a part of their Bedu heritage, the UAE's rulers have spent millions of Dirhams on racing circuits, prize money and thoroughbred racing camels. However, as Sulayman Khalaf has recently demonstrated, the competitive racing of camels was rarely a popular pursuit in traditional times with most camel races being more of a show ( $a r d h a)$ reserved for special occasions. Thus, in the contemporary UAE the status of these races has been greatly elevated. ${ }^{70}$ Indeed, as Dubai camel expert and author Sa'id Abu 'Āthira has explained:

"Camel races used to be run [only] on special occasions such as weddings.

Now they are sponsored by governments to help people keep their camels and not lose their traditional way of life."

Other important and almost mythological symbols would include the many monuments and displays dedicated to the memory of the pearling industry; the many preserved examples of jalbüts, baggalas, and other traditional Arab vessels, and of course the region's numerous forts and towers, almost all of which have now been restored.

In a similar fashion to these cultural resources, the region's long history of Islamic tradition must also be seen as an important legitimising bridge between the traditional polity and contemporary Emirati society, as religious association has united both modern and traditional groups behind a common cause. ${ }^{72}$ Certainly, Islam has continued to be an integral part of the UAE's legitimacy formula, not only serving as the official state religion, but with Islamic shari 'a law and the traditional qā dí system still providing many of the principles upon which the state's constitution and judicial system are based. ${ }^{73}$ Although the discussion of globalisation and civil society in the final chapter will further expand upon the state's relationship with Islam and Islamic 
groups, ${ }^{74}$ it is nevertheless necessary to underscore the polity's clear commitment to bolstering its religious resources. Unless preserved and well maintained it is undoubtedly feared that any future erosion of Islamic standards and criteria will reduce the importance of an Islamic variant of Weber's 'natural law' as an additional basis for legitimacy and survival. ${ }^{75}$ To this end many of the UAE's constituent emirates and their rulers have embarked on massive Islamic-oriented projects, including the building of new mosques and Islamic centres, the funding of Islamic charities, and in some cases the introduction of new local legislation to combat declining standards.

As a result, in much the same way as in Saudi Arabia where it estimated there are just 100 male citizens for every mosque, ${ }^{76}$ any visitor to $\mathrm{Abu}$ Dhabi would be overwhelmed by the incredibly high density of mosques; a number that grows every year, with some of the largest and grandest mosques in the world now being built on the outskirts of the city. Furthermore, in Sharjah, the Saudi insistence on maintaining the outward appearance of Islamic propriety is also very much in evidence. Indeed, the emirate is now entirely alcohol free (even in hotels and private residences), and only very recently a number of stringent 'decency laws' have been declared (and enforced) in an effort to preserve and improve the Islamic nature of the community. These have covered matters such as dress codes, public conduct, gender separation, and promiscuity. ${ }^{77}$ While some have privately voiced their disapproval, the majority seem to accept the necessity of such measures and the legitimacy of their ruler's actions. ${ }^{78}$ See appendix (ii).

Moreover, given that in recent years Islamic fundamentalism has emerged as one of the greatest political opponents and internal security threats to the surviving traditional polities in the other Gulf States, ${ }^{79}$ the need for the continued incorporation of mainstream Islamic resources into the UAE's legitimacy formula remains as crucial as ever. Although the UAE survived the aftershock of the Iranian revolution and has not suffered from car bombings, ambushes, or assassination attempts as have Saudi Arabia and Kuwait, there has nevertheless been an appreciable rise in the number of Islamic related terrorist incidents. Early examples would include the 1981 bomb attack on the 
Hyatt Regency in Dubai following the hotel's serving of alcohol to locals in traditional dress, thereby violating an unwritten code of conduct for UAE Muslims. ${ }^{80}$ Other examples would include the discovery of explosives in Dubai 'City Center', an upmarket shopping mall hosting a number of western outlets and popular with both expatriates and Dubai locals. ${ }^{81}$ Most significantly, however, has been the growing evidence linking Al-Qaeda activity to the UAE in the wake of the September $11^{\text {th }}$ attacks. Recent indications are that a number of the conspirators received their initial funding in the UAE, with US Intelligence tracing $\$ 500,000$ used to pay for flight training, airplane tickets and other logistics back to Abu Dhabi; with Mulhammad Atta, the ringleader, believed to have received $\$ 100,000$ into his bank account via moneychangers in Sharjah; and with Marawan al-Shehli also believed to have received money while in Sharjah. ${ }^{82}$ Indeed, in late 2002 this link with the UAE was finally confirmed with the discreet arrest of Abdel al-Nashri in Abu Dhabi. ${ }^{83}$ As Al-Qaeda's head of Gulf operations, al-Nashri was believed to have masterminded the 2000 attack on the USS Cole, and more recently was alleged to have been planning suicide attacks using oil tankers as weapons. Most worrying for Emirati internal security, he was reportedly captured as, "he prepared to blow up economic installations in the country... aimed at causing the highest numbers of casualties among nationals and foreigners." 84

\subsection{4-Ideological resources}

In addition to these cultural and religious resources, ideology can also form an important component of the legitimacy formula. ${ }^{85}$ As this section will demonstrate, while secular nationalism has had relatively little impact on Emirati politics, there have nevertheless been certain key issues, especially the Palestinian question, which have undoubtedly formed important ideological symbols and, when harnessed by the state, have provided additional layers of legitimacy for the UAE's polity.

Perhaps the first example of organised secular nationalism in the region was in the 1930s when a group was set up in the Falah School in Dubai. Many of the expatriate 
Arab teachers had begun to spread the nationalist sentiments existing in Iraq at that time and, as Abdullah describes, they encouraged many of their pupils to

"...parade through the narrow streets of the town, carrying flags and chanting Arab nationalist songs, applauded by their parents and citizens. "86

More significantly, in 1953 a number of Dubai merchants formed a loose organisation called the National Front. Although few in members, the front attempted to voice its concern over the growing influence of Persian and Indian merchants, and called for greater privileges and protection for local Arab merchants. ${ }^{87}$ Later, at the time of the Suez Crisis there were again demonstrations, this time by a number of locals wishing to express their sympathy with Egypt in the fight against Israeli invasion and what was perceived to be an anti-Arab Anglo-French collaboration. ${ }^{88}$ Indeed, a group of students were even caught trying to set fire to the British air base in Sharjah as an act of protest. $^{89}$ More recently, in the 1970 s, the Arabic language newspaper Al-Azmina alArabiyya kept pressing the UAE government to assume stronger Arab nationalist positions and to oppose more firmly an expanded American presence in the Gulf. ${ }^{90}$ Although on certain occasions the government did seek to acknowledge such sentiments, most notably the Dubai administration's naming of a new city square after Nasser and a new city quarter after Port $\mathrm{Sa}^{2} \mathrm{id}^{91}{ }^{91}$ secular Arab nationalism has nevertheless remained firmly in the background of Emirati politics, perhaps due to the abovementioned persistence of kinship loyalties, ${ }^{92}$ and of course also due to the contrary demonstration effect of failing Arab republics, ${ }^{93}$ their military defeats, and their economic collapse. ${ }^{94}$

A far greater concern has, however, been the plight of the Palestinians, and predictably, given the issue's unifying popularity and its much closer association with Islamic brotherhood, this has been one of the chief ideological symbols to be adopted by the polity, both publicly and constitutionally. ${ }^{95}$ Indeed, the rulers' support for the Palestinian people has a long history in the region. In response to the Palestinian Islamic Congress in Jerusalem of 1930 , a meeting was held in the chief mosque in 
Sharjah during which young educated locals were encouraged to give enthusiastic speeches and to help collect money for the cause. Moreover, during the inter-war period, a number of articles published in pro-Palestinian Cairo magazines were believed to have been sent anonymously from various locals in the Trucial States. ${ }^{96}$ In more recent years there have of course been a multitude of carefully organised statesanctioned anti-Israeli demonstrations, many of which are televised, and some of which are attended by the rulers and other notables. ${ }^{97}$ In addition, generous governmentsponsored aid packages are supplied to Palestine via the UAE's Red Crescent Society or through agencies such as the Abu Dhabi Fund for Arab Economic Development. Finally, again underscoring the polity's commitment to the cause, it is also important to note how the federal government has even sought to formalise its total boycott of all things Israeli by introducing prohibitive legislation:

"Articles $1 \& 2$ of this law [Federal law 15] stipulate that any natural or legal person shall be prohibited from directly or indirectly concluding an agreement with organisations or persons either resident in Israel, connected therewith by virtue of their nationality or working on its behalf...' Also the entry, exchange or possession of all types of Israeli merchandise, commodities or products, or any form of trading in them, is forbidden and the embargo shall apply to monetary papers and other Israeli movable amounts in the UAE". ${ }^{98}$

\subsection{5 - The two-level Emirati identity}

Closely related to these ideological resources is the role of identity in the UAE's legitimacy formula. Although, as will be argued later in this thesis, the UAE is in many ways more a loose confederation than a true federation and on one level retains many emirate-level identities and loyalties, ${ }^{99}$ the greater awareness of communal solidarity arising from the union of the seven emirates should nevertheless not be underestimated. Certainly, a sense of identity and membership of a distinct political community that does not conflict with other sub-national or supranational identifications may be crucial 
in a heterogeneous population comprising of differing tribal affiliations, different emirate loyalties and different ethnic populations. Indeed, it has been claimed that such an identity can serve as a necessary horizontal axis in the state-building process, an axis which can actually complement the vertical patrimonial axis between the ruler and the ruled. ${ }^{100}$

Even before the creation of the UAE, the need for some kind of greater 'Emirati' identity was already beginning to be recognised by the various Trucial rulers. A broader identity was seen as providing a stronger platform upon which to build future legitimacy without necessarily weakening other personal, cultural and religious legitimacy resources. Indeed, even in 1966, upon his accession in Abu Dhabi, part of Shaykh Zãyid's speech underlined his commitment to the building of such an identity;

"It is the way to power, the way to strength, the way to well-being, a high reputation... Lesser entities have no standing in the world today, and so it has ever been in history." $10 \mathrm{i}$

Throughout the 1970s identity building continued unabated with the introduction of a new national flag, a new national anthem, national holidays, a 'national university', and many other highly visible symbols of the new UAE / Emirati identity. At the time most observers viewed this overt process within the context of nationalism and as part of the Gulf's commitment to 'Arabism', ${ }^{102}$ but as Findlow has demonstrated in her recent study of contemporary Emirati identity, these were not the true foundations of the new identity. ${ }^{103}$ As already shown, secular nationalism had only a limited impact on the region, and although the UAE's provisional constitution and various other official documents in the 1970s did emphasise the need for a broader Arab identity, Findlow convincingly argues that because the majority of these were constructed during the Nasserite era of pan-Arabism they were merely historical by-products. ${ }^{304}$ Certainly, as a wealthy oil-producing Arab state the UAE and its population did provide considerable economic aid and moral support to the Arab republics during this period, ${ }^{105}$ but this assistance should be perhaps be viewed as more of a commitment to Arab brotherhood 
than Arab nationalism. The UAE / Emirati identity should not therefore be regarded as simply another derivative of pan-Arab nationalism but instead as a part of a distinct identity fostered by the traditional polity, an identity which serves as another key layer in the UAE's legitimacy formula.

In an effort to determine the success of the identity building process in the UAE, Findlow's 1999 survey attempted to demonstrate how UAE citizens not only possessed an Arab identity but also a strong UAE / Emirati identity. Her results were rather disappointing given that only $30 \%$ claimed to be 'UAE / Emirati', with the remainder claiming either a more general Arab identity, an emirate-level identity, and in some cases even their home town or village. ${ }^{106}$

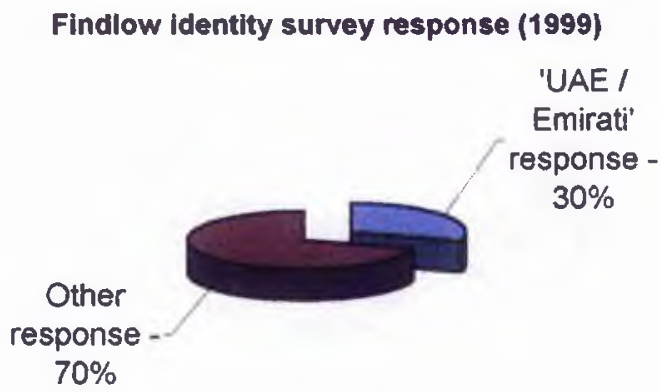

[Source: Sally Findlow, "The UAE: Nationalism and Arab-lslamic Identity"] ${ }^{107}$

However, it is important to note that this low Emirati response may have been due to the non-contextualised and geographic nature of the survey question ("Where are you from?"), the single location of the survey (Al-'Ayn), and the lack of a broad demographic cross-section.

The author's own survey, conducted in 2002, canvassed a similar number of citizens (250 male UAE nationals) but applied a more specific identity-related question ("Which of the following best describes your identity?"), and provided three possible choices: 'UAE / Emirati', an emirate-specific response (e.g. Abu Dhabi for those surveyed in Abu Dhabi), and a more general 'Arab' response. Furthermore, the survey was conducted in five separate locations across the UAE, and aimed to question a variety of age groups. 


\begin{tabular}{|l|l|l|l|}
\hline Location & $\begin{array}{l}\text { 'UAE / Emirati' } \\
\text { response }\end{array}$ & $\begin{array}{l}\text { Emirate-specific } \\
\text { response }\end{array}$ & 'Arab' response \\
\hline Abu Dhabi & $86 \%$ & $8 \%$ & $6 \%$ \\
\hline Dubai & 36 & 60 & 4 \\
\hline Sharjah & 76 & 16 & 8 \\
\hline 'Ajman & 98 & 0 & 2 \\
\hline Al-'Ayn & 100 & 0 & 0 \\
\hline Overall & $\mathbf{7 9 \%}$ & $\mathbf{1 7 \%}$ & $\mathbf{4 \%}$ \\
\hline
\end{tabular}

[Source: Davidson identity survey, 2002]

Unsurprisingly the 'UAE / Emirati' results from Abu Dhabi, the federation's capital, and Al-'Ayn, also part of Abu Dhabi emirate, were very high. Similarly in 'Ajman, the UAE / Emirati response was also very high, perhaps due to the emirate's small size, its non oil-producing status, and its dependence on federal aid for much of its economic and social development. Conversely, in Sharjah and far more notably in Dubai, the UAE / Emirati response was much lower with many more giving emirate-specific answers, clearly reflecting the relative economic power and the proud history of the emirate. ${ }^{108}$ Nevertheless, despite these important regional variations, it is clear from the overall results of the survey that a sense of a UAE / Emirati identity is emerging, with a significant number of UAE citizens now regarding themselves primarily as Emirati rather than 'Arab' or any more localised identity:

\section{Davidson identity survey response (2002)}

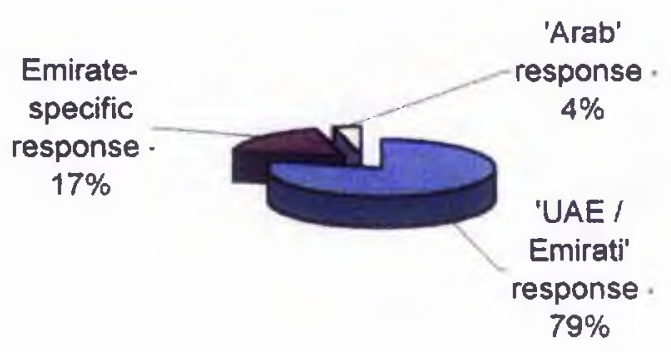

[Source: Davidson identity survey, 2002]

Indeed, a substantial $79 \%$ gave a UAE / Emirati response to the survey question, with $17 \%$ giving an emirate-specific answer such as 'Abu Dhabi' or 'Dubai', and with only $4 \%$ giving a more general answer such as 'Arab' or 'Middle Eastern'. See appendix (iii). 


\subsection{6-Structural resources and 'neo-patrimonialism'}

Alongside these essentially traditional resources, it is also imperative to consider the increasing importance of structural resources and their role in the UAE's evolving legitimacy formula. As explained in the discussion of patrimonialism, the increasing needs of the region's expanding and rapidly urbanising population required the polity to create many new intermediaries and bureaucracies. Although the resulting institutions have remained extremely limited and, as will be analysed in the fourth chapter of this study, are still very far from the Weberian legal-rational ideal, ${ }^{109}$ these new institutions have nevertheless appreciably enhanced the traditional polity's legitimacy. Indeed, if well balanced, it would seem that a 'neo-patrimonial' network can provide some degree of durable legitimacy without necessarily short-circuiting the polity's more traditional structures. Essentially, by openly institutionalising processes and introducing accepted regulations, both new and existing organisations and procedures can acquire much greater value and stability, ${ }^{110}$ even if these seemingly modern institutions are still controlled by older personal and patrimonial networks.

Writing in the early 1960 s, Halpern had argued that any political system which still relied upon 'face to face relationships', monarchy or otherwise, could never hope to establish any lasting authority or any firm consensus on public purpose, public interest or public duty. ${ }^{11}$ Although, as will be demonstrated in the following section, the UAE's oil wealth certainly removed some of the urgency for institutional development, at least by allowing the polity to avoid the need for the kind of penetrative extractive structures championed by Tilly and Kiren Aziz Chaudhry, ${ }^{112}$ Shaykh Zāyid and his fellow Trucial rulers were nonetheless keenly aware of the need to supplement their personal and patrimonial networks with more elaborate structures. Indeed, as described in the historical background, the need for institutional development was a key issue in federal negotiations and, following the creation of the UAE in 1971, a number of federal laws immediately sought to streamline the new government by creating a Supreme Council of Rulers, a Council of Ministers and a national consultative council. ${ }^{113}$ Given that these new structures effectively institutionalised the authority of the traditional 
rulers and their patrimonial subordinates, their position and legitimacy at the apex of all networks was undoubtedly strengthened. Certainly, at this time both indigenous popular opinion and the view of foreign observers was that such structures were most definitely worthwhile, ${ }^{114}$ adding an air of legitimacy to what were previously very simple traditional governments and, as Hudson noted with direct reference to the UAE, clearly reflecting the way in which

"... both the royal and the technocratic sectors of the elite seemed convinced that future legitimacy would depend upon the building of a modern government apparatus". 115

The functioning of these institutions, together with the plethora of other structures and establishments including the chambers of commerce, the industrial parastatals, and the various supreme councils ${ }^{116}$ will be explored more thoroughly in the study of the UAE's political process later in this thesis, ${ }^{117}$ but at this stage it is important to note how the rulers' views regarding structural legitimacy from the early 1970 s have remained relatively unchanged, with the present (and next) generation of Emirati rulers continuing to stress not only the need for strong personal leadership and innovation, but also the need for greater institutionalisation. Indeed, speaking at a recent conference, Shaykh Muhammad Al-Maktūm, the Crown Prince of Dubai and one of the leading political personalities in the Gulf effectively summed up these notions:

"... we [Gulf leaders] realise that the challenges we face are crucial and difficult... naturally, new realities create new challenges and responsibilities for Arab leadership... The modern leader, lays the cultural basis of questioning and accountability, as well as forges ahead and cares for others. In addition, the leader needs to crystallise an innovative vision that provides the platform for the takeoff for humane resources capabilities, and realise the projected targets endeavoured. It is therefore imperative that we increase the participation of people by developing institutions, while emphasising transparency and fighting corruption." 118 
Similarly, presenting at a recent symposium, Shaykh Fahim al-Qāsimi, the UAE's Minister of Economy and Commerce, described the continuing need for neopatrimonialism and the balancing of the 'best of the old with the best of the new':

"Our system, like the American, is based on a living constitution. Our system combines the best of the old with the best of the new. We have retained democratic Islamic traditions, foremost amongst which are the majlis, the open council in which national and local leaders meet regularly with citizens to discuss issues of concern. Another pillar of our constitutional system is the national assembly, our parliament, which serves as a forum for debating government policies and legislation."

Finally, with reference to the actual mechanisms used for promoting such institutionalisation and structural legitimacy, the UAE's efforts, like those of many other developing states, can be seen as falling into two main categories: those of bureaucratic development and those of 'constitutional engineering'. Certainly, most of the institutionalisation that has taken place in the UAE has been through the development of a large number of bureaucracies. While these are used primarily for administrative purposes with innovation and policymaking remaining within the rulers' domain, these new bureaucracies nevertheless provide an important link, and often represent the sole means of contact between the government and the population. ${ }^{120}$ Alongside these, constitutional engineering can be used to establish the prevalence of certain principles and the routinisation of seemingly modern political procedures, and in some cases can be used to guarantee certain civil liberties and democratic rights. In more authoritarian regimes, the mechanism can of course also be used to fulfil specific political purposes and to provided 'window-dressing' legitimacy to cover up abuses of power and any norms or practices usually considered unpopular. ${ }^{121}$ As this thesis will reveal, the UAE's constitutional engineering would seem to fall somewhere in between the two extremes. On the one hand certain articles of the federal constitution do claim to guarantee certain basic rights, including equality before the law, the abolition of torture, the freedom of worship, and the right of assembly: ${ }^{122}$ 
"Article 14 guarantees equality for all before the law, without distinctions between citizens on the basis of race, nationality, religion or social status. $A$ person's liberty is also protected, and no individual may be arrested or detained except in accordance with provisions of the law. Torture and degrading treatment are forbidden.

Articles 29-34 guarantee freedom of movement and residence, freedom to hold opinions and expression of the same, freedom of communication, the freedom to exercise religious worship, right to assembly and the right to choose one's occupation, trade or profession.

Article 40 describes how foreigners shall enjoy, within the Union, the rights and freedom stipulated in international charters which are in force or in treaties and agreements to which the Union is party.

Article 41 details how every person shall have the right to submit complaints to the competent authorities, including the judicial authorities, concerning the abuse or infringement of the rights and freedoms. "123

Indeed, in some respects the actual existence of such articles has provided the polity with a degree of structural legitimacy, given that they are components of a national constitution seemingly predicated on internationally accepted standards. ${ }^{124}$ However, on the other hand it remains important to note that not only has the constitution remained in a provisional state for much of the past thirty years, ${ }^{125}$ but, as the final two chapters of this thesis will demonstrate, in many cases these original constitutional guarantees have now been clearly contradicted and undermined by numerous other official documents and revisions, many of which seem more concerned with covering up potentially unpopular controlling practices including the limitation and co-option of civil society organisations, the restrictions on clergy, and even the enforcement of press censorship. ${ }^{126}$ 


\subsection{Rentierism}

Building upon this neo-patrimonial network of old and new legitimacy resources, the region's vast oil wealth has of course also reinforced the polity's legitimacy, and indeed has enhanced its prospects for survival in almost every way. This section will therefore attempt to highlight how enormously significant material resources have been, will provide an overview of the manner in which the rulers' newfound wealth has been carefully used and distributed as part of a new 'rentier network', and will explain how such wealth and its associated structures and relations have formed another key component of the 'ruling bargain' between the polity and the population.

Even as late as the 1960 s, Halpern felt it, "doubtful that most Middle Eastern countries would be able to muster such savings from domestic sources during the next decade so as to enable them to invest a sufficient proportion of national income to keep up with population growth and to create a modern society capable of self-sustaining growth." 127 By this stage, however, the Trucial States and the other Gulf monarchies, while still comparatively poor, were already beginning to emerge as important regional exceptions. With relatively small populations and, especially in the case of Abu Dhabi, with easily exploitable oil reserves, these new Arab states were seemingly on the cusp of great prosperity. Thus, as a model for the early modernisation theories, the UAE in the 1970s should have been perfect, as Abu Dhabian oil wealth and the resulting abundance of capital should have facilitated extensive socio-economic development programmes, which in turn should have engendered greater political mobilisation and the rapid disintegration of the traditional polity. While socio-economic development has indeed taken place, such political development has clearly not happened and, to the contrary, oil wealth and selective oil-financed modernisation can instead be seen as having greatly strengthened the traditional polity's legitimacy.

Central to explaining this crucial relationship between oil wealth and the monarchy is the concept of the 'rentier state'; a state that can rely on very high levels of 
unearned economic rent which, in some circumstances, can often sustain the economy without any real need for a strong productive domestic sector. ${ }^{128}$ While the concept was originally applied to the Latin American 'cash crop' states, there has however, also been a long history of rentier activity in the lower Gulf. Indeed, as demonstrated in the historical background, since the beginning of the twentieth century the Trucial rulers were able to gather economic rent from a number of important natural and geographical resources including Abu Dhabi's guano deposits, Abū Mūsā's red oxide deposits, the air bases in Sharjah and Dubai, and of course the exploration concessions granted to the Iraqi Petroleum Company. ${ }^{129}$ The oil exports of the late 1960 s were, of course, on a much larger scale and by the early 1970 s, following a four-fold price increase, oil began to provide the region with enormous levels of economic rent. ${ }^{130}$ Indeed, towards the end of this period the extent of this new wealth was such that the oil producing Gulf States, particularly Abu Dhabi and Kuwait, became seen as the purest examples of rentierism. After all, given the relatively low labour requirements of their oil industries, accounting for less than $2 \%$ of the total workforce, ${ }^{131}$ these Gulf states seemed much closer to the rentier model than any of the agrarian developing states, which always required the involvement of at least some of their domestic workforce in the wealth creation process. ${ }^{132}$ Thus, as Beblawi described of these oil monarchies in his study of rentier wealth in the Arab world:

"... their promotion to the forefront of world trade and finance resuscitated the concept of rentier economies. A windfall wealth of unprecedented magnitude in such short time revived the idea of unearned income, hence the epithet of rentier economies. The impact of the oil phenomenon on the role of the state and on economic behaviour in general has been so profound in the Arab world during the seventies as to justify special treatment..." 133

Given that this vast unearned wealth accrued directly to the rulers and their offices, the new opportunities for state-sponsored largesse soon became boundless. Indeed, although subsidies had always played a key role in traditional politics, the oil 
revenues of the 1970s allowed for far greater wealth distribution and the creation of a new allocative state. ${ }^{134}$ By providing schools, hospitals, jobs, housing, and in some cases even direct payments such as the aforementioned 'marriage funds', rentier wealth enabled the state to become the principal economic actor, ${ }^{135}$ and consequently created a new material link between the polity and the population. Thus, while the relative achievements of these various projects and the full impact of rentier wealth on the UAE's development planning will be discussed more thoroughly in the following chapter, it is nevertheless important to note in the context of legitimacy and monarchical survival how this 'rentier package' has served to consolidate and boost the existing patrimonial network of vertical linkages and socio-economic privileges. Certainly, it will emerge that UAE nationals are clearly the primary recipients of the bulk of the distributed wealth (recent surveys indicate that nearly $11 \%$ of per capita income for UAE nationals is now made up of government transfers ${ }^{136}$ ), with most fitting into a well-defined hierarchy of rentiers with the rulers at the top and with other locals linked into the material network at different layers beneath. Indeed, it has been claimed of 'rentier' Gulf citizens:

"... a rentier is more of a social function than an economic category, and is perceived as a member of a special group who, though he does not participate actively in the economic production, receives nevertheless a share in the produce and at times a handsome share... "137

Moreover, it is important to note that the rentier network also has the flexibility to tie in virtually all other members of the community, including the UAE's many expatriate workers. Although undeniably more closely involved with the wealth creation process and of course not in receipt of explicit government transfers, ${ }^{138}$ expatriates are nevertheless also a part of this rentier network as the majority reap the rewards of the generous salaries afforded by the oil-rich state. They may not be accorded with the same privileges as the local rentiers, but their access to wealth is nonetheless high, and likely to be much higher than in their country of origin. ${ }^{139}$ Thus, it would seem that something of a material pact may have emerged in the UAE; an unwritten and unspoken 
contract in which almost all of the population accept the legitimacy of the polity in exchange for the stability and rewards of their well-paid and tax-free employment.

\subsection{1-Rentier wealth and ruling coalitions}

Expanding upon the concept of rentier networks, it is also important to consider the manner in which rentier wealth has allowed the traditional rulers to break down old and well-established ruling coalitions and replace them with newer, materially based arrangements with segments of the Emirati population more likely to support the longevity of their traditional polities. As described in the historical background, direct and often personal access to the early sources of rentier wealth had already allowed the rulers to gain some degree of structural space and political distance from the merchant elite. ${ }^{140}$ However, with the massive economic rent from oil exports this structural space widened to such an extent that the historical ruler-merchant relationship soon became irrelevant, and was eventually replaced by a much broader ruler-citizen coalition in which all members of the national population, including those of the hinterland and the recently urbanised Bedu, became materially bound to the ruler and the traditional polity. Thus, with a well-financed distributive state in place, the formerly politically active merchant elites were essentially marginalised: ${ }^{141}$ the rulers were no longer reliant on their support and taxes and, by generously allocating the new wealth, ${ }^{142}$ could instead forge a more one-sided political relationship with the remaining bulk of the population.

Moreover, in most cases these sidelined merchants were themselves incorporated into the new rentier coalition, effectively trading in their former political clout for a share of the new wealth. Indeed, using the example of Kuwait, Crystal illustrates this important political adjustment by showing how the merchants

"... renounced their historical claim to participate in the decision-making process, and in exchange the rulers guaranteed them a large share of the oil revenues... where economic elites once entered politics to protect their 
economic interests, after oil, merchants left the realm of formal politics to preserve those [same] interests." 143

However, as shown in the earlier discussion of the Shaykh's Dilemma and the various short-term strategies available to traditional rulers, even in Kuwait there have been a series of parliament-related political concessions made to the non-ruling elites. Similarly in Bahrain there are constitutional developments underway which appear to point to the re-entry of non-ruling elites into the emirate's formal political structure. Once again, the UAE appears to be distinct from its oil-producing neighbours in the Gulf, given that the rentier ruling coalition and the pattern of political control remains relatively unchanged, and, as this thesis will demonstrate, the non-ruling elite remains firmly outside of the highest levels of the decision-making process. Thus, while one might expect that oil wealth should lead to a patterned response in state building, the variation between these nearby states clearly indicates this may not always be the case. $^{144}$ Obviously, on one level this discrepancy can be explained by the comparative oil wealth and the corresponding rentier packages of these Gulf states, especially given that the Abu Dhabi-backed UAE controls nearly $10 \%$ of the world's proven oil reserves and its exports now rival those of Iran and Russia, ${ }^{145}$ whereas the oil wealth of emirates such as Bahrain and Qatar is considerably more finite. ${ }^{146}$ This in itself cannot, however, be a sufficient explanation given that Kuwait, like the UAE, still commands considerable material resources. ${ }^{147}$

Instead, as Crystal has convincingly argued in her comparative study of rulers and merchants in Kuwait and Qatar, the answer may lie in the historic foundations of the Gulf's rentier ruling coalitions. In Kuwait for example, oil production began far earlier than in the other Gulf States, and at that time the merchant classes and other economic elites remained strong and powerful. They had not yet been weakened by economic depression, the collapse of the Gulf's pearling industry, and the aftermath of the Second World War. Instead they were able to bargain from a position of strength when the ruler first began to receive oil revenues, and as such the new Kuwaiti ruling coalition had to make at least some attempt to incorporate rather than sideline the non- 
ruling economic elite. ${ }^{148}$ In complete contrast, the Trucial States did not begin to receive significant oil revenues until the late 1960s and even then only Abu Dhabi and Dubai were in any way affected. By this stage the old merchant elites that had previously held the rulers' powers in check were already considerably weakened with their main sources of livelihood having long been in decline. As such, they had little option but to accept the rulers' new coalitions, and thus began to receive distributed wealth and many of the described financial patrimonial-clientalist favours in exchange for their complete political acquiescence. ${ }^{149}$

Indeed, as the example of the Dubai reform movement demonstrated in the previous chapter, by the 1940s the merchant elites had already lost much of their former bargaining power. ${ }^{150}$ Similarly in Abu Dhabi and the other Trucial states, with little hope of re-establishing the old and more equitable ruler-merchant ruling coalition, the merchants became relatively easy targets for absorption into a new ruling coalition which offered them tempting distributed wealth for the mere price of political compliance. Essentially therefore, the historic foundations of the UAE's rentier coalition can be seen as being far stronger than those in the other Gulf States, primarily due to the rulers' almost complete co-option of the economic elites by the beginning of the oil era. Although, as will be discussed later in this thesis, there have certainly been occasions in which former merchant elites have attempted to re-enter UAE politics, ${ }^{151}$ the severity and frequency of these demands have clearly been far less than in the UAE's neighbours, again pointing to the legitimacy and stability that a traditional polity can derive from a well-established rentier ruling coalition.

\subsection{2 - Rentier wealth and favourable international relations}

Further related to rentier wealth, the region's favourable international relations with its oil purchasing customers must be seen as adding another materially based layer to the traditional polity's survival formula. ${ }^{152}$ While a full discussion of UAE foreign policy remains beyond the scope of this study, it is nevertheless crucial to consider the key role of external support in ensuring the continuing survival of the monarchy. 
Indeed, without oil and the continuing military support of its former patron, Britain, and the new superpower, the USA, it would seem unlikely that the UAE would have been able to secure itself from foreign aggression in an increasingly volatile region. As demonstrated in the discussion of the federal negotiations, on the eve of independence Iran had already forcibly occupied three strategic Emirati islands. ${ }^{153}$ Moreover, with the fresh memories of Iraqi annexation threats on Kuwait in the $1960 \mathrm{~s},{ }^{154}$ and with increasing Marxist activity in neighbouring Oman and southern Arabia, ${ }^{155}$ powerful western backing became seen as more important than ever before. More recently, the continuing territorial disputes with Saudi Arabia, the ongoing Iranian occupation of Abū Mūsā, and of course the clear ambitions of Ba'thist Iraq to assume greater control over Gulf oil, have also constituted considerable threats to UAE security and, with the exception of Iraq, continue to underscore the need for external military support. ${ }^{156}$

Although sizeable western forces have rarely been based on Emirati soil since British withdrawal in 1971, the perceived support and belief in the rapid reaction of a military superpower to a local conflict has nonetheless been of equal significance. Like the populations of Kuwait, Bahrain, and Qatar, many UAE nationals accept that their own armed forces, albeit modern and well-equipped, cannot realistically expect to expel any determined foreign invader, ${ }^{157}$ but do believe that these forces can still serve as a vital 'tripwire' buying enough time for western military support to arrive and reinforce their country's defences. ${ }^{158}$ The rulers' close military relations with the western powers are therefore commonly viewed as necessary and legitimate measures in safeguarding national security and preserving the Emirati way of life. ${ }^{159}$ Indeed, symbolised by Abu Dhabi's annual IDEX event (International Defence Exhibition) which attracts over 800 leading arms manufacturers, the UAE's Defence Minister recently claimed of this international presence that:

"The fact that many renowned defence manufacturers from around the world are showcasing their products here is a proof of the success of this year's show. It is also a message that the UAE, under the leadership of the 
President, His Highness Shaykh Zāyid Al-Nuhayyān, is a stable and secure country. "m60

Of course, this continuing western military support may prove something of a double-edged sword for the rulers unless a necessary balance is reached. Indeed, there are many instances where a ruler's other legitimacy resources, namely the commitment to Islamic and Arab brotherhood, have been seriously compromised by an all too public presence of foreign and non-Muslim support. Particularly strong examples would include the Iranian Shah's very open backing from the USA, and of course the Iraqi monarchy, which almost certainly suffered from its overly close relationship with Britain, eventually alienating most segments of its largely anti-western population. ${ }^{161}$ Indeed, Elie Kedourie argues that the rapid decline in the Iraqi polity's legitimacy stemmed primarily from

"... a nagging feeling that it was a make-believe kingdom built on false pretences and kept going by a British design for a British purpose." 162

Thus, in the case of the UAE, the rulers have had to ensure that they carefully weigh up their country's immediate security needs against a potential backlash caused by any overt non-Muslim and non-Arab alliance. In 1990 and 1991, in the months preceding Operation Desert Storn and the liberation of Kuwait this legitimacy balance was particularly keen given that the proposed target of the western troops was a fellow Arab state. $^{163}$ In retrospect, the carefully managed 'coalition' which included many other Arab nations, together with the relative invisibility of western forces in the UAE (with the majority of personnel being stationed outside of the cities and restricted in their 'downtown' activities ${ }^{164}$ ) circumvented this problem, allowing the UAE's rulers to be seen as supporting a joint Arab military initiative while playing host to a discreet and essential foreign force. ${ }^{165}$ The military build-up of late 2002 and 2003 was, however, far more difficult to contain within the legitimacy formula given that no Arab coalition emerged to enforce the disarmament of Iraq, given that many of the UAE's neighbours remained reluctant in supporting the deployment of western forces, ${ }^{166}$ and given that a 
number of anti-US grass roots movements were already beginning to emerge in the UAE with the aims of boycotting American goods and promoting solidarity with the Iraqi people. ${ }^{167}$ Thus, although the UAE quietly permitted the use of its Dhafrah base, ${ }^{168}$ if future situations are not adequately addressed then any further non-UN and non-Arab League sanctioned attacks in and around Iraq that are launched from UAE territory may considerably delegitimise the rulers' positions by weakening their religious and ideological unifying resources.

\section{4-Dynastic monarchy and the evolution of the traditional polity}

Rentier coalitions and materially based legitimacy resources may, however, still be unable to guarantee the long-term survival of the neo-patrimonial polity. Most obviously, hydrocarbon reserves are finite, and although Abu Dhabi's oil will last for at least another generation, the other oil-producing emirates of Dubai and Sharjah will not be so fortunate. ${ }^{169}$ If austerity measures are ever required due to declining revenues it may become difficult to impose extractive measures and placate a once privileged population. $^{170}$ Furthermore, no matter how historically well-founded the UAE's ruling rentier coalition is, new and younger generations of Emiratis unfamiliar with the region's early state formation may begin to assume the distributive economy as a birthright, and may therefore begin to regard rentier pacts of political acquiescence as being both illegitimate and anachronistic. Added to this, it still remains possible that the formerly weakened merchant elites, or rather their sons, may be able to re-enter politics via the back door: the described plethora of new institutions and bureaucracies required by the neo-patrimonial state and its extensive distributive economy may provide future opportunities for parallel power bases and, ${ }^{171}$ in much the same way as the wälis of the pre-oil era, may allow for personal fiefdoms to develop outside of the patrimonial and rentier networks.

Although, as will be explored in the following chapter, the UAE's development planners and 'modernising monarchs' are keenly aware of the need for economic diversification in order to supplement and reduce the reliance on rentier wealth and 
rentier derived legitimacy, it is also important to consider at this stage how the ruling families themselves have actually evolved in an effort to better ensure their stability and longevity, and to bolster their polity's material resources. Parallel power bases have, as of yet, largely been prevented by the rise of a more unitary and more extensive state which has allowed for greater power-sharing opportunities for royals and notables within the patrimonial network. In addition, alongside the maintenance of the described bay'a mechanism there has been the institutionalisation of a dynastic crown prince mechanism which has practically put an end to damaging succession struggles. Thirdly, the evolution of collective action mechanisms and 'bandwagoning' have served to reduce the divisiveness and factionalism which has historically plagued and delegitimised the Gulf's monarchies for much of the last century. As will be shown, the result of these mechanisms has been, in Michael Herb's terms, the emergence of 'dynastic monarchy' in the lower Gulf: with greatly expanded membership these extensive ruling families can be seen as having become self-regulating protoinstitutions, ${ }^{172}$ perhaps providing the strength and stability normally associated with large-scale single-party political systems.

As demonstrated in the historical background, the Trucial States were originally rather segmented as the rulers often had to delegate control over their more far-flung provinces to local representatives; the wātšs, 'amirs, and nā'ibs. ${ }^{173}$ Furthermore, before oil wealth, the state was simply too small to accommodate any real power-sharing mechanisms. Consequently, any attempts to allow powerful relatives key positions tended to lead to the creation of parallel states, or in some circumstances even resulted in the wăli returning to the main town and usurping the ruler. Indeed, as mentioned, the nephew of the ruler of Sharjah's takeover of Ra's al-Khaimah in the 1940s, and of course Shaykh Zãyid's succession in Abu Dhabi in the 1960s, were both facilitated by their relative autonomy and their development of independent power bases in relatively remote regions. ${ }^{174}$ With the beginning of the oil era, however, the region's segmentary politics were considerably reduced: the explorations and advanced communications required by the new industry brought the region's many outlying regions within much closer range of the rulers' influence, but far more importantly the increasing size of the 
distributive rentier state began to provide the rulers with many more 'safe' consolation prizes. Indeed, the many new posts created by the new government ministries, the bureaucracies, the oil companies, and crucially, the armed forces, could be distributed to powerful and potentially influential members of the ruling families and their associates. In this more unitary state, the ruler could therefore share power within a more closely supervised patrimonial hierarchy without fearing autonomy or any loss of personal authority.

Abu Dhabi provides a very strong example of this power sharing mechanism, with Shaykh Zāyid having made great effort to create and fill executive positions in the expanding rentier state with less powerful members of the Āl-Nuhayyān family. Indeed, of particular interest during this period was the seemingly successful accommodation of the two rival branches of the dynasty whose disputes had frequently destabilised the ruling shaykh's position over the previous two centuries. Whereas both Shaykh Zäyid and his brother, the former ruler Shaykh Shakhbut, were both from the Sultān family line, a number of other prominent Abu Dhabi shaykhs were of the Khalifa line. Shaykh Zāyid therefore accorded all members of the Bin Khalifa Al-Nuhayyān with an appropriate share of power in the new administration. Indeed, this astute dynastic balancing act involved appointing Shaykh Mubarak Al-Nulhayyān as the UAE's first Minister of the Interior, while his brother, Shaykh Surūr Al-Nuhayyān, was elevated to serving as one of Zāyid's closest advisers. ${ }^{175}$ Although the Āl-Maktūm of Dubai remained segmented and quarrelling for longer; following British intervention against the trouble-causing Shaykh Juma and his sons, ${ }^{176}$ the emirate's ruling family was also able to consolidate itself in a similar fashion to the $\bar{A} l$-Nuhayyân by using the new positions and opportunities created by the rentier state to share power and to accommodate potentially divisive members of the family and the ruling elite. ${ }^{177}$ More recently in Sharjah, which has remained the least stable of the seven emirates; ${ }^{178}$ following a failed coup attempt in 1987 , the re-instated ruler immediately ensured that his new administration accommodated the main protagonists and provided them with significant consolation prizes. Most notably, Shaykh Abdul-Aziz al-Qāsimī, the leader of the coup, was appointed Crown Prince and deputy chairman of the new Sharjah 
Executive Council. Although these appointments were only temporary, with the ruler eventually dismissing Shaykh Abdul-Aziz in favour of his son, high-level power sharing was nevertheless a useful stopgap measure until the ruler was able to re-affirm his position. ${ }^{179}$

Conversely, it can be demonstrated that those traditional monarchies which have not allowed for greater power sharing and accommodation of other members of the ruling family have often suffered from considerable internal instability and, as a result, have been more vulnerable to divisive and revolutionary forces. The example of Libya is especially appropriate for this study as, with a small population, a tribal structure, and oil wealth, it in many ways used to resemble the Gulf States. However, unlike the dynastic monarchs of the Gulf, King Idris of Libya effectively blocked all of his relatives and their key associates from gaining any positions of power. Thus when revolution came in 1969, the monarchy quickly collapsed as all stood to gain, both those inside and outside of the ruling family. ${ }^{180}$ Similarly in Afghanistan, the traditional monarch Shah Zahir forced through a new constitution which barred all other members of the ruling family from occupying significant posts. Once again, when the inevitable struggle for power occurred, the monarchy soon disintegrated and a republic was duly formed. ${ }^{181}$ Thus, in states which fail to develop additional patrimonial mechanisms within the ruling families, their non-dynastic monarchies are more prone to failure as the ruler has to balance all forces of opposition on his own, and when he falls the monarchy will fall with him. Indeed, the crucial difference between these 'one bullet regimes' and the power sharing dynastic monarchies of the Gulf, and to a lesser extent Oman and Morocco, ${ }^{182}$ is that, quite apart from increasing the polity's vulnerability to assassinations, ${ }^{183}$ these regimes are far more likely to stccumb to internal challenges from disgruntled rival claimants, many of whom will have nothing to lose given their existing exclusion from power.

A second identifiable priority of these dynastic monarchies has been to safeguard the succession process from divisive and weakening forces. By maintaining the traditional bay'a mechanism and by institutionalising a crown prince mechanism, 
instability arising from succession disputes has now largely been eliminated in the Gulf States, and especially in the UAE. Indeed, many of the weaknesses normally associated with primogeniture have been avoided by requiring potential successors to have wide political support within the family in order to receive the necessary bay'a and approval from their elders. Thus, instead of following a clear succession pattern from father to eldest son, the strongest member of the family is able to succeed, thus preventing any unworthy or potentially discordant rulers from coming to power. ${ }^{184}$ Although technically a contradiction to the bay'a mechanism, the practice of appointing crown princes has further strengthened the succession process by formalising the inheritance of power and delegitimising rival claims. Crucially however, crown princes do not necessarily follow the primogeniture system and can therefore be used to complement bay'a approval by guaranteeing the succession of the most popular and able future ruler. $^{185}$

Dubai provides a particularly strong example of such succession arrangements. When Shaykh Rāshid Al-Maktūm, the aforementioned 'Father of Dubai', died in 1990 he was left with four sons. As would be expected, his eldest son, Shaykh Maktūm AlMaktūm, immediately succeeded his father and became the new Emir, while the second eldest son, Shaykh Hamdan Al-Maktūm, predictably became the deputy ruler. However, in April 1994, the late ruler's third son, Shaykh Muhammad Al-Maktūm, was proclaimed crown prince. ${ }^{186}$ To most observers accustomed with primogeniture this would seem an unusual development given that in most monarchies the crown prince would have automatically been the eldest son (or at least one of the sons) of the new ruler, Shaykh Maktūm Al-Maktũm, and certainly not one of his younger brothers. This awkward arrangement serves to indicate the internal bargaining that must have taken place within the dynasty shortly after their father's death. The highly motivated and ambitious Muhammad was satisfied with crown prince status and therefore the promise of future rulership. Moreover, nine years later the internal dynamics of Dubai's dynastic monarchy seem to be working given that the status quo is maintained, there exists a formal division of powers, and Muhammad is effectively able to run the day to day affairs of the emirate with the approval of his older brothers. ${ }^{187}$ 
In the near future Abu Dhabi will also be faced with the need for careful succession compromises. Although, thus far, the crown prince appointment remains in accordance with the customs of primogeniture, it is nevertheless important to note how Shaykh Zayid has attempted to balance the ambitions of the numerous other AlNuhayyān princes in an effort to safeguard his eldest son's succession. Essentially, the problem stems from the perceived division between the crown prince, Shaykh Khalifa, and Shaykh Zāyid's other prominent sons, many of whom are half brothers from the 'Bani Fatima bloc': the sons of Shaykh Zāyid's favoured wife, Shaykha Fatima. Such a rival faction may be led by either Shaykh Muhammad Al-Nuhayyān, the eldest of Fatima's sons and a dynamic personality who has carved out an important niche for himself in Abu Dhabi politics, or by the second eldest Bani Fatima, Shaykh Sultān AlNuhayyān. $^{188}$ Moreover, in addition to their common bloodline, these sons are predominantly western university educated and, as will be detailed later in this thesis, given the recent emergence of more technocratic blocs in Emirati politics, the Bani Fatima bloc may be more favoured by the UAE's government than Shaykh Khalifa. ${ }^{189}$ As such, Shaykh Zāyid has been actively brokering a détente between the different $\bar{A} l$ Nuhayyān factions by distributing positions of power in the federal and Abu Dhabi administrations amongst his various sons, with the objective that all factions should recognise the succession. ${ }^{190}$ Thus, on the one hand Shaykh Khalifa's position has been consolidated by a number of important appointments including the chairmanships of Abu Dhabi's Executive Council, Abu Dhabi's Supreme Petroleum Council, and the Khalifa Committee, which, as Abu Dhabi's highest financial body is responsible for the distribution of Abu Dhabi's funds. On the other hand, however, significant succession consolation prizes have included the appointment of Shaykh Muhammad Al-Nuhayyān to the important position of Army Chief of Staff, ${ }^{191}$ Shaykh Sultān Al-Nuhayyān's appointment as the UAE's Deputy Prime Minister, ${ }^{192}$ and more recently Shaykh Zāyid's creation of a new ministerial post, Head of the Presidential Office, specifically for his other Bani Fatima son, Shaykh Mansūr. ${ }^{193}$

Thirdly, also related to power sharing and the distribution of consolation prizes, the increasing evidence of collective action both within and between the dynastic ruling 
families of the Gulf must be seen as another key stabilising mechanism. Although it may be preferable for individuals to seek absolute rule, for the rest of the ruling family it is, however, collectively preferable for them to prevent such an occurrence and instead to preserve the dominance of the family as a group. Conforming to a 'prisoner's dilemma' model in which one's options have to be carefully considered alongside another's, collective action therefore promotes 'groupthink' logic. ${ }^{194}$ Thus, the preservation of dynastic monarchy may rest on the crucial ability of the majority of family members to bandwagon against any breakaway factions, normally exiling the renegade princes or accommodating their supporters within the dynasty. ${ }^{195}$ A key example of such collective action would of course be the replacement of Shaykh Shakhbut with his younger brother, Shaykh Zäyid, as ruler of Abu Dhabi. In 1966 several key members of the Âl-Nuhayyān family approached the British and requested that the ruler be removed and that measures be taken to preserve law and order during the transition. ${ }^{196}$ Thus, while it is popularly believed that the British ousted Shakhbut in favour of the more energetic and forward thinking Zāyid, ${ }^{197}$ it was really more of an internal decision within the ruling family. By building upon his popular support as governor of Al-'Ayn and by offering his relatives positions of power in the new oil state, Zāyid effectively became the leader of a bandwagon among the Āl-Nuhayyān dynasty, one which eventually grew to include every single member of the family except, unsurprisingly, Shakhbut's eldest son. ${ }^{198}$ More recently, following the aforementioned 1987 coup attempt in Sharjah, a bandwagon soon emerged which included not only members of the Sharjah ruling family, but also members of the other Emirati ruling families. Indeed, although initially supported by Abu Dhabi, ${ }^{199}$ Shaykh Abdul-Aziz and his supporters soon found themselves opposed not only by the many Sharjah notables still loyal to Shaykh Sultān, but also by the Āl-Maktūm of Dubai and even by the ruling families of other Gulf states. ${ }^{200}$ Similarly, in 2003 the government of Abu Dhabi chose to send tanks to the smaller emirate of Ra's al-Khaimah in an effort to safeguard the octogenarian Qāsim̄̄ ruler and his new crown prince following a controversial decision to remove power from his eldest son, Shaykh Khalid, who had effectively been regent for twenty years. ${ }^{201}$ Accordingly, it would seem there is growing evidence that Emirati rulers can now be reinstated or considerably reinforced 
following collective action from other neighbouring dynastic monarchies, which in turn suggests the emergence of a strong network of mutual support between these families.

\section{5 - Conclusion}

This chapter has provided an overview of how the UAE's polity and its traditional monarchies have managed to circumvent the 'Shaykh's Dilemma' of assimilating new groups alongside old by carefully combining traditional sources of legitimacy with structural and material resources in an effort to create a stable and resilient 'ruling bargain'. ${ }^{202}$ Specifically, it has been demonstrated how the polity has continued to draw upon personal legitimacy resources and, by fostering a patrimonialclientalist system of privileges, loyalties, and vertical linkages; how personal authority has remained a key component of the UAE's legitimacy formula even during an era of rapid population growth and urbanisation. Moreover, by reviving and in some cases reinventing cultural, religious, and ideological resources, the polity has further augmented its position by unifying most segments of the population behind shared memories, common causes, and a greater sense of identity. Thirdly, through astute constitutional engineering and the development of new bureaucracies and institutions it is also clear how the polity has managed to provide some degree of structural legitimacy while at the same time retaining its carefully managed patrimonial, or rather 'neo-patrimonial' network of relations.

At all levels, the region's substantial oil wealth has strengthened the UAE's legitimacy formula by providing enormous material resources and by facilitating the development of a distributive economy which, in turn, has allowed for a powerful 'rentier pact'. Essentially, by providing the bulk of the population with a package of distributed wealth and a comprehensive welfare state, the rulers have been able to purchase political acquiescence and considerable popular support from both locals and expatriates. Moreover, it is also important to note how this rentier pact has been particularly strong in the UAE given the relative weakness of the region's merchant elites at the beginning of the oil era. Unlike many of the other Gulf States, whose 


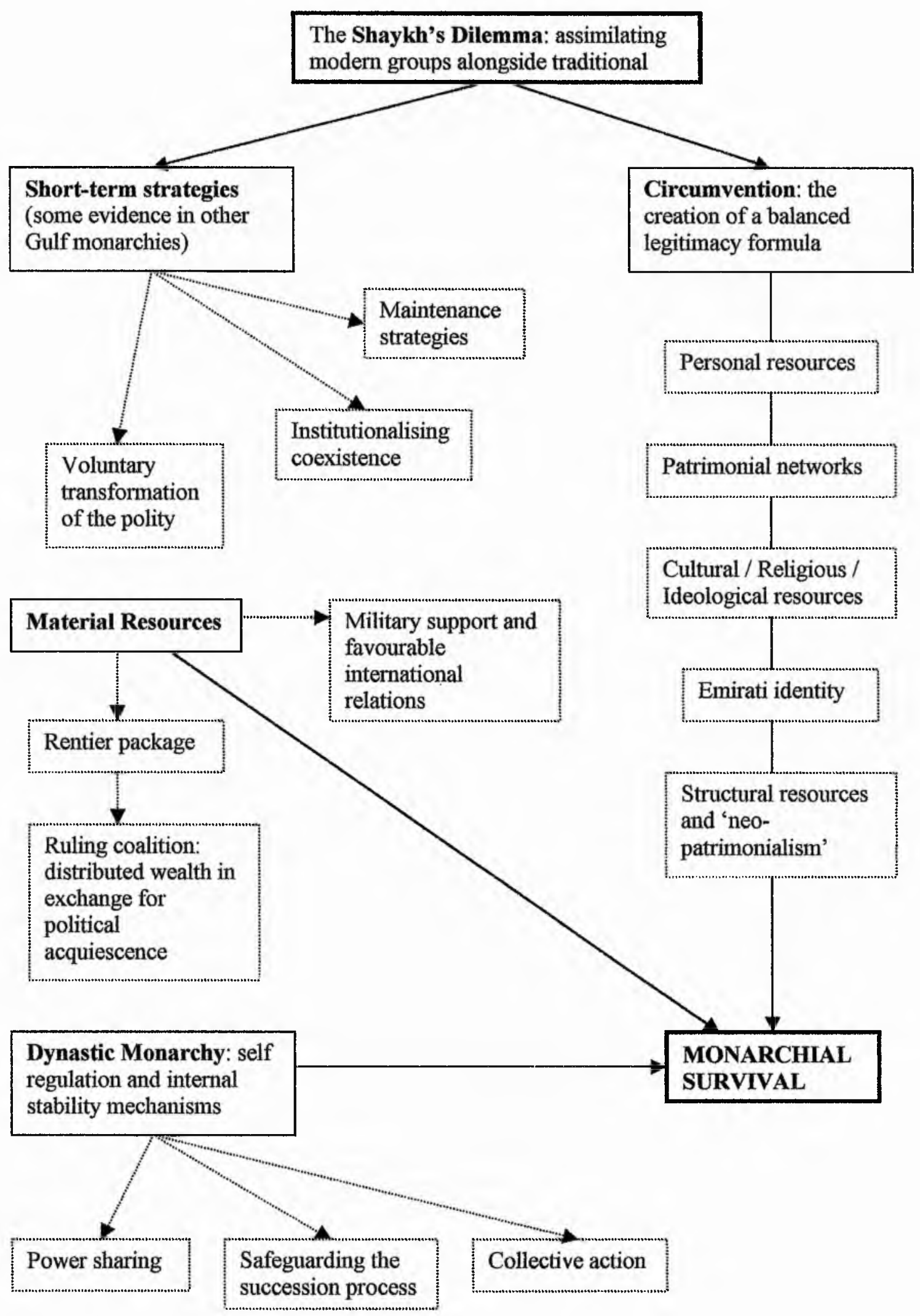


merchants were comparatively powerful when oil exports began; in the lower Gulf the merchants had suffered numerous setbacks and years of economic depression, thus making it easier to absorb them into a new rentier coalition and less likely for them to press for political reform. Further relating to the UAE's material resources, there is also little doubt that the region's favourable international relations with its powerful oilpurchasing allies have provided an important security umbrella. Indeed, without such protection and perceived support it would seem likely that the UAE and its monarchies would have eventually succumbed to the threat of more powerful expansionary states in an increasingly volatile region.

Finally, by evolving into large-scale dynasties complete with their own internal self-regulating mechanisms, the UAE's traditional monarchies have been able to warrant even better stability and far greater longevity. By carefully sharing positions of power in the new and more unitary rentier state, by safeguarding and guaranteeing the succession process, and by promoting greater collective action and bandwagoning against harmful factions, the ruling families have managed to avoid both internal divisiveness and damaging external influences. Essentially, the family itself has become an institution and has formed a layer of structural legitimacy in its own right. Indeed, as surrogate political parties, dynastic monarchies can be seen to have developed their own internal dynamic; a dynamic capable of making their members act positively for the group as a whole, and ultimately capable of reinforcing the existing neo-patrimonial and materially-based legitimacy formulae. See figure (vi).

\footnotetext{
${ }^{1}$ UAE MINISTRY OF PLANNING (2001), "UAE and Dubai: GDP at factor cost and per capita GDP 2000", in DUBAI DEPARTMENT OF ECONOMIC DEVLOPMENT (2001), "Development Statistics", Government of Dubai, pp.44, a GDP per capita of approximately $\$ 21,190$ can be calculated using current prices from the listed figure of 77,828 Dirhams

2 The UAE's GDP per capita of $\$ 21,190$ is higher than Italy's $\$ 19,962$, and only just below the UK's $\$ 21,921$. See UNITED NATIONS STATISTICS DIVISION (2002)

${ }^{3}$ FREEDOM HOUSE (2001), "Freedom in the World Country Ratings, 1972-73 to 2000-2001", New York, Freedom House, since 1972 Freedom House has published an annual assessment of states of freedom by assigning each country and territory the status of "Free," "Partly Free," or "Not Free" by averaging their political rights and civil liberties ratings. The UAE was given a political rights score of 6 and a civil liberties score of $5(6,5)$. Those whose ratings average 1-2.5 are generally considered "Free," 3-5.5 "Partly Free," and 5.5-7 "Not Free." Comparisons would include a score of $(1,1)$ for the USA, a score of $(4,5)$ for Turkey, and a score of $(7,7)$ for Saudi Arabia.
} 
${ }^{4}$ For a greater discussion of the 'King's dilemma' see HUNTINGTON, Samuel P (1968), "Political Order in Changing Societies", New Haven, Yale University Press, pp.142

${ }^{5}$ For a greater discussion of 'dynastic monarchy' see HERB, Michael (1999), "All in the Family: Absolutism, Revolution, and Democracy in the Middle Eastem Monarchies", New York, State University Press

6 LERNER, Daniel $(1958,1964)$, “The Passing of Traditional Society: Modernising the Middle East", Toronto, Free Press, pp.399

${ }^{7}$ See DEUTSCH, Karl W (1961), "Social mobilisation and political development", in AMERICAN POLTICAL SCIENCE REVIEW, Volume 55 Number 3, September 1961; and HUDSON, Michael C (1977), "Arab Politics: the Search for Legitimacy", New Haven, Yale University Press, pp.11-12, Deutsch posits social mobilisation as being an "interrelated set of growth processes including economic development, mass media exposure, interpersonal communications, urbanisation, and education."

${ }_{9}^{8}$ HUNTINGTON (1968), pp. 142

${ }^{9}$ Ibid. pp. 140

${ }^{10}$ Ibid. pp. 169

${ }^{11}$ Ibid. pp.191

12 lbid. pp.179-191

${ }^{13}$ HALPERN, Manfred (1963, 1965), "The Politics of Social Change in the Middle East and North Africa", Princeton University Press, pp. 42; for a discussion of such pre-emptive action to reform from above see NONNEMAN, Gerd (2001), "Rentiers and autocrats, monarchs and democrats, state and society: the Middle East between globalisation, human 'agency', and Europe", in INTERNATIONAL AFFAIRS, Volume 77 Number 1, January 2001, pp.144-145

${ }^{14}$ HERB (1999), pp.23, a letter from TC Fowle, Political Resident in the Persian Gulf to Shaykh Sa'id Al-Maktûrm, Ruler of Dubai, $1^{\text {st }}$ October 1938 (IOR:LP\&S/12/3827)

${ }^{15}$ Following merchant unrest and coaxed by the British, Shaykh 'Ahmad Al-Sabāh established a council in June 1938 comprising of elected members. The Kuwaiti merchants had previously requested universal education, immigrant control, a government-sponsored hospital, and a demand that Kuwait work more closely with Iraq to improve cultural cooperation and trading links. See JOYCE, Miriam (1998),

"Kuwait 1945-1996: An Anglo-American perspective", London, Frank Cass, introduction xiv-xv

${ }^{16}$ Al-ABED, Ibrahim (2001), "The Historical Background and Constitutional Basis of the Federation" in Al-ABED, Ibrahim (ed.) (2001), "The United Arab Emirates: A New Perspective", Abu Dhabi, Trident

${ }^{17}$ HEARD-BEY, Frauke (1982), "From Trucial States to United Arab Emirates", London, Longman, pp.356-257, Heard-Bey describes how, during the federal negotiations, Bahrain had, "modified its position in the light of the recent survey of public opinion conducted by the UN emissary and in response to the popular requests for more democratic institutions".

${ }_{18}^{18}$ BBC MONITORING (2002), "Change in Bahrain Welcomed", London, $15^{\text {th }}$ February 2002

${ }^{19}$ see KAMRAVA, Mehran (2002), "Civil Society and Political Democratisation in Comparative Perspective: Lessons from Latin America and the Middle East", presented to the University of Warwick in February 2002

${ }^{20}$ See section 1.3

${ }^{21}$ See section 4.2.1

${ }^{22}$ See UNITED STATES LIBRARY OF CONGRESS (2001), "Country Study: Jordan"

${ }^{23}$ See UNITED STATES CENTRAL INTELLIGENCE AGENCY (2001), "World Fact book: Morocco", January 2001

${ }^{24}$ See KAMRAVA (2002), as Kamrava describes, King Hassan and his son Muhammad VI, the patrons of such coexistence in Morocco, considered the role of democracy and the concept of political participation as "only letting political parties debate and fight over issues that in the grand scheme of things are politically marginal insofar as state-society relations are concerned."

${ }^{25}$ HUNTINGTON (1968), pp.181

${ }^{26}$ HIRO, Dilip (1987), "Iran under the Ayatollahs", London, pp. 31-36

${ }^{27}$ ISMAEL, Jacqueline S (1993), "Kuwait: Dependency and Class in a Rentier State", University Press of Florida, pp.82-83

${ }^{28}$ Ibid. pp.86-87

${ }^{29}$ Ibid. pp. 185

${ }^{30}$ HUNTINGTON (1968), pp. 188-190

${ }^{31}$ See CORDESMAN, AH (1997), "Bahrain, Oman, Qatar and the UAE: Challenges of Security", Colorado, Westview Press

${ }^{32}$ Personal Interviews, Abu Dhabi, March 2001; Sharjah, December 2001 and March 2002

${ }^{33}$ See for example, the level of financial co-option in Sharjah's civil society organisations, PRESS

AFFAIRS DIRECTORA'TE OF SHARJAH EMIRI COURT, (1988), "Sharjah in Fifteen Years Time: 1974-1988", Sharjah, Al-Bayan Press, pp.183-185 
${ }^{34}$ See for example, MADAD, Sanã (2001), "Welfare societies will need a federal licence", in KHALEEJ TIMES, $27^{\text {th }}$ September 2001

${ }^{35}$ UNITED STATES DEPARTMENT OF STATE (2001), "United Arab Emirates: Country Reports on Human Rights", Bureau of Democracy, Human Rights, and Labour, $23^{\text {rd }}$ February 2001, section 2(a)

${ }^{36}$ KHALEEJ TIMES (2001), "Country's judiciary is independent: Dhahiri", 6 th December 2001, referring to the Minister of Islamic Affairs' admission that the ministry either provides written sermons or approves suggested topics by Islamic clergy in the UAE. Also, as will be discussed in the final chapter of this thesis, over $99 \%$ of Sunni mosques are state-owned, with most of the Shr' a mosques receiving substantial government subsidies.

${ }^{37}$ ZABARAH, Muhammad 'Ahmad (1982), "Yemen: Traditionalism versus Modernity", New York, Praeger, pp.43-44, writing of the Imâm, Zabarah explains, "The traditionalist recognising that his powers are derived from his acceptance of traditional values, fights to preserve those values that are familiar to him, and those unfamiliar to him cannot be tolerated."

${ }^{38}$ Ibid. pp. $44-45$

${ }^{39}$ HUDSON (1977), pp.1-2 and 7-11, In his 'mosaic model' for conceptualising change and legitimacy in traditional polities Hudson emphasises the persistence and resilience of selected primordial and parochial loyalties during rapid modernisation, and even accepts that in some cases these traditional structures can be formalised and strengthened.

${ }^{40}$ Like Hudson, David Easton reasoned that there were three main areas of resources available to traditional rulers: personal, ideological and structural, see.EASTON, David (1965), "A systems analysis of political life", New York, Wiley, pp.287-303, and HUDSON (1977), pp.18

${ }^{41}$ See section 1.3

42 ENCYCLOPAEDIA OF ISLAM NEW EDITION (1960), London, pp. 1 114, for a definition of the bay'a principle

${ }^{43}$ As explained in the historical background, the Bedu's notion of citizenship underscored allegiance to a specific ruler rather than any sense of equality or territorial identity, also see NONNEMAN (2001),

pp. 154

${ }^{44}$ HUDSON (1977), pp.84

${ }^{45}$ Personal interviews, Abu Dhabi, September 2002, with reference to Shaykh Zāyid's ongoing popular support. For a discussion of the role of charisma in determining personal authority see MOORE, Clement H (1970), "Politics in North Africa", Boston, Brown, pp.94; and HUDSON (1977), pp.19-20 ${ }_{46}$ Personal interviews, Abu Dhabi, September 2002, with reference to Shaykh Zãyid's ongoing popular support.

${ }_{47}^{4 L}$-QASIMII, Shaykh Fahim bin Sultân (1999), "Symposium on Shaykh Zāyid", in MIDDLE EAST POLICY, Volume 6 Number 4, June 1999, pp.2, this is an extract from the speech made by the UAE's Minister of Economy and Commerce to a conference convened by the Middle East Policy Council on $20^{\text {th }}$ April 1999

${ }_{48}^{4}$ Personal interviews, Dubai, March 2001 and October 2002, with reference to the popular memory of Shaykh Rāshid Al-Maktūm

${ }_{49}$ HUDSON (1977), pp.200, Hudson is quoting a 'high-ranking subordinate' of Shaykh Rāshid AlMaktūm

${ }^{50}$ Personal interviews, Sharjah, December 2001; and Ra's al-Khaimah, December 2001

${ }^{51}$ See section 2.3.2 with regard to the Iragi monarchy's unpopular relations with Britain, and section 2.4 with regard to the weaknesses associated with the Afghani and Libyan thrones

${ }^{52}$ See section 1.3

${ }^{53}$ See sections 2.4 and 4.2

${ }^{54}$ ABDULLAH, Muhammad Morsy (1978), "The United Arab Emirates: A Modern History", London, Croom Helm, pp.138

${ }^{55}$ Ibid. pp. 140

${ }^{56}$ HUNTINGTON (1968), pp.186, see Huntington's argument with reference to Ethiopia

${ }^{57}$ Any visitor to the Gulf States is struck by the way traditional dishdäsha and abāya are worn exclusively by the local nationals, almost as a uniform of privilege. See GAUSE, F Gregory (1999), "The persistence of monarchy in the Arabian Peninsula: a comparative analysis", in KOSTINER, Joseph (ed.) (2000), "Middle East monarchies: the challenge of modernity", Colorado, Rienner, pp.177; and CRYSTAL, Jill $(1990,1995)$, "Oil and Politics in the Gulf. Rulers and Merchants in Kuwait and Qatar", New York, Cambridge University Press, pp.161-164

${ }^{58}$ HEARD-BEY, Frauke (1999), "The UAE: A Quarter Century of Federation" in HUDSON, Michael C (ed.) (1999), "Middle East Dilemma: The politics and economics of Arab integration", London, Tauris, pp. 145

${ }^{59}$ UAE government spokesman speaking in Abu Dhabi, March 2002, quoting Shaykh Zãyid's speech regarding marriage funds in the UAE 
${ }^{60}$ HEARD-BEY, Frauke (1996), "From Trucial States to United Arab Emirates - new edition", London, Longman, pp. 397

${ }^{61}$ Ibid. pp. 397

${ }^{62}$ See CITIBANK UAE (2002), “Annual report", Citibank Dubai

${ }^{63}$ FEDERAL LAW (1984, 1988), Article 3 of Updated Federal Law No. (8) of 1984 as amended by

Federal Law No. (13) of 1988 regarding Commercial Companies

${ }^{64}$ FEDERATION OF UAE CHAMBERS OF COMMERCE AND INDUSTRY (1993), "The establishment of economic enterprises in the UAE: in light of the provisions of the law and its executive regulations", Abu Dhabi, pp.34

${ }_{65}$ Personal interviews, Dubai, April 2001; and Al-Ayn, April 2001; and see section 3.3

${ }^{66}$ FENELON, Kevin (1973), "The United Arab Emirates: An Economic and Social Survey", London, Longman, pp. 106

${ }^{67}$ See DAVIS, E (1991), "Theorising statecraft and social change in Arab oil-producing countries" in DAVIS, E and GAVRIELIDES, N (eds.) (1991), "Statecraft in the Middle East: oil, historical memory and popular culture", Miami, Florida International Press, pp.13, as cited by Khalaf

${ }^{68}$ FINDLOW, Sally (2000), "The UAE: Nationalism and Arab-Islamic Identity", Abu Dhabi, Emirates Centre for Strategic Studies and Research, ECSSR OCCASIONAL PAPER, Number $39, \mathrm{pp} .2$

${ }^{69}$ See sections 3.4 and 5.4

${ }^{70}$ KHALAF, Sulayman (1999), "Camel Racing in the Gulf: notes on the evolution of a traditional cultural sport", ANTHROPOS 1999, pp.85-106; also see KHALAF, Sulayman (2000), "Poetics and politics of newly invented traditions in the Gulf: camel racing in the United Arab Emirates", in ETHNOLOGY, Volume 39 Number 3, Summer 2000, pp.243-261

${ }^{71}$ ABU 'A THIRA, Sa'id (1987), "Ship of the desert sails back", in KHALEEJ TIMES, 24 "March 1987

${ }^{72}$ HUDSON (1977), pp.203

${ }^{73}$ Indeed, Islam can be interpreted to justify and legitimise absolute rule (a shepherd, $r a$ ' $i y y$ was to look after his flock, ra' aiyya), HUDSON (1977), pp.91

${ }^{74}$ See section 5.5.2

${ }^{75}$ See ABERCROMBIE, Nicholas, HILL, Stephen, and TURNER, Bryan S (1994), "The Penguin Dictionary of Sociology", London, Penguin, "Within the natural law tradition, the justice of social laws and institutions was thought to depend on their conformity to certain universal laws of nature. All human beings, by virtue of their membership in humanity and as part of this natural order, enjoyed certain natural rights, such as a right to freedom. Natural law theory concerned itself with the moral content of laws and developed the criterion that true laws could not be unjust laws."

${ }^{76}$ See FIELDS, Michael (1987), "Arabia keeps the faith", in The FINANCIAL TIMES, $10^{\text {th }}$ January, 1987, "There has been an extraordinary and totally unnecessary increase in the number of mosques. Two years ago, James Bill, Professor of Government and the University of Texas, conducted his own survey and discovered that the number of mosques has tripled in the previous decade. Saudi Arabia had at least 20,000 , one for every 100 adult male citizens."

${ }^{77}$ SHARJAH LAW (2001), Local Instructions No 1 of 2001 and Executive Council Resolution No 12 of 2001, supplied by AFRIDI \& ANGELL, Dubai, see appendix (ii)

${ }^{78}$ Personal interviews, Sharjah, March and April 2002

${ }^{79}$ See GAUSE (1999); also see GAUSE, F Gregory (1994), "Oil monarchies: domestic and security challenges in the Arab Gulf states", New York, Council on Foreign Relations Press, pp.31-39

${ }^{80}$ THE ECONOMIST (1981), London, $25^{\text {th }}$ April 1981, pp.47

${ }^{81}$ Personal interviews, Dubai, April 2002

82 JOHNSTON, Philip (2001), "Fingers point at Iraqi leader as evidence grows", in The DAILY TELEGRAPH, $1^{\text {st }}$ December 2001, "How were the terrorists funded? There is no record of direct transactions of money from bin Laden to any of the hijackers. However, American officials have traced $\$ 500,000$ used to pay for flight training, airplane tickets, car rentals and other logistics back to the United Arab Emirates. Atta received $\$ 100,000$ in his bank account from moneychangers in Sharjah, one of the emirates. Marawan al-Shehhi, believed to have piloted the second plane to the World Trade Centre, also received money through Sharjah. Jarrah is said to have met Iraqi intelligence officers in the UAE."

${ }^{83}$ The arrest took place in October 2002, but details were withheld, including the arrest's location which was reported to be an 'undisclosed Gulf state'. Only on $24^{\text {th }}$ December 2002, Christmas Eve and a traditionally low impact news day, were details finally released.

${ }^{84}$ McGRORY, Daniel (2002) "UAE seizes Al-Qaeda's Gulf leader", in The TIMES, $24^{\text {th }}$ December 2002, "One of Al-Qaeda's most wanted terrorists has been arrested in the United Arab Emirates as he was about to launch a wave of bomb attacks on vital oil installations. Abdel Rahim al-Nashri, a Saudi national, is seen as one of Al-Qaeda's top ten agents. He is said to be its head of operations in the Gulf. US authorities have been questioning him since his arrest in the Gulf at the end of October, though it is 
now suggested he was plotting suicide attacks including using oil tankers as weapons. A UAE official said yesterday that al-Nashri was seized as 'he prepared to blow up economic installations inside the country'. The official said 'he planned operations aimed at the highest number of casualties among nationals and foreigners, but shifted to alternative plans when that failed.' He is alleged to have played a major role in the attack on the USS Cole in Yemen in October 2000 in which 17 US personnel died".

${ }^{85}$ For a discussion of ideology and secular nationalism in conservative regime see APTER, David E (1965), "The Politics of Modernisation", Chicago, Chicago University Press, pp.266; and HUDSON (1977), pp.21\&22

${ }^{86}$ ABDULLAH (1978), pp. 112

${ }^{87}$ AL-SAYEGH, Fatma (1998), "Merchants' role in a changing society: the case of Dubai, 1900-1990", in MIDDLE EASTERN STUDIES, Volume 34 Number I, January 1998, pp.98

${ }^{88}$ ABDULLAH (1978), pp.74

${ }^{89}$ Ibid. pp. 144

90 PECK, Malcolm C (1986), "The United Arab Emirates: A Venture in Unity", Boulder Colorado, Westview Press, pp.80

91 ABDULLAH (1978), pp. 144

${ }^{92}$ Also see ANDERSON, Lisa (2000), "Dynasts and nationalists: why monarchies survive", in

KOSTINER, Joseph (ed.) (2000), "Middle East monarchies: the challenge of modernity", Colorado, Rienner, pp.61, Anderson argues that nationalism can be limited due to the primacy of kinship and the nourishment and strengthening of existing kinship patterns and loyaities, as "... this denies the notion of equality that under girds the nationalist conception of citizenship"

${ }^{93}$ Examples would include Syria's withdrawal from the United Arab Republic and Egypt's distrust of Iraq. See YAPP, ME (1996), "The Near East since the First World War. a History to 1995", London, Longman, pp.43

${ }^{94}$ With reference to the Gulf monarchies see HALLIDAY, Fred (1999), "Monarchies in the Middle East: a concluding appraisal", in KOSTINER, Joseph (ed.) (2000), "Middle East monarchies: the challenge of modernity", Colorado, Rienner, pp. 290

${ }^{95}$ See: WAM (2001), "UAE paper calls for an international coalition against Israeli terror", Abu Dhabi (Wikālat Anbä" al-Imārāt: the UAE News Agency), $21^{\text {st }}$ October 2001; ECSSR (2002), "UAE and the Red Crescent", Abu Dhabi, Emirates Centre for Strategic Studies and Research; WAM (2002), "UAE to rebuild demolished Palestinian houses", $15^{\text {th }}$ January 2002; HELLYER, Peter (2001), "The Evolution of UAE Foreign Policy", in AL-ABED, Ibrahim (ed.) (2001), "The United Arab Emirates: A New

Perspective", Abu Dhabi, Trident, pp.169-170 for discussion on UAE aid for Iraq, pp.172-173 for UAE aid for Palestine, and pp. 177 for UAE aid for Kosovo; see PECK (1986), pp.381; ABDULLAH (1978), pp.143; and HEARD-BEY (1982), pp.381 for discussion of Abu Dhabi economic aid for developing Arab states

96 ABDULLAH (1978), pp.112

${ }^{97}$ Recent examples would include the 2002 rallies staged in Sharjah and Dubai, the latter of which was attended by Shaykh Muhammad Al-Maktum, the Crown Prince of Dubai.

${ }^{98}$ HALL, Marjories J (1987), "Business Laws of the UAE", Volume 1, London, for a discussion of Federal Law No.15 of 1972 regarding the boycott of Israel

${ }^{99}$ See section 4.3.1

100 HUDSON (1977), pp.4

101 UAE government spokesman speaking in Abu Dhabi, March 2002, quoting part of Shaykh Zãyid's 1966 accession speech

102 See for example, HUDSON (1977), pp.202

${ }^{103}$ FINDLOW (2000), pp. 16-17 and $21-23$

${ }^{104}$ Ibid. pp. 21-23

${ }^{105}$ see PECK (1986), pp.381; ABDULLAH (1978), pp.143; and HEARD-BEY (1982), pp.381 for a discussion of Abu Dhabi economic aid

106 FINDLOW (2000), pp. 29-30

${ }^{107}$ Ibid. pp. $29-30$

${ }^{108}$ Interestingly Findlow's responses from Al-'Ayn university students of Dubai and Ra's al-Khaimah origins were similarly emirate-specific (with only $15 \%$ claiming 'UAE / Emirati' identity), again reflecting the relative economic power and proud histories of these emirates. See FINDLOW (2000), pp.29-30 and see appendix (ii); for a greater discussion of Dubai's commercial history see section 3.8 ${ }^{109}$ For an explanation see ABERCROMBIE, HULL and TURNER (1994), "legal-rational authority is the characteristic form of authority in modern society. Within bureaucracy, a command is held to be legitimate and authoritative if it has been issued from the correct office, under the appropriate regulations and according to appropriate procedures. The authority of officials depends, not on tradition or charisma, but on a consensus as to the validity of rules of procedure which are perceived as rational, fair and impartial."; also see HUDSON (1977), pp.199 
${ }^{110}$ Ibid. pp.199; and see HUNTINGTON (1968), pp.12

${ }^{111}$ HALPERN (1963,1965), pp.353

${ }^{112}$ Tilly argues that the origins of a strong state must lie in its fiscal ability and tax-gathering structures, for a good discussion of Tilly's views see CRYSTAL $(1990,1995)$, pp.194; similarly Chaudhry argues that extractive structures are a crucial sign of state strength, see CHAUDHRY, Kiren Aziz (1997), "The price of wealth: economies and institutions in the Middle East", New York, Cornell University Press ${ }^{113}$ See section 1.5

${ }^{114}$ Personal Interviews, Abu Dhabi, April 2001, December 2001, March 2002, September 2002

${ }^{115}$ HUDSON (1977), pp.200

${ }^{116}$ UAE government spokesman speaking in Abu Dhabi, March 2002, described there being, ".... nine national government ministries, one state bank and one social security authority in the UAE, in addition to a plethora of emirate-specific government departments, e.g. Dubai's Department for Tourism and Commerce Marketing. Parallel to, and, on occasion, interlocking with, the federal institutions, each of the seven emirates also has its own local government. Although all have expanded significantly as a result of the country's growth over the last 27 years, these differ in size and complexity from emirate to emirate, depending on a variety of factors such as population, area, and degree of development."

${ }^{117}$ See section 4.4

${ }^{118}$ BUSINESS IN DUBAI (2001), Dubai Chamber of Commerce and Industry, Volume 1 Issue 3, March 2001, pp.14-15, excerpt taken from a speech given in Switzerland in early 2001 by Shaykh Muhammad Al-Maktũm

${ }_{119}$ AL-QASIMII, Shaykh Fahim bin Sultān (1999), "Symposium on Shaykh Zāyid", in MIDDLE EAST

POLICY, Volume 6 Number 4, June 1999, pp.2, this is an extract from the speech made by the UAE's Minister of Economy and Commerce to a conference convened by the Middle East Policy Council on $20^{\text {th }}$ April 1999

${ }_{120}$ KAMRAVA, Mehran (2000), "Politics and society in the developing world", New York, Routledge, pp. 6 for a discussion of bureaucracies in developing states

${ }_{121}^{12}$ Ibid. pp.4-5

122 SALDAMANDO, Martin (2001), "Human rights in the UAE", in STAR MAGAZINE, 23"th September 2001

${ }^{123}$ Ibid.

${ }^{124}$ Personal interviews, Abu Dhabi, March 2001; Dubai, December 2001; Sharjah, December 2001 and September 2001

${ }_{125}$ For a further discussion of the UAE's constitution see (in Arabic) BATIKH, Ramadban Muhammad (1997), "The Development of Political and Constitutional Thought in the UAE", University of the UAE, Al-"Ayn; and see (in Arabic) SHARAH, Naji Sadiq (1995), "The UAE: Politics and Rulership", Al-Kitab al-Jamiy, UAE

${ }^{126}$ For a detailed analysis of government co-option and control over various civil society, religious, and press associations, see the final chapter of this thesis, section 5.5.2

${ }^{227}$ HALPERN (1963,1965), pp. 356-357

128 BEBLAWI, Hazem (1987), "The rentier state in the Arab world" in BEBLAWI, Hazem, and LUCIANI, Giacomo (eds.) (1987), "The rentier state", New York, Croom Helm, pp.51

${ }^{129}$ See section 1.4 .2

${ }^{130}$ GAUSE (1994), see chapter 3 'oil and politics', Gause argues that the four-fold increase in oil prices between 1973 and 1974 made oil revenue the overwhelming controlling factor in the economies of the Gulf states. See Gause's tables $2 \mathrm{a}-2 \mathrm{f}$ for a statistical analysis of how oil came to dominate these economies.

${ }^{131}$ To give an idea of the relatively small numbers of workers involved in the UAE's oil industry, of the present-day workforce of around $1,853,000$ only 26,000 or $1.4 \%$ are actively employed in the oil sector. Calculated from figures supplied by UNITED ARAB EMIRATES MINISTRY OF PLANNING (2002), "UAE and Dubai: employment by economic sectors - 2001", in DUBAI DEPARTMENT OF ECONOMIC DEVELOPMENT (2002), "Development Statistics", Government of Dubai, pp.30

${ }^{132}$ CRYSTAL (1990,1995), pp.6-7, Moreover, as Crystal noted in her study of oil and politics, almost all other single commodity-exporting states require at least some accommodation between the rulers and the economic elites who control the workforce

${ }_{133}$ BEBLAWI (1987), pp.50

${ }^{134}$ Ibid. pp.52; for a greater explanation see LUCIANI, Giacomo (1987), "Allocation versus production states: a theoretical framework", in BEBLAWI, Hazem, and LUCIANI, Giacomo (eds.) (1987), "The rentier state", New York, Croom Helm, pp.63-82

${ }^{135}$ PECK (1986), pp.93

${ }^{136}$ With regard to UAE nationals in Dubai, $10.4 \%$ of their per capita wealth is derived from government transfers, see DUBAI MUNICIPALITY (1999), "Results of income and expenditure survey - Dubai city, 1997-1998", Administrative Affairs Department, Statistics Centre, May 1999, pp.151 
${ }^{137}$ BEBLAWI (1987), pp.50

${ }^{138}$ According to recent income surveys, only $0.4 \%$ of non-UAE national Arab income is derived from government transfers, with $0 \%$ of European and Asian income derived from transfers. See DUBAI MUNICIPALITY, pp.151

${ }^{139}$ Personal interviews, Dubai, September 2002

${ }^{140}$ See section 1.4.2

${ }^{141}$ CRYSTAL (1990,1995), pp. 10-11, with reference to merchants in Kuwait and Qatar

${ }^{142}$ For a discussion of the massive extent of the oil resources of the UAE and the other GCC states see (in Arabic) AL-KAWARI, Ali Khalifa and AL-SĀDUN, Jasim (1996), "The GCC Countries - A Futuristic View", Development Forum Annual Meeting Documents, January 1995, Girttas Publishing House, Kuwait, pp.32

${ }^{143}$ CRYSTAL (1990,1995), pp.1

${ }^{144}$ Ibid. pp. 196

${ }^{145}$ The UAE commands $9.8 \%$ of the world's proven crude oil reserves. In 1997, the UAE's petroleum exports amounted to nearly 800 million barrels making it the world's $6^{\text {th }}$ greatest exporter. Iran's exports were around 944 million barrels and Russia's were around 910 million barrels. See UNITED STATES ENERGY INFORMATION ADMINISTRATION - EIA (1997), "Energy and Petroleum Exports thousands of barrels per year"

${ }^{146}$ Qatar produces around 170 million barrels per year making it only the world's $18^{\text {th }}$ largest oil exporter, and Bahrain's oil industry has now all but closed down with the emirate now ranked $74^{\text {th }}$ in global oil exports. See UNITED STATES ENERGY INFORMATION ADMINISTRATION (1997)

${ }^{147}$ At over 400 million barrels per year, Kuwait is only just ranked outside of the world's top ten oil exporters. See UNITED STATES ENERGY INFORMATION ADMINISTRATION (1997)

${ }^{148}$ See CRYSTAL $(1990,1995)$

149 Personal interviews, Abu Dhabi, March 2001, with reference to the rentier compensation of former merchant elites

${ }^{150}$ See section 1.4.3

${ }^{151}$ See section 4.3.1 with reference to the constitutional crisis

${ }^{152}$ Gause, Halliday and Weitzman all contend that in addition to oil wealth and rentier networks, an explanation of the survival of these monarchies would be incomplete without also taking into account the external military and political support that many of these states have enjoyed. See GAUSE (1999);

HALLIDAY (1999); and WEITZMAN, Bruce Maddy (1999), "Why did Arab monarchies fall? An analysis of old and new explanations", in KOSTINER, Joseph (ed.) (2000), "Middle East monarchies: the challenge of modernity", Colorado, Rienner

${ }^{153}$ See (in Arabic) Al-A YDERUS, Muhammad Hassan (1983), "Political Developments in the UAE", Zat al-Salasil Publications, Kuwait, pp.164-165, the two smaller islands were the Greater and Lesser Tunbs, or rather 'Tunb al-Kubrā and Tunb al-Sughră.

${ }^{154}$ See JOYCE, Miriam (1998), "Kuwait 1945-1996: An Anglo-American perspective", London, Frank Cass, pp.93-114

${ }_{155}^{155}$ PECK (1986), pp.120

${ }^{156}$ Personal interviews with regard to western military support, Abu Dhabi, April 2001 and April 2002 (at IDEX); Dubai, December 2001 and September 2002

${ }^{157}$ Ibid.

${ }^{158}$ See FOLEY, Sean (1998), "The United Arab Emirates: Political Issues and Security Dilemmas", Middle East Review of International Affairs (MERIA), Volume 3 Number 1 March 1998

${ }_{159}$ Personal interviews with regard to western military support, Abu Dhabi, April 2001 and April 2002 (at IDEX); Dubai, December 2001 and September 2002

${ }_{160}$ Quoting Shaykh Muhammad Al-Maktūm, Crown Prince of Dubai and UAE Minister of Defence, speaking at the 2003 IDEX conference in Abu Dhabi. EMIRATES TELEVISION (2003), "Emirates stable and secure, says Muhammad", Abu Dhabi, 17 ${ }^{\text {th }}$ March 2003

${ }_{161}$ WEITZMAN (1999), pp.41

${ }^{162}$ KEDOURIE, Elie (1984), "The Kingdom of Iraq: a retrospect", in KEDOURIE, Elie (ed.) (1984),

"The Chatham House version and Other Middle Eastern Studies", New Haven, University Press of New England, pp.278

${ }^{163}$ See GAUSE, F Gregory (1992), "Gulf Regional Politics: Revolution, War and Rivalry", in

WRIGGINS, Howard (ed.) (1992), "The Dynamics of regional politics: four systems on the Indian Ocean Rim", New York, Columbia University Press

${ }^{164}$ Personal interviews with regard to western military support, Abu Dhabi, April 2001 and April 2002 (at IDEX); Dubai, December 2001 and September 2002

${ }_{165}$ For a further discussion of oil and favourable superpower relations see (in Arabic) AL-KHALIJ

ARAB STUDIES (1991), "Guif and Arab Security", November 1991, pp.3; and see (in Arabic) AL- 
HAMID, Muhammad 'Ahmad (1997), "Gulf Security and its impacts on the GCC", ECSSR, Abu Dhabi, Emirates Lectures Series, Number 16

166 See KEEGAN, John (2002), "Bush faces long wait to build up enough forces against Baghdad", in The DAILY TELEGRAPH, $5^{\text {th }}$ September 2002

${ }^{167}$ BUSINESS MONITOR INTERNATIONAL (2003), "The United Arab Emirates", second quarter report, pp.9, these groups were to boycott US goods to show solidarity with the Palestinians and the innocent Iraqis

${ }_{168}$ Personal correspondence, Sharjah, March 2003

${ }^{169}$ Personal interviews with UAE nationals, Dubai Chamber of Commerce and Industry, December 2001; and Abu Dhabi, April 2002. Both Dubai and Sharjah are now believed to have run out of oil.

${ }^{170}$ CRYSTAL (1990,1995), pp. 10-11

${ }^{171}$ Ibid. pp. 2

172 HERB (1999), pp. 3 Herb claims in his comparative study of ruling families in the Middle East that the dominance of one large and cohesive family over the state, rather than oil wealth, education, military support, external political support, representative institutions, selective marriages, charismatic rulers, or any other factors is the key to survival.

${ }^{173}$ See section 1.3

174 HERB (1999), pp.136-137, In 1948 the nephew of the ruler of Sharjah used his position as a wäli to gain immense local popularity and power by supporting those who wanted a reduction in the pearling tax imposed by the ruler. By successfully defying the ruler he managed to build sufficient support to enable him to take over as ruler of nearby Ra's al-Khaimah.

${ }^{175}$ PECK (1986), pp.126-27

176 HERB (1999), pp. 141-144

177 Personal interviews, Dubai, March 2001, with reference to the British intervention against Shaykh

Juma and new job opportunities for prominent Al-Maktûm members at the beginning of the oil era.

${ }^{178}$ In 1972 Shaykh Khalid al-Qāsimī was assassinated in an attempted coup by one of his cousins. See

PECK (1986), pp.128

${ }^{179}$ BROWN, Gavin (1998), "OPEC and the World Energy Market", London, Longman, pp.359

${ }^{180}$ HERB (1999), pp.184, see table 7.1 "Libya, the Gulf monarchies and Saudi Arabia compared"

181 Ibid. pp.239

182 Ibid. pp. 9

${ }^{183}$ Ibid. pp. 237

184 Ibid. pp. $237-238$

185 Ibid. pp.36-37

${ }^{186}$ ECONOMIST INTELLIGENCE UNIT' (2000), "United Arab Emirates", pp.5

187 Ibid. pp.7

${ }^{188}$ Ibid. pp. 7

189 Personal interviews, Abu Dhabi, April 2001 and April 2002; and personal interviews, Al-Maktūm Institute of Dundee, July 2002; also see FOLEY (1998); see section 4.5

${ }^{190}$ ECONOMIST INTELLIGENCE UNIT (2000), pp.5

191 Ibid. pp.9

${ }^{192}$ See BUSINESS MONITOR INTERNATIONAL (1998), "The United Arab Emirates"; and MIDDLE EAST RESEARCH INSTITUTE OF JAPAN (2002) statistics relating to UAE cabinet compositions; and POLSCI.COM (2001), "Political reference Almanac - UAE Political System", New York, Keynote Publishing; and personal interviews, Abu Dhabi, September 2002 ${ }^{193}$ BUSINESS MONITOR INTERNATIONAL (1998)

${ }^{194}$ See IRVING, Janis (1972), "Victims of groupthink", Boston, Houghton Mifflin; and IRVING, Janis (1982), "Groupthink: psychological studies of policy decisions and fiascos", Boston, Houghton Mifflin. Groupthink is a concept that was identified by Irving Janis and refers to faulty decision-making in a group. Groups experiencing groupthink do not consider all alternatives and they desire unanimity at the expense of quality decisions.

${ }^{195}$ HERB (1999), pp.47

${ }^{196}$ JOYCE, Miriam (1999), "On the road towards unity: the Trucial States from a British perspective, 196-1966”, in MIDDLE EASTERN STUDIES, Volume 35 Number 2, April 1999, pp.56

${ }^{197}$ Ibid. pp.48-49, Shaykh Shakhbut was continuing to restrict the number of merchants permitted entry to Abu Dhabi, even from the other Trucial States, whereas Shaykh Zäyid proposed more rapid development. 198 HERB (1999), pp.137

199 See FEDERAL RESEARCH DIVISION (2003), "United Arab Emirates: a country study", Blackmask, USA

${ }_{200}$ Personal interviews, Sharjah, April 2002 and September 2002, with reference to the 1987 coup and the support for Shaykh Sultān from both the Sharjah family and Dubai's Āl-Maktûm family. Also see

BROWN (1998), pp.359 
${ }^{201}$ In June 2003 Shaykh Saqr al-Qāsimi, ruler of Ra's al-Khaimah, chose to switch his crown prince appointment from Shaykh Khalid to the much younger Shaykh Saud. According to personal interviews, this decision may have been based on the ruler's desire to promote greater foreign investment in Ra's alKhaimah (specifically allowing a new concrete production plant to be build), a policy which the businesssavvy Saud was seen as being better suited for. Given that Khalid had been crown prince for nearly twenty years and had enjoyed a high profile in the struggle with Iran for control over the disputed Tunbs islands, instability was feared and Abu Dhabi sent tanks to protect the palaces of the ruler and the new crown prince. In the event, from eyewitness observations, the protests were entirely peaceful, with a number of Khalid's supporters declaring "we will give our blood and souls for you, Khalid". Also see REUTERS (2003), "Tanks back succession move in UAE's Ra's al-Khaimah", $15^{\text {th }}$ June 2003

${ }^{202}$ See KAMRAVA (2002) 


\section{Socio-economic Development and the Diversification Effort}

Alongside the consolidation of the polity and the preservation of political stability, which are themselves key prerequisites for successful modernisation, the United Arab Emirates has undergone significant socio-economic development over the past thirty years as its 'modernising monarchs' have sought to consolidate the material components of their ruling bargain while also attempting to adapt to their situation by carefully removing and reducing some of the most patent weaknesses of their dependent economies. As such, viewed within the context of selective modernisation shaped by inherited and persisting dependent circumstances, it will be the purpose of this chapter to consider the UAE's major development plans and objectives and, crucially, to determine not only their level of achievement, but also to highlight some of the key problems which have yet to be overcome and which continue to face the Emirati planners.

In particular, following a discussion of the planners' early recognition of the need to modify many of the UAE's dependent socio-economic structures, it will be demonstrated how there have been concerted efforts to diversify the oil-reliant economy, to boost the UAE's indigenous social growth, and to reduce the state's chronic reliance on foreign labour. Firstly, therefore, it will be revealed how the industrial, agricultural, commercial and tourist sectors are all being developed as part of an ongoing strategy to boost the non-oil sectors of the economy; secondly how a comprehensive welfare and educational state is being built to provide for a healthy and skilled national population; and thirdly how there are now numerous initiatives focusing on the nationalisation or 'emiratisation' of the workforce and the gradual replacement of expatriates. Moreover, although it will be shown how there have been moderate successes in attaining these goals, especially with the emergence of muttully supportive development initiatives in the two wealthiest emirates, the final section will, however, serve to underscore those development pathologies which still remain, including many 
which have not been readily solved by injections of oil wealth and which in some cases continue to induce costly duplication, regional disequilibrium and other features of damaging 'lopsided' development.

\section{1-Modifying dependent development}

Orthodox neo-classical economic theory predicted the emergence of an interdependent world economy within which each national economy would seek to maximise its comparative advantage. In turn, it was suggested that this interdependence would eventually lead towards the long-term equalisation of incomes, ${ }^{1}$ and for some time many of the developing world's rulers accepted the inevitability of this argument. By the 1920s, however, the prevailing model had become one of 'economic nationalism', as adverse economic conditions prompted many developing states to intervene and assist in building up and protecting their domestic industries. ${ }^{2}$ As this chapter will demonstrate, while certain aspects of both these models did find some purchase amongst the planners and co-ordinators of the UAE's development strategies, these early economic development theories were nevertheless seen as insufficient in addressing the key concerns of the small and oil-rich Gulf state. Instead, the UAE's continuing reliance on the export of a single primary product export, its reliance on foreign technology, its international division of labour, and its asymmetrical relationship with the oil-purchasing economies were seen as being the most pressing issues.

Indeed, while the oil industry and its various requirements had certainly allowed the region to prosper and to escape from immediate poverty, it was nonetheless feared that any long-term dependency would eventually lead to serious structural problems and underdevelopment. Certainly, as Samir Amin warned, even by the late 1970s there were already several very marked features of economic disintegration beginning to appear in the 'dependent Arab oil economies' as a result of persisting peripheral relations with the core economies and unchecked dependent structures: 
- The economic structure of most Arab countries had become more externally orientated than that of any other group of countries in the developing world. Taken as a whole, the Arab world had become one of the most fully integrated and potentially dependent regions in the contemporary global economic system.

- Despite the availability of vast capital, industrialisation remained comparatively weak and desultory, trailing behind other developing regions such as Latin America.

- Domination by the multinationals was leading to a corresponding technological dependency. The Arab world imported virtually all its industrial means of production and depended more and more for its agricultural development on multinational 'agribusiness'. As such, the economy of the Arab world had become a disabled one, characterised by disjointed industrial development, growing consumerism and widening inequality in income distribution, growing distortion of development orientation, and the increasing waste of human and natural resources.

- Oil wealth, which rose astronomically after 1973 , served only to aggravate distorted development and to strengthen economic, military and cultural dependency on the West. Thus, the illusion of wealth created by oil was having the same effect on the Arab world as American gold had on Spain in the seventeenth century: it was delaying the fundamental changes that are necessary for any genuine renaissance. $^{3}$

As such, in addition to straightforward growth and expansion, the reversal, or rather the reduction of dependency-related features soon became a main feature of socio-economic development planning in the UAE. Certainly, if the UAE needed proof of the precariousness of its economy then the oil price fluctuations and slumps of the 1980s soon provided clear indicators as Saudi Arabia and other neighbouring oil exporters were forced to contemplate austerity measures, ${ }^{4}$ thereby highlighting the 
unpredictable nature of the international oil economy and the dangers of relying on a narrow economic base and the demands of other economies. Moreover, it was recognised that many other external factors could also adversely affect the UAE's oil economy; including changing global energy consumption patterns resulting from stronger international anti-pollution legislation, ${ }^{5}$ and new oil-producing regions in Central Asia and Latin America coming on-stream. ${ }^{6}$ Of course, further compounding this vulnerability was the continuing insistence of the core economies on purchasing only crude oil, thereby preventing any refinement or value addition to the commodity in the UAE. Indeed, as former Egyptian oil minister Hussain Abdullah recently explained to the Dubai Cultural and Scientific Association:

"... the real benefits of oil as a support for the industry were being gained by the West who refused our repeated attempts to sell them refined oil and insist on buying it from us as a crude product. We were not making enough profit from oil as far as selling it for a good price as well as refining it and manufacturing its products is concerned."

Internally, it was feared that any long-term dependency on oil rents and distributed wealth would lead to the emergence of a consumerist society as the population's purchasing power accelerated independently of their productive capacity. Ultimately this would lead to excessive imports and a serious trade imbalance, while of course also reducing employment incentives and creating a potentially parasitic national workforce dependent on the labour of foreigners.

Initially, a partial solution to reducing the UAE's dependency on oil was seen to be through savings and investment. Undoubtedly, overseas assets have long been considered an important safety valve for the region's future and, as will be shown later in this chapter, such savings continue to play a key role in Abu Dhabi's financial planning. By investing billions of 'petrodollars' abroad it was hoped that the UAE would be able to survive a post-oil future and maintain its oil boom standard of living by relying on considerable interest payments. Certainly, the UAE's investments have 
steadily increased over the years as in 1994 it was revealed by the Central Bank that almost $97 \%$ of its assets were placed overseas, ${ }^{8}$ and by the end of 1999 it was reported that the UAE's total foreign reserves had climbed to over $\$ 100$ billion, with the UAE also holding substantial assets with many of the Bank for International Settlements' reporting banks. ${ }^{9}$ However, no matter how substantial the interest payments, it was also accepted that such investments would never be able to provide long-term solutions for reducing the actual structures of dependency and the resulting domestic socio-economic problems. Indeed, as early as the mid-1970s the UAE's planners had already begun to favour a more multidimensional approach based on economic diversification with the hope that the non-oil based sectors and the necessary physical infrastructure could all be developed using the UAE's massive oil revenues. As such, the planners began to regard oil not merely as an expendable resource, but as a 'gift from God' with which to develop a diverse, multiple-sector economy for future generations. ${ }^{10}$

\section{2 - Diversification through industrialisation}

Industrialisation has historically been one of the most favoured tools for the governments of developing states attempting to achieve economic growth and selfsufficiency. The UAE has been no exception as, in the 1970s, the planners identified industrial expansion, specifically that of the non-oil related manufacturing sector, as being the best hope for successful diversification. In particular, as the 1979 Federal Industrial Law states, there were four main objectives associated with such development:

1) "For the government to prepare a productive base capable of allowing manufacturing industries to thrive and thereby reduce the reliance on oil.

2) To give the manufacturing sector priority at all times with the aim of creating a sector capable of generating significant production linkages. 
3) To encourage industrialisation as a way of providing foreign exchange.

4) To use the UAE's comparative advantage of low-cost energy to best effect by helping to make the UAE's industries regionally and internationally competitive"."

Moreover, with regard to the context of these aims, it is important to note that during this early period of Emirati development planning two different industrialisation substrategies were prevalent elsewhere in the developing world: export-oriented industrialisation (EOI) and import-substitution industrialisation (ISI).

On the one hand, an EOI strategy based around large-scale industries was regarded as a means of quickly achieving industrialisation and limited diversification. Although the plants would continue to rely on foreign technology, their growth would nevertheless serve to raise GDP, would provide a base for further domestic industrialisation, and would make the best use of the UAE's comparatively low energy costs. Certainly, it was reasoned that if the UAE could develop internationally competitive industries and thereby penetrate other regional markets, then the reliance on oil exports and the dependence on external economies could be reduced. ${ }^{12}$ Indeed, as Mehran Kamrava has shown, a number of developing states have embarked upon this strategy, some having met with considerable success in supplying other emerging markets with competitively priced and reliable goods. ${ }^{13}$ On the other hand, while the alternative ISI approach was also to rely upon the importation of foreign technology, this was only to be a temporary stopgap measure until the UAE could substitute imported technology with its own domestic technology. Thus, foreign teclnology was to be used to build up a domestic industrial infrastructure which would eventually be able to use local technology to produce goods that would have otherwise been costly to import. $^{14}$ By the early 1970 s there were already indications that both approaches were being employed in the UAE, with Kevin Fenelon remarking on the clear-cut division between three different categories of manufacturing industries: the first being those of 
the EOI group, the second being the traditional manufacturing activities, and the third clearly being those of the ISI group:

"One [group] consists of large-scale, highly capitalised industries employing the most modern technology, export-oriented and based on oil or natural gas. The other group is composed of small, traditional and labourintensive handicrafts working for a local market. In between there is a small though growing intermediate group, based like the first group on imported technology and machinery, but less highly capitalised and of more moderate size. For the most part, these industries serve local markets and are engaged in servicing, repair, and maintenance, or manufacture such articles as soft drinks or cement blocks, which if imported would involve high transport costs in relation to their value." 15

Furthermore, as Fatima al-Shamsi demonstrates in her study of industrialisation in the Gulf, there are now clear signs that each of these strategies continued to be implemented in the UAE well into the 1980 s and $1990 \mathrm{~s} .{ }^{16}$ With reference to $\mathrm{EOI}$ in the UAE, a particularly strong example would be the combination of natural gas, cheap energy and large-scale plants, especially in the resource-rich Abu Dhabi. Before the 1970s, the UAE's considerable reserves of natural gas were underutilised with the only gas produced being a side product of oil drilling, over $90 \%$ of which was simply flared off. However, one of the earliest EOI strategies was to reverse this trend and to begin harnessing this potentially valuable resource. Early success came with the establishment of three major gas plants, one on Abu Dhabi's Dās Island, a second in Al-Ruways, and a third in Dubai, each of which were producing nearly four million tonnes per annum by the mid-1970s. ${ }^{17}$ More recently, and as part of the UAE's continuing commitment to upstream gas developments, proposals for the Dolphin Gas Project were signed in the late 1990s, establishing Qatar as a major co-supplier, and committing Abu Dhabi to the large-scale transportation and marketing of Qatari and Emirati natural gas. ${ }^{18}$ Alongside the main national gas companies of ADGAS and Atheer, other heavy export-oriented industries such as DUBAL (Dubai Aluminium) 
have also met with considerable success. Indeed, as the Economist Intelligence Unit estimated in 2000 , aluminium exports have risen to account for nearly $60 \%$ of Dubai's non-oil exports, thereby placing DUBAL at the very heart of the emirate's industrial sector. ${ }^{19}$ Crucially, in addition to aluminium many other non-hydrocarbon based heavy industries, including the UAE's various steel and plastics companies, have also grown in number and in capacity over the years, and in several cases have become regionally and internationally competitive. Moreover, as Soheir el-Sabā explains, the future may be even more promising for EOI as the rising use of solar energy in Saudi Arabia and Kuwait extends to the UAE, thereby allowing for the development of new industries powered by a renewable energy source which, significantly for the diversification process, is entirely independent of the oil industry. ${ }^{20}$

Although, perhaps unsurprisingly, ISI-led growth has been less impressive given its concentration in smaller industries less able to benefit from the comparative advantages of the UAE's low-cost energy, there have nevertheless been appreciable results and important signs of technology substitution and diversification. Indeed during the 1970s a number of uncomplicated small and medium-scale manufacturing firms were successfully established, each supplying a number of locally produced goods to the domestic market. ${ }^{21}$ Most notably, construction goods such as piping and cement could be sold at competitive prices given the high cost of importing such bulky freight into the UAE. Certainly the resulting reduction in such imports was reflected during this period, even during the massive construction boom, with the UAE's percentage of foreign trade to GDP gradually falling from $113 \%$ to $106 \%,{ }^{22}$ and, in the case of Dubai, with the cost of imports being held in check at around 20 billion Dirhams (at fixed prices) until the late $1980 \mathrm{~s}^{23}$ Although the importation of such goods has risen in more recent years, and, as will be discussed later in this chapter, continues to pose a serious structural problem for the Emirati economy, this does not necessarily indicate the failure of ISI. Indeed, there continues to be a significant rise in the number of new ISI projects, especially in the packaging and bottling industries, many of which initially licensed foreign technology but have now made successful substitutions. ${ }^{24}$ As such, the perceived slowdown in ISI in the 1990s may have simply been due to the unsustainable 
growth of the early 'easy stage': ISI was originally applied to relatively straightforward industries requiring only minor technology injections and minimal planning, but recent attempts to apply ISI to more technologically advanced industries may take more time and greater investment.

Overall, by applying a combination of these strategies, the UAE's non-oil manufacturing sector has grown steadily over the years from a practically negligible starting point in 1971, and now accounts for around 19\% of the non-oil GDP, and more significantly for around $14 \%$ of the UAE's total GDP, ${ }^{25}$ therefore indicating the increasingly important contribution of non-oil industries to the diversification effort. Moreover, although the sector's rate of growth may have slowed in recent years, ${ }^{26} \mathrm{Al}-$ Sharhan consultants do, however, present a slightly more positive picture. Using data from the last few years and calculating projections for 2002 and 2003, they demonstrate that by streamlining and improving efficiency, domestic industries are now rapidly increasing the value added to their manufactured goods. Indeed, arguing that the sector's growth in manufacturing value added is as equally important as the manufacturing sector's growth in contribution to the UAE's total GDP, it is illustrated how, over the course of just five years, the sector's value added will more than double:

\section{Dubai's manufacturing sector: value added to domestic manufactures (2000 prices)}

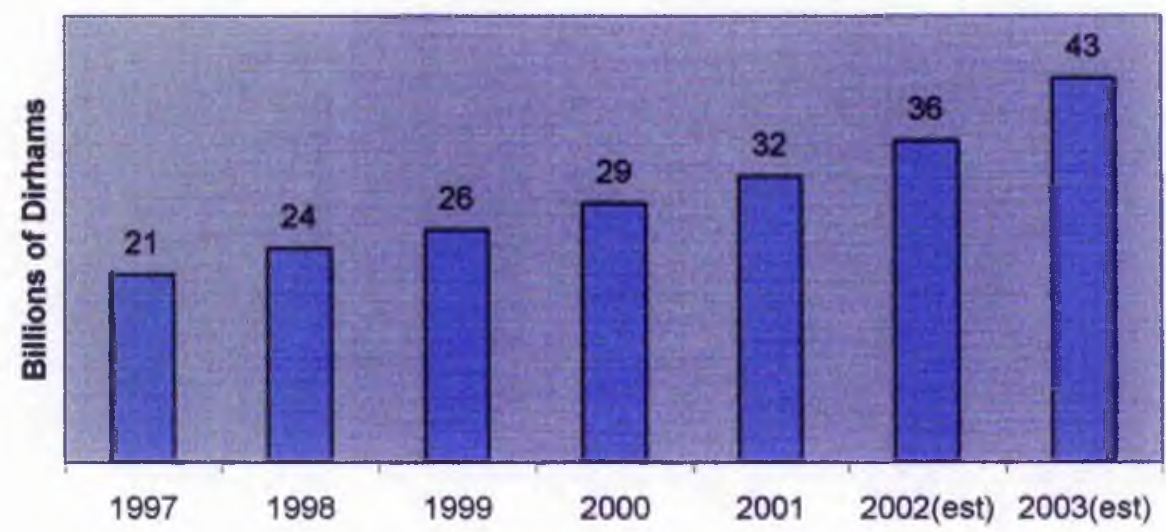

[Source: Al-Sharhan International Consultancy, Dubai] ${ }^{27}$ 
With value added or 'net output' being the difference between the total revenue of a firm and the cost of bought-in raw materials, services and components, these figures would indicate that Emirati firms are beginning to add more and more value to their bought-in materials and components by improving their processes of production. ${ }^{28}$ If this trend is able to continue then the manufacturing sector's contribution to GDP will begin to grow more rapidly, thus renewing the sector's crucial diversification role.

\subsection{1 - Fostering technology linkages with foreign firms}

Further related to industrialisation and diversification, it is also important to note how the UAE's planners have attempted to generate meaningful technology linkages between infant Emirati firms and the many foreign firms which operate in the UAE. In particular, there has been a clear attempt to prevent the emergence of foreign enclaves and a 'dual economy'; an asymmetrical economy in which little or no technology transfer takes place between foreign and local firms. ${ }^{29}$ Certainly, by the late 1970 s it was becoming increasingly clear that the oil sector, given its distinct role and its high degree of specialisation, would never generate such linkages on its own, and that any 'natural filter' of technology was unlikely to occur without more active government assistance. $^{30}$ As such, a number of high-tech foreign industries were targeted with schemes aiming to encourage, and in some cases enforce, the transfer of their teclnnology and expertise to the UAE's diversifying domestic industries.

Indeed, by 1984 the UAE's Federation of Chambers of Commerce and Industry was already proposing that profitable foreign companies should be compelled to reinvest a significant portion of their revenue back into local enterprises. Furthermore, there were also calls for taxation and other restrictions to be imposed on these companies, and, as will be discussed in the following chapter, although such measures were not implemented their proposal nevertheless indicated the growing realisation of the potential role that foreign companies could be made to play in the UAE's diversification process. ${ }^{31}$ Although direct government intervention did not begin until the early 1990 s, it nonetheless represented a very important step given that it took 
the form of a comprehensive arrangement requiring certain foreign firms, especially those having signed defence contracts with the UAE, to invest and assist in a number of commercial ventures with local partners. Thus, administered by the newly formed 'UAE Offsets Group', these domestic recipients of foreign technology transfers were seen to be offsetting the enclaves being created by the high-tech foreign arms manufacturers, many of which only required limited local manpower, and most of which were thought unlikely to provide any genuine linkages with the domestic economy under normal circumstances. As such, the UAE's Offsets project can be seen as a clear attempt to take advantage of the world anns market and to promote vested interests in the UAE's stability and security ${ }_{2}^{32}$ while simultaneously escaping the 'guns versus butter' quandary which has plagued many other developing economies. ${ }^{33}$

Specifically, the group's rules stipulate that such local 'offsetting' ventures should yield accumulated profits of $60 \%$ of the arms procurement contract value over a period of seven years. In other words, by entering into profitable and sustainable joint ventures with members of the local private sector, the supplier would have to bring back to the UAE economy some sort of "value addition' worth $60 \%$ of the original contract. Furthermore, all projects have to be completed within seven years, and if the obligations are not met by the target dates, then the foreign company is penalised $8.5 \%$ of the unfulfilled portion of the obligation. ${ }^{34}$ Although there have been some instances of offsets failure and ineffective technology linkages, most notably concerning Giat's missed targets, ${ }^{33}$ there have nevertheless been a large number of highly successful joint ventures. Among others, these have included:

- A local shipbuilding company

- An enzyme manufacturer in partnership with McDonnell Douglas

- A healthcare centre with Lockheed Martin

- An agricultural exporter

- A solar energy panel manufacturer with GEC-Marconi

- A seafood company with Dassault

- Assistance with the aforementioned Dolphin Gas Project ${ }^{36}$ 
Indeed, to date, the Offsets group has co-ordinated over 20 such projects which, combined, are now valued at over $\$ 1$ billion, ${ }^{37}$ thus representing an important contribution to the UAE's productive base and, given their autonomy from the oil sector, also representing an important contribution to the diversification of the UAE's manufacturing sector.

\section{3 - Diversification through agriculture}

Another major component of the UAE's diversification strategy has been the development of the agricultural sector. Although never likely to provide the same levels of growth and contributions to non-oil GDP as manufacturing and other sectors of the economy, the agricultural sector's improvement was nevertheless seen as necessary for reducing the UAE's dependency on imported foodstuffs and thereby achieving greater food security. In addition, the sector's development was also seen as a means of expanding the domestic market and complementing the growth of other local non-oil related industries, especially the many dairy and poultry ISI industries which rely heavily on agricultural products. ${ }^{38}$ Thirdly, it is important to note that the sustained growth of the agricultural sector, which employs a higher percentage of UAE nationals than any other sector ( $85 \%$ of all farm workers and $75 \%$ of all fishermen), ${ }^{39}$ has assumed great socio-economic significance in a country which, as will be described later in this chapter, has become increasingly overwhelmed by expatriate workers. ${ }^{40}$

In 1976, the directive documents of the UAE's Ministry of Planning emphasised the need to increase agriculture's contribution to the GDP, either by improving the productivity of the land itself (vertical expansion) or by increasing the total cultivatable area (horizontal expansion). ${ }^{41}$ With regard to the former, there has been substantial government investment in the form of considerable subsidies which have been used to slow the migration of farmers to the cities, and to provide for superior equipment, irrigation, and water wells. Moreover, in practice, the subsidies have often extended far beyond these initial objectives and, as interviewees revealed, in the rural areas of Abu Dhabi and Dubai it is now possible for new farmers to walk into almost ready-made 
farms complete with housing, fencing, roads, and of course all the necessary farming equipment. $^{42}$ Also, as described in the appendices, there has been considerable investment in the development of new crop strains, with a number of agricultural trials stations now producing hardier crops better suited to the harsh desert conditions. ${ }^{43}$ With regard to increasing the cultivatable area, the primary strategy has been to concentrate on afforestation. Although when asked by curious university students as to why the government was spending so much on planting trees in the desert, Shaykh Zāyid famously claimed it was 'so people could see what they looked like', the principal aim, however, has been to plant sufficient trees in order to reduce soil erosion and to help crops be better protected from the wind and sand. Furthernore, it has also been theorised that afforestation can stimulate increased rainfall which would in turn lead to greater vegetation in previously desert regions. ${ }^{44}$ See appendix (i).

With reference to the first of these strategies, productivity gains have led to a massive increase in agricultural output in recent years. Indeed, using Dubai as an example, vegetable production more than tripled from less than two thousand tonnes in 1990 to over six thousand tonnes in $1999 .^{45}$ Similarly successful has been the emirate's fruit production, which rose from just over a thousand tonnes in 1990 to nearly 17 thousand tonnes in $2000 .^{46}$ Most impressive, however, has been Dubai's dairy production, which rose from just three hundred tonnes in 1981 to nearly 32 thousand tonnes in 2000 , representing a hundred-fold increase in less than 20 years. ${ }^{47}$ Equally promising, though undoubtedly far from cost-effective given the region's unforgiving climate, have been the results of the land cultivation strategy. Certainly, with figures made available by the Ministry of Agriculture, it can be demonstrated that there has been a substantial $82 \%$ increase of arable land since the mid-1980s: 


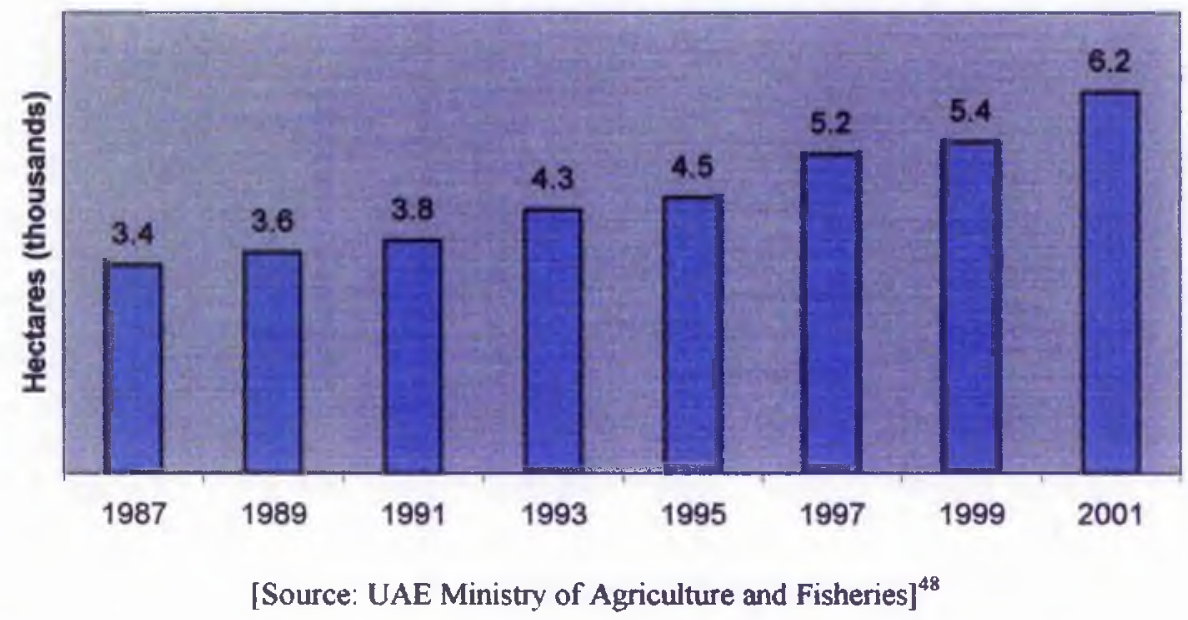

Further related to the growth of the agricultural sector has been the modest increase in Emirati fishing. As demonstrated earlier in this thesis, fishing has always been one of the region's main economic activities ${ }^{49}$ and, although cautious of over-fishing and unable to benefit from increasing land under cultivation, the industry has nevertheless also benefited from productivity gains and government subsidies in recent years. Indeed, over the past decade the catches for Dubai and the other northern emirates have risen from 12.5 thousand tonnes to 21.3 thousand tonnes, thus representing a $70 \%$ increase in their annual fish production..$^{50}$

Although the sector's growth is unlikely to lead to complete self-sufficiency given the many challenges of the desert and, as will be discussed later in this thesis, due to it's reliance on subsidies from the allocative state, ${ }^{51}$ these overall improvements have nevertheless considerably boosted the UAE's food security and, of course, have also directly and indirectly contributed to the diversification effort, especially by consolidating the UAE's many food related ISI industries. Indeed, speaking at a recent Gulf food security conference, Sa'id al-Raqabani, the UAE's Minister of Agriculture and Fisheries underscored this considerable progress by claiming that the UAE had now managed to reach $83 \%$ sufficiency in vegetables, $80 \%$ sufficiency in dairy products, $32 \%$ in eggs, $25 \%$ in meat, and $21 \%$ in poultry. ${ }^{52}$ Furthermore, it is also worth noting that, with the exception of Saudi Arabia, the UAE now possesses a higher per capita agricultural product than any of the other GCC states and, in addition to the impressive 
increases in production and arable land, the number of workers employed in the sector has more than tripled since the first development plans of the 1970s. ${ }^{53}$

\section{4 - Diversification through commerce and tourism}

Alongside the industrialisation of the domestic manufacturing sector and the development of the agricultural sector, in the mid-1970s the UAE's planners believed that the expansion of the commercial and tourist sectors would also play an important role in the growth of the UAE's diversified economy. Indeed, although on one level such activities may actually increase the UAE's dependence on external economies, the sectors were nevertheless seen as a direct and effective means of building up non-oil related activities which would not necessarily be reliant on foreign technology or foreign labour. Furthermore, as Ali Abdulsalam, a former director of the UAE Planning Department explains, it was hoped that the development of these sectors would also contribute to the promotion of many of the region's traditional industries, the encouragement of various cultural and social activities, and most crucially would assist in developing the UAE's internal trading sector. ${ }^{54}$

As such, by the early 1980 s, with chambers of commerce in each emirate, an umbrella federation of chambers of commerce, and, in the case of Dubai, a World Trade Centre, the UAE began to position and promote itself as a world-class commercial and tourist hub. ${ }^{55}$ Moreover, in 1989 the government of Dubai underscored its commitment to the development of this sector by establishing a Department of Tourism and Commerce Marketing, the first of its kind in the UAE. Essentially the department sought to implement and support many of the original diversification plans within a more co-ordinated and effective framework by:

1. "Contributing to economic diversification by promoting non-oil development; and creating new opportunities for the Dubai business community by attracting trade, investment and tourism. 
2. Supervising tourist and archaeological sites, to lay down and implement plans and programmes that aim at encouraging tourism in the Emirate, to implement comprehensive media campaigns, to study projects related to tourism, to stage seminars and exhibitions inside and outside the Emirate, to regulate the services of tourist guides and others in the tourist sector, to license hotels and furnished apartments, to supervise restaurants, and to develop commercial relations between the Emirate and other countries. " 56

As these ambitious objectives indicate, the department was keen to transform the emirate of Dubai into the Gulf's leading commercial zone and premier tourist destination. While the results of this emirate-level strategy will be discussed in greater depth in the later analysis of dual development plans, it is nevertheless important to note some of the considerable successes which have been achieved over a short period of time, and the increasing evidence of similar strategies beginning to be employed in the other emirates. Perhaps the greatest success so far has been the 'Dubai Shopping Festival' (DSF) which was set up in 1996 with the aim of transforming Dubai into an international shopping centre, attracting much higher numbers of tourists, and boosting expenditure in all sectors and on all types of goods and services. ${ }^{57}$ The DSF runs for approximately one month every year and claims to offer massive discounts in all participating stores and hotels, ${ }^{58}$ and, although in practice prices actually rise during the festival, the event's popularity and reputation nevertheless continues to increase. ${ }^{59}$ More recently, the DSF's success has been complemented by the 'Dubai Summer Surprises' festival held during the out of season summer months, and the 'Dubai the city that cares' festival held during the month of Ramadan. ${ }^{60}$ Crucially, over the last few years a number of other commercial events and festivals have also begun to be staged by the other emirates and their new tourism and commerce departments, most notably Sharjah's Ramadan festival and 'Ajman's 'Fantasia' festival. In the same way as the Dubai events, these have also appreciably boosted the local economies, with an increasing number of shoppers and tourists now being attracted to the smaller emirates. ${ }^{61}$ 
With reference to the actual growth of the UAE's commercial sector, perhaps the clearest indicator of expansion has been the sheer increase in the value and volume of international non-oil related trade, especially in Dubai. Indeed, quite remarkably the emirate's total non-oil foreign trade rose from a modest eight billion Dirhams in 1975 to nearly 112 billion Dirhams in 2001 (measured at fixed 1995 prices), representing over 15 million tonnes of traded goods: ${ }^{62}$

Dubai's non-oil foreign trade - value (1995 prices)

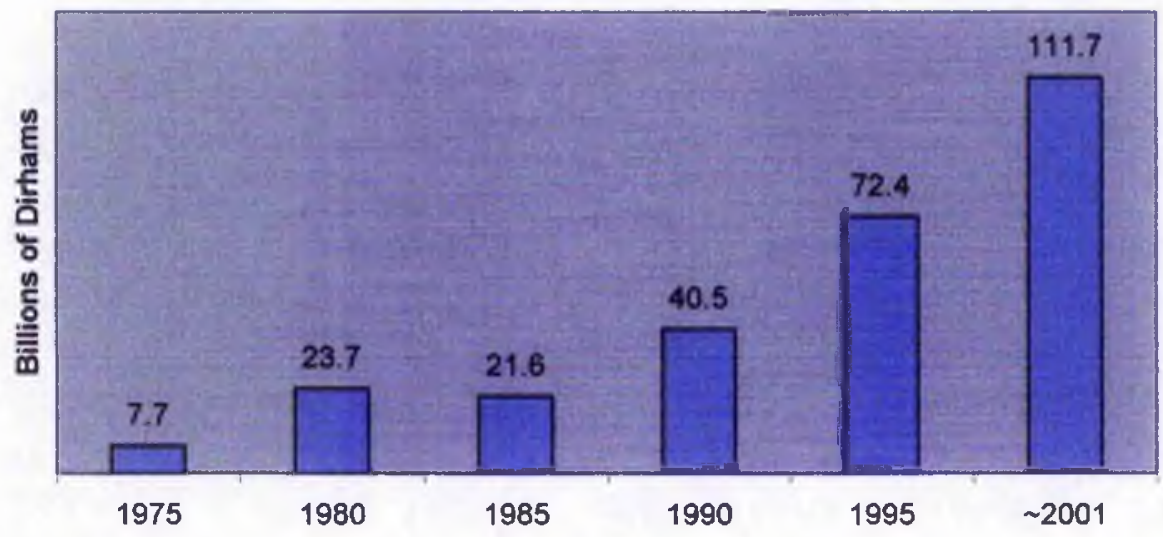

[Source: Dubai Department of Ports and Customs] $]^{6.3}$

However, in addition to this fifteen-fold rise in the total value of non-oil foreign trade and a $140 \%$ rise in the total volume of foreign trade since $1980,{ }^{64}$ the emirate's substantial increase in re-exporting activity over the past 25 years must also be taken into consideration. Certainly, given the UAE's historically high levels of imports, a problem which will be discussed later in this chapter, ${ }^{65}$ the value and quantity of reexports together with their relative contribution to total trade may provide an even more accurate indicator of the recent commercial expansion: 


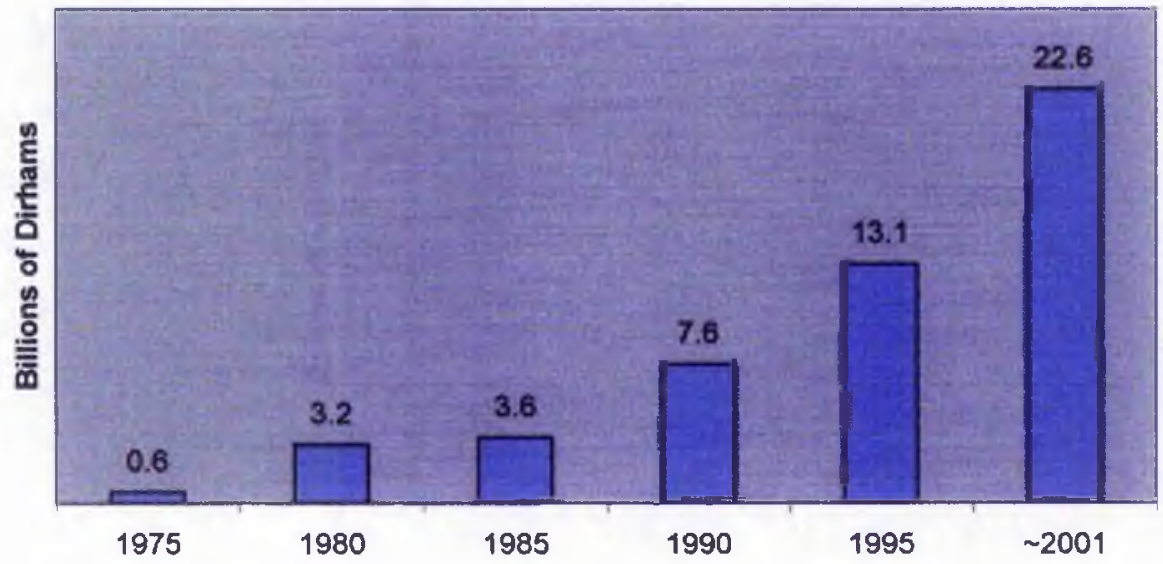

Dubai re-exports (as a percentage of the value of total trade at 1995 prices)

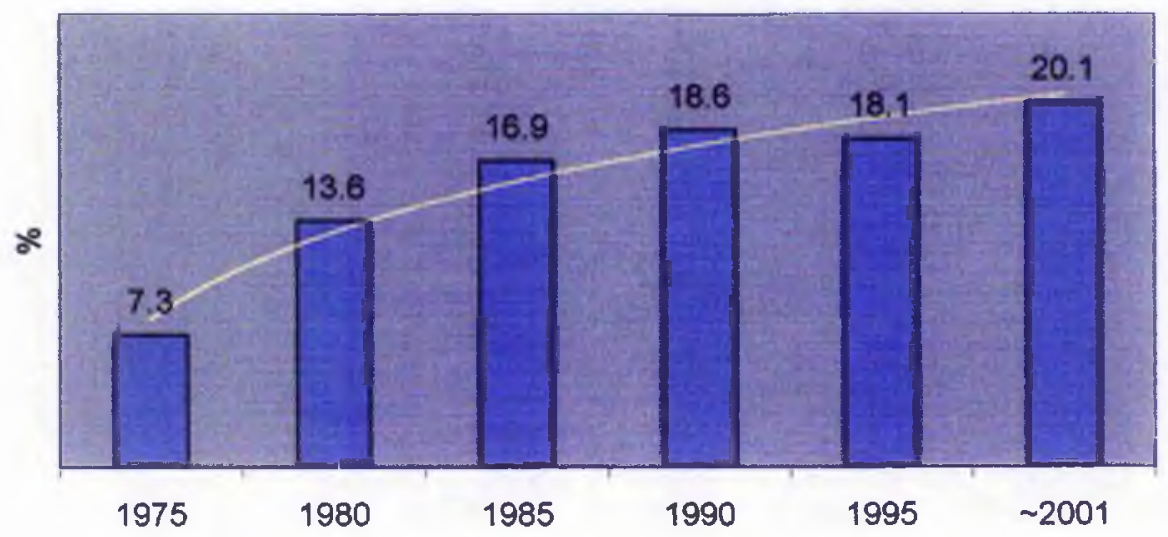

[Source: Dubai Department of Ports and Customs] ${ }^{66}$

Thus, with a massive increase in the value of re-exported goods between 1975 and 2001 (and with the volume of re-exported goods more than doubling between 1980 and 2001 from 0.9 million to 2.5 million tonnes ${ }^{67}$ ) and, as the above trend line indicates, with reexports accounting for a much higher proportion of total trade, it is evident that the emirate is indeed generating considerable non-oil related commercial activity. Moreover, when compared to the value of foreign trade and re-exports for the other GCC States, ${ }^{68}$ these figures clearly confirm Dubai's position as one of the main trading hubs of the Persian Gulf and the greater Middle East. See appendix (iv).

With reference to the actual growth of the UAE's tourist sector, the figures are similarly impressive, especially with regard to the dramatic increase in the number of 
hotels, resorts and other tourist-related establishments, and of course with the rising number of tourists and businesspeople now choosing to visit the UAE. Once again, Dubai has been at the forefront of such development, with its rapidly constructed tourist industry boasting nearly 300 hotels and now attracting nearly three millions visitors per annum, ${ }^{69}$ compared with just 40 hotels and 0.4 million visitors in $1985:^{70}$

\section{Dubal Hotels}

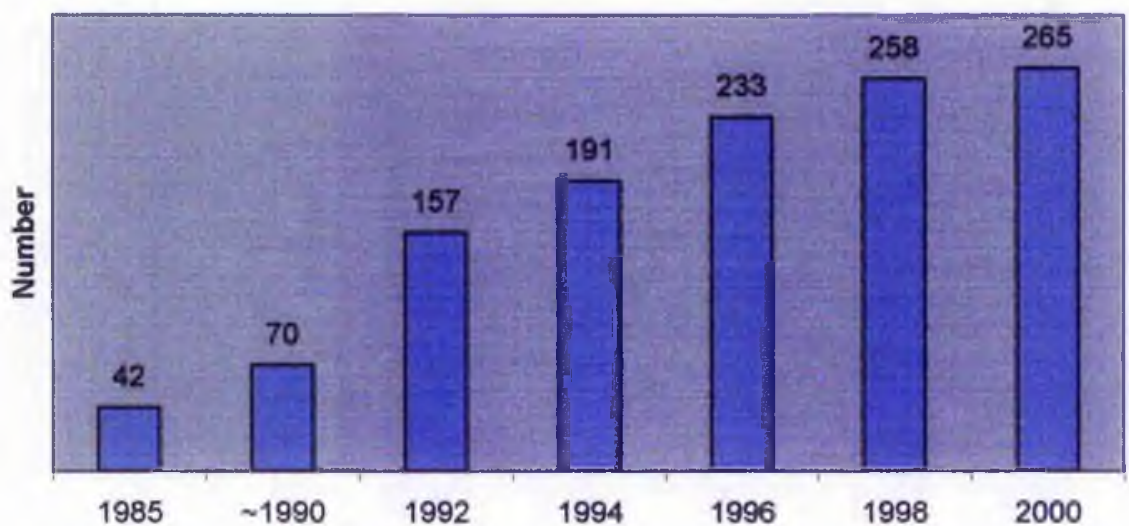

Dubal Tourists (per annum)

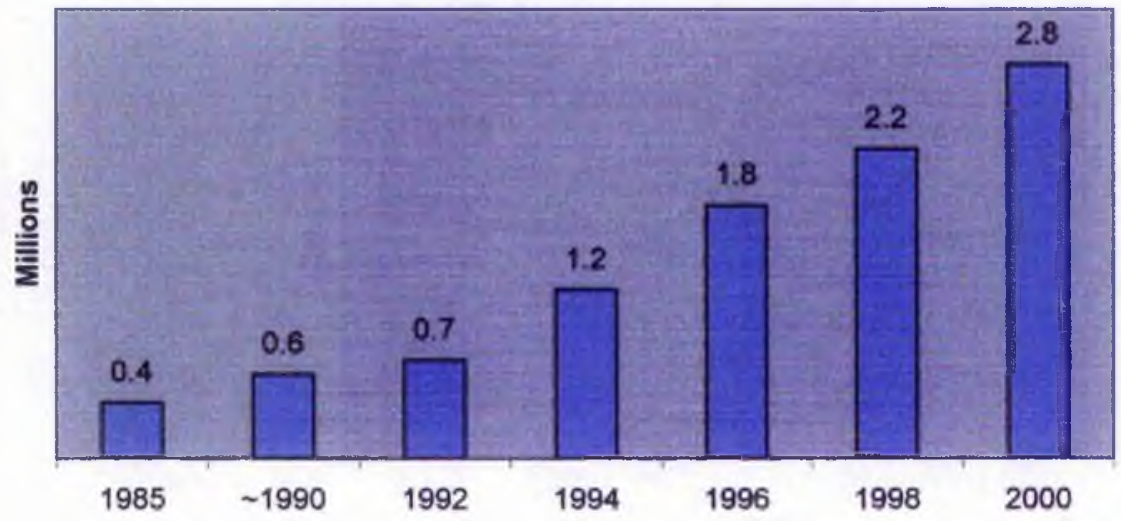

[Source: UAE Ministry of Planning (for 1985-1994), Dubai Department of Economic Development (1985-1998), and Dubai Department of Tourism and Commerce Marketing (1999+) $]^{71}$

Furthermore, given the major hotel developments which have taken place since 2000 , including the Dubai Fairmont, Dusit Dubai, and the Grand Hyatt, and given the only temporary decline in UAE tourism following the September 2001 attacks, these positive trends seem set to continue. Crucially, it is also important to break down this sector and to show how the most rapid growth has been in the luxury tourist market, thus 
underscoring Dubai's objective of transforming itself into an important winter sun resort for affluent European holidaymakers, thereby boosting the emirate's supply of foreign exchange and further consolidating diversification. ${ }^{72}$ Indeed, of the 265 hotels operating in 2000,78 were either 'deluxe' or 'first-class' rated, ${ }^{73}$ with many of the most prestigious Asian and international chains having chosen Dubai as the location for their flagship hotels. ${ }^{74}$ Also, given that these deluxe hotels are far larger than most of the other hotels, they actually provide the bulk of tourist accommodation in the emirate. In fact, these 78 hotels account for nearly 20,000 of the total of 31,000 hotel beds in Dubai and, more importantly, have enjoyed much higher occupancy rates than the other hotels, averaging nearly $70 \%$, compared with less than $36 \%$ for some of the lower class hotels. ${ }^{75}$ These occupancy rates have therefore translated into a high and growing number of luxury tourists staying in Dubai: 1.8 of the 2.5 million visitors in $1999,^{76}$ representing nearly $72 \%$ of the sector total and almost double the size of the emirate's normal population.

In much the same way as the commercial sector, the other emirates have also been able to follow Dubai's lead in developing a successful international tourist industry. Indeed, Abu Dhabi now attracts around 18\% of the UAE's tourists while Sharjah quite remarkably manages to attract nearly $13 \%,{ }^{77}$ despite the aforementioned decency laws and the emirate's ban on alcohol. ${ }^{78}$ Furthermore, the UAE's many natural beauty spots in the mountains, its rock pools, and its relatively untouched Indian Ocean coastline are now also being developed, with the aim of providing additional destinations for those tourists hoping to travel a little further afield. Examples of such projects would include the recent recreation of a traditional village in the mountainous town of Hatta, the redevelopment of Dibba al-Fujairal, the construction of hotels on the coastal strip between Rol Dibba and Al-Faqit, and the construction of an aqua leisure park in the tiny emirate of Umm al-Qawain. ${ }^{79}$ Significantly, where natural beauty does not exist, artificial beaches and breakwaters are also being created and, in the case of 'Ajman, an entirely new corniche and seafront is currently being constructed with federal funds. ${ }^{80}$ 
Finally, in addition to their previously described role in the Emirati polity's legitimacy formula, the increasing number of cultural and sporting activities can also be seen as assisting and consolidating the growth of these important sectors. Certainly, the many museums, local art galleries, reconstructed forts, and 'heritage villages' provide educational and charming distractions for the numerous tourists. Most notably the pearling village, the Bedu village and the Shaykh Sai'd art gallery, all of which line the creek side in Shindigha, provide Dubai's tourists with a pleasant open-air network of live entertainment, sights and sounds. Moreover, the growing number of sporting events, many of which have achieved world circuit status, have undoubtedly boosted the UAE's commercial and tourist sectors by attracting wide audiences and greatly enhancing the UAE's international reputation. Key examples would include the European golf tour's Dubai Desert Classic, the UAE's annual ATP and WTA tennis tournaments, Sharjah's international cricket tournaments, and most significantly the Dubai World Cup - the world's most lucrative horserace.

\section{5 - The physical infrastructure for diversification}

Without a new infrastructure, the UAE's plans for industrialisation and the development of the agricultural, commercial and tourist sectors would have remained unattainable. While the UAE's evolving legal and financial infrastructures will be discussed in greater detail in the following chapter, ${ }^{81}$ it is essential to underline at this stage how the massive investments needed to create and maintain the physical infrastructure must be regarded as another key building block of the diversification strategy. Certainly, as Al-Sharhan consultants have described:

"[The UAE government] has continuously given high priority to the development of the country's infrastructure and has invested over $25 \%$ of its GDP annually in recent years to build the present modern system of seaports, roads and telecommunication services. This in turn has paid back handsomely enabling the once oil dependent state to now actively promote 
its non-oll sectors and draw in income from a myriad of sources thereby enabling the country to further reduce its dependence on oil reserves". ${ }^{82}$

Remarkably, of course, it must be remembered that most of these impressive infrastructural improvements took place over just a few decades, with the Trucial States having previously been one of the most backward and undeveloped regions of the Middle East. Indeed, even as late as 1965 , Fenelon observed on his visit that

"... there was not a single yard of surfaced public road in the whole of Abu Dhabi; the only bit of made road was a short stretch within the compound of the Political Agency between the Agent's house and his office. The airport runway was a strip of levelled sand, the office a tiny shed, and the customs and immigration offices a Land-Rover. "83

By the early 1970s, however, the situation had already begun to improve. Although Abu Dhabi and Dubai were still separated by over 100 miles of desert, ${ }^{84}$ there were nevertheless many miles of brand new first-class roads, dual carriageways, and even a four-lane highway connecting Abu Dhabi and Al-'Ayn. As such, journeys between the outlying emirates which had previously taken nearly a week had been reduced to just two hours, and lorries were able to transport goods all over the region within a day. Moreover, in the space of just a few years, the airstrips were also changed beyond recognition as new international airports capable of handling the largest aircraft were being constructed in Dubai and Abu Dhabi. ${ }^{85}$ Ten years later, in the mid-1980s, the infrastructural developments were even more manifest, especially in the cities, with Peck describing the enormous transformation he had observed in the centres of Abu Dhabi, Dubai and Sharjah:

"The virtual absence of any physical structure more than ten years or fifteen years old in Abu Dhabi reflects the extraordinary pace of change; only a few old buildings survive in Dubai and Sharjah. Glass, steel and concrete towers give the UAE's cities the appearance of transplanted 
Houstons rising above the flat sands of the Gulf. Almost overnight the greater part of the population has been displaced from traditional rural (and/or maritime) modes of existence to a setting of artificially sustained vegetation, broad boulevards, luxury hotels, and replicated Wimpys, SevenElevens, and Burger Kings, where only a scattering of barasti huts might have been found a generation ago". ${ }^{86}$

This fast-paced development was sustained throughout the 1990s and in many cases has continued unabated to the present day. Notable among the many achievements has been the completion of the Shaykh Zāyid Highway linking Abu Dhabi with Dubai: with 24 hour lighting along its entire $210 \mathrm{~km}$ stretch it is one of the longest roads in the Middle East. ${ }^{87}$ Similarly impressive has been the continuing expansion of Dubai's international airport. Now hosting an award winning passenger airline, the airport has grown under the auspices of Dnata ${ }^{88}$ and the Dubai Cargo Village to become one of the world's major cargo-handling hubs, ${ }^{89}$ with over 40 loading quays and with sufficient apron space to handle simultaneously four jumbo jets. ${ }^{90}$ Moreover, with new terminals under construction and a modern underground rail network to link air passengers to the city centre and the emirate's commercial and industrial districts, the airport looks set for further development in the near future. ${ }^{91}$ With regard to seaports, there have also been considerable accomplishments in recent years, with the total tonnage handled by Port Rāshid and Jebel Ali having risen by over $75 \%$ in just five years, and with more than 100 shipping lines now calling at the UAE. ${ }^{22}$ These important maritime infrastructural developments have consolidated and facilitated the growth of Dubai as a major trade transit hub, while also allowing the UAE to compete with other regional container ports in Aden and Salalah, both of which are situated much nearer to international shipping lanes. ${ }^{93}$

With specific regard to the physical infrastructure required by the UAE'S industrialisation, there has been similarly rapid progress. Most notable have been the fully equipped 'export-processing zones' (EPZs) which now exist in most of the emirates. In much the same way as the 'ready-made' government farms in the rural 
areas, the aim of these EPZs has been to create an environment conducive to the development and rapid growth of manufacturing industries in the UAE. Lease office buildings (LOBs) ${ }_{s}{ }^{94}$ cheap energy, road links, transport depots and administrative staff are all in place in an effort to provide new firms instantly with their entire required infrastructure. Although these zones and their implications for long-term development will be examined in the following chapter, it is nevertheless worthwhile to emphasise the massive growth that they have experienced over a relatively short period. Perhaps the best example of the EPZs has been the Jebel Ali Free Zone west of Dubai. Established in 1985 by the Dubai Department for Industry, the Jebel Ali Free Zone Authority began operating with the objectives of supplying all of the necessary administration, engineering and utility services required by their clients. ${ }^{95}$ The zone expanded from a modest 298 companies in 1990 to over 2000 by 2001, is now home to nearly 37,000 workers, and has attracted somewhere in the region of $\$ 4$ billion in investments. ${ }^{96}$ For high-tech and media companies, other more specialist zones also exist, including the Dubai Internet City and the Dubai Media City. Having opened in late 2000 , their aims were to provide Internet and media free zones with the entire necessary communications infrastructure in place for prospective computer-oriented firms. ${ }^{97}$ A number of multinationals have been already attracted by the high standards and impressive facilities, and the list of tenants now includes Microsoft, Compaq, IBM and Hewlett-Packard.

\section{6-Social growth}

Also necessary for the successful diversification of the economy and of course an essential component of the described rentier package of distributed wealth and the political 'ruling bargain', the UAE has made social growth another of its major priorities. In particular, education has been regarded as a key socio-economic building block; one which will allow the country's youth to contribute in a better way to the national economy, and, as will be shown, one which will create a workforce more capable of reducing the UAE's chronic dependency on expatriate labour than the present generation. Similarly, improved healthcare and a comprehensive welfare 
system have been seen as the necessary foundations for the creation of a healthy and happy society in which every individual can vigorously contribute to the UAE's future development.

Many of these aims were formally recognised in the early 1970 s with the oilfinanced actualisation of social welfare and the provision of acquired rights being among the basic objectives of the UAE's first development plans:

"These [social development objectives] were to be attained through a continuous improvement in the standard of living... This was to be carried out on an equitable basis and in a manner which would emphasise and preserve the welfare benefits for the generations to come.

In the 1990 s, after more than 20 years of sustained social development, the objectives remained much the same and, complemented by various other initiatives including the increased provision of facilities for women and expatriates, ${ }^{99}$ continue to form part of an ongoing strategy to maintain and improve social growth for the UAE's expanding

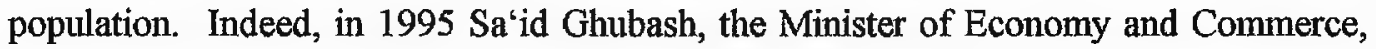
re-affirmed the government's commitment to these plans and re-emphasised the importance of such development for the future of the UAE:

"The government of the UAE strongly believes in human development as a process of expanding and augmenting its people's choices. The most critical in the long list of these choices are to have a comfortable command of goods and services, to live a long and healthy life, to be educated, to feel safe and secure, and to have access to resources needed for an adequate standard of living. The choices people make are their own concern. However, the process of development must create a conducive environment that allows them to generate their full potentials. "100 
Given the relative simplicity of these goals and their clearly positive relationship with oil wealth and economic growth, most areas of social development enjoyed considerable success from a very early stage. Indeed, the provision and rapid implementation of educational and welfare services were already considered by the planners to have been, "one of most remarkable achievements of the UAE during the period 1975 to $1980 . " 101$ The continuing successes throughout the $1980 \mathrm{~s}$ and $1990 \mathrm{~s}$ were also highly regarded, and more recently with the UNDP's positive report in 2000 on the UAE's first national human development statistics, the trend seems set to continue:

"The UAE has recently released its first national human development report... It is the outcome of the nationally executed programme of 'Sustainable Human Development Profile and Strategy for the UAE' begun in 1994. It shows how the UAE has risen from a global rank of 77 to 42 in just 8 years, and praises Shaykh Zäyid's often cited vision that "true development is not measured by cement and steel buildings, but by developing the human being." 102

Certainly, with specific regard to education, the number of primary and secondary schools, teachers, and students have multiplied, providing the UAE with one of the most developed systems in the Middle East, and one comparable to those of many western states. Again, perhaps the most significant feature has been the speed of this progress, especially when one considers the region's rather modest background and its relatively recent urbanisation. Among the most remarkable results have been the rise in the literacy rate of the UAE's youth, which is now estimated at $90 \%,{ }^{103}$ the gradual rise of primary and secondary school enrolment ratios, which now stand at $87 \%$ and $67 \%$ respectively, ${ }^{104}$ and the doubling of Emirati secondary school graduates over the past ten years: 


\section{UAE secondary school graduates (per annum)}

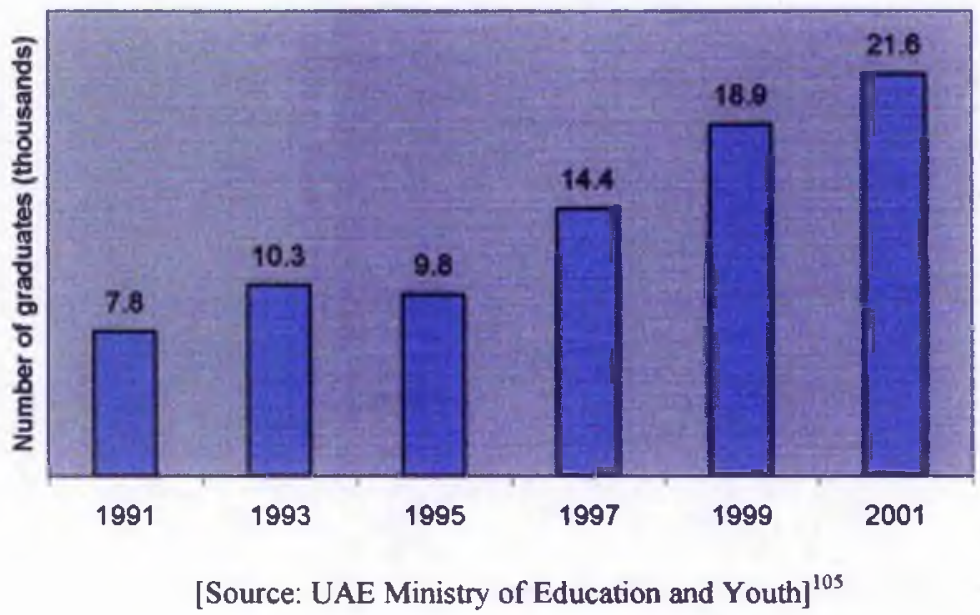

In addition to this massive increase in the number of graduates, another important indication of improvement in the UAE's schooling system has been the steady decline in the student/teacher ratio. As the number of enrolled pupils has risen, the UAE has more than matched its population's needs, and the number of teachers has risen at an even higher rate, allowing the UAE's schools to provide an extremely conducive environment for both teaching and learning. Moreover, with ratios of around 15:1 in primary schools, and just 10:1 in secondary schools, it is worth noting that the UAE's state sector ratios have been consistently lower than the private sector for much of the last 15 years. ${ }^{106}$ See appendix (v).

Similarly in the UAE's tertiary sector, there has been rapid expansion with the number of universities and students increasing almost every year (with the enrolment ratio having risen from practically zero in 1971 to around $12 \%$ in $1999^{107}$ ). Sharjah provides a particularly strong example of recent development with its 'University City' which now houses two large universities, a technical college, and various other training academies. Other, more recent examples would include the expansion of the dual campus Zāyid University, the opening of the new Abu Dhabi University, and the forthcoming launch of the British University of Dubai. However, the success of the UAE's first university, situated in Al-'Ayn, probably provides the best measure of the UAE's tertiary education boom given that it was established in 1978 and continues to enjoy consistently high growth: 


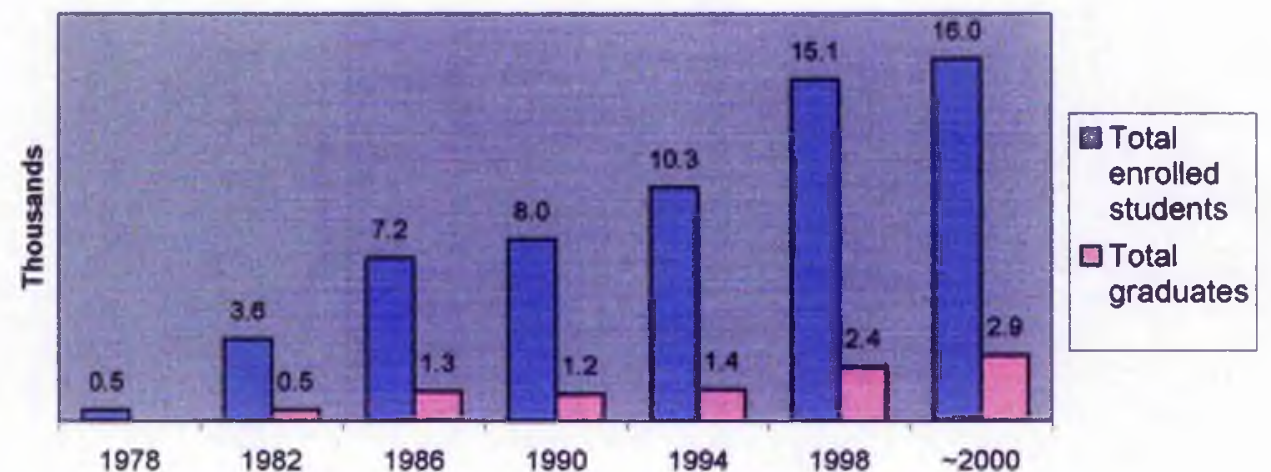

[Source: UAE University in Al- Ayn] ${ }^{108}$

Evidently, the total number of students enrolled per annum has climbed from around 500 to over 16 thousand, representing a thirty-fold increase in just 22 years. Thus, as a result, the number of university graduates has now risen to nearly three thousand per annum. Moreover, the UAE University in Al-'Ayn is not only an excellent example because of its considerable growth, but also because it provides a clear indicator of the increasing importance attached to the educational development of UAE women:

Graduates of the UAE University in Al-Ayn - by gender

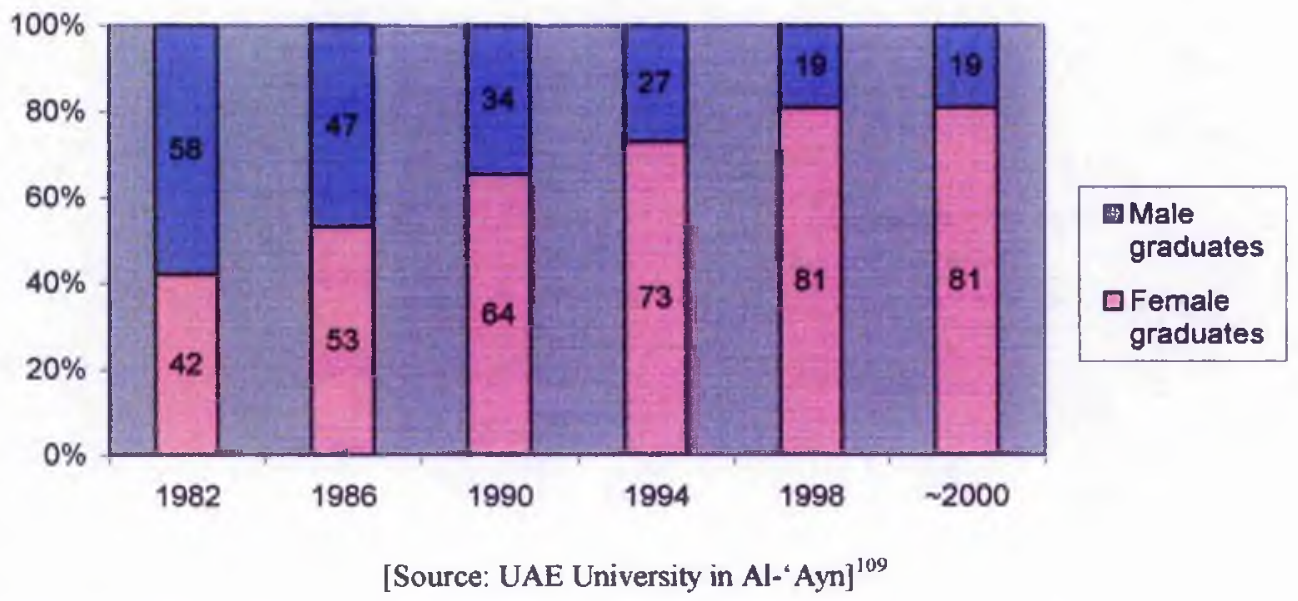

Clearly, female students have outnumbered males in every year group from 1983 onwards, and now account for over three-quarters of all graduates and currently enrolled students. Given that the university specialises in the humanities and social sciences, these statistics would probably not be replicated in more technical and science-based colleges which one may expect to be traditionally more male-dominated. Also, given 
that there has been a greater tendency for Emirati males to study abroad, these figures are perhaps unsurprising, but nevertheless the increasing number of female students and graduates does indicate an appreciable increase in female education at the highest levels and the continuing expansion of an important literary and skilled segment of the UAE's population.

With regard to healthcare, the UAE's attempts to create and maintain a welfare state have experienced similarly impressive results, especially given the region's rapidly increasing population. ${ }^{110}$ Certainly, to illustrate the scale of this challenge it is worth noting that in 1975 approximately 28,000 patients were being admitted to health centres in the UAE, yet by 1995 this figure had reached nearly 100,000 per annum. ${ }^{11}$ In most areas, this challenge has been met, and in many cases the level of care continues to improve. Almost all health-related problems can now be dealt with locally in first-rate hospitals, and the number of overseas consultations has fallen as the number of specialists resident in the UAE has risen. Indeed, focusing on Dubai, the following figures serve to highlight some of the more tangible results in healthcare development:

\section{Healthcare improvements in Dubai}

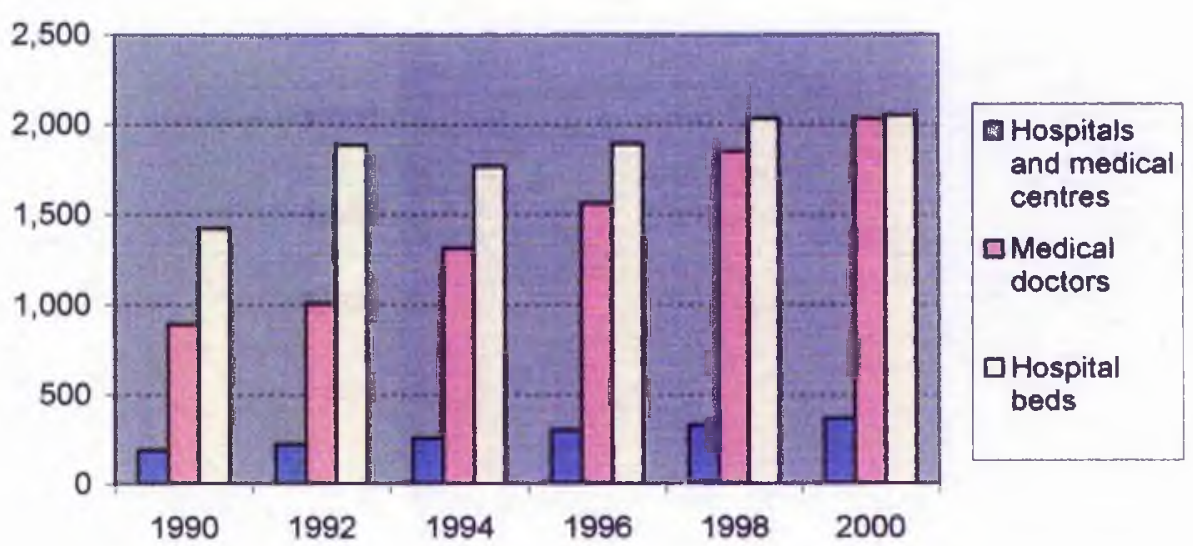

[Source: UAE Ministry of Health and Medical Services] ${ }^{112}$

Evidently, the provision of hospitals, health centres and hospitals beds has risen appreciably in just ten years, but even more impressive has been the considerable increase in healthcare professionals. Between 1990 and 2000, the number of medical doctors practising in Dubai more than doubled, with the number of pharmacists, nurses 
and other medical related staff having risen by $66 \%{ }^{113}$ As such, the population/doctor ratio continues to improve, having fallen from around $600: 1$ to just over $400: 1{ }^{114}$ thus placing the emirate close to the USA, and ahead of the United Kingdom and many other European welfare states. ${ }^{115}$ Furthermore, the number of hospital beds per thousand of population has remained stable between two and three, despite the expanding population. $^{116}$ Finally, other important indicators of these successful healthcare developments must include the UAE's average life expectancy at birth which is now close to 76 years, and the falling infant mortality rate, which now stands at around 13 per 1000 , both placing the UAE comfortably within the world's top 50 healthcare systems. ${ }^{117}$

\section{7 - Emiratisation}

As demonstrated in the historical background, expatriate labour has long been an important socio-economic characteristic of the lower Gulf, with the pearling industry and its associated activities having always attracted large numbers of Indians, Iranians and other nationalities to the main coastal towns. ${ }^{118}$ However, by the early 1970 s, the UAE's massive labour requirements for its oil financed development projects soon led to far greater numbers of foreign workers, both skilled and unskilled, entering the workforce and assuming semi-permanent residence. Indeed, this influx continued more or less unabated right up to the 1990 s, leaving the indigenous 'locals' a minority in their own country and, as most would agree, rendering them totally reliant on the millions of foreigners who have built and continue to build the UAE. In much the same way as the need for diversification of the oil dependent economy, the UAE's planners therefore recognised the need to reduce their population's persistent dependency on foreign labour and skills, not only to help achieve a more desirable level of labour self sufficiency in both the private and public sectors, but also to control in a better way the many other socio-economic problems that could result from the continuing presence of a large number of expatriate workers (both Arab and non-Arab). As such, the need for greater 'emiratisation' of the workforce has not only been viewed within the context of labour nationalisation, but is also increasingly regarded as a necessary safeguard against 
the negative implications for the UAE's money supply growth resulting from salaries and other payments being transferred out of the country, as a check on the unhealthy gender imbalances arising from a predominantly male immigrant workforce, and as a curb on the perceived erosion of cultural and religious identities.

To give an idea of the scale of this foreign presence it is worth noting that in 1968 , three years before the creation of the UAE, a sizeable, but perhaps containable $38 \%$ of the region's workforce were expatriates. ${ }^{119}$ By the year 2000 , however, with a population of somewhere between three and four million, recent surveys in the big cities have indicated that less than $17 \%$ of households may be UAE national, and that over $70 \%$ of the municipal populations now comprise of either Asian households or Asian labour collectives: ${ }^{120}$

\section{Breakdown of Dubai households - 1998}

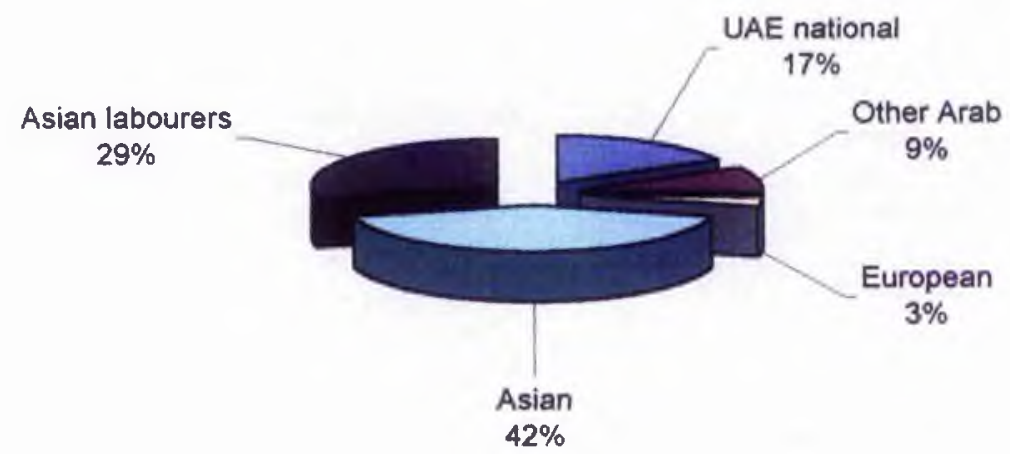

[Source: Dubai Municipality, Administrate Affairs Department, Statistics Centre ${ }^{\mathrm{t} 21}$ ]

Indeed, it is now privately estimated that over $90 \%$ of workers may be expatriates, with the head of the Abu Dhabi Planning Department's statistics unit having recently admitted that UAE nationals now account for less than $7.5 \%$ of the private sector workforce. $^{122}$ As Rawhi Abeidoh describes, this has of course been an enormous change over a relatively short period of time, a change which has led to increasing socio-economic concerns for the UAE's future, even at the highest levels of Emirati politics: 
"United Arab Emirates citizens are rapidly becoming a shrinking minority in their own country. UAE officials and businessmen say they are alarmed by what they see as a growing reliance on foreign workers who now form more than 90 per cent of the country's three million workforce. This is by far the highest percentage in the Gulf Arab states, their economies transformed by vast oil and gas riches. The UAE's rapid transformation from small tribal societies into a modern state with eight-lane highways and gleaming skyscrapers came at a heavy cost in a country where citizens have traditionally shied away from menial jobs. Foreigners now virtually dominate the private sector and form around 60 per cent of the public sector workforce, delegates said. According to the latest official census in 1997, the UAE population stood at 2.7 million, more than 75 per cent of it foreign. UAE officials privately say the figure was now around four million, 85 per cent of them foreigners, mainly from India, Pakistan and other Asian countries. The expatriates-to-locals ratio is higher in the workforce as UAE immigration laws ban low-paid labourers from bringing in their families. In 1968, three years before the country's independence from Britain, UAE nationals represented 62 per cent of the workforce, said Matar Juma'a, head of the statistics unit at the Abu Dhabi government-planning department. 'We are now less than 7.5 per cent', Juma'a added. The UAE does not issue a detailed breakdown of its population. 'We are facing a grave issue that demands a swift solution. We are shackled and I want a solution now before I become a mere one per cent', said Muhammad Mazroui, secretary-general of the Federal National Council, the UAE's appointed parliament. Mazroui said a lack of laws setting limits on the country's need for foreign labour was also to blame for the situation. A study of the workforce in the private sector released last month found that construction and services employed the majority of the UAE's 1.4 million overseas workers, two-thirds of whom do not have a secondary education. Delegates said the flood of the foreign labour was wiping out the Arab 
character of the country where some areas now resembled parts of India or Pakistan."123

Certainly, up until very recently expatriates have dominated virtually all segments of the private sector and, as Abeidoh describes, even the public sector is now comprised of $60 \%$ foreigners. Perhaps most worrying of all though has been the increasing domination of expatriates in the middle and lower ranks of the government administration, areas one may have expected to remain the preserve of nationals, with official studies having estimated that more than four-fifths of Abu Dhabi government employees may be foreigners, and the majority of these non-Arabs: ${ }^{124}$

\section{Breakdown of Abu Dhabi government employees by nationality - 1995}
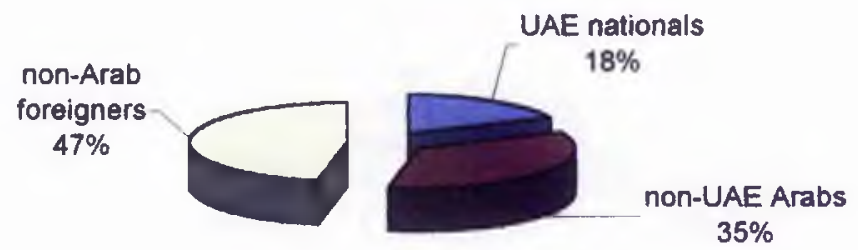

[Source: Crown Prince Court. Department of Research and Studies, Abu Dhabi] ${ }^{125}$

Thus, with non-Emirati Arabs accounting for 35\%, and with a staggering $47 \%$ being non-Arab foreigners, ${ }^{126}$ the size of the expatriate workforce also has serious implications for the functioning of the government itself. Not only reliant on foreigners for the continuing success of its economy, the UAE has also become dependent on foreigners for the functioning of its bureaucracies and much of the day-to-day public administration of the country.

It is worth noting that even in the 1970 s the government had recognised the potential problem of such 'shackling', ${ }^{127}$ with the Abu Dhabi Planning Department recommending in 1977 that there needed to be state-sponsored encouragement for far greater nationalisation, or 'emiratisation' of the workforce. ${ }^{128}$ Essentially, in economic 
terms, it was felt that a continuing reliance on foreign labour would lead to persistently high development costs, and that the growing expatriate population would also adversely affect the UAE's money supply. ${ }^{129}$ Indeed, even today a considerable portion of the money supply growth fails to find its way back into the UAE's banking system, and this is primarily due to the estimated $\$ 3.3$ billion that is being repatriated overseas annually by foreign workers sending remittances back to their country of origin. ${ }^{130}$ Furthermore, by the mid-1980s there was also a growing consensus that without such an emiratisation drive, the UAE's employment structure would become even more distorted with fewer nationals capable or willing to undertake jobs normally associated with expatriate labour. Certainly, as Peck observed:

“... as in the other wealthy oil states of the Arabian Peninsula, there is little evident connection in UAE society between wealth and work. As one analyst remarks, 'the message is clear: without effort or self-denial one can simply accept a world made by others.' As a result, there are incipient signs of the kind of social malaise already evident in Kuwait with its long history of very high per capita wealth and advanced welfarism. Some young men with large amounts of money and leisure at their disposal are tempted to spend them on such things as expensive cars and mistresses and to avoid meaningful employment."

Greater emiratisation has also been seen as an essential measure in lessening the growing gender imbalance in the UAE. Given that the vast majority of expatriate labourers are Pathan bachelors or married Keralite men unable to bring their spouses and families to the UAE (a minimum salary is required before a worker is eligible to invite family members to accompany them), this has inevitability led to a skewed demographic structure and a rather unpleasant atmosphere, with adult males vastly outnumbering adult females. Indeed, the results of the UAE's population censuses illustrate the scale of this imbalance over the years: 


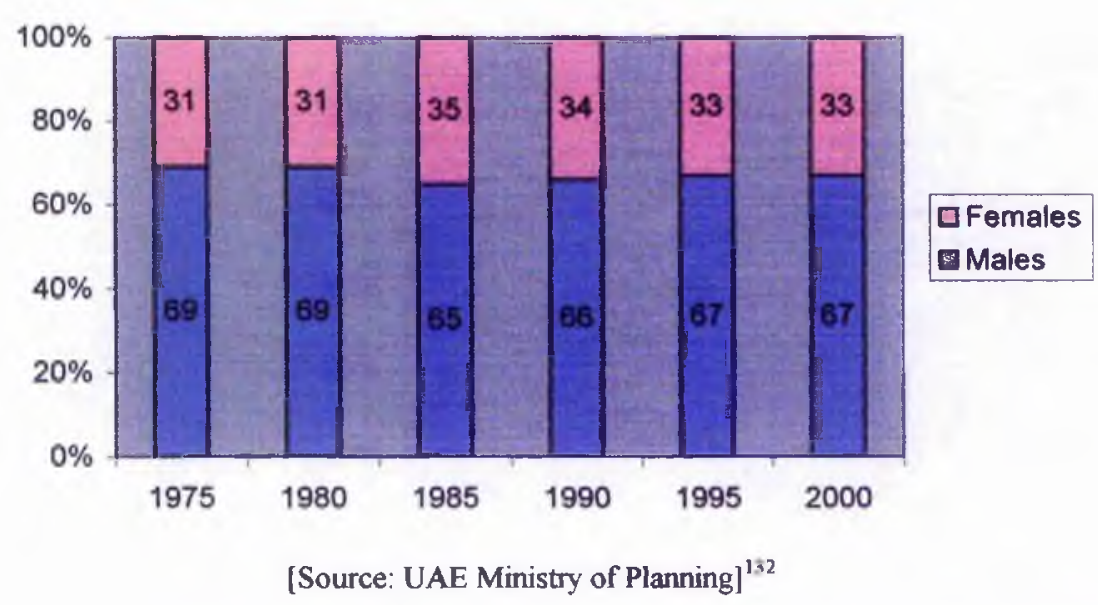

As such, even though there were slight improvements in the $1990 \mathrm{~s}$, it is evident that of the three million or so registered in the census of 2000; more than two-thirds are still male, thus making the UAE's population one of the most imbalanced in the world. Moreover, the proportion of males is probably even higher than this official figure given that many short-term contract workers are not included in census data. Also, given that the vast majority of the expatriates are based inside or close to the major cities, it is important to note that the gender imbalance may be even higher in these areas. Indeed, if the census statistics for the individual emirates are analysed then it becomes clear that the problem is most marked in the urban areas of Abu Dhabi, Sharjah, and especially Dubai where the percentage of males has been consistently higher than the UAE average, and now stands at around $71 \%{ }^{133}$ Conversely, those emirates with less developed economies, smaller conurbations and fewer labour intensive activities such as 'Ajman, Umm al-Qawain, and Ra's al-Khaimah have much lower male to female ratios, but with males still accounting for around $59 \%$ of their populations, ${ }^{134}$ gender imbalance is nevertheless still a nationwide problem. If more UAE nationals, both men and women, can be brought into the workplace and eventually be used to fill positions previously requiring expatriates, then it is hoped that this disparity and its negative social implications can be somewhat reduced. See appendix (v).

With regard to the socio-cultural impact of such a large population of foreign workers residing in the UAE, it is worth noting that in Findlow's recent investigation 
into emiratisation, she was informed that such factors were not important, and that the initiative was an entirely pragmatic policy designed to lessen the serious economic and demographic imbalances:

\begin{abstract}
"When pressed during my interviews, people either told me that culture was not an issue in this project, or they were non-committal. The impression was given that the action agenda is firmly a pragmatic one and that religious considerations and the nation's religious identity were not linked to this issue." 135
\end{abstract}

However, although not an official aim of the emiratisation process, there is little doubt that it has also been seen as an increasingly necessary preventative check on the perceived cultural and religious erosion resulting from the massive influx of expatriates. Indeed, while such erosion will be discussed in greater depth in the discussion of globalising forces later in this thesis, ${ }^{136}$ it is important to emphasise how many UAE nationals not only voice their misgivings over their minority status in the workforce and their reliance on foreign labour, but also voice very deep concerns over their increasing cultural marginalisation in a country dominated by non-Arabs and, in many areas, by non-Muslims. ${ }^{137}$ Moreover, given the earlier discussion of cultural legitimacy resources and the crucial role of identity in the traditional polity, there is little doubt that emiratisation is also considered a multidimensional strategy by the ruling elite, many of whom are keen to foster and preserve a distinct, loyal, and culturally rich Emirati Arab patrimonial class.

Finally, although of less direct interest to the UAE government and the planners, it is perhaps also worth considering that the emiratisation strategy and indeed 'Saudification' and the various other labour nationalisation initiatives in the Gulf States are being increasingly viewed by both indigenous and Asian scholars as necessary measures for correcting what have developed into serious two-way population problems. Certainly, it has been argued that massive labour migrations on the scale such as that between the Gulf and the subcontinent have caused marked gender 
imbalances and other socio-economic problems for the supplier countries as well as the host. Indeed, as Peck noted in the early 1980 s, severe strains were already beginning to emerge in these South Asian supplier countries with the cause often being dubbed 'the Dubai syndrome':

"... social strains are generated not only in the host societies by the presence of foreign workers, but in the latter's societies as well. Although many of the Asian labourers live in physically and psychologically difficult situations in the UAE and in its neighbour states, their wives left at home fall victim to frustration and attendant disorders dubbed 'Dubai syndrome' (as coined by a Pakistani psychiatrist). The prolonged absences of heads of families cause a breakdown of social controls in some Asian settings, and the remittances that are sent back often create resentments and divisions in the workers ' home communities." 138

Moreover, twenty years later, these psychosocial problems are still very much in evidence, with recent Sharjah-based studies concluding that the majority of the millions of Asian expatriate workers not only suffer from some sort of psychological depression themselves, but also, due to their long periods of absence, are beginning to cause significant socio-economic problems in their home country. ${ }^{139}$ If therefore, as part of a broader labour nationalisation policy, there can be time limits or other restrictions placed on foreign workers, especially those unable to bring their families to the UAE, it is theorised that these pathologies can be somewhat reduced before conditions further deteriorate.

\subsection{1 - Emiratisation strategies}

With regard to the strategies themselves, the encouragement of locals to participate in the workforce actually has a long history in the region and, as such, the present-day emiratisation initiative can be viewed as an extension of existing ideas and practices, albeit on a much more comprehensive scale. Indeed, with the beginning of 
'Al-khawiya' (the oil exploration by foreign firms in the early 1930s) the rulers had already begun to insist that as part of their concession agreements, the firms would be obliged to recruit and train up some of the local population, rather than simply importing all of their labour. ${ }^{140}$ Moreover, by the late 1930 s, the ruler of Dubai had taken this agreement one stage further by insisting that Petroleum Development Trucial Coast Ltd. (PDTC) employ only Dubai subjects. ${ }^{141}$ Following the decline of the pearling industry, and faced with the prospect of unemployment, it was reasoned that Dubai locals needed far more stable jobs, and with the training provided by the foreign oil companies this early emiratisation was seen as a suitable long-term solution. ${ }^{142}$ Certainly, writing in the 1960 s, Fenelon remarked upon the apparent successes of these early initiatives, including those in Abu Dhabi, and described how the oil firms had been responsible for training a modest number of locals in skilled professions:

"... the contributions made by the oil companies in Abu Dhabi by providing training facilities for craftsmen and technicians have been of the greatest importance in producing a nucleus of skilled workers. A sizeable number of ex-trainees are now engaged in skilled jobs both inside and outside the oil industry". 143

Indeed, Abu Dhabi Marine Areas Ltd. (ADMA), one of the largest of the concession holders, had opened a number of such training centres with the twin aims of providing Abu Dhabi locals with greater responsibility within the organisation and training them to such a level that they could eventually replace expatriate employees in technical and administrative departments. Similarly, the Abu Dhabi Petroleum Company (ADPC), the principal land-based concession holder, began to provide training facilities almost as soon as oil production began. Although many of the locals trained by the ADPC subsequently left the company, they soon began to contribute towards other activities in the emirate, thereby continuing to fulfil the company's responsibility to the local population. ${ }^{144}$ 
By the late 1970s and 1980s the emiratisation strategy became far more extensive, with the official economic and social development plans outlining a comprehensive programme aiming to rehabilitate as many UAE nationals as possible by educating them, training them, and by giving them added incentives to participate and become an active part of the workforce. ${ }^{145}$ Indeed, as has been shown, the development of the UAE's education system was already a key priority, and, with specific regard to emiratisation, a special emphasis was placed on courses and subjects relating to business practices and the professional skills demanded by other areas of the UAE's development. This commitment to investment in education was to be matched in the workplace by a number of government-sponsored schemes to encourage greater work experience and full-time employment. Prominent examples in recent years have included the Al-Futtaim Trading Group's summer courses offered to young UAE nationals, with the group claiming it intends to "pioneer the training of national personnel"; ${ }^{146}$ the work of the UAE Women's Federation which aims to bring more young Emirati women into the workplace; ${ }^{147}$ and the various Emirati-specific training programmes offered by the major banks. Indeed, Speaking about Mashriq Bank's role in the emiratisation process, Abdul Al-Ghurair, Chief Executive Officer of Mashriq, explained why the bank was the first to launch such a programme:

"In our continuous quest for excellence, Mashriq Bank has never neglected to play the role of the responsible corporate, forever striving to create practical and innovative solutions in response to the direct needs of the UAE market. The contributions of Mashriq Bank in the process of emiratisation has been quite significant as we go ahead with our plans to increase the presence of UAE nationals in our bank."

Moreover, Mohammed al-Sayari, chairman of the bank's human resources department, explained how such a programme would actually contribute to the emiratisation process: 
"Our aim is to train 60 UAE nationals every year by running four courses throughout the year. The first 15 passed out in March and completed the programme successfully. Some are now working in Mashriq and some have started careers in other banks. The course concentrates on improving practical skills through on-the-job training rather than theory work. The course runs for five full working days to give the young nationals a feeling of the work place. They learn how to write a professional CV, how to behave in an interview and where to go if they have a problem. The training is definitely more practical than theoretical. "148

In addition to these educational programmes, there have also been more direct strategies, many of which have focused on the granting of specific privileges to UAE nationals with the aim of assisting their introduction into the workplace and reducing competition from expatriates. Certainly, as Abdullah Sultān Abdullah, the secretary general of the Federation of the UAE Chambers of Commerce and Industry has explained, although the UAE's chambers do place great emphasis on training and qualifying nationals, this can only go so far, and in certain cases the government has had to intervene in order to provide additional incentives and encouragement. ${ }^{149}$ Most recently this strategy has been reinforced by a new labour law aimed at regulating the employment of UAE nationals in the private sector. As part of the new law, UAE nationals will benefit from special pension funds and better guarantees of their rights as employees in the private sector. ${ }^{150}$ Alongside these initiatives there have, of course, been more restrictive schemes, including the longstanding ' $k a f i l l$ ' sponsorship system in which all non-Emirati entrepreneurs require a local partner, thereby ensuring that UAE nationals, even as parasites, have at least some involvement in the management and profits of the domestic economy. In addition, there have also been specific emiratisation quotas introduced, requiring certain companies to increase their percentage of Emirati employees over a set period. Once again, the banking sector provides a strong example, where up until recently locals accounted for just $12 \%$ of the workforce. To redress this situation, the government chose to impose quotas, requiring all banks to increase their percentage of locals to $40 \%$ over the next ten years. ${ }^{151}$ As 
such, Mashriq Bank and many of the other banking houses have publicly stated their intention to have an 'emiratisation growth rate' of over $4 \%$ per year in an effort to meet these targets. ${ }^{152}$ Moreover, it is worthwhile noting that in certain circumstances there have also been more extreme measures including, for example, highly contentious directives such as the Ministry of Agriculture and Fishing's decree that UAE nationals must captain all fishing boats. Explained by the Minister as being a necessary step in order to "help check over-fishing and eliminate illegal practices resorted to by expatriate fishermen at sea", in practice it is simply a part of the government's overall drive for emiratisation in the agricultural sector. ${ }^{153}$

Thirdly, and also deserving mention, are those emiratisation strategies concerned not so much with the encouragement of UAE nationals, but rather the discouragement of expatriates, or more specifically, the discouragement of employers intent on hiring foreigners. Indeed, an important recent example would be the draft law released by the Ministry of Labour which will require companies to pay a fee for every foreigner they hire, thus making UAE nationals a more attractive alternative. ${ }^{154}$ In addition, other more severe laws have aimed at stemming the flow of immigrant labour and actually reducing the size of the current expatriate population. Examples would include the restrictions placed on new visas requested by unskilled workers from India and Pakistan, ${ }^{155}$ and the introduction of lengthy immigration amnesties which have allowed all foreign workers without valid visas to leave the UAE with only minimal penalties. Indeed, it has been estimated that during the 1996 amnesty as many as 200,000 workers unexpectedly took advantage of the favourable terms and left before its deadline, thereby creating massive labour shortages. ${ }^{156}$

Given the enormity and complexity of the challenge, the results of these various emiratisation strategies have, however, been far less impressive than most would have expected (although it remains important to note that many serious observers had always remained sceptical ${ }^{157}$ ). Certainly, the original objectives of the early 1980 s, which proposed that national management and labour in all sectors should reach at least $25 \%$ of the UAE's total within five years, ${ }^{158}$ have clearly not been met. Thus, unlike the 
comparatively straightforward diversification and welfare objectives, the nationalisation of the UAE's workforce has not been solved with financial packages and massive investment. Indeed, the experiences of the 1990 s point to the opposite, given that the improved incentives, higher salaries, and pension schemes encouraged by the emiratisation initiative may have actually priced UAE graduates out of the market. Certainly, many employers baulked at paying the $\$ 26,000$ average salary for a local graduate in addition to the obligatory $12.5 \%$ pension contribution, ${ }^{159}$ and much preferred to hire well-qualified and experienced South Asians at a fraction of the cost. ${ }^{160}$ Nevertheless, although few of the official targets may have been reached, there has undoubtedly been a rise in the number of UAE nationals participating in very diverse areas of the workforce and, as demonstrated in the previous section, with the rapidly increasing number of young Emiratis entering higher education, it is likely that emiratisation, especially in managerial positions, will mushroom in the near future. Thus, although lacking the immediacy of the incentives, quotas, and sponsorship systems, the various emiratisation education programmes and the UAE's considerable investment in higher education may lead to important long-term results, especially in the nationalisation of professional occupations which is, after all, a far more realistic objective than nationalising $25 \%$ of the total workforce. Indeed, there are already important glimmers of hope, as in just the past year or so the proportion of UAE nationals gaining such positions, in both the private and public sectors, has appreciably increased. Again referring to the banking sector, the emiratisation process has really taken hold since 2000 , with UAE nationals now accounting for around $20 \%$ of the workforce, thus representing a rise of nearly $8 \%$. Moreover, some banks have been particularly successful and, in the case of EIBFS, the general manager confidently expected their proportion of UAE nationals to rise to $23 \%$ by the end of 2002 as a direct result of fresh Emirati graduates. ${ }^{161}$ Using a very different example, emiratisation has also been extremely successful in the UAE's judiciary, a key area of the public sector. Although most judges are still foreign nationals, primarily from other Arab countries, the number of UAE nationals serving as public prosecutors and judges has nevertheless continued to grow, ${ }^{162}$ and, as the Minister of Justice, Muhammad al-Dhahiri, has 
claimed, nationals now account for $32 \%$ of the workforce, a proportion likely to double within the next few years. ${ }^{163}$

\section{8 - Sub-strategies: Abu Dhabi and Dubai, a comparative analysis}

Given that Abu Dhabi and Dubai are by far the largest, wealthiest, and most populous members of the federation, there is little doubt that the developments which have taken place in these two principal emirates have most directly contributed to UAE's overall diversification, social growth, and emiratisation objectives. It is, therefore, essential to consider the important differences and sub strategies which have emerged in these emirates and, although inter-emirate politics and the viability of the federation will be discussed in greater detail in the following chapter, ${ }^{164}$ it is nevertheless crucial at this stage to understand the relative flexibility of Emirati socioeconomic planning and to appreciate how, at least in some respects, this has led to mutually reinforcing and beneficial dual approaches.

Indeed, as the above analyses have shown, especially with regard to industrialisation, commerce, and tourism, very often Abu Dhabi and Dubai have chosen to emphasise and pursue different elements of what remain very broad strategies. The immediate explanation for such divergent sub-strategies would of course be the relative differences in oil resources, with Abu Dhabi possessing some of the world's largest reserves, and with little secret being made of the more finite supplies in Dubai. ${ }^{165}$ Certainly, as the Middle East Economic Digest noted in the mid-1990s:

\footnotetext{
"The contrast between Abu Dhabi and Dubai, less than two hours apart by desert road, is striking. The capital city [Abu Dhabi] has risen as a glittering showcase for the modern Middle East, exuding an air of leisure and luxury. Dubai presents an altogether different aspect of the UAE with a sprawling townscape that hums to the rhythm of business... Dubai has staked everything on trade, its traditional lifeblood... Dubai's oil production is sustained by a huge re-injection programme and costly
} 
recovery techniques. Some analysts predict that Dubai may soon have to become a net oil and gas importer. Thus, for the long-term prospects, nothing less than massive development will do."166

Thus, as one might expect, Dubai has been pressed into more wholesale diversification, needing to promote the growth of ISI industries and rapidly expand its non-oil related commercial and tourist sectors, while Abu Dhabi has instead been able to diversify at a slower pace and rely on its comparative advantage of cheap energy by concentrating on heavier, oil-related and EOI industries. Furthermore, although unrelated to diversification, Abu Dhabi's massive oil wealth has also allowed the emirate to rely more heavily on oil-financed investments overseas. Indeed, although the government of Dubai is reported to hold approximately $\$ 35$ billion overseas, the undisclosed foreign assets held by the Abu Dhabi investment authority, the Abu Dhabi ruling family, and many private Abu Dhabi citizens are nevertheless believed to dwarf this figure. ${ }^{167}$

A full explanation of how these different development paths have helped to shape the contemporary UAE cannot, however, rest solely on the relative oil wealth of the two emirates. Instead it must also be appreciated just how varied the pace of development had been for these two emirates during the first half of the twentieth century. It is often assumed that these emirates began the 1970s in much the same situation as they had both been Trucial shaykhdoms and, as explained in the historical background, they possessed similar traditional social and political structures. However, while Abu Dhabi still remained something of a backwater even by the 1950s, Dubai had long since grown into the largest town of the lower Gulf. Indeed, when former British political agent Donald Hawley visited Abu Dhabi during this period, he felt obliged to remark on its comparative visible backwardness:

"... the approach to the town, which is on an island, was appalling. High winds drove in the sea over miles of salt flats and only one narrow track, glistening with thick white cakes of salt, was passable. A square fort guarded a causeway (replaced only in 1968 with a bridge) and even the 
causeway was only built in the 1950s. Earlier, visitors had to drive through the shallows of the sea to reach Abu Dhabi. The town itself was a place of palm-frond houses, barastis, built on white sand among palm trees. A small market with tiny shops stood in higgledy-piggledy fashion between simple houses, and the streets were narrow and roofed with palm-fronds. Little was to be bought. The white palace of the ruler, turreted and crenellated like a Beau Geste fort, stood among the palms, dominating the place, with the red and white flag of Abu Dhabi fluttering over it."

By the late 1950s, and in complete contrast to the "small dilapidated town' of Abu Dhabi, ${ }^{169}$ Dubai was already beginning to display noticeable signs of prosperity and development. Certainly, as the early aerial photographs of the emirate illustrate, the town was already rapidly expanding with an extensive commercial district in Deira and with many large merchant houses along the creek side. ${ }^{170}$ Moreover, even following the oil boom and with Abu Dhabi developing into a modern city with much greenery, Dubai has always maintained a highly visible edge, and now of course boasts one of the most celebrated skylines in the Middle East. ${ }^{171}$

This manifestly differing pace of development can be best accounted for by the many underlying differences between the two emirates during the critical pre-oil period. Unlike Dubai, where prominent merchant families had been established for generations, Abu Dhabi's business community was really more of a post-oil boom phenomenon and, as Peck has noted, "therefore lacked the roots, scope and energy of its Dubai counterpart". Prominent Abu Dhabi families did of course succeed in launching themselves in business, but very often they lacked the necessary experience and had to rely on expatriate managers to carry out the daily affairs of their enterprises, whereas the stronger business traditions in Dubai allowed many prominent families to assume a more hands-on role. ${ }^{172}$ In most cases these early structural differences were the result of Dubai's long history of relative attractiveness over Abu Dhabi. Indeed, with regard to commerce and other coastal activities, Dubai had always possessed a geographical advantage over the other Trucial shaykhdoms given its sheltered creek which extends 
much further inland than any of the other inlets along the lower Gulf. Moreover, this considerable natural asset was further complemented by Dubai's relatively low tariff structure and the ruler's active encouragement of foreign trade (an encouragement which remains very much in evidence even today, with the entrepreneurial spirit of the ruling Āl-Maktūm dynasty seen as being inextricably linked to the emirate's ongoing commercial success), especially compared to Abu Dhabi, where, as Miriam Joyce describes, the overly cautious rulers continued to restrict entry for foreign merchants and even other merchants from the Trucial States. ${ }^{173}$

Most significantly, when the major ports on the Persian coast were forced to impose new customs regulations in the early 1900s, the towns of the Trucial coast suddenly became far more appealing prospects, and Dubai was best placed to accommodate the new influx of merchants. ${ }^{174}$ Indeed, as DK Chaudhry, the general manager of the Persian Sharaf Shipping Agency explains, much of the early success of the emirate's dhow trade and its commercial sectors can be attributed to the increasing tariffs in $\operatorname{Iran}^{175}$ and the almost simultaneous abolition of the existing $5 \%$ customs duty in Dubai. ${ }^{176}$ Certainly, the Shah's expanding control over southern parts of Iran had disrupted the relative freedom in the busy harbours of Lingah and Bushire, and consequently Iran's coastal business community began to shift its operations to Dubai. ${ }^{177}$ As such, when the Swiss traveller Burckhardt visited the area in 1904 he remarked that Dubai had been declared a 'free port' and was therefore unsurprised to find an abundance of British and German merchandise in the port, and a large number of immigrants fresh from Lingah. ${ }^{178}$ Thus, Dubai soon emerged as the main distribution centre for imported goods along the coast from Qatar to Ra's al-Jibãl (East of Ra's alKhaimah), and even became the favoured stop-off point for the British Indian Steam Navigation Company. ${ }^{179}$

Many states have been born from trading modes of production, ${ }^{180}$ and as the century progressed and its commercial success continued to grow, Dubai became one of these. By the $1920 \mathrm{~s}$ it was becoming clear that the restrictions which had been strangling the economy of southern Iran were unlikely to lift. Thus, many of the Persian 
merchants who had taken up temporary residence in Dubai earlier in the century soon realised that they were unlikely to return to Lingah and decided to take up the ruler of Dubai's offer to settle permanently in the emirate. ${ }^{181}$ These merchants had made great contributions towards Dubai's prosperity, and by deciding to remain they cemented Dubai's commercial pre-eminence. As such, business skills, entrepreneurship, and trading links with Asia and Africa were effectively transferred from Iran to Dubai. Indeed, these Persians even introduced the concept of wind towers to the region, and examples of this early form of air-conditioning can still be seen in the Bastakiyah quarter of Bur Dubai where the ruler had originally donated land to the merchants. By the $1960 \mathrm{~s}$, the emirate received another boost, this time from the British, when it was decided that Dubai, rather than Abu Dhabi or Sharjah, should host the headquarters of the Trucial States Council and the Development Office. As explained in the historical background, this office administered considerable funds provided by the British Ministry of Overseas Development and brought a number of agricultural, medical, and technical experts to the emirate. ${ }^{182}$ Thus, as Frauke Heard-Bey contends, its presence in Dubai gave the emirate a more cosmopolitan air than the other shaykhdoms, and more importantly allowed Dubai's rulers to discuss projects informally with the foreign advisers and witness the office's achievements first-hand. ${ }^{183}$ Finally, with regard to Dubai's continuing commercial advantages it is worth noting that in the 1970 s the emirate was still benefiting from its free ports, especially following the Iranian government's renewed attempts to raise the tariff wall. Indeed, as a direct result of these new tariffs, often touching $40 \%$, a fresh wave of Persian merchants began to transfer their businesses to Dubai. As before, these merchants recognised that it was far preferable to import goods through Dubai and then distribute them in the Arab world than it was to suffer the heavy infrastructural liabilities of trading through Iran. Furthermore, as Chaudhry also notes, by this stage the advanced development of Dubai's Port Rāshid and its Port Jebel Ali mega-project had led many Iranian merchants to assume that Dubai would soon become the one convenient stopping point for longdistance shipping and therefore the most sensible location for any long-term commercial base in the Gulf. ${ }^{184}$ 
Thus, in light of these different historical circumstances, it is apparent why Dubai's strong commercial traditions coupled with its comparatively modest oil wealth have facilitated and spurred a more rapid and wholesale diversification of the economy, especially in the non-oil related trade sector. Conversely, Abu Dhabi's non-commercial foundations and its massive oil wealth have engendered a more oil-focused development strategy, using cheap energy to encourage the growth of heavy EOI industries and using oil revenues to finance large-scale overseas investments. Indeed, evidence of these differing diversification sub-strategies has become clearer as the UAE has matured, especially given the relatively small size of Abu Dhabi's non-oil sector and the increasingly large non-oil sector contributions being made to Dubai's economy:

\section{Comparison of oil and non-oil sector contributions to Dubai's GDP}

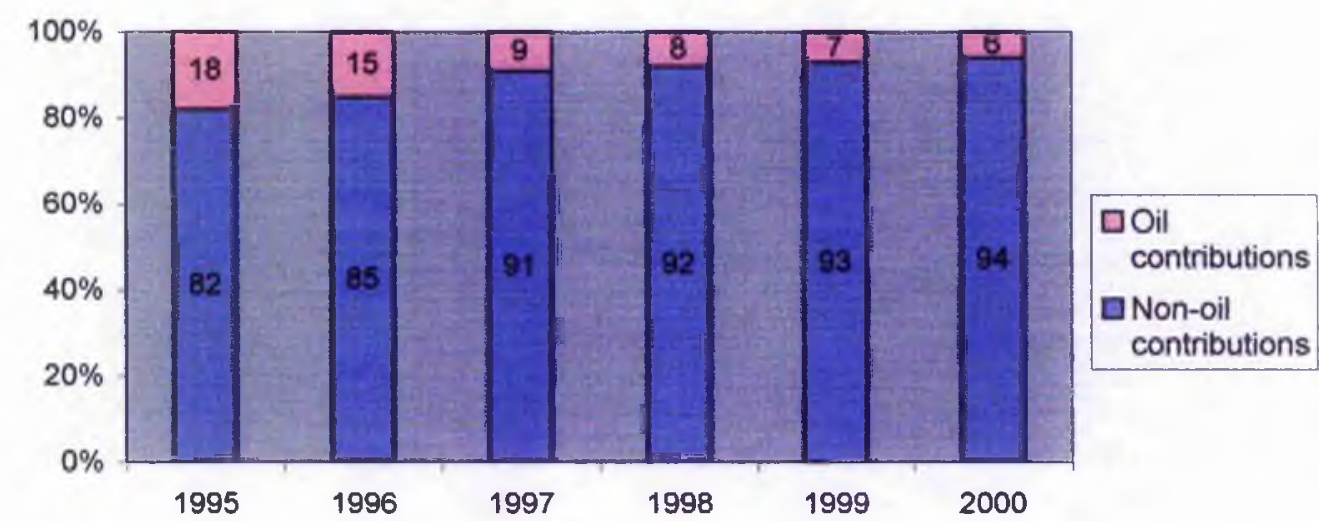

[Source: UAE Ministry of Planning. Dubai's GDP at factor cost calculated on fixed 1995 prices] ${ }^{185}$

Thus, by the mid-1990s Dubai's non-oil economic sectors were already contributing $82 \%$ of the emirate's GDP, and perhaps most remarkably, over a period of just five years, Dubai's non-oil economic sectors have continued to grow and now account for around $94 \%$ of the emirate's total GDP. Moreover, while Dubai's total GDP accounted for around $24 \%$ to $25 \%$ of the UAE's total in 2000 , its share of the UAE's non-oil GDP had risen to $34 \%,{ }^{186}$ demonstrating the emirate's far greater commitment to non-oil related development than Abu Dhabi.

Secondly, with regard to attracting foreign direct investment, another key indicator of successful diversification and relative economic attractiveness, Dubai has 
been similarly successful and clearly ranks first among the emirates, attracting $54 \%$ of all FDI in the UAE's manufacturing sector. This compares with Sharjah's share of $21 \%$ and 'Ajman's share of $10 \%$. Accounting for just $9 \%$, Abu Dhabi ranks only fourth, ${ }^{187}$ indicating the emirate's different outlook on FDI and its preference for state-sponsored heavy industries. ${ }^{188}$

\section{Distribution of foreign direct investment in the UAE}

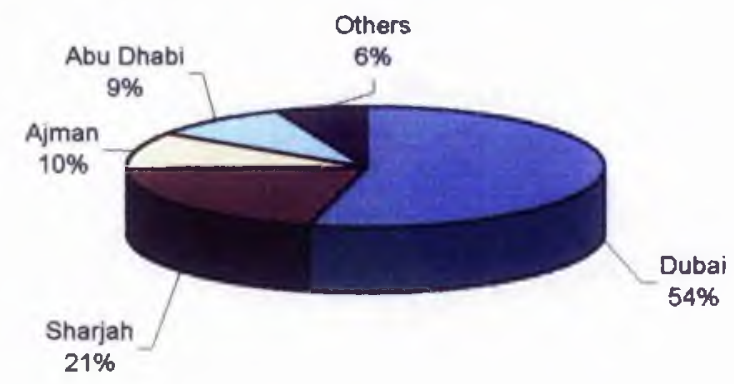

[Source: UAE Ministry of Finance and Industry ${ }^{189}$

Indeed, Abu Dhabi's commitment to heavy industries can be further confirmed by the fact that although the emirate hosts only 224 industrial establishments, a mere $10 \%$ of the total number of plants in the UAE, these plants account for more than half of the UAE's total manufacturing output. In comparison, Dubai has 817 plants, Sharjah has 716, and 'Ajman 316. This clearly indicates the preference for lighter, smaller-scale ISI industries in Dubai and the northern emirates: ${ }^{190}$

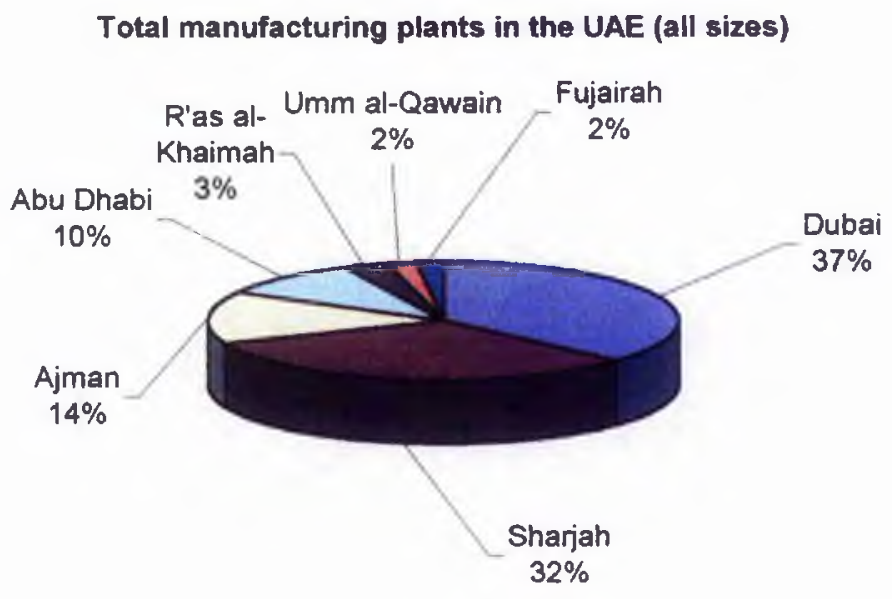

[Source: Al-Sharhan International Consultancy, Dubai $]^{191}$ 
Thirdly, and also with regard to the comparative success of Dubai's non-oil development, it is important to note the appreciable improvements in the emirate's labour productivity scores, especially in its diversifying sectors. Using data from 2000 , the labour productivity scores for the various economic sectors in Dubai can be calculated and compared with the UAE averages:

\section{Labour productivity scores - Dubai compared with the UAE average}

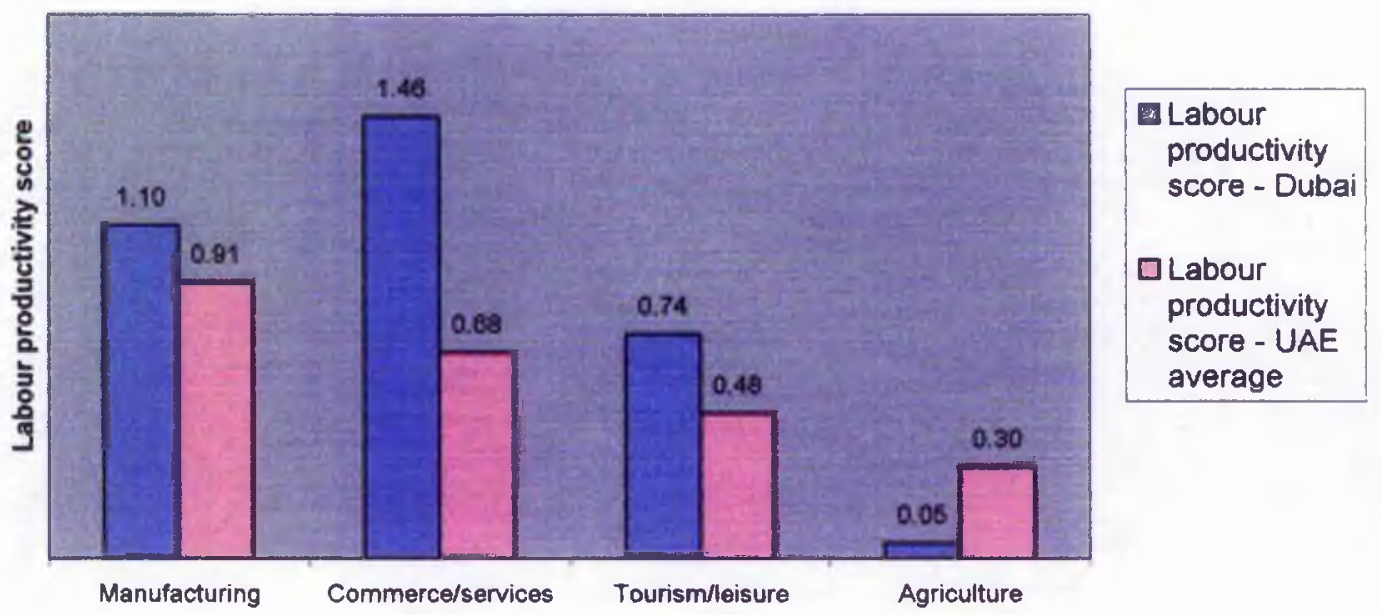

[Source: UAE Ministry of Planning. Calculated from Dubai's total GDP of 54741 million Dirhams in 2000 using sectors' shares of total employment and total GDP] ${ }^{192}$

Thus, if compared to the labour productivity statistics for the entire UAE, it is evident that in the three main non-oil sectors Dubai has enjoyed significantly higher productivity than the other emirates, particularly in the commercial sector where the emirate has now achieved internationally competitive labour productivity rates (indicated by a score substantially higher than 1.0). Only in the agricultural sector does Dubai fall short of the UAE average, indicating the emirate's historical preference for coastal and trading activities, and Abu Dhabi's greater development of its hinterland.

Despite these marked differences between Abu Dhabi and Dubai, there is, however, a growing consensus that such diversity will bring added strength to the federation and will eventually provide the UAE with 'the best of both worlds'. Indeed, as Business Monitor International has claimed, the differing macro-economic strategies of Abu Dhabi and Dubai can be regarded as complementary rather than divisive and are 
likely to ensure that the UAE's overall economy remains resilient and prosperous even in times of low oil prices. ${ }^{193}$ Abu Dhabi can draw upon massive financial reserves if the oil industry falters whereas Dubai can provide greater diversification and more diverse employment opportunities for the emiratisation process. Moreover, Jamal al-Suwaidi of the Emirates Centre for Strategic Studies and Research (ECSSR) has also emphasised these positive aspects of the relationship, explaining how Abu Dhabi needs to support Dubai's rapid development, as "keeping Dubai strong is important for the federation and important for the future of the federation." Thus, even though Dubai's contribution to the federal budget is low, he recognises that Dubai's expanding non-oil sectors are more likely to solve the employment / emiratisation problem than Abu Dhabi. ${ }^{194}$ Similarly, as Muhammad Al-Fahim has acknowledged, it is increasingly believed that Abu Dhabi will be unable to achieve many of the UAE's long term goals on its own as "its economy is built on selling oil to build infrastructure whereas Dubai's more diversified and imaginative development projects offer a means whereby job creation can be encouraged". 195

As a result, there has been growing evidence of greater financial and physical links between the two emirates. One such link may be the widely rumoured decision by Abu Dhabi to donate 100,000 barrels of oil a day to support Dubai's development projects. At current prices, this 'gift' represents more than $\$ 650$ million a year. ${ }^{196}$ Physical links have included the recent opening of the Maqta-Jebel Ali natural gas pipeline which, by 2005, will feed 700cf per day from Abu Dhabi into Dubai's industrial zones as part of the aforementioned Dolphin Project. ${ }^{197}$ Indeed, as the Economist Intelligence Unit reports, this UAE-Qatar landmark gas deal provides the clearest indicator to date of closer economic ties between Abu Dhabi and Dubai. ${ }^{198}$ As such, much of the UAE's recent economic development can be seen to have taken place within a context of increasing coexistence between two different but mutually supportive economies. As the discussion of the creation of the federation in the historical background emphasised, the UAE survived the initial dangers of the early years due to its ability to balance and include the different demands and concerns of the individual emirates. Similarly, the federation's socio-economic development planning 
Figure (vii) "Abu Dhabi and Dubai, a comparative analysis"

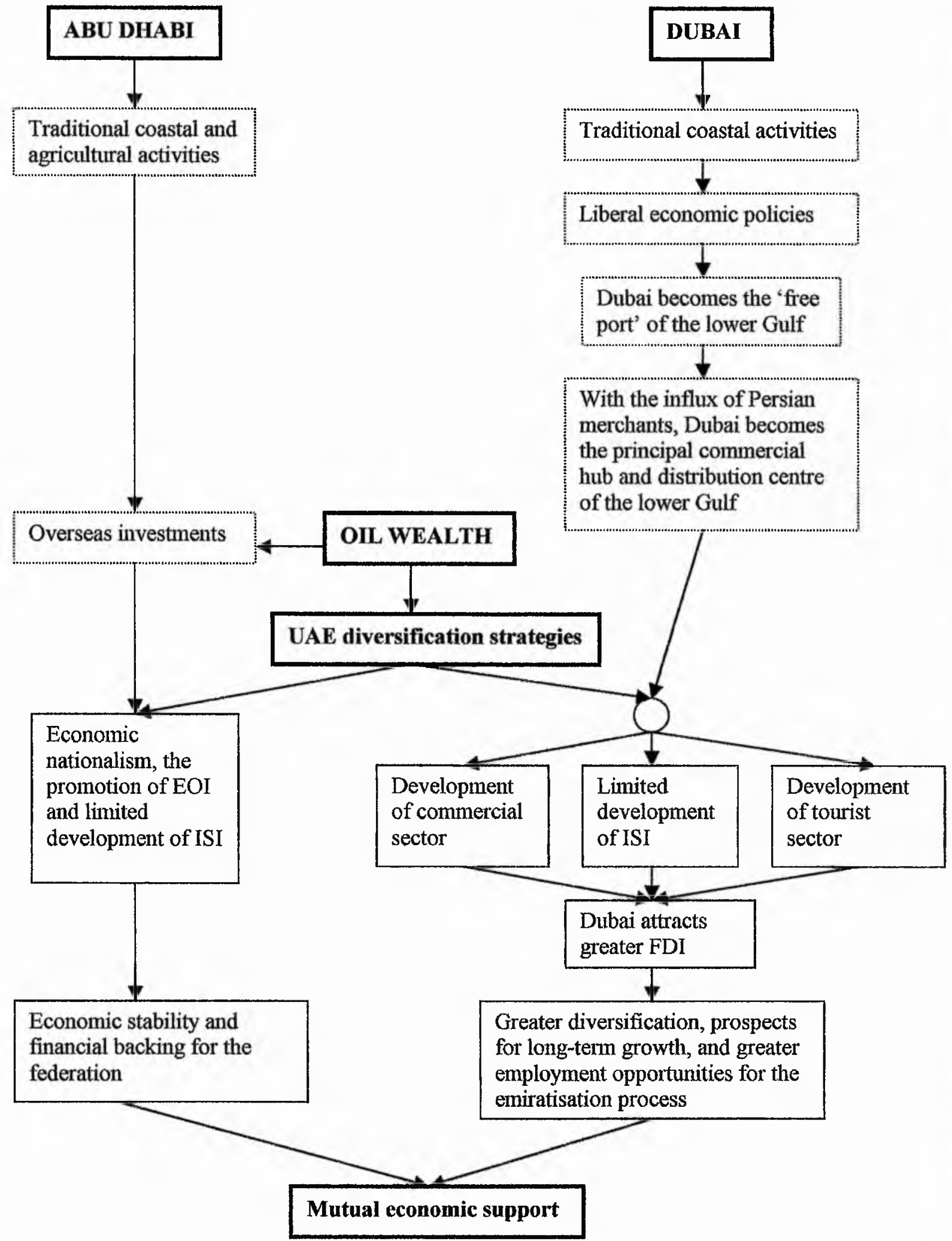


has not led to uniformity and adherence to one rigid strategy, but has instead embraced a number of sub-strategies which, at least in this case, have complemented and reinforced the UAE's overall development. Moreover, there is every indication that this coexistence and flexibility will continue for the foreseeable future: Abu Dhabi will continue to pursue its long-term strategies of "economic nationalism" 199 by developing government sponsored heavy industries and downstream operations such as oil refineries, gas processing, and polyethylene plants; while in contrast it is predicted that Dubai's macro-economic strategy will remain more neo-liberal and oriented towards private sector activity, with the government providing the infrastructure and focusing on the international promotion of the emirate. ${ }^{200}$ See figure (vii).

\section{9-Development Problems}

Despite the visible success of most areas of diversification, infrastructure building, and social development, and despite the existence of mutually beneficial dual development strategies in the two principal emirates, the UAE has nevertheless been faced with certain other development problems, many of which have remained unresolved. Broadly speaking, these are the problems which have resulted from internal pathologies, and problems which, in much the same way as the inexorable over-reliance on foreign labour, cannot be easily overcome with oil wealth. Indeed, in some cases the difficulties have actually been caused by surplus wealth and over-budgeting, linked of course to the actual kind of subsidy-based development which has taken place in the rentier / allocative state and, as will be described in the following chapter, the nature of many of the prevailing domestic structures. ${ }^{201}$ Most notably these persisting problems have included chronic over-consumption and a contimual trade imbalance despite the modest expansion of the UAE's productive sectors; the expensive and wasteful duplication of investments; and finally the problem of substantial disequilibrium between the constituent emirates. By assessing these difficulties, this section will therefore attempt to highlight some of the UAE's more serious development limitations, and also some of the more serious underlying problems which continue to exist. 
Firstly, with regard to excessive consumption, there has long been a concern that oil wealth and strong purchasing powers will lead to worryingly high levels of consumer imports, which will in turn present serious long-term problems for the growth of domestic manufacturing, and of course for the UAE's balance of payments. ${ }^{202}$ Indeed, many of these pessimistic predictions were soon realised as the UAE's current surplus of balance of payments began to fall from highs of nearly 39 billion Dirhams in 1980 to less than two billion Dirhams in the mid-1990s ${ }^{203}$ Similarly, the UAE's trade balance fell from over 50 billion Dirhams to less than 15 billion Dirhams over the same period, leaving the UAE with the lowest trade balance of all GCC states by some considerable margin. ${ }^{204}$ Moreover, in the specific case of Dubai, the most commercially developed of the emirates, imports rose from around 7 billion Dirhams in 1975 to a staggering 83 billion Dirhams in 2001 and although as shown there has been an appreciable increase in re-exporting activity, these imports still represent around $74 \%$ of total non-oil trade (and with approximately half of these being accounted for by consumer durables). ${ }^{205}$

Dubai non-oil foreign trade - 1975

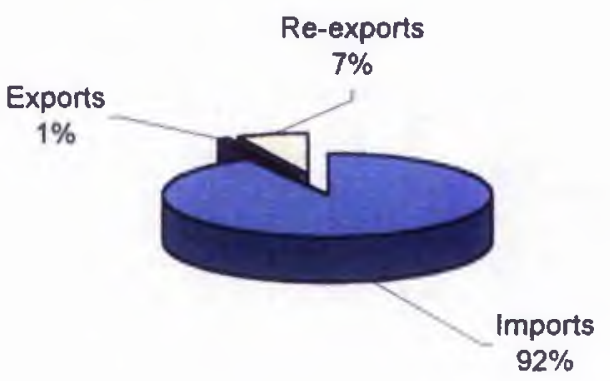

Dubai non-oil foreign trade - 2001

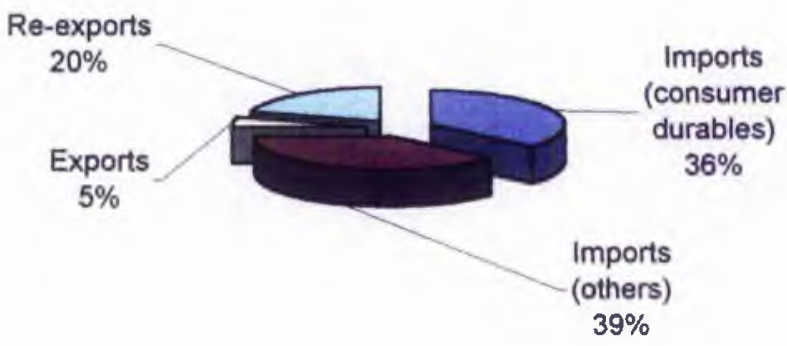

[Source: based on data from the Dubai Department of Ports and Customs] ${ }^{200}$ 
Thus, despite a number of plans to set both governmental and private consumption limits, ${ }^{207}$ over the past 25 years relatively little has been achieved. Certainly, with accelerating imports and an increasingly dominant consumption structure, the issue would seem to retain much of its original urgency, especially as the UAE's attempts to reduce reliance on oil by boosting the non-productive commercial sector can be seen as having actually compounded the problem. Indeed, as al-Shamsi notes of this conundrum:

"Great emphasis has been put into encouraging the non-oil sector, and that share of the GDP has increased. However, such development has its shortcomings... a prevalence of high income and consumption sustained without recourse to local production and the existence of high levels of conspicuous investment." 208

Similarly, despite the potential effectiveness of Abu Dhabi and Dubai's dual development paths, the UAE's spectacularly costly duplication of investments and a lack of region-wide co-operation, especially between the larger and smaller emirates, has also persisted and continues to undermine the overall diversification strategy. ${ }^{209}$ Particularly strong and much discussed examples would include the UAE's disorganised development of its airports and factories, and the apparent absence of any meaningful co-ordination between these projects. ${ }^{210}$ Indeed, even in the mid-1970s Sa'id 'Ahmad Ghubash, the UAE's Minister of Planning, was already complaining of this problem:

"Economic necessity will require the eventual cessation of the costly duplications of projects that have occurred thronghout the UAE since it was established. UAE officials recognised that this duplication of projects only wastes time and money that could be used more effectively elsewhere. The intense rivalry between the various emirates and the important status issue dictated that if one emirate acquired an airport or factory then a similar one had to be built in the other emirates. "211 
Writing in the mid-1980s, Peck also emphasised this lack of co-ordination and the resulting unnecessary duplications:

"Abu Dhabi, Dubai, Sharjah and Ra's al-Khaimah all have airports that service both international and domestic flights. This overbuilding, prompted by inter-emirate rivalry, has left the latter two facilities underutilised. Abu Dhabi, on the one hand, recently opened a new, large civilian airport to handle its traffic. Dubai, with the busiest airport in the Gulf, is upgrading its facilities..." 212

Clearly, this under-utilisation of major airports was a direct result of so many facilities having been built in a relatively small country. Of course, the problem is still very much in evidence today, with a new international airport in Al-"Ayn and with foreign airlines cutting back their flights to Sharjah airport as a result of the continuing expansion of Dubai International only a few miles away. ${ }^{213}$ In fact, Dubai airport is now closer and far more accessible to most parts of Sharjah than the Sharjah airport. Similarly, with regard to the UAE's airlines, there has been much the same problem. Although jointly owned between Abu Dhabi, Bahrain, Qatar, and Oman; Gulf Air was nevertheless originally intended to be the UAE's principal carrier, but has experienced difficulties in recent years and has always faced stiff competition from its awardwinning Dubai-based rival, Emirates Airline. Certainly, few other countries of a similar population and geographic size as the UAE have successfully supported more than one major airline. $^{214}$

The problem would therefore appear to remain the lack of any high-level organisation of development projects between the emirates. Thus, although interemirate political relations will be considered more closely in the following chapter, it is important to note that persisting rivalries, overlapping local government departments, and the continuing lack of certain federal ministries (most significantly the absence of a UAE Ministry of Tourism), have clearly clouded any overall vision and in many cases have led to underused facilities, aborted projects, and expensive mistakes. Indeed, it 
later emerged that one of the causal factors behind the 1987 coup attempt in Sharjah was Shayklı Abdul-Aziz al-Qāsimī's opposition to the nuler's sanctioning of expensive and unnecessary 'prestige projects' including the airport, an unfinished television station and several empty museums. ${ }^{215}$ Thus, the initial lack of co-ordination and necessary period of transition predicted by the planners of the early 1970 s still remains a significant issue. ${ }^{216}$ Certainly, in many ways it has become even more of a concern than before given that the shock absorbing effects of oil wealth may have allowed the UAE to survive the duplication and disorganisation of the $1980 \mathrm{~s}$ and $1990 \mathrm{~s},{ }^{217}$ but in a future of potentially greater scarcity, and in a future requiring greater diversification, such haphazardness may prevent more long-term sustainable growth.

Perhaps the most considerable problem has, however, been the lack of equilibrium between the various emirates. Indeed, the need for a reduction in regional disparity, in much the same way as the reduction in the UAE's reliance on oil, foreign technology, and foreign labour, has long been a key concern of the development planners, many of whom believed that if the different emirates could better pool and balance their resources then socio-economic growth would be more achievable for the entire country. Moreover, and clearly addressing another major feature of dependency theory, it was understood that greater equilibrium would also serve to prevent any 'super-exploitation' of the UAE's less well-developed areas by either indigenous or foreign forces. ${ }^{218}$ As such, in 1975 the development planners clearly stated their objective of "finding the optimum allocation of projects according to the relative importance of each emirate". ${ }^{219}$ Specifically, the strategy was to ensure that the smaller non-oil producing emirates were to be targeted for appropriate federal-funded developments based on their individual characteristics, while all major development projects were to be better supervised to ensure more balanced investments and the best possible utility for the country.

A major and immediate obstacle to this strategy was Article 23 of the UAE's provisional constitution which stated that the "natural wealth and resources of each emirate should remain the public property of that individual emirate." Although, as 
demonstrated in the discussion of the early federal negotiations, such articles allowed for greater flexibility and guarded against fragmentation, ${ }^{220}$ they nevertheless also set the rich apart from the poor, thus hindering full economic integration at an early stage. $^{221}$ To a limited extent some of the UAE's regional imbalances were improved during the 1970s as the federal government, at that stage funded almost entirely by Abu Dhabi, began to intervene and assist outlying regions which would have otherwise remained underdeveloped and would have fallen into further decline. Indeed, as a byproduct of the UAE's expanding physical infrastructure, many previously remote regions became better connected and more assimilated with the national economy than ever before. In particular, certain coastal and desert regions which had recently been linked by new roads and telecommunications, but which still remained reliant on traditional economic activities such as fishing and date farming, were targeted to receive additional development grants in an effort to prevent worsening disparity. A strong example of this regeneration programme would be the island of Dalmā, which, as described in the historical background, had long been one of the lower Gulfs' most prosperous pearling centres. Unlike the nearby island of Dās which had been transformed into an offshore oil terminal for ADMA, Dalmā possessed no oil, and following the collapse of the pearling industry became entirely reliant on fishing. Consequently, the population of the once bustling island fell to less than a hundred by the late $1970 \mathrm{~s},{ }^{222}$ and seemed set to fall even further as the result of increasing migration to the cities. Yet, as Heard-Bey explains, the community's decline was successfully held in check as Dalmā, along with the remote interior towns surrounding the Liw $\bar{a}$ oases, began to receive substantial government aid:

"The increase in oil company activities eventually diverted most of the manpower away from the pearling industry, which was already at a low $e b b$ in the 1950s. With this the importance of Dalmā also declined. In the later 1970 s the small community of tribal fishermen was given new incentives to stay there by the establishment of government-financed houses, schools, new mosques, a market complex, and a small hospital; free transport to and from the island by helicopter was organised by the army; several 
construction projects are proposed for the island. Thus, Dalmā, like the Līwā and Bida 'Zâyid and the Al-'Ayn area, entered the era of departmentalised administration, co-ordinated by government institutions in Abu Dhabi town."223

However, despite these hinterland aid packages, the sustained growth of Sharjah's manufacturing sector throughout the 1980s, and the expansion of Fujairah's Indian Ocean ports in the $1990 \mathrm{~s}$, most of these regional developments have remained dwarfed by the growth of the two principal emirates. Indeed, as the Economist Intelligence Unit has noted, the vast bulk of the UAE's development projects have been undertaken in Abu Dhabi and Dubai, while the smaller emirates still have very few commercially viable ventures apart from some small-scale tourism. ${ }^{224}$ Certainly, as the UAE's indicators for the period 1975-1995 illustrate, the UAE's regional disparities, at least in terms of economic development, have persisted, and the goal of greater equilibrium would seem as elusive as before. Although Abu Dhabi's share of the UAE's GDP fell from nearly $71 \%$ to $61 \%$, this still represented by far the greatest contribution. Moreover, with Dubai's share of GDP rising from $20.5 \%$ to $24 \%$, the two major emirates still accounted for over $85 \%$ of the UAE's GDP in 1995, despite Dubai's declining oil revenues. In contrast, the combined share of the four smaller emirates accounted for just 7\% of GDP in 1995, and although this is nearly double the 1975 share of $4 \%$, this nevertheless represents a very small increase in total contributions over a considerable twenty-year period, ${ }^{225}$ and would therefore seem to indicate few major non-oil related developments in these outlying regions: 


\section{Contributions to UAE GDP in 1975}

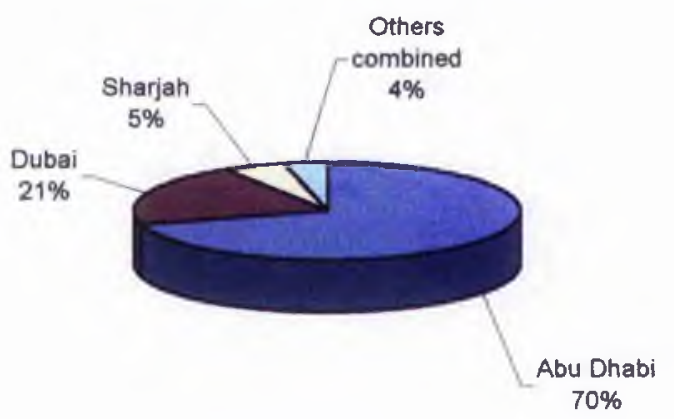

Contributions to UAE GDP in 1995

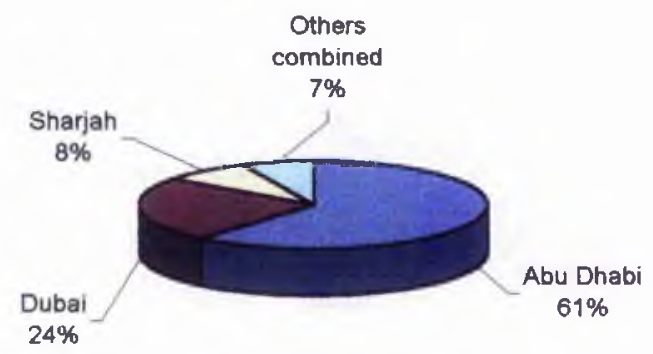

[Source: Crown Prince Court, Department of Research and Studies, Abu Dhabi] ${ }^{226}$

Finally, although the problem is unlikely to be resolved in the near future, and regional disequilibrium will remain a feature of the UAE's lopsided development for some time, it is nonetheless worth noting that a number of regeneration projects and developments are in the pipeline or on the horizon, and at the very least these underscore the planners' continuing commitment to reducing regional disparity. Such examples include the Offsets Group's proposed ventures in the northern emirates and in Al-'Ayn, ${ }^{227}$ and the generous sponsorship of coastal revival projects and festivals in 'Ajman by the National Bank of Dubai and the UAE's telecom company, Etisalat. ${ }^{228}$ Similarly, the western desert region of Abu Dhabi has also been earmarked for future development with a multi-million Dirhām project already underway in an effort to transform what is probably the UAE's least developed area into a network of rural tourist attractions. Among others, these will include settlements close to Līwă and in Ghayathi, near to the Saudi border. ${ }^{229}$ Moreover, there have also been comprehensive plans drawn up by some of the smaller emirates in co-operation with the federal 
government and the UNDP, and given time these may also lead to greater regional development. In particular, Ra's al-Khaimah recently launched its 'UNDP-RAK Vision'; a plan aiming to achieve sustainable growth in the non-oil producing emirate by promoting Ra's al-Khaimah-specific policies for the expansion and diversification of its economy. Indeed, as part of his official announcement, the ruler, Shaykh Saqr, stated his clear intentions to boost the emirate's relatively small contribution to the UAE's economy and to reduce the gap between Ra's al-Khaimah and the three larger emirates. $^{230}$

\subsection{0-Conclusion}

By the mid-1970s the UAE's economy was already heavily reliant on overseas demand for its oil exports, on foreign technology for the functioning of its industries, and on foreign labour for supplying both its skilled and unskilled workforces. Thus, in an effort to promote greater self-sufficiency and more sustained autonomous growth, and of course to ensure the longevity of the crucial material components of their ruling bargain, the 'modernising monarchs' and their development planners initiated a number of strategies which aimed to reduce some of the most damaging features of their dependent development. In particular there were calls for the greater diversification of the economy: specifically the promotion of the UAE's non-oil related sectors and the encouragement of technology linkages and transfers between foreign and domestic enterprises; the creation of a first-class educational and welfare state to provide for a trained and healthy workforce; and the 'emiratisation' of labour, encouraging UAE nationals to assume positions previously requiring expatriates. See figure (viii).

With regard to diversification, over the past thirty years the UAE has experienced the modest growth of its non-oil related industries and in some cases, particularly in the ISI manufacturing sector, has managed to encourage the transmission and domestic substitution of foreign technologies. Perhaps more significantly, the UAE's commercial and tourist sectors have expanded considerably over this period and, even though not reducing dependency as such, these sectors have nevertheless greatly 


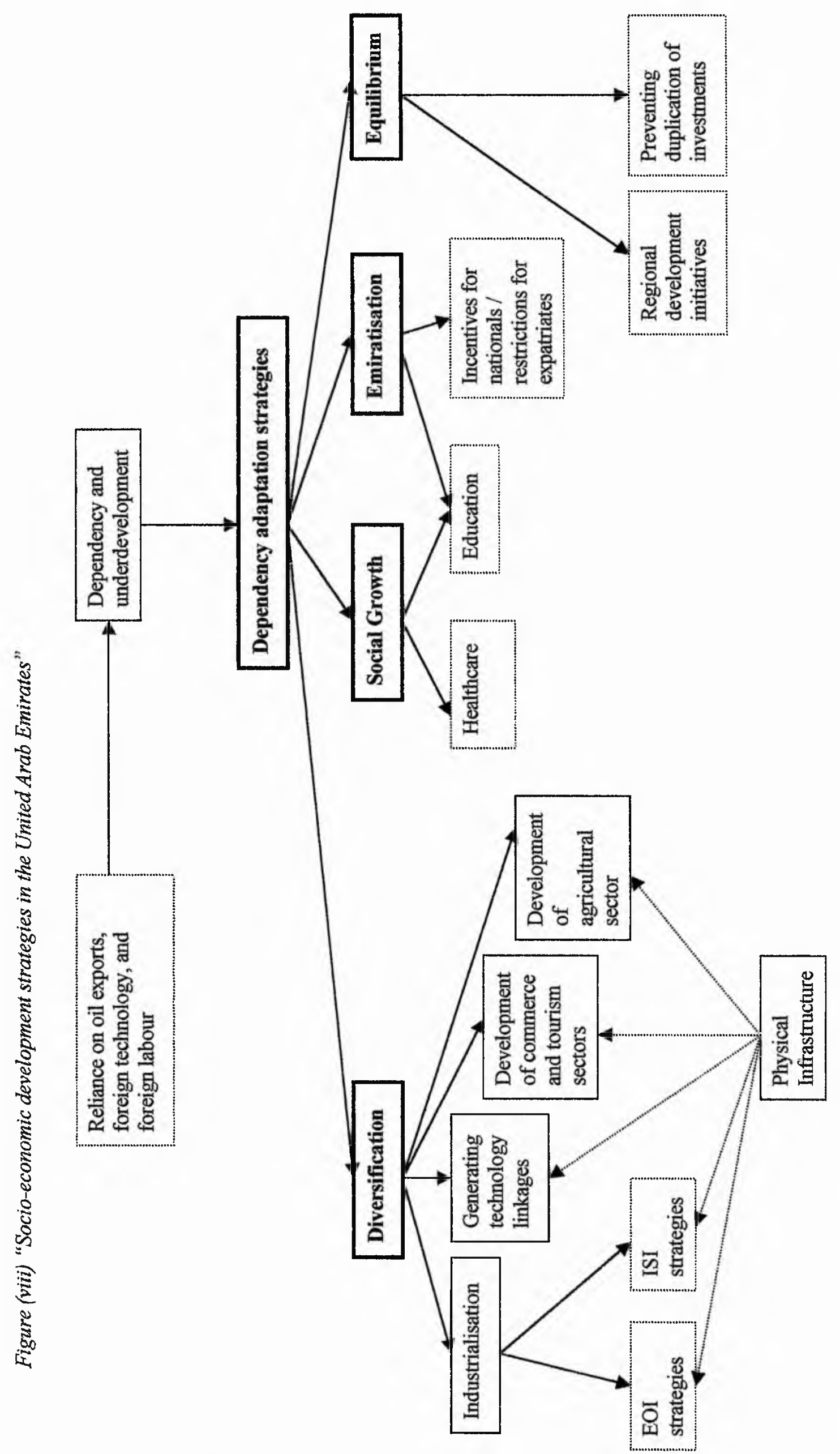


reduced the economy's reliance on oil. Furthermore, although with understandably less impressive results, the agricultural sector has also grown, providing an additional nonoil related contribution to the UAE's GDP, while of course providing greater food security. Finally, underpinning these developments has been the creation of a brand new physical infrastructure of roads, ports, industrial parks, and communications. Financed by the UAE's remaining oil wealth, this infrastructure continues to expand, facilitating fresh diversification opportunities and better ensuring a stable and prosperous post-oil future. Thus, although the oil sector still remains the greatest contributor to the UAE's GDP, accounting for somewhere between a quarter and a half of all exports, ${ }^{231}$ and although the various diversifying sectors have periodically suffered bouts of sluggish growth, ${ }^{232}$ the non-oil sector has nevertheless become extremely significant, especially given the small timescale and the region's comparative backwardness as late as the 1960s.

Social growth has been equally forthcoming, again of course aided by the UAE's massive oil-financed investments. A large number of schools and universities staffed by qualified and experienced teachers and lecturers have provided the UAE's youth with the highest standards of education, with small class sizes, and with excellent facilities. Similarly the quantity of hospitals and medical centres has mushroomed over this short period, with the ever-increasing number of medical professionals ensuring low doctor-patient ratios and providing effective care for almost all conditions within the UAE. These accomplishments have therefore not only symbolised and consolidated the welfare state component of the rentier coalition, but have also demonstrated the planners' clear commitment to human development in the UAE and the conception of an educated and strong Emirati population.

Although by comparison the emiratisation of the labour force has met with only limited success, and the UAE remains as reliant as ever on foreign labour, there have nevertheless been a number of promising signs, especially in recent years, which point to the much greater emiratisation of managerial, professional, and high-level public sector positions in the very near future. Moreover, given that this has been an area of 
strategy which has not directly benefited from oil wealth, and indeed may have been hampered by financial incentives which have priced UAE nationals out of the market, these results have been far harder to achieve. Indeed, it would appear that the planners have been forced to adopt a multidimensional approach, relying not only on wealth inducements for locals and restrictive practices such as quotas and visa limitations for expatriates, but also on greater educational and motivational opportunities for the increasing quantity of UAE graduates. Certainly, by providing and sponsoring vocational courses, internships, and other professional training programmes, the government has successfully begun to place far higher numbers of young UAE nationals than ever before into both public and private sector jobs, many of which previously required the expertise of expatriate workers.

In addition to these broad strategies, it must also be noted how the relative flexibility of the UAE's federal system has allowed for the pursuit of differing substrategies, especially in the two largest and wealthiest emirates of Abu Dhabi and Dubai. Quite simply, Abu Dhabi's substantial oil wealth has engendered a more cautious diversification strategy based around heavy EOI industries which aim to maximise the emirate's comparative advantages of cheap energy and abundant natural resources. On the other hand, Dubai's rich history of commercial development and the entrepreneurial spirit of the ruling Āl-Maktūm dynasty, coupled with more modest and depleting oil reserves has instead promoted far more rapid and far truer diversification. Indeed, with an emphasis on smaller ISI industries largely unrelated to the oil sector and with the massive expansion of its commercial and tourist sectors, Dubai's non-oil sector has long since accounted for the vast bulk of the emirate's GDP. Crucially, these differing strategies are now being regarded as complementary and mutually reinforcing, as Abu Dhabi's considerable wealth and heavy industries can continue to provide the UAE's financial backbone and support the other emirates, while Dubai's more diversified economy and strong commercial links can better promote the UAE internationally and can better contribute to the emiratisation strategy by providing more varied and appropriate employment opportunities for UAE nationals. Thus, far from 
conflicting, the UAE's sub-strategies may become a vital factor in ensuring successful future socio-economic development.

Finally, however, it is also important to consider a number of critical development problems which have periodically surfaced and which, in some cases, have remained unresolved. Indeed, despite the planners' best efforts, the UAE has remained heavily consumption rather than production oriented, with a resulting trade imbalance and a declining balance of payments. Furthermore, despite the evidence of increasing co-operation between Abu Dhabi and Dubai, there has also been the highly visible duplication of projects in the smaller emirates, with expensive and unnecessary developments often taking place in adjacent territories, many of which have remained under-utilised and empty. Thirdly, there has been the continuing problem of regional disequilibrium, with the wealth and development gap between the oil-producing emirates and the other emirates remaining almost as great as it was thirty years ago. In much the same way as the plans for emiratisation, these have not been problems which can easily be addressed by greater investment and oil-financed development projects. Instead, given the nature of the problems, it would appear that a number of internal pathologies must be responsible, namely the primarily allocative nature of the state, the persistent consumerist mentality of the rentier population, the lack of inter-emirate coordination, the absence of effective inter-departmental co-operation, and presumably, on occasion, the mismanagement of resources and a lack of transparency. Thus, although the planners have clearly been able to reduce and overcome some of the weaknesses of the UAE's dependent socio-economic structures, future attempts to modify other features of the development path may be undermined as the UAE continues to experience the more deeply entrenched disadvantages of its inherited and reinforced dependent circumstances, many of which, as the following chapter will demonstrate, can be viewed as the hidden costs of the UAE's ruling bargain, its political stability, and the persistence of traditional forces. 


\footnotetext{
${ }^{1}$ For a discussion of orthodox economic development theories see ARNDT, HW (1987), "Economic development: The History of an Idea", Chicago, Chicago University Press

${ }^{2}$ For a discussion of economic nationalism see HARRIS, N (1987), "The End of the Third World", London, Penguin

${ }^{3}$ AMIN, Sanir (1982) "The Arab Economy Today", New York, pp.56-78, summarised by SHARABI, Hisham (1988), "Neopatriarchy: A Theory of Distorted Change in Arab Society", New York, Oxford University press, pp.133-135

${ }^{4}$ Regarding the collapse in oil prices in the mid-1980s see PRADO, Alfred B (1996), "Saudi Arabia: post-war issues and US relations", CRS ISSUE BRIEF, Number 93113, December 1996. Also for a discussion of the continuing trend towards austerity measures in Saudi Arabia, see UNITED STATES EMBASSY TO SAUDI ARABIA (1999), "Economic Trends", Riyadh, October 1999

${ }^{5}$ See for a more recent example KHALEEJ TIMES (2001), "Arabs should unite to take Oil Advantage", $4^{\text {th }}$ May 2001, for a report on Dr. Hussain Abdullah (the former under-secretary for Arab and International Affairs at the Ministry of Petroleum in Egypt) speaking in May 2001 to the Dubai Cultural and Scientific Association. "Another major threat is the Kyoto Protocol which aims to decrease the intensity of carbon dioxide in the air because 50 years down the road it might lead to an unbearable increase in the earth's temperature and might cause disasters. If the industrialised countries signed this protocol, they might be forced to rationalise the consumption of power and look for alternatives, because oil production increases the quantity of $\mathrm{CO}_{2}$ in the air."

${ }^{6}$ See for a more recent example LOCKWOOD, Christopher (1996), "Warring Nation holds Key to Oil Riches of Central Asia", in The DARY TELEGRAPH, $11^{\text {th }}$ October 1996, for a discussion of the emerging oil-producing Central Asian states

${ }^{7}$ KHALEEJ TIMES (2001), "Arabs should unite to take Oil Advantage", 4" May 2001

8 UAE CENTRAL BANK (1994), “Annual Report 1994”, Abu Dhabi

9 ECONOMIST INTELLIGENCE UNIT (2000), "United Arab Emirates", pp.47

${ }^{10}$ Personal interview with a representative of the Studies and Research Department in the Dubai Chamber of Commerce and Industry, December 2001

${ }^{11}$ AL-SHAMSI, Fatima S (1999), "Industrial Strategies and Change in the UAE during the

1980s", in ABDEKARIM, Abbas (1999), "Change and Development in the Gulf", London,

Macmillan, pp.83-84

${ }^{12}$ Personal interview with a representative of the Studies and Research Department in the Dubai Chamber

of Commerce and Industry, December 2001

${ }^{13}$ KAMRAVA, Mehran (2000), "Politics and society in the developing world", London, Routledge, pp.42-43

Personal interview, with a representative of the Studies and Research Department in the Dubai

Chamber of Commerce and Industry, December 2001

${ }^{15}$ FENELON, Kevin (1973), "The United Arab Emirates", London, Longman, pp.70

${ }^{16}$ AL-SHAMSI (1999), pp. 86-89

17 GCC DEVLOPMENT PLANS - UNITED ARAB EMIRATES (1982), "Economic and Social Development Plans for the UAE, 1975-1980", Abu Dhabi, pp.50

${ }^{18}$ ECONOMIST INTELLIGENCE UNIT (2000), pp.30

${ }^{19}$ Ibid. pp. 33

${ }^{20}$ See EL-SABĀ, Soheir (2002), "The Impediments to Industrial Development in the UAE", Dubai,

Dubai Chamber of Commerce and Industry Studies and Research Department

${ }^{21}$ AL-SHAMSI (1999), pp.88

${ }^{22}$ GCC DEVLOPMENT PLANS - UNITED ARAB EMIRATES (1982), pp. 17

${ }^{23}$ DUBAI DEPARTMENT OF ECONOMIC DEVELOPMENT (2001), "Development Statistics",

Government of Dubai, pp.110, imports valued at fixed 1995 prices

${ }^{24}$ A good example would be the Sharjah based 'London Dairy'. As an ice cream manufacturer and packager, the firm originally licensed British technology, but in recent years has substituted domestic technology.

${ }^{25}$ UAE MINISTRYOF PLANNING (2002), "UAE and Dubai: GDP at factor cost and per capita GDP 2000", in DUBAI DEPARTMENT OF ECONOMIC DEVLOPMENT (2002), "Development

Statistics", Government of Dubai, pp.44, all calculations based on figures for 2001 and at current prices

${ }^{26}$ UNITED STATES CENTRAL INTELLIGENCE AGENCY (2001), "World Fact book: United Arab Emirates", January 2001, for 1997 estimates on industrial growth: some recent estimates put the industrial production growth rate in the local non-oil manufacturing sector at close to $0 \%$

${ }^{27}$ AL-SHARHAN INTERNATIONAL CONSULTANCY (2001), "UAE Country Report 2001", Dubai, pp.14-15

${ }^{28}$ BANNOCK, G, BAXTER, RE and DAVIS E (1992), "The Penguin Dictionary of Economics", London, Penguin, pp.438, for definition of 'value added'

${ }^{29}$ KAMRAVA (2000), pp.43
} 
${ }^{30}$ AL-SHAMSI (1999), pp.83-87

${ }^{31}$ PECK, Malcolm C (1986), "The United Arab Emirates: A Venture in Unity", Boulder Colorado, Westview Press, pp.111; and MIDDLE EAST ECONOMIC DIGEST, (1984), "Foreign firms reject investment proposal", in "MEED Special report: UAE", pp.73

${ }^{32}$ EL-DIN, Amin Badr (1997), "The Offsets program in the UAE", in MIDDLE EAST POLICY, Volume 5 Number 1, January 1997, pp.120-123, As El-Din argues, another aspect of these local joint ventures has been to encourage strategic alliances with multi-nationals and, given that these projects and their financial gains are output based, this has led to such companies developing a vested interest in the future security and stability of the UAE

${ }_{33}$ Ibid. pp. 120-123

${ }^{34}$ Ibid. pp.120-123

35 FOLEY, Sean (1998), "The United Arab Emirates: Political Issues and Security Dilemmas", in Middle East Review of International Affairs (MERIA), Volume 3 Number 1, March 1998; also see KEMP, Peter (1997), "MEED Special report: France", in MIDDLE EAST ECONOMIC DIGEST, 24 "th October 1997; JANE'S DEFENCE WEEKLY (1997), "Gulf States told to get tough over Offsets", $10^{\text {th }}$ December 1997; and BLANCHE, E (1997), "Offset Industry to gain from UAE programs", in JANE'S DEFENCE WEEKLY, $29^{\text {ith }}$ January 1997

${ }^{36}$ AL-SHARHAN INTERNATIONAL CONSULTANCY (2000), "UAE Country Report 2000", Dubai, pp.29-30

${ }^{37}$ ECONOMIST INTELLIGENCE UNIT (2000), pp.35

${ }^{38}$ ABU DHABI PLANNING DEPARTMENT ECONOMIC DIVISION (1976), "Directive Documents for the Preparation of the Economic and Social Development Plan (1977-1979)", Abu Dhabi, June 1976, pp.21-22

${ }^{39}$ GCC DEVLOPMENT PLANS - UNITED ARAB EMIRATES (1982), pp.46

${ }^{40}$ ECONOMIST INTELLIGENCE UNIT (2000), pp.28

${ }^{41}$ ABU DHABI PLANNING DEPARTMENT ECONOMIC DIVISION (1976), pp $21-22$

${ }^{42}$ Interview with Sulayman Khalaf, Dubai, April 2001; and personal interviews, Al-'Ayn, April 2001

${ }^{43}$ FENELON (1973), pp.46-50

${ }^{44}$ PECK (1986), pp.107

${ }^{45}$ UAE MINISTRY OF AGRICULTURE AND FISHERIES (2001), "Dubai: vegetables production", in DUBAI DEPARTMENT OF ECONOMIC DEVELOPMENT (2001), "Development Statistics", Government of Dubai, pp.75

${ }^{46}$ UAE MINISTRY OF AGRICULTURE AND FISHERIES (2001), "Dubai: fruit production", in DUBAI DEPARTMENT OF ECONOMIC DEVELOPMENT (2001), "Development Statistics", Government of Dubai, pp.78

${ }^{47}$ UAE MINISTRY OF AGRICULTURE AND FISHERIES (2001), "Dubai: cattle farms - milk production", in DUBAI DEPARTMENT OF ECONOMIC DEVELOPMENT (2001), "Development Statistics", Government of Dubai, pp.80

${ }^{48}$ UAE MUNISTRY OF AGRICULTURE AND FISHERIES (2002), "Dubai: agricultural holdings", in DUBAI DEPARTMENT OF ECONOMIC DEVELOPMENT (2002), "Development Statistics",

Government of Dubai, pp.73

${ }^{49}$ See section 1.1

${ }^{50}$ UAE MINISTRY OF AGRICULTURE AND FISHERIES (2002), "Dubai: fish production", in DUBAI DEPARTMENT OF ECONOMIC DEVELOPMENT (2002), "Development Statistics",

Government of Dubai, pp.83

${ }^{31}$ See section 4.1

${ }^{52}$ RAO, Sunil (2002), "UAE makes progress in achieving food security", in GULF NEWS, 20 th January 2002, quoting Sacid al-Raqabani, minister for Agriculture and Fisheries speaking at the second GCC Food Security Conference in early 2002

${ }^{33}$ CROWN PRINCE COURT DEPARTMENT OF RESEARCH AND STUDIES (1996),

"Development Indicators in the UAE: Achievements and Projections", Abu Dhabi, pp.31 and 76, the number of agricultural workers in the UAE rose from 23,156 in 1975 to 67,500 in 1995

${ }^{54}$ GCC DEVLOPMENT PLANS - UNITED ARAB EMIRATES (1982), pp.56, Ali Abduisalam recognised that unless such development took place, then the UAE's small geographic and demographic size would restrict the potential market capacity and restrain the growth of any domestic industries, thereby short-circuiting the UAE's overall diversification strategy. Also see Ibjd. pp.18-19; and CROWN PRINCE COURT DEPARTMENT OF RESEARCH AND STUDIES (1996), pp.26, data provided by UAE Central Bank Economic Bulletins 1979, 1982, 1987, and 1992; by the UAE Ministry of Planning Statistical Abstracts 1975-1995; and by the UAE Ministry of Finance and Industry

55 DUBAI DEPARTMENT OF ECONOMIC DEVELOPMENT (1999), "Development Statistics", Government of Dubai, pp.257

${ }^{56}$ Ibid. pp. 247 
${ }^{57}$ Ibid. pp. 221

${ }^{38}$ See http://www.mydsf.com/ for the official Dubai Shopping Festival (and Dubai Summer Surprises) website.

${ }^{59}$ Personal interviews, Dubai, March 2001 and March 2002

${ }^{60}$ See http://www.mydsf.com/

${ }^{61}$ Personal interviews, Sharjah, December 2001

${ }^{62}$ DUBAI DEPARTMENT OF PORTS AND CUSTOMS (2002), “Dubai: non-oil foreign trade total", in DUBAI DEPARTMENT OF ECONOMIC DEVELOPMENT (2002), "Development

Statistics", Government of Dubai, pp.109, values for non-oil foreign trade given at fixed 1995 prices

${ }_{63}$ Ibid. pp. 109

${ }^{64} 169 \%$ increase in volume calculated from 1980 to 2001 , as 1975 remains unavailable, pp. 109

os Ibid. pp. 109 , imports currently account for around $75 \%$ of the total value of non-oil trade

${ }^{66}$ Ibid. pp. 109

67 Ibid. pp. 109

${ }^{68}$ Personal interview with a representative of the Studies and Research Department in the Dubai Chamber of Commerce and Industry, December 2001

"9 DUBAI DEPARTMENT OF ECONOMIC DEVELOPMENT' (2001), "Development Statistics",

Government of Dubai, pp. 167 and 172, figures for 1985-1994 supplied by UNITED ARAB EMIRATES MINISTRY OF PLANNING, figures for 1995-1998 supplied by DUBAI DEPARTMENT OF

ECONOMIC DEVELOPMENT, and figures for 1998 onwards supplied by DUBAI DEPARTMENT

OF TOURISM AND COMMERCE MARKETING

${ }^{70}$ Ibid.

${ }^{71}$ Ibid.

${ }^{72}$ Personal interviews with representatives of the Radisson, Metropolitan and Le Meridien hotel chains, Dubai, December 2001 and October 2002

${ }^{73}$ DUBAI DEPARTMENT OF ECONOMIC DEVELOPMENT (2001), "Development Statistics", Government of Dubai, pp.167, figures supplied by DUBAI DEPARTMENT OF TOURISM AND COMMERCE MARKETING

${ }^{74}$ Personal interview, Dubai Hilton Creek, December 2001, following the hotel's opening

75 DUBAI DEPARTMENT OF ECONOMIC DEVELOPMENT (2001), "Development Statistics", Government of Dubai, pp.171, figures supplied by DUBAI DEPARTMENT OF TOURISM AND COMMERCE MARKETING

${ }^{76}$ Ibid. pp. 172

77 See UAE MINISTRY OF PLANNING (1995), "Annual Statistical Report on UAE Holels", Abu Dhabi, Central Statistics Department

${ }^{78}$ See section 2.2.3 and appendix (ii); Unlike Dubai and Abu Dhabi which attract western luxury tourists Sharjah predominately attracts Russian and eastern European tourists. Indeed, during the 1980s many tourists from the Soviet Union would travel to Sharjah to purchase luxury goods in the Al-Wahda Street district.

${ }^{79}$ See TRIDENT GUIDE (1996), "United Arab Emirates", Abu Dhabi, Trident Press

${ }^{80}$ Between 2001 and 2003 'Ajman's seafront has been extensively redeveloped with a long corniche and an extended beach.

${ }^{81}$ See sections 4.4 .2 and 4.4 .3

82 AL-SHARHAN INTERNATIONAL CONSULTANCY (2000), pp.61

${ }^{83}$ FENELON (1973), pp. 18

${ }^{84}$ PECK (1986), pp.51

${ }^{85}$ FENELON (1973), pp. 18

${ }^{86}$ PECK (1986), pp.66

${ }^{87}$ Personal interviews, Dubai, March 2001

${ }^{88}$ Dnata is the cargo-handling branch of Emirates Airline

${ }^{89}$ DUBAI DEPARTMENT OF ECONOMIC DEVELOPMENT (2001), "Development Statistics", Government of Dubai, pp.257, over the past ten years, the village's total cargo-handling tonnage has risen almost four-fold.

${ }^{90}$ Ibid.

${ }^{21}$ AL-JANDALY, Bassma (2003), "Rail project may take six years", in GULF NEWS, 14" January 2003, Dubai's rapid rail transit system will be completed within the next four to six years and will ease the strain on Dubai's roads by providing fast links to the city centre, to the border with Sharjah, and to Jebel Ali.

${ }^{92}$ DUBAI DEPARTMENT OF ECONOMIC DEVELOPMENT (2001), "Development Statistics", Government of Dubai, pp.243

${ }^{93}$ ECONOMIST INTELLIGENCE UNIT (2000), pp. 18 
${ }^{94}$ Large lease office buildings can be seen close to the entrances of the Jebel Ali Free Zone south of Dubai. They provide ready-made office space for new firms at an affordable rent.

${ }^{95}$ DUBAI DEPARTMENT OF ECONOMIC DEVELOPMENT (1999), "Development Statistics", Government of Dubai, pp.241

${ }^{96}$ DUBAI DEPARTMENT OF ECONOMIC DEVELOPMENT (2002), "Development Statistics", Government of Dubai, pp. 255

${ }^{97}$ ECONOMIST INTELLIGENCE UNIT (2000), pp.5

${ }^{98}$ GCC DEVLOPMENT PLANS - UNITED ARAB EMIRATES (1982), pp. 10

${ }^{99}$ See for example, WAM (2001), "New avenues for UAE women", Abu Dhabi (Wikālat Anbã' alImārät: the UAE News Agency), $17^{\text {th }}$ May 2001

100 UAE MINISTRY OF INFORMATION AND CULTURE (1995), "UAE Yearbook: 1995", Abu Dhabi, pp.97, taken from a speech by Sa'id 'Ahmad Ghubash, Minister of Economy and Commerce

${ }^{101}$ GCC DEVLOPMENT PLANS - UNITED ARAB EMIRATES (1982), pp. 18-19

102 UNDP-UAE (2000), "Press Release - National HRD Report", $8^{\text {th }}$ July 2000

${ }^{103}$ UNESCO (2001), literacy rates have risen from $81.8 \%$ in 1987 to $91.1 \%$ in 2001 for $15-24$ year olds

${ }^{104}$ UNESCO (2000/2001), regarding the net enrolment ratios (the percentage of children of the relevant age attending school)

${ }^{105}$ UAE MINISTRY OF EDUCATION AND YOUTH (2002), "UAE and Dubai: secondary school graduates", in DUBAI DEPARTMENT OF ECONOMIC DEVELOPMENT (2002), "Development Statistics", Government of Dubai, figures are for graduates of all types of secondary schools, pp.209

${ }^{106}$ UAE MINISTRY OF EDUCATION AND YOUTH (2001), "Dubai: government schools student/teacher ratio", "Dubai: private schools - teachers by sex", and "Dubai: private schools enrolment by sex", all in DUBAI DEPARTMENT OF ECONOMIC DEVELOPMENT (2001), "Development Statistics", Government of Dubai, figures for government sector schools taken from ratios published on pp. 199, ratios for private sector schools calculated from teacher and student totals listed on pp. 208-209

${ }_{117}$ UNESCO (1998/1999), regarding the net enrolment ratio (based on a five year age group following the secondary school leaving age)

${ }^{108}$ UAE UNIVERSITY IN AL-“AYN (2001), "UAE University registered students", and "UAE University graduates", in DUBAI DEPARTMENT OF ECONOMIC DEVELOPMENT (2001), "Development Statistics", Government of Dubai, pp.212-213

${ }^{109}$ Ibid. pp212-213, percentages calculated from listed totals by gender

${ }^{110}$ GCC DEVLOPMENT PLANS - UNITED ARAB EMIRATES (1982), pp.62-63, the planners foresaw this challenge in the early $1970 \mathrm{~s}$, "the health care system would primarily face difficulties in setting up the best programmes to suit the changing conditions of society which will result from the large increase in the volume and type of expatriate population"

${ }^{111}$ CROWN PRINCE COURT DEPARTMENT OF RESEARCH AND STUDIES (1996), pp.95, figures are for Abu Dhabi Emirate

${ }^{12}$ UAE MINISTRY OF HEALTH and DUBAI DEPARTMENT OF MEDICAL SERVICES

(2001), "Dubai: health centres", "Dubai: hospitals", "Dubai: hospital beds", and "Dubai: medical doctors" all in DUBAI DEPARTMENT OF ECONOMIC DEVELOPMENT (2001), "Development Statistics", Government of Dubai, pp.181-182 and pp. 184, all figures include private healthcare

113 UAE MINISTRY OF HEALTH and DUBAI DEPARTMENT OF MEDICAL SERVICES

(2001), "Dubai: nursing staff", and "Dubai: medical technical assistants", all in DUBAI DEPARTMENT OF ECONOMIC DEVELOPMENT (2001), "Development Statistics”, Government of Dubai, pp.185-

186 , figures include pharmacists

${ }^{114}$ UAE MINISTRY OF HEALTH and DUBAI DEPARTMENT OF MEDICAL SERVICES (2001), "Dubai: health development indicators", in DUBAI DEPARTMENT OF ECONOMIC

DEVELOPMENT (2001), "Development Statistics", Government of Dubai, pp.188

115 WORLD HEALTH ORGANISATION (2002)

${ }^{116}$ UAE MINISTRY OF HEALTH and DUBAI DEPARTMENT OF MEDICAL SERVICES (2001), "Dubai: health development indicators", in DUBAI DEPARTMENT OF ECONOMIC DEVELOPMENT (2001), "Development Statistics", Government of Dubai, pp.188

${ }^{117}$ UNITED STATES CENSUS BUREAU (2002), International Programs Centre, International database

118 See section 1.2

119 ABEIDOH, Rawhi (2000), "Arabs: a shrinking minority in the UAE", in DAWN MAGAZAINE, $28^{\text {th }}$ October 2000 , calculations based upon quoted figures

${ }^{120}$ DUBAI MUNICIPALITY (1999), "Results of income and expenditure survey - Dubai city, 1997 1998", Administrative Affairs Department, Statistics Centre, May 1999, pp.133, with regards to Dubai the survey indicated that $17 \%$ of households were local, $8.9 \%$ were non-local Arabs, $3.2 \%$ were European, 
$41.9 \%$ were Asian, and the remaining $29 \%$ of the population were collective labourers (based in labour camps).

${ }_{121}^{121}$ DUBAI MUNICIPALITY (1999), pp.133

122 ABEIDOH

${ }^{123}$ See ABEIDOH

${ }^{124}$ CROWN PRINCE COURT DEPARTMENT OF RESEARCH AND STUDIES (1996), pp.95

125 Ibid. pp. 95

${ }^{126}$ Ibid. pp.95

${ }^{127}$ For a further discussion of the demographic problem see (in Arabic) BILAL, Muhammad (1990),

"Changes in population and power among immigrants and citizens of the UAE, 1976-1980", Sharjah

Sociologist Society

${ }^{128}$ ABU DHABI PLANNING DEPARTMENT ECONOMIC DIVISION (1976), pp. 14-16

${ }^{129}$ GCC DEVLOPMENT PLANS - UNITED ARAB EMIRATES (1982), pp. 17

130 AL-SHARHAN INTERNATIONAL CONSULTANCY (2000), pp.54

${ }^{131}$ PECK (1986), pp.68

132 UNITED ARAB EMIRATES MINISTRY OF PLANNING and DUBAI MUNCIPALITY (2001),

"UAE and Dubai: population", in DUBAI DEPARTMENT OF ECONOMIC DEVELOPMENT

(2001), "Development Statistics", Government of Dubai, pp.25

133 Ibid.

${ }^{134}$ Calculated from official figures reported in GULF NEWS (2002), "Dubai tops nation in urban population", $4^{\text {th }}$ December 2002

${ }_{135}$ FINDLOW, Sally (2000), "The UAE: Nationalism and Arab-Islamic Identity", Abu Dhabi, Emirates Centre for Strategic Studies and Research, ECSSR OCCASIONAL PAPER, Number

$39, \mathrm{pp} .34$

${ }^{136}$ See section 5.4

${ }^{137}$ Personal interviews, Dubai 2001-2002; Abu Dhabi 2001; and Sharjah 2001-2002

138 PECK (1986), pp.72

139 'AHMAD, Ashfaq (2003), "Majority of expats suffer from some sort of depression", in GULF NEWS, $11^{\text {th }}$ January 2003, reporting the findings of Dr. Ali Harjan, a leading Sharjah-based psychologist

140 HEARD-BEY, Frauke (1982), "From Trucial States to United Arab Emirates", London, Longman, pp. 252

${ }^{141}$ HAWLEY, Donald (1970), "The Trucial States", London, George Allen \& Unwin, pp. 212, for details on article 14 of 1937 agreement with PDTC

142 Ibid. pp. 212

143 FENELON (1973), pp.98

144 Ibid. pp.98 and pp.100-101

145 ABU DHABI PLANNING DEPARTMENT ECONOMIC DIVISION (1976), pp. 14

146 AL-MUSHARRAKH, Zaikya (2000), "University Students take Al-Futtaim Trading Courses", in KHALEEJ TIMES, $26^{\text {th }}$ July 2000, quoting Jassim Al-Banay, Al-Futtaim's 'Emiratisation Manager'

147 WAM (2001), "New avenues for UAE women", $17^{\text {th }}$ May 2001

${ }^{148}$ LANGLEY, Joanna (2000), "Mashriq Bank joins hand with NHR to promote Emiratisation", in GULF NEWS, $3^{\text {rd }}$ September 2000

${ }^{149}$ BUSINESS IN DUBAI (2001), Dubai Chamber of Commerce and Industry, Volume 1 Issue 6, June 2001, pp. 26

150 BIBBO, Barbara (2002), "New contract rule to benefit nationals", in GULF NEWS, $14^{\text {th }}$ December 2002 , as explained by Dr. Khazraji, undersecretary of the Ministry of Labour and Social Affairs

${ }^{151}$ AL-SHARHAN INTERNATIONAL CONSULTANCY (2000), pp. $12-13$

${ }^{152}$ LANGLEY, Joanna (2000), "Mashriq Bank joins hand with NHR to promote Emiratisation", in GULF NEWS, $3^{\text {td }}$ September 2000

${ }^{153}$ See for example, RIZVI, Meraj (2000), "Only Nationals to be Captains of Fishing Vessels", in

KHALEEJ TIMES, $26^{\text {th }}$ July 2000 , quoting A. Abdulrazzaq, the Director of Fisheries in the Ministry of Agriculture and Fisheries and head of the Fishing Regulations Committee, speaking to Khaleej Times about the Ministry's plans.

${ }^{154}$ AL-SHARHAN INTERNATIONAL CONSULTANCY (2000), pp. 12-13

${ }^{155}$ Ibid. pp. 12-13

${ }^{156}$ ECONOMIST INTELLIGENCE UNIT (2000), pp.5, also, with regard to the 2002 amnesty see BUSINESS MONITOR INTERNATIONAL (2003), "The United Arab Emirates", second quarter report, pp. 8

${ }^{157}$ Personal correspondence, June 2003

${ }^{158}$ AL-SHAMSI (1999), pp. 83-84

${ }^{159}$ ECONOMIST INTELLIGENCE UNIT (2000), pp. 14

${ }^{160}$ Personal interviews, Dubai, April 2002 
${ }^{161}$ BUSINESS IN DUBAI (2002), Dubai Chamber of Commerce and Industry, Volume 2 Issue 15, March 2002, pp.2, quoting from Humaid al-Qutami, general manager of EIBFS

${ }^{162}$ UNITED STATES DEPARTMENT OF STATE (2001), "United Arab Emirates: Country Reports on Human Rights", Bureau of Democracy, Human Rights, and Labour, 23 ${ }^{\text {rd }}$ February, 2001, section 1(e)

${ }^{163}$ KHALEEJ TIMES (2001), "Country"s judiciary is independent: Dhahiri", $6^{\text {th }}$ December 2001 , from a lecture at the Zāyid Centre for Co-ordination and Follow-up by Muhammad bin Kakhira alDhahiri, the Minister of Justice, Islamic Affairs and the Auqauf

${ }_{164}^{164}$ See section 4.3.1

${ }^{165}$ Personal interview with a representative of the Studies and Research Department in the Dubai Chamber of Commerce and Industry, December 2001

${ }^{166}$ MIDDLE EAST ECONOMIC DIGEST (1994), "UAE Special Report", $1{ }^{\text {st }}$ December 1994, pp. 14

${ }_{167}^{6 C O N O M I S T ~ I N T E L L I G E N C E ~ U N I T ~(2000), ~ p p .47 ~}$

${ }^{168}$ HAWLEY (1970), pp. 241-242

${ }^{169}$ THESIGER, Wilfred (1991), "Arabian Sands", London, Penguin, pp.262, describing Theisger's reaction upon arriving in Abu Dhabi from Sulaiyil in 1950

${ }_{170}$ Aerial photographs of the pre-oil era are held in Shaykh Sa'id Al-Maktūm House in Shindagha, Dubai

${ }^{171}$ MANNAN, MA (2001), "Dubai Stands high in list of Best Skylines", in KHALEEJ TIMES, 12 th May 2001, "The impressiveness of Dubai's skyline has been generating encomiums from near and far in recent times, especially after the opening of the Burj al-Arab and Emirates Towers."

${ }_{172}$ PECK (1986), pp.109

173 JOYCE, Miriam (1999), "On the road towards unity: the Trucial States from a British perspective, 196-1966", in MIDDLE EASTERN STUDIES, Volume 35 Number 2, April 1999, pp.48-49, with particular reference to Shaykh Shakhbut Al-Nuhayyān

${ }_{174}$ FEARD-BEY (1982), pp. 189-191

${ }^{173}$ AL-JUM'A SUPPLEMENT (1981), "The reason for the Iran connection", in GULF NEWS, $21^{\text {st }}$ August 1981, pp.11, quoting DK Chaudhry, the general manager of the Sharaf Shipping Agency

${ }^{176}$ ABDULLAH, Muhammad Morsy (1978), "The United Arab Emirates: A Modern History", London, Croom Helm, pp.104; also see HEARD-BEY (1982), pp.243, where she describes the considerable tax exemptions in Dubai, with 200 boats and 4000 men being exempt from customs duties

177 AL-JUM'A SUPPLEMENT (1981), quoting DK Chaudhry, the general manager of the Sharaf Shipping Agency

178 ABDULLAH (1978), pp. 104

${ }_{179}$ HEARD-BEY (1982), pp.189-191

${ }^{180}$ AMIN, Samir (1978), 'The Arab Nation: Nationalism and Class Struggles", London, pp.84-85

${ }^{181}$ HEARD-BEY (1982), pp. 245

${ }^{182}$ See section 1.4.4

183 HEARD-BEY (1982), pp. 265

${ }^{184}$ AL-JUM'A SUPPLEMENT (1981), quoting DK Chaudhry, the general manager of the Sharaf Shipping Agency

185 UAE MINISTRY OF PLANNING (2001), "Dubai: GDP at factor cost", in DUBAI

DEPARTMENT OF ECONOMIC DEVELOPMENT (2001), "Development Statistics", Government of Dubai, pp.42, GDP calculated at fixed 1995 prices

${ }^{186}$ UAE MINISTRY OF PLANNING (2001), "UAE and Dubai: GDP at factor cost and per capita GDP - 2000", in DUBAI DEPARTMENT OF ECONOMIC DEVELOPMENT (2001), "Development Statistics, Government of Dubai, pp.44, GDP for 2000 calculated at current prices

${ }^{197}$ UAE MINISTRY OF FINANCE AND INDUSTRY (2001), Abu Dhabi

${ }^{188}$ This poor performance has also been blamed on the absence of an official stock market and the lack of official trading, see ABU DHABI ECONOMY (1999), "Abu Dhabi Economy: Special Issue", Abu Dhabi Chamber of Commerce and Industry, Publications and press relations Department, Volume 28 Number 322, March 1999, pp.17-18

189 UAE MINISTRY OF FINANCE AND INDUSTRY (2001), Abu Dhabi

${ }^{190}$ AL-SHARHAN INTERNATIONAL CONSULTANCY (2001), pp. 14-15

${ }^{191}$ Ibid. pp.14-15

192 UAE MINISTRY OF PLANNING (2001), "UAE and Dubai: employment by economic sectors", and "UAE and Dubai: GDP at factor cost and per capita - 2000", in DUBAI DEPARTMENT OF ECONOMIC DEVELOPMENT (2001), "Development Statistics", Government of Dubai, pp.30 and pp.44, GDP for 2000 calculated at current prices using sectors' shares of total employment and total GDP ${ }^{193}$ BUSINESS MONITOR INTERNATIONAL (1997), "The United Arab Emirates, 1995-1997", pp.56 
${ }^{194}$ EVERETT-HEATH, T, and DUTTA, A (2002), "Bridging the gap", in MIDDLE EAST

ECONOMIC DIGEST, Volume 46 Number 10, $8^{\text {" }}$ March 2002, pp.27-30, quoting Jamal Sanad alSuwaidi of the Emirates Centre for Strategic Studies and Research (ECSSR)

${ }_{193}$ Ibid. pp. 27-30

${ }^{196}$ Ibid. pp. 27-30, corroborated with personal interviews, Dubai Chamber of Commerce and Industry,

December 2001; and with personal interviews, ĀI-Maktûm Institute of Dundee, July 2002

${ }_{197}$ Ibid. pp. 27-30

${ }^{198}$ ECONOMIST INTELLIGENCE UNIT (2000), pp.4-5

199 HARRIS (1987), see Harris for discussion of 'economic nationalism' and economic development theories

${ }^{200}$ BUSINESS MONITOR INTERNATIONAL (1997), pp.5-6

${ }^{201}$ See chapter 4

${ }^{202}$ GCC DEVLOPMENT PLANS - UNITED ARAB EMIRATES (1982), pp. 15

${ }^{203}$ CROWN PRINCE COURT DEPARTMENT OF RESEARCH AND STUDIES (1996), pp.32

${ }^{204}$ Ibid. pp.32 and pp.76

${ }^{205}$ DUBAI DEPARTMENT OF ECONOMIC DEVELOPMENT (2002), "Development Statistics", Government of Dubai, pp.114, imports valued at fixed 1995 prices. Also see GCC DEVLOPMENT PLANS - UNITED ARAB EMIRATES (1982), pp.15

${ }^{206}$ DUBAI DEPARTMENT OF PORTS AND CUSTOMS (2002), "Dubai: non-oil foreign trade total", in DUBAI DEPARTMENT OF ECONOMIC DEVELOPMENT (2002), "Development

Statistics", Government of Dubai, pp.109 and pp.114, calculated from values for non-oil foreign trade given at fixed 1995 prices

${ }^{207}$ GCC DEVLOPMENT PLANS - UNITED ARAB EMIRATES (1982), pp.15 and pp.46, a number of restrictions on spending were proposed but none were implemented

${ }^{208}$ AL-SHAMSI, Fatima S (2001), "Symposium on Shaykh Zāyid", in MIDDLE EAST POLICY, Volume 6 Number 4, June 1999, pp.4

${ }^{209}$ AL-SHAMSI (1999), pp. 83-84

${ }^{210}$ BROWN, Gavin (1998), "OPEC and the World Energy Market", London, Longman, pp. 360

211 OVERTON, JL (1983), "Stability and change: Inter-Arab politics in the Arabian Peninsula and Gulf", $\mathrm{PhD}$ thesis, University of Maryland, pp. 184, taken from Overton's interview with Sa'id 'Ahmad Ghubash, in Abu Dhabi in 1976

${ }^{212}$ PECK (1986), pp. 100

${ }^{213}$ In 2002 the German carrier Lufthansa reduced its flights to Sharjah. Moreover, Lufthansa is now the only Western airline still serving the airport.

${ }^{214}$ Personal interviews, Dubai, October 2002

${ }^{215}$ BROWN (1998), pp.359; also see FEDERAL RESEARCH DIVISION (2003), "United Arab Emirates: a country study", Blackmask, USA, it was believed that by 1987 Shaykh Sultān had amassed debts of nearly $\$ 920$ million following several ambitious construction projects. On assuming power Shaykh Abdel-Aziz made a news broadcast claiming that his brother had voluntarily stepped down due to economic mismanagement

${ }^{216}$ ABU DHABI PLANNING DEPARTMENT ECONOMIC DIVISION (1976), pp.19

${ }^{217}$ RIZVI, SN Asad (1993), "From tents to high rise: economic development of the UAE", in MIDDLE EASTERN STUDIES, Frank Cass, Volume 29 Number 4, October 1993, pp.666

${ }^{218}$ Personal interviews, Dubai Chamber of Commerce and Industry, December 2001

${ }^{219}$ GCC DEVLOPMENT PLANS - UNITED ARAB EMIRATES, pp. 17

${ }^{220}$ See section 1.5

${ }^{221}$ RIZVI, SN Asad (1993), "From tents to high rise: economic development of the UAE", in MIDDLE EASTERN STUDIES, Frank Cass, Volume 29 Number 4, October 1993, pp.665

222 FENELON (1973), pp.3

${ }^{223}$ HEARD-BEY (1982), pp. 112

${ }^{224}$ ECONOMIST INTELLIGENCE UNIT (2000), pp. 28

${ }^{225}$ CROWN PRINCE COURT DEPARTMENT OF RESEARCH AND STUDIES (1996), pp.54, comparison between 1975 and 1995

${ }^{226}$ Ibid. pp. 54

${ }^{227}$ See BUSINESS MONITOR INTERNATIONAL (2001), "The United Arab Emirates", second quarter 2001

${ }^{228}$ KHALEEJ TIMES, “" Ajman Fantazia to begin tomorrow", $15^{\text {th }}$ January 2002

${ }^{229}$ IBRAHIM, ME (2002), "Dalmă Island to emerge as regional tourist spot", in KHALEEJ TIMES, $2^{\text {nd }}$ September 2002

${ }^{230}$ UNDP-UAE (2000), "Press Release - The Launch of Ra's al-Khaimah Vision ", $28^{\text {th }}$ March 2000 
${ }^{231}$ AL-SHARHAN INTERNATIONAL CONSULTANCY (2000), pp. 23-25, Al-Sharhan claims 22\% of GDP accounted for by oil sector; and see UNITED STATES CENTRAL INTELLIGENCE

AGENCY (2000), "World Fact book: United Arab Emirates", which claims $45 \%$ of total exports are oilrelated

${ }^{232}$ ABU DHABI PLANNING DEPARTMENT ECONOMIC DIVISION (1976), pp.9 and pp.18 for agricultural sector growth; and see UNITED STATES CENTRAL INTELLIGENCE AGENCY

(2001), "World Fact book: United Arab Emirates", January 2001, for 1997 estimates on industrial growth 


\section{Domestic Pathologies and the Political Process}

While the United Arab Emirates has enjoyed moderately successful socioeconomic development over the past thirty years, and while the planners have managed to reduce some of the most manifest weaknesses resulting from the UAE's dependency on oil, foreign technology, and foreign labour, there have however been a number of significant under-the-surface pathologies which have continued to undermine the development path. Certainly, as the previous chapter demonstrated, a number of concerns including the massive duplication of investments and the UAE's chronic regional disequilibrium would seem to indicate serious internal problems, perhaps stemming from the domestic political process, the lack of inter-emirate co-ordination, the lack of inter-departmental comoperation, the need for greater transparency, and the interaction of conflicting interest groups. Crucially, without contradicting the growing economic neo-liberal emphasis on internal factors shaping development, ${ }^{1}$ the aim of this chapter will be to demonstrate that such pathologies are in many ways by-products of the same reinvigorated traditional structures which allowed for the consolidation of the polity and the reinforcement of the dependent client elite in the first place. Indeed, it will be shown how many of these persistent development concerns can be seen as the hidden cost of the UAE's political stability and therefore the long-term price which must be paid in order to circumvent the Shaykh's dilemma and escape the inevitability of the early modernisation theories.

Firstly, explaining more clearly how such dependency-related internal structures may lead to a lag in development and inhibit any evolution towards Weberian legal-rational ideals, it will be shown how rentierism / allocation, neo-patrimonial networks, bureaucratic self interests, and complex client elite orientations can readily influence a state's goals, its domestic political process, and the interactions of its key interest groups. Working within this framework, the chapter will then explore the UAE's decision-making structure, outlining the key political institutions and, critically, their social compositions and comparative effectiveness. In addition, the all-important 
relationship between the key federal state-level structures and the many existing emirate-level institutions will also be discussed; a unique feature of UAE politics and essential to a greater understanding of regional co-ordination and co-operation. Thirdly, this chapter will consider the role of the UAE's bureaucracies, parastatals and those other institutions responsible for policy implementation and regulation, with an assessment of their relative strengths and weaknesses, and of course their perceived level of opaqueness. Finally, the existence of significant elite interest groups within the Emirati political process will also be contemplated, especially the ongoing struggle between the well-established conservatives and the more technocratic reformers, both of whom seek to perpetuate rentier wealth, but whose different preferences and strategies have in many cases directly influenced and shaped the UAE's development path.

\section{1-Domestic pathologies}

A number of theoretical models have been devised in an effort to explain the relative impact of domestic pathologies in developing states and, as this chapter will demonstrate, elements of these can be readily applied to the UAE. Firstly, in light of the various development problems discussed in the previous chapter, it is necessary to consider the inherent weaknesses of a political economy which is still by and large dominated by oil: that is an allocative rentier state which is still able to rely primarily on hydrocarbon resources, and which therefore by definition lacks the same impetus to build up a productive sector as other non-allocative developing states. Thus, although as shown there have been concerted attempts to diversify in the UAE, Giacomo Luciani and other scholars have argued convincingly that such efforts may ultimately be limited as developing a domestic productive economy in many ways still represents something of a bonus rather than a necessity for these states:

"Growth in the domestic economy is one of the various luxuries that the state can buy with its oil income in one case, it is an essential precondition for its existence and survival in others. "2 
Crucially this feature (and in some ways attitude) of rentier states, may significantly hold back overall development and growth as goals will invariably remain linked to the primary hydrocarbon sectors:

"... the strengthening of the domestic economic base may be included, but not necessarily so. Even if this happens to be one of the goals of the state... the strengthening of the domestic economy is not reflected in the income of the state, and is therefore not a precondition for the existence and expansion of the state." 3

As shown, despite improvements in import-substitution industrialisation, hydrocarbon resources are still behind many of the UAE's manufacturing activities, especially in Abu Dhabi, as many plants remain geared towards heavy export-oriented plants reliant on cheap energy. ${ }^{4}$ Similarly, the agricultural sector continues to rely heavily on government subsidies (providing ready-made farms, equipment, irrigation, etc.), ${ }^{5}$ which are of course a luxury afforded by the oil-rich allocative state. Moreover, as also demonstrated in the previous chapter, allocated wealth has indirectly hindered the emiratisation drive as UAE nationals have been priced out of the market and, in many cases, have been stripped of incentives to enter the workforce. ${ }^{6}$ Thus, while rentierism provides great wealth, allows for social growth, and engenders much needed stability, in certain key instances such a phenomenon may do little to curb long-term development problems which, in other economies more reliant on fostering strong productive sectors, could be more easily solved.

Building upon these implications, and of course given the earlier discussion of the survival of traditional monarchy and the polity's increased reliance on patrimonial networks alongside seemingly modern institutional structures, another important starting point would be the 'neo-patrimonial' model. As there is little doubt that the ruling families continue to dominate the UAE's political system, continue to control the highest offices of state and, significantly, administer the bulk of the state's allocated wealth, it would seem reasonable to hypothesise that patrimonial elites direct 
policy formulation while the more modern burequcracies simply act as augmentations of the patrimonial network and as tools for policy implementation. In this scenario

"... the bureaucracy is turned into an extension of a self-serving patrimonial elite which provides no coherent or dynamic administrative leadership. Particularistic distrust prevents the delegation of authority, stifles initiative, and frustrates teamwork and the co-ordination of functions. The chain of command is unreliable; legal prerogatives of office may give little real authority where power derives from personal connections and loyalties or legal commands are short-circuited by 'personal fiefdoms'... "7

Indeed, Ray Hinnebusch summarises how such a neo-patrimonial political process and the resulting pathologies can greatly affect development policy:

"Development policy is subverted by a patrimonial strategy of control in which economic rationality is subordinated to the creation of clienteles, cooptation, and payoffs of potential opposition. In such an uninstitutionalised regime, instability and fragmentation paralyse or induce swings in policy, rendering it incoherent, and effective instruments of policy implementation are wholly lacking. In short, state policy, put in the service of narrow group interests, is 'irrational' from the point of view of the larger society."

Thus, given this hybrid of traditional groups and new institutions, one would expect to find considerable competition between the various patrimonial elites and their clients over policymaking and the management of the state's resources. ${ }^{9}$ Moreover, one would expect to uncover a system far removed from the Weberian ideals of legal-rational priorities, issues, and procedures, and therefore a political process likely to significantly impede and slow socio-economic development.

Furthermore, it is also important to note how the neo-patrimonial expansion of the UAE's bureaucracies may also lead to the emergence of self-interested 
bureaucratic interest groups whose members may seek to secure themselves and their careers as well as consolidating the future of their particular institution within the hybrid political network. Certainly, as Fred Riggs has argued, such a behavioural pattern may lead to additional pathologies as bureaucracies and their staffs pursue irrational motives in an effort to further their own interests rather than those of greater society or indeed even the patrimonial elites. ${ }^{10}$

Finally, while such models may be able to highlight the particularistic struggles that can take place within neo-patrimonial structures, they do not however take into account the actual nature and complexity of the elite's orientation at the apex of this system. ${ }^{11}$ Indeed, as Wallerstein noted in the 1970 s, elites cannot always be viewed as homogeneous entities pursuing the narrow interests of patrimonial politics, as they will very often have conflicting economic interests with some favouring an 'open' economy while others favour some form of protection. ${ }^{12}$ Certainly, as this chapter will demonstrate, with new generations of western educated and professional technocrats, many of whom control big businesses and are now beginning to gain positions of high office, the UAE's patrimonial elite and, in Hisham Sharabi's Marxist terms, its dominant rentier class, ${ }^{13}$ is becoming distinctly heterogeneous, with a clear divide emerging between those conservatives seeking to perpetuate oil-derived rentier wealth and those 'new rentier' reformers attempting to liberalise the economy in order to exploit fresh sources of economic rent. Thus, recognition of these domestic elite interest groups and their differing development priorities and preferences must form another crucial layer of understanding.

\section{2 - The decision-making structure}

At the federal level, the UAE's decision-making structure comprises of a split executive, with a 'President for life' chairing a supreme council of the various hereditary rulers, and with a Prime Minister presiding over an appointed council of government ministers. Underneath this executive operates a unicameral legislative council comprising of selected representatives from the seven emirates. As one might 
expect, given the described neo-patrimonial model, the powerful executive is almost entirely dominated by members of the ruling families and representatives of other notable Emirati families, and most importantly, as this section will demonstrate, is largely unrestrained by the weak and ineffective legislature which has primarily served as an optional consultative body allowing for the limited co-optation of other privileged families.

At the apex of this decision-making structure is the institution of the Presidency, with the President acting as the head of state, representing the UAE in foreign relations, performing both procedural and ceremonial functions, and serving as an important bridge between the two executive bodies:

“... [He] convenes meetings of the Supreme Council of Rulers. He also represents the UAE in foreign relations, stupervises the implementation of federal laws and decrees. He appoints the Prime Minister with the approval of the Supreme Council of Rulers, and then selects the Council of Ministers with the approval of the Prime Minister. Perhaps most importantly, given his sole responsibility for calling joint meetings between the Supreme Council of Rulers and the Council of Ministers he plays a crucial role in linking the UAE's two highest political bodies. "i4

Certainly, as Khoury described in his study of the UAE's political system, this linking role has often allowed the President to balance and regulate conflicts within the political system, thus satisfying his monarchical need to reinforce personal legitimacy and his position at the centre of patrimonial power. ${ }^{15}$ Indeed, the Presidency of the UAE is entirely synonymous with the traditional rulership of Abu Dhabi, the largest and wealthiest of the constituent emirates, with Shaykh Zāyid Al-Nuhayyān having been reelected to the position every five years by the six other rulers. Moreover, with Abu Dhabi being by far the largest contributor to both the federal budget and the UAE's GDP, this historical association of the presidency with the ruler of Abu Dhabi has now been informally accepted by the other emirates. ${ }^{16}$ Thus, barring any major inter-emirate 
challenge, or as discussed in the study of dynastic monarchies, any internal power struggle amongst the $\bar{A}$ l-Nuhayyān family, it would seem likely that Shaykh Zāyid's eldest son and crown prince, Shaykh Khalifa, will succeed as both ruler of Abu Dhabi and as President of the UAE. Accordingly, in much the same way that many of the republican Middle Eastern states have been described as 'presidential monarchies', the UAE can be seen as having evolved into a 'monarchical presidency', with a continuously re-elected royal president.

Comprising the seven hereditary rulers, the Supreme Council of Rulers (the SCR) is the UAE's highest federal authority with the powers to initiate policy, to review and reject laws passed by the ministerial government, to admit new members to the federation, and to appoint or dismiss any civil servant including the judges of the Federal Supreme Court, the Prime Minister, and even the President. Officially, the SCR's annual sessions last for eight months of the year, during which time four formal meetings are supposed to take place, ${ }^{17}$ but given that no constitutional provision exists for enforcing such regular meetings, these have often been infrequent. Indeed, over the years the rulers have generally preferred the ease of informal gatherings, and as this chapter will reveal, this essentially traditional process has often left major controversial issues in abeyance, sometimes even to the detriment of the national interest. ${ }^{18}$ Moreover, while the SCR's procedural issues are in theory decided by a simple majority, with each of the seven members having a single vote, in the case of more substantive matters both the nulers of Abu Dhabi and Dubai in addition to at least three of the five smaller emirates must approve all decisions and ratifications. Thus, at this highest level, it is important to note that the UAE's formal political process serves to underscore the supremacy of Abu Dhabi and Dubai, the two wealthiest emirates. ${ }^{19}$ Finally, with regard to social formation, the SCR naturally remains the most exclusive of the UAE's political institutions, with its members having always been the seven respective emirs, all of whom are descendants of the 'paramount shaykhs' or tamima of the long-established tribal dynasties originally supported and favoured under the British Trucial system. Indeed, Abu Dhabi is represented by Shaykh Zāyid, the head of the $\bar{A} l-$ Nuhayyān, with Dubai represented by Shaykh Maktūm Al-Maktūm, with Sharjah and 
Ra's al-Khaimah being represented by Shaykh Sultān and Shaykh Saqr, their respective Qawāsim rulers, with 'Ajman represented by Shaykh Humayd of the Al-Na'īm, with

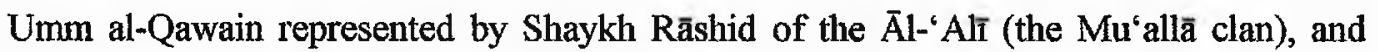
with Fuijarah being represented by Shaykh Hamad of the Sharqiyin. ${ }^{20}$

The Council of Ministers (the COM) is effectively the UAE's formal cabinet, with its ministers responsible for most of the day-to-day running of the federation. Although clearly subordinate to the SCR, the COM is nevertheless responsible for formulating the bulk of the UAE's policies, and can initiate its own legislation after receiving ratification from the SCR. In addition, the COM approves the federal budget, oversees all public expenditure, and supervises all decrees, regulations, Supreme Court decisions, and international treaties. ${ }^{21}$ Currently, there are nearly 30 members of this executive, including 17 government ministers and five ministers of state, along with the President, the Vice-President, the Prime Minister (currently also the vice-president), the Deputy Prime Minister, the governor of the Central Bank and, on occasion, the UAE's permanent representative to the United Nations and the UAE's ambassador to the USA ${ }^{22}$ See appendix (vii).

Although each of the seven emirates are represented by at least one minister, the COM is however, in a similar fashion to the SCR, also clearly structured in favour of Abu Dhabi and Dubai, with these larger emirates controlling the most significant portfolios. Originally, six of the ministries were allotted to Abu Dhabi (including foreign affairs, interior, and information), while the premiership in addition to three other important ministries were given to Dubai (including defence and finance), three were also given to Sharjah, two each were given to Ra's al-Khaimah and Fujairah, and one each was given to the smallest emirates of 'Ajman and Umm al-Qawain." This composition of the cabinet was first negotiated in 1971 and was eventually formalised in 1996 when the constitution was finally made permanent. Thus, over the years, the allotments have remained relatively unchanged, with the main additions having instead come from newly created cabinet posts, including the previously discussed Minister of 
State for the Presidential Office, which has been assigned to another of Shaykh Zāyid's sons. ${ }^{24}$

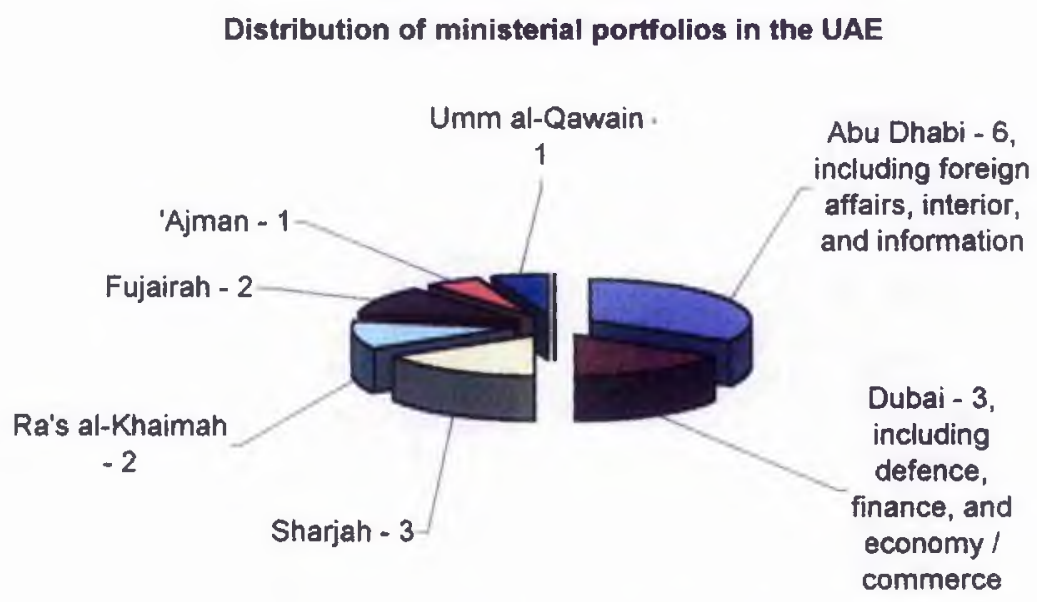

[Source: Economist Intelligence Unit] ${ }^{25}$

Conforming to the neo-patrimonial model, the COM's social formation is perhaps best viewed as an extension of monarchical authority with many of the ministerial posts being occupied by either key members of the various ruling families (around $40 \%$ of posts ${ }^{26}$ ) or by representatives of other long-established and powerful tribal families. Most obviously, in much the same way as the President's overlapping role, the UAE's Prime Minister, Shaykh Maktūm Al-Maktūm (as the ruler of Dubai and also the Vice-President), serves on both the COM and the SCR. Shaykh Muhammad Al-Maktūm, Dubai's crown prince, is also represented in the cabinet, serving as the Minister for Defence, as is his older brother Shaykh Hamdan Al-Maktūm, who serves as the Minister of Finance and Industry. In addition to Shaykh Zāyid, Abu Dhabi's ruling family is well represented by Shaykh Sultān Al-Nuhayyãn, the Deputy Prime Minister, by Shaykh Nuhayyân Al-Nuhayyān serving as the Minister for Higher Education and Scientific Research, by Shaykh Abdullah Al-Nuhayyān as the Minister of Information and Culture, and by Shaykh Hamdan Al-Nuhayyān, the UAE's Minister of State for Foreign Affairs. Other royals currently include Sharjah's Shaykh Fahim al-Qāsimī who heads the Ministry of Economy and Commerce, and Umm al-Qawain's Shaykh Humayd al-Mu'allā who serves as the UAE's Minister of Planning. ${ }^{27}$ Examples of prominent non-royal families serving in the COM have included Abu Dhabi's Dhaheris, 
the Suwaidis and the Otaibis. ${ }^{28}$ Indeed, Muhammad al-Dhahiri currently heads the Ministry of Justice and Islamic Affairs; Sultân al-Suwaidi serves as the governor of the Central Bank ${ }^{29}$, and in the past 'Ahmad Khalifa al-Suwaidi was the UAE's first ever Minister for Foreign Affairs, with Mana Sa'id al-Otaibi having presided over the UAE's Ministry for Petroleum. ${ }^{30}$ Finally, however, as revealed in the earlier discussion of broader patrimonial networks and their contribution to the ruling bargain, ${ }^{31}$ it must be noted that in recent years a number of ministerial posts have also been granted to members of other Emirati families, often those possessing both professional experience and overseas postgraduate education. Certainly, the number of these 'technocrats' in the UAE's cabinet is steadily increasing and their expanding role in federal politics will be detailed later in this chapter.

The UAE's legislature consists of the unicameral 40-member Al-majlis alwatant lil-ittihād or Federal National Council (the FNC). In 1971 it was quite naturally assumed that the relatively small local populations of the constituent emirates could be sufficiently represented by a few people chosen from among the leading merchant families and those tribal elders who had traditionally held the confidence of their people. $^{32}$ Thus, by consolidating the principle of shürā (consultation), it was intended that the FNC would function as a contemporary federal majlis, offering the people direct democracy via respected intermediaries. Indeed, as Kevin Fenelon remarked soon after its creation, the FNC was certainly structured in such a way that it could raise local issues and debate all matters of public interest before the responsible ministers. Furthermore, in theory the FNC was to be informed of all government decisions, was to be able to ratify all international treaties signed by the UAE, and, to ensure the independence of its views, its members were to be excluded from all other public posts and ministerial portfolios. ${ }^{33}$

However, unlike the parliamentary legislatures normally associated with democracies, the FNC, in much the same way as the COM, has remained entirely appointive, with the seven rulers (or their associates ${ }^{34}$ ) being required to select rather than elect the FNC representatives for their emirates. ${ }^{35}$ Moreover, again resembling the 
COM, this selection procedure is further controlled so as to favour the two wealthiest emirates. Thus, while eight members each are chosen from Abu Dhabi and Dubai, six members each are chosen from Sharjah and Ra's al-Khaimah, and only four each are chosen from the smaller emirates of Fujairah, 'Ajman, and Umm al-Qawain: ${ }^{36}$

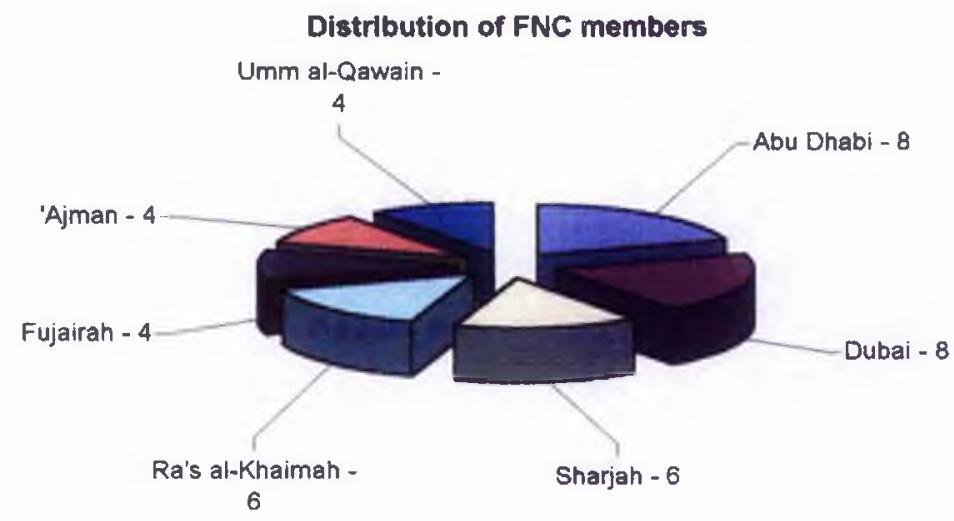

[Source: Economist Intelligence Unit] ${ }^{37}$

With reference to the social formation of the FNC, the institution's membership can again be interpreted as an attempt to incorporate representatives of prominent non-ruling families into the neo-patrimonial political process, even if they are granted little real authority. Certainly, as Fatma Al-Sayegh has shown in her study of merchants in the UAE, these FNC members, especially those from Dubai, often represent the new generations of the merchant elite families which previously dominated the Trucial States. ${ }^{38}$ Furthermore, in a similar fashion to the COM, there has also been an appreciable increase in the number of distinguished professionals from less well established families serving as FNC members, and, as will be shown later in this chapter, these technocrats are now even represented by the FNC's speaker, Muhammad Al-Habtur. ${ }^{39}$ Other recent examples would include Dr. Juma Belhoul, Dr. Hussein AlMutawa, and Dr. Tariq Al-Tayer, ${ }^{40}$ along with a number of other prominent businessmen, well-known doctors, and experienced lawyers. Indeed, the Dubai-based lawyer Dr. Muhammad Al-Roken provides a typical example of the latter. Educated in the UK and having taught at the University of the UAE in Al-'Ayn, Dr. Al-Roken is a published researcher and academic in addition to practising general commercial law in both local and federal courts. ${ }^{41}$ Indubitably, such well-established legal experts are seen 
as best placed for representing the individual emirates in a federal council which advises on pending draft legislation. See figure (ix).

Finally, however, also important to highlight the many weaknesses which are now increasingly associated with the FNC and the UAE's legislature. Quite apart from its non-elected membership and its inappropriateness for the UAE's ever expanding population, the original powers described by Fenelon have rarely been put into practice, often rendering the FNC a purely consultative body and a civilised 'talking shop', with its members limited to discussing and reviewing only the legislation referred to it by the COM. ${ }^{42}$ Moreover, in the most part the FNC is seldom able to submit any of its reports directly to the President or the SCR; instead all queries and findings have to be referred to the relevant minister, thus locking it into a subordinate role underneath the COM $^{43}$ Indeed, writing in the early 1980s, Malcolm Peck had already noted how

"... its real power is virtually nil because it does not initiate legislation but only offers recommendations on draft laws issued by the Council of Ministers, which is not, in turn, obliged to accept any of the FNC's proposals. Although the FNC may prove to be a useful exercise in developing political expertise and leadership and might someday provide the basis for a real legislature, it is now only a consultative institution and debating forum, entirely dominated by the Council of Ministers. "4t

There are, of course, occasions when the system has worked, and, often supported by special committees, ${ }^{45}$ the FNC has managed to have its suggestions incorporated into government policy, but as the following recent case studies will suggest, the FNC's powers have continued to remain limited, with the council often unable to extract information on more substantive matters from the COM. Furthermore, when information is gathered and recommendations are made, often following serious delays, there appears to be little evidence of FNC proposals actually being implemented unless they reinforce existing government policy. Certainly at present there appears to be no 


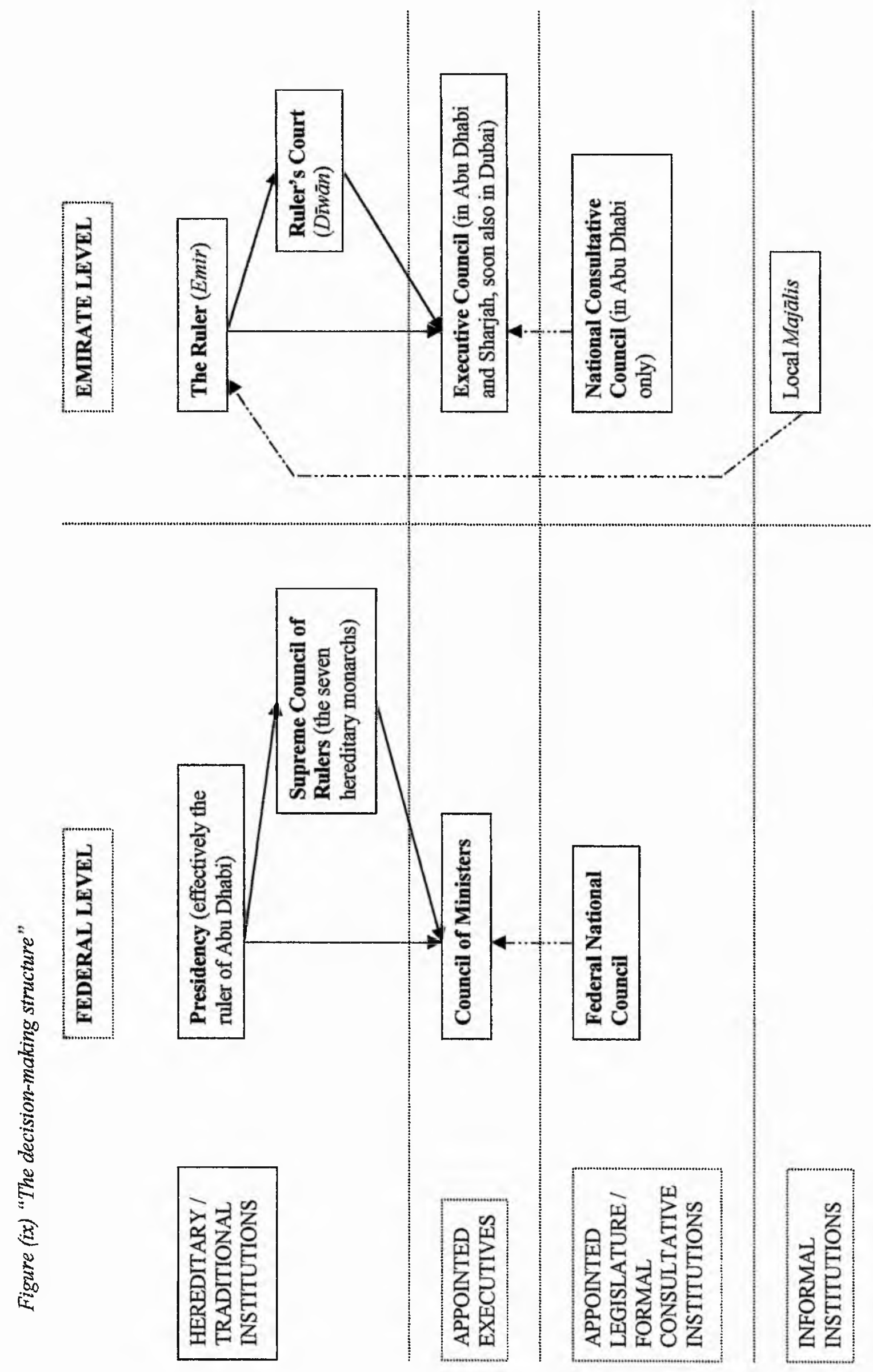


official requirement or even precedent for the COM or the individual minister in question to address the FNC's concerns within a specific time frame, or indeed for them to reply at all.

\subsection{1 - The Federal National Council: a paralysed legislature}

Firstly, it is worth noting that the FNC's standard procedure normally follows a pattern whereby a member or a group of members will submit a query or request to the rest of the council. This will normally be concerned with a pressing matter that these members wish to debate. Following approval from a majority of other FNC members, the matter can then be referred to the COM, usually in the form of a recommendation to the relevant federal minister. In theory, the minister should then promptly discuss the matter with the FNC or an appointed special committee of FNC members, and, if deemed necessary, the minister should then seek to initiate policy with the approval of his colleagues in the COM. By drawing upon FNC minutes from a number of meetings throughout the $1990 \mathrm{~s}$, this section will highlight many of the issues that have been raised by FNC members, while also attempting to demonstrate the ineffectiveness of this procedure and the relative weakness of the legislature in influencing the UAE's executive bodies.

The FNC meetings of July 1990 raised the matter of foreign ownership of real estate in the UAE. A request was submitted to discuss government policy on this issue, culminating in an FNC recommendation to "prevent foreigners from owning real estate without fixed restrictions in an effort to preserve the UAE's resources in the interest of future generations." Unsurprisingly, given that the content of this recommendation was already a long standing feature of government policy, the proposal was forwarded directly to the $\mathrm{SCR}^{46}$ Similarly, the FNC's March 1994 recommendation to uphold the UAE business statutes which require foreign ownership of businesses to be limited to $49 \%$ was entirely compatible with the aforementioned kafil sponsorship system, ${ }^{47}$ another well established policy. Predictably, the recommendation was met with a swift and detailed response, with the relevant minister 
attending the FNC's discussion, demonstrating exactly how the ministry was tackling the problem, and agreeing to refer the FNC's concerns to the COM. ${ }^{48}$ Also successful was the FNC's May 1993 proposal for greater investment in youth anti-drug awareness. Closely related to the government's ongoing development of the Supreme Council for Youth and Sports, the proposal was forwarded to the SCR and the necessarily policies were soon drawn up. ${ }^{49}$

However, with regard to more complicated matters requiring either the modification of existing legislation or the initiation of new policy, the FNC's recommendations and criticisms have not been so well received. A strong example would be the long-running FNC debate over the alarming size of the expatriate workforce and the need for drastic new emiratisation measures. Indeed, in 1990 a request was submitted to discuss the measures being taken by the Ministry of Labour and Social Affairs to address what was then believed to be a workforce comprising of just $15 \%$ nationals. This eventually took the form of a recommendation stating that the FNC's members accepted the continuing need for expatriate manpower, but that they were nevertheless alarmed by what appeared to be an 'uncontrolled random increase', and as such the COM needed to issue legislation forcing both public and private sector establishments to employ a portion of trained nationals as part of their workforce. ${ }^{50}$ Delayed by the Kuwaiti crisis, the debate was resumed in May 1991 with the FNC deciding to send several members to brief the Prime Minister on their renewed demands. ${ }^{51}$ Clearly, given the previously discussed emiratisation strategies, such strong demands were not completely in step with the government's more cautious approach to solving this sensitive problem, ${ }^{52}$ resulting in the matter being temporarily shelved and little further interaction taking place between the FNC and the COM on the subject. Indeed, it was not until May 1994 that the Minister of Labour and Social Affairs finally attended an FNC discussion on the nationalisation of labour, and it was not until January 1996, nearly six years after the original recommendation, that the FNC at last began to receive relevant draft legislation from the $\mathrm{COM}^{53}$ Another similar example of slow and ineffectual procedure would be the FNC's June 1993 request to discuss the performance of the Ministry of Information and Culture in improving the cultural 
content of mass media in the UAE. Although the minister attended the initial meeting and agreed to refer the matter to the COM, when in March 1994 the FNC remained dissatisfied with the ministry's progress, especially with regard to the lack of TV programs relating to Emirati culture, the minister failed to attend the FNC's scheduled debate. Moreover, when the minister finally did attend in April 1994, he promised to provide the FNC with a detailed letter outlining all of the ministry's forthcoming TV and radio projects, but it was not until April 1996, two years later, that the FNC actually received such a letter. ${ }^{54}$

The worst instances of FNC paralysis have, however, been those occasions when formal recommendations and requests have failed to elicit any response from the minister in question. As one might expect, these have often been those issues connected with substantive and highly sensitive matters such as national security, political reform, and oil policy. While the FNC's abortive attempts to press for limited political reform will be considered in greater depth in the following section, the recent oil-related requests provide another very clear insight into the FNC's subordinate relationship with the COM. In January 1994 a query was submitted by FNC members with regard to the worrying escalation of petrol prices in the UAE. In the normal manner, a request for information was presented to the Minister of Petroleum and Mineral Resources emphasising the FNC's concern that petrol prices were much higher in the UAE than in any of the other GCC states. Moreover, the FNC requested that the ministry should fully explain its plans for reducing the prices and eliminating the hardships faced by local businesses reliant on petrol products. Unable to bring the minister to question and unable to extract any information from the COM, despite following the established procedure, the FNC was forced to postpone its petrol-related questions indefinitely. ${ }^{55}$

\section{3 - The emirate-level decision-making structure}

At the emirate level, the rulers' courts, or dîwān, preside over local governments, most of which possess their own civil services, economic affairs departments, public works departments, finance departments, and, as will be detailed 
below, in some cases even their own oil departments, civil aviation authorities, and internal security organisations. Moreover, Abu Dhabi operates its own Executive Council, a 16-member organisation chaired by the crown prince and made up of heads of Abu Dhabi local government departments, in addition to a National Consultative Council which acts as a scaled down emirate-level version of the FNC. ${ }^{56}$ Similarly, Sharjah also has an Executive Council comprising of 26 nominated members of the ruling family and the local elite which, as explained earlier, was formed in 1987 by the reinstated ruler following the coup leader's promise for greater political participation in the emirate. ${ }^{57}$ Likewise, following the recent February 2003 announcements, Dubai will soon be establishing an executive council to supervise its large number of local government institutions. ${ }^{58}$ Indeed, reflecting the emirate's greater diversification and the development of its non-oil sectors, there are unsurprisingly a number of additional government departments and authorities at the local level in Dubai. Among others these include the aforementioned Department of Tourism and Commerce Marketing, ${ }^{59}$ the Department of Ports and Customs, the Dubai Ports Authority, the Jebel Ali Free Zone Authority, the World Trade Centre Association, and a Department for Economic Development. $^{60}$

In addition to these formal emirate-level structures, the region's majālis, although originally an integral part of the traditional tribal huküma and now perhaps less able to cope with the demands of large urban populations, nevertheless continue to provide an important informal consultative channel between the citizen and the ruler. ${ }^{61}$ In fact, as the UAE's Minister for Information and Culture explains, these majâlis have, like the more modern institutions, tried to adapt to the country's needs and in some cases still serve as useful forums for raising topics of debate more directly affecting the individual and their specific emirate:

"Just as the modern institutions have developed in response to public need and demand, however, so the traditional forms of tribal administration have adapted. With many relatively routine matters now being dealt with by the modern institutions, so the traditional ones, like the majālis, have been able 
to focus on more complex issues rather than on the routine matters with which they were once heavily involved... On matters more directly affecting the individual, such as the topic of unemployment among young UAE graduates, debates often tend to begin in the majälis, where discussion can be fast and furious, before a consensus approach is evolved that is subsequently reflected in changes in government policy." 62

Indeed, even the United Nations Development Project in the UAE has reported on the continuing relevance of informal majālis in emirate-level politics. In particular, the frequent discussions over issues such as role of women, the management of the expatriate population, and youth employment prospects have led the majallis to be recognised by the UNDP as providing an important forum for local social and political development. ${ }^{63}$ Certainly the rulers and their courts are aware of this function, with Abu Dhabi having deliberately augmented its majālis to include not only established tribes but also the many urban families and other groups who had previously lacked such local participation. ${ }^{64}$ Similarly in Dubai, there are currently plans to allow for

elected regional majālis in various parts of the emirate by mid $2003 .{ }^{65}$ Finally, it is also notable how a number of local businesses have sought to embrace such forums, with many now promoting open majālis between managers and employees in an effort to raise issues of concern and improve the workplace environment. ${ }^{66}$ See figure (ix).

\subsection{1 - The relationship between federal and emirate level structures}

Under the terms of the UAE's constitution the federal government is responsible for a wide range of matters including defence, foreign policy, immigration, nationality, communications, health, justice, and education. As such, while these local branches, offices, and institutions exist throughout the emirates, the majority are in theory subordinate to the COM's ministries based in the federal capital of Abu Dhabi. Furthermore, although the constitution does enable local-level powers to provide public services, to maintain law and order, to uphold standards, and to enforce local 
ordinances; ${ }^{67}$ at present the individual emirates are all obliged to contribute half of their revenue to the federation. Indeed, as Shaykh Abdullah Al-Nuhayyān describes:

"... all the emirates contribute to the federal budget and the federal budget funds projects in all of the emirates, including the three emirates that have no oil and gas production. Thus, while Fujairah, for example, has no oil revenues, the federal government funds projects in Fujairah, that are, in turn, funded by the contributions to the federal budget made by oil producers like Abu Dhabi and Dubai. The oil revenues of the emirates that do have oil are used through the medium of the federal budget, to fund development in the emirates which do not have oil. "68

Under this redistributive system Abu Dhabi and Dubai, the two major oil producing emirates, have therefore been required to make larger contributions, and, as Shaykh Abdullah contends, federal spending is shared proportionately by the seven members depending on their domestic populations and their specific needs. Thus, it would appear that some aspects of the federal-emirate level relationship, especially with regard to financial contributions, are now becoming formalised or at least better accepted by the constituent emirates. However, this was not always the case, with the past thirty years providing a rich history of federal-emirate struggles, and, even now (as Shaykh Abdullah admits) with the individual governments of the seven emirates still retaining certain autonomous powers and often maintaining duplicate and parallel local government departments, many of which overlap existing federal institutions. ${ }^{69}$

Thus, critical to a fuller understanding of the UAE's decision-making structure is the relationship between its federal, centralised political institutions and the local, emirate level structures. Significantly, it will be shown that in many respects the term 'federation' is something of a misnomer. Although the UAE is widely acknowledged to be one of the most successful examples of Arab unity and federation, it is really more of a confederation. True federations, such as the USA and Australia normally represent groups of regions or states which maintain their own local governments and laws, but 
are also united with a central government that is responsible for defence, foreign policy and other matters of national interest. ${ }^{70}$ As this study will reveal, there has so far been little real unity under the UAE's surface, with many crucial policy areas having often remained outside of federal control. Indeed, although the federation is undoubtedly evolving, the UAE at present remains more of a loose confederation with its constituent emirates more closely resembling the Swiss Cantons than the federated American states or the six Australian regions.

The first signs of potential disunity were acts of violence when, after just one year of federation, a number of inter-emirate territorial disputes escalated into bloody tribal skirmishes. Most of these confrontations were the results of border disagreements within the complex patchwork of villages and settlements in the hinterland of the northern emirates - a particularly violent example being the 1972 dispute between tribesmen of Sharjah and Fujairah after which twenty were left dead and many more were wounded. ${ }^{71}$ As described in the historical background, many of the tribes and villagers claimed allegiance to specific rulers, sometimes even to those in different and far-away shaykhdoms, and were therefore reluctant to recognise any newer, more central forms of authority. ${ }^{72}$ A combination of Federal Defence Force coercion (which had replaced the Trucial Oman Scouts) and negotiations were eventually able to settle most of these issues and reduce the frequency of the outbursts, but until the housing boom of the late $1970 \mathrm{~s}$ and the increasing urbanisation of the Bedu during the $1980 \mathrm{~s}$, the prospect of tribal insurgence remained a serious threat to political stability and domestic security, especially in the rural areas. Indeed, speaking in 1977 Shaykh Zāyid specifically referred to this ongoing problem, emphasising the need for greater cooperation and a stronger union:

"... unification steps must be continued and deepened and legislation supporting the federation must be a prime importance and above boundary disputes and individual disputes. "73 
By the mid-1970s there also began to emerge significant divisions over the direction of federal policymaking, and moreover, serious doubts over the future of the federation itself. While many of those high-up in the political system believed that the federation was little more than a transitional stage before a more coherent state could be established, there were many others, especially in Dubai, who continued to believe that the relative autonomy of each separate emirate was the federation's greatest strength as it better preserved the region's tribal democratic systems and all of the other emiratespecific characteristics which would be lost under a more centralised state. ${ }^{74}$ As such, these conflicting views led to political struggles over delicate matters such as oil and immigration. As these were policy areas which required the individual emirates to relinquish control over what were seen as their private resources and their means of livelihood, immediate consensus was understandably unforthcoming with the local rulers and their governments reluctant to concede existing powers. Indeed, this was especially the case with regard to oil as Dubai and Sharjah, the second and third wealthiest oil-producing emirates, preferred to retain full autonomy over their oil policies and were disinclined to contribute a large share of their oil revenue to the federal budget and the Abu Dhabi-based federal ministries. ${ }^{75}$ This problem stemmed primarily from Article 23 of the provisional constitution; a clause which allowed the individual emirates to manage independently their own hydrocarbon industries. ${ }^{76}$ As demonstrated, such emirate-specific articles may have provided much needed accommodation during the early federal negotiations, ${ }^{77}$ but in this case, with no formal provisions for future regulations to ensure proportional contributions to the federal budget, the clause effectively inhibited any greater financial centralisation. Similarly, when the federal government called for a more uniform inmigration policy to enforce passports, residence visas, and work permits, some of the local governments were hesitant to co-operate, preferring to retain control over the rate of immigration in their own particular emirate rather than hand over power to a distant ministry in Abu Dhabi. ${ }^{78}$

Eventually, this increasing lack of co-operation and unwillingness to integrate and contribute led to the first major crisis in UAE politics. When in 1976 the time came to draw up a new and more permanent constitution, ${ }^{79}$ a committee of 28 prominent 
citizens and legal experts was formed to consider the matter. Essentially this committee was divided between those who continued to regard themselves as representatives of their native emirate and who sought to promote the preferences of their particular Emir, and those 'independents' who saw the creation of a new constitution as an ideal opportunity for updating many aspects of Emirati political life. Indeed, as Zaki Nusseibeh, Shaykh Zāyid's former press secretary explains, these independents, many of whom can be considered among the first generation of Emirati technocrats given their educational and professional backgrounds, sought greater centralisation at the expense of individual inter-emirate politics and intended to remove Article 23 in order to encourage more efficient wealth distribution. ${ }^{80}$ As a reflection of these differing views, the committee's draft of the new constitution was something of a compromise: Article 23 would be abolished, but each emirate would still be able to retain $25 \%$ of its hydrocarbon income. ${ }^{81}$ However, when the draft was forwarded to the SCR later that year, the rulers of Dubai and some of the other emirates chose to reject the signing of such a constitution and insisted on retaining the original provisional constitution. This direct challenge to the federal vision prompted Shaykh Zãyid to threaten his resignation from the presidency. Given his level of personal commitment to the federation, and given Abu Dhabi's single-handed financing of the federation during its early years, Zāyid argued that the other emirates should have been more appreciative and more enthusiastic in accepting moves towards a more permanent and centralised government. $^{82}$ Furthermore, as Adnan Bajaje, Zāyid's personal political advisor explained, this threat of resignation was also coupled with an offer to move the capital from Abu Dhabi if it would bring about a more viable federation, such was Zāyid's dedication to the UAE's future stability. ${ }^{83}$ Regardless of the motives, the bluff could not be called as the other rulers recognised the important mediating role of their illustrious and statesmanlike President, and of course his control over the largest and most powerful of the emirates. Thus, Abu Dhabi managed to remain the centre of the federation, but only after a costly four month crisis just five years after the creation of the $\mathrm{UAE}^{84}$ 
Nevertheless, just two years later the tensions resurfaced, this time over the issue of the UAE's armed forces. In 1978 Shaykh Zāyid decided to appoint his son, Shaykh Sultān Al-Nuhayyān, as Commander in Chief of the Federal Defence Force. ${ }^{85}$ Given that Shaykh Muhammad Al-Maktūm, the son of Dubai's ruler, was the UAE's Defence Minister, many in Dubai and the northern emirates interpreted this move as a clear attempt by $\mathrm{Abu}$ Dhabi to assume even greater control over the federation. Indeed Shaykh Rāshid even reportedly threatened to pull Dubai out of the UAE along with Ra's al-Khaimah and Umm al-Qawain unless the decision was reversed. ${ }^{86}$ Thus, although the situation was eventually de-fused following a clearer definition of the two posts, ${ }^{87}$ the dispute nevertheless highlighted the continuing reluctance of the smaller emirates to fully integrate with Abu Dhabi. Indeed, in a similar fashion to the proposed centralisation of oil and immigration policies, the amalgamation of the emirate-level armed forces started to become an increasingly unlikely prospect. Certainly, as Frauke Heard-Bey explains, the individual rulers continued to derive much power and prestige from their respective militaries, and many were reluctant to hand over such control to a more centralised command:

"... before the 1970s the various armed forces had always been the traditional manifestation of a ruler's standing. Therefore, the political price to be paid for trying to enforce amalgamation and thereby alienating some rulers would have been disproportionate to the fighting strength which these forces would have added to the capability of the newly formed federal forces. $" 88$

The most serious dispute did not, however, occur until the following year when a widely supported multipart memorandum for reform was submitted to the SCR. In 1979 the Islamic revolution in nearby Iran and the ensuing threat of Shi $\mathbf{r}$ a insurgency in Sunni Muslim states led to the fear of a 'fifth column' of Islamic revolutionaries in the Gulf. Secondly, the Soviet invasion of Afghanistan and the anticipated American reaction left many expecting a superpower conflict close to the Gulf. Thirdly, this was also the time that Sadat, the Egyptian President, had attended the Camp David meetings 
and had set in motion the Egyptian-Israeli peace process; a controversial diplomatic move which divided the Arab world and clearly placed the conservative Islamic rulers of the Gulf states in an awkward position. ${ }^{89}$ Given this increasingly uncertain regional political climate many groups in the UAE called for a strengthened federation, a more unified leadership, and an end to the inter-emirate squabbles of the 1970s. Essentially, therefore, the 'independents' were reacting to regional instability by renewing their backing for Shaykh Zāyid's drive for greater centralisation. Crucially, the resulting memorandum was drawn up by members of both the COM and the FNC, and was also believed to represent the views and concerns being expressed in more informal assemblies such as the majālis. In particular, the memorandum called for an end to the autonomy of the individual emirates, stating that they should unify in the national interest, and, quite significantly, it also called for the SCR, which had been meeting less and less frequently, to meet monthly to decide policy, and for it to devolve far more of its policymaking powers to the COM. Moreover, although evidently not the memorandum's main emphasis, it was also requested that the FNC be given full legislative powers (thereby elevating the council from its limited consultative capacity), ${ }^{90}$ and an 'expanded base', perhaps paving the way for public elections.

The result was a protracted five month long 'constitutional crisis'; demonstrations were held across the UAE and Shaykh Zāyid enjoyed much popular support from a number of diverse groups ranging from students to local businessmen, all of whom were calling for greater unification. ${ }^{92}$ Predictably, the opposition came

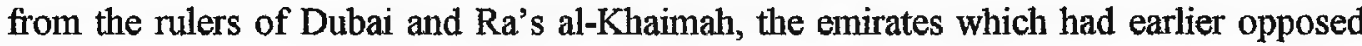
the permanent constitution and blocked any proposed military amalgamation. The claim was that such a move towards a more centralised state as demanded by the memorandum was clearly unconstitutional given the loose nature of the federation outlined by the original constitution. Furthermore, Dubai argued that any unification of services was only justified if better results could be promised than the existing emiratelevel services and, as a relatively prosperous oil-producing emirate with an independent revenue, it was clear that Dubai was still unwilling to contribute its wealth to the development of the smaller emirates via the medium of a federal budget. ${ }^{93}$ Indeed, as 
Valerie Yorke explained of Shaykh Rāshid, Dubai's ruler and the main challenge to Zāyid's leadership, "It was said that Shaykh Zāyid was in the union for what he could put into it; Shaykh Rāshid for what he could get out of it." 94 However, this issue of revenue contribution perhaps clouds the fundamental political differences between the emirates at this time. In many ways what Dubai really preferred was not an end to unity, but simply that the UAE remained a much looser federation, or as described earlier, more of a confederation; a collection of states in which the central authority never exceeded the total of all the individual authorities. Undoubtedly Shaykh Zāyid and the 1979 proposals were seen as exceeding this total.

The crisis was only resolved with the help of outside mediation from experienced Kuwaiti negotiators, and the compromise solution has remained in place ever since, albeit now with a new generation of rulers. A new cabinet was formed and Shaykh Rāshid was appointed Prime Minister. Thus, in addition to serving as the federation's Vice-President, the ruler of Dubai was to take on the extra function of presiding over the COM. Shaykh Zāyid and his supporters hoped that this greater and more direct involvement from Dubai in federal matters would encourage Dubai to remain a part of the $\mathrm{UAE}$ and to take a more active interest in improving the services provided by the federal ministries. The agreement worked and Dubai soon began to contribute $50 \%$ of its oil revenue to the federal budget, ${ }^{95}$ with the two smaller oilproducing emirates of Sharjah and Ra's al-Khaimah also beginning to contribute by the mid-1980s. ${ }^{96}$ Thus, although the other aspects of the memorandum regarding the increased powers of the COM and the expansion of the FNC were not implemented, the crisis can nevertheless still be viewed as something of a watershed in federal politics as its resolution not only averted the secession of Dubai and the eventual break-up of the $\mathrm{UAE}$, but also demonstrated that, if necessary, political opposition to the hereditary SCR could be mobilised.

Alongside this centralisation debate, another important aspect of federal politics and again a source of confusion and tension has been the persistence of relatively autonomous foreign relations maintained by the various emirates. Although in theory 
the constituent emirates were to be represented by the federal Ministry of Foreign Affairs and the President, a number of disputes during the 1970s and 1980s served to undermine the UAE's international standing, with different emirates pursuing different objectives based on their individual interests. Perhaps the most damaging of these early disagreements were those concerning OPEC, as the UAE's provisional constitution permitted each emirate to either take up or withdraw from OPEC membership. ${ }^{97}$ While Abu Dhabi had decided to follow Saudi Arabia's lead and had joined the international oil cartel in the $1960 \mathrm{~s},{ }^{98}$ Dubai had instead opted to remain an independent producer. Thus, when the time came to create a federal oil ministry in the early 1970s, it soon became apparent that such an institution would have little control over oil and oilrelated foreign policies outside of Abu Dhabi. Indeed, this lack of control became particularly problematic for Abu Dhabi from 1974 onwards when OPEC began to treat the UAE as a single entity rather than recognising Abu Dhabi's individual membership. Consequently, when OPEC production quotas were first introduced in the early 1980s, Abu Dhabi was obliged to take the sole responsibility for ensuring that the UAE's overall oil production met these requirements. With Dubai regularly refusing to accept any pro-rata share of the necessary cutbacks, Abu Dhabi was often forced to underproduce in order to stay within the quota. ${ }^{99}$ Moreover, by the mid-1980s Dubai's unrestrained production was not only leading to tense relations between Abu Dhabi and OPEC, but was also attracting the unwanted attention of Iraq. Embroiled in a costly and lengthy conflict with Iran, Iraq was threatening to punish all fellow OPEC members which persistently violated the designated quotas; this list of offenders not only included Iraq's future victim, Kuwait, but also the UAE. ${ }^{100}$ Indeed, when Dr. Subroto of OPEC visited the capital in 1987, Shaykh Zãyid assured him that the UAE was "at the forefront of preserving the unity and cohesion of OPEC"; however at the same time the UAE was strongly suspected by OPEC of actually being the worst offender by producing an estimated $20 \%$ above its assigned quota. ${ }^{101}$ In 1988 the supervision of Abu Dhabi's embattled oil industry was finally reorganised under a Supreme Petroleum Council which effectively sidelined the powerless federal ministry, assumed sole responsibility for ADNOC (the main Abu Dhabi oil company), ${ }^{102}$ and unilaterally declared a higher oil output for Abu Dhabi, regardless of Dubai. ${ }^{103}$ Thus, in many 
ways, this new emirate-specific oil council can be seen as symbolising Abu Dhabi's grudging acceptance of the limitations of federal control over not only oil policy, but also over the other emirates' interactions with neighbouring states and foreign organisations. Today, despite its chequered history, Abu Dhabi does manage to adhere to OPEC's quota for the UAE, ${ }^{104}$ but this task is perhaps only easier because of the declining oil reserves in Dubai and Sharjah.

Moreover, the 1970s and 1980s also saw divided opinion over superpower relations. The majority of the Emirates were naturally inclined to the Western powers given the region's long association with Britain and their continuing reliance on Western advisers and skills for their respective development programmes. Remarkably, however, Ra's al-Khaimah, still the most reluctant member of the federation, attempted to seek support from the Soviet Union in an effort to create a new breakaway state which would have included Sharjah, and which would have involved seizing a part of Oman. ${ }^{105}$ Furthermore, in the 1980 s during the height of the Iran-Iraq War, Ra's alKhaimah again sought to further its own interests by offering Iraq the opportunity to establish airbases in its territory in exchange for greater independent recognition in the Arab community. ${ }^{106}$ Significantly, the war also resulted in a split between the six other emirates, with Abu Dhabi, 'Ajman and Fujairah also supporting Iraq, but with Dubai, Sharjah and Umm al-Qawain choosing to support Iran, their primary trading partner and the home of many of their merchant expatriates. ${ }^{107}$ Thus, as Peck noted at the time:

"Dubai and Sharjah's pro-Iranian stance subjected the UAE's federal government, which has the sole responsibility for conducting foreign political and diplomatic relations, to embarrassment and pressure from Saudi Arabia and other Gulf neighbours. "108

Although the UAE has presented a more unified front in recent years, divisions over foreign policy have still existed, with some of the Emirates having been reluctant to support the Desert Storm coalition in 1991, and with only mixed support for the US-led invasion of Afghanistan in 2001. ${ }^{109}$ 
In summary, it is perhaps useful first to consider Fatma Al-Sayegh's view that federal-emirate relations have evolved over three distinct phases: the early years, 19711979 can be seen as having been the 'creation of the federation', during which federal institutions were being built and teething troubles were being resolved; 1980-1986 can be seen as 'accepting the federation', during which the seven emirates conceded some of their former powers in the national interest; and thirdly, 1987 to the present can be viewed as the 'maturity of the federation', a period in which many of the former difficulties have been overcome and those that have remained unresolved have been effectively contained. ${ }^{110}$ Indeed, in recent years the federation has certainly strengthened as the threat of internal rivalry has subsided and as the federal institutions have become better established. Furthermore, the resolution of the majority of outstanding boundary disputes, the establishment of a Central Bank, and the increasing contributions to the federal budget from the other emirates have all combined to create a more cohesive federation. Perhaps the most important development has, however, been the greater integration of Dubai. Agreeing to accept a permanent constitution and, also in 1996, finally agreeing to integrate its armed forces into the federal command were clear signs that Dubai had chosen to concentrate on its ambitious economic development programme while accepting Abu Dhabi's leading role as the financial backbone and protector of the federation. Indeed, in 1997 Dubai officials were even quoted as saying:

\footnotetext{
"... there is no obvious need to maintain an independent force in Dubai because the UAE armed forces GHQ provides a fully fledged and costeffective defence capability"."11
}

Thus, with declining oil revenues and with the need to pursue greater diversification, it would appear that Dubai has relinquished its claims to regional leaderslip and now prefers to assign otherwise costly services to federal control.

Nevertheless, as this section has revealed, it is also clear that any "maturity of federation' view remains decidedly over-optimistic. In many areas it is evident that the 
strained and loosely defined relationship between federal and emirate-level powers has led to significant divisions which, on occasion, have led to policy disputes over key issues such as immigration, military integration and budget contributions. While some of these differences have certainly abated over the years, there are nevertheless certain grey areas which have persisted, and over time these may resurface and again play a determining role in the federation's future. Indeed, in addition to the obvious differences over critical matters such as oil policy and foreign relations there are a number of other very recent internal inconsistencies which continue to undermine the federal framework. Each emirate, for example, still maintains its own independent police force. While all emirate level internal security organs are theoretically branches of one federal organisation, in practice they operate with considerable independence. ${ }^{112}$ Furthermore, the UAE's Shari' a courts, which are administered by each emirate and which are supposed to answer to the Federal Supreme Court, still do not always do so. In 1994 the President decreed that the Sharīa courts would have the authority to try almost all types of criminal cases, but this decree has not affected the emirates of Dubai and Ra's al-Khaimah, which have lower courts independent of the federal system and special $\mathrm{Sh}^{\natural}$ a councils to act on matters pertaining to Shr a law. ${ }^{113}$

Finally, with regard to development pathologies, it is also clear how the numerous inter-emirate disputes and other internal problems which have arisen as a result of opposition to federal policies may in many cases have directly affected the UAE's socio-economic planning. The divisions in wealth distribution and the initial reluctance to commit to the federal budget certainly contributed to the uneven development and regional disequilibrium described in the previous chapter, and can therefore be seen as a causal factor behind many of the problems being addressed by the development planners today. Secondly, the lack of co-ordination and the distrust of federal control must also have exacerbated the described duplication of investments, with inter-emirate rivalry leading to inappropriate and often wasteful developments which may have been avoided under a more comprehensive federal development plan. ${ }^{114}$ Thirdly, the significant overlap between federal and emirate-level powers and the constant need for informal consultation between the various bodies must be seen as having slowed the 
overall formulation and implementation of development policies, ${ }^{115}$ especially, as will be shown later in this chapter, given that federal laws often require further enabling legislation in the individual emirates. Indeed, as Heard-Bey has explained:

"... this can be a cause for the tardiness of some legislation... and this opportunity for emirate level input does not necessarily improve the draft or make the law more universally enforceable... local legislation, which is passed by the individual emirates in most instances still retains the hallmarks of their rulers, who are used to acting directly and even autocratically, when they perceive the need for their regulatory intervention. $" 1116$

\section{4- Other institutions, parastatals and bureaucracies}

By examining a number of the UAE's other major institutions, parastatals and bureaucracies, this section will explore the UAE's policy implementation infrastructure while attempting to highlight some of the more serious pathologies which have arisen and which may, in the same way as the fragmented decision-making structure, have also contributed to development problems. Specifically, it will be shown how these seemingly modern legal-rational institutions are essentially hybrid extensions grafted onto a greater neo-patrimonial network, with rigid chains of command inextricably linked to the traditional rulers and their appointed representatives. Furthermore, it will also be shown how many of these institutions, even the major regulatory bodies, have enjoyed little real autonomy and, on occasion, have been forced to acquiesce in order to survive. Firstly, the structure and role of the various chambers of commerce and industry will be considered; key institutions in the promotion of the UAE's diversified economy. Secondly, the powers of the UAE's judiciary and other related institutions will be considered, with a special emphasis on the relative independence of these establishments. Thirdly, the UAE's banking sector and the functioning of the Central Bank will be discussed, and, by tying together the sector's regulatory performance with the questionable independence of the judiciary, this case 
study will attempt to underscore the domestic foundations of the ultimate combination of neo-patrimonial and bureaucratic self-interest pathologies: Abu Dhabi's BCCI scandal. ${ }^{117}$ Finally, by highlighting the many recent attempts to improve the UAE's bureaucratic transparency, it will also be shown that while many accept the in-built and long-term nature of most of these problems, there has nonetheless been recognition from certain elements of the polity that immediate improvements are needed if the UAE's future growth and development are to be sustained.

\subsection{1-Chambers of commerce and industry}

Established in 1976, the Federation of UAE Chambers of Commerce and Industry serves as both an umbrella organisation and as a general forum for members of all the emirate-level chambers of commerce. ${ }^{118}$ Broadly speaking, the organisation's objectives have been to enhance co-operation between the commercial sector and the government, to promote better co-ordination between traders and manufacturers in different economic sectors, and to provide reconciliation and arbitration in instances of commercial and industrial dispute. ${ }^{119}$ To this end, the chamber collects and processes data, commercial statistics, and other pertinent information from its members before finally submitting its suggestions to a federal board of directors. Consisting of the directors of each of the seven individual chambers in addition to a second delegate from each emirate, this board annually elects a chairman on a rotation system to ensure

greater regional representation and to improve the unity of the federal chamber. ${ }^{120}$ If the board deems the chamber's recommendations appropriate, these are then forwarded to the relevant minister or government department and, on occasion, may also be raised in specialist commercial and industrial committees hosted by the FNC. ${ }^{121}$ Indeed, recent examples of such involvement would include the chamber and the legislature's joint reviews of draft ordinances on commercial transactions, trade licences, and the protection of Emirati industries. ${ }^{122}$

More significant than this umbrella organisation are, however, the constituent local chambers, as these deal with most of the UAE's day-to-day commercial and 
industrial administration, and are of course responsible for appointing the directors and associates who then serve on the federal board. Unsurprisingly, given the described pace of commercial development in the emirate, the Dubai chamber was the first such institution, established by Emiri decrees in 1965 and 1975 to be an "autonomous and non-profit-making institution" responsible for regulating economic life in Dubai. ${ }^{123}$ Essentially the chamber is responsible for reviewing all legislation and orders relating to commercial and industrial activities such as trade mark laws and the various free zone laws required by the new export-processing zones. To fulfil this task, the chamber hosts a research and studies department employing economic analysts and industrial experts to advise its director, ${ }^{124}$ and more recently has begun to host a number of business oriented conferences and symposia for the benefit of its members and other interested parties. These have been held on a wide variety of subjects including business contracting, human resources, arbitration of disputes, management of technology, and the implications of the UAE's WTO membership. ${ }^{125}$ A good early example would be the 1988 conference on the subject of the usefulness of free zones for promoting investment in Dubai. Attended by representatives of the Ministry of Finance and Industry, the Islamic Development Bank, and the Islamic Bank of Dubai, it was hoped that a forum could be created for informed members to voice their opinions and concerns on what was to become a controversial and far-reaching development for Dubai. Indeed, much discussion was generated with several papers delivered on the subject of the Jebel Ali Free Zone, with reports made on the success of similar EPZs in other GCC states, and with an informative UNIDO report being presented on the international experience of free zones. ${ }^{126}$

Similarly, the Abu Dhabi Chamber of Commerce and Industry has also played a key role in local development and commercial affairs. In much the same way as the Dubai chamber, the ADCCI has hosted a number of seminars and conferences for the benefit of its members and, in addition, has hosted mumerous exhibitions and has invited numerous trade missions to the emirate in an effort to increase foreign investment and to boost the diversification of the local economy. ${ }^{127}$ A strong example of the former would be the chamber's 1993 symposium on industrial investment opportunities in Abu 
Dhabi. ${ }^{128}$ Attended by the ADCCl's members in addition to a number of prominent UAE and Gulf-based institutions including the Gulf Investment Organisation, Emirates Industrial Bank, and Gulf Industrial Consultations, the event reportedly led to an 'enriched dialogue' between the chamber and the government which eventually led to the drafting of policy recommendations based on the findings and agreements of the conference guests and representatives. ${ }^{129}$

However, despite these instances of successful and meaningful interaction, the UAE's chambers have been routinely criticised for their inflexible hierarchical structure and their otherwise limited participatory opportunities. Indeed, the Dubai chamber not only excludes a number of categories of small businesses from membership, ${ }^{130}$ but also still lacks a formal assembly for Dubai businessmen, industrialists, and other members to meet and discuss their concerns with each other and with members of the board. Moreover, the $\mathrm{Abu}$ Dhabi chamber provides a particularly interesting example given that its organisational structure has changed considerably over the years. Indeed, as former member Salam Al-Saman describes, the board of directors was originally made up of elected members of Abu Dhabi's business community, yet as the chamber grew in size and numbers, the board expanded to over 20 members, all of which became appointed positions, including members of influential $\mathrm{Abu}$ Dhabian families such as the aforementioned Dhahiris. ${ }^{131}$ Crucially, the chairmanship of the Abu Dhabi chamber also became a permanent, non-elected position, and is now held by Shaykh Sultān bin Khalifa Al-Nuhayyān, a member of the ruling family and also the chairman of the Crown Prince's Court. ${ }^{132}$ Thus, many observers have contended that with this apparent reinvigoration of patrimonial client networks, the Abu Dhabi chamber's organisation is no longer appropriate for a modern institution claiming to represent the emirate's business community. ${ }^{133}$ Certainly, in addition to shouldering more responsibilities, providing greater chamber-sponsored advice for investors, introducing more comprehensive services aimed at meeting the needs of Abu Dhabi businessmen, and addressing many of the usual business community concerns, it has also been argued that the chamber should provide more direct channels of communication between the nonelected board and its members. ${ }^{134}$ 


\subsection{2 - The judiciary and related institutions}

The judicial branch of the federal government is represented by a Federal Supreme Court and a number of Courts of First Instance. This Federal Supreme Court is made up of a president and five judges, all of whom are appointed by the UAE's President and the COM. ${ }^{135}$ At the formal request of the individual emirates these judges can act as adjudicators between the different emirates or between an emirate and the federal government. Moreover, like the FNC, the Supreme Court also has a consultative role, deciding on the constitutionality and viability of the federal laws drafted by the COM (although as explained, in practice the status of these laws often depend on further enabling legislation in the individual emirates). ${ }^{136}$ The Courts of First Instance adjudicate administrative, commercial, and civil disputes between the federal government and individuals, leaving local matters to the emirate-level judicial bodies. ${ }^{137}$ In theory, these emirate-level Shari'a courts, which deal primarily with criminal cases, are also answerable to the Federal Supreme Court, but as demonstrated, these often maintain independence from the federal system, especially in Dubai. ${ }^{138}$ Supporting these institutions at all levels, the UAE's judicial staff has mushroomed to satisfy the needs of the rapidly expanding population, and as the Minister of Justice, Muhammad al-Dhahiri, claims, is now comprised of a greater number of carefully monitored and well qualified professionals capable of ensuring independence and promoting greater transparency from within the system. Indeed, speaking recently at the Zäyid Centre for Co-ordination and Follow-up, al-Dhahiri chose to re-emphasise his ministry's continuing commitment to these key objectives:

"... we have an independent judicial system that does not accept interference in its work from whatever quarters. The judiciary is closely watched by the supreme authority in the country, the Supreme Council of Rulers, to ensure that justice is administered efficiently and with fairness, and also to ensure that nobody other than the Supreme Court of Appeal should interfere in court cases." 
However, as the US Bureau of Democracy, Human Rights and Labour indicated in its comprehensive 2001 report, while the UAE's judicial institutions are now generally independent, there is still considerable room for improvement and further development. ${ }^{140}$ The federal government remains opposed to any form of external monitoring of the UAE's judicial system and its prisons, many of which are believed to be overcrowded and lacking in basic amenities such as air-conditioning. Furthermore, an archaic 'blood money' compensation system continues to be applied across the UAE, especially in the event of motoring accidents which can lead to financial interventions and indefinite incarceration for those unable to pay. Moreover, many of the courts (except those in Dubai) still impose harsh corporal punishments on both Muslim and non-Muslim offenders with sentences of between 40 to 200 lashes not uncommon for 'moral' crimes such as adultery and prostitution ${ }^{141}$ (although mutilations have been phased out with such sentences now being overturned by the Supreme Court of Appeal). ${ }^{142}$ Perhaps the most severe weaknesses, however, have been the long bureaucratic delays which have often left prisoners languishing behind bars for several months beyond their court-mandated release dates. ${ }^{143}$ In the most part, these delays have been blamed on the restricted access to legal counsel. The accused is usually only permitted to seek counsel after the police have finished their investigation, thereby allowing the police to question suspects for long periods before they can be released. ${ }^{144}$ Even more seriously, and implying an underlying lack of genuine autonomy, these delays have also been blamed on the frequent involvement of the aforementioned rulers' courts, or dīwãn, which still reserve the right to review sentences and to return cases to the courts. Occasionally, in cases of personal interest, there have also been alleged cases where rulers of other emirates have attempted to intervene in local cases. ${ }^{145}$

\subsection{3 - The UAE's banking sector and the Central Bank}

As late as 1960 there were still only two banking houses represented in the Trucial States, and both of these were foreign: Eastern Bank and the British Bank of the Middle East (BBME). However, when Shaykh Rāshid Al-Maktūm chartered the National Bank of Dubai, other locally chartered banks soon followed suit and by the 
time of federation fifteen other foreign banks from Britain, Pakistan, Iran, and Jordan had joined these. Understandably, the main weaknesses during this early period were the lack of basic controls and accountability. Indeed, as Fenelon noted in the early 1970s, apart from seeking permission to operate (which was granted by the ruler), the UAE's banks had to follow very few other guidelines. Certainly, the currency boards, which had been established earlier by the British, were concerned primarily with the issue and redemption of coins and notes, and occasionally with the provision of a few statistics, rather than with providing a regulatory framework for the UAE's financial institutions. ${ }^{146}$ As such, by the mid-1970s the need for far greater control over the banking sector had become a major priority, especially given the UAE's increasing need to provide a sound financial base in support of its industrial and commercial development. ${ }^{147}$

While some controls to prevent the over-extension of credit and the excessive expansion of foreign banks were implemented during the late $1970 \mathrm{~s},{ }^{148}$ the establishment of the UAE Central Bank in 1980 was the first major step forward. Replacing the currency boards, the bank was set up to control credit policy while fostering more balanced economic growth and to advise the government on all monetary and financial matters. ${ }^{149}$ Indeed, along similar lines to other state banks such as the Bank of England, the Central Bank is regularly represented at the meetings held by the Ministry of Finance and Industry and the Ministry of Planning and, on occasion, is required to submit reports to the IMF and other international agencies. ${ }^{150}$ In much the same way as the chambers of commerce, the bank is organised around an appointed board of directors, ${ }^{151}$ many of whom hold multiple high-level positions in the UAE's business community, and are sometimes even prospective ministers. ${ }^{152}$ Along with a treasury department and a department of current accounts, the board is advised by a banking supervision department, a research and statistics department, and an internal audit department, all of which can make recommendations for future resolutions. ${ }^{153}$ Essentially, the supervision department ensures the financial soundness of all UAEbased financial institutions and, crucially, their compliance with the provisions of federal law and monetary policy. Recent departmental recommendations have included 
the need for important measures such as the requirement for certified stockbrokers, ${ }^{154}$ the upwards revision of the CRR (cash reserve requirement) for commercial banks in an effort to improve the sector's stability, ${ }^{155}$ and the curbing of any bank's excessive concentration of credit to a single borrower. ${ }^{156}$ The research and statistics department provides the board with annual and quarterly reports advising on the success or failure of current policies such as the UAE's pegging of the Dirhăm to the US Dollar, the viability of off-shore banking projects in the UAE, and the possibility of liquidating the bank's certificates of deposit. ${ }^{157}$ Similarly, in addition to checking the bank's various transactions, the internal audit department is also given the task of supplying monthly reports to the board. Significantly, these reports not only concentrate on the external auditor's findings and provide the bank's management with suitable responses to the auditor's questions, but also contain recommendations for improved performance and better internal organisation. In recent years such recommendations have included the setting up of a department to advise on the automation of banking services, the need for a system to compensate those with damaged banknotes, and a scheme to reward those employees obtaining higher academic qualifications. ${ }^{158}$

Another important financial institution, especially given the UAE's plans for greater industrialisation, has been the Emirates Industrial Bank. Created in 1982, its express aims were to promote economic growth and to assist the diversification process by encouraging the development of the industrial sector. ${ }^{159}$ Essentially the bank has acted as a parastatal: providing aid to the establishment of new, non-oil based industries, while consolidating the UAE's existing industries. Moreover, given that the bank supposedly seeks to promote long-term diversification, it carefilly monitors its loans to ensure that the most suitable industrial projects are given the necessary assistance. As such, its activities have often taken the form of comprehensive feasibility studies, financial and engineering analyses, marketing and legal consultations, and supplying UAE firms with essential industrial information. ${ }^{160}$

Also worthy of mention have been the more recent attempts, especially those in Dubai, to expand the UAE's financial markets further by establishing regulated stock 
exchanges. The first such example came in early 2000 when the Dubai Financial Market opened for business. Although it suffered from a slow start it nevertheless showed much promise. Certainly, as the Economist Intelligence Unit noted:

"... trading volumes were low in the first few months, but moves to allow foreign investors to buy shares and the imminent opening of a sister bourse in Abu Dhabi should boost liquidity." "Ial

In early 2002 it was announced that this financial market would be supplemented by the opening of the Dubai International Financial Centre (the DIFC) which would, as the crown prince claimed, allow Dubai and the UAE to join the international financial markets of London, New York, and Tokyo. Indeed, as the chairman of the centre's board elaborated:

"We want to be able to satisfy the regional needs of business and investors by building a hub in Dubai. We want to create a place for regional blue chips to find financial solutions and a place for international banks to seek regional investment opportunities." 162

Similar projects are underway in Abu Dhabi with the Emirates Global Capital Corporation having been launched with the express purpose of implementing Abu Dhabi's ambitious $\$ 3.3$ billion Sādiyat project. This was to be an island free zone bridging the time zones between Asia and Europe by housing a stock exchange, a commodities exchange, and an offshore banking centre. ${ }^{163}$ Although this particular project has since changed direction and, as will be described later in this chapter, is now destined to become a real estate development, ${ }^{164}$ there is nevertheless every indication that such an Abu Dhabi-based bourse will soon be established. ${ }^{165}$

In summary, the UAE's banks and financial institutions have undergone significant development over the past 25 years, a trend which is set to continue for the foreseeable future, thereby further strengthening and complementing the overall 
diversification effort. Impressively, by 2001 there were already well over 430 banks in the UAE, with no fewer than 324 of these being locally chartered, and with over 100 of these being based in Dubai alone. ${ }^{166}$ Indeed, when gauging the size and development of the banking and financial system relative to the domestic economy, the UAE fares particularly well, especially given its ratio of money to the GDP. Certainly, as Alan Richards explains:

"[the ratio of money to GDP] stands at about 54\% in the UAE. That's comparable to $59 \%$ in the USA and $51 \%$ in Ireland. So we are dealing, at this very simple macro indicator level, with a developed financial system." 167

Furthermore, it had also been claimed that the UAE has enjoyed relatively good macroeconomic policy consistency due to its Central Bank and, although the government does not formally guarantee deposits, the UAE is also believed to enjoy relatively low moral hazards given the government's relative wealth and implicit guarantees. ${ }^{168}$ In addition, the UAE has also been seen as providing increasingly respectable regulatory oversight by requiring all commercial banks to adopt new administrative structures more representative of their shareholders, ${ }^{169}$ and by promoting simultaneous deregulation and re-regulation it is also hoped that the banking sector's accountability and disclosure will be further enhanced. Indeed, as Richards again explains:

"One can only hope that in the next thirty years the UAE will continue to modernise its banking system by simultaneously deregulating (privatising certain key banks), and also re-regulating (making them conform to international standards of information disclosure). If they do this, I suspect that in 2030 the UAE banking system will be a fully developed component of the global financial system." 170 
However, despite the many improvements, the UAE's banking sector still exhibits a number of serious problems and continues to draw both domestic and international criticism. ${ }^{171}$ Most obviously, the sector very much conforms to an 'oligopoly with a competitive fringe model' dominated by a few large banking houses preventing free competition, and more significantly, there is also still believed to be very poor transparency of information:

"In general it is believed that the UAE's banking system suffers from a relatively low level of disclosure. Quoting a recent assertion made by Standard \& Poors, 'the disclosure falls short of international best practice and even compares unfavourably with some regional peers like Saudi Arabia.' Any analysis of the UAE's banking system must thus take into account a rather high information risk." 172

Moreover, in much the same way as the UAE's other political institutions and bureaucracies, and most crucially for the sector's regulatory future, the Central Bank's real powers and autonomy have remained rather questionable, especially given the appointed board's clear incorporation into the neo-patrimonial network, and the organisation's historic inability to assert control over emirate-level authorities. Indeed, the Central Bank has only had as much or as little power as the individual emirates and their ruling families have been prepared to give it. It has tried with only limited success to control unmonitored loans to directors and to demand disclosures of balance sheets in certain emirates. Furthermore, its powers of persuasion with regard to mergers among the UAE's numerous commercial banks have also been dwarfed by those of the emiratelevel governments. ${ }^{173}$ Certainly, the mergers that took place in the mid-1980s in Abu Dhabi and Dubai were entirely the work of the two local governments, since it was they rather than the Central Bank that put up the necessary funds. Similarly, in 1985, when the $\mathrm{Ra}^{2} \mathrm{~s}$ al-Khaimah government failed to provide the necessary funds to rescue the Ra's al-Khaimah National Bank, the Central Bank was also powerless in intervening. ${ }^{174}$ By far the most notable example of such failure was, however, the BCCI scandal in Abu Dhabi in the early 1990s. Although a new Central Bank board of directors was 
appointed to try and assert more control and restore confidence in the UAE's banking sector, ${ }^{175}$ the Central Bank was nevertheless relegated to a secondary bystander role as the local Abu Dhabi government and ruling family assumed complete responsibility for the restructuring and subsequent closure of the branches. Indeed, as the following case study will demonstrate, quite remarkably the Central Bank was to play only a minimal part in what was destined to be the region's most serious and damaging financial disaster.

\subsection{4 - The BCCI scandal}

Collapsing in 1990-1991 against a backdrop of scandal and corruption, the demise of the Bank of Credit Commerce International (the BCCI) was a major source of discomfort for the UAE, the home of many of the bank's largest and most influential backers. The ensuing international investigation lifted the lid on a world of patrimonial politics, unethical dealings, and criminal practices, thereby exposing the weaknesses of the UAE's banking sector, the lack of judicial independence, the high levels of bureaucratic self-interest, and the overall opaqueness of the state's political process. This was especially true for Abu Dhabi given the bank's close links to the emirate's local government and its seemingly undefined relationship with representatives of members of the Âl-Nuhayyān ruling family, some of whose personal fortunes had played a key role in the bank's history since its establishment in 1972.

Originally, Abu Dhabi's planners and advisors may have seen the bank as a means of building up a strong financial base capable of supporting the non-petroleum sector, thereby complementing the emirate's early diversification efforts. Certainly, as the Washington Post reported in the aftermath of the scandal, Abu Dhabi's later attempts to buy up the $\mathrm{BCCI}$ could in some ways be seen as the realisation of the emirate's long-term ambition to transform itself into an offshore banking centre using the BCCI as a 'flagship bank'. ${ }^{176}$ Ultimately, however, the crisis which unfolded in the early 1990 s had severe consequences for the UAE's international credibility, seriously delaying any such transformation. Indeed, as US senators John Kerry and Hank Brown 
reported in their 1992 investigation, the BCCI was found to have hosted an almost criminal structure centred around an "elaborate corporate spider-web... which was both an essential component of its spectacular growth, and a guarantee of its eventual collapse". ${ }^{177}$ Furthermore, their explanation of the bank's ability to evade regulation seems to have placed particular emphasis on the weaknesses arising from its multilayered, top-down and non legal-rational structure; not dissimilar to the pathologies normally associated with neo-patrimonialism:

"Unlike any ordinary bank, BCCI was from its earliest days made up of multiplying layers of entities, related to one another through an impenetrable series of holding companies, affiliates, subsidiaries, bankswithin-banks, insider dealings and nominee relationships. By fracturing corporate structure, record keeping, regulatory review, and audits, the complex BCCI family of entities created by Abedi [Agha Abedi being the founder of the BCCI] was able to evade ordinary legal restrictions on the movement of capital and goods as a matter of daily practice and routine. In creating the BCCI as a vehicle fundamentally free of government control, Abedi developed in the BCCI an ideal mechanism for facilitating illicit activity by others, including such activity by officials of many of the governments whose laws BCCI was breaking. "I78

Specifically, this impenetrable layering of the BCCI's corporate structure was believed to have facilitated the operation of a number of illegal mechanisms ranging from shell corporations, secrecy havens, kickbacks for front men, and the use of falsified documentation. Moreover, as a result of its closed patrimonial structure, the bank was able to maintain a high level of opaqueness, easily avoiding existing controls in the $\mathrm{UAE}$, and, as the investigation claims, allowing its administrators and their associates to engage in a wide range of international criminal activities including money laundering, gun running, the management of prostitution, the facilitation of income tax evasion, and perhaps most significantly the financing of terrorist organisations. ${ }^{179}$ 
Given that Abu Dhabi represented the BCCl's largest depositors, borrowers, and shareholders, it is of little surprise that many of the bank's structural failings were seen as being inextricably linked to its long association with the emirate's local government, especially as Abedi had long been granted the powers of attorney to act in the name of Shaykh Zāyid. ${ }^{180}$ Indeed, as the UK-based auditor Price Waterhouse informed the Bank of England, the relationship between the two entities was not only 'very close', but was also "far beyond the ordinary relationship of a bank to either its shareholders or depositors." ${ }^{181}$ Moreover, while Abu Dhabi persistently presented itself as a victim and claimed only a passive role in the affair, its lack of co-operation in providing key documents and witnesses left the international community less convinced and even more determined to unravel the layers of deceit. ${ }^{182}$ While many questions have been left unanswered, the investigators nevertheless exposed several of the less desirable features of the UAE's political structures in the course of their study. Of these, perhaps the most pertinent to this discussion were the findings regarding the lack of any clear division between the polity and the judiciary; the continuing ability of $\mathrm{BCCI}$-connected individuals to arbitrarily manipulate the UAE's judicial system; and of course the lack of disclosure surrounding the extent of involvement of representatives of members of the ruling family and other notables in the BCCI's affairs.

Although members of the Âl-Nuhayyān family held more than $\$ 750$ million worth of the BCCI's shares by the time of its collapse, their total contribution to the bank's capitalisation quite remarkably appears to have been only $\$ 0.5$ million: the initial start-up contribution paid to the bank by Shaykh Zãyid in the early 1970s. Indeed, as the investigation claims, the majority of these supposed shares were acquired as a result of fake 'investments' where the Shaykhs' representatives (presumably without the knowledge of their employers) would make payments on a risk free, guaranteed return basis, thereby allowing the bank to project an illusion of substantial royal backing: ${ }^{183}$

"...Price Waterhouse specifically found that representatives of the ruling family of Abu Dhabi acquired shares on the basis of guaranteed rates of 
return and buy-back arrangements, with the result that they were not at risk for their ostensible 'shareholdings' of the BCCI."184

Determining the level of actual participation from these 'front men' proved less straightforward due to a lack of information and numerous logistical obstacles. Nevertheless, as the investigation did uncover, there had undoubtedly been a long and familiar association between the $\mathrm{BCCI}$ and the ruling family for many years, with the bank and its advisors having, "handled almost every financial matter of consequence for the Shaykh and his family, as well planning, managing, and carrying out trips abroad, and a wide range of services limited only by the desires of the $\bar{l} l$-Nuhayyān family itself."185

Central to this close relationship was the founder of the BCCI, Agha Abdei, who for over twenty years created and managed a network of foundations, corporations, and investment entities for Abu Dhabi's ruling family, of a complexity similar to the network he had created at the $\mathrm{BCCI}$ itself. Consequently the $\mathrm{BCCI}$ handled the financial arrangements for many of these entities, managed a variety of Abu Dhabi's portfolio accounts in US Dollars, and "provided members of the ruling family with personal services ranging from Shaykh Zâyid's own modest needs to the more elaborate requirements of his sons and members of his retinue."186 Certainly, given the previously described rise of the unitary state and the expansion and demands of the evolving dynastic monarchy it is quite conceivable that the BCCI's finances quickly became so intermingled with the finances of Abu Dhabi that it became difficult even for BCCI insiders to determine where one left off and the other began. ${ }^{187}$

Moreover, even more conclusive than the longstanding association with Abedi was the Abu Dhabi government's strong links with two other prominent $\mathrm{BCCI}$ bankers: al-Mazrui and Iqbal. For more than fifteen years, Ghanim al-Mazrui served Shaykh Zāyid as a financial advisor and manager, and as such he was a central figure in the $\bar{A} 1$-Nuhayyăn financial network. Furthermore, from 1981, al-Mazrui also served on the board of directors of $\mathrm{BCCI}$ itself, in his capacity as secretary general of the Abu 
Dhabi Investments Authority (ADIA), an organisation which at that time held around 10 percent of the BCCI's shares, and which continues to handle the principal government investments of Abu Dhabi. ${ }^{188}$ As such, al-Mazrui represented a clear three-way connection between the employees of the ruling family, the $\mathrm{BCCI}$, and an important local government institution; a link which effectively blurred the financial autonomy of one entity from another. However, although the auditors and investigators discovered that al-Mazrui had received substantial personal financial benefits from the $\mathrm{BCCI}$, had made bogus loans to members of the ruling family, and had lied about his earlier misdemeanours, when he finally confessed to Abu Dhabi authorities in 1990 he was not held in custody and was even permitted to remain in place as the head of Abu Dhabi's working group to deal with the BCCI. Clearly, given that he was neither fired nor forced to resign from positions of trust he had clearly violated, his existence brought into question the accountability of the emirate's regulatory and judicial processes, and again indicated the significant role which may have been played by 'higher-ups':

\begin{abstract}
"...al-Mazrui's continued role in handling Abu Dhabi's response to the collapse of BCCI raises additional questions. One possible explanation is that Shaykh Zãyid and the ruling family are remarkably tolerant of incompetence, deception, fraud, and the personal enrichment of top advisors. Alternative explanations are that al-Mazrui's improprieties had previously been sanctioned by higher-ups, or were consistent with ordinary practices in the Emirate."
\end{abstract}

Similarly, when the time came to appoint a new team to manage the Abu Dhabi-based rebuilding of the BCCI, Zafar Iqbal, the former head of the BCCE (the BCCI affiliated UAE-based bank) was selected. This was also seen as being highly controversial given Iqbal's previously close ties with employees of the ruling family and his perceived lack of banking expertise. As the investigation claimed, based on reports by junior BCCI staff: 
"IIqbal] had long had a close personal relationship with important employees of the ruling family of Abu Dhabi... Within the bank [the BCCE], Iqbal was not considered to be an expert on much besides pleasing Abu Dhabi..." 190

With specific reference to the independence of the emirate's judiciary during the affair, Al-Sayegh, Abu Dhabi's chief witness and a BCCI employee, argued that one of the main difficulties in making available key documents to foreign investigators was that Abu Dhabi's legal system forbade such interference as it was based on a separation of powers to ensure that the executive branch could never exercise any influence over the judicial process. As such, he contended that there were no short cuts that could be undertaken in order to supply more quickly the much-needed documents and witnesses. However, as the BCCI investigators uncovered, this was claim was highly inaccurate as the judicial system at this time was found to be far from autonomous, with many examples of external influence and manipulation, thus reinforcing the belief that important witnesses and information were being deliberately withheld. ${ }^{191}$ Indeed, one particularly weak area was believed to be the UAE's detainment law which appeared to have been left completely open to outside interference:

"... Following his arrest, an accused may not be detained for more than forty-eight hours [unless there is an order by the prosecutor] to detain him provisionally pending interrogation for a period of seven days subject to renewal for further periods not exceeding fourteen days... [A judge may] extend the detention for a period not to exceed thirty days, subject to renewal..." $" 192$

This law, especially regarding the possibility of 'renewal' was believed to be serving as a primary mechanism for keeping accused BCCI officials and other staff with connections to representatives of the ruling family away from international investigators: 
"... these final provisions were the basis for the ordering of the summary arrest of the BCCI officials suspected of being involved in the irregularities and fraudulent activities, and their detention since, as under the interpretation given the law, the phrase 'subject to renewal' allows the judge to continue to hold the accused from month to month so long as the prosecution wishes, without any limit whatsoever, for years, decades, or life, if matters remain under investigation. Indeed, Subcommittee staff have interviewed one knowledgeable Pakistani insider about BCCI and Abu Dhabi who spent years in prison in Abu Dhabi without trial, after being involved in a dispute with a representative of the ruling family. "193

Moreover, the separation of powers was also called into question with regard to the federal civil court's 'protective custody' of many of the BCCl's records. In AlSayegh's prepared testimony it was stated that the court restricted access to these records to the majority shareholders and that the UAE prosecutor, appointed by Shaykh Zāyid, "ordered that the documents... remain confidential" for reasons not explained. ${ }^{194}$ Thus, given that the majority shareholders were members of the Abu Dhabi ruling family and their guardians, and given the apparent closeness of the judiciary to the ruling family, the senators' rather damning report concluded that:

"Given the fact that Shaykh Zâyid, according to his own attorneys in submissions with the Federal Reserve, owns most of Abu Dhabi's resources and land, and that the laws themselves are styled as decrees by Shaykh Zäyid, in consultation with other bodies and officials who are appointed by Shaykh Zayid, not by popular vote at elections, the notion that the United Arab Emirates' justice system is somehow completely independent from the interests of the ruling family of Abu Dhabi stretches credulity. "195

Although clearly over-simplistic and with little appreciation of the intricacies of the complex Emirati political process, such a statement nevertheless indicates the potential damage that can be caused by such neo-patrimonial pathologies not only to domestic 
development, but of course also to the UAE's high standing in the international community.

\subsection{5 - The drive for greater transparency}

While the alleviation of the UAE's more serious bureaucratic pathologies, especially those deriving from the persistence of informal neo-patrimonial networks and the lack of institutional independence, may be extremely difficult to overcome; attacking opaqueness and improving accountability have, however, become increasingly regarded as more realistic and immediate objectives. Indeed, the drive for greater transparency has attracted much support in recent years from a wide number of sources including, most notably, the Dubai government and ruling family whose very future, as demonstrated, rests on the creation of a successful diversified economy and the establishment of a sound international reputation in order to counter the emirate's declining oil revenues. ${ }^{196}$ Broadly speaking this drive has, thus far, consisted of three identifiable sets of initiatives: the ruling families' frequent personal attempts to expose opaque bureaucracies, the attempts to mobilise the UAE's press as a greater organ of accountability, and most significantly the creation of new formal organisations and legislation capable of institutionalising and enforcing better answerability.

The crown prince of Dubai, in much the same way as the old Venetian Doges, has personally spearheaded his emirate's drive to reduce corruption and incompetence. Indeed, over the last few years Shaykh Muhammad Al-Maktūm has attempted to shake up Dubai's civil service, sometimes even resorting to early morning raids on government offices and firing any officials not present at their desks. ${ }^{197}$ Furthermore, he has also publicly called upon the editors of all local newspapers to act as "watchdogs to ensure that governments and their bureaucracies correct their mistakes and take the right decisions in the interests of the people." Along similar lines, the UAE's Minister of Information, Shaykh Abdullah Al-Nuhayyān, has openly encouraged all federal institutions and bureaucracies to become more sophisticated in their approach to press and public criticism and "not to regard it as disloyal, or even traitorous". Moreover, 
Abdullah has also called for information services such as the Internet to be embraced by both the press and public, and to be used as tools to encourage greater bureaucratic accountability. ${ }^{198}$ Although highly visible, these individual efforts and royal interventions are, however, by themselves unlikely to lead to any wholesale improvement. Certainly, while there have been cases where the press has criticised alleged inefficiencies in the provision of government services and in the judicial system, ${ }^{199}$ these are still extremely rare and the strengthening of the UAE's press should be viewed as more of a long-term objective. Indeed, as the following chapter will explain, the UAE's media remains in a considerably weakened state, caught between existing government controls and the continuing self-censorship exercised by the many cautious expatriate journalists. ${ }^{200}$

Instead, it would seem that significant improvements in transparency are, at least in terms of public relations, far more likely to result from the work of strong organisations granted the powers they need to enforce better accountability in the UAE's bureaucracies. A good example would be the work of the recently created 'Anti-Corruption Unit' in Dubai, another of Shaykh Muhammad's initiatives. In February 2001 the unit first came into effect and soon began investigating and arresting a large number of officials in the Dubai customs, ports and immigration services on charges of corruption. Six suspects were detained including the director-general of Dubai's customs authorities, and these were soon joined by a further fourteen including the head of the immigration section of Dubai International Airport. All were accused of taking part in the embezzlement of millions of Dollars, thus leading to the first public acknowledgement of corruption by the Dubai authorities. Initially, the accusations and findings considerably shook the political and business environment in the city, but many have contended that by exposing the great extent of corruption in Dubai, the long-term benefits have been considerable. Indeed, with signs that the emirate is now beginning to 'get its house in order', it is believed that more foreign investors will be inclined to consider the UAE as a viable option. ${ }^{201}$ 
Similarly, new anti-money laundering organisations and legislation have been seen to have encouraged greater formal accountability in the UAE's financial sector. Certainly, under the 1987 federal law concerning the promulgation of the penal code, the UAE was one of the first countries to adopt specific anti-money laundering articles. In 1993 these articles were strengthened by the Central Bank's requirement for comprehensive customer identification for the opening of all accounts, including those purportedly for charitable institutions. In 1999 an 'Anti-Money Laundering and Suspicious Cases Unit' was established and given access to all relevant authorities, and in 2000 this was followed by the formation of a national anti-money laundering committee responsible for all such policy in the UAE. In late 2001 an anti-money laundering law was passed by the COM and duly approved by the FNC, in an almost immediate response to the widespread accusations of Al-Qaeda funding following the September 2001 terrorist attacks. $^{202}$ As such, by February 2002, at a meeting of the Financial Action Task Force (FATF) held in Hong Kong, the UAE was declared to have finally established a comprehensive anti-money laundering system, comprising of all the necessary laws, regulations and procedures, and was said to be now "in a very good position to co-operate in the internationally declared fight against money laundering." Moreover, the team also declared that any deficiencies in the UAE's previous antimoney laundering systems had now been eliminated. ${ }^{203}$

In the near future, these anti-corruption and anti-money laundering organisations and legislation will be angmented by other transparency initiatives. One important example will be the Central Bank's forthcoming establishment of a customer credit worthiness database. This database will oversee all transactions and will aim to reduce the number of fraud-related incidents which have plagued the UAE's financial sector. For the first time, a database will gather financial information on selective clients along with details of their operations, the magnitude of their business, and the nature of their transactions. ${ }^{204}$ At a more grass-roots level will be the Dubai Government's forthcoming 'Excellence Programme' which will play host to a number of projects including a 'mystery shopper' operation designed to call anonymously on 
government departments and directors and rate their performance. Indeed, as the progranme's sponsor explains:

"... some people think that closed doors can hide the facts and conceal the fact that this applies to some directors... who did not come up with a single idea or project during the whole year. What are they waiting for, while their colleagues have succeeded in transforming their departments into active cells."205

Similarly, it is also hoped that the aforementioned Dubai International Finance Centre can play a key role in promoting the UAE's drive for transparency. ${ }^{206}$ Indeed, as emphasised by its chairman, Al-Jallaf, there will be a brand new regulatory and executive system set up in the DIFC with strong regulatory codes and rules based on respected international standards. Moreover, it is intended that the DIFC's regulatory agency will be divided into a council and a commission to ensure the separation of oversight and execution. As such, Al-Jallaf argues that the DIFC will be

"... even more tightly regulated than the developed markets. We have to be more careful because of the scrutiny we will come under from the USA and the dangers of money laundering. "207

As such, one of the DIFC's main priorities will be to reach a high level of internationally recognised transparency. Indeed, as Al-Jallaf hopes, the DIFC will soon gain recommendation from the OECD, and all institutions based in the DIFC will be accredited entities with their headquarters in either a member country of the FATF, or a country committed to the Wolfsberg principles and guidelines relating to money laundering. ${ }^{208}$ 


\section{5-Elite interest groups: old rentiers versus new rentiers}

Far from homogenous, the UAE's powerful client elite can increasingly be divided into two main socio-economic interest groups: the conservatives and the reformers. Although both are clearly components of a dominant class seeking to perpetuate rentier wealth and rent-channelling structures, this section will attempt to illustrate the important differences between those 'old rentiers' remaining reliant on oilderived economic rent and aiming to maintain the status quo, and those 'new rentiers' seeking fresh and less finite sources of economic rent from non-oil related activities such as the leasing of real-estate and the ownership of business parks. To facilitate the development of these more diversified sources of rentier wealth, the new rentiers have been pressed to seek a number of liberalising reforms in an effort to remove existing restrictive practices, to attract greater foreign investment, and to boost the UAE's international credibility. Crucially, on occasion, these proposed reforms have led to significant conflicts, sometimes at the highest levels, with the more conservative elements of the Emirati elite keen to block any potentially destabilising initiatives or amendments to existing legislation. Moreover, although as shown, the differing substrategies of cautious oil-related development in Abu Dhabi and more vigorous diversification in oil scarce Dubai are being increasingly seen as mutually beneficial, it is also worth noting that the UAE's inter-elite conflict can in some ways be interpreted as a struggle between the two principle emirates. ${ }^{209}$

To explain more fully the interaction of these interest groups and their relevance to Emirati development, this section will first consider the very different backgrounds of the conservatives and the reformers, with a particular emphasis on the emergence of the new 'technocratic' elite. Secondly, a number of key issues which have sparked furious debate and which have on occasion led to serious quarrels between the two camps will be considered, before turning to three detailed case studies, each of which will highlight an aspect of desired reform which has provoked strong opposition from the conservatives. Specifically, the controversial question of foreign ownership of property in the UAE will be assessed in light of the new rentiers' need to reform 
existing laws and practices in order to boost real estate rent, and the old rentiers' conflicting desire to preserve the existing restrictions in an effort to safeguard the privileges and resources of the Emirati population. Similarly, the new rentiers' need to promote innovative new legislation for the many proposed free zones, and their subsequent need to allow greater foreign ownership of commercial ventures will also be studied. Finally, the more general issue of foreign direct investment and the clear contrast between the requirements of the new rentiers and the fears of the conservatives will demonstrate how the seemingly irreconcilable differences between these two main interest groups are likely to contimue shaping the UAE's socio-economic development for the foreseeable future.

For the most part, the UAE's prominent conservatives, many of whom are believed to be supported by Shaykh Zāyid and his crown prince, Shaykh Khalifa, ${ }^{210}$ are those members of leading families either closely related to the ruling families or associated with the UAE's oil industry. Many have been understandably reluctant to permit sweeping changes lest their oil-related sources of revenue be jeopardised or their high-level positions be lost. Certainly, examples of such conservatives would include many of the members of the previously discussed Dhaheri family. Originally from Buraimī and now one of the most influential Abu Dhabian families, the Dhaheris presently hold more than 25 senior positions in the UAE's hierarchy, including executive posts in the Abu Dhabi National Oil Company (ADNOC), the federal judiciary, and the Abu Dhabi Financial Department. Similarly, the Bin Yousefs, another prominent Abu Dhabian family, have for some time also been closely linked with the emirate's oil industry. Although, as Business Monitor International reported, Yousef bin Yousef resigned as Minister for Petroleum and Resources in the early $1990 \mathrm{~s}^{211}$ this was only because of the federal ministry's impotence and his subsequent lack of control over oil-related policies. Significantly he was soon appointed general manager of ADNOC and later became the secretary-general of the Supreme Petroleum Council which, as described, ${ }^{212}$ now formulates the bulk of Abu Dhabi's oil policies and has therefore become one of the most powerful bodies in the UAE. ${ }^{213}$ 
In contrast, the UAE's most prominent reformers have tended to be those businessmen and families with closer links to the non-oil related sectors, and therefore those with a greater personal interest in successful diversification. Moreover, it is also important to note that many of these are believed to have a more technocratic background, with the majority having studied abroad, holding academic qualifications, and in some cases also having had professional and entrepreneurial experience. Prime examples of such technocrats would include the influential and well renowned Dubai businessmen Muhammad Al-Abbar, Majd Al-Futtaim, and Jumā Al-Majid Abdullah. As director-general of Dubai's Economic Development department, the North American educated Al-Abbar has been instrumental in formulating and implementing many of the emirate's recent economic reform programmes and, as the Economist Intelligence Unit claims, deserves much of the credit for their apparent success. Indeed, he is believed to have championed a number of liberal economic strategies in an effort to boost local businesses, including his own highly successful Emār Properties which, as will be demonstrated, has now achieved considerable international status. Similarly, AlFuttaim, another household name in Dubai, has also been a major driving force behind a number of thriving property developments and business ventures. Moreover, in much the same way as Al-Abbar, he has also been seen to have embraced free market economics, and is now thought to wield an enormous liberalising influence in Dubai's rapidly developing financial sector. ${ }^{214}$ Al-Majid Abdullah, again from Dubai, can be regarded as another key member of this new technocratic elite. His business and educational interests are much in evidence in the emirate, with many successfil local enterprises to his name, with his vice chairmanship of both Emirates Bank International and the Central Bank, and with his establishment of a cultural foundation dedicated to local scholarship. ${ }^{215}$

Crucially, as a greater proportion of the UAE's youth begin to experience higher education and professional environments, and as the need for diversification and reform becomes even more pressing, it is believed that the size and relative political weight of this technocratic group will continue to grow. Although, as described in the earlier outline of patrimonial sources of legitimacy, the traditional rulers have always 
carefully sought to accommodate and incorporate such 'modern groups' into their polities, ${ }^{216}$ in more recent years there have, however, been very visible signs that the technocrats are finally beginning to assume many more positions, sometimes even those previously occupied by powerful conservative families. Indeed, there has been much evidence that the technocrats may now even be gaining a foothold in the COM, which, as explained, is the most influential non-hereditary political institution in the UAE and is responsible for the bulk of day-to-day policy formulation. ${ }^{217}$ Either as a result of growing pressure or out of a genuine desire to achieve broader representation, in 1997 Shaykh Zāyid admitted to the COM a group of western-educated professionals with considerable experience in commerce, banking and other non-oil related activities. Furthermore, despite their youthfulness, these new appointees were not restricted to minor cabinet portfolios, with Dr. Muhammad Kharbash even being appointed Minister of Finance and Industry; ${ }^{218}$ one of the UAE's key development related ministries.

Moreover, in 1998 the influence of the technocrats was further enhanced after another western-educated graduate, Muhammad Al-Habtur, won an election to become speaker of the FNC. Although, as described, the FNC only commands limited legislative powers, the position of speaker is nevertheless of great significance, not least because it is one of the few genuinely elected positions in the UAE's political system. Indeed, whereas all previous speaker elections had been uncontested formalities, the 1998 election was fiercely contested. Democracy was in action given that both the proreform Al-Habtur and his more conservative opponent canvassed for support from individual FNC members. ${ }^{219}$ Most importantly, Al-Habtur's victory was far from unanimous, with Al-Wasat newspaper reporting the result as being 24 to 15 , with only one abstention. 220 Furthermore, given that voting patterns did not necessarily reflect regional or family origin, ${ }^{221}$ the split would seem to confirm that politically opposed blocs and differing elite orientations do exist underneath the surface of UAE politics, and, as in most other states, the political elite is far from being a single homogenous unit. 
Thus, given this increasing strength of technocratic reformers alongside the continuing presence of powerful conservatives, it is of little surprise that a number of major 'new rentier' versus 'old rentier' development-related policy struggles have surfaced in recent years which, on occasion, have led to counter policies and attempts to slow and block controversial reforms. Certainly, some of the more notable examples would include:

\section{Attempts to promote liberalising reforms}

The liberalisation of property rights. Traditionally only UAE nationals have been allowed to own property, but these rules are now being relaxed and changed by those seeking to open up the UAE economy and attract greater foreign direct investment. In 1999, Al-Abbar's Emär Properties allowed GCC citizens and even wealthy non-GCC citizens to purchase 99-year leases at its exclusive Emirates Hills development. Similarly, in 2000, Union Properties, a subsidiary of the Al-Majid Abdullah-linked Emirates Bank International, announced it would offer 30-year leases to foreigners on selected developments. In much the same way, in the commercial sector, Dubai Internet City has allowed investors to purchase 50-year renewable leases from the year 2000 onwards. Thus, as the case studies later in this section will reveal, although these developments have remained within the letter of the law, it is quite clear that by offering such long-term leases, the reformers clearly have attempted to bypass the existing restrictive legislation.

The liberalisation of business ownership laws. In 1997 the governor of the Central Bank recommended to the COM that some of these restrictions be relaxed and that nonnationals should be allowed to invest in the public offerings of a future stock exchange with the intention of pushing the UAE's capital market towards maturity and further expansion. Following approval, Al-Abbar's Emär Properties once again led the way by being the first listed Emirati company to allow foreigners to buy shares: up to $20 \%$ of its equity at first, then eventually rising to $49 \%$. ${ }^{222}$

The provision of investment work-arounds for non-UAE nationals. By providing nonvoting investment opportunities for foreigners, some of the UAE's banks have attempted to create an investment alternative for those restricted by the current regulations. The first of such schemes, the Emirates Equity Fund, was sponsored by Emirates Bank International and offered more than 30 million Dirhams worth of openended units and, as BSP Management Consultants claim, other banks are soon expected to follow suit. ${ }^{223}$

\section{Attempts to block liberalising reforms and augment existing restrictions}

The introduction of 'exclusive agency" agreements in which certain UAE-based companies have been given the sole distribution rights for imported goods. These were intended to eliminate the threat of competition in certain areas, thereby safeguarding the interests of established UAE enterprises. ${ }^{224}$ 
The introduction of a $4 \%$ customs duty, imposed by the federal government on most goods since 1994. ${ }^{225}$ Although a relatively low figure, as this thesis has shown Dubai's merchants have relied upon a tax-free trading environment for much of the twentieth century, ${ }^{226}$ Indeed, as the Middle East Economic Digest notes, many of the UAE bankers have vigorously opposed this policy, cautioning that the duty may impede Dubai's further growth as a trading centre if companies find more attractive alternatives such as Hong Kong or Singapore. 227

The constant efforts to maintain the ban on foreign ownership of real estate in the UAE, as demonstrated in the earlier discussion of the FNC's July 1990 recommendations. ${ }^{228}$

The efforts to reinforce the kafil sponsorship system and the minimum $51 \%$ ownership share by nationals in all UAE businesses, as noted in the earlier discussion of the FNC's March 1994 recommendations. ${ }^{229}$

Calls from some members of the FNC for the government to impose a $5 \%$ corporation tax on non-UAE companies, thereby weakening the competition. ${ }^{230}$ While many domestic companies would surely thrive under free market conditions, it was feared that a number of companies, especially the many infant light manufacturing industries, would suffer without some form of protection. ${ }^{231}$

The opposition to Dubai Media City and the proposed plans to allow greater freedom for Dubai-based media companies. Indeed, as was reported in 2001, a number of FNC members recoiled at the prospect of potentially uncontrollable and culturally eroding media outlets,

"The FNC members generally expressed deep reservations about what kinds of content the media companies setting up in the trade free zones like the Media City would be producing. Some said that the content might erode the national culture and morals. Such nervousness is understandable, as the individual Emirates establish the free zones, and the federal government has no authority or control over their activities. "232

\subsection{1 - Foreign property ownership}

As the first of three case studies highlighting these 'new rentier' reforms and their greater impact on socio-economic development, this section will consider the controversial issue of foreign property ownership, or rather foreign long-term leasing and the struggle to overcome the existing federal property laws. Attempting to establish new sources of economic rent, improve foreign investment, and of course boost the diversification of the economy, many have sought to challenge or circumvent the ban on non-national property ownership by either bending regulations or working around restrictions. Perhaps the first example of such an endeavour was the result of a strategic alliance formed between Dubai's crown prince, Shaykh Muhammad Al-Maktūm, and 
Al-Abbar's Emār Properties. Significantly, for much of the early and mid-1990s, Emār Properties had confined its activities to the construction and letting of condominiums on the Shaykh's donated land, and both parties had been content to restrict the sale of completed apartments to UAE nationals, thereby upholding the foreign ownership ban. However, by 1997 an important change had taken place. Emār announced the launch of 'Emirates Hills'; a 700 million Dirhām golfing-cum-residential project which would overlook the Emirates Golf Club close to Dubai's busiest commercial centre. Given the scale of the project, Shaykh Muhammad began to take a more active role by personally supervising its progress. ${ }^{233}$ Thus, with a powerful supporter and benefactor, Al-Abbar finally began to contradict publicly the existing laws by underscoring his commitment to foreign ownership:

"We have had strong response [for Emirates Hills] from citizens of Abu Dhabi, Dubai, Saudi Arabia, and Kuwait, and even from ex-patriates. We will also allow locally incorporated companies to purchase the villas." 234

Thus, for the first time in the UAE's history, residential plots were not only being marketed to Emirati and GCC citizens, but also to "...those 'others' that can either buy fully built-up villas or plots". 235

Moreover, Emār's much-publicised follow-up project, the Westside Marina, further consolidated the reformist Al-Abbar / Shaykh Muhammad position. Indeed, in much the same way as Emirates Hills, the project's stated objective was not so much to meet the needs of the local population, but rather to increase the attractiveness of Dubai to foreign investors. Specifically, it was to comprise of:

"A marina complex with mixed usage low, medium and high-rise buildings along with comprehensive infrastructure features, complete with shopping centres, swimming pools and golf courses... which would accommodate the expected growth of Dubai for tourists, international expatriates, and UAE 
and GCC citizens. Properties within the community complex would also be available for UAE, GCC and other companies, he added. "236

Thus, by condoning the long-term leasing of property to all interested parties, regardless of nationality, the marketing aims of these two projects have strictly speaking been outside of UAE law. However, given that both Emirates Hills and the Marina have been resounding successes for Dubai's real estate sector, Emār appears to have set a precedent with many other developers having followed their lead.

By far the most ambitious and noteworthy of these new property developments has been the creation of the vast Palm Island project which is being built on a manmade atoll off the coast of Dubai. With its $120 \mathrm{~km}$ of artificial sandy beaches, a monorail linking the palm's various fronds, high rise hotels, and three thousand luxury villas, Palm Island will join the Great Wall of China as one of the few man-made structures visible from space. The project has reportedly cost over 15 billion Dirhams and has been funded primarily by the government of Dubai along with a number of local and international banks. Crucially, although not under the auspices of Emār Properties, this project is also being personally supervised by Shaykh Muhammad. Furthermore, in much the same manner as the groundbreaking Al-Abbar developments, the properties on Palm Island are being made available to overseas buyers on one hundred year leases. ${ }^{237}$ Accordingly, while this does not actually constitute foreign ownership, the semi-permanency of the proposed leases and the overall objectives of the project are best viewed as careful work-arounds of the law.

Significantly, it would appear that even the UAE's federal ministries are now beginning to recognise the importance of these successful developments in Dubai, and as a recent communiqué from the Ministry of Information and Culture indicates, it would seem that the reformers' strategies are gradually being accepted, even if not yet officially approved: 
"In general, expatriates are not allowed to buy properties in the UAE, however it is now possible to do so in some emirates, for example, Dubai. The ambitious Palm Island Project - the world's largest man-made island shaped like palm trees, being developed by the Dubai Government, offers villas to be sold on a free-hold basis." 238

In addition, the pioneering role of Dubai-based companies such as Emär Properties, and their use of long-term leases as legal loopholes are now also being acknowledged by the ministry:

"Last year Dubai Lands and Properties Department has announced that expatriates, including non-resident foreigners, can now buy property in Dubai in the form of 99-year leases with properties managed by Emär Properties. Earlier, only GCC citizens were entitled to this privilege, now foreigners are entitled to the same rights as UAE citizens and Gulf nationals as far as buying, selling and renting lands and property in Dubai is concerned." 239

Finally, it is worth noting that in the last few years there have been indications that such developments are also beginning to take shape in other emirates, even in Abu Dhabi. A good example would be the Sādiyat Island project. As described earlier in this chapter, the development was originally intended to house an offshore financial market in Abu Dhabi. ${ }^{240}$ However, as the Economist Intelligence Unit reports, it now appears that the project has become a real estate development, offering 99-year leases and free zone status to prospective foreign companies. ${ }^{241}$ Thus, in Abu Dhabi it would seem that there are also efforts being made to bypass the existing property restrictions by exploiting ambiguities such as long-term leases and offshore status. Sādiyat Island and a number of similar projects underway in the smaller emirates may therefore indicate that, in this case at least, Dubai's example and the strength of the reformers are having a liberalising influence across the UAE's previously restricted real estate sector. 


\subsection{2 - Commercial ventures and free zones}

Another important source of new rentier wealth has been the economic rent accruing from the leasing of free zone plots and industrial parks to productive tenants. Thus, in much the same way as the efforts to reform and circumvent real estate laws, there have also been clear attempts to relax and avoid the existing foreign business restrictions. Indeed, without such liberalisation it is undoubtedly feared that potential foreign investors will be put off by the $49 \%$ cap on foreign business ownership and the much maligned kafil sponsorship system requiring all foreign businesses to take on an Emirati partner. Once again, Dubai's technocrats have been at the forefront of this mission, with the creation of the massive Jebel Ali Free Zone in the mid-1980s having already clearly confirmed their intentions. As demonstrated in the earlier discussion of physical infrastructure, the JAFZ was to serve as a major non-oil related industrial export-processing zone for both domestic and foreign firms, and as such there was a pressing need to remove all unpopular commercial restrictions. ${ }^{242}$ Thus, in 1985 , a local Dubai law was passed with the express aim of providing the JAFZ authority with greater freedom and exemptions from existing UAE business regulations. Specifically, the law empowered JAFZ companies to be released from all export fees and turnover taxes, and most crucially allowed all of the zone's foreign companies to be exempt from local partner conditions and to claim full repatriation of the invested capital. ${ }^{243}$

In recent years a number of innovative development projects have attempted to follow this pattern, with many of the new free zones and parks also claiming to permit $100 \%$ foreign ownership. Indeed, if the Dubai-based Emār Properties can be viewed as the pioneer of residential real estate development in the UAE, then Dubai Investments Park Development Co. (DIPD) can be regarded as its commercial equivalent. In 1998 the firm was seeking approval to allow foreigners to hold a majority stake in ventures in its business park situated close to the JAFZ. Certainly, although general manager Khalid Kalban accepted that the park was likely to remain distinct from Jebel Ali and its free zone status, he nevertheless stated his "hope for $100 \%$ foreign ownership in the business park. ${ }^{244}$ Since then, DIPD intensified its marketing campaign to attract 
foreign investors and businesses by offering them first-rate infrastructure with complete freedom from any restrictions, ${ }^{245}$ and, backed by a new Dubai decree in 2000 to promote such freedom in commercial developments, these promises were soon realised. Although the "Dubai Technology, Electronic Commerce and Media Free Zone Law No.1" was not a federal law, it was nonetheless the first of its kind in the UAE, again underscoring the emirate's strong commitment to the liberalisation of the UAE's economy. Indeed, by expanding upon the earlier JAFZ enabling legislation, this new local ordinance responded to the needs of the business community by allowing for a number of significant amendments and relaxations of the existing restrictions:

- Article 9, "Entry into leases of plots and buildings may extend to periods of up to 50 years, with any establishment in the free zone, to enable it to carry on its activity according to terms and conditions agreed upon."

- Article 15, "Free zone establishments shall be exempt from all taxes, including income tax, with regard to their operations in the free zone. They shall also be excluded from any restrictions on repatriation and transfer of capital, profits and wages in any currency to any place outside the free zone for a period of 50 years..."

- Article 16, "Assets or activities of the free zone establishments shall not be subject to nationalisation or any measures restricting private ownership throughout the period of their activities in the free zone."

- Article 17, "Free zone establishments may employ or hire whomsoever they choose in their operations in the free zone, provided that such employees are not subject to any countries politically or economically boycotted by the UAE."

- Article 18, "The operations of free zone establishments or employees, within the free zone, shall not be subject to the laws and regulations of Dubai Municipality, the Department of Economic Development of the Government of Dubai, or the powers and authority falling within their jurisdiction. ${ }^{246}$ 
Essentially, therefore, these articles formalised the practice of granting long-term leases to foreign firms while guaranteeing them exemption from any possible nationalisation of industry and from any future implementation of taxation, such as the proposed $5 \%$ corporation tax. $^{247}$ Furthermore, they also granted all free zone companies exemption from municipal laws thereby effectively placing them outside of federal law.

Benefiting from this custom-made legislation, a flurry of new ventures have sought to maximise these new advantages. One such example would be the Dubai Airport Free Zone which became operational in late 2000. Close to the city centre, the zone began to offer prospective high-tech companies a number of incentives, many of which relied heavily upon the recent relaxations. Indeed, in much the same way as the JAFZ, but without needing a specific Emiri decree, the zone was able to promise tax exemptions, $100 \%$ foreign ownership, and $100 \%$ repatriation of capital and profits. ${ }^{248}$ An even stronger example of such a development has of course been the Dubai Internet City, another of Shaykh Muhammad's personally supervised projects. Certainly, the DIC seems intent to capitalise on all of the benefits granted by the new law, as its marketing brochure reads:

\begin{abstract}
"100\% foreign ownership, 0\% problems! To attract IT and internet-focused companies, Dubai Internet City will offer an extremely attractive set of benefits. In addition to 100\% foreign ownership, companies will also get land on renewable leases of up to 50 years. They can move into ready-tooperate-from offices or build their own offices. The aim is to facilitate immediate commencement of business operations. Towards this end there will be a 'single-window' for all government clearances, including those pertaining to trade licences and work permits. ${ }^{249}$
\end{abstract}

Thus, given the many similarities between these objectives and the described articles, developments such as the DIC can be regarded as direct products of this new legislation. Moreover, it is also worth noting that as these new free zones grow in size and number, they may catalyse further amendments to existing UAE regulations. Indeed, it is 
believed that the DIC's requirements for more comprehensive Internet access may soon even lead to a relaxation in the UAE's telecommunications restrictions. For a long time the topic of Internet access has been a delicate issue in the UAE, with freedom of use currently being sacrificed for state control. However, with a clear reference to the DIC, a spokesman for the federal government recently raised this very issue of censorship by stating that

"... the current regulations enforced in the UAE may need to be examined and even dropped altogether as a concession to the fact that electronic information knows no borders and it is virtually impossible to stop its flow in and out of the UAE... businesses located in the Dubai Internet City would soon be able to by-pass the Etisalat proxy server [the imposed intermediate server and information filter] for the purposes of sending and receiving electronic information." 250

Lately there have also been indications of similar efforts to reform and liberalise the UAE's financial zones. Indeed, it has been reported that the aforementioned Dubai International Finance Centre will attempt to defy current UAE laws in much the same way as the commercial and industrial parks. Moreover, this challenge will be especially significant for the reformers given that the DIFC, lacking any official free zone status, will not be able to rely upon the Dubai 2000 legislation and, as is widely believed, has not yet received support from the Central Bank. Certainly, as Sultān al-Suwaidi the governor of the Central Bank has stated, the DIFC remains "entirely a Dubai initiative, with no connection to either the Central Bank or any other UAE institution". 251 However, despite its ambiguous status, the chairman of the DIFC, Al-Jallaf, has confidently stated that the centre's offices and banks, “... will not be operating under the laws and regulations of the UAE", and that, " $100 \%$ foreign ownership will definitely be permitted. ${ }^{252}$ Unsurprisingly, Al-Jallaf's bold statement soon received support from Shaykh Muhammad who reiterated that the DIFC would parallel international laws and conventions similar to those in the USA and the UK, rather than local UAE laws. ${ }^{253}$ It would therefore seem likely that the DIFC, in a similar fashion to Emãr Properties and 
DIPD, will at first be operating outside of UAE law, perhaps until fresh legislation is introduced in order to disable the existing restrictions.

Lastly, it is also noteworthy that in the same way as the other emirates have slowly begun to follow Dubai's lead in liberalising property markets, there are now also signs of greater commercial freedom emerging in other parts of the UAE. Indeed, in what has been described as an unprecedented move, the Sharjah Economic Department has drawn up a framework which will allow $100 \%$ foreign ownership in certain Sharjah businesses. Moreover, although this Sharjah Service Agent Law is still in the draft stages and has yet to be approved, it is thought unlikely that any opposition will be able to block such development, especially given the spate of legislation and exemptions in neighbouring Dubai. Similarly in Fujairah, it has been reported that the emirate's local government has drawn up plans to boost its local industries by allowing for $100 \%$ foreign ownership. With the only major port on the UAE's Indian Ocean coastline, the emirate intends to become the region's main distribution point for the Indian and East African markets, and by sharing the same views as Dubai's reformers, there has been an increasing realisation that such objectives can only be met if existing federal regulations are removed. ${ }^{254}$

\subsection{3 - The foreign investment debate}

As both of these case studies have demonstrated, many of the reformers' attempts to amend and circumvent existing restrictions have been directly related to the issue of foreign direct investment (FDI), whether regarding foreign ownership of residential real estate, foreign ownership of commercial and industrial plots, or even foreign ownership of financial centres. The reformers clearly hope that by liberalising the UAE's laws, a more competitive commercial environment will develop and greater foreign investment can be attracted to the region, thereby bringing new technologies to the country and reducing the UAE's reliance on oil, while also providing a fresh source of rentier wealth. Conversely, more conservative groups have contended that such developments and attempts to relax regulations may have dangerous consequences for 
the future of the UAE's economic structures. Indeed, as explained in the previous chapter, it is thought that the transfer of technology and skills between foreign and domestic enterprises may prove unattainable unless unaccompanied by emiratisation, joint ventures, or other government-sponsored initiatives. ${ }^{255}$ Moreover, it is undoubtedly feared that any greater liberalisation may further encourage technology enclaves and dual economies, especially if the free zones remain distinct from the domestic productive base. Finally, these conservatives have also argued that by creating the free zones, the reformers are actually being short sighted given that such zones are essentially onshore tax havens, and that their autonomous existence may make it difficult for the UAE to implement corporation tax or any other form of control in future years.

In a recent study on this debate by the Dubai Chamber of Commerce and Industry, results indicated that there are indeed such identifiable groups for and against greater FDI in the UAE, in addition to a sizeable third group stressing the need for a more moderate path. Firstly, with regard to the conservatives, it was noted that there are a considerable number of officials and observers in the UAE who continue to stress the need to proceed with caution when 'opening the door to FDI'. These conservatives have pointed out a number of the negative implications which may result from an overly liberal approach to investment in the $\mathrm{UAE}$, and have voiced their intention to oppose such policies as and when they are brought to discussion. A good example being Muhammad al-Khūri, the president of the International Central Circle Group, who emphasises not only the tax-related drawbacks associated with unrestrained FDI, but also its worsening effects on the UAE's already imbalanced population structure and the considerable risks posed to local UAE markets if a high value of FDI were to be suddenly withdrawn. As such, al-Khüri argues that:

"What is important is not to go for more foreign investments, but to lay down the basis and controls that govern existing investments and find out the best methods of benefiting from them and avoiding negative effects which may arise as a result of their expansion. "256 
In contrast, the study also highlighted the opinions of certain pro-reform officials who contend that FDI plays a crucial role in all developed countries and that, with a veiled reference to the oil-dependent Abu Dhabian economy, a financial surplus in the hands of citizens cannot be considered a valid reason for conservatism and the restriction of FDI. Moreover, this group also argues that the risks of greater FDI are far outweighed by its important benefits; the most important of which are seen to be technology linkages, the provision of jobs and training for nationals, and the diversification of the productive base. These officials also claim that low FDI and economic isolation will ultimately lead to higher costs and reduced competitiveness, reminding their opposition that other developing states such as Singapore, Malaysia, and Korea have all succeeded in embracing FDI while having seemingly overcome the associated problems and dangers. Advocates of greater FDI have included FNC member Musallam bin Hum, who maintains that if such investments do not duplicate local projects, then they are wholly advantageous to the UAE and that $100 \%$ foreign ownership in the free zones is entirely acceptable. ${ }^{257}$ Similarly, Muhammad Yasin, the director general of Emirates Commercial Centre, has joined these supporters of greater FDI by claiming that:

"... more FDI would support the local economy and lead to equilibrium in the trade balance, diverting the UAE from being an importer of products and exporter of investments to a recipient of investments. "258

Moreover, Jasim al-Shamsi, the director of the Budget Department of the Ministry of Finance and Industry, shares this structural view, arguing that greater FDI in the manufacturing sector will eventually improve the UAE's integration with international production systems, and that instead of fearing the creation of foreign enclaves, local UAE companies should instead embrace FDI, as foreign investors are likely to allow them to improve penetration of export markets by providing them with important contacts and information such as the location of the best distribution outlets. ${ }^{259}$ Also, in much the same way, Dr. Muhammad Shihab, an economics expert in the federal Planning Department, believes that greater FDI is entirely beneficial to the UAE and 
that the fears of multinational dominance and loss of national identity have been greatly exaggerated. Indeed, in an interview with the chamber he stated that:

"The UAE, being a mono-resource economy country, where oil dominates the local resources, should strive to develop its local investments and attract FDI to lessen dependence on the oil revenue in its development process. The importance of FDI in the UAE is not restricted to being a means of economic development, but should be considered as a factor which helps in increasing the country's economic integration in the international economic system as well." 260

The third group identified by the chamber's study were those moderates who stress the need for a balance between reforms and conservatism. Essentially, the moderates maintain that by introducing appropriate laws and regulations, the benefits of FDI can be maximised while at the same time preserving national heritage and avoiding the dangers of unbridled foreign investment. Such foreign investment laws would prevent economic dumping and other harmful consequences of FDI, while also directing FDI into the most beneficial sectors. ${ }^{261}$ To this end, these moderates have called for an institution capable of both promotion and restraint, citing the successful examples of moderate strategies in Taiwan and Japan where FDI has been both encouraged and limited, and where foreign companies have transferred much of their technology within a comprehensive package of industrial policies. ${ }^{262}$ Indeed, Dr. Muhammad al-Assouri, the director of research in Emirates Industrial Bank, sums up this group's preference for such a dual strategy:

"We [the UAE] should act as an open market allowing free and fair competition, but at the same time, we should prepare our public and private institutions and companies for the inevitable forthcoming competition. This way the UAE will have an effective role in the new global economic relations." 263 


\section{6 - Conclusion}

In addition to reiterating the potentially negative implications of rentierism / allocation, this chapter focused heavily on the role of internal structures and their associated pathologies in an effort to explain some of the more persistent development problems facing the UAE's modernising monarchies, especially those which have seemingly stemmed from a lack of co-operation, mismanagement, opaqueness, and other primarily domestic concerns. Indeed, by underscoring the impact of reinvigorated neo-patrimonial networks, bureaucratic self-interests, and differing client elite orientations on the UAE's policymaking and policy implementation processes, it was shown how in many cases the same strengthened traditional and dependent structures which have allowed for monarchical survival and political stability are now so deeply entrenched that they actively shape, and often undermine, socio-economic development objectives and the planners' attempts to modify the UAE's circumstances. Specifically, this investigation required an examination of the UAE's decision-making structure at both federal and emirate levels, an analysis of the organisation and performance of the many other institutions and bureaucracies which make up the UAE's rapidly expanding administration, and finally a consideration of the existence and interaction of key interest groups within the UAE's apparently heterogeneous elite.

Essentially, it was shown how the UAE's decision-making structure at the federal level is still dominated by hereditary rulers and their appointees in what would appear a hybrid neo-patrimonial government of seemingly modern institutions grafted onto powerful traditional authorities. Moreover, although a legislature does exist, the unicameral non-elected chamber of appointed representatives has remained in a paralysed state, often unable to exercise its constitutional rights and frequently incapable of questioning or restraining the executive. Furthermore, at the emirate level, local governments and departments continue to exist, some of which are subordinate but many of which run parallel to and overlap their federal counterparts. Certainly, there have been numerous occasions when the fabric of the union has been stretched to breaking point, often over vital issues of national interest such as oil policy, foreign 
affairs and defence. Thus, while the federation has certainly strengthened in recent years with the greater incorporation of Dubai, it is nevertheless still more accurate to consider the UAE as something of a loose confederation with its relatively autonomous and at times uncoordinated emirate-level powers continuing to shape the state's development.

Also capable of influencing Emirati development have been the various other institutions, parastatals, and bureaucracies tasked with policy implementation and advisory roles. Case studies of the various chambers of commerce, judicial institutions, and financial institutions have provided examples of how these are also very much part of a rigid neo-patrimonial network of non-elected appointments and close links to the traditional polity. Furthermore, it was shown how in certain circumstances these institutions have suffered from a number of other pathologies including bureaucratic self-interest, opaqueness, and a lack of genuine independence. Indeed, the $\mathrm{BCCI}$ scandal of the early 1990 s can be seen as a prime example of the devastating effect of such a combination of pathologies; with the management and fortunes of one of the UAE's most prominent development-related institutions having been inextricably linked to the traditional polity, with the offending bureaucracies having prevented disclosure in the interests of self-preservation, with the major regulatory bodies being powerless to intervene, and with the host emirate's local government and legal system left vulnerable to external interference and corruption.

Finally, in an attempt to highlight the non-homogenous nature of the UAE's client elite, the third section of this chapter revealed the increasing struggle over the future of Emirati development between the reformers and conservatives. Although both orientations are of course components of the same dominant rentier class deriving income from economic rent, the reformers can be seen as 'new rentiers' while the conservatives can be seen as 'old rentiers'. Essentially the new rentiers have sought fresh sources of economic rent from non-oil related activities such as the letting of real estate and commercial free zones, while the old rentiers have sought to perpetuate the 
steady flow of oil revenues. As demonstrated, a number of controversial issues such as foreign property ownership, foreign business ownership, and foreign direct investment have led to protracted disputes between those attempting to liberalise the economy and foster the growth of these non-oil related activities, and those attempting to preserve the status quo and safeguard what they believe to be the UAE's national interests. Thus, with conflicting legislation, work-arounds, pioneering projects, and attempts to circumvent existing regulations, the interactions of these opposing elite interest groups must be regarded as another major domestic influence on the UAE's socio-economic development.

\footnotetext{
${ }^{1}$ See for example TODARO, M (1994), "Economic Development in the Third World", London, Longman, pp.85; and WORLD BANK (1985), "Research News 1985", pp. 1 cited by TOYE, J (1987), "Dilemmas of Development", Oxford, Blackwell, Todaro explains, "Contrary to the claims of the dependence theorists, the neoclassical counterrevolutionaries argue that the Third World (many don't even accept this terminology) is underdeveloped not because of the predatory activities of the First World and the international agencies that it controls but rather because of the heavy hand of the state and the corruption, inefficiency and lack of economic incentives that permeate the economies of developing nations."

${ }^{2}$ LUCIANI, Giacomo (1987), "Allocation versus production states: a theoretical framework", in BEBLAWI, Hazem, and LUCIANI, Giacomo (eds.) (1987), "The rentier state", New York, Croom Helm, pp. 70

${ }^{3}$ Ibid. pp. 69

${ }^{4}$ See section 3.2

${ }^{5}$ See section 3.3

${ }^{6}$ See section 3.7 .1

${ }^{7}$ HINNEBUSCH, RA (1989), "Peasant and Bureaucracy in Ba'thist Syria: the political economy of rural development", Colorado, Westview, pp.7

${ }^{8}$ Ibid. pp.3

${ }^{9}$ Ibid. pp. 3

${ }^{10}$ See RIGGS, F (1991), "Bureaucratic links between administration and politics", in FARAZMAND, A (1991), "Handbook of comparative and development public administration", New York, Marcel Dekker, pp.485-504, cited by JREISAT, JE (1992), "Managing national development in the Arab states", in ARAB STUDIES QUARTERLY, Volume 14 Numbers 2 and 3, Spring / Summer 1992, pp.11

${ }_{11}$ Ibid. pp.3

12 See WALLERSTEIN, I (1979), "The rise and future demise of the world capitalist system: concepts for comparative analysis", in WALLERSTEIN, I (eds.), "The capitalist world economy", Cambridge University Press, cited by RANDALL, V and THEOBALD, R (1998), "Political change and underdevelopment", London, Macmillan, pp. 145

${ }^{13}$ SHARBAI, H (1998), "Neopatriarchy: a theory of distorted change in Arab society", New York, Oxford University Press, see Sharabi for discussion of a neo-patrimonial dominant class

${ }_{14}$ PECK, Malcolm C (1986), "The United Arab Emirates: A Venture in Unity", Boulder Colorado, Westview Press, pp. 122

15 KHOURY, EM (1980), "The United Arab Emirates: It's Political System and Politics", Institute of Middle Eastern and North African Affairs, University of Michigan, pp.87

${ }_{16}^{16}$ ECONOMIST INTELLIGENCE UNIT (2000), "United Arab Emirates", pp.6, in 1996 the provisional constitution was formalised, with Abu Dhabi being agreed upon as the capital and the seat of the presidency

${ }^{17}$ PECK (1986), pp. 122

${ }^{18}$ HEARD-BEY, Frauke (1999), "The UAE: A Quarter Century of Federation", in HUDSON, MC (ed.) (1999), "Middle East Dilenma: The politics and economics of Arab integration", London, Tauris, pp.136

${ }_{19}$ ECONOMIST INTELLIGENCE UNIT (2000), pp.6
} 
${ }^{20}$ POLSCI.COM (2001), "Political reference Almanac - UAE Political System", New York, Keynote Publishing; and personal interviews, Abu Dhabi, September 2002

${ }^{21}$ PECK (1986), pp. 122

${ }^{22}$ See BUSINESS MONITOR INTERNATIONAL (1998), "The United Arab Emirates"; and MIDDLE EAST RESEARCH INSTITUTE OF JAPAN (2002); POLSCI.COM (2001); and personal interviews, Abu Dhabi, September 2002

${ }^{23}$ ECONOMIST INTELLIGENCE UNIT (2000), pp.7

${ }^{24}$ See BUSINESS MONITOR INTERNATIONAL (1998)

${ }^{25}$ ECONOMIST INTELLIGENCE UNIT (2000), pp.7

${ }^{26}$ Calculated from COM members lists supplied by BUSINESS MONITOR INTERNATIONAL (1998); MIDDLE EAST RESEARCH INSTITUTE OF JAPAN (2002); POLSCI.COM (2001); and personal interviews, Abu Dhabi, September 2002

${ }^{27}$ POLSCI.COM (2001); and personal interviews, Abu Dhabi, September 2002

${ }^{28}$ PECK (1986), pp. 126

${ }^{29}$ POLSCI.COM (2001); and personal interviews, Abu Dhabi, September 2002

${ }^{30}$ PECK (1986), pp. 126; and UNITED STATES CENTRAL INTELLIGENCE AGENCY (2001),

"Chiefs of Staff and Cabinet Members of Foreign Governments", 1 st August 2001

${ }^{31}$ See section 2.2 .2

${ }^{32}$ HEARD-BEY (1999), pp. 135

${ }^{33}$ FENELON, Kevin (1973), "The United Arab Emirates", London, Longman, pp. 24

${ }^{34}$ It would seem likely that if there are to be female FNC members in the near future, Shaykha Fatima will be responsible for drawing up a list of suitable candidates, see BUSINESS MONITOR

INTERNATIONAL (2003), "The United Arab Emirates", first quarter report

${ }^{35}$ RIZVI, SN Asad (1993), "From tents to high rise: economic development of the UAE", in MIDDLE

EASTERN STUDIES, Volume 29 Number 4, October 1993, pp.665, for discussion of article 69 of the UAE's provisional constitution

${ }^{36}$ ECONOMIST INTELLIGENCE UNIT (2000), pp.7

${ }^{37}$ Ibid. pp.7

${ }^{38}$ Al-SAYEGH, Fatma (1998), "Merchants' role in a changing society: the case of Dubai, 1900-1990", in MIDDLE EASTERN STUDIES, Volume 34 Number 1, January 1998

${ }^{39}$ See section 4.5

${ }^{40}$ These were members during the FNC's $12^{\text {th }}$ term $(2000-2002)$, see www.almailis.gov.ae

${ }^{41}$ Information provided by Busit, Al-Roken \& Associates law firm, Dubai

${ }^{42}$ ECONOMIST INTELLIGENCE UNIT (2000), pp. 7

${ }^{43}$ FENELON (1973), pp.24

${ }^{44}$ PECK (1986), pp.123

${ }^{45}$ In April 1996, for example, the FNC formed a combined committee to follow up the execution of the presidential directions aimed at providing greater employment opportunities for national graduates. A recommendation was drawn up for presentation to the COM stressing the passive consequences ensuing from large numbers of unemployed nationals. In June 1996 the document was reviewed by the COM and many of its suggestions were incorporated into the government's plan. See AL-NUHAYYAN, Shaykha Shamma bint Muhammad bin Khalid (2000), "Political and Social Security in the UAE", Dubai, pp.147148

${ }^{46}$ Ibid. pp. 184

${ }^{47}$ See section 3.7.1

${ }^{48}$ AL-NUHAYYAN (2000), pp.122-123

${ }^{49}$ Ibid. pp.143-144

${ }^{30}$ Ibid. pp. 185

${ }^{51}$ Ibid. pp. 186

${ }^{52}$ See section 3.7.1

${ }^{53}$ AL-NUHAYYĀN (2000), pp. 188

${ }^{54}$ Ibid. pp. $178-179$

${ }^{55}$ Ibid. pp. 121

${ }_{56}^{56}$ ECONOMIST INTELLIGENCE UNIT (2000), pp.8

${ }^{57}$ PETERSON, JE (1988), "The Arab Gulf states: steps towards political participation", in The WASHINGTON PAPERS, Number 131, New York, Praeger, pp. 101; and HEARD-BEY, Frauke (1996), "From Trucial States to United Arab Emirates - new edition", London, Longman, pp.411-412; also see section 2.4

${ }^{58}$ Personal correspondence, Dubai, February 2003

${ }^{59}$ See section 3.4

${ }^{60}$ For more information see DUBAI DEPARTMENT OF ECONOMIC DEVELOPMENT (2002),

"Development Statistics", Government of Dubai, pp.222-271 
${ }^{61}$ RIZVI (1993), pp.666
${ }^{62}$ UAE MINISTRY OF INFORMATION AND CULTURE (1995), "UAE Yearbook: 1995", Abu Dhabi, pp. 28

${ }^{63}$ UNDP-UAE (2000), $27^{\text {th }}$ May 2000

${ }^{64}$ PETERSON (1988); also see (in Arabic) AL-WASAT (1994), Number 147, $21^{\text {st }}$ November 1994

${ }^{65}$ WAM (2003), "Elected Councils for Dubai", Abu Dhabi (Wikălat Anbā" al-Imārāt: the UAE News Agency), $2^{\text {tid }}$ April 2003

66 HEARD-BEY (1999), pp. 145

${ }^{67}$ UNPAN (2002), United Nations online network in Public Administration and Finance, see http://unpan1,un.org/intradoc/groups/public/documents/un/unpan000199.pdf

68 KAWACH, Nadim (2002), "UAE refutes report on oil sharing", in GULF NEWS, $13^{\text {th }}$ October 2002, quoting Shaykh Abdullah Al-Nuhayyān, the UAE's Minister of Information and Culture, responding to allegations of financial disunity within the federation

69 lbid.

${ }^{70}$ Taken from the CAMBRIDGE INTERNATIONAL DICTIONARY OF ENGLISH (2002)

"Federation - a group of regions or states united with a central government which has control over some things such as defence, but with each region having its own local government and laws, or the act of forming such a group."

${ }^{71}$ ANTHONY, John Duke (1981), "Transformation amidst tradition: the UAE in transition" in CHUBIN, Sharam (ed.) (1981), "Security in the Persian Gulf: domestic political factors", Montclair, New Jersey, Allenheld Osman, pp.27

${ }^{72}$ See section 1.3

73 WAM (1977), $16^{\text {th }}$ November 1977

${ }^{74}$ HEARD-BEY, Frauke (1982), "From Trucial States to United Arab Emirates", London, Longman, pp.387-393

${ }^{5}$ Personal interviews, Abu Dhabi, September 2002, with regard to oil revenue contributions to the federal budget

${ }^{76}$ HEARD-BEY (1999), pp.135

${ }^{77}$ See section 1.5

${ }^{78}$ HEARD-BEY (1982), pp.387-393

79 The original provisional constitution, signed in 1971 , was intended to be replaced by a more permanent constitution after five years.

${ }^{80}$ OVERTON, JL (1983), "Stability and change: Inter-Arab politics in the Arabian Peninsula and Gulf", $\mathrm{PhD}$ thesis, University of Maryland, pp. 186, citing an interview in 1976 with Zaki Nusseibeh, Press Secretary to Shaykh Zāyid. As Nusseibeh predicted of these 'independents' in the mid-1970s, "... a new generation of educated citizenry that identifies with the federal system, leading the forces of localism to appreciably diminish. Also, these younger people of the Emirates who are becoming part of the federal bureaucracy will be the ones holding the union together."

${ }^{81}$ HEARD-BEY (1999), pp. 137-138

82 HEARD-BEY (1982), pp.387-393

83 OVERTON (1983), taken from Overton's interview with Adnan Bajaje, Zāyid's personal political advisor, in Abu Dhabi on $25^{\text {th }}$ May 1976

${ }^{84}$ HEARD-BEY (1982), pp.387-393

${ }^{85}$ MIDDLE EAST ECONOMIC DIGEST (1978), $10^{\text {th }}$ February 1978, pp.48.

${ }^{86}$ MIDDLE EAST ECONOMIC DIGEST (1977), $7^{\text {th }}$ July 1977 , pp. 3

${ }^{87}$ It would appear that the duties associated with the two posts were more clearly defined, thereby reducing the likelihood of overlapping responsibilities

${ }_{88}^{8}$ HEARD-BEY (1996), pp.390

${ }^{89}$ As described, a key component of the rulers' legitimacy formula was strict adherence to Islamic values and the support of the Palestinian cause. With Egypt, one of the leading Arab states at that time, being drawn into closer relations with Israel, the UAE and the other Gulf states were placed in an awkward situation, not least due to their ongoing boycott of Israeli goods and personnel.

${ }^{90}$ PECK (1986), pp.131; and HEARD-BEY (1982), pp.397-401

${ }^{91}$ HEARD-BEY (1982), pp.397-401

${ }^{92}$ Personal interviews, Abu Dhabi, October 2002, with regard to the 1979 constitutional crisis

${ }^{93}$ HEARD-BEY (1982), pp.397-401

94 YORKE, V (1980), "The Gulf in the 1980s", London, Royal Institute of International Affairs, pp. 42

${ }_{95}$ HEARD-BEY (1982), pp.397-401

96 AL-SAYEGH, Fatma (1999), "Symposium on Shaykh Zäyid" taken from a conference convened by the Middle East Policy Council on $20^{\text {th }}$ April 1999, in MIDDLE EAST POLICY, Volume 6 Number 4, June 1999, pp.15-16 
${ }^{97}$ See UNDP-POGAR (2002), "Programme on Governance in the Arab region - UAE", OPEC refers to the Organisation of petroleum exporting counties, and OAPEC refers to the Organisation of Arab petroleum exporting countries

${ }^{88}$ See PLATTS GLOBAL ENERGY (2002), http://www.platts.com/opec

99 BROWN, Gavin (1998), "OPEC and the World Energy Market", London, Longman, pp.361

${ }^{100}$ Ibid.

${ }^{101}$ Ibid. pp.724

${ }_{102}$ Ibid. pp.361; also see ECONOMIST INTELLIGENCE UNIT (2000), pp.8, Indeed, as the

Economist Intelligence Unit notes, the Supreme Petroleum Council is now effectively a federal institution given that the Federal Oil Ministry was downgraded in the 1990 s with much of its formal power being transferred. As one would expect given the UAE's continuing reliance on oil exports, the SPC plays a major role in the policymaking process as it approves all oil-related policies and development projects for the companies falling under the umbrella of the state-owned Abu Dhabi National Oil Company

(ADNOC).

${ }^{103}$ BROWN (1998), pp.366

${ }^{104}$ GULF NEWS (2002), "UAE oil industry overcomes political and economic developments", 2 nd December 2002

${ }^{105}$ Information gathered from personal interviews in Ra's al-Khaimah, September 2002; and for confirmation also see UNDP-POGAR (2002)

${ }^{106}$ Ibid. This rather maverick orientation is perhaps best explained by the emirate's proud history and, as described in the historical background, its constant need for greater recognition and some kind of parity with the wealthier oil-producing emirates

${ }^{107}$ Ibid.

${ }^{108}$ PECK (1986), pp.133

${ }^{109}$ Personal interviews, Abu Dhabi, September 2002, with regard to UAE foreign policy

${ }^{110}$ AL-SAYEGH (1999), pp.15-16

111 MIDDLE EAST ECONOMIC DIGEST (1997), December 1997; also see FOLEY, Sean (1998), "The United Arab Emirates: Political Issues and Security Dilemmas", in Middle East Review of International Affairs (MERIA), Volume 3 Number 1, March 1998

${ }^{112}$ UNITED STATES DEPARTMENT OF STATE (2001), "United Arab Emirates: Country Reports on Human Rights", Bureau of Democracy, Human Rights, and Labour, 23 ${ }^{\text {rd }}$ February, 2001, section 1 113 Ibid. section 1(e)

114 OVERTON (1983), pp.184, based on a 1976 interview with Sa'id 'Ahmad Ghubash, the UAE Minister of Planning; also see section 3.9

${ }_{115}$ ECONOMIST INTELLIGENCE UNIT (2000), pp.7

${ }^{116}$ HEARD-BEY (1996), pp.415-416

117 ' $\mathrm{BCCI}$ ' refers to the Bank of Credit Commerce International of which the majority shareholders were based in Abu Dhabi

${ }^{118}$ This forum is referred to as the 'Federation of UAE Chambers of Commerce and Industry General Assembly'

119 FEDERATION OF UAE CHAMBERS OF COMMERCE AND INDUSTRY (1994), “Goals and achievements", Abu Dhabi, pp.11-12

${ }^{120}$ Ibid. pp. 5

${ }^{121}$ Ibid. pp.11-12

${ }^{122}$ Ibid. pp. 21

${ }^{123}$ DUBAI CHAMBER OF COMMERCE AND INDUSTRY (2001), “Our Services”, Dubai, pp.1-8 124 Ibid. pp. 1-8

${ }^{125}$ FEDERATION OF UAE CHAMBERS OF COMMERCE AND INDUSTRY (1994), "The components of Investment and the methods of promoting investment opportunities in the UAE", Abu Dhabi, pp.14-15

${ }_{126}$ Ibid. pp.45-46, UNIDO being the United Nations Industrial Development Organisation

${ }^{127}$ Ibid. pp. 14-15

128 Ibid. pp. 47

129 Ibid. pp.45-46

130 DUBAI CHAMBER OF COMMERCE AND INDUSTRY (2001), pp. 1-8, According to article 6 of the Emiri decree establishing the chamber, membership was to include all "except small businesses or those whose profession depend on personal efforts rather than financial resources"

${ }^{131}$ ABU DHABI ECONOMY (1999), "Abu Dhabi Economy: Special Issue", Abu Dhabi Chamber of Commerce and Industry, Publications and press relations Department, Volume 28 Number 322, March 1999, pp.4; also see section 4.2

132 Ibid. pp. 4

${ }^{133}$ Personal Interviews, Abu Dhabi, April 2001 
134 ABU DHABI ECONOMY (1999), pp. 4
${ }^{135}$ PECK (1986), pp. 123
136 ECONOMIST INTELLIGENCE UNIT (2000), pp.7
137 PECK (1986), pp.123
138 UNITED STATES DEPARTMENT OF STATE (2001), section 1(e)
${ }^{139}$ KHALEEJ TIMES (2001), “Country's judiciary is independent: Dhahiri", 6 th December 2001,

${ }^{139}$ KHALEEJ TIMES (2001), "Country's judiciary is independent: Dhahiri", 6 th December 2001,
from a lecture at the Zãyid Centre for Co-ordination and Follow-up by Muhammad bin Kakhira alDhahiri, the Minister of Justice, Islamic Affairs and the Auqauf

${ }^{140}$ UNITED STATES DEPARTMENT OF STATE (2001), section 1

${ }^{141}$ Ibid. section 1

${ }^{142}$ Personal interviews, Fujairah, September 2002, it was revealed that in 1998 an expatriate Arab judge imposed mutilation sentences on two offenders in Fujairah, this was sentence was soon overturned by the Supreme Court of Appeal.

${ }^{143}$ UNITED STATES DEPARTMENT OF STATE (2001), section 1(d)

${ }^{144}$ Ibid. section $1(\mathrm{e})$

${ }^{145}$ Ibid.

${ }^{146}$ FENELON (1973), pp.80-83

147 ABU DHABI PLANNING DEPARTMENT ECONOMIC DIVISION (1976), "Directive

Documents for the Preparation of the Economic and Social Development Plan of 1977-1979", Abu Dhabi, June 1976, pp.14

${ }^{148}$ A limit of eight branches was placed on each foreign banking house, thus allowing local banks such as the National Banks of Abu Dhabi and Dubai to dominate, see PECK (1986), pp.111-112

${ }^{149}$ ECONOMIST INTELLIGENCE UNIT (2000), pp.38-39

${ }^{150}$ UAE CENTRAL BANK (1991), “Annual Report 1991”, Abu Dhabi, pp.43

${ }^{151}$ UAE CENTRAL BANK (1996), "Annual Report 1996", Abu Dhabi

${ }^{152}$ In recent years these directors have included the bank's deputy chairman, Jumā Al-Majid Abdullah, who also serves as vice-president of Emirates Bank International, and Dr. Muhammad Kharbash, who now serves on the Council of Ministers as Minister of State for Finance and Industry, see APS REVIEW (1998), "UAE Profile: Dr. Muhammad Khalifa bin Kharbash" in "APS review gas market trends", New York, June 1998

${ }^{153}$ UAE CENTRAL BANK (1991), pp.39-47

${ }^{154}$ Ibid. pp.39-41, this recommendation was made in 1991

${ }^{155}$ AL-SHARHAN INTERNATIONAL CONSULTANCY (2000), "UAE Country Report 2000",

Dubai, pp.43, this recommendation was made in 2000

${ }^{156}$ See UAE CENTRAL BANK (1994), "Annual Report: 1994", Abu Dhabi, this recommendation was made in 1994

${ }^{157}$ AL-SHARHAN (2000), pp.41-42

${ }^{158}$ Ibid. pp. $43-45$

${ }^{159}$ DUBAI DEPARTMENT OF ECONOMIC DEVELOPMENT (1999), "Development Statistics",

Government of Dubai, pp.267

${ }^{160}$ ABU DHABI PLANNING DEPARTMENT ECONOMIC DIVISION (1976), pp.14; and personal interviews, Dubai, March 2002

${ }^{161}$ ECONOMIST INTELLIGENCE UNIT (2000), pp.6

162 EVERETT-HEATH, Tom (2002), "Dubai's financial future", in MIDDLE EAST

ECONOMIC DIGEST Volume 26 Number 8, $22^{\text {nd }}$ February 2002, pp.4, quoting Anis Al-Jallaf,

chairman of the DIFC's board of directors

${ }^{163}$ ECONOMIST INTELLIGENCE UNIT (2000), pp.6

${ }^{164}$ Ibid. pp.41; see section 4.5.1

${ }^{165}$ Personal Interviews, Abu Dhabi, March 2002

166 UAE CENTRAL BANK (2002), "UAE and Dubai: commercial banks", in DUBAI DEPARTMENT OF ECONOMIC DEVELOPMENT (2002), "Development Statistics", Government of Dubai, pp.155

${ }^{167}$ RICHARDS, Alan (2001), "Symposium on Shaykh Zāyid", in MIDDLE EAST POLICY, Volume 6 Number 4, June 1999, pp.7-11, quoting Alan Richards speaking at the $20^{\text {th }}$ April 1999 conference convened by the Middle East Policy Council

${ }^{168}$ Ibid.

${ }^{169}$ ECONOMIST INTELLIGENCE UNIT (2000), pp.38-39

${ }_{170}$ RICHARDS (2001), pp.7-11

${ }^{171} \mathrm{HSBC}$ and other organisations including Business Monitor International recently stated that the prevailing regulatory and commercial environment in the UAE would have to improve rapidly in order for high levels of investment to be maintained. Indeed, in the second quarter of 2001 Business Monitor International quite explicitly called for greater transparency concerning the UAE's economic data, and tighter federal legislation to counteract persistent fraud. See BUSINESS MONITOR 
INTERNATIONAL (2001), "The United Arab Emirates", second quarter 2001, pp. 15; and see HSBC Middle East (2001), "Foreign investment statistics for GCC states", Dubai, Second Quarter 2001

${ }^{172}$ RICHARDS (2001), pp.7-11

${ }^{173}$ RIZVI (1993), pp.669

174 lbid. pp.669

${ }^{175}$ HEARD-BEY (1996), pp.400

${ }^{176}$ See MUGSON, Steven (1991), "A Slam Heard 'Round the World: Closing of BCCI's Doors Leaves Unresolved Dilemmas", in The WASHINGTON POST, 23 ${ }^{\text {th }}$ July 1991; MUGSON, Steven (1991), "British Judge Delays Plan to Dismantle BCCI", in The WASHINGTON POST, $31^{\text {st }}$ July 1991;

HOAGLAND, Jim (1991), "Across the Cultural Chasm: BCCI Viewed from East and West", in The WASHINGTON POST, $5^{\text {th }}$ August 1991; and see TRUED, Peter and GURWIN, Larry (1992), "False Profits", New York, Houghton Mifflin

${ }^{177}$ KERRY, John and BROWN, Hank (1992), "The BCCI Affair: A Report to the Committee on Foreign Relations in the United States Senate by Senator John Kerry and Senator Hank Brown", Washington DC, 102nd Congress 2nd Session Senate Print, December, pp.102-140, in particular see 'Executive Summary: 'BCCI constituted international financial crime on a massive and global scale' 178 Ibid.

179 Ibid.

${ }^{180}$ Ibid. see 'Abu Dhabi: BCCI's founding and majority shareholders'

${ }^{181}$ Price Waterhouse Report Section 41 to the Bank of England, June 1991, Section 1.33, cited by KERRY and BROWN (1992), see 'Abu Dhabi: BCCl's founding and majority shareholders'

${ }^{182}$ Referring to the statements made by Al-Sayegh, Abu Dhabi's witness in the BCCI investigation, cited by KERRY and BROWN (1992), see 'Abu Dhabi: BCCI's founding and majority shareholders' 183 Ibid.

${ }^{184}$ Price Waterhouse Report Section 41 to the Bank of England, June 1991, cited by KERRY and BROWN (1992), see 'Abu Dhabi: BCCI's founding and majority shareholders: Abu Dhabi's Ownership Interest In $\mathrm{BCCI}$ '

${ }^{185}$ KERRY and BROWN (1992), see 'Abu Dhabi: BCCl's founding and majority shareholders: findings'

186 Ibid.

${ }^{187}$ See section 2.4 for a discussion of the unitary state

${ }^{188}$ Referring to the statements made by Al-Sayegh, Abu Dhabi's witness in the BCCI investigation, cited by KERRY and BROWN (1992), see 'Abu Dhabi: BCCl's founding and majority shareholders: Ghanim al-Mazrui'

${ }^{189}$ Price Waterhouse Report Section 41 to the Bank of England, June 1991, cited by KERRY and BROWN (1992), see 'Abu Dhabi: BCCI's founding and majority shareholders: Ghanim al-Mazrui' ${ }^{190}$ Based on staff interviews in BCCI and BCCE, cited by KERRY and BROWN (1992), see 'Abu Dhabi: BCCl's founding and majority shareholders: Abu Dhabi's Commitments in April-May, 1990’

191 KERRY and BROWN (1992), see 'Abu Dhabi: BCCI's founding and majority shareholders: AlSayegh's Testimony And Answers to Questions'

${ }_{192}$ Extracts, Federal Law No. (6) of 1973, Federal Law No. (10) of 1973, Federal Law No. (3) of 1983, cited by KERRY and BROWN (1992), see 'Abu Dhabi: BCCl's founding and majority shareholders'

${ }^{193}$ KERRY and BROWN (1992), see 'Abu Dhabi: BCCI's founding and majority shareholders: AlSayegh's Testimony And Answers to Questions'

194 Ibid.

195 Ibid.

196 See section 3.8 with regard to Dubai's diversification strategy

197 Personal interviews, Dubai, December 2001

198 BUSINESS MONITOR INTERNATIONAL (2000), "The United Arab Emirates", 2000 third quarter report, pp.9-10

${ }^{199}$ UNITED STATCS DEPARTMENT OF STATE (2001), section 2(a), newspapers began publishing articles critical of alleged inefficiencies in the delivery of services by the Ministries of Health, Education, and Electricity and Water. In August the English-language daily newspaper Gulf News featured a twopart expose on life in the Dubai women's central prison. A rare look into a women's correctional facility, the series included interviews with citizen and foreign prisoners, describing in depth a typical day in the prison.

${ }^{200}$ See section 5.5 .2

201 BUSINESS MONITOR INTERNATIONAL (2001), "The United Arab Emirates", 2001 second quarter report, pp.4-5

${ }_{202}$ KHALEEJ TIMES (2002), "UAE gets a clean chit", $6^{\text {th }}$ February 2002 ; also see section 2.2 .3

${ }^{203}$ Ibid.

${ }^{204}$ AL-SHARHAN INTERNATIONAL CONSULTANCY (2000), pp.41 
${ }^{205}$ BUSINESS IN DUBAI (2001), Dubai Chamber of Commerce and Industry, Volume 1 Issue 5, May 2001, pp.6, the programme's sponsor being Shaykh Muhammad Al-Maktūm

206 See section 4.4 .3

207 EVERETT-HEATH (2002), pp.4

${ }^{208}$ BUSINESS IN DUBAI (2002), "DIFC puts emirate on International financial Map", Dubai Chamber

of Commerce and Industry, Volume 2 Issue 15, March 2002, pp.8-9

${ }^{209}$ ECONOMIST INTELLIGENCE UNIT (2000), pp.22; also see section 3.8

${ }^{210}$ Ibid. pp.23

211 BUSINESS MONITOR INTERNATIONAL (1997), "The United Arab Emirates, 1995-1997", pp.17

${ }^{212}$ See section 4.3.1

${ }^{213}$ ECONOMIST INTELLIGENCE UNIT (2000), pp.9; and BUSINESS MONITOR

INTERNATIONAL (1997, pp. 17

${ }_{214}$ ECONOMIST INTELLIGENCE UNIT (2000), pp.9

${ }^{215}$ One such example being the Jumā Al-Majid Cultural Foundation east of Deira, where a number of Arabic language books and journals are made available to the public.

${ }^{216}$ See the earlier discussion of Shaykh Zäyid's policy in the late 1960s to accommodate certain graduates into his administration, and Shaykh Khalid al-Qẩsimi?'s attempts to give young graduates a role in the Sharjah government. See ABDULLAH, Muhammad Morsy (1978), "The United Arab Emirates: A Modern History", London, Croom Helm, pp.138 and pp.140; also see section 2.2.2

217 See section 4.2

${ }^{218}$ See APS REVIEW (1998)

219 Personal interviews, Abu Dhabi, March 2001

220 (in Arabic) AL-WASAT (1997), "UAE: youthful trend in UAE parliament", $22^{\text {ndt }}$ January 1997

221 Personal interviews, Abu Dhabi, March 2001

222 JOHNSON, ME (1997), "The lessons from Emār Properties Issue", in GULF NEWS, $17^{\text {th }}$ May 1997 , Michael Johnson is an associate of BSP Management Consultants, Abu Dhabi

223 Ibid.

${ }^{224}$ MIDDLE EAST ECONOMIC DIGEST (1994), "UAE Special Report", $1^{\text {st }}$ December 1994, pp.1416

225 Ibid.

${ }^{226}$ See section 3.8

${ }^{227}$ MIDDLE EAST ECONOMIC DIGEST (1994), pp. 14-16

${ }^{228}$ AL-NUHAYYAN (2000), pp.184

${ }^{229}$ Ibid. pp.122-123

${ }^{230}$ ECONOMIST INTELLIGENCE UNIT (2000), pp. 23

${ }^{231}$ Personal Interviews, Abu Dhabi, March 2002, "There are many efficient and dynamic organisations that would be more than capable of successfully competing in a liberalised economy without any of these restrictive rules and regulations. Indeed there are numerous Dubai and Abu Dhabi-based family companies ranging from Arabian sword vendors and tailors to cake shops and luxury soap manufacturers which not only offer value for money and efficient service, but have also embraced the opportunities of ecommerce and Internet marketing. Equally however, there are also many other groups that realise their businesses would be inefficient and uncompetitive in such an environment. Obvious examples would include those family businesses reliant on outdated technology and of course the many infant light manufacturing industries striving to make economies of scale."

232 SALDAMANDO, Martin (2001), "Big news for a dogged freedom", in STAR MAGAZINE, 11th November 2001

${ }_{233}$ GULF NEWS (1997), "Emăr to set up Dh700 million complex", $25^{\text {th }}$ November 1997

234 GULF NEWS (1997), "Emăr ups project outlay", 26 $6^{\text {th }}$ February 1998

${ }^{235}$ GULF NEWS (1997), "Emār to set up Dh700 million complex", $25^{\text {th }}$ November 1997

${ }^{236}$ GULF NEWS (1998), "Emār flies high with mega project", $19^{\text {th }}$ August 1998

237 THEODOULOU, M (2002), "Biggest man-made isles rise from the Gulf", in The TIMES, $5^{\text {th }}$ January 2002

${ }^{238}$ UAE MINISTRY OF INFORMATION AND CULTURE (2002), see www. uaeinteract.com, the

Ministry's official website

${ }^{239}$ Ibid.

${ }^{240}$ See section 4.4 .3

241 ECONOMIST INTELLIGENCE UNIT (2000), pp.41

${ }^{242}$ See section 3.5

243 FEDERATION OF UAE CHAMBERS OF COMMERCE AND INDUSTRY (1994), "The components of Investment and the methods of promoting investment opportunities in the UAE", Abu Dhabi, pp.36-37 
${ }^{244}$ KHALEEJ TIMES (1998), "Dubai Investments to lift returns, assets", $13^{\text {th }}$ May 1998

${ }^{245}$ KHALEEJ TIMES, (1998), "Dubai Investments Park excites investors Dubai", $25^{\text {th }}$ October 1998

${ }^{246}$ DUBAI GOVERNMENT (2000), "Dubai Technology, Electronic Commerce and Media Free Zone Law No.1", issued by Shaykh Maktūm Al-Maktūm in 2000

${ }^{247}$ ECONOMIST INTELLIGENCE UNIT (2000), pp. 23

${ }^{248}$ AL-SHARHAN INTERNATIONAL CONSULTANCY (2000), pp. 25-30

${ }^{249}$ DUBAI INTERNET CITY (2001), taken from the DIC's official brochure

${ }^{250}$ HOBBY, G (2001), "The development of the Dubai Internet City", Dubai, Gerard Hobby is an associate of al-Tamimi consultants

${ }^{251}$ EVERETT-HEATH (2002), pp.4, quoting Jamal Sanad al-Suwaidi of the Emirates Centre for Strategic Studies and Research (ECSSR)

${ }^{252}$ Ibid. pp.5

253 BUSINESS IN DUBAI (2002), pp.8n9

${ }^{254}$ AL-SHARHAN INTERNATIONAL CONSULTANCY (2000), pp. 25-30

${ }^{255}$ See section 3.2.1; and section 3.7

${ }^{256}$ BUSINESS IN DUBAI (2001), "Foreign Investments - Total blockade vis-a-vis open door policy", Dubai Chamber of Commerce and Industry, Volume 1 Issue 6, June 2001, pp.19-21

${ }^{257}$ Ibid. pp. $20-22$

${ }^{258}$ Ibid. pp. $20-22$

${ }^{259}$ Tbid. pp. $20-22$

${ }^{260}$ Ibid. pp. 20-22

${ }^{261}$ Ibid. pp. $18-19$

${ }^{262}$ Ibid. pp.16-18

${ }^{263}$ Ibid. pp.18-19 


\section{Globalisation and the prospects for Civil Society}

With the described reforms of the UAE's 'new rentiers' clearly encouraging the much touted forces of 'globalisation' and the 'new economy', it is the aim of this final chapter to assess the seemingly ambiguous impact of such increasing external influences on the UAE's dependent development and the future of its domestic structures. In particular, it will be suggested on the one hand how globalising forces, as extensions of the same international forces which created the dependent structures in the first place, may continue to reinforce the UAE's dependency-related domestic pathologies; while on the other hand something of a second wave of globalisation may be capable of surmounting such obstacles and engendering genuinely liberalising reforms. More specifically, following an overview of the main academic debate and a brief history of globalising forces in the region, the effects of globalisation on domestic businesses will be discussed, alongside the controversial 'globalisation versus regionalisation' issue, and the growing influence of international non-governmental organisations on Emirati economic structures. Secondly, the socio-cultural impact of globalisation will be measured, with particular emphases placed on the perceived erosion of Emirati heritage, the role of the Arabic language, and the influence of global mass media. Thirdly, this chapter will also outline what are believed to be the main preconditions for the development of civil society, before assessing the current state of rentier-dependency weakened associational life in the UAE, and the potential role of globalising forces in overcoming such impediments and fostering meaningful political development.

\section{1 - The globalisation dilemma}

Internationalised economies with widespread inter-state activities have existed for centuries, but in most cases individual national economies remained distinct and predominant. In more recent years, however, there has been a growing trend towards a more globalised economy in which such individual economies have been 
"subsumed and re-articulated into a system by international processes and transactions". This 'globalisation' can, therefore, be viewed as both an evolution and as a qualitative shift from internationalisation as it supplies functional integration to the previously dispersed economic activities of separate national economies. ${ }^{2}$ Furthermore, although globalisation has been regarded by political scientists as being primarily a characteristic of economic activity, it is, however, also a multidimensional force with the power of not only subsuming national economies but also of re-shaping national identities. Indeed, as many planners in the developing world have realised, while globalisation may on the one hand offer an escape route avoiding future economic marginalisation, at the same time it may also have serious implications for their indigenous political systems, societies, and cultures.

If the slogan of the annual Dubai Shopping Festival, "One World, One Family, One Festival" is to be taken literally, ${ }^{3}$ it would seem that the UAE, or at least Dubai, is prepared to embrace wholeheartedly the forces of globalisation. Certainly, as demonstrated earlier in this thesis, it would appear that the government of Dubai and its business community are both welcoming and actively encouraging foreign investment, international communications, and many of the other developments commonly associated with globalisation. Indeed, in citing a recent speech by Dubai's energetic and reforming crown prince, David Hirst illustrates this point well:

"Early last year His Highness General Shaykh Muhammad bin Makiüm announced at a press conference that the Internet revolution and the 'new global economy' were coming to Dubai. It was an incongruous spectacle: so traditional a figure, in distinctive black dishdāsha, delivering a pep talk like some wired and with-it corporate executive. As 'synergy', 'internetenabled solutions', 'cycle-time reduction' and suchlike flashed across a screen behind him, he swore he would have his globalised 'government@Dubai'fully in place within 18 months or else..."4 
Moreover, in the near future globalisation in Dubai is predicted to reach even higher levels following the much publicised 'Dubai 2003'; a massive event which will host members of the World Bank, the IMF, and other international organisations. This gathering is seen as confirming Dubai's position at the crossroads of the new global economy and, as the event's co-ordinator, Ibrahim Belselah, has described, "it will offer the opportunity for Dubai to reach out to global investors and decision-makers while affirming the emirate's credibility and stability." But has this same pro-globalisation attitude been shared by the other emirates and interest groups? As the earlier case studies regarding foreign property ownership and foreign business ownership have indicated, there has clearly been little consensus with many of the more conservative 'old rentiers' remaining firmly opposed to such reforms and wary of the perceived dangers of greater global integration. Certainly, by building upon the previous chapter's discussion of the role of foreign direct investment, ${ }^{6}$ it would appear that there is now also something of a national debate between those seeking to maximise the benefits of 'benign globalisation', and in contrast those wishing to maintain and augment the existing restrictions and regulations in an effort to preserve not only the UAE's national economy but also its distinct national society and culture.

To complicate the matter further, it would seem that neither camp has been able to present a definitive argument in their favour, given the paucity of real-world examples from other developing states experiencing similar conditions. Furthermore, on a more conceptual level, the abundance of both convincing pro and anti-globalisation literature has only served to fuel the debate, especially as both schools of thought would appear to be directly applicable to the UAE's development. Predictably, the antiglobalisation writings of Samir Amin ${ }^{7}$ and others reinforce dependency theory by tying in globalising forces with the capitalist interests of the core economies and the notion of unequal 'underdevelopment'. As such, globalisation is seen as a collection of 'predatory' socio-economic forces which will eventually incorporate and undermine peripheral nation states in order to allow for the greater expansion of capitalist markets. Therefore, within such a framework, globalisation is seen as leading to the loss of control over domestic economies and resources, generating disequilibrium and 
fragmentation within developing states, ${ }^{8}$ and of course also threatening national identity and eroding social cohesion. Thus, mindful of these dangers, the solutions suggested by the anti-globalisation theorists and many of the UAE's conservatives have centred around a more activist nation state capable of regulating potentially harmful forces and offering greater protection. In contrast, much of the recent pro-globalisation literature has provided support and solutions for those reformers seeking to liberalise the UAE's economy and welcome the forces of globalisation. ${ }^{9}$ Indeed, arguing that greater global integration, labour migration, improved communications, and other manifestations of 'convergence' will not only bring economic improvements but will also provide longterm social and political benefits, ${ }^{10}$ the pro-globalisation theorists suggest that developing states should not resist such changes, but should instead remove all obstacles in order to facilitate this inevitable transformation.

\section{2 - The historical antecedents of globalisation}

As Frauke Heard-Bey notes in her study of the Trucial Coast, for a long period the shared waters of the Persian Gulf not only served as conduits between the various shaykhdoms, but also as an economic lifeline to the rest of the world. ${ }^{11}$ Indeed, this 'lifeline' became especially evident at the turn of the century when a common regional interest in the profitable pearling industry began to encourage far greater contact and co-operation between the various towns and ports. Although certainly stunted by the described British exclusivity agreements and the region's subsequent incorporation into the British-Indian economic network; international trade, overseas markets, and labour migration nevertheless all became key features of the lower Gulf's economic life during this early period.

More recently, following the creation of the federation in the early 1970 s, there began a fresh wave of greater regional and international economic integration. As demonstrated, at this time the UAE's planners were concentrating heavily on a broad strategy of diversification, requiring the UAE's non-oil related sectors to expand in an effort to reduce the economy's reliance on its single primary product export. Such a 
strategy, especially with regard to the UAE's domestic export-based industries and commercial activities, therefore called for a far superior framework of co-operation not only between the UAE and the other Gulf States, but also between the UAE and potential international markets. ${ }^{12}$ Thus, from the 1970 s and onwards, the attempts to establish greater trade links led to a plethora of mutually beneficial industrial, commercial, and tourist agreements linking the UAE with many other states, predominantly those in South Asia and Africa, but also with some as far afield as Singapore and Brunei. ${ }^{13}$ Indeed, thirty years later many of these bilateral agreements are still in place, and can therefore be regarded as important antecedents of the region's more recent global economic integration.

Similarly, with regard to the socio-cultural globalisation of the region, it is also important to note that by the late nineteenth century the lower Gulf was already beginning to experience greater cultural influences from other parts of the Middle East and North Africa. Certainly, as Abdullah explains, this was especially evident following the opening of the Suez Canal in 1869:

\begin{abstract}
"Steam navigation routes reconnected the lower Gulf with Egypt after a rupture of about three hundred years. These new lines of communication also brought to the Gulf, as well as international mail, Cairo daily newspapers and literary magazines, thus helping to foster more of a political awareness within the educated groups. This was especially significant given the fact that before the First World War the Gulf did not even possess an Arabic printing press. "14
\end{abstract}

Moreover, during this period the region's previously narrow economic links with the Indian subcontinent also began to expand to include much greater cultural stimulation. Indeed, as the pearling industry reached its zenith, the international trading hub of Bombay had already grown rapidly in size and diversity, with the city widely regard as being a cosmopolitan cultural centre and as a symbol of 'British-western civilisation'. ${ }^{15}$ Given Bombay's close links with the Trucial Coast, particularly with Dubai, there is 
little doubt that much of this foreign influence also began to filter through to the lower Gulf. Bombay, like Cairo, possessed many printing presses, and a mixture of Indian and Egyptian-published volumes duly found their way into private libraries along the Trucial Coast. ${ }^{16}$ Furthermore, as Fatma Al-Sayegh describes, the increasingly frequent contact with Indian and other Arab merchants in Bombay was already leading to a much greater awareness of world developments and stimulated much greater political thinking among those in the lower Gulf. ${ }^{17}$

Of course by the time of the oil booms, the massive influx of foreign workers together with the vast consumption of imported goods, the improved communications, and the Emiratis' newfound ability to travel overseas, all considerably accelerated the region's socio-cultural global integration. Indeed, even in 1973, just two years after the creation of the federation, Kevin Fenelon remarked how

"... the presence of a large number of expatriates, drawn from many nations, cannot but have a great influence in breaking down conservatism, old habits, and prejudices against other ways of life, such as might have been felt in more isolated communities".18

Moreover, Fenelon also foresaw the influence of mass media and foreign travel on Emirati society and culture:

"... television and radio have done much to widen horizons, as these media penetrate into the home and thus reach all members of the family, including the women's quarters. The almost universal possession of transistor radios has brought the happenings of the outside world into relatively remote regions. In the towns, modern cinemas that show films in Arabic, English and Indian languages are very popular, again providing links' with the outside world. Merchants are well travelled, and it is not unusual for them to travel abroad several times a year. Many now are bringing their families on visits to Beirut, Cairo and Europe. In Oxford Street, London, ladies from 
the Gulf can be seen not infrequently in the summer doing their shopping, masked and veiled as they would be at home - a striking combination of the ultra-traditional with the most modern." 19

Writing ten years later, Malcolm Peck made similar observations, especially with regard to the increasing number of foreigners in the UAE's schools and universities. Certainly, by focusing on the example of the University of the UAE in Al'Ayn, he demonstrated how in the late 1970s and early 1980s local UAE students were beginning to come into much greater contact than ever before with foreign students and staff. In particular, he highlighted the Palestinian contingent of students, which at that time comprised the largest non-local student body in the UAE. The assumption was that increasing interaction with such groups would soon widen the socio-cultural horizons of Emirati students, and at the very least make them more receptive towards ideas such as Arab nationalism than previous generations. ${ }^{20}$ Although, as this thesis has shown, Arab nationalism has never really taken a firm hold in the UAE, ${ }^{21}$ there is nevertheless little doubt that Peck's broader socio-cultural predictions are being realised as expanding expatriate contingents continue to exchange ideas and experiences with the local youth.

\section{3 - The impact of globalising forces on the contemporary economy}

In more recent years, one of the most debated features of increasing economic integration and globalisation has been the seemingly inevitable increase in international competition, and of course the extent to which this will affect the UAE's domestic businesses. Unsurprisingly, in much the same way as the foreign investment question, the UAE's reformers and conservatives have remained at odds over the way in which the government and local Emirati enterprises should best adapt to these changes. On the one hand, many local Dubai businessmen appear positive and seem ready to accept a more liberal and global trading environment. Certainly, as 'Ahmad A1-Shaykh argues, Dubai family-based businesses will always have a place, and although they may have suffered initially due to international competition, they are nevertheless going to 
be well suited to change as their small size will allow for more streamlined decisionmaking and less bureancracy:

\begin{abstract}
"As such, their growth should be fast, and as long as laws are introduced to improve the transparency of family businesses, they can hope to reap the benefits of international markets, e-commerce, and improved global communications. "22
\end{abstract}

On the other hand, however, Muhammad Al-Meshrikh, a member of the Sharjah Chamber of Commerce and Industry, offers a more cautious perspective. Claiming that family-owned businesses cannot possibly hope to compete "in an open market with multinationals that own expert houses and huge capitals", he contends that globalising forces will soon require the UAE's family firms to either merge or to go public simply in order to survive. ${ }^{23}$ Although, as of yet, there are perhaps too few examples to accurately assess the impact of these forces on domestic businesses, it would seem that the pro-globalisation thinkers can nevertheless draw much comfort from the many small family enterprises, especially those in Dubai and Abu Dhabi, which have clearly seized the opportunities of globalisation and which have definitely begun to prosper in a greater international market. Among others, these have ranged from Arabian sword vendors and tailors to cake shops and luxury soap manufacturers, all of which not only offer value for money and efficient service, but have also adopted the concepts of ecommerce and Internet marketing in order to expand their customer bases. ${ }^{24}$

An equally complex issue has been the debate over globalisation versus regionalisation, with many UAE nationals arguing that another major economic impact of greater globalisation has been the stagnation and sidelining of the UAE's regional economic integration with the other Gulf States and the rest of the Arab world. Indeed, claiming that the UAE is now pursuing globalisation without first promoting regionalisation, many have asserted that individual national economies also need to be part of a strong regional economy which can be used as a safety net in times of crisis and instability as, in the event of an economic downswing, it is thought likely that the 
multinationals and other foreign companies will be the first to withdraw their investments from the UAE. Thus, it is argued that greater regionalisation should be seen as a necessary first step in order to consolidate the national economy and to provide a more effective launch pad from which to enter the global economy. ${ }^{25}$ Although in much the same way as the implications for domestic businesses, it is perhaps again too early to judge the long-term effects of globalisation over regionalisation, there are nevertheless already clear indications of such unbalanced economic integration. Certainly, as the following statistics highlight, there is now little doubt that the UAE's key trading partners have become almost exclusively nonregional, non-Arab economies:

Dubai: Major non-oil trading partners - imports

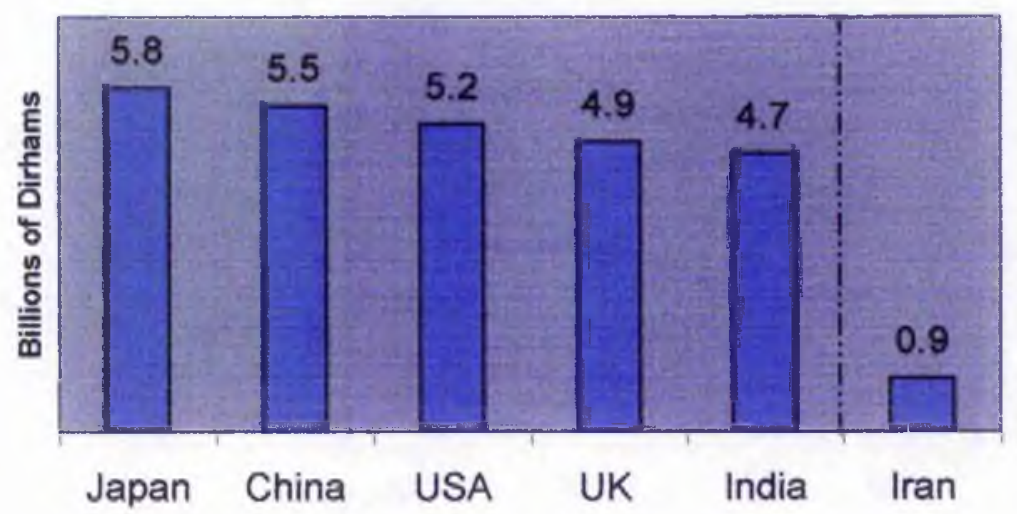

[Source: Dubai Department of Ports and Customs] ${ }^{26}$

Clearly, in the case of Dubai, the central hub of the UAE's trading activities, almost all of the emirate's imports currently originate from Western or Asian trading partners, with Iran, traditionally the UAE's highest placed regional partner, now ranking just twentieth. 


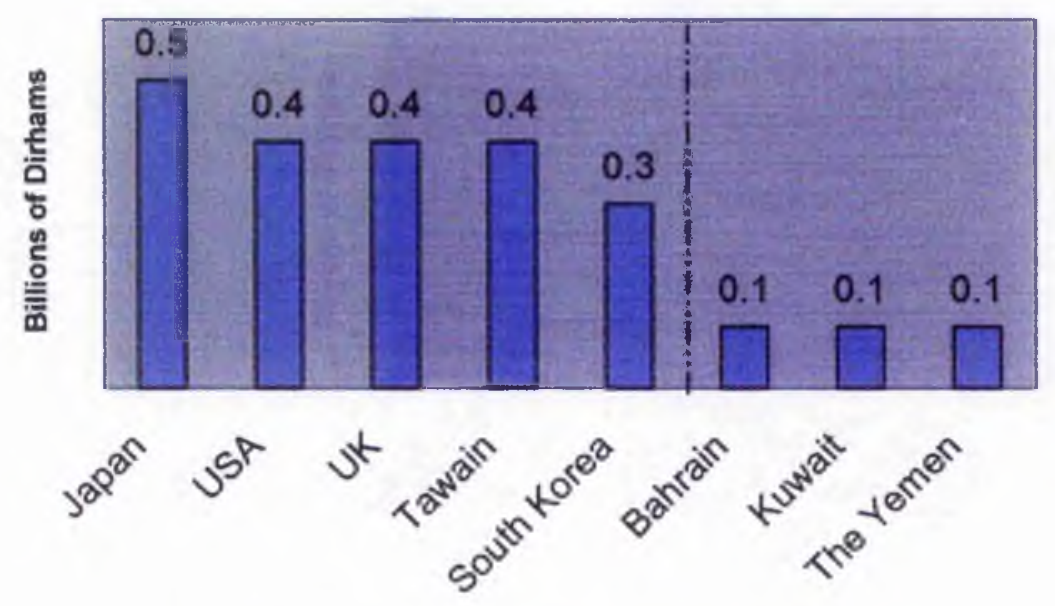

[Source: Dubai Department of Ports and Customs] ${ }^{27}$

Similarly, if Dubai's re-exporting activity is excluded, ${ }^{28}$ it would appear that, in addition to the aforementioned consumption / import bias and the resulting trade imbalance, ${ }^{29}$ almost all of the major trading partners for the UAE's exports are either Western or Far Eastern, with formerly significant regional partners such as Bahrain, Kuwait, and the Yemen now placed well outside of the top ten.

Moreover, with regard to investments, there is also believed to have been a discernable shift away from regional investment towards more global investment. Indeed, writing in the early 1990s, JE Jreisat had already highlighted the fact that although total Arab foreign investment was around $\$ 65$ billion (almost of all of which was held by the governments, banks, and ruling families of the Gulf), only $5 \%$ of all surplus funds accumulated by these oil rich states was actually invested back into the region. ${ }^{30}$ Similarly, with regard to foreign direct investment, it has been shown by Sari Hanafi in his recent study of the 'paradoxical effects of the UAE's political economy' how the UAE has become increasingly reliant on FDI from multinationals, with relatively little input from the Arab region. Specifically, the Jebel Ali Free Zone and the UAE's other export processing zones are seen as being particularly strong examples of this trend, and have been accused of being geared entirely towards globalisation while doing little to support and promote regional integration. Indeed, by 2000 , the 
Jebel Ali Free Zone comprised of over 1000 registered companies, of which about $32 \%$ were Asian, 30\% were European, 14\% were North American, and less than a quarter were Arab or Middle Eastem: ${ }^{31}$
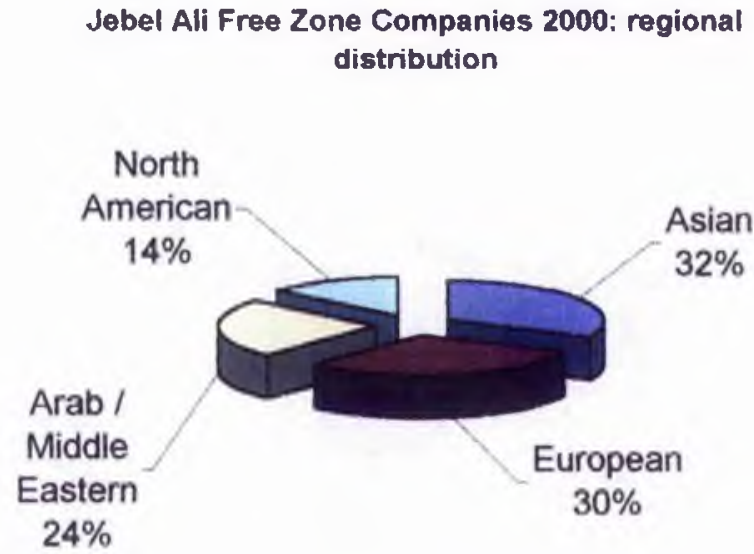

[Source: Jebel Ali Free Zone Authority 2000$]^{22}$

Thus, Hanafi convincingly argues that Arab investors have shied away from investing in such zones, claiming they feel less integrated with the structures than their European and North American counterparts. Moreover, it is also widely believed that many Arab investors are now reluctant to invest in the UAE and the other Gulf States given the long history of restrictive business practices and ownership regulations, such as the aforementioned kafil sponsorship system. Indeed, citing the experiences of many Palestinian businessmen and investors in the UAE, Hanafi claims that even though some of these restrictions are now being relaxed, the old memories are taking time to fade, and many prefer to invest elsewhere believing that the UAE is specifically targeting western investors and multinationals. ${ }^{33}$

Another significant aspect of globalising forces on the UAE's national economy has been the increasing presence and involvement of supranational economic organisations, most notably the Word Trade Organisation (WTO), the International Monetary Fund (IMF), and the United Nations Development Programme (UNDP). Although again it is perhaps rather premature to ascertain the relative positive or negative impact of such globalising influences on the UAE, it is nonetheless important to note that in some cases the ink has already dried on agreements signed between these 
organisations and the UAE, and in the very near future a number of these will come into effect, thereby permanently altering domestic economic structures. Moreover, as with all other globalisation-related issues in the $\mathrm{UAE}$, it is also important to recognise the deep divide which has emerged between the supporters and opponents of such involvement. While the most controversial of these future changes are likely to result from the region's increasing co-operation with the IMF, which is already believed to be urging the GCC states, including the UAE, to strengthen their extraction capabilities and maybe even to levy some form of income tax, ${ }^{34}$ the UAE's contentious membership of the WTO remains, however, the most visible example at present.

Regarded as institutionalising the national economy's integration into the global economic system, many local observers contend that WTO membership can only have long-term benefits for the economies of the Gulf States. ${ }^{35}$ Most notably, it is believed that the technical and organisational assistance now being provided to the Arab Monetary Fund by the WTO will soon enhance multilateral trading in the Arab region, thereby dispelling any of the above mentioned concerns over globalisation without regionalisation. ${ }^{36}$ Furthermore, many UAE businessmen and industrialists argue that WTO membership will soon lead to very tangible benefits resulting from the improved copyright controls and international patent law outlined by the WTO's TRIPS (Trade Related aspects of International Property Rights) agreement. ${ }^{37}$ Certainly it would seem that the UAE's infant industries require much greater protection from copying and infringement by third parties, which remains a very real problem given the slew of copyright-breaking products which flow into the region from South Asia and the Far East. Indeed, as Muhammad Al-Jabi1, a prominent Dubai banker, has explained, in recent years many of the UAE's new computer programming and media companies have a faced a serious threat from computer pirates operating throughout the country. Following the TRIPS agreement, however, Al-Jabil claims that pirated software have already begun to disappear from the UAE's computer stores, allowing copyrighted products to claim a greater market share. ${ }^{38}$ Other clear examples of beneficial patent control would include the rapid growth of the UAE's indigenous pharmaceutical industry. For some time, the UAE's pharmaceutical companies (most notably Julphar, 
Globalpharma, and Gulf Inject ${ }^{39}$ ) have struggled to establish their products alongside the plethora of low-cost, non-patented imports which have filled the shelves of most pharmacies, but following TRIPS, their position appears to have been greatly strengthened. ${ }^{40}$

In addition, other perceived advantages of WTO membership have included the proposed loosening of existing monopolies in the Gulf. Although such openings have not yet taken place, the UAE's WTO monopoly exemptions will expire in 2003, and the government may soon be required to promote full competition in previously monopolised sectors. A prime example will be the telecommunications sector where Etisalat's monopoly position will be reduced by 2005 as a direct result of the UAE's WTO agreements. Many locals argue that this will lead to lower prices and improved Internet products, especially as new independent service providers (ISPs) will be able to offer competitive alternatives. ${ }^{41}$ Also, excepting these potentially harmful monopolies, given that membership of the WTO still allows for a wide array of special customs and trade practices specific to particular members, many argue that the UAE and the other Gulf States need not fear any real loss of control over their national economies. Indeed, as the UAE's Minister of Economy and Commerce, Shaykl Fahim al-Qăsimi, has explained, although the UAE committed itself to the General Agreement on Tariffs and Trade (GATT) when it joined the WTO in 1996, the country nevertheless still maintains the right to impose special duties on imports in order to protect indigenous infant industries from harmful competition, and to prevent other undesirable aspects of greater openness such as economic dumping. ${ }^{42}$ Furthermore, as al-Tamimi consultants note, many of the existing restrictions on foreign firms based in the UAE will be unaffected by WTO membership. For example, the aforementioned $49 \%$ cap on foreign capital participation will remain unchanged, at least by the WTO, given that this specific Emirati business requirement applies equally to all WTO members operating inside the UAE, and therefore does not violate the organisation's principles of fair trade. ${ }^{43}$ Similarly, the UAE's continuing requirement that all registered commercial agents be $100 \%$ nationals of their respective country does not violate the General Agreement on Trade in Services (GATS). Thus, although fellow WTO member Bahrain has already 
voluntarily removed such a requirement, and the USA has lobbied heavily for such change elsewhere in the Gulf, the UAE remains well within its rights to retain these restrictions until it feels more comfortable to incorporate them into its own WTO 'Schedule of Commitments'. ${ }^{44}$ See appendix (viii).

In contrast, the opponents of WTO membership and the UAE's agreements with other international organisations have argued that such affiliations and commitments will soon lead to costly changes to the economic structures of the Gulf States. ${ }^{45}$ Indeed, presenting the flipside to the question of monopolies and the example of Etisalat, these opponents contend that it may be unwise to open up certain key components of the UAE's technological infrastructure to foreign and non-state controlled competition during what remains a relatively early stage of the UAE's development. Moreover, it also feared that despite the current WTO permitted UAEspecific restrictions, other future WTO agreements may still seek to remove the necessary layers of protection currently enjoyed by many of the UAE's infant industries. Without these layers, it is argued that some of the more recently established industries, including the UAE's booming textile and ready-made clothes firms, are likely to falter as they will face stiff competition from Asian and African imports. ${ }^{46}$

Furthermore, it has also been argued that at present there are insufficient long-term economic incentives to balance the losses likely to result from such a removal of protection. Indeed, as Ali Merza of the UNDP has demonstrated, membership of the WTO does not even provide any real assistance in the restructuring of economic systems for developing states, and as the UAE and the other Gulf States already have clear development strategies in place, they are believed to be already capable of implementing their own changes when deemed necessary. ${ }^{47}$ In addition, the UAE and its oil producing neighbours are seen to be especially disadvantaged by such membership given that they continue to rely on oil and gas products which, as of yet, remain outside of the WTO's list of reciprocal concessions. Thus, until hydrocarbons are explicitly included by the WTO, the Gulf States have few major financial incentives to join. Moreover, although the opponents accept that membership of the WTO does 
not interfere with a country's right to employ its own citizens first, it is nevertheless feared that such WTO affiliation may still affect the UAE's future labour nationalisation strategies, with 'emiratisation' legislation becoming harder to adopt as the UAE becomes increasingly expected to conform to international norms. ${ }^{48}$ Finally, it has also been noted that WTO membership may lead to certain unwanted political complications for the UAE and other Arab states. Indeed, as 'Ahmad Jiyad explains, although the UAE currently only grants 'most favoured nation' status to other GCC states, ${ }^{49}$ and still tends to rely on its long-established bilateral 'double taxation' treaties with other friendly countries, ${ }^{50}$ the terms of WTO agreements may, however, eventually require the UAE to grant the same favourable trade conditions to all other WTO member states, including boycotted states such as Israel. ${ }^{\text {si }}$

\section{4 - The impact of globalising forces on contemporary society and culture}

Alongside economic considerations, the impact of globalisation on a developing state's society and culture has also been recognised as a key motor of change, ${ }^{52}$ and the UAE has been no exception, with accelerating and often highly intrusive socio-cultural globalising forces having caused local divisions between those fearing and those ready to embrace such changes. Firstly, with regard to the opponents, perhaps the greatest concern has been over the perceived 'cultural contamination' of the UAE. Indeed, although the UAE's ALESCO (Arab League for Educational, Scientific, and Cultural Organisation) representatives now no longer publicly speak of a cultural invasion, ${ }^{53}$ and have instead begun to express their desire to promote 'fairness among other equally worthy cultures', ${ }^{54}$ there is, however, little doubt that a significant number of UAE nationals continue to blame globalising forces for the near-destruction of their country's heritage (turāth). ${ }^{55}$ Certainly as Sulayman Khalaf explains in his case study of Emirati culture, much of the lower Gulf's heritage was lost over the past thirty years, ${ }^{56}$ especially during the oil booms of the 1970 s and 1980 s when many of the region's traditional buildings were rapidly replaced with tenements and skyscrapers, and when many began to exchange their traditional ways of life for seemingly more westem and urban lifestyles. See appendix (ix). 
As such, many in the UAE and the other GCC states have reacted to the eroding effects of globalisation by initiating something of a modem-day cultural revival. Indeed, as Khalaf notes:

"...cultural revival is growing so fast as to reach levels of national industry in the Arabian Gulf societies... with... heritage revival appearing at this time juncture as an expanding national cultural industry. ".57

Indeed, museums were simply not necessary in the region in earlier times as traditional activities remained a part of everyday life, but as Khalaf argues, there is now seen to be an increasing need for 'living museums' and 'imagined communities' such as the Dubai Heritage Village, the Pearling Village, and the recently constructed Hatta Heritage Village, all of which have been created and promoted by the emirate-level tourism departments. Of course, this speedy reaction to potentially damaging globalising forces is of particular significance, especially given the government's in-built need to preserve and create 'living memories' to remind the population of their culture and heritage. ${ }^{58}$ Certainly, as this thesis has demonstrated, these museums and heritage centres are not only seen to be performing an increasingly necessary role in the UAE's economic diversification through tourism strategy, but have also served to reinforce an integral component of the traditional polity's legitimacy formula.

Related to this cultural erosion, the impact of globalising forces on the UAE's national language, Arabic, has also roused considerable opposition and has prompted strong reactions, often from the highest levels. Indeed, long considered a symbol of advanced civilisation and a source of great pride in the Arab world, the Arabic language is now becoming increasingly marginalised in the UAE. With massive and diverse non-Arab expatriate populations from the subcontinent and East Asia, in addition to significant British and European minorities, English has quickly become the lingua franca for almost all private sector gatherings ranging from board meetings to secretarial functions. Indeed, English is now the primary language in even some of the major semi-governmental organisations such as Dubai's Emirates Airlines. Similarly, 
Hindi is universally understood and frequently used by the less educated sections of the population engaged in retailing, transport, construction, and other blue-collar activities. In fact, even many of the young UAE nationals are now well acquainted with Hindi, having been brought by up Asian childcarers. Moreover, while other globalising forces such as English language television (including Arab-run English TV stations), ${ }^{59}$ films, DVDs, radio stations, and pop music are of course also contributing towards this marginalisation of the Arabic language, perhaps the most important factor, at least for the UAE's youth, will be the increasing use of English in their secondary and tertiary education. Certainly, for those schooled in the private sector, English will have been their primary medium of instruction from an early age. ${ }^{60}$ Indeed, in her recent study of the UAE's national identity, Sally Findlow supports this view by demonstrating the changing attitudes of Emirati students towards the use and necessity of Arabic. In a 1999 survey, she investigated student preferences for English and Arabic in UAE colleges, finding that nearly half of respondents were in favour of solely English instruction, 30\% wanted to have mixed English and Arabic instruction, and only $23 \%$ preferred to be taught in Arabic, simply claiming that it was 'their language':

UAE students' language preferences 1999

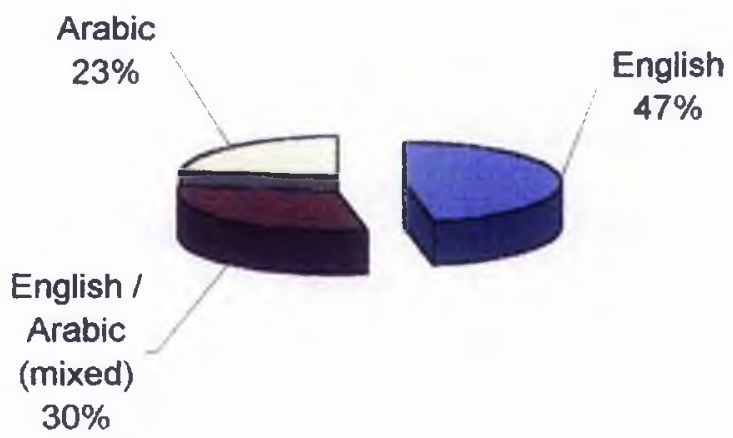

[Source: Findlow/ECSSR 2000] $]^{61}$

Understandably, groups such as the Arabic Language Protection Association have attempted to limit this erosion of the national language by unwanted globalising 
forces. As Abdullah Al-Madfa, the association's chairman explains, the main aim has been to:

\begin{abstract}
"...preserve the Arabic language from an awkward mix of foreign vocabularies and dialects, and to limit the negative influences of the multicultural environment on the UAE's official language. A quick observation of the language used at present indicates a looming catastrophe. The new generations are becoming more and more distant from their native tongue, fovouring other languages such as English. This has given rise to a new form of broken Arabic that combines various accents emerging on the surface. "62
\end{abstract}

Among its activities have been plans to correct miss-spelt Arabic shop signs and street names, plans to introduce new and more interesting Arabic language lessons in schools, and plans to increase the number of Arabic language tutors for expatriate workers. Significantly, these initiatives have found much support from government organisations, especially in Sharjah, where in an effort to check the spread of English and broken Arabic, the ruler decreed in late 2002 that all public departments shall in future use only Arabic in their correspondence and meetings. ${ }^{63}$

Although by no means universally supported, perhaps the most popular feature of greater socio-cultural globalisation in the UAE has been the improvement in global communications, especially given its perceived positive effects on improving government accountability and transparency. Indeed, as Mai Yamani notes with reference to the Gulf States, transnational media including satellite television stations and Internet sites have considerably loosened the state's grip over information and therefore reduced the relevance of state-controlled media. In particular, Yamani highlights the Kuwaiti Crisis as being a major turning point for public perception, arguing that the credibility of state television in the Gulf was irreversibly damaged as a result of its delayed and sanitised broadcasts regarding the Iraqi invasion and the cross border forays into Saudi territory. ${ }^{64}$ Gulf citizens could simply no longer rely on their 
own television stations for reliable information and instead switched their loyalties to global satellite channels such as CNN and the BBC. Moreover, although more closely related to regionalisation, these global-scale events were also seen as improving Arab media, by leading to greater demands for more probing and comprehensive Gulf news services capable of providing accurate information and reducing government opaqueness. Perhaps the strongest example of such development has been the creation of the Qatari-based Al-Jazira satellite station which, as Gerd Nonneman explains:

"... has broken through these traditions fof submissiveness, narrowness and dogmatism], and as a consequence has become one of the favourite sources of information in the Arab World (even if avoiding crilicism of Qatar's own ruler), however much regional regimes at times fulminate against it. ${ }^{\circ 55}$

Indeed, in 1994 the BBC World Service assisted in training Al-Jazira's Arab production crew and, as part of their training, the staff were encouraged to be more critical and questioning of government officials, a trend which appears to have been followed by most of the other Gulf satellite television stations in recent years. Certainly, as Yamani asserts, Al-Jazira and these other stations have led to something of a cultural competition between Gulf television stations as each attempts to produce the most sensationalist programming. ${ }^{66}$ Thus, although as the latter part of this chapter will demonstrate, the UAE's television stations have remained more cautious than their Qatari and Bahraini counterparts, it nevertheless remains possible that the snowball effect taking place elsewhere in the Gulf may eventually lead to changes in the UAE's media, thereby complementing the existing transparency initiatives.

\section{5 - Civil society and globalisation}

In his revealing study of neopatriarchal society and political change, Hisham Sharabi contends that many of the existing power structures in the Arab world cannot be overcome simply by revolution, modernisation or development. Instead, it is argued that the state-society relationship needs to fundamentally change from one of 
authoritarianism to one capable of humanising social relations and liberating political life. $^{67}$ Thus, for long-term political development and a shift in the existing order, Sharabi and many others believe that there first needs to be greater and more genuine civil society in the Arab world. Indeed, with regard to the UAE, this would seem a particularly sound hypothesis given the confirmed stability of its political structures and the resistance of its neo-patrimonial networks to rapid socio-economic development and the forces of modernisation. As such, this section will concentrate on the emergence of such civil society in the UAE, the problems faced, and the prospects for the future. In particular, following a suitable definition of the concept within the context of the UAE and a theoretical framework outlining the commonly regarded preconditions for successful indigenous growth, the contemporary state of Emirati civil society will be assessed and, specifically, it will be shown how high levels of financial and organisational co-option and the absence of any real cultural milieu (problems which can be seen as the rentier-dependency products of persisting patrimonial networks and a contimuing reliance on vast quantities of expatriate labour) have repressed and stunted associational life in the UAE. Finally, however, it will also be shown how certain new globalising forces including improved communications and the increasing presence of international NGOs may, unlike the earlier dependency-related external forces, be capable of reshaping these domestic civil society structures and catalysing the growth of stronger associations.

\subsection{1-Preconditions for the emergence of civil society}

What exactly is meant by 'civil society', and how should the term be best applied to the UAE? In her survey of civil society in southern Arabia, Sheila Carapico explored the strength of associational life and the proliferation of voluntary associations. ${ }^{68}$ Working within a similar framework to de Toqueville's earlier study of civil society, ${ }^{69}$ she demonstrated that in the Yemen there existed a network of institutions and associations which "operated in a pluralistic, continuously contested

public space or public civic realm, a zone between the state and private sectors". Moreover, she contended that the existence of such a zone in the emerging Arab states 
could serve as a "layer or buffer between government and households... representing a third, non-governmental, non-profit making, voluntary sector of modern society."70 Crucially, it was also suggested that such a layer might also include many seemingly traditional and tribal groups: a key factor with regard to the study of Emirati associational life given the previously described tribal nature of society in the lower Gulf. $^{71}$ Writing with a more general reference to the developing world, Mehran Kamrava has largely concurred with Carapico's view, while also highlighting the potential political power of civil society and, on a more individual level, also emphasising the existence of the many important social actors that often constitute civil society:

"Civil society gives rise to a very specific type of organisation, one that is social in its genesis and composition but can be political in its agendas and initiatives. It is an organisation that is formed out of the independent, autonomous initiatives of politically concerned individuals. These social actors are united by a common concern, ofien rallying around a specific issue (e.g. greater political space, less literary censorship, etc.). But irrespective of their specifics, if their demands on the state were met, they would either directly or indirectly result in a greater opening up of the political process. "72

Thus, in light of these definitions, examples of such civil society organisations could be seen to include a wide variety of voluntary and socially orientated associations ranging from women's organisations, charities, and expatriate community centres, to those with potentially greater political motivations such as human rights organisations, religious groups, media societies, and workers' associations. Secondly, as Carapico asserts, any evidence of independent intellectual production, including newsletters, poetry readings, and literary journals must also be considered, as these all form part of what Europeanists would define as being the 'civic realm'. Thirdly, any voluntarily organised, non-governmental, and non-commercial events such as academic seminars, conventions, demonstrations, and celebrations can 
also be considered a part of civil society, not least because they also provide an important outlet for the dissemination of ideas and the creation of public opinion. ${ }^{73}$ Finally, complementing these organisations, certain social actors can also be identified in most emerging civil societies, and, as Kamrava has shown, these can include a wide range of motivated persons including politicians, intellectuals, and journalists. ${ }^{74}$

Despite visibly possessing many examples of these associations and actors, civil society in the UAE has, however, remained weak, at least on one level, due to the absence of certain key prerequisites. Firstly, there is clearly a severe lack of "civic space'. Indeed, in their highly relevant study of resurgent associational life in Eastern Europe following the demise of the USSR, Weigle and Butterfield emphasised the necessity of autonomous civic space above all else. In particular, it was argued that without an institutional base capable of defining such space, a country's associations and actors would be rendered incapable of participation and voluntary organisation. ${ }^{75}$ As Carapico notes, in most states this civic space can usually be determined by an interrelated set of four factors:

1. The level of suppression or liberalisation as determined by the regime

2. The existence of a legal framework and constitutional framework that either excludes, tolerates or fosters civil society organisations

3. The level of public infrastructure necessary for the growth of civil society organisations, e.g. communications, buildings, etc.

4. The availability of economic resources for public, private, and voluntary sector investment

Together these factors effectively set the parameters within which associations and actors can press for greater tolerance, expanded services, and clearer separation of private from public wealth. ${ }^{76}$ Thus, on first inspection the UAE would appear to meet many of these preconditions, as both the regime and constitutional framework seem relatively tolerant of associational life, and the level of public infrastructure and the availability of economic resources are undoubtedly far higher than in most other 
developing states. However, as will be revealed, the UAE's civic space has actually remained extremely limited with a number of under-the-surface circumstances combining to prevent and discourage the emergence of genuinely independent associations. Certainly, as Carapico described of the nearby Yemen, "civil society is rarely a binomial event, either there or not, but instead a variable that assumes different forms under different circumstances." 37

Moreover, alongside these four factors regarding civic space, another important precondition for the emergence of civil society must also be considered, especially given the UAE's demonstrated reliance on large numbers of resident expatriates. $^{78}$ Specifically, it has been argued that for successful growth there must exist a homogenous national culture, rather than smaller cultural sub-groups which are likely to retain their own specific norms, rituals, and status. A vibrant civil society may therefore require a nationally uniform cultural milieu where there is seen to be a "standardisation of idiom" and where people are bound "not by segmentary, exclusivist institutions that differentiate, but rather by associations that are unsanctified, instrumental, revocable and yet effective."79 The many disparate groups of expatriates working and living in the UAE, many with little common middle ground, can therefore be seen as blocking this necessary precondition. Indeed, as former US Ambassador to the UAE, William Rugh, claims:

"... the UAE is not a 'melting pot'. Many separate and distinct social and ethnic groups reside in the UAE side by side, each maintaining its own cultural identity and tolerating the other in a 'live and let live' environment. The largest groups - Indians, Pakistanis, Bangladeshis, and Filipinos as well as the smaller ones such as the British, all have their own schools, their own clubs, and their own places of worship, and they tend to spend their leisure time with their own people. The foreigners learn just enough Arabic to get by. Many spend a minimal amount of their earnings, sending most of the money home to relatives. "80 
Although there are of course countries such as India where large sub-groups do exist and civil society does thrive, the sub-groups in the UAE are often temporary workers unwilling to involve themselves in what is perceived to be an alien society. As Rugh noted, this has led to an overall lack of engagement and a general sense of apathy in most of the expatriate groups. Moreover, by citing a rare example of street protests by Pathans in the UAE, he showed how the wealth and employment security offered by the rentier state was easily sufficient to quell any sustained civil society activism by expatriates:

"In December 1992 when a mob of Hindus in the Indian city of Ayodhya destroyed the Bahri Masjid Mosque, and Muslims protested in many places, Muslims in the UAE (mainly Pakistani) also took to the streets... These demonstrations lasted only about two days, however, as the government promptly rounded up several hundred suspects and deported them. The protests suddenly stopped. Jobs were more important. "8I

Indeed, given their cautious acceptance of their employers' sponsorship and their strictly temporary view of life in the Gulf, which is often regarded as a stepping stone to other countries and as a quick means of making money, ${ }^{82}$ the majority of the UAE's resident expatriates are extremely weak civil society actors lacking any strong cultural and institutional ties with the constituencies they serve or claim to represent. ${ }^{83}$

\subsection{2 - The co-option and patronage of civil society}

By further investigating the underlying problems which appear to be restricting Emirati civic space, and by combining these with the fragmented cultural milieu and the wealth-driven objectives of most of the population, this section will attempt to highlight some of the main weaknesses of contemporary civil society in the UAE. In particular, it will be shown how very few civil society associations are able to gain any genuine autonomy, with almost all being organisationally and financially tied to government ministries and ruling families, and with many of the more independent 
expatriate societies now facing increasing restrictions and regulations. Thus, as demonstrated in the discussion of the UAE's ruling bargain, even though there has of yet been little pressure for the polity to pursue a repressive maintenance strategy, ${ }^{84}$ there are nevertheless subtle indications of greater control being exercised over the UAE's many civil society organisations.

Certainly, in her study of the history of Emirati civil society, Fatma AlSayegh has emphasised this trend, arguing (albeit indirectly) that although there exists a long tradition of civil society in the region, in recent years almost all organisations have suffered from increasing government co-option:

"Civil society started before independence; in 1967 the first female society was established in Ra's al-Khaimah. Arab communities also were established before independence, and in 1978 there were 17 of them. During the 1980, many other civil society organisations appeared, all of which were dependent on government support... their development has been dependent largely on the development of the legal and executive bodies of the society itself." 85

Indeed, while the Federal Social Welfare Societies Law of 1974 did allow for the establishment of community societies, it is important to note that most public assemblies and associations in the UAE now require government approval, and, crucially, all private associations must now be licensed by local authorities. This follows an amendment in 1981 which effectively suspended the issuing of licences to such associations, reasoning that their existence posed a "significant threat to internal security" ${ }^{86}$ Moreover, even though by the end of 1999 there were still estimated to be more than 100 associations operating without such licences, a forthcoming amendment will ensure that all of these 'illegal' associations are soon brought under the govermment umbrella. In fact, this amendment will require all societies to legalise their status within six months of the new law, otherwise they will be automatically dissolved. Furthermore, as a senior official from the Ministry of Labour and Social affairs 
explained in late 2001, the law will give the ministries full "legal authority to oversee their activities" by allowing for the supervision of all their programmes, projects, and financial performances. ${ }^{87}$

By measuring, or at least indicating the extent of this co-option and dependence on government support, the following case studies will demonstrate some of the problems faced by the wide variety of UAE-based organisations. Specifically, the UAE's cultural, educational, and environmental groups, and their close ties to the government and the ruling families will be discussed. In addition, the many recreational, welfare, and women's groups will be investigated and, perhaps most significantly, the functioning of the UAE's religious groups, the freedom of its media associations, and the capabilities of its workers and professional associations will be considered. Finally, the restricted role of the many expatriate societies, which account for the vast majority of civil society organisations in the UAE, will also be assessed.

\begin{tabular}{|c|c|c|}
\hline $\begin{array}{l}\text { Cultural / Educational / } \\
\text { Environmental }\end{array}$ & National / Emirate specific & Description \\
\hline $\begin{array}{l}\text { Emirates Internet } \\
\text { Association }\end{array}$ & National & $\begin{array}{l}\text { Chaired by Shaykh Maktūm Al-Maktūm, } \\
\text { ruler of Dubai and the UAE's Prime } \\
\text { Minister. Membership restricted to UAE } \\
\text { Nationals }\end{array}$ \\
\hline $\begin{array}{l}\text { Emirates Association for } \\
\text { Revival of Folk Arts }\end{array}$ & National & $\begin{array}{l}\text { Receives funding from the Ministry of } \\
\text { Finance and Industry }\end{array}$ \\
\hline $\begin{array}{l}\text { Arabic Language Protection } \\
\text { Association }\end{array}$ & National & $\begin{array}{l}\text { An association which aims to preserve the } \\
\text { use of Arabic in UAE society }\end{array}$ \\
\hline Abu Dhabi Science Club & Abu Dhabi & \\
\hline $\begin{array}{l}\text { Emirates Heritage Club, Abu } \\
\text { Dhabi }\end{array}$ & Abu Dhabi & $\begin{array}{l}\text { Chaired by Shaykh Sultān Al-Nuhayyān, } \\
\text { deputy Prime Minister of the UAE }\end{array}$ \\
\hline Amateur Astronomers Group & Abu Dhabi & $\begin{array}{l}\text { Under the umbrella of the Emirates } \\
\text { Heritage Club }\end{array}$ \\
\hline Writers' Club & Abu Dhabi & \\
\hline $\begin{array}{l}\text { Dubai Art Lovers' } \\
\text { Association }\end{array}$ & Dubai & \\
\hline Emirates Art Centre, Sharjah & Sharjah & Close links to the Sharjah government \\
\hline $\begin{array}{l}\text { Sharjah Arts and Theatre } \\
\text { Association }\end{array}$ & Sharjah & Close links to the Sharjah government \\
\hline $\begin{array}{l}\text { Sharjah National Thealre } \\
\text { Group }\end{array}$ & Sharjah & Close links to the Sharjah government \\
\hline $\begin{array}{l}\text { Marine Club for Arts and } \\
\text { Tourism }\end{array}$ & Sharjah & Close links to the Sharjah government \\
\hline Kalba Folklore Association & Kalba, Sharjah & Close links to the Sharjah government ${ }^{92}$ \\
\hline $\begin{array}{l}\text { Filipino Association for } \\
\text { Computer Excellence }\end{array}$ & Nalional & $\begin{array}{l}\text { Elhnic (Far-east Asian) educational } \\
\text { association }\end{array}$ \\
\hline $\begin{array}{l}\text { Filipino Computer Club, } \\
\text { Dubai }\end{array}$ & Dubai & $\begin{array}{l}\text { Ethnic (Far-east Asian) educational } \\
\text { association }\end{array}$ \\
\hline
\end{tabular}




\begin{tabular}{|l|l|l|}
\hline $\begin{array}{l}\text { Filipino Culture and Sports } \\
\text { Club, Abu Dhabi }\end{array}$ & Abu Dhabi & $\begin{array}{l}\text { Ethnic (Far-east Asian) educational } \\
\text { association }\end{array}$ \\
\hline $\begin{array}{l}\text { Environmental Friends } \\
\text { Society }\end{array}$ & National & \\
\hline $\begin{array}{l}\text { Emirates Environmental } \\
\text { Group }\end{array}$ & National & \\
\hline
\end{tabular}

As one of the longest rumning cultural organisations in the UAE, the Emirates Association for the Revival of Folk Arts provides a good example of the increasing cooption of civil society. Formed in the 1980 s as a voluntary organisation aiming to revive traditional folk arts and protect Arab traditions from the influence of modern trends, the association issued 20,000 shares to its members and those interested in its activities in order to raise funds. However, before long the association was granted 'federal status', and although its activities remained seemingly autonomous, its budget began to be administered and allocated by the Ministry of Finance and Industry. ${ }^{94}$ In much the same way, the UAE's environmentalist groups also provide very clear examples of financial support from federal ministries. Normally associated with political activism in campaigning for animal rights and anti-pollution measures in most countries, the UAE's groups such as the Environment Friends Society and the Emirates Environmental Group have remained more restrained, concentrating on more limited goals regarding the UAE's nature reserves. These more sanitised objectives are undoubtedly due to the high level of co-option by the state, as these groups now receive generous annual budgets from the Ministry of Labour and Social Affairs. ${ }^{95}$ Similarly, at the individual emirate-level the picture is much the same, with obvious examples of cooption including the Abu Dhabi-based Emirates Heritage Club. Established by Emiri decree in 1997 and chaired by Shaykh Sultān Al-Nuhayyân, the UAE's deputy prime minister and a key member of the Abu Dhabian ruling family, the club effectively functions as an authority belonging to the Abu Dhabi government. Moreover, the club also acts as an umbrella organisation for a number of other Abu Dhabi clubs and societies including the Amateur Astronomers' Group, Marine Races, and the Emirates Sailing Academy. ${ }^{26}$ Indeed, this 'umbrella system' appears to have been replicated throughout civil society in the UAE, with many smaller organisations falling under the direct or indirect control of larger organisations which are either goverument controlled, or receiving patronage from members of the various ruling families. Significantly, in 
recent years some of these umbrella systems have even expanded to include formerly independent clubs and societies. Examples would include the many youth and youthrelated recreation clubs for UAE nationals, which although originally voluntary associations with autonomous budgeting, are now all linked under a federal umbrella organisation represented by the Supreme Council for Youth. ${ }^{97}$

Perhaps the strongest examples of the co-option of cultural and educational organisations are, however, to be found in the emirate of Sharjah which, as explained, has long prided itself as being the cultural and intellectual capital of the UAE. Indeed, as the Press Affairs Directorate of the Sharjah Emiri Court describes, by the end of the 1980s there were 26 such organisations based in the emirate. These included eight cultural societies, six art associations such as the Sharjah Arts and Theatre Association, the Sharjah National Theatre Group, the Marine Club for Arts and Tourism, and five significant 'public interest' associations ranging from literary societies to folklore associations. Between the mid-1970s and the late 1980s these associations received more than 100 million Dirhams in financial contributions from the Sharjah government and, as described by the Directorate, also received significant "financial and / or moral support from the ruler, HH Shaykh Dr. Sultān bin Muhammad al-Qāsimī" ${ }^{98}$ As this royal patronage and high level of government sponsorship appears to have continued unabated in Sharjah throughout the 1990s, ranging from financial backing for theatrical gatherings to organisational support for anti-smoking rallies, ${ }^{99}$ it would seem that the smaller cultural and educational civil society organisations at the emirate level have lacked autonomous civic space in much the same way as their federal counterparts, even if this may have been unintentionally caused by their ruler's great benevolence and genuine patronage of the arts.

Finally, with regard to educational associations, the role of academics must also be discussed. As described in the study of social growth, there has been a rapid increase in the number of academics and other university-related staff in the UAE given the massive expansion of the higher education sector in recent years, ${ }^{100}$ and, as many civil society theorists claim, such intellectual social actors can play a major part in 
associational life. To a limited extent, this has taken place in the UAE as, following the Gulf War, it was observed that:

"In 1991, after Desert Storm, there was some informal discussion among a small group of educated nationals about the possibility of increased democratic participation in governance, and this was reported in the press at the time. Although it did not result in a significant movement in the UAE working for democratic reform, students and intellectuals still occasionally discuss the subject privately. "101

However, for the most part there exists an unwritten but generally recognised ban on criticism of the government from such circles. In practise, this unwritten ban is normally enough to enforce self-censorship among academics, especially given that many are expatriates and are therefore cautious of jeopardising their employment in their host country, although on some occasions, as will be detailed later in this section, the ban can become very real. Furthermore, given that the government now tightly restricts the freedom of peaceful assembly and that all public gatherings require a permit, there would appear to be considerable disincentives for those academics attempting to organise seminars and conferences on sensitive subjects. ${ }^{102}$

\begin{tabular}{|c|c|c|}
\hline Recreational & National / Emirate speciffc & Description \\
\hline UAE Football Association & National & \\
\hline $\begin{array}{l}\text { UAE Equestrian and Racing } \\
\text { Federation }\end{array}$ & National & $\begin{array}{l}\text { Federation of all Emirati horseracing } \\
\text { organisations }\end{array}$ \\
\hline UAE Golf Association & National & $\begin{array}{l}\text { Chaired by Muhammad Al-Abbar, } \\
\text { Director General of Dubai's Economic } \\
\text { Development Department, chairman of } \\
\text { Dubai Aluminium and chairman of Emañ } \\
\text { Properties }{ }^{103}\end{array}$ \\
\hline Emirates Cricket Club & National & \\
\hline $\begin{array}{l}\text { Emirates Gentlemen's Golf } \\
\text { Society }\end{array}$ & National & \\
\hline $\begin{array}{l}\text { Abu Dhabi International } \\
\text { Marine Sports Club }\end{array}$ & Abu Dhabi & \\
\hline Marine Races, Abu Dhabi & Abu Dhabi & $\begin{array}{l}\text { Under the umbrella of the Emirates } \\
\text { Heritage Club }\end{array}$ \\
\hline $\begin{array}{l}\text { Emirates Sailing Academy, } \\
\text { Abu Dhabi }\end{array}$ & Abu Dhabi & $\begin{array}{l}\text { Under the umbrella of the Emirates } \\
\text { Heritage Club }\end{array}$ \\
\hline Al-'Ayn Cricket Associalion & Al-'Ayn, Abu Dhabi & \\
\hline Dubai Football Club & Dubai & $\begin{array}{l}\text { The president and main organiser of the } \\
\text { club is Shaykh Rāshid bin Muhammad Al- }\end{array}$ \\
\hline
\end{tabular}




\begin{tabular}{|l|l|l|}
\hline & & Maktūm, the son of the Crown Prince \\
\hline Dubai R/C Pilots Club & Dubai & $\begin{array}{l}\text { Club for radio-controlled aircraft } \\
\text { enthusiasts }\end{array}$ \\
\hline Filipino Chess Players Club & National & $\begin{array}{l}\text { Ethnic (Far-east Asian) club for Filipino } \\
\text { members }\end{array}$ \\
\hline Indian Sports Club Dubai & Dubai & Ethnic (sub-continent) club for Indians \\
\hline Filipino Dance Club, Dubai & Dubai & $\begin{array}{l}\text { Ethnic (Far-east Asian) club for Filipino } \\
\text { members }\end{array}$ \\
\hline $\begin{array}{l}\text { Light form Filipino } \\
\text { Pholographers Guild, Dubai }\end{array}$ & Dubai & $\begin{array}{l}\text { Ethnic (Far-east Asian) club for Filipino } \\
\text { members }\end{array}$ \\
\hline Filipino Dance Club, Sharjah & Sharjah & $\begin{array}{l}\text { Ethnic (Far-east Asian) club for Filipino } \\
\text { members }\end{array}$ \\
\hline
\end{tabular}

The recreational and sports clubs which exist in the UAE also paint a picture of government co-option and royal patronage. Although, unlike some of the cultural and educational organisations, their membership is not always restricted to UAE nationals, they nevertheless clearly cater for a divided heterogeneous society, with certain clubs aimed at Emiratis, with some targeting western expatriates, and with separate and specific ethnic-based groups existing for the various other expatriate communities. As demonstrated, a number of the smaller recreational clubs such as the Emirates Sailing Academy and Marine Races are operated by emirate-level semi-governmental authorities such as the Emirates Heritage Club, while in much the same way many of the larger associations responsible for the more popular sports such as horseracing, golf, cricket, and football, are controlled by federal umbrellas organised and chaired by government ministers, members of the ruling families, or other notables. The UAE Golf Association provides such an example given that its chairman is Mulhammad AlAbbar who, as described in the previous chapter, is not only a key associate of Shaykh Muhammad Al-Maktūm but also serves as the Director General of the Dubai Department of Economic Development and as the chairman of Emār Properties. ${ }^{105}$ Similarly, the Dubai Football Club also has very close links with the ruling family given that its president and main organiser is Shaykh Răshid bin Muhammad Al-Maktūm, one of Shaykh Muhammad's sons. Indeed, in a recent Ramadan football tournament organised by the club, it was clear just how far the club's royal patronage extended with many of the participating teams being captained by young Shaykhs and with the prize money and 'inspiration' for the event having been provided by Shaykh Muhammad himself. ${ }^{106}$ 


\begin{tabular}{|c|c|c|}
\hline Welfare & National / Emirate specific & Description \\
\hline $\begin{array}{l}\text { Handicapped Guardians' } \\
\text { Association }\end{array}$ & National & $\begin{array}{l}\text { This association restricts membership to } \\
\text { UAE nationals and is presided over by } \\
\text { Shaykh Sultān al-Qāsimī, ruler of } \\
\text { Sharjah } \\
{ }^{107}\end{array}$ \\
\hline Juveniles Association & National & \\
\hline $\begin{array}{l}\text { Emirates Volunteers } \\
\text { Association }\end{array}$ & Sharjah & $\begin{array}{l}\text { An organisation aiming to encourage } \\
\text { volunteer workers in the field of } \\
\text { healthcare, care for the elderly, etc. Has a } \\
\text { close relationship with Shaykh Sultân al- } \\
\text { Qāsimi, the ruler of Sharjah, and is } \\
\text { chaired by Humaid al-Qutami, the general } \\
\text { manager of the government-funded } \\
\text { Enirates Institute for Banking and } \\
\text { Financial Studies }{ }^{108}\end{array}$ \\
\hline $\begin{array}{l}\text { Emirates Volunteers } \\
\text { Association }\end{array}$ & Khor Fakkān, Sharjah & $\begin{array}{l}\text { Under the umbrella of the Sharjah } \\
\text { Association }\end{array}$ \\
\hline $\begin{array}{l}\text { Emirates Volunteers } \\
\text { Association }\end{array}$ & Ra's al-Khaimah & \\
\hline
\end{tabular}

Voluntary organisations and associations attempting to provide care for the handicapped and elderly also exhibit clear signs of government co-option. They are required to hold licences from the Ministry of Labour and Social Affairs and most, like many of the UAE's cultural associations, restrict their membership to UAE nationals. The Handicapped Guardian's Association is one such example. Established in 1996 in accordance with the directions of Shaykh Sultān al-Qāsimi, the ruler of Sharjah, the organisation is now also headed by Shaykh Sultān in addition to being funded by the government. ${ }^{109}$ The Emirates Volunteers Association is broader in scope than many of the UAE's other welfare organisations given that it accepts both UAE national and expatriate members in its attempt to create a large body of volunteer workers in the fields of healthcare, helping the elderly, and protecting the environment. However, the association also displays clear signs of co-option and patronage, maintaining close links with the Sharjah ruling family and other local elites. Indeed, it receives generous awards and prizes from Shaykh Sultān and is chaired by Humaid al-Qutami, the general manager of a key government funded institute ${ }^{110}$ (the Emirates Institute for Banking and Financial Studies ${ }^{111}$ ). Also, given that subordinate branches of the association are now opening in Khor Fakkān and Ra's al-Khaimah, it would appear that the civil society unbrella system is again being reproduced with the newer associations operating under the auspices of the original Sharjah-based authority. 


\begin{tabular}{|c|c|c|}
\hline Women's groups & National/Emirate specific & Description \\
\hline UAE Women's Federation & National & $\begin{array}{l}\text { The honorary president is Shaykha Fatima } \\
\text { Al-Nuhayyãn }\end{array}$ \\
\hline General Women's Union & National & $\begin{array}{l}\text { The president is Shaykha Fatima Al- } \\
\text { Nuhayyān }\end{array}$ \\
\hline $\begin{array}{l}\text { Women's Committee of the } \\
\text { Red Crescent Society }\end{array}$ & National & $\begin{array}{l}\text { Sub-committee of the Red Crescent } \\
\text { Society charity organisation. The } \\
\text { president is Shaykha Fatima Al-Nuhayyân }\end{array}$ \\
\hline $\begin{array}{l}\text { Abu Dhabi Women's } \\
\text { Society }\end{array}$ & Abu Dhabi & $\begin{array}{l}\text { The president is Shaykha Fatima Al- } \\
\text { Nuhayyân }\end{array}$ \\
\hline $\begin{array}{l}\text { Association for the } \\
\text { Awakening of Abu Dhabian } \\
\text { Women }\end{array}$ & Abu Dhabi & $\begin{array}{l}\text { The president is Shaykha Fatima Al- } \\
\text { Nuhayyän }\end{array}$ \\
\hline $\begin{array}{l}\text { Women's Business Council } \\
\text { Abu Dhabi }\end{array}$ & Abu Dhabi & $\begin{array}{l}\text { The president is Shaykha Fatima Al- } \\
\text { Nuhayyän }\end{array}$ \\
\hline Dubai Women's Association & Dubai & \\
\hline Sharjah Women's Club & Sharjah & $\begin{array}{l}\text { Established by Shaykh Sultän al-Qāsimī, } \\
\text { ruler of Sharjah, and chaired by his wife, } \\
\text { Shaykha Jawehr }\end{array}$ \\
\hline Young Ladies' Club & Sharjah & $\begin{array}{l}\text { Under the umbrella of the Sharjah } \\
\text { Women's Club }\end{array}$ \\
\hline $\begin{array}{l}\text { Emirates Women Writers' } \\
\text { Association }\end{array}$ & Sharjah & $\begin{array}{l}\text { Under the umbrella of the Sharjah } \\
\text { Women's Club }\end{array}$ \\
\hline $\begin{array}{l}\text { Umm al-Mominīn Women's } \\
\text { Association }\end{array}$ & Ajman & $\begin{array}{l}\text { Recipient of 'Rāshid Award' funding from } \\
\text { the 'Ajman ruling faunily }\end{array}$ \\
\hline Tamil Ladies Association & National & $\begin{array}{l}\text { Ethnic (sub-continent) women's } \\
\text { association for Tamilian Indians }\end{array}$ \\
\hline $\begin{array}{l}\text { Indian Ladies Association, } \\
\text { Abu Dhabi }\end{array}$ & Abu Dhabi & $\begin{array}{l}\text { Ethnic (sub-continent) women's } \\
\text { association for Indian expatriates }\end{array}$ \\
\hline $\begin{array}{l}\text { Kerala Emirates Ladies } \\
\text { Association, Abu Dhabi }\end{array}$ & Abu Dhabi & $\begin{array}{l}\text { Ethnic (sub-continent) women's } \\
\text { association for Keralites from the South of } \\
\text { India }\end{array}$ \\
\hline
\end{tabular}

Many of the national and Abu Dhabi-based women's organisations are government funded and are indirectly connected to the Abu Dhabi ruling family by either their chairperson or president, often Shaykha Fatima Al-Nuhayyãn, the wife of Shaykh Zāyid and therefore the UAE's 'first lady'. A recent example of such co-option would be the establishment of the Women's Business Council in 2001 by a number of female entrepreneurs in Abu Dhabi. The Council's main aim has been to provide a forum for female nationals to

"... meet and discuss the issues of their common interest and exchange views on their expectations and aspirations in the world of business and finance... and to provide a connecting link between government and semi-government authorities on the one hand, and businesswomen on the other hand, to overcome obstacles and problems. These would include marriage and 
family responsibilities, and society's perception of a businesswoman and its doubts about her ability to succeed." 114

Recent actions have included applying pressure on the government to grant greater maternity leave at full pay and to provide superior childcare facilities in the workplace. $^{115}$ However, while apparently a voluntary association organised by likeminded businesswomen, the Council does not have true autonomy over its organisation. In addition to requiring approval for its actions from the Federation of Chambers of Commerce and Industry, the association is also closely linked to Shaykha Fatima, who also serves as the chairperson of the UAE Women's Federation, the Abu Dhabi Women's Society, the Women's General Union, the Association of the Awakening of Abu Dhabian Women, and the Women's Committee of the Red Crescent Society. ${ }^{116}$ As such, the genuine independence of the Council's views and activities from those of the state and the Âl-Nuhayyān would seem questionable.

Similarly in Sharjah, most women's groups are linked to the establishment through Shaykha Jawaher al-Qāsimī, the wife of Shaykh Sultān. Specifically, the Sharjah Women's Club, which was set up in 1982 and financed by the ruler's office, has since been chaired by Shaykha Jawaher and has now branched out to include clubs in other parts of Sharjah and Khor Fakkān. Predictably, many of the other women's associations in the emirate, such as the Emirates Women Writers Association and the Young Ladies Club, fall under the club's administrative and financial umbrella. In other emirates, including 'Ajman, the pattern is much the same with organisations such as the Uimm al-Mominīn Women's Association receiving 'Rāshid Award' funding from the 'Ajman ruling family and support from the local government. ${ }^{117}$

\begin{tabular}{|l|l|l|}
\hline $\begin{array}{l}\text { Islamic / Charity } \\
\text { organisations }\end{array}$ & National / Emirate spectfic & Descriptlon \\
\hline Al-Muntada al-Islami & Sharjah & $\begin{array}{l}\text { A society dedicated to promulgating and } \\
\text { popularising lslamic principles among all } \\
\text { sectors and classes of the local } \\
\text { population. }\end{array}$ \\
\hline Indian Islahi Centre, Sharjah & Sharjah & Ethnic (sub-continent) Islamic centre \\
\hline $\begin{array}{l}\text { Indian Islahi Centre, Ra's al- } \\
\text { Khaimah }\end{array}$ & Ra's al-Khaimah & Ethnic (sub-continent) Islanic centre \\
\hline
\end{tabular}




\begin{tabular}{|c|c|c|}
\hline Indian Islamic Centre, Dubai & Dubai & Ethnic (sub-continent) Islamic centre \\
\hline $\begin{array}{l}\text { Indian Islamic Centre, Abu } \\
\text { Dhabi }\end{array}$ & Abu Dhabi & Ethnic (sub-continent) Islamic centre \\
\hline $\begin{array}{l}\text { Indian Islamic Centre, Ra's } \\
\text { al-Khaimah }\end{array}$ & Ra's al-Khainalı & Ethnic (sub-continent) Islamic centre \\
\hline Red Crescent Society UAE & National & $\begin{array}{l}\text { Umbrella Islamic charity organisation. } \\
\text { Receives funding from local governments } \\
\text { and the ruling families and often } \\
\text { distributes funding to other Islamic } \\
\text { charities in the UAE. Shaykh Hamdan } \\
\text { Al-Nuhayyān, the Minister of State for } \\
\text { Foreign Affairs is the president, and } \\
\text { Khalifa al-Suwaidi is the chairman } \\
\text { 119 }\end{array}$ \\
\hline $\begin{array}{l}\text { Women's Committee of the } \\
\text { Red Crescent Society }\end{array}$ & National & $\begin{array}{l}\text { Sub-comminttee of the Red Crescent } \\
\text { Society charity organisation. The } \\
\text { president is Shaykha Fatima Al- } \\
\text { Nuhayyân, the wife of Shaykh Zâyid and } \\
\text { the 'first lady' of the UAE' }\end{array}$ \\
\hline $\begin{array}{l}\text { Al-Islah wal-Tawjith } \\
\text { Association }\end{array}$ & National & $\begin{array}{l}\text { Charitable association which has most } \\
\text { recently concentrated on raising funds for } \\
\text { the Iraqi people }\end{array}$ \\
\hline $\begin{array}{l}\text { Shaykh Muhammad Al- } \\
\text { Maktūm Humanitarian and } \\
\text { Charitable Foundation }\end{array}$ & Dubai & $\begin{array}{l}\text { Unifies the relief efforts of other Dubai } \\
\text { charities. Presided over by Shaykh } \\
\text { Muhammad Al-Maktūm, Crown Prince of } \\
\text { Dubai, and chaired by Ibrahim Bu Melha, } \\
\text { Dubai's equivalent of an Attorney } \\
\text { General' }{ }^{122}\end{array}$ \\
\hline $\begin{array}{l}\text { Shaykha Latifa Charity for } \\
\text { Children's Creativity }\end{array}$ & Dubai & $\begin{array}{l}\text { Chaired by Shaykh Muhammad's } \\
\text { daughter and operates under the auspices } \\
\text { of the Shaykh Muhammad Humanitarian } \\
\text { and Charitable Foundation }\end{array}$ \\
\hline Sharjah Charity Association & Sharjah & \\
\hline $\begin{array}{l}\text { Inlernational Islamic Relief } \\
\text { Organisation of Sharjah }\end{array}$ & Sharjah & \\
\hline Fujgarah Charity Association & Fujairah & $\begin{array}{l}\text { Most recently, the association has been } \\
\text { concentrating on fund raising for } \\
\text { Palestinian relief }\end{array}$ \\
\hline $\begin{array}{l}\text { Zakāt Committee of Ra's al- } \\
\text { Khaimah }\end{array}$ & Ra's al-Khaimah & $\begin{array}{l}\text { Most recently the committee has co- } \\
\text { operated with the Shaykh Muhammad } \\
\text { Humanitarian and Charitable foundation } \\
\text { in raising funds for the Iraqi people }{ }^{124}\end{array}$ \\
\hline Indian Relief Committee & Ra's al-Khaimah & $\begin{array}{l}\text { Ethnic (sub-continent) charitable group } \\
\text { patronised by Indian expatriates }\end{array}$ \\
\hline Marniage Fund Associations & Local, informal & $\begin{array}{l}\text { A plethora of informal associations exist } \\
\text { with the aim of raising funds for UAE } \\
\text { national men to marry UAE national } \\
\text { women }{ }^{\text {j2S }}\end{array}$ \\
\hline
\end{tabular}

As explained earlier in this thesis, religious resources continue to play a key unifying role in the polity's legitimacy formula. ${ }^{126}$ As such, almost all mosques, ulamä', and Islamic related organisations are carefully controlled by the government in its efforts to prevent any potentially harmful radicalism or religious-political opposition. Indeed, $95 \%$ of Sunni mosques in the UAE are state-owned, with the remaining $5 \%$ receiving large government subsidies. The only exceptions being the small number of 
privately funded Shi'a mosques, but even these, in Dubai at least, are now being brought under local government control. In addition to this financial co-option, the federal Ministry of Justice and Islamic Affairs (together with local emirate-specific departments) employs all Sunni Imāms and distributes weekly guidance to Sunni clergymen regarding their religious sermons, thereby ensuring adherence to ministryapproved topics. $^{127}$ Indeed the Minister of Justice and Islamic Affairs, Muhammad alDhahiri, has been quite clear on this point, having admitted in a recent interview that his departments do exercise considerable 'quality control' over religious preaching and the UAE's mosques:

"The Islamic world is teeming with people who claim knowledge about Islam, but experience has shown that many of the people who applied to the Awqaf department for the posts of Imâms in the mosques were far below the required standards. ... It was therefore necessary to set regulations and criteria for regulating religious teachings... The ministry also provides written Friday sermons (Khutba) to be read out to the faithful. Those Imâms who have proven themselves to be qualified and skilful are allowed to choose topics on their own free will provided that they inform the ministry about these topics. "l2s

Moreover, in much the same way as the mosques, most of the UAE's other Islamic associations and charities have also been co-opted by the government. Certainly, while some Islamic societies which aim to popularise Islam are permitted, these are either government funded, or are carefully screened. Examples would include Al-Muntada al-Islami in Sharjah with its primarily Emirati membership, ${ }^{129}$ and the various expatriate Islamic societies serving the many Pakistani and Indian Muslims working in the UAE. With regard to Islamic charities, the most obvious example of cooption has of course been the UAE Red Crescent Society which receives considerable financial and organisational support from the various ruling families and, predictably, serves as an umbrella organisation for other smaller charities. Shaykh Hamdan AlNuhayyän, the UAE's Minister of State for Foreign Affairs and a key member of the 
Abu Dhabi ruling family serves as the Red Crescent's president, with Khalifa alSuwaidi (a member of another prominent Abu Dhabian family) chairing the organisation. Moreover, many of the society's projects to promote activities for disabled citizens have been assisted and supervised by both the Ministry of Education and Youth and the Ministry of Labour and Social Affairs, and a number of other recent activities such as competitions for the disabled and first-aid training courses have been organised under the patronage of Shaykha Fatima who naturally serves as the president of the society's Women's Committee. ${ }^{130}$ Significantly, the Red Crescent also distributes its considerable funds to other Islamic charity organisations in the UAE, a recent example being Shaykh Zāyid's donation of 12 million Dirhams via the society to the Shaykha Fatima Charity Award in order to improve the lives of orphans in the UAE. $^{131}$ Correspondingly, if the Red Crescent Society can be seen as an Abu Dhabi dominated umbrella organisation, then Shaykh Muhammad's Humanitarian and Charity Foundation in Dubai can be seen as a smaller, and more northern emirate-specific counterpart. Presided over by Dubai's crown prince and chaired by Ibrahim Bu Melha, Dubai's equivalent of an attorney general, the foundation effectively unifies the relief efforts of other Dubai-based Islamic charities within the framework of a controlled and co-opted organisation. Indeed, most recently the foundation co-ordinated and supported the efforts of a number of charitable associations in the northern Emirates aiming to raise funds for the Iraqi people. These included the Fujairah Charity Association, the Sharjah Charity Association, Al-Islah wal-Tawjīh, the Zakāt Committee of Ra's alKhaimah, and Shaykh Muhammad's daughter's 'Shaykha Latifa Charity for Children's Creativity' ${ }^{132}$

\begin{tabular}{|l|l|l|}
\hline Media / Press related & Nutional / Emirute specific & Description \\
\hline $\begin{array}{l}\text { Three English language } \\
\text { newspapers }\end{array}$ & National & $\begin{array}{l}\text { All are privately owned, but all receive } \\
\text { government subsidies }\end{array}$ \\
\hline $\begin{array}{l}\text { Six Arabic language } \\
\text { newspapers }\end{array}$ & National & $\begin{array}{l}\text { Three are government owned, and the } \\
\text { other three are privately owned but receive } \\
\text { government subsidies }\end{array}$ \\
\hline $\begin{array}{l}\text { UAE Journalists' } \\
\text { Association }\end{array}$ & National & \\
\hline UAE Writers' Association & National & $\begin{array}{l}\text { Forum for Dubai-based journalists and } \\
\text { media professionals }\end{array}$ \\
\hline Dubai Press Club & Dubai & \\
\hline GulC Voice & Ajman & \\
\hline
\end{tabular}


With regard to the press and press-related organisations, the UAE's newspapers have, like the UAE's other associations, also become more limited, despite having their freedom guaranteed by article 30 of the UAE's constitution. ${ }^{133}$ Certainly, as of yet they do not constitute the 'independent intellectual production' described by Carapico, ${ }^{134}$ and although they may be tolerated, they are ultimately controlled. However, as Peck explains, this was not always the case, with many associations, especially workers' organisations, having found much support from the UAE's press in the late 1970s and early 1980s, especially from the Arabic newspaper Al-Azima alArabiyya. In particular, this newspaper played a key role in helping strikers, including many who worked in agencies of federal ministries, to gain their demands. Moreover, Al-Azima also kept addressing more general socio-economic and political issues which other papers had previously shied away from, such as the human cost of the UAE's massive infrastructural development taking place at that time. ${ }^{135}$ Another example, again from the early 1980 s, would be the role of the press in successfully opposing government education policy. When, in 1981, the under-secretary of education issued an edict permitting corporal punislment in schools, the press vehemently objected and subsequently the policy was revoked. ${ }^{136}$ Nevertheless, by the mid-1980s the press was obliged to become more cautious over such matters following increasing government disapproval. Moreover, after the forced closure of Al-Azima due to its anticipated opposition to a further extension of the UAE's provisional constitution, ${ }^{137}$ the UAE's press assaciations were seen to be as restricted and ineffectual as most of the UAE's other civil society organisations.

Indeed, the reality, as understood and practised by both editors and journalists, became one of staying within the boundaries and respecting certain limits. After all, as described, the majority of the UAE's journalists are Arab and South Asian expatriates and are therefore reluctant to step out of line in their wealthy host nation. ${ }^{138}$ Furthermore, this control over the media was formalised in 1988 by a new federal law which clearly stipulated that all publications, including both books and periodicals, had to be licensed for approval by the Ministry of Information and Culture. ${ }^{139}$ Crucially of course, the law also governed the content of these licensed publications, thus effectively 
requiring journalists to exercise self-censorship when reporting on potentially sensitive issues such as national security, political development, and the ruling families. ${ }^{140}$ In addition, the Ministry also became empowered to review all imported publications and ban any materials deemed to be derogatory of Islam, supportive of Israel, or critical of the establishment. ${ }^{141}$ In more recent years, this censorship has of course been extended to the Internet and all Emirati web sites, given that, as explained in the previous chapter, the Ministry co-operates with the UAE's telecommunications monopoly (Etisalat) by running a proxy server which aims to block undesirable web content. Not only are sites relating to gambling, pornography, and alcohol banned, as one might expect, but also restricted are links relating to civil society, democratisation, and political development in general.

Interestingly, however, at a formal gathering to mark the launch of the Dubai Media City in January 2001, Shaykh Muhammad Al-Maktūm proclaimed his formal agreement to allow freedom for the press and media in Dubai. Although clearly made in the context of the aforementioned transparency initiatives and the attempts to boost the attractiveness of the new free zones for foreign investors, the agreement was nevertheless seen by some, in Dubai at least, as being the beginning of a new awakening for the UAE's press. Indeed, as was reported at the time:

"Having such freedom suddenly guaranteed was remarkable, as before this, open and uninhibited debate in the media on any issue was not sanctioned by any of the local governments making up the UAE... This bold precedent heralded a new beginning in the Arabian Gulf. Following the announcement in Dubai, an oasis has appeared for the mass media."142

Of course, not all were convinced, and many continued to believe that the press would still need to avoid any direct criticism of the government and would therefore need to proceed with caution: ${ }^{143}$ 
"While Arabic-language publishers and media professionals are called here from far and near to quench their decades-long thirst for freedom, caution is still the order of the day, lest it turn out to be just another mirage on the edge of the blistering sands... Although guaranteed in the Constitution, the UAE Criminal Code in its current form still does not allow the press to comment on certain issues. It remains to be seen whether or not, once media companies in the new free zone start to take off, the freedom promised to them by the Crown Prince will have any effect on the host country that nurtures them."144

Within only months of this announcement many of these suspicions were confirmed, as a number of press-related incidents seemed to indicate that little had changed, at least when it came to the need for self-censorship. In March 2001 the Ministry of Information and Culture filed a lawsuit against the Dubai-based newspaper Gulf News in response to a series of sharply satirical columns published by a Qatari journalist, Abdul-Wahid al-Mawlawi, which allegedly featured self-deprecatory humour regarding stereotypical Gulf Arabs. The government considered the articles to be offensive to Gulf citizens in general and to the country's citizens in particular. More worryingly, according to a US government human rights report, in addition to the lawsuit, al-Mawlawi was also arrested shortly after the publication of the last of his columns. He was purportedly subjected to sleep deprivation and physical abuse during a two-week detention, before finally being expelled to Qatar. ${ }^{145}$ Eventually the lawsuit against the offending newspaper was withdrawn, but only after the editor agreed to publish a front-page apology for the offensive material. Moreover, later that year a similar dispute arose between the Ministry and the media, culminating in ten prominent writers, including four university professors, being banned from publishing opinion pieces in both the Arabic and English newspapers. Apparently the ban was imposed following the writers' support of over 100 employees who had been made redundant by the government financed Emirates Media Corporation. As with the al-Mawlawi dispute, no official justification was given for the ban, although it was eventually lifted after the dust had settled. ${ }^{146}$ 
In addition to this self-censorship and often heavy-handed enforcement, another important characteristic of the UAE's press and press-related associations has been their increasing financial dependence on the government and semi-governmental organisations. Indeed, three of the country's six Arabic language newspapers are now state owned with the other three receiving substantial government subsidies. ${ }^{147}$ The case is much the same for the three English language newspapers which, although privately owned, all receive generous subsidies. ${ }^{148}$ Similarly, most of the UAE's television stations and other broadcast media organisations are also very closely linked to the government and as such tend to present only government views, ${ }^{149}$ and strictly conform to official reporting guidelines. ${ }^{150}$ The only exception had been 'Ajman's popular satellite television station, but in July 1999 even this was purchased by Emirates Media, a corporation which already owns Abu Dhabi's television and radio stations, publishes the Arabic Al-Ittihăd newspaper, and has recently forbidden all of its employees, including its journalists, from speaking with unapproved foreigners and representatives. ${ }^{151}$

\begin{tabular}{|c|c|c|}
\hline Workers / Professional & National / Emirate specific & Description \\
\hline UAE Journalists Association & National & $\begin{array}{l}\text { Limited to making recommendations on } \\
\text { behalf of its members }\end{array}$ \\
\hline UAE Lawyers Association & National & $\begin{array}{l}\text { Limited to making recommendations on } \\
\text { behalf of its members }\end{array}$ \\
\hline UAE Writers Association & National & $\begin{array}{l}\text { Limited to making recommendations on } \\
\text { behalf of its members }\end{array}$ \\
\hline UAE Teachers Association & National & $\begin{array}{l}\text { Limited to making recommendations on } \\
\text { behalf of its members }{ }^{152}\end{array}$ \\
\hline $\begin{array}{l}\text { Emirates Medical } \\
\text { Association }\end{array}$ & National & $\begin{array}{l}\text { Chaired by Shaykh Mansür Al-Nuhayyān } \\
\text { of the Abu Dhabi ruling family }{ }^{153}\end{array}$ \\
\hline $\begin{array}{l}\text { Emirates Bankers } \\
\text { Association }\end{array}$ & National $^{154}$ & \\
\hline $\begin{array}{l}\text { Emirates National Student } \\
\text { Association }\end{array}$ & National & \\
\hline $\begin{array}{l}\text { Medical Sludents" } \\
\text { Association }\end{array}$ & Nalional & \\
\hline Jurists Society & National & \\
\hline $\begin{array}{l}\text { Society for Petroleum } \\
\text { Engineers }\end{array}$ & National & $\begin{array}{l}\text { More of a social and educational forum } \\
\text { than a workers' association geared to } \\
\text { protecting engineers' rights, etc. } 155\end{array}$ \\
\hline $\begin{array}{l}\text { Women's Business Council } \\
\text { Abu Dhabi }\end{array}$ & Abu Dhabi & $\begin{array}{l}\text { The president is Shaykha Fatima Al- } \\
\text { Nuhayyān }{ }^{156}\end{array}$ \\
\hline $\begin{array}{l}\text { Air Passengers Welfare } \\
\text { Association }\end{array}$ & Abu Dhabi & \\
\hline $\begin{array}{l}\text { Spare Parts Employees } \\
\text { Welfare Association }\end{array}$ & Dubai & \\
\hline $\begin{array}{l}\text { American Business Council } \\
\text { of Dubai and the Northern }\end{array}$ & Dubai & $\begin{array}{l}\text { Maintains extremely close and deferential } \\
\text { ties with the UAE's political elite, }\end{array}$ \\
\hline
\end{tabular}




\begin{tabular}{|l|l|l|}
\hline Emirates & manifested by its award scheme \\
\hline $\begin{array}{l}\text { Indian Pharmaceutical } \\
\text { Forum }\end{array}$ & National & $\begin{array}{l}\text { Ethnic (sub-continent) professional } \\
\text { organisation for Indian members }\end{array}$ \\
\hline $\begin{array}{l}\text { Overseas Filipino Civil } \\
\text { Engineers' Association }\end{array}$ & National & $\begin{array}{l}\text { Ethnic (Far-East Asian) professional } \\
\text { organisation for Filipino members }\end{array}$ \\
\hline $\begin{array}{l}\text { Filipino Institute of Certified } \\
\text { Public Accountants }\end{array}$ & National & $\begin{array}{l}\text { Ethnic (Far-East Asian) professional } \\
\text { organisation for Filipino members }\end{array}$ \\
\hline $\begin{array}{l}\text { Indian Business / } \\
\text { Professional Group }\end{array}$ & Abu Dhabi & $\begin{array}{l}\text { Ethnic (sub-continent) professional } \\
\text { organisation for Indian members }\end{array}$ \\
\hline $\begin{array}{l}\text { NRI Business Council, } \\
\text { Dubai }\end{array}$ & Dubai & $\begin{array}{l}\text { Ethnic (sub-continent) professional } \\
\text { organisation for Indian members, NRI } \\
\text { being Non-Resident Indians }\end{array}$ \\
\hline $\begin{array}{l}\text { NRI Investors' Forum, } \\
\text { Dubai }\end{array}$ & Dubai & $\begin{array}{l}\text { Ethnic (sub-continent) professional } \\
\text { organisation for Indian members }\end{array}$ \\
\hline $\begin{array}{l}\text { Indian Engineers' Forum, } \\
\text { Dubai }\end{array}$ & Dubai & $\begin{array}{l}\text { Ethnic (sub-continent) professional } \\
\text { organisation for Indian members }\end{array}$ \\
\hline
\end{tabular}

All employees in the UAE, both white and blue collar, have the right to lodge grievances with officials from the Ministry of Labour and Social Affairs, who are then obliged to investigate all complaints. Moreover, in theory all workers are also able to appeal against the Ministry's rulings and, if necessary, can take the matter to the courts. However, as has been reported, many workers simply choose not to protest for fear of reprisals or deportation, and for those who do, their complaints and compensation claims are often severely backlogged due to understaffing and under budgeting in the Ministry. ${ }^{158}$ Indeed, the press often carries reports of employers punishing or abusing those employees, especially domestic servants, who lodge official complaints. ${ }^{159}$ With regard to workers' groups and associations, although UAE law does not yet permit employees to engage in collective bargaining, many associations are granted some degree of freedom to collectively raise work-related issues, to lobby for redress, and, on occasion, to file protests with the government. ${ }^{160}$ Thus, while these groups are essentially limited to making recommendations on behalf of their members and therefore possess few of the characteristics of fully functioning labour unions, they nevertheless offer the only real opportunity for employees to group together in order to voice their concerns.

In some cases these groups, especially the professional associations, have achieved relative autonomy in recent years and have been able to lobby the government successfully over certain work-related problems. A good example would be the 
Emirates Bankers' Association. Established in 1982 as a non-profit making organisation enabling employees of both local and national banks to subscribe to its membership, the association aimed to exchange opinions and knowledge between its members and to provide assistance and services to its members and all of those working in the banking profession. ${ }^{161}$ In 1991, during a period of increasing automation in the banking sector, the association was capable of independently representing its members' concerns to the UAE Central Bank. As such, the association was able to provide something of a mouthpiece for the banking workforce and was able to extract concessions and reassurance for those fearing unemployment and transitional problems. $^{162}$

However, in much the same way as the UAE's press and media associations, it would appear that when more serious employment matters arise, the illusion of freedom and autonomy is swiftly dispelled as government ministries retain the right to supervise, inspect, and disband all such organisations. ${ }^{163}$ The UAE Teachers Association, one of the largest of the UAE's professional bodies, provides such a case study given its repeated failures in confronting government ministries over recent years. One such example would be a teachers' dispute in 2002 which resulted in the Ministry of Education and Youth summarily suspending an instructor for his alleged beating of a pupil. Duly, the Teachers Association attempted to defend the teacher's rights and began to sue the Ministry. Within days, however, the association soon found itself fighting a losing battle and unable to uphold the interests of its members. Indeed, as a source from the Ministry indicated with regard to the incident, such associations are effectively powerless in these disputes:

"... the Ministry has the right to take any legal action which it deems necessary against those violating rules, noting that beating students was prohibited in schools. The association does not have the legal power to sue the Ministry on behalf of its members. Its resolutions are just recommendations which do not have any legal value." 
Moreover, the source also inferred that the recent stand taken by the association may well result in it being dissolved, observing that

"... the association should have advised the teachers to settle the dispute in a peaceful manner without letting the issue reach the court." 164

In addition, while some associations have found themselves unable to mount legal challenges against government ministries, others have of course been weakened by high levels of patronage from either the government or the ruling families. With formal and informal ties to the neo-patrimonial network they are thought unlikely to ever evolve into autonomous labour organisations and are therefore believed to be incapable of independently representing their members' interests. While some of these associations, such as the Emirates Medical Association and the Women's Business Council, chaired respectively by Shaykh Mansūr Al-Nuhayyān and Shaykha Fatima A1Nuhayyān, are clearly linked to the ruling families, ${ }^{165}$ others, especially those catering for expatriates, are often more subtly linked. Indeed, even the American Business Council of Dubai and the Northern Emirates, which has elected officers and an exclusively American membership, is remarkably keen to maintain close and deferential ties with the various ruling families. In fact, in a form of reverse patronage, the recipients of the Council's prestigious annual business award have included no less than four of the UAE's shaykhs since 1995: Shaykh Muhammad Al-Maktūm and his brother Shaykh 'Alımad, Shaykh Sultān al-Qāsimī the ruler of Sharjah, and Shaykh Hamad alSharq $\overline{1}$ the ruler of Fujairah. ${ }^{166}$ Similarly, other predominantly expatriate organisations such as the Society of Petroleum Engineers and the many Indian and Filipino associations also observe polite respect, with most tending to keep a low profile by focusing more on providing social and educational forums than seeking to protect their members' legal rights. ${ }^{167}$

\begin{tabular}{|l|l|l|}
\hline Expatriate communities & National/Emirate specific & Description \\
\hline Indian Association & $\begin{array}{l}\text { Dubai, Sharjah, Ra's al- } \\
\text { Khaimah, Umm al-Qawain }\end{array}$ & $\begin{array}{l}\text { Indian community associations, serving as } \\
\text { umbrellas for other sub-organisations }\end{array}$ \\
\hline Goan Cultural Society & Dubai & $\begin{array}{l}\text { Community association for Goanese } \\
\text { Indians. Operating under the umbrella of }\end{array}$ \\
\hline
\end{tabular}




\begin{tabular}{|c|c|c|}
\hline & & the Indian Association, Dubai ${ }^{168}$ \\
\hline Indian Cultural Association & Dubai & \\
\hline Indian Social Centre & Abu Dhabi, Al-'Ayn & \\
\hline Kerala Social Centre & Abu Dhabi & $\begin{array}{l}\text { Social centre for Keralites from Southern } \\
\text { India }\end{array}$ \\
\hline $\begin{array}{l}\text { UAE Kerala Muslim } \\
\text { Cultural Centre }\end{array}$ & Abu Dhabi, Dubai, Sharjah & $\begin{array}{l}\text { Social centre for Muslim Keralites from } \\
\text { Southern India }\end{array}$ \\
\hline $\begin{array}{l}\text { UAE Gulf Malayalee } \\
\text { Coordination Commillee }\end{array}$ & Dubai & $\begin{array}{l}\text { Organisation for Malayalee expatriates } \\
\text { from Southern India }\end{array}$ \\
\hline $\begin{array}{l}\text { Overseas Malayalee } \\
\text { Residing Association }\end{array}$ & Abu Dhabi & $\begin{array}{l}\text { Organisalion for Malayalee expatriales } \\
\text { from Southem India }\end{array}$ \\
\hline $\begin{array}{l}\text { World Malayalee Council } \\
\text { (WMC) }\end{array}$ & Dubai & $\begin{array}{l}\text { Organisation for Malayalee expatriates } \\
\text { from Southern India }\end{array}$ \\
\hline $\begin{array}{l}\text { Malayalee Muslim Welfare } \\
\text { Association }\end{array}$ & Dubai & $\begin{array}{l}\text { Organisalion for Muslim Malayalee } \\
\text { expatriates from Southern India }\end{array}$ \\
\hline $\begin{array}{l}\text { Priyadarshini Cultural } \\
\text { Association }\end{array}$ & Dubai & $\begin{array}{l}\text { Association for Priyadarshini expatriates } \\
\text { from Bombay }\end{array}$ \\
\hline Overseas Friends Meet & Abu Dhabi & Organisation for Indian expatriates \\
\hline $\begin{array}{l}\text { Panchayat Expatriate } \\
\text { Association }\end{array}$ & Dubai & $\begin{array}{l}\text { Association for expatriate Indians from } \\
\text { self-governed provinces (the Panchayat } \\
\text { villages) }\end{array}$ \\
\hline Assam Society of the UAE & National & $\begin{array}{l}\text { Associalion for Assam expatriates from } \\
\text { India }\end{array}$ \\
\hline $\begin{array}{l}\text { Filipino Association for } \\
\text { Compuler Excellence }\end{array}$ & National & \\
\hline $\begin{array}{l}\text { Filipino Computer Club, } \\
\text { Dubai }\end{array}$ & Dubai & \\
\hline $\begin{array}{l}\text { Filipino Culture and Sports } \\
\text { Club, Abu Dhabi }\end{array}$ & Abu Dhabi & \\
\hline Singles for Christ & Dubai & Organisation for Filipino Catholics \\
\hline Bicol Anom & Dubai & Association for Bicol speaking Filipinos \\
\hline Pangasinense Aligwas Club & Abu Dhabi & $\begin{array}{l}\text { Welfare and charitable organisation for } \\
\text { expatriates from the Northem } \\
\text { Phillipines }{ }^{169}\end{array}$ \\
\hline Kenya Friendship Society & National & African expatriate society ${ }^{170}$ \\
\hline
\end{tabular}

A survey of civil society organisations in the UAE would be incomplete without also considering the many expatriate welfare organisations and associations which exist in the major cities. Indeed, given the size of these foreign communities, many of which dwarf the local Emirati populations, it is little surprise that these are high in membership and probably constitute the bulk of civil society activity in the country. Among others, there are clubs for Europeans, North Americans, Indians, Filipinos, Africans, and indeed for almost all of the diverse nationalities which make up the UAE's vast expatriate labour force. Many of these societies concentrate on social events and on building up a sense of community and familiarity for those far from their homelands, while others offer compatriots the opportunity to network with each other and learn how best to do business in the UAE and the Gulf. Some of these societies are even regionspecific, with many offering social services and support to immigrants from particular 
areas of India, the Philippines and the other main labour providing nations. Examples would include the Goan societies which operate under the umbrella of the Indian Association, ${ }^{171}$ the various Keralite and Malayalee associations for South Indians, the Bicol Anom organisation for Bicol speaking Filipinos, and the Pangasinense Aligwas Club for expatriates from Luzon and the northern Philippines. ${ }^{172}$

As one might expect, given the cautious nature of expatriate workers and their presence in a comparatively conservative state, these organisations are, like many of the UAE's other associations, self-censoring and self-limiting. All are careful to emphasise their goals of providing solely welfare and cultural activities, with some even going so far as to state explicitly their non-political agenda. One such example would be the Kenya Friendship Society, which is a non-profit making and volunteer-based organisation designed to help and support the large Kenyan community in the UAE. Among its aims are the provision of welfare services for members and their families, the encouragement of cultural and recreational activities, and the encouragement of 'intellectual association' between like-minded Kenyans. On this last point, however, the society's chairman, Jalal Balala, felt it necessary to assert in a recent speech that, "this society will involve strictly social, cultural, educational and humanitarian activities. Absolutely non-political. All Kenyans will benefit". ${ }^{173}$ Similarly keen to stress its apolitical nature has been the Goan Cultural Society. Established in 1988 to provide a social community for non-resident Indians in Dubai from the Catholic province of Goa, the society's mission statement has always been to the effect that, "...the society is purely a social and cultural organisation without any political affiliations and its membership is open to all Goans residing in the United Arab Emirates". 174

Of all the civil society organisations in the UAE, these expatriate welfare organisations appear to have been the least co-opted. Almost all have constitutions, committees elected from their membership, and, given their foreign and often nonMuslim constituencies; they have few if any ties to the ruling families or governmentfunded bodies. However, it is perhaps because of this relative autonomy that these are 
the organisations which are now facing the strictest regulations and government control, Indeed, another important aspect of the recent amendment to the Federal Social Welfare Societies Law is that the creation of any new social welfare societies, whether they be "religious, professional, cultural, humanitarian, theatre-related or concerning women," will be restricted to UAE nationals alone. As a senior official explained:

"We do realise the importance of allowing communities of various nationalities to have a forum where they can get together and practise their cultural and social activities. But at the same time, we believe that the number of the community bodies should be restricted... ".75

Presumably this will allow for greater control over future civil society associations while limiting the growth of the less easy to co-opt expatriate forums. Moreover, if any expatriate societies avoid or defy these restrictions, or indeed if they refuse to allow the ministries to inspect their books, records and activities, then Article 43 of the amendment will provide the Ministry of Labour and Social Affairs with the right to immediately dissolve the association. ${ }^{176}$

\subsection{3 - Globalising forces and external motivation}

Clearly, regardless of whether such civic corporatism and control is part of an uninstitutionalised strategy to reduce the potential constituencies of an emerging civil society thereby consolidating the state's position, or in Michael Hudson's terms, is merely the product of non-participatory patrimonial structures, ${ }^{177}$ what is apparent is that under such conditions any significant indigenous growth of autonomous civil society in the UAE will remain a distant prospect. More optimistically, however, there is a growing recognition that such a deactivated and demobilised civil society can be significantly boosted by certain globalising forces, in particular by the increasing number of international organisations now operating in the UAE which are believed to be capable of promoting more stable and democratic structures in domestic civil society organisations; by the increasing penetration of international communications which, as 
shown, may not only increase transparency and accountability in Emirati society, but may also provide indigenous associations with a 'demonstration effect' of successful examples of civil society elsewhere; and also by the civil society-related influences and requirements of those global organisations attempting to implement and uphold international standards.

Indeed, on one level it may be that domestic civil society organisations can become stronger and more internally democratic if they are operating alongside and cooperating with UAE-based branches of international NGOs. Certainly, as Carapico noted in her study of the Yemen, an increasing number of international NGOs were seen to be fostering greater liberalism and civil society institution building from below, thereby significantly boosting domestic associational life. ${ }^{178}$ Thus, as more of these NGOs and development assistance agencies establish themselves in the UAE, their influence may continue to grow as more of the local population become directly and indirectly involved with their activities. By employing local staff and providing training and greater expectations, these international NGOs may provide an insight into democratic practices and methods, and may supply blueprints for future local organisations. Examples of such UAE-based branches already include the United Nations Development Project in Abu Dhabi (employing several dozen UAE nationals), the World Health Organisation, and the Medécin sans Frontiers relief organisation. Furthermore, when a critical mass of these democratically organised NGOs, employees, and volunteers exists, there may also develop an atmosphere of collective security in which indigenous civil society organisations can develop with greater confidence. ${ }^{179}$ Thus, with greater internal democracy and moral support it is thought likely that the UAE's associations will better resist the weakening effects of corporatism and control.

Secondly, in addition to their profound socio-cultural impact, mass communications may also provide a boost for the emergence of domestic civil society. Indeed, as Samuel Huntington noted in 1991 following the demise of the Soviet Union, such technological advances were already seen as providing a 'demonstration effect' where people in one society were able to learn quickly how people in another society 
had either pressed for greater liberalisation or had even brought down an authoritarian government. Furthermore, the ability to exchange ideas and views also allowed people to learn how these objectives could be achieved. ${ }^{180}$ As such, with increasing access to the Internet, satellite television and many other global information sources capable of bypassing state-imposed restrictions, Emirati civil society organisations may be able to forge greater links with similar organisations in other countries, thereby providing mutual support and a greater opportunity to share experiences. Indeed, there are already a number of such examples with some of the described associations, especially those providing recreational activities, having established Internet links with their overseas counterparts. $^{181}$ Although these are of course relatively apolitical, they nevertheless provide an early indication of the potential role of global communications for other existing and future Emirati associations.

Perhaps most significantly, in much the same way that global organisations such as the WTO and the World Bank have recently begun to influence the UAE's economic structures, so too may international NGOs begin to shape domestic associational life, especially in the workplace. A strong example would be the recommendations drawn up at the International Labour Organisation's 2002 symposium in Dubai on the 'Declaration on Fundamental Rights and Principles at Work'. Essentially, the proposal's aims were to create new associations and enhance existing groups so as to

$$
\begin{aligned}
& \text { "... look after the interests of workers, including any private or government } \\
& \text { employee of any nationality, to defend their rights, to seek to improve their } \\
& \text { social and economic status, and to represent them in all matters of concern } \\
& \text { to them." } 182
\end{aligned}
$$

Furthermore, and most crucially, it was also hoped that the new legislation would redress the balance of power between employers and employees by allowing these organisations to file lawsuits against the government. ${ }^{183}$ Thus, given the previously discussed case studies of ineffective workers' associations in the UAE, if, as it is predicted, the Ministry of Labour and Social Affairs approves such ILO-inspired 
legislation, this will represent a significant departure from the past. Indeed, as Mattar Al-Tayer explains, the ILO's recent promotion of labour standards has certainly had a major impact on the UAE, requiring his ministry to "adapt to foreign influences and the tremendous development of the world economy" by better supporting professional and workers' groups:

"... the economic situation in the country [the UAE] and the structure of its labour market will have to adapt to foreign influences and the tremendous development of world economy. International conventions and commitments require the development of legislation in the UAE in order to ensure continuation of economic development without neglecting the ILO's Declaration on Fundamental Principles and Rights of Workers. In the light of economic changes, a review of the country's laws has become a pressing issue. We have professional associations and we do not object to the formation of workers' hodies. In this context, the UAE has signed six ILO conventions despite being a young and developing country. These conventions are not binding, but being a member of the ILO, we feel that we should sign the conventions which benefit us and which reflect the civilised image of the UAE as a country committed to basic labour standards and rights which our constitution guarantees. ${ }^{184}$

Similarly, in the near future, motivation from international organisations may extend beyond reforms for labour associations to include support for other areas of civil society, including types of organisations which do not presently exist in the UAE. One such example would be human rights groups, which have thus far been unable to perform meaningful investigations in the UAE due to the described restrictions on the press and the freedom of public participation. Although a small section now exists within Dubai's police force to monitor allegations of human rights abuses, genuinely independent domestic groups have yet to emerge. However, with increasing criticism from foreign sources, including influential bodies such as the US Bureau of Democracy and Human Rights, ${ }^{185}$ this may change as the UAE government is pressured and 
embarrassed into implementing reforms more consistent with those of its global partners. $^{186}$

\section{6 - Conclusion}

As this final chapter has demonstrated, with the seemingly inevitable acceleration of global integration, in part due to the liberalising reforms of the "new rentiers' seeking to boost foreign investment and promote fresh sources of economic rent, certain new external forces, perceived as both benign and malignant, are now also beginning to shape and influence indigenous structures, and must therefore be included alongside domestic factors in a comprehensive assessment of Emirati development. Firstly, with regard to the UAE's economic structures, it has been indicated how globalisation has led to both increased international competition and greater marketing opportunities for Emirati firms. Secondly, and equally controversially, it has been suggested that increasing global economic integration may have led to a neglect of regional integration, widely believed to serve as an important safety net for most developing economies. Thirdly, the impact of international organisations such as the WTO and the IMF on the domestic economy has also been shown to be both farreaching and ambiguous, with clear divisions having emerged over the UAE's acceptance of any international agreements thought likely to alter existing structures permanently. On the one hand, certain groups have championed the prospects of the WTO-led removal of monopolies and the implementation of copyright controls, while on the other hand conservatives have cautioned against the opening up of key industries and the political complications which may result from the UAE's commitments.

In the second part of this chapter, the equally contentious impact of sociocultural external forces was considered, with particular regard to globalisation's role in the perceived erosion of Emirati culture and heritage, with reference to the rapid marginalisation of the Arabic language and, more positively, with regard to international communications and increased accountability. Indeed, it has been demonstrated how globalising forces have been blamed for the increasing 'cultural 
contamination' which appears to have all but destroyed the traditional Emirati way of life, and how in turn this socio-cultural attack has provided an additional impetus for the government's multipurpose cultural revival. Similarly, it has been shown how the increasing presence of non-Arabs, foreign media, and foreign-language education have all combined to marginalise the Arabic language, again prompting a reaction to what is widely believed to be the consequence of intrusive globalisation. However, with regard to the improvements in global communications and their accessibility in the UAE, it is evident that such developments have been better received, with many agreeing that such supra-national sources of information have already begun to increase the accountability and transparency of neighbouring Gulf communications networks, a trend which may soon reach the UAE.

In addition to these significant influences on domestic socio-economic development, some of which have helped to reinforce existing pathologies while others have helped to overcome such obstacles, this chapter has also explained how globalising forces may begin to play an important role in reshaping civil society and associational life in the UAE. Specifically, following a demonstration of how the UAE's current civil society remains in a weakened state due to a combination of rentier-dependency related structures (namely cultural heterogeneity resulting from the massive foreign labour force, increasing levels of government co-option, royal patronage, and in some circumstances greater control and repression), it was suggested that a fresh wave of external forces may nevertheless offer a means of reactivating and supporting demobilised associations in the near future. In particular, the transfer of ideas and methods from the increasing number of UAE-based branches of international organisations may lead to stronger internal structures for indigenous associations and a greater network of collective security and mutual support. Secondly, the improvements in global communications may also provide a demonstration effect for the UAE's civil society organisations as they become better connected and more able to share experiences with their counterparts in other parts of the world. Finally, and perhaps most significantly, it was also shown how certain external bodies may be capable of motivating the UAE government to free up civic space from above, with domestic 
labour groups and human rights associations already likely to benefit from recommendations and proposals made to the relevant ministries by prominent global NGOs and major international partners.

\footnotetext{
${ }^{1}$ HIRST, P (1995), "Globalisation in Question" in "Occasional Paper Number 11", Political Economy Research Centre, University of Sheffield, pp.3

${ }^{2}$ DICKEN, P (1992), "Global Shift and the Intemationalisation of Economic Activity", London, pp.1

${ }^{3}$ See http://www. mydsf.com/

${ }^{4}$ HIRST, David (2001), "The Emirs in the Internet era", in LE MONDE DIPLOMATIQUE, February 2001

${ }^{5}$ EMIRATES CORPORATE COMMUNICATIONS (2002), "Countdown to Dubai 2003", press release issued by Emirates Airlines Media Relations Department, $23^{\text {rd }}$ October 2002

${ }^{6}$ See section 4.5.3

7 See AMIN, Samir (1997), "Capitalism in the age of globalisation: the management of contemporary
} society", London; and AMIN, Samir (1982) "The Arab Economy Today", New York, for a discussion of anti-globalisation theory

${ }^{8}$ As Herb states with reference to the Gulf monarchies, the fragmentary effects of globalising forces are often readily blamed for many of the serious intenal antagonisms in the more unstable developing states, resulting in hardship and suffering for much of the population. See HERB, Michael (1999), "All in the Family", New York

${ }^{9}$ Held, who although wanning of the dangers of predatory globalisation, concludes that globalisation is not beyond regulation and can be harnessed as a civilising and democratising force, see HELD, David, MCGREW, Anthony, GLODBLATT, David, and PERRATON, Jonathan (1999), "Global transformations: politics, economics and culture", Oxford, Polity Press, pp.444-452

${ }^{10}$ PRATT, N (2001), "Conceptualising Globalisation: some Political Implications for the Arab World", excerpt from a presentation given at the "Globalisation and the Gulf" conference at the University of Exeter, July 2001

${ }^{11}$ HEARD-BEY, Frauke (1982), "From Trucial States to United Arab Emirates", London, Longman, pp, 11

${ }^{12}$ GCC DEVLOPMENT PLANS - UNITED ARAB EMIRATES (1982), "Economic and Social

Development Plans for the UAE, 1975-1980", Abu Dhabi, pp.10 and pp.18-19

${ }^{13}$ Personal interview, Dubai Chamber of Commerce and Industry, Research and Studies Department, December 2001

I4 ABDULLAH, Muhammad Morsy (1978), "The United Arab Emirates: A Modern History", London, Croom Heim, pp. 106-107

15 AL-SAYEGH, Fatma (1998), "Merchants' role in a changing society: the case of Dubai, 1900-1990", in MIDDLE EASTERN STUDIES, Volume 34 Number 1, January 1998, pp.92

${ }^{16}$ ABDULLAH (1978), pp.106-107

${ }^{17}$ AL-SAYEGH (1998), pp.92

${ }^{18}$ FENELON, Kevin (1973), "The United Arab Emirates: An Economic and Social Survey", London, Longman, pp. $18-19$

${ }^{19}$ Ibid. pp. 18-19

${ }^{20}$ PECK, Malcolm C (1986), "The United Arab Emirates: A Venture in Unity", Boulder Colorado, Westview Press, pp.76

${ }^{21}$ See section 2.2 .4

22 BUSINESS IN DUBAI (2002), "Family companies the day after: how would local family owned businesses survive in globalisation?", Dubai Chamber of Commerce and Industry, Volume 2 Issue 15, March 2002, pp. $18-19$

${ }^{23}$ Tbid. pp. $18-19$

${ }^{24}$ Personal Interviews, Abu Dhabi, March 2002

${ }^{25}$ Personal Interviews, Dubai, December 2001, March 2002, and September 2002

${ }^{26}$ DUBAI DEPARTMENT OF PORTS AND CUSTOMS (2001), "Dubai: major (non-oil) trade partners - imports", in DUBAI DEPARTMENT OF ECONOMIC DEVELOPMENT (2001), "Development Statistics", Government of Dubai, pp.129

27 DUBAI DEPARTMENT OF PORTS AND CUSTOMS (2001), "Dubai: major (non-oil) trade partners - exports", in DUBAI DEPARTMENT OF ECONOMIC DEVELOPMENT (2001), "Development Statistics", Government of Dubai, pp.130 
${ }^{28}$ DUBAI DEPARTMENT OF PORTS AND CUSTOMS (2001), "Dubai: major (non-oil) trade
partners - re-exports", in DUBAI DEPARTMENT OF ECONOMIC DEVELOPMENT (2001) "Development Statistics", Government of Dubai, pp.131

${ }^{29}$ See section 3.9

${ }^{30}$ JREISAT, JE (1992), "Managing national development in the Arab states", in ARAB STUDIES

QUARTERLY, Volume 14 Numbers 2 and 3, Spring / Summer 1992, pp.1-2

${ }^{31}$ HANAFI, Sari (2001), "Globalisation without Regionalisation; the Paradoxical Effects of the Political Economy of the United Arab Emirates", excerpt and statistics from a presentation given at the

"Globalisation and the Gulf" conference at the University of Exeter, July 2001. Sari Hanafi is director of the Palestinian Diaspora and Refugees Centre in Ramallah

${ }^{32}$ Ibid; and JEBEL ALI FREE ZONE AUTHORITY (2000), Jebel Ali, Dubai, for investment statistics

${ }^{33}$ See HANAFI (2001)

${ }^{34}$ KAWACH, Nadim (2001), "IMF urges GCC to levy income tax," in GULF NEWS, $16^{\text {th }}$ October 2001

${ }^{35}$ Personal Interviews, Dubai Chamber of Commerce and Industry, Research and Studies Department,

December 2001

${ }^{36}$ WORLD TRADE ORGANiSATION NEWS (2002), "Press Releases, Press/293", 3 rd May 2002

${ }^{37}$ TRIPS being the 'Trado Related aspects of International Property Rights'

${ }^{38}$ AL-JABĪL, Muhammad (2002), "GCC: the emerging common market", in AFRICA BUSINESS

GUIDE, Cairo, December 2002

${ }^{39}$ See BUSINESS MONITOR INTERNATIONAL (2003), "The United Arab Emirates", second quarter report

${ }^{40}$ Personal Interviews, Sharjah, October 2002

${ }^{41}$ ECONOMIST INTELLIGENCE UNIT (2000), “United Arab Emirates", pp.17

42 TAMIMI LAW UPDATE (2001), "Law update: UAE committed to implementing WTO agreements", Tamimi Consultants, Dubai, January 2001

${ }^{43}$ ASHOUR, MF (2001), "The GCC and the WTO", in AL-TAMIMI, January 2001

${ }^{44}$ Ibid.

${ }^{45}$ STAUFFER, Thomas (2001), "Global Oil Markets and their Implications for Revenue Instability in the Gulf", excerpt from a presentation given at the "Globalisation and the Gulf" conference at the University of Exeter, July 2001

${ }^{46}$ TAMIMI LAW UPDATE (2001), Shaykh Fahim al-Qāsimī, the Minister of Economy and Commerce, said the UAE would free up the textile and ready-made clothes industry through three stages which would end by 2005

${ }^{47}$ MERZA, Ali (2001), "Economic Reforms in the Major Oil-Producing Countries", excerpt from a paper given at the "Globalisation and the Gulf" conference at the University of Exeter, July 2001, p.16, Ali Merza represents the UNDP project in Libya

${ }_{48}$ BIBBO, Barbara (2002), "New contract rule to benefit nationals", in GULF NEWS, $14^{\text {th }}$ December 2002, as explained by Dr. Khazraji, undersecretary of the Ministry of Labour and Social Affairs. For a discussion of US pressure for the UAE to reform, see MALLETT, Robert L (2001), "Symposium on Shaykh Zāyid", in MIDDLE EAST POLICY, Volume 6 Number 4, June 1999, pp.13, quoting Robert Mallett, Depuly Secretary of Commerce, US Department of Commerce, speaking at the $20^{\text {th }}$ April 1999 conference convened by the Middle East Policy Council

${ }^{49}$ See TAMIMI LAW UPDATE (2001)

${ }^{50}$ Double taxation treaties (DTTs) are bilateral agreements ensuring the mutual reduction or elimination of import/export duties

${ }^{51}$ JYAD, 'Ahmad (2001), "The Role of Foreign Direct Investment in the Globalisation of the Gulf", excerpt from a presentation given at the "Globalisation and the Gulf" conference at the University of Exeter, July 2001

${ }_{52}$ ROBERTSON, R (1992), "Globalisation: social theory and global culture", London, Sage, cited by RANDALL, V and THEOBALD, R (1998), "Political change and underdevelopment", London, Macmillan, pp. 248

${ }^{53}$ ALESCO being the 'Arab League for Educational, Cultural and Scientific Organisation'

${ }^{54}$ FINDLOW, Sally (2000), "The UAE: Nationalism and Arab-Islamic Identity", Abu Dhabi, Emirates Centre for Strategic Studies and Research, ECSSR OCCASIONAL PAPER, Number 39, pp.36, citing the contrasting examples of ALESCO conferences in 1977 and 1998. See appendix (vii).

${ }_{35}$ Personal interviews, Abu Dhabi; March 2001; Dubai December 2001; and Sharjah, October 2002

${ }^{56}$ KHALAF, Suleyman (2001), "Globalisation and Heritage Revival in the Gulf; an Anthropological Look at the Dubai Heritage Village", excerpt from a presentation given at the "Globalisation and the Gulf" conference at the University of Exeter, July 2001

${ }^{57}$ KHALAF, Suleyman (1999), "Camel Racing in the Gulf: notes on the evolution of a traditional cultural sport", ANTHROPOS 1999, pp.85-106; also see KHALAF, Sulayman (2000), "Poetics and 
politics of newly invented traditions in the Gulf: camel racing in the United Arab Emirates", in

ETHNOLOGY, Volume 39 Number 3, Summer 2000, pp. 243-261

${ }^{58}$ See KHALAF (2001); and section 2.2 .3

59 Personal interviews, Abu Dhabi, September 2002. There are plans to establish a major UAE-based English language satellite television station, this is hoped to offer an altemative to Al-Jazira and to provide western journalists with a more accessible source of Arab opinion; also see KAWACH, Nadim (2003), "Call for Arab TV in English", in GULF NEWS, 20" January 2003

${ }_{60}$ Interview with English-language library staff, Sharjah Public Library, September 2002

${ }^{61}$ FINDLOW, Sally (2000), pp.33

${ }^{62}$ ZEITOUN, Doā (2002), "Direct Quote: safeguarding purity of Arabic", in GULF NEWS, $22^{\text {nd }}$ December 2002

${ }^{63}$ Ibid.

${ }^{64}$ YAMANI, Mai (2001), "Challenged by Example; Globalisation and the New Arab Awakening", excerpt from a presentation given at the "Globalisation and the Gulf" conference at the University of Exeter, July 2001. Mai Yamani is a member of the Royal Institute of International Affairs, London

${ }^{65}$ NONNEMAN, Gerd (2001), "Rentiers and autocrats, monarchs and democrats, state and society: the Middle East between globalisation, human 'agency', and Europe", in INTERNATIONAL AFFAIRS, Volume 77 Number 1, January 2001, pp.150

${ }^{66}$ Ibid.

${ }^{67}$ SHARABI, Hisham (1988), "Neopatriarchy: A Theory of Distorted Change in Arab Society", New York, Oxford University press, pp.150-152

${ }^{68}$ CARAPICO, Sheila (1998), "Civil society in Yemen: the political economy of activism in modern Arabia", Cambridge, Cambridge University Press, pp.2

${ }^{69}$ DE TOQUEVILLE, A (1981), "Democracy in America", New York, McGraw-Hill, cited by

RANDALL and THEOBALD (1998), pp.202

${ }^{70}$ CARAPICO (1998), pp. 2

${ }^{71}$ See CARAPICO (1998), and see sections 1.2 and 1.3 with regard to tribal society

${ }^{72}$ KAMRAVA, Mehran (2000), "Politics and society in the developing world", London, Routledge, pp. 192

CARAPICO (1998), pp. 12

${ }^{74}$ KAMRAVA (2000), pp. 202-203

${ }^{75}$ WEIGLE, MA and BUTTERFIELD, J (1992), "Civil society in reforming Communist regimes: the logic of emergence", in COMPARATIVE POLITICS, Volume 25 Number 1, October 1992, pp.1-22, cited by RANDALL and THEOBALD (1998), pp.203-204

${ }^{76}$ CARAPIC.O (1998), pp. 15

77 Ibid. pp. 12

${ }^{78}$ See section 3.7

79 KAMRAVA (2000), pp. 195

"8 RUG, WA (1997), "The United Arab Emirates: What are the sources of its stability?" in MIDDLE

EAST POLICY, Volume 5 Number 3, September 1997, pp.16, quoting William Rugh, US Ambassador to the UAE between 1992 and 1995

${ }^{81}$ Ibid. pp. 16

${ }^{82}$ Most middle class NRIs (non-resident Indians) working in the Gulf will claim they are simply there to earn sufficient money so as to emigrate to Canada, Australia, New Zealand, etc. within the next few years.

${ }_{83}$ For a similar discussion see KAMRAVA (2000), pp.202-203

${ }^{84}$ See section 2.1 .3

85 AL-SAYEGH, Fatima (1999), "Symposium on Shaykh Zāyid", in MIDDLE EAST POLICY,

Volume 6 Number 4, June 1999, pp.13-16, quoting Fatima Al-Sayegh, University of the UAE, Al- Ayn, speaking at the $20^{\text {th }}$ April 1999 conference convened by the Middle East Policy Council

${ }^{86}$ see UNDP-POGAR (2002), "Programme on Governance in the Arab region - UAE"

${ }^{87}$ MADAD, Sanā (2001), "Welfare societies will need a federal licence", in KHALEEJ TIMES, $27^{\text {th }}$ September 2001

${ }^{88}$ see http://www. emiratesit.org/

"99 "Folk art forum to be given federal status" in KHALEEJ TIMES, Dubai, $10^{\text {th }}$ October 1987

${ }^{90}$ See ZEITŨN, Doã (2002), "Direct Quote: safeguarding purity of Arabic", in GULF NEWS, 22 "nl December 2002

${ }^{91}$ See EMIRATES HERITAGE CLUB (2000), as its mission statement explains, "In June 1997 Enirates Heritage Club is considered as an independent authority belonging to Abu Dhabi Government headed by His Highness Shaykh Sultān Bin Zāyiḍ Al-Nuhayyān, Deputy Prime Minister, chairman of the Emirates Heritage Club according to the Emiri Decree number 14/1997" 
92 PRESS AFFAIRS DIRECTORATE OF SHARJAH EMIRI COURT, (1988), "Sharjah in Fifteen Years Time: 1974-1988", Sharjah, Al-Bayan Press, pp.183-185

${ }^{93}$ CALLAN, L and ROBISON, G (2000), "Oman and the United Arab Emirates", Hawthorn, Australia, Lonely Planet Publications, pp. 187, see heading under 'environmental organisations'

${ }^{94}$ KHIALEEJ TIMES 1987), "Folk art forum to be given federal status", $10^{\text {th }}$ October 1987

${ }^{95}$ CALLAN and ROBISON (2000), pp.187, see heading under 'environmental organisations'

${ }^{96}$ See EMIRATES HERITAGE CLUB (2000)

${ }^{97}$ Personal interviews, Dubai, December 2001

${ }^{98}$ PRESS AFFAIRS DIRECTORATE OF SHARJAH EMIRI COURT, (1988), pp. 183-185

${ }^{99}$ Recent examples include Sharjah's hosting of 'Thealtical Gatherings' sponsored by both the Sharjah Department of Culture and Information and by the ruler, Shaykh Sultān al-Qāsimī, see ZEITŪN, Doā (2002), "Theatre artistes to gather in Shariah", in GULF NEWS, $13^{\text {th }}$ October 2002; examples of rallies and public demonstrations would include the recent anti-smoking campaign supported by Shaykh Muhammad bin Saqr al-Qăsimĩ, Director of the Sharjah Medical District, see, KHALEEJ TIMES (2002), "Anti-smoking rally in Sharjall", $10^{\text {th }}$ October 2002

${ }^{100}$ See section 3.6

${ }^{101}$ RUGH (1997), pp.18

${ }^{102}$ UNITED STATES DEPARTMENT OF STATE (2001), "United Arab Emirales: Country Reports on Human Rights", Bureau of Democracy, Human Rights, and Labour, $23^{\text {rd }}$ February, 2001, section 2(b)

${ }^{103}$ See hitt://www. ugagolf.com

${ }^{104}$ ALI, Sayed (2002), "Ramadan Tournament gets big cash boost", in GULF NEWS, $3^{\text {rd }}$ December 2002

${ }^{105}$ See http://www.ugagolf.com: also see section 4.5

${ }^{106}$ See ALI (2002); and personal observations

${ }^{107}$ See http://ww.hga-uae org.ae. Membership is restricted to UAE nationals, as per condition 1 of the association's working membership requirements

108 'AHMAD, Ashfaq (2002), "Volunteers play key role in society", in GULF NEWS, 29. ${ }^{\text {th }}$ November 2002

${ }^{109}$ See http://ww.hga-uae org.ae

${ }^{110}$ See 'AHMAD (2002)

111 The Emirates Institute for Banking and Financial Studies is a government funded institute for upgrading the knowledge and skills of UAE bankers, see hltp://www. eibfs.com

${ }_{112}$ ABU DHABI ECONOMY (2001), "A big boost for businesswomen", Abu Dhabi Chamber of

Commerce and Industry, Publications and press relations Department, May 2001, pp.5-7

${ }^{113}$ see http://www. moumineen.org.ael

${ }^{114}$ ABU DHABI ECONOMY (2001), pp.5-7

${ }^{115}$ See UNITED STATES DEPARTMENT OF STATE (2001)

${ }_{116}^{116}$ ABU DHABI ECONOMY (2001), pp.5-7

${ }^{117}$ see http://www. moumineen.org.ael

${ }^{118}$ see hittp://www.muntada. org.ae

${ }_{119}$ KI BOOKS (1999), "Monthly News", see http://members.tripod.com/kibooks/news/ian99.htm; and MUSSALLAM, NS (2002), "RCS projects to help disabled", in KHALEEJ TIMES, 1 st December 2002 ${ }^{120}$ See MUSSALLAM (2002)

${ }^{121}$ MĀDAD, Sanā (2003), "Dubai charity telethon to support Iraqi people", in KHALEEJ TIMES, $23^{\text {rd }}$ March 2003

122 Ibid.

${ }^{12.3}$ KHALEEJ TIMES (2002), "National Panel set up for Palestinian Relief, 6" April 2002

${ }^{124}$ MĀDAD (2003)

${ }^{125}$ FLEIHAN, Tarek (2002), "Informal association to raise marriage funds for nationals", in KHALEEJ TIMES, $19^{\text {th }}$ October 2002

${ }^{126}$ See section 2.2 .3

${ }^{127}$ UNITED STATES DEPARTMENT OF STATE (2001), section 2

${ }^{128}$ KHALEEJ TIMES (2001), "Country's judiciary is independent: Dhahiri", $6{ }^{\text {th }}$ December 2001

129 see hitp://www.muntada.org.ae

${ }^{130}$ See MUSSALLAM (2002)

${ }^{131}$ KI BOOKS (1999)

${ }^{132}$ MĀDAD, Sanā (2003)

133 UAE MINISTRY OF INFORMA TION AND CULTURE (2002), free press is guaranteed in the

UAE as per the Constitution under Article 30 which states that, "Freedom of opinion expressing it verbally, in writing or by other means of expression shall be guaranteed within the limits of the law".

${ }^{134}$ CARAPICO (1998), pp.12

135 PECK (1986), pp.78-80 
${ }^{136}$ Tbid. pp. 80

${ }^{137}$ Tbid. pp.80

${ }^{138}$ See section 4.4 .5

${ }^{139}$ UAE MINISTRY OF INFORMATION AND CULTURE (2002), regarding Federal Law No. (15) of 1988

${ }^{140}$ UNITED STATES DEPARTMENT OF STATE (2001), section 2(a)

141 Ibid.

142 SALDAMANDO, Martin (2001), "Big news for a dogged freedom", in STAR MAGAZINE, $11^{\text {th }}$ November 2001

${ }^{343}$ UNITED STATES DEPARTMENT OF STATE (2001), section 1

144 SALDAMANDO (2001)

145 UNITED STATES DEPARTMENT OF STATE (2001), section 1(c) and section 1(d)

${ }^{146}$ Ibid. section 2(a)

147 Ibid

148 SALDAMANDO (2001)

149 Ibid.

150) UNITED STATES DEPARTMENT OF STATE (2001), section 2(a)

${ }^{151}$ Ibid.

152 MADAD, Sanā and FLEIHAN, Tarek (2002), "Issue of teacher beating student may go to court", in KHALEEJ TIMES, $29^{\text {th }}$ May 2002

153 EMIRATES MEDICAL ASSOCIATION (2002), "Annual Report", Abu Dhabi, Shaykh Dr. Mansțr Al-Nuhayyān is son of Shaykh Zäyid, ruler of Abu Dhabi and president of the UAE

154 EMIRATES BANKERS ASSOCIATION (1997), "Financial position of commercial banks of the UAE, 1996-1997", Dubai, pp.4-6

${ }^{155}$ see htton://www.spedubai.org/

${ }^{156}$ ABU DHABI ECONOMY (2001), pp.5-7

157 see http://www, abcdubai.com

${ }^{158}$ UNITED STATES DEPARTMENT OF STATE (2001), section 6(e)

${ }^{159}$ Ibid. Workers are ollen reluctant to lodge complaints for lear of reprisal, “... the press periodically carries reports of abuses suffered by domestic servants, particularly women, at the hands of some employers. Allegations have included excessive work hours, non-payment of wages, and verbal and physical abuse"

160 Ibid. section 6(b)

161 EMIRA TES BANKERS ASSOCIATION (1997), pp.4-6

${ }^{162}$ See UAE CENTRAL BANK (1991), "Annual Report 1991", Abu Dhabi

${ }_{16.3}$ MĀDAD, Sanā (2002), "Ministry details proposal for workers' associations", in KHALEEJ TIMES, $15^{\text {th }}$ January 2002

${ }^{164}$ MĀDAD, Sanā and TLEIHAN, Tarek (2002), "Issue of teacher beating student may go to court", in KHALEEJ TIMES, $29^{\text {th }}$ May 2002

${ }^{165}$ See EMIRATES MEDICAL ASSOCIATION (2002); and see ABU DHABI ECONOMY (2001), pp. 5-7

${ }^{60}$ See http://www.abcdubai.com

167 See http://www.spedubai. org/

${ }^{168}$ See hitp://www.goanculturaldubai.com/

${ }^{109}$ See http://www. pinovuae.com/clubs pang.htm

${ }^{170}$ See http://www.kfs-uae.org

171 See http://www.goanculturaldubai.com/

${ }^{172}$ See http://www.pinoyuae, com/clubs pang.htm

${ }^{173}$ See http://www.lfs-uae. org. this speech was made in Abu Dhabi, 1999 by Jalal Balala, the Kenya Friendship Society's chairman

${ }_{174}$ See http://www, goanculturaldubai.com/

${ }^{175}$ MADAD, Sanā (2001), "Welfare societies will need a federal licence", in KHALEEJ TIMES, 27 "th September 2001

${ }^{176}$ Ibid.

${ }^{177}$ HUDSON, Michael C (1977), "Arab Politics: the Search for Legitimacy", New Haven, Yale University Press, pp.85-88

178 CARAPICO (1998), pp.4-5

${ }^{179}$ KAMRAVA (2000), pp.195

${ }^{180}$ HUNTINGTON, Samuel P (1991), "The Third Wave: Democratisation in the Late Twentieth Century", Norman, University of Oklahoma Press, cited by RANDALL and THEOBALD (1998), pp. 242

${ }^{181}$ Personal interviews, Dubai, March 2002 and September 2002 
182 MĀDAD, Sanā (2002), "Ministry details proposal for workers' associations", in KHALEEJ TIMES, $15^{\text {th }}$ January 2002

183 Ibid.

${ }^{184}$ KHALEEJ TIMES (2002), "UAE seeks ILO help on labour reforms", $16^{\text {th }}$ January 2002, citing the UAE Minister for Labour and Social Affairs speaking at the Dubai Chamber of Commerce and Industry ${ }^{185}$ UNITED STATES DEPARTMENT OF STATE (2001), section 4

${ }^{186}$ Personal Interviews, Dubai, December 2001 


\section{Summary of Conclusions}

As the first chapter of this thesis described, in many ways the lower Gulf was doomed to a future of peripheralisation given the region's scant geographical resources and the local economy's early reliance on both foreign labour and the export of a single primary product. Nevertheless, despite these conditions there were important signs of indigenous socio-economic development. Indeed, with the pearling booms there began to evolve something of a capitalist mode of production and, significantly, a domestic merchant / entrepreneurial class began to emerge from the wealthier strata of the old desert hierarchy. Capable of funding local development projects and even checking the power of their rulers, these merchants were powerful players in lucrative economic networks stretching from South Asia to East Africa. Moreover, alongside these formations there also existed remarkably flexible and relatively de-centralised political structures which allowed for direct channels of access to the rulers and highly effective systems of mobile and consultative democracy. Crucially these traditional polities were also comparatively strong given that they possessed efficient extractive institutions which were capable of both collecting taxes and financing a range of rudimentary government services.

Working within a dependency framework, the chapter demonstrated how this inherited situation was fundamentally altered as the lower Gulf's increasing contact with the core economy and Imperial power of Britain led to the elimination of certain traditional structures and the reinforcement of others. In particular, it was shown how Britain's initial conflict with the Qawasim traders of Ra's al-Khaimah not only secured the British East India Company's trade routes but also displaced a major indigenous economic network and, through a system of maritime treaties, effectively transformed the remaining local rulers into a British client elite. Indeed, by guaranteeing lasting peace in exchange for recognition of their sovereignty, these externally strengthened Trucial rulers, many of whom would have otherwise held only precarious control over their rivals, effectively formalised their dependence on British support and thereby 
brought to an end the fluidity of the traditional tribal political structure. Moreover, as the region's strategic worth and the value of its resources increased, these clients were gradually persuaded by a combination of economic benefits and the implicit threat of renewed conflict to allow almost total British control over their foreign affairs and their local industries. Thus, by excluding all forms of outside intervention, Britain had for all intents and purposes turned the Gulf into a 'British lake' isolated from other economic and political powers. Certainly, without such control and the detachment of the lower Gulf from the wider region it is highly likely that the Trucial States would have either fallen under French influence, or would have been absorbed into a Persian, Ottoman, or other indigenous economic bloc.

By the 1920 s the dependency and responsiveness of these clients to their core patron was further reinforced as the rulers began to receive substantial and often personal incomes from British air companies and British oil exploration firms. Although the lower Gulf has experienced a long history of rent-gathering, these new sources of unearned rentier wealth were on a much greater scale and can be seen to have laid the foundations for many of the region's contemporary structures long before the first oil exports. Indeed, with access to such revenues the rulers were not only able to discontinue most of the existing extractive institutions and instead distribute wealth to their populations, but were also able to shift the traditional ruler-merchant balance of power. Certainly, with the rulers no longer reliant on their merchants for taxation, they were able to assume a new degree of autonomy over their people and, although there were attempts to reinvigorate indigenous development and share the rentier wealth (most notably the Dubai reform movement), these were easily suppressed by the British-backed clients.

Furthermore, even as the Empire began to withdraw in the late 1960s, the British went to great lengths to ensure the survival of their former clients and their future oil suppliers by helping to build up region-wide institutions such as the Trucial States Council and the Trucial States Development Office. Indeed, by encouraging greater unity and a federal framework it was hoped that the newly independent state could be 
guaranteed at least some measure of security from nearby powers and the threat of internal fragmentation. Significantly, many of the region's existing local systems and preferences, such as the emphasis on consultation and the direct channels of communication, were incorporated alongside these seemingly central institutions, and as such the new state was able to ensure a relatively smooth transition without any significant break with the past. Thus, through careful negotiation and compromise the federation was able to steer its way through the initial complications, and in its early years, against the expectations of many, became one of the most stable and successful examples of Arab political union.

The second chapter provided an overview of how the UAE's polity and its traditional monarchies have managed to circumvent the 'Shaykh's Dilemma' of assimilating new groups alongside old by carefully combining traditional sources of legitimacy with structural and material resources in an effort to create a stable and resilient 'ruling bargain'. Specifically, it was demonstrated how the polity has continued to draw upon personal legitimacy resources and, by fostering a patrimonialclientalist system of privileges, loyalties, and vertical linkages; how personal authority has remained a key component of the UAE's legitimacy formula even during an era of rapid population growth and urbanisation. Moreover, by reviving and in some cases reinventing cultural, religious, and ideological resources, the polity has further augmented its position by unifying most segments of the population behind shared memories, common causes, and a greater sense of identity. Thirdly, through astute constitutional engineering and the development of new bureaucracies and institutions it is also clear how the polity has been able to provide some degree of structural legitimacy while at the same time retaining its carefully managed patrimonial, or rather 'neo-patrimonial' network of relations.

At all levels, the region's substantial oil wealth has strengthened the UAE's legitimacy formula by providing enormous material resources and by facilitating the development of a distributive economy which, in turn, has allowed for a powerful 'rentier pact'. Essentially, by providing the bulk of the population with a package of 
distributed wealth and a comprehensive welfare state, the rulers have been able to purchase political acquiescence and considerable popular support from both locals and expatriates. Moreover, it is also important to note how this rentier pact has been particularly strong in the UAE given the relative weakness of the region's merchant elites at the beginning of the oil era. Unlike many of the other Gulf States, whose merchants were comparatively powerful when oil exports began; in the lower Gulf the merchants had suffered numerous setbacks and years of economic depression, thus making it easier to absorb them into a new rentier coalition and less likely for them to press for political reform. Further relating to the UAE's material resources, there is also little doubt that the region's favourable international relations with its powerful oilpurchasing allies have provided an important security umbrella. Indeed, without such protection and perceived support it would seem likely that the UAE and its monarchies would have eventually succumbed to the threat of more powerful expansionary states in an increasingly volatile region.

Moreover, by evolving into large-scale dynasties complete with their own internal self-regulating mechanisms, the UAE's traditional monarchies have been able to warrant even better stability and far greater longevity. By carefully sharing positions of power in the new and more unitary rentier state, by safeguarding and guaranteeing the succession process, and by promoting greater collective action and bandwagoning against harmful factions, the ruling families have managed to avoid both internal divisiveness and damaging external influences. Essentially, the family itself has become an institution and has formed a layer of structural legitimacy in its own right. Indeed, as surrogate political parties, dynastic monarchies can be seen to have developed their own internal dynamic; a dynamic capable of making their members act positively for the group as a whole, and ultimately capable of reinforcing the existing neo-patrimonial and materially-based legitimacy formulae.

As the third chapter described, by the mid-1970s the UAE's economy was already heavily reliant on overseas demand for its oil exports, on foreign technology for the functioning of its industries, and on foreign labour for supplying both its skilled and 
unskilled workforces. Thus, in an effort to promote greater self-sufficiency and more sustained autonomous growth, and of course to ensure the longevity of the crucial material components of their ruling bargain, the 'modernising monarchs' and their development planners initiated a number of strategies which aimed to reduce some of the most damaging features of their dependent development. In particular there were calls for the greater diversification of the economy: specifically the promotion of the UAE's non-oil related sectors and the encouragement of technology linkages and transfers between foreign and domestic enterprises; the creation of a first-class educational and welfare state to provide for a trained and healthy workforce; and the 'emiratisation' of labour, encouraging UAE nationals to assume positions previously requiring expatriates.

With regard to diversification, over the past thirty years the UAE has experienced the modest growth of its non-oil related industries and in some cases, particularly in the ISI manufacturing sector, has managed to encourage the transmission and domestic substitution of foreign technologies. Perhaps more significantly, the UAE's commercial and tourist sectors have expanded considerably over this period and, even though not reducing dependency as such, these sectors have nevertheless greatly reduced the economy's reliance on oil. Furthermore, although with understandably less impressive results, the agricultural sector has also grown, providing an additional nonoil related contribution to the UAE's GDP, while of course providing greater food security. Finally, underpinning these developments has been the creation of a brand new physical infrastructure of roads, ports, industrial parks, and communications. Financed by the UAE's remaining oil wealth, this infrastructure continues to expand, facilitating fresh diversification opportunities and better ensuring a stable and prosperous post-oil future. Thus, although the oil sector still remains the greatest contributor to the UAE's GDP, accounting for somewhere between a quarter and a half of all exports, and although the various diversifying sectors have periodically suffered bouts of sluggish growth, the non-oil sector has nevertheless become extremely significant, especially given the small timescale and the region's comparative backwardness as late as the 1960s. 
Social growth has been equally forthcoming, again of course aided by the UAE's massive oil-financed investments. A large number of schools and universities staffed by qualified and experienced teachers and lecturers have provided the UAE's youth with the highest standards of education, with small class sizes, and with excellent facilities. Similarly the quantity of hospitals and medical centres has mushroomed over this short period, with the ever-increasing number of medical professionals ensuring low doctor-patient ratios and providing effective care for almost all conditions within the UAE. These accomplishments have therefore not only symbolised and consolidated the welfare state component of the rentier coalition, but have also demonstrated the planners' clear commitment to human development in the UAE and the conception of an educated and strong Emirati population.

Although by comparison the emiratisation of the labour force has met with only limited success, and the UAE remains as reliant as ever on foreign labour, there have nevertheless been a number of promising signs, especially in recent years, which point to the much greater emiratisation of managerial, professional, and high-level public sector positions in the very near future. Moreover, given that this has been an area of strategy which has not directly benefited from oil wealth, and indeed may have been hampered by financial incentives which have priced UAE nationals out of the market, these results have been far harder to achieve. Indeed, it would appear that the planners have been forced to adopt a multidimensional approach, relying not only on wealth inducements for locals and restrictive practices such as quotas and visa limitations for expatriates, but also on greater educational and motivational opportunities for the increasing quantity of UAE graduates. Certainly, by providing and sponsoring vocational courses, internships, and other professional training programmes, the government has successfully begun to place far higher numbers of young UAE nationals than ever before into both public and private sector jobs, many of which previously required the expertise of expatriate workers.

In addition to these broad strategies, it must also be noted how the relative flexibility of the UAE's federal system has allowed for the purstit of differing sub- 
strategies, especially in the two largest and wealthiest emirates of Abu Dhabi and Dubai. Quite simply, Abu Dhabi's substantial oil wealth has engendered a more cautious diversification strategy based around heavy export-oriented industries which aim to maximise the emirate's comparative advantages of cheap energy and abundant natural resources. On the other hand, Dubai's rich history of commercial development and the entrepreneurial spirit of the ruling Āl-Maktūm dynasty, coupled with more modest and depleting oil reserves has instead promoted far more rapid and far truer diversification. Indeed, with an emphasis on smaller import-substitution industries largely unrelated to the oil sector and with the massive expansion of its commercial and tourist sectors, Dubai's non-oil sector has long since accounted for the vast bulk of the emirate's GDP. Crucially, these differing strategies are now being regarded as complementary and mutually reinforcing, as Abu Dhabi's considerable wealth and heavy industries can continue to provide the UAE's financial backbone and support the other emirates, while Dubai's more diversified economy and strong commercial links can better promote the UAE internationally and can better contribute to the emiratisation strategy by providing more varied and appropriate employment opportunities for UAE nationals. Thus, far from conflicting, the UAE's sub-strategies may become a vital factor in ensuring successful future socio-economic development.

However, as the third chapter also demonstrated, it is important to consider a number of critical development problems which have periodically surfaced and which, in some cases, have remained unresolved. Indeed, despite the planners' best efforts, the UAE has remained heavily consumption rather than production oriented, with a resulting trade imbalance and a declining balance of payments. Furthermore, despite the evidence of increasing co-operation between Abu Dhabi and Dubai, there has also been the highly visible duplication of projects in the smaller emirates, with expensive and unnecessary developments often taking place in adjacent territories, many of which have remained under-utilised and empty. Thirdly, there has been the continuing problem of regional disequilibrium, with the wealth and development gap between the oil-producing emirates and the other emirates remaining almost as great as it was thirty years ago. In much the same way as the plans for emiratisation, these have not been 
problems which can easily be addressed by greater investment and oil-financed development projects. Instead, given the nature of the problems, it would appear that a number of internal pathologies must be responsible, namely the primarily allocative nature of the state, the persistent consumerist mentality of the rentier population, the lack of inter-emirate co-ordination, the absence of effective inter-departmental cooperation, and presumably, on occasion, the mismanagement of resources and a lack of transparency.

Thus, in an effort to explain more fully some of these ongoing development problems, the fourth chapter focused heavily on the role of domestic structures and their associated weaknesses. Indeed, by reiterating the potentially negative implications of rentierism / allocation, and by underscoring the impact of reinvigorated neo-patrimonial networks, bureaucratic self-interests, and differing client elite orientations on the UAE's policymaking and policy implementation processes, it was shown how in many cases the same strengthened traditional and dependent structures which have allowed for monarchical survival and political stability are now so deeply entrenched that they actively shape, and often undermine, socio-economic development objectives and the planners' attempts to modify the UAE's circumstances. Certainly, in many ways these problems can be viewed as the hidden costs of the UAE's ruling bargain, its political stability, and the persistence of traditional forces; and therefore the price which must be paid in order to permanently circumvent the Shaykh's dilemma and the inevitability of the early modernisation theories.

Essentially, it was shown how the UAE's decision-making structure at the federal level is still dominated by hereditary rulers and their appointees in a hybrid neopatrimonial government of seemingly modern institutions grafted onto powerful traditional authorities. Moreover, although a legislature does exist, the unicameral nonelected chamber of appointed representatives has remained in a paralysed state, often unable to exercise its constitutional rights and frequently incapable of questioning or restraining the executive. Furthermore, at the emirate level, local governments and departments continue to exist, some of which are subordinate but many of which run 
parallel to and overlap their federal counterparts. Certainly, there have been numerous occasions when the fabric of the union has been stretched to breaking point, often over vital issues of national interest such as oil policy, foreign affairs and defence. Thus, while the federation has certainly strengthened in recent years with the greater incorporation of Dubai, it is nevertheless still more accurate to consider the UAE as something of a loose confederation with its relatively autonomous and at times uncoordinated emirate-level powers continuing to shape the state's development.

Also capable of influencing Emirati development have been the various other institutions, parastatals, and bureaucracies tasked with policy implementation and advisory roles. Case studies of the various chambers of commerce, judicial institutions, and financial institutions provided examples of how these are also very much part of a rigid neo-patrimonial network of non-elected appointments and close links to the traditional polity. Furthermore, it was shown how in certain circumstances these institutions have suffered from a number of other pathologies including bureaucratic self-interest, opaqueness, and a lack of genuine independence. Indeed, the BCCI scandal of the early 1990s can be seen as a prime example of the devastating effect of such a combination of pathologies; with the management and fortunes of one of the UAE's most prominent development-related institutions having been inextricably linked to the traditional polity, with the offending bureaucracies having prevented disclosure in the interests of self-preservation, with the major regulatory bodies being powerless to intervene, and with the host emirate's local government and legal system left vulnerable to external interference and corruption.

Furthermore, in an attempt to highlight the non-homogenous nature of the UAE's client elite, the fourth chapter also revealed the increasing struggle over the future of Emirati development between the reformers and conservatives. Although both orientations are of course components of the same dominant rentier class deriving income from economic rent, the reformers can be seen as 'new rentiers' while the conservatives can be seen as 'old rentiers'. Essentially the new rentiers have sought fresh sources of economic rent from non-oil related activities such as the letting of real 
estate and commercial free zones, while the old rentiers have sought to perpetuate the steady flow of oil revenues. Significantly, a number of controversial issues such as foreign property ownership, foreign business ownership, and foreign direct investment have led to protracted disputes between those attempting to liberalise the economy and foster the growth of these non-oil related activities, and those attempting to preserve the status quo and safeguard what they believe to be the UAE's national interests. Thus, with conflicting legislation, work-arounds, pioneering projects, and attempts to circumvent existing regulations, the interactions of these opposing elite interest groups must be regarded as another major domestic influence on the UAE's socio-economic development.

As the fifth chapter demonstrated, with the seemingly inevitable acceleration of global integration, in part due to the liberalising reforms of these non-oil rent seekers, certain new external forces, perceived as both benign and malignant, are now also beginning to shape and influence indigenous structures, and must therefore be included alongside domestic factors in a comprehensive assessment of Emirati development. Firstly, with regard to the UAE's economic structures, it was indicated that globalisation has led to both increased international competition and greater marketing opportunities for Emirati firms. Secondly, and equally controversially, it was suggested how increasing global economic integration may have led to a neglect of regional integration, widely believed to serve as an important safety net for most developing economies. Thirdly, the impact of international organisations such as the WTO and the IMF on the domestic economy was also shown to be both far-reaching and ambiguous, with clear divisions having emerged over the UAE's acceptance of any international agreements thought likely to alter existing structures permanently. On the one hand, certain groups have championed the prospects of the WTO-led removal of monopolies and the implementation of copyright controls, while on the other hand conservatives have cautioned against the opening up of key industries and the political complications which may result from the UAE's commitments. 
In the second part of the chapter, the equally contentious impact of sociocultural external forces was considered, with particular regard to globalisation's role in the perceived erosion of Emirati culture and heritage, with reference to the rapid marginalisation of the Arabic language and, more positively, with regard to international communications and increased accountability. Indeed, it was demonstrated how globalising forces have been blamed for the increasing 'cultural contamination' which appears to have all but destroyed the traditional Emirati way of life, and how in turn this socio-cultural attack has provided an additional impetus for the government's multipurpose cultural revival. Similarly, it was shown how the increasing presence of non-Arabs, foreign media, and foreign-language education have all combined to marginalise the Arabic language, again prompting a reaction to what is widely believed to be the consequence of intrusive globalisation. However, with regard to the improvements in global communications and their accessibility in the UAE, it is evident that such developments have been better received, with many agreeing that such supra-national sources of information have already begun to increase the accountability and transparency of neighbouring Gulf communications networks, a trend which may soon reach the UAE.

Finally, in addition to these significant influences on domestic socio-economic development, some of which have helped to reinforce existing pathologies while others have helped to overcome such obstacles, the chapter also explained how globalising forces may begin to play an important role in reshaping civil society and associational life in the UAE. Specifically, following a demonstration of how the UAE's current civil society remains in a weakened state due to a combination of rentier-dependency related structures (namely cultural heterogeneity resulting from the massive foreign labour force, increasing levels of government co-option, royal patronage, and, in some circumstances, greater control and repression), it was suggested that a fresh wave of external forces may nevertheless offer a means of reactivating and supporting demobilised associations in the near future. In particular, the transfer of ideas and methods from the increasing number of UAE-based branches of international organisations may lead to stronger internal structures for indigenous associations and a 
greater network of collective security and mutual support. Secondly, the improvements in global communications may also provide a demonstration effect for the UAE's civil society organisations as they become better connected and more able to share experiences with their counterparts in other parts of the world. Lastly, and perhaps most significantly, it was also shown how certain external bodies may be capable of motivating the UAE government to free up civic space from above, with domestic labour groups and human rights associations already likely to benefit from recommendations and proposals made to the relevant ministries by prominent global NGOs and major international partners. 


\section{Appendices}

Appendix (i) - Early agricultural development

The Liwā chain of oases in southern Abu Dhabi offered some support for farming even in the heart of the desert, but it was only in the oases and towns close to the Hajar Mountains in the North and East of the region that agriculture was really able to flourish. ${ }^{1}$ Hatta, Dhayd, and the twin oases of Buraimi and Al-'Ayn were surrounded by a green landscape of well-irrigated farms and a forest of palm trees. They hosted a number of important markets and emerged as major trading posts for travellers from all over southern Arabia and Oman. The key to their success was in their use of an ancient but effective system of irrigation and water transportation. This 'falaj' system (pl. aflâj) comprised of subterranean stone tunnels which were designed to bring water down to the level of the towns from the high water tables of the nearby mountains. When the tunnels reached the agricultural gardens they would become surface channels allowing the water to be regulated and re-directed to wherever it was most needed. ${ }^{2}$ It is uncertain when the first of these tunnels were constructed, as although it is widely believed that they were originally introduced to the area by the Persians, ${ }^{3}$ more recent studies have claimed they were the work of indigenous Omani people. ${ }^{4}$ Nevertheless, regardless of their origin, the majority were probably built during pre-Islamic times with many having been restored in more recent years. Indeed, working examples can still be seen today in the mountainous village of Hatta in Dubai emirate, and more extensively in the date gardens of Al-'Ayn where a network of aflāj help to maintain a huge mumber of palms close to the city centre.

The introduction of more modern technology and methods allowed for some modest development in the agricultural sector, but this took time, and it was only in the 1950s that tangible improvements were seen. The first real progress was in Ra's alKhaimah following the establishment of an Agricultural Trials Station at Diqdaqa. Agriculture had always been more developed and diversified in Ra's al-Khaimah given 
the northern emirate's slightly cooler climate and its proximity to the mountains. Indeed, there has always been a higher than average proportion of the labour force engaged in agricultural activity in this emirate, and after the station began operating in 1955 the proportion began to grow. In 1967 a Department of Agriculture was set up with the assistance of the Trucial States Development Office $^{5}$ and this further expanded the operation in Ra's al-Khaimah by adding an agricultural school, a veterinary clinic and a new network of afläj to help support the recent growth. ${ }^{6}$ The department had its headquarters in the main agricultural centre close to Al-'Ayn in the Abu Dhabi emirate, and continued to introduce more experimental farms with the dual aims of testing varieties of plants for their suitability in the desert climate, and also of helping to demonstrate modern agricultural techniques to local farmers, many of whose families still farm the land today. ${ }^{7}$

\section{Appendix (ii) - The Sharjah Decency Laws}

"The Emirate of Sharjah has promulgated a set of rules aimed at promoting public decency and proper conduct. The rules include a dress code for both men and women; rules regarding bathing suits; rules on places where only women are allowed; a prohibition on men and women who are not married or related from being alone; a prohibition on antisocial behaviour; and a prohibition on wearing certain clothing in mosques. The rules were promulgated as Local Instructions No 1 of 2001 and Executive Council Resolution No 12 of 2001. A multi-lingual booklet has been published to direct the attention of the public to the new rules. The dress code prohibits men from wearing shorts in public or commercial places and in public offices. It also prohibits men from appearing in public shirtless or wearing only an ezar (a type of local undergarment). Women may not wear clothing that exposes their backs or abdomens, shorts or skirts that are cut above the knee, or other clothes that are tight or transparent. The rules require all swimmers to wear conservative swimwear that is acceptable to the culture of Sharjah. They prohibit wearing bathing suits in the streets or other public places. The rules provide that men may not enter specified private areas to be used only by women, except in emergency circumstances. An unmarried man and woman may not be alone in 
a public place or in suspicious circumstances. The rules prohibit disturbing the peace with acts of vulgarity or loud noise and also prohibit acts of harassment that violate public decency. People may not enter a mosque wearing pyjamas or clothing that has images or improper slogans. The Sharjah police, security officers and building guards are charged with ensuring adherence to the rules, and they may issue warnings or refuse to provide public services to persons who violate the rules."

[Source: Sharjah Law, Local Instructions No 1 of 2001 and Executive Council Resolution No 12 of 2001, supplied by Afridi and Angell, Dubai $]^{8}$

Appendix (iii) - Emirati identity surveys

Sally Findlow's identity survey was conducted in 1999 at the University of the $\mathrm{UAE}$ in Al-'Ayn. 500 university students were asked to answer the question, "Where are you from?"

\begin{tabular}{|l|l|l|}
\hline Student's home emirate & 'UAE / Emirati' response & Other response \\
\hline $\begin{array}{l}\text { Abu Dhabi (including Al- } \\
\text { 'Ayn) }\end{array}$ & $50 \%$ & $50 \%$ \\
\hline Dubai & 15 & 85 \\
\hline Ra's al-Khaimah & 15 & 85 \\
\hline Overall & 30 & 70 \\
\hline
\end{tabular}

[Source: Sally Findlow, "The UAE: Nationalism and Arab-Islamic Identity"]

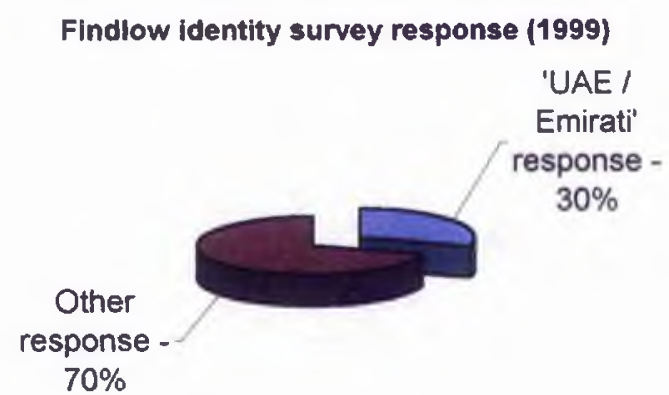

[Source: Sally Findlow, "The UAE: Nationalism and Arab-Islamic Identity"]

The author's identity survey was conducted in April 2002 in five locations across the UAE. 250 male UAE citizens of varying age groups were asked, "Which of the following best describes your identity?", and were provided with three choices: 'UAE / 
Emirati', an emirate-specific response (e.g. Abu Dhabi for those surveyed in Abu Dhabi), and a more general 'Arab' response.

\begin{tabular}{|l|l|l|l|}
\hline Location & $\begin{array}{l}\text { 'UAE / Emirati' } \\
\text { response }\end{array}$ & $\begin{array}{l}\text { Emirate-specific } \\
\text { response }\end{array}$ & 'Arab' response \\
\hline Abu Dhabi & $86 \%$ & $8 \%$ & $6 \%$ \\
\hline Dubai & 36 & 60 & 4 \\
\hline Sharjah & 76 & 16 & 8 \\
\hline 'Ajman & 98 & 0 & 2 \\
\hline Al-Ayn & 100 & 0 & 0 \\
\hline Overall & $\mathbf{7 9 \%}$ & $\mathbf{1 7 \%}$ & $\mathbf{4 \%}$ \\
\hline
\end{tabular}

[Source: Davidson identity survey, 2002]

\section{Davidson identity survey response (2002)}

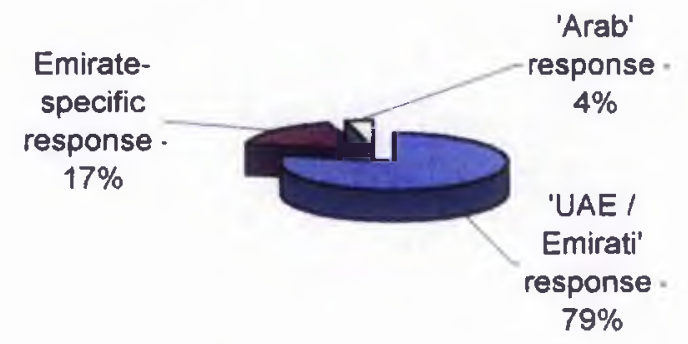

[Source: Davidson identity survey, 2002]

Appendix (iv) - Volume of non-oil trade and re-exports in Dubai

Dubai's non-oil foreign trade - quantity

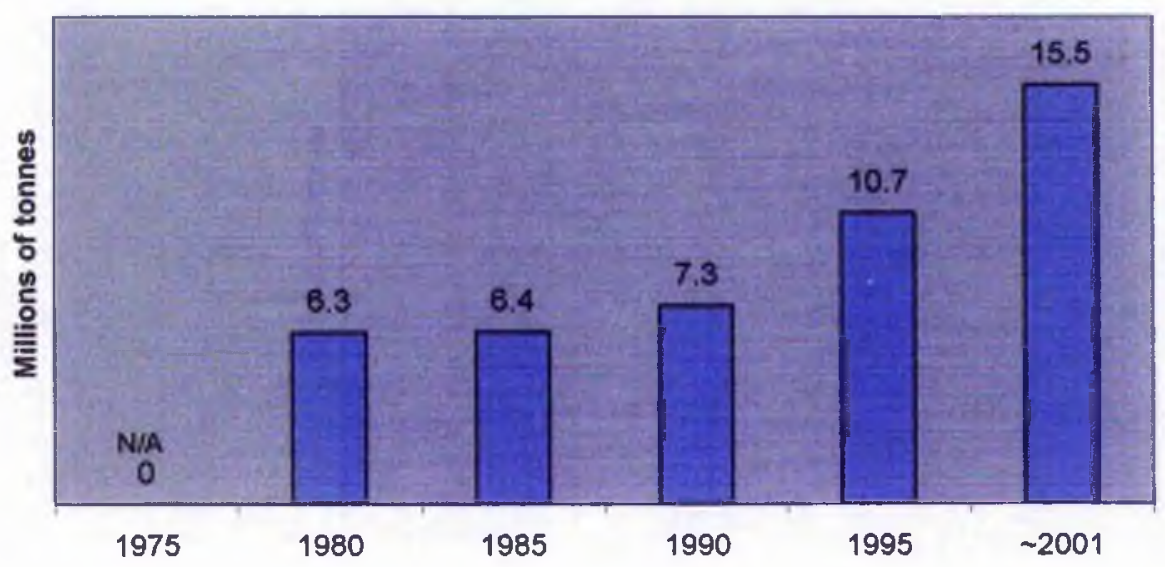




\section{Dubai re-exports - quantity}

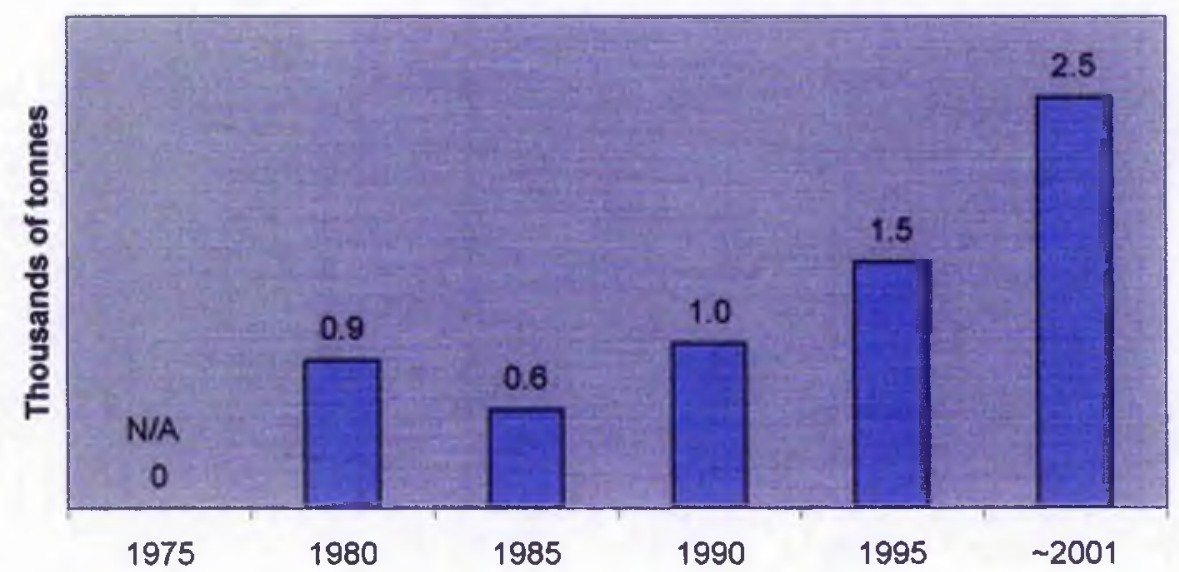

[Source: Dubai Department of Ports and Customs] ${ }^{11}$

Appendix (v) - Net enrolment ratios and Student/teacher ratios

\begin{tabular}{|l|l|l|}
\hline Educational Sector & Year & Net enrolment ratio \\
\hline Primary & $2000 / 2001$ & 86.6 \\
\hline Secondary & $2000 / 2001$ & 67.4 \\
\hline Tertiary & $1998 / 1999$ & 12.1 \\
\hline
\end{tabular}

[Source: UNESCO $]^{12}$

Student/teacher ratios in Dubai schools

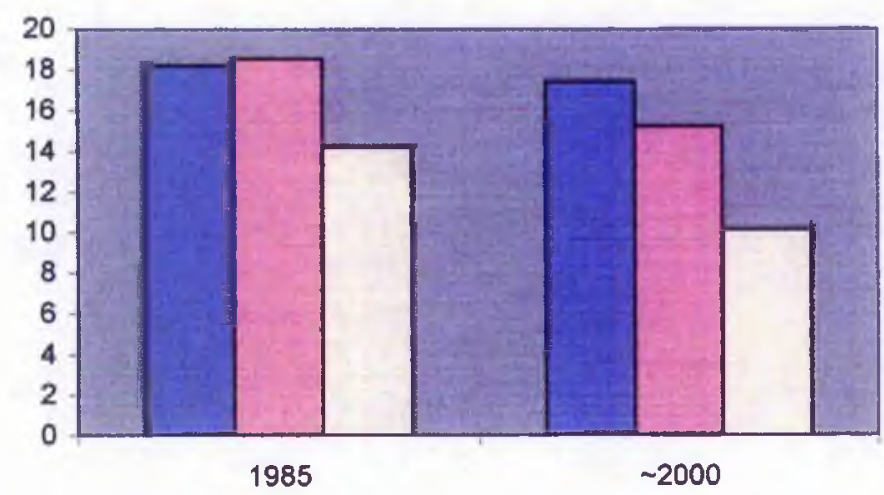

- Private sector -

primary and

secondary

a Primary

schools

D Secondary

schools

[Source: UAE Ministry of Education and Youth] ${ }^{13}$ 
UAE population breakdown - by gender

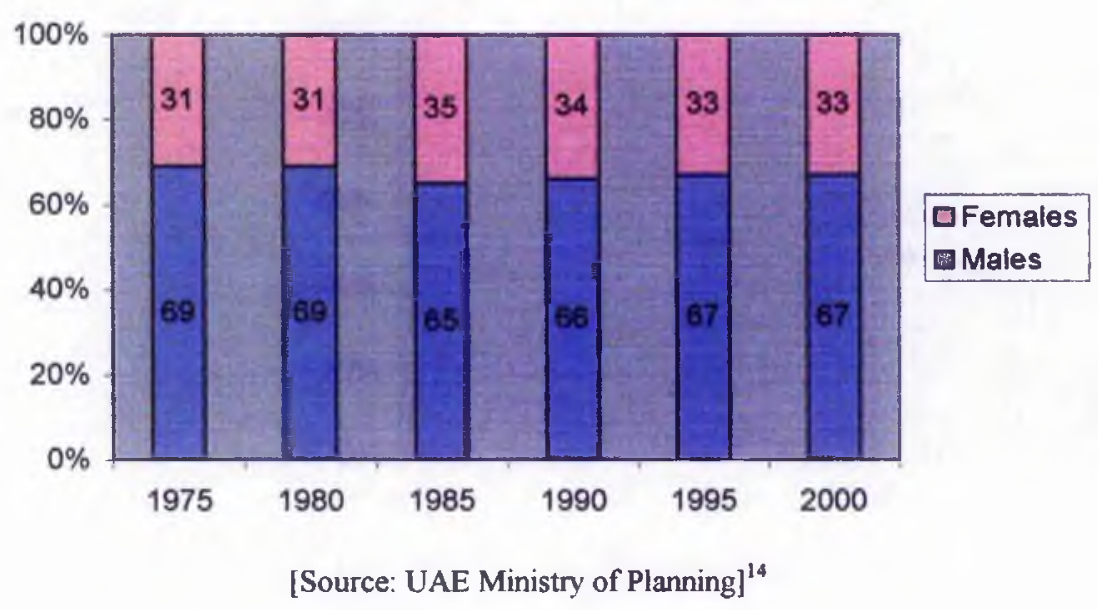

Dubai population breakdown - by gender

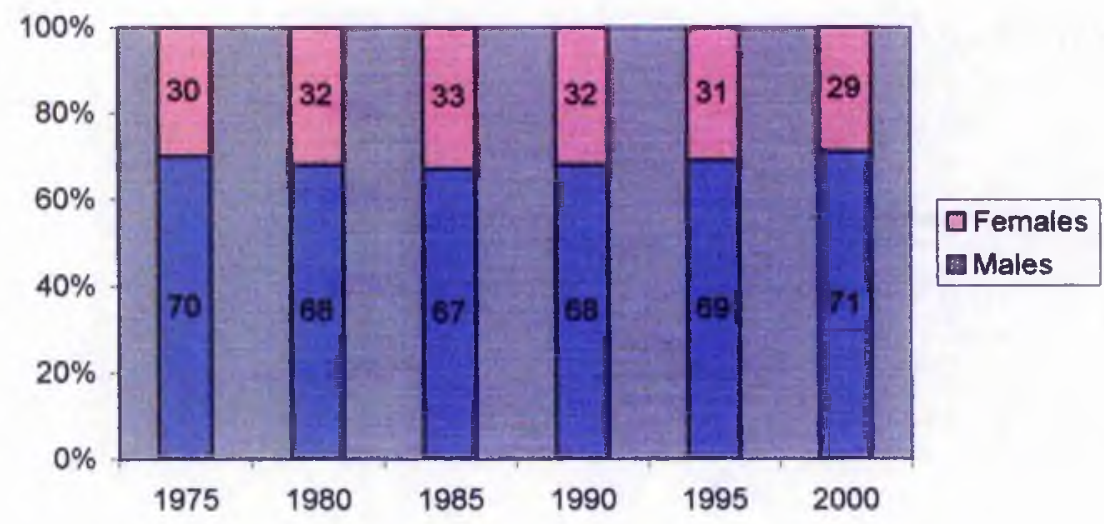

[Source: Dubai Municipality] ${ }^{15}$

Appendix (vii) - The UAE Council of Ministers, 2002

President

Vice President / Prime Minister

Deputy Prime Minister

Agriculture and Fisheries

Communications

Defence

Economy and Commerce

Education and Youth

Electricity and Water

Finance and Industry
Shaykh Zāyid Al-Nuhayyān

Shaykh Maktūm Al-Maktūm

Shaykh Sultān Al-Nuhayyān

Sa'id al-Raqabani

'Ahmad Al-Tayir

Shaykh Muhammad Al-Maktūm

Shaykh Fahim al-Qāsimī

Dr. Ali Al-Sharhan

Humayd Al-Uways

Shaykh Hamdan Al-Maktūm 
Foreign Affairs

Health

Higher Education and Research

Information and Culture

Interior

Justice and Islamic Affairs

Labour and Social Affairs

Petroleum and Mineral Resources

Planning

Public Works and Housing

Minister of State for Cabinet Affairs

Minister of State for Finance and Industry

Minister of State for Foreign Affairs

Minister of State for Supreme Council Affairs

Minister of State for Presidential Office (1998)

Governor of the UAE Central Bank

Ambassador to the USA

Permanent Representative to the United Nations
Rāshid al-Na'īmī

Hamad Al-Madfa

Shaykh Nuhayyān Al-Nuhayyān

Shaykh Abdullah Al-Nuhayyān

Lt. General al-Badi

Muhammad al-Dhahiri

Matar Al-Tayir

Ubayd al-Nasiri

Shaykh Humayd al-Mu'allā

Raqad Al-Raqad

Sa'id Al-Ghayth

Dr. Muhammad Kharbash

Shaykh Hamdan Al-Nuhayyān

Majid al-Na'imi

Shaykh Mansūr Al-Nuhayyān

Sultăn al-Suwaidi

Muhammad al-Shāli

Muhammad Samhan

[Source: Business Monitor International, the Middle East Research Institute of Japan, and Polsci.com] ${ }^{16}$

Appendix (viii) - US pressure for economic reform in the UAE

As one of the UAE's most important trading partners and a major source of the UAE's foreign investment, the USA has recently lobbied for economic reform in the UAE. Indeed, the USA has openly criticised the UAE's current business environment and has indicated that if changes are forthcoming then the UAE can expect greater American investment. In the words of Robert Mallet, the US Deputy Secretary of Commerce, speaking in 1999:

"Are there areas where we could be moving more quickly? There certainly are. We believe that the UAE has the potential to become a rôle model for the rest of the Middle East. We think that the UAE can set new standards for good business practices, including more privatisation, increased transparency and more respect for intellectual property rights - including the enactment of copyright patent laws consistent with World Trade Organisation practices. We hear from American firms that they are eager to participate in additional privatisation projects. They are eager to invest 
in the pharmaceutical domain, for instance, if their rights are fully respected and protected. American companies would like greater flexibility regarding commercial agents, majority ownership and more vigorous contract-dispute resolution methodologies. "17

Appendix (ix) - Contrasting ALESCO recommendations regarding globalisation and Emirati culture

In 1977, the UAE's representatives at the ALESCO (Arab League for Educational, Scientific, and Cultural Organisation) conference stated their country's need to safeguard against globalising forces:

“... while stating its [the League's] belief in the value of keeping pace with modern science and technology, it resolved first to explore in depth the foundations of Arab Islamic authenticity in order to safeguard it against the ideological influences contaminating it from so many sources".

However, in 1998, on the same subject, the indication was one of greater acceptance of globalisation and the need for increased cultural coexistence rather than resistance:

"... the approach is that particular cultures and value systems should not dominate over others. It is no longer an issue of dealing with cultural invasion, but of ensuring fairness among other equally worthy cultures. Thus, every effort should be made to profess and promote the strengths of the Arab and Islamic culture as part of the major intellectual cultures of the world." 18

${ }^{1}$ LORIMER, JG (1915), "Gazetteer of the Persian Gulf, Oman and Central Arabia" Volume 1 Historical Part II, Calcutta. Superintendent Government Printing [republished 1970 by Gregg International Publishers], pp. 2296

${ }^{2}$ HEARD-BEY, Frauke (1982), "From Trucial States to United Arab Emirates", London, Longman, pp. $177-180$ 
${ }^{3}$ British historians such as Hawley claim the aflaj date from the Sassanid occupation of Oman between the third and seventh centuries, see HAWLEY, Donald (1970), "The Trucial States", London, George Allen \& Unwin, pp.203

${ }^{4}$ Recent UAE-based archaeological studies contend that the indigenous Omanis were the original creators of the afläj, not the Persians. Moreover, it is believed that the word ' $f a l a j$ ' is a derivate of the Arabic verb 'felj' which means 'to divide something into two parts', especially with regard to water or money. See (in Arabic) AL-TIKRITI, Walid (2003), "Aflajj", Department of Antiquities and Tourism, Al-'Ayn

${ }^{5}$ See references to the British funded Trucial States Development Office, section 1.4.4

${ }^{6}$ FENELON, Kevin (1973), "The United Arab Emirates: An Economic and Social Survey", London, Longman, pp.49-50

${ }^{7}$ Ibid. pp.46-47

${ }^{8}$ SHARJAH LAW (2001), "Local Instructions No 1 of 2001 and Executive Council Resolution No 12 of 2001", supplied by AFRIDI \& ANGELL, Dubai

${ }^{9}$ FINDLOW, Sally (2000), "The UAE: Nationalism and Arab-Islamic Identity", Abu Dhabi, Emirates Centre for Strategic Studies and Research, ECSSR OCCASIONAL PAPER, Number 39, pp.29-30 ${ }^{10}$ Ibid.

11 DUBAI DEPARTMENT OF PORTS AND CUSTOMS (2002), "Dubai: non-oil foreign trade total", in DUBAI DEPARTMENT OF ECONOMIC DEVELOPMENT (2002), "Development Statistics", Government of Dubai, pp. 109

${ }_{12}$ UNESCO (1998/1999/2000/2001), the net enrolment ratio being the percentage of children attending from the relevant age group

${ }^{13}$ UAE MINISTRY OF EDUCATION AND YOUTH (2001), "Dubai: government schools student/teacher ratio", "Dubai: private schools - teachers by sex", and "Dubai: private schools enrolment by sex", all in DUBAI DEPARTMENT OF ECONOMIC DEVELOPMENT (2001), "Development Statistics", Government of Dubai, figures for government sector schools taken from ratios published on pp.199, ratios for private sector schools calculated from teacher and student totals listed on

pp.208-209
UNTTED ARAB EMIRATES MINISTRY OF PLANNING and DUBAI MUNCIPALITY (2001), "UAE and Dubai: population", in DUBAI DEPARTMENT OF ECONOMIC DEVELOPMENT (2001), "Development Statistics", Government of Dubai, pp.25

is Ibid.

${ }^{16}$ See BUSINESS MONITOR INTERNATIONAL (1998), "The United Arab Emirates"; and MIDDLE EAST RESEARCH INSTITUTE OF JAPAN (2002) statistics relating to UAE cabinet compositions; and POLSCI.COM (2001), "Political reference Almanac - UAE Political System", New York, Keynote Publishing; and personal interviews, Abu Dhabi, September 2002

${ }^{17}$ MALLETT, Robert L (2001), "Symposium on Shaykh Zãyid", in MIDDLE EAST POLICY, volume 6 number 4, June 1999, pp.13 quoting Robert Mallett, Deputy Secretary of Commerce, US Department of Commerce, speaking at the $20^{\text {th }}$ April 1999 conference convened by the Middle East Policy Council ${ }^{18}$ FINDLOW (2000), pp.36 citing the contrasting examples of ALESCO conferences in 1977 and 1998 


\section{Glossary of Terms, Abbreviations and Acronyms}

\begin{tabular}{|c|c|}
\hline 'Āmil & $\begin{array}{l}\text { a person involved in an almost capitalist system of } \\
\text { pearling in which boats would be fitted out by an } \\
\text { entrepreneur who would then claim a share of all profits }\end{array}$ \\
\hline 'Amir & $\begin{array}{l}\text { the ruler's local representative, especially on the Ábu } \\
\text { Dhabian island of Dalmā }\end{array}$ \\
\hline 'Ārif & $\begin{array}{l}\text { an official responsible for the maintenance of falaj } \\
\text { irrigation channels in agricultural towns such as Hatta and } \\
\text { Al-"Ayn }\end{array}$ \\
\hline 'Askars & $\begin{array}{l}\text { armed tribesmen paid a salary to enforce the ruler's } \\
\text { authority in outlying regions }\end{array}$ \\
\hline 'Azima & $\begin{array}{l}\text { a voluntary contribution paid by pearling merchants to } \\
\text { provide for feasts in honour of visiting dignitaries, } \\
\text { especially on the Abu Dhabian island of Dalmā }\end{array}$ \\
\hline$A b \bar{a} y a$ & a form of traditional dress \\
\hline$A b \bar{u} M \bar{u} s a ̄$ & $\begin{array}{l}\text { strategic island in the lower Gulf, formerly belonging to } \\
\text { Sharjal, but currently occupied by Iran }\end{array}$ \\
\hline Ardha & a show or display, e.g. camel races in Bedu society \\
\hline 'Ashīra & a narrowly defined familial organisation or tribe \\
\hline Atheer & a major Abu Dhabian gas company \\
\hline Baggala & $\begin{array}{l}\text { a type of fishing / trading vessel commonly used in the } \\
\text { Gulf }\end{array}$ \\
\hline Banian & a British Indian subject \\
\hline Bani Yas & a powerful Abu Dhabi-based tribal federation \\
\hline Baraka & charisma \\
\hline Bastakiyah & $\begin{array}{l}\text { an old quarter of Bur Dubai once donated by the ruler to } \\
\text { Persian merchants, some of the Bastakiyah houses still } \\
\text { have their original wind towers }\end{array}$ \\
\hline Bay'a & collective recognition of another person's authority \\
\hline Bedu & $\begin{array}{l}\text { nomadic people (the double plural 'bedouin' is not } \\
\text { commonly used in the lower Gulf) }\end{array}$ \\
\hline Buraimĩ & $\begin{array}{l}\text { a conurbation of Omani villages surrounding a large oasis } \\
\text { close to } \mathrm{Al}^{\prime} \text {-Ayn and the UAE border }\end{array}$ \\
\hline Bushire & an important Iranian harbour town \\
\hline Dalmā & $\begin{array}{l}\text { a small Abu Dhabian island, formerly a thriving centre of } \\
\text { the pearling industry }\end{array}$ \\
\hline Dãr al-harb & $\begin{array}{l}\text { the non-Muslim world, referring to the Wahäbbi attempts } \\
\text { to conquer non-Wahābbi lands }\end{array}$ \\
\hline Dãs & $\begin{array}{l}\text { an Abu Dhabian island transformed into an offshore oil } \\
\text { terminal }\end{array}$ \\
\hline Dhayd & an agricultural town due east of Sharjah \\
\hline Dibba al-Fujairah & $\begin{array}{l}\text { a small town on the UAE's Indian Ocean coastline, } \\
\text { currently being redeveloped into a tourist resort }\end{array}$ \\
\hline Dirhäm & the UAE's currency \\
\hline Diqdaqa & $\begin{array}{l}\text { an agricultural town south of Ra's al-Khaimah, the site of } \\
\text { the first agricultural trials station in the Trucial States }\end{array}$ \\
\hline Dira & $\begin{array}{l}\text { the elastic concept of an area in which a tribe exercised } \\
\text { sway }\end{array}$ \\
\hline Dīwān & the Ruler's court \\
\hline
\end{tabular}




\section{Dishdāsha}

Dnata

Duris

\section{Etisalat}

Falaj (pl. afläj)

\section{Al-Faqï}

Al-Ghanima

Ghasō

Ghayathi

Ghazu

Hadhr

Hajar Mountains

Haras

Hāsila

Hatta

Huküma

Ikhluwi

Imầm

Jalbūt

Julfar

Jumeirah

Kafil

Kalbā

Al-Khawiya

Khojah

Khor Fakkān

Khutba

Lakh

Lingah

Līwā Oases

Majlis (pl. majālis)

Majlis al-tujjär a form of traditional dress

a Dubai Government-owned supplier of cargo air services armed guards in the oasis towns and outlying regions responsible for protecting camels and other livestock from raiders

the UAE's telecommunications monopoly

subterranean stone tunnels designed to bring water down from the mountains and provide irrigation in agricultural areas

a small town on the UAE's Indian Ocean coastline, currently being redeveloped into a tourist resort the booty collected by desert raiders, of which four-fifths would be divided amongst the tribesmen and one-fifth retained by the leader

the 'pearling proletariat' of crewmen which emerged as a result of the 'ámil system

an Abu Dhabian settlement close to the Saudi border desert raiding

settled people

a range of mountains running down from the Musandam

Peninsula into the UAE's hinterland

armed guards at the ruler's fort in the main town

a pearling tax requiring all pearling boats to contribute a share equal to income of one crewmember

a town in the Hajar Mountains, an enclave of Dubai emirate and an increasingly popular tourist destination the traditional tribal administration

a communal system of pearling in which the crew would jointly own a boat and share all profits

a communal prayer leader

a type of fishing / trading vessel commonly used in the Gulf

the former name for Ra's al-Khaimah

a western district of Dubai, now dominated by European expatriates

a sponsor - all foreign businesses operating in the UAE require at least one local partner

a small town on the Indian Ocean coastline, it was briefly granted independence from Sharjah in order to facilitate British negotiations over air landing rights

the period of oil exploration by foreign firms in the 1930s

a Punjabi region of present-day Pakistan

a container port on the UAE's Indian Ocean coastline, part of Sharjah emirate

Friday sermons

a denomination of British-Indian currency

an important Iranian harbour town

a string of oases deep inside the Abu Dhabian hinterland a meeting place / council

the council convened by Shaykh Sa'id Al-Maktūm in the 1940 s to rejuvenate many of the projects originally proposed during the Dubai reform movement of 1938 
Al-Majlis al-watañ lil-ittihädthe Federal National Council of appointed representatives

Mäshā

Al-Mashriq

Al-Mithaq

Mutārizaya

Muzakki

$N \bar{a} ' i b$

Naub

Al-Nisab

Qãdi

Qalta

Qawäsim (adj. Qāsimī)

Qishm

Ra'iyy / Ra'aiyya

Rams

Rol Dibba

$R u b^{\prime} a l-K h a ̈ l i ̄$.

Sādiyat

Saib

Salalah

Sälifa al-ghaus

Sambük

Shari'a

Sharif

Shaykh

Shaykhdom

$S h i^{i} a$

Al-Shindagha

Shürā

Souq

Straits of Hormuz

Sunni a tax collected by the 'ärifs to help maintain the falaj

irrigation channels in agricultural towns

the eastern Arab world

the pact between rulers and other groups, also the name of the Bahraini Emir's new national charter

the ruler's armed retainers

an official responsible for tax collection

the ruler's local representative, especially in Al-'Ayn

a pearling tax levied on all pearl merchants proportionate to the size of their business

the tax threshold quantity of dates

a judge responsible for dispensing justice according to

Islamic law

a pair of pearling crewmen, normally a diver and a hauler a tribal federation that grew prosperous from maritime trade in the early nineteenth century and whose descendents continue to rule Sharjah and Ra's al-Khaimah a large island close to the Straits of Hormuz and the present day Iranian port of Bandar 'Abbās

a shepherd / his flock

a small coastal town north of Ra's al-Khaimah

a small town on the UAE's Indian Ocean coastline, currently being redeveloped into a tourist resort

the 'Empty Quarter', a desert which stretches across the

Najd Peninsula into Oman and the UAE

an Abu Dhabian island currently being redeveloped as a

real estate investment park

a pearling boat crewman, normally a hauler or rope-puller for divers

an Omani deep-water container port

'pearling courts' used to settle disputes relating to pearling and the pearl trade

a type of fishing / trading vessel commonly used in the

Gulf

Islamic law

referring to the camel herding tribes who achieved a

higher socio-economic status / noble status over their

sheep herding counterparts

the leader of a tribe / a title of respect

a Shaykh's area of influence

the general name for a large group of Muslim sects, all of which contest the recognition of "Ali as the legitimate

Caliph following the death of the Prophet Muhanmad

a creek side district of Bur Dubai

consultation

a town's marketplace

the strategic straits between Iran and the Musandam

Peninsula which all shipping must pass through in order

to enter the Persian Gulf

orthodox Muslims accounting for the majority of the

UAE's Arab population 
Sur

\section{Ta'addudiya \\ T'amima \\ Tarāz}

Tumbs

Turäth

Ulamä'

Wãdĩ

Wādīi al-Mawt

Wahhābi / Wahhabism

Wâlī

Wikâlat Anbã ' al-Imārāōt

Zakāt

Zarāra

Zaya

$A D C C I$

$A D G A S$

$A D I A$

$A D M A$

$A D P C$

ALESCO

ARAMCO

$B B M E$

$B C C E$

$B C C I$

COM

$D C C I$

$D I C$

$D I P D$

$D S H^{\circ}$

DUBAL

ECSSR

EOI

EPZ

FATF

FDI

FNC an Omani port, its slaving merchants were offered French citizenship in the 1890 s

pluralism or multi-partyism

a paramount shaykh / the 'Shaykh of Shayklis'

a tax collected to pay guards to protect the towns during

the pearling season when many of the men were out at sea two small islands in the lower Gulf currently occupied by Iran, specifically the Greater Tunbs (Tunb al-Kubrä) and the Lesser Tunbs (Iunb al-Sughrã)

cultural heritage

Islamic clergymen

a dry watercourse

the 'Valley of Death' - an area on the border between

Abu Dhabi and Dubai, originally planned to be the site of the UAE's new capital city

followers of Muhammad ibn Abdul-Wahhāa's movement, many of whom preached a purified form of Islam and sought to renew the Prophet's golden era of Islam the ruler's local representative in an outlying region WAM - the UAE News Agency

an Islamic mandated tax levied on livestock / agricultural production and other movable property

Abu Dhabian oilfields close to the Saudi border, reportedly offered to Saudi Arabia in an effort to settle the long-running Buraimī dispute

a small coastal town close to Ra's al-Khaimah, a key target for the British attacks in 1819

Abu Dhabi Chamber of Commerce and Industry

Abu Dhabi Gas

Abu Dhabi Investments Authority

Abu Dhabi Marine Areas Limited

Abu Dhabi Petroleum Company

Arab League for Educational, Scientific and Cultural

Organisation

Arab-American oil Company

British Bank of the Middle East

Bank of Credit Commerce Emirates

Bank of Credit Commerce International

Council of Ministers

Dubai Chamber of Commerce and Industry

Dubai Internet City

Dubai Investments Park Development Company

Dubai Shopping Festival

Dubai Aluminium

Emirates Centre for Strategic Studies and Research

Export Oriented Industrialisation

Export Processing Zone

Financial Action Task Force

Foreign Direct Investment

Federal National Council 


\begin{tabular}{|c|c|}
\hline GATS & General Agreement on Trade in Services \\
\hline GATT & General Agreement on Tariffs and Trade \\
\hline$G C C$ & Gulf Co-operation Council \\
\hline$G U P A C$ & Gulf Permanent Assistance Committee \\
\hline$I D E X$ & International Defence Exhibition \\
\hline ILO & Intemational Labour Organisation \\
\hline$I M F$ & International Monetary Fund \\
\hline$I P C$ & Iraqi Petroleum Company \\
\hline IS1 & Import Substitution Industrialisation \\
\hline$I S P$ & Internet Service Provider \\
\hline$\angle O B$ & Lease Office Building \\
\hline NGO & Non-Governmental Organisation \\
\hline$O A P E C$ & Organisation of Arab Petroleum Exporting Countries \\
\hline$O E C D$ & $\begin{array}{l}\text { Organisation for Economic Co-operation and } \\
\text { Development }\end{array}$ \\
\hline OPEC & Organisation of Petroleum Exporting Countries \\
\hline PDTC & Petroleum Development Trucial Coast \\
\hline POGAR & Programme on Governance in the Arab Region \\
\hline$S C R$ & Supreme Council of Rulers \\
\hline TRIPS & $\begin{array}{l}\text { Trade Related aspects of International Property Rights (a } \\
\text { WTO agreement) }\end{array}$ \\
\hline$U A E$ & United Arab Emirates \\
\hline$U N D P$ & United Nations Development Programme \\
\hline LNESCO & $\begin{array}{l}\text { United Nations Educational, Scientific, and Cultural } \\
\text { Organisation }\end{array}$ \\
\hline$U N I D O$ & United Nations Industrial Development Organisation \\
\hline$U N P A N$ & $\begin{array}{l}\text { United Nations online network in Public Administration } \\
\text { and Finance }\end{array}$ \\
\hline USSR & Union of Soviet Socialist Republics \\
\hline$W A M$ & Wikālat Anbā' al-Imārāt, the UAE News Agency \\
\hline WTO & World Trade Organisation \\
\hline
\end{tabular}




\section{SELECTED SOURCES}

\section{Personal Interviews}

Interviews were conducted for the purpose of this thesis between March 2001 and May 2003 in a variety of locations in the UAE, including Abu Dhabi, Dubai, Sharjah, Ra's al-Khaimah, Fujairah, and Al-'Ayn. These encounters are listed in the endnotes in as specific a manner as consented to by the informants themselves.

\section{Primary Sources (including government and NGO documents)}

Sources are English or dual English / Arabic unless stated otherwise

ABU DHABI ECONOMY, Abu Dhabi Chamber of Commerce and Industry, Publications and press relations Department

- (2001), "A big boost for businesswomen", May 2001

- (1999), “Abu Dhabi Economy: Special Issue”, Volume 28 Number 322, March 1999

ABU DHABI PLANNING DEPARTMENT ECONOMIC DIVISION (1976), "Directive Documents for the Preparation of the Economic and Social Development Plan of 1977-1979", Abu Dhabi, June 1976

BUSINESS IN DUBAI, Dubai Chamber of Commerce and Industry

- (2002), "DIFC puts emirate on International financial Map", Volume 2 Issue 15, March 2002

- (2002), "Family companies the day after: how would local family owned businesses survive in globalisation?", Volume 2 Issue 15, March 2002

-(2001), "Foreign Investments - Total blockade vis-a-vis open door policy", Volume 1 Issue 6, June 2001

- (2001), Volume 1 Issue 5, May 2001

- (2001), Volume 1 Issue 3, March 2001

\section{BUSINESS MONITOR INTERNATIONAL}

- (2003), "The United Arab Emirates", second quarter report

- (2003), "The United Arab Emirates", first quarter report

- (2001), "The United Arab Emirates", second quarter report

- (2000), "The United Arab Emirates", third quarter report 
- (1998), "The United Arab Emirates"

- (1997), "The United Arab Emirates, 1995-1997"

CITIBANK UAE (2002), “Annual report”, Citibank Dubai

CROWN PRINCE COURT DEPARTMENT OF RESEARCH AND STUDIES (1996), "Development Indicators in the UAE: Achievements and Projections", Abu Dhabi

DUBAI CHAMBER OF COMMERCE AND INDUSTRY (2001), “Our Services”, Dubai

DUBAI DEPARTMENT OF ECONOMIC DEVELOPMENT, Government of Dubai

- (2002), "Development Statistics"

- (2001), "Development Statistics"

- (1999), "Development Statistics"

DUBAI DEPARTMENT OF PORTS AND CUSTOMS in DUBAI DEPARTMENT OF ECONOMIC DEVELOPMENT (2001), "Development Statistics", Government of Dubai

- (2001), "Dubai: non-oil foreign trade - total"

- (2001), "Dubai: major (non-oil) trade partners - imports"

- (2001), "Dubai: major (non-oil) trade partners - exports"

- (2001), "Dubai: major (non-oil) trade partners - re-exports"

DUBAI GOVERNMENT (2000), "Dubai Technology, Electronic Commerce and Media Free Zone Law No.1", Dubai

DUBAI INTERNET CITY (2001), official brochure

DUBAI MUNICIPALITY (1999), "Results of income and expenditure survey Dubai city, 1997-1998", Administrative Affairs Department, Statistics Centre, May 1999

ECONOMIST INTELLIGENCE UNIT, London

- (2001), "United Arab Emirates"

- (2000), "United Arab Emirates"

ECSSR (2002), "UAE and the Red Crescent", Abu Dhabi, Emirates Centre for Strategic Studies and Research 
EMIRATES BANKERS ASSOCIATTON (1997), "Financial position of commercial banks of the UAE, 1996-1997", Dubai

EMIRATES CORPORATE COMMUNICATIONS (2002), "Countdown to Dubai 2003", press release issued by Emirates Airlines Media Relations Department, $23^{\text {rd }}$ October 2002

EMIRATES MEDICAL ASSOCIATION (2002), "Annual report", Abu Dhabi FEDERAL RESEARCH DIVISION (2003), "United Arab Emirates: a country study", Blackmask, USA

FEDERATION OF UAE CHAMBERS OF COMMERCE AND INDUSTRY, Abu Dhabi

- (1994), "The components of investment and the methods of promoting investment opportunities in the UAE"

- (1994), "Goals and achievements"

- (1993), "The establishment of economic enterprises in the UAE: in light of the provisions of the law and its executive regulations"

FOREIGN OFFICE HISTORICAL SECTION (1920), "Persian Gulf", London, HMSO, Issue 76

FREEDOM HOUSE (2001), "Freedom in the World Country Ratings, 1972-73 to 2000-2001", New York, Freedom House

GCC DEVLOPMENT PLANS - UNITED ARAB EMIRATES (1982), "Economic and Social Development Plans for the UAE, 1975-1980", Abu Dhabi

HSBC Middle East (2001), "Foreign investment statistics for GCC states", Dubai, Second Quarter 2001

JEBEL ALI FREEZONE AUTHORITY (2000), investment statistics, Jebel Ali, Dubai

(in Arabic) AL-KAWARI, Ali Khalifa and AL-SĀDŪN, Jasim (1996), "The GCC Countries: A Futuristic View", Development Forum Annual Meeting Documents, January 1995, Girttas Publishing House, Kuwait

KERRY, John and BROWN, Hank (1992), "The BCCI Affair: A Report to the Committee on Foreign Relations in the United States Senate by Senator John Kerry and Senator Hank Brown", Washington DC, 102nd Congress 2nd Session Senate Print, December 1992

LORIMER, JG

- (1915), "Gazetteer of the Persian Gulf, Oman and Central Arabia" Volume 1 Historical Part 1A, Calcutta, Superintendent Government Printing [republished 1970 by Gregg International Publishers 
- (1915), "Gazetteer of the Persian Gulf, Oman and Central Arabia" Volume I Historical Part 1B, Calcutta, Superintendent Government Printing [republished 1970 by Gregg International Publishers

- (1915), "Gazetteer of the Persian Gulf, Oman and Central Arabia" Volume 1 Historical Part II, Calcutta, Superintendent Government Printing [republished 1970 by Gregg International Publishers]

- (1915), "Gazetteer of the Persian Gulf, Oman and Central Arabia" Volume 2B Geographical and Statistical, Calcutta, Superintendent Government Printing [republished 1970 by Gregg International Publishers]

MIDDLE EAST RESEARCH INSTITUTE OF JAPAN (2002), statistics relating to UAE cabinet compositions

PRESS AFFAIRS DIRECTORATE OF SHARJAH EMIRI COURT, (1988), "Sharjah in Fifteen Years Time: 1974-1988", Sharjah, Al-Bayan Press

EL-SABĀ, Soheir (2002), "The Impediments to Industrial Development in the UAE", Dubai, Dubai Chamber of Commerce and Industry Studies and Research Department

\section{AL-SHARHAN INTERNATIONAL CONSULTANCY, Dubai}

- (2001), "UAE Country Report 2001"

- (2000), "UAE Country Report 2000"

SHARJAH LAW (2001), Local Instructions No 1 of 2001 and Executive Council Resolution No 12 of 2001, supplied by AFRIDI \& ANGELL, Dubai

TAMIMI LAW UPDATE (2001), "Law update: UAE committed to implementing WTO agreements", Tamimi Consultants, Dubai, January 2001

UAE CENTRAL BANK (2002), "UAE and Dubai: commercial banks", in DUBAI DEPARTMENT OF ECONOMIC DEVELOPMENT (2002), "Development Statistics", Government of Dubai

UAE CENTRAL BANK, Abu Dhabi

- (1996), "Annual Report 1996"

- (1994), "Annual Report 1994"

- (1991), "Annual Report 1991"

UAE MINISTRY OF AGRICULTURE AND FISHERIES in DUBAI DEPARTMENT OF ECONOMIC DEVELOPMENT (2001), "Development Statistics", Government of Dubai

- (2001), "Dubai: agricultural holdings" 
-(2001), "Dubai: vegetables production"

- (2001), "Dubai: fruit production"

- (2001), "Dubai: cattle farms - milk production"

- (2001), "Dubai: fish production"

UAE MINISTRY OF EDUCATION AND YOUTH, in DUBAI DEPARTMENT OF ECONOMIC DEVELOPMENT (2001), "Development Statistics", Government of Dubai

- (2001), "UAE and Dubai: secondary school graduates"

- (2001), "Dubai: government schools - student/teacher ratio"; "Dubai: private schools - teachers by sex"; and "Dubai: private schools - enrolment by sex"

UAE MINISTRY OF FINANCE AND INDUSTRY (2001), various statistics, Abu Dhabi

UAE MINISTRY OF HEALTH and DUBAI DEPARTMENT OF MEDICAL SERVICES, in DUBAI DEPARTMENT OF ECONOMIC DEVELOPMENT (2001), "Development Statistics", Government of Dubai

- (2001), "Dubai: health centres", "Dubai: hospitals", "Dubai: hospital beds", "Dubai: medical doctors"

- (2001), "Dubai: nursing staff", and "Dubai: medical technical assistants"

- (2001), "Dubai: health development indicators"

UAE MINISTRY OF INFORMATION AND CULTURE, Abu Dhabi

- (2002), various statistics

- (1995), "UAE Yearbook: 1995"

- FEDERAL LAW (1988), Federal Law No. (15) of 1988

- FEDERAL LAW (1984, 1988), Article 3 of Updated Federal Law No. (8) of 1984 as amended by Federal Law No. (13) of 1988 regarding Commercial Companies

- FEDERAL LAW (1973, 1983), No. (6) of 1973, Federal Law No. (10) of 1973, Federal Law No. (3) of 1983

UAE MINISTRY OF PLANNING in DUBAI DEPARTMENT OF ECONOMIC DEVLOPMENT (2002), "Development Statistics", Government of Dubai

- (2002), "UAE and Dubai: GDP at factor cost and per capita GDP - 2001"

- (2002), "Dubai: GDP - real growth rates" 
- (2002), "UAE and Dubai: employment by economic sectors"

- (2002), "UAE and Dubai: population"

- (2002), "Dubai: GDP at factor cost"

UAE MINISTRY OF PLANNING (1995), “Annual Statistical Report on UAE Hotels", Abu Dhabi, Central Statistics Department

UAE UNIVERSITY IN AL-'AYN (2001), "UAE University registered students", and "UAE University graduates", in DUBAI DEPARTMENT OF ECONOMIC

DEVELOPMENT (2001), "Development Statistics", Government of Dubai

UNDP-POGAR (2002), "Programme on Governance in the Arab region - UAE", various reports

UNDP-UAE, Abu Dhabi

- (2000), "Press Release - The Launch of Ra's al-Khaimah Vision", $28^{\text {th }}$ March 2000

- (2000), various reports, $27^{\text {th }}$ May 2000

- (2000), "Press Release - National HRD Report", $8^{\text {th }}$ July 2000

\section{UNESCO}

$-(2001)$, literacy rates

- (1998/1999/2000/2001), primary, secondary, and tertiary enrolment ratios

UNITED NATIONS STATISTICS DIVISION (2002), various UAE-related statistics

UNITED STATES CENSUS BUREAU (2002), various UAE-related statistics, International Programs Centre, International database

\section{UNITED STATES CENTRAL INTELLIGENCE AGENCY}

- (2001), "Chiefs of Staff and Cabinet Members of Foreign Governments", $1^{\text {st }}$ August 2001

- (2001), “World Fact book: United Arab Emirates", January 2001

- (2001), "World Fact book: Morocco", January 2001

\section{UNITED STATES DEPARTMENT OF STATE}

- (2001), "United Arab Emirates: Country Reports on Human Rights", Bureau of Democracy, Human Rights, and Labour, $23^{\text {rd }}$ February 2001

-(1975), "US policy in the area of the Persian Gulf", Bulletin 73, $14^{\text {th }}$ July 1975 
UNITED STATES EMBASSY TO SAUDI ARABIA (1999), "Economic Trends", Riyadh, October 1999

UNITED STATES ENERGY INFORMATION ADMINISTRATION - EIA (1997),

"Energy and Petroleum Exports - thousands of barrels per year"

UNITED STATES LIBRARY OF CONGRESS (2001), "Country Study: Jordan"

UNPAN (2002), various UAE-related statistics, United Nations online network in Public Administration and Finance

WORLD BANK (1985), "Research News 1985"

WORLD HEALTH ORGANISATION (2002), various UAE-related statistics

WORLD TRADE ORGANISATION NEWS (2002), "Press Releases, Press / 293 ", $3^{\text {rd }}$ May 2002

\section{Secondary Sources (books, chapter contributions, journal articles, conference papers, and dissertations)}

Sources are English or dual English / Arabic unless stated otherwise

ABDEKARIM, Abbas (1999), "Change and Development in the Gulf, London, Macmillan

ABDULLAH, Muhammad Morsy (1978), "The United Arab Emirates: A Modern History", London, Croom Helm

AL-ABED, Ibrahim (2001), "The Historical Background and Constitutional Basis of the Federation" in AL-ABED, Ibrahim (ed.) (2001), "The United Arab Emirates: A New Perspective", Abu Dhabi, Trident

(in Arabic) AL-AYDERŨS, Muhammad Hassan (1983), "Political Developments in the UAE", Zat al-Salasil Publications, Kuwait

AMIN, Samir

- (1997), "Capitalism in the age of globalisation: the management of contemporary society", London

- (1982) "The Arab Economy Today", New York

- (1978), "The Arab Nation: Nationalism and Class Struggles", London

ANDERSON, Lisa (2000), "Dynasts and nationalists: why monarchies survive", in KOSTINER, Joseph (ed.) (2000), "Middle East monarchies: the challenge of modernity", Colorado, Rienner 
ANTHONY, John Duke

- (1981), "Transformation amidst tradition: the UAE in transition" in CHUBIN, Sharam (ed.) (1981), "Security in the Persian Gulf: domestic political factors", Montclair, New Jersey, Allenheld Osman

- (1975), "Arab States of the Lower Gulf: People, Politics, Petroleum", Washington DC, Middle East Institute

APTER, David E (1965), "The Politics of Modernisation", Chicago, Chicago University Press

ARNDT, HW (1987), "Economic development: The History of an Idea", Chicago, Chicago University Press

ASHOUR, MF (2001), "The GCC and the WTO", in AL-TAMIMI, January 2001

AYALON, Ami (1999), "Post-Ottoman Arab monarchies: old bottles, new labels?", in KOSTINER, Joseph (ed.) (2000), "Middle East monarchies: the challenge of modernity", Colorado, Rienner

AYUBI, Nazih N (1995), "Over-stating the Arab State", London

(in Arabic) BATIKKH, Ramadban Muhammad (1997), "The Development of Political and Constitutional Thought in the UAE", University of the UAE, Al-'Ayn

BEBLAWI, Hazem (1987), "The rentier state in the Arab world", in BEBLAWI, Hazem, and LUCIANI, Giacomo (eds.) (1987), "The rentier state", New York, Croom Helm

BECK, Nelson R (1978), "Britain's withdrawal from the Persian Gulf and the formation of the United Arab Emirates, 1968-1971", in TOWSON STATE JOURNAL OF INTERNATIONAL AFFAIRS, Volume 12 Number 2

BELGRAVE, Charles (1966), "The Pirate Coast", London, G. Bell and Sons

(in Arabic) BILAL, Muhammad (1990), "Changes in population and power among immigrants and citizens of the UAE, 1976-1980", Sharjah Sociologist Society

BROWN, Gavin (1998), "OPEC and the World Energy Market", London, Longman

CARAPICO, Sheila (1998), "Civil society in Yemen: the political economy of activism in modern Arabia", Cambridge, Cambridge University Press

CARDASO, FH and FALETTO, E (1979), "Dependency and Development in Latin America", Berkeley, University of California Press

CHAUDHRY, Kiren Aziz (1997), "The price of wealth: economies and institutions in the Middle East", New York, Cornell University Press

CHUBIN, Sharam (ed.) (1981), "Security in the Persian Gulf: domestic political factors", Montclair, New Jersey, Allenheld Osman 
CORDESMAN, AH (1997), "Bahrain, Oman, Qatar and the UAE: Challenges of Security", Colorado, Westview Press

CRYSTAL, Jill (1990,1995), "Oil and Politics in the Gulf: Rulers and Merchants in Kuwait and Qatar", New York, Cambridge University Press

DAVIES, Charles E (1997), "The Blood Red Arab Flag: an investigation into Qāsimī piracy", Exeter, University of Exeter Press

DAVIS, E (1991), "Theorising statecraft and social change in Arab oil-producing countries" in DAVIS, E and GAVRIELIDES, N (eds.) (1991), "Statecraft in the Middle East: oil, historical memory and popular culture”, Miami, Florida International Press

DE TOQUEVILLE, A (1981), "Democracy in America", New York, McGraw-Hill

DEUTSCH, Karl W (1961), "Social mobilisation and political development", in AMERICAN POLITICAL SCIENCE REVIEW, Volume 55 Number 3, September 1961

DICKEN, P (1992), "Global Shift and the Internationalisation of Economic Activity", London

EL-DIN, Amin Badr (1997), "The Offsets program in the UAE", in MIDDLE EAST POLICY, Volume 5 Number 1, January 1997

EASTON, David (1965), “A systems analysis of political life”, New York, Wiley

FALK, Richard A (1999), "Predatory Globalisation: a critique", Cambridge, Polity press

FARAZMAND, A (ed.) (1991), "Handbook of comparative and development public administration", New York, Marcel

FENELON, Kevin (1973), "The United Arab Emirates: An Economic and Social Survey", London, Longman

FINDLOW, Sally (2000), "The UAE: Nationalism and Arab-Islamic Identity", Abu Dhabi, Emirates Centre for Strategic Studies and Research, ECSSR OCCASIONAL PAPER, Number 39

FINKLE, JL and GABLE, RW (1971), "Political Development and Social Change", New York, John Wiley

FOLEY, Sean (1998), "The United Arab Emirates: Political Issues and Security Dilemmas", in Middle East Review of International Affairs (MERIA), Volume 3 Number 1, March 1998

FRANK, André Gunder (1971), "Capitalism and Underdevelopment in Latin America: Historical studies of Chile and Brazil”, New York, Monthly Review Press 
GAUSE, F Gregory

- (1999), "The persistence of monarchy in the Arabian Peninsula: a comparative analysis", in KOSTINER, Joseph (ed.) (2000), "Middle East monarchies: the challenge of modernity", Colorado, Rienner

- (1994), "Oil monarchies: domestic and security challenges in the Arab Gulf states", New York, Council on Foreign Relations Press

- (1992), "Gulf Regional Politics: Revolution, War and Rivalry", in WRIGGINS, Howard (ed.) (1992), "The Dynamics of regional politics: four systems on the Indian Ocean Rim", New York, Columbia University Press

GELLNER, E (1981), "Muslim Society", Cambridge, Cambridge University press

(in Arabic) GHUBASH, Moza (1996), "Human Development in the UAE, 1971-1994", Abu Dhabi Cultural Foundation, Abu Dhabi

GRAHAM, GS (1967), "Great Britain in the Indian Ocean, 1810-1850", Oxford

GREEN, Timothy (1968), "The World of Gold", London, Michael Joseph

HALL, Marjories J (1987), "Business Laws of the UAE", Volume 1, London

HALLIDAY, Fred (1999), "Monarchies in the Middle East: a concluding appraisal", in KOSTINER, Joseph (ed.) (2000), "Middle East monarchies: the challenge of modernity", Colorado, Rienner

HALPERN, Manfred $(1963,1965)$, "The Politics of Social Change in the Middle East and North Africa", Princeton University Press

(in Arabic) AL-HAMID, Muhammad 'Ahmad (1997), "Gulf Security and its impacts on the GCC", ECSSR, Abu Dhabi, Emirates Lectures Series, Number 16

HANAFI, Sari (2001), "Globalisation without Regionalisation; the Paradoxical Effects of the Political Economy of the United Arab Emirates", excerpt and statistics from a presentation given at the "Globalisation and the Gulf" conference at the University of Exeter, July 2001

HARRIS, N (1987), "The End of the Third World", London

HAWLEY, Donald (1970), "The Trucial States", London, George Allen \& Unwin

HEARD-BEY, Frauke

- (1999), "The UAE: A Quarter Century of Federation", in HUDSON, Michael C (ed.) (1999), "Middle East Dilemma: The politics and economics of Arab integration", London, Tauris

- (1996), "From Trucial States to United Arab Emirates - new edition", London, Longman 
- (1982), "From Trucial States to United Arab Emirates", London, Longman

AL-HEGELAN, Abdelrahman, and PALMER, Monte (1985), "Bureaucracy and development in Saudi Arabia", in MIDDLE EAST JOURNAL, Volume 39 Number 1, Winter 1985

HELD, David, MCGREW, Anthony, GLODBLATT, David, and PERRATON, Jonathan (1999), "Global transformations: politics, economics and culture", Oxford, Polity Press

HELLYER, Peter (2001), "The Evolution of UAE Foreign Policy", in AL-ABED, Ibrahim (ed.) (2001), "The United Arab Emirates: A New Perspective", Abu Dhabi, Trident

HERB, Michael (1999), "All in the Family: Absolutism, Revolution, and Democracy in the Middle Eastern Monarchies", New York, State University Press

HINNEBUSCH, RA (1989), "Peasant and Bureaucracy in Ba'thist Syria: the political economy of rural development", Colorado, Westview

HIRO, Dilip (1987), “Iran under the Ayatollahs", London

HIRST, P (1995), "Globalisation in Question", Political Economy Research Centre, University of Sheffield, Occasional Paper Number 11

HITTI, PK (1964), "History of the Arabs", $8^{\text {th }}$ Edition, London

HOLDEN, David

- (1971), "The Persian Gulf after the British Raj", in FOREIGN AFFAIRS, Volume 49 Number 4, July 1971

- (1966), “Farewell to Arabia”, New York

HUDSON, Michael C

- (1999), "Middle East Dilemma: The politics and economics of Arab integration", London, Tauris

- (1977), "Arab Politics: the Search for Legitimacy", New Haven, Yale University Press

HUNTINGTON, Samuel P

- (1991), "The Third Wave: Democratisation in the Late Twentieth Century", Norman, University of Oklahoma Press

- (1968), "Political Order in Changing Societies", New Haven, Yale University Press 
IRVING, Janis

- (1982), "Groupthink: psychological studies of policy decisions and fiascos", Boston, Houghton Mifflin

- (1972), "Victims of groupthink", Boston, Houghton Mifflin

ISMAEL, Jacqueline S (1993), "Kuwait: Dependency and Class in a Rentier State", University Press of Florida

JIYAD, 'Ahmad (2001), "The Role of Foreign Direct Investment in the Globalisation of the Gulf", excerpt from a presentation given at the "Globalisation and the Gulf" conference at the University of Exeter, July 2001

JOYCE, Miriam

- (1999), "On the road towards unity: the Trucial States from a British perspective, 196-1966", in MIDDLE EASTERN STUDIES, Volume 35

Number 2, April 1999

- (1998), “Kuwait 1945-1996: An Anglo-American perspective", London, Frank Cass

JREISAT, JE (1992), "Managing national development in the Arab states", in ARAB STUDIES QUARTERLY, Volume 14 Numbers 2 and 3, Spring/Summer 1992

KAMRAVA, Mehran

- (2002), "Civil Society and Political Democratisation in Comparative Perspective: Lessons from Latin America and the Middle East", presented to the University of Warwick in February 2002

- (2000), "Politics and society in the developing world", London, Routledge

KEDOURIE, Elie (1984), "The Kingdom of Iraq: a retrospect", in KEDOURIE, Elie (ed.) (1984), "The Chatham House version and Other Middle Eastern Studies", New Haven, University Press of New England

KELLY, John B

- (1986), "Arabia, the Gulf and the West: A Critical View of the Arabs and their Oil Policy", New York

- (1968), "Britain and the Persian Gulf", London

KEMP, Peter (1997), "MEED Special report: France", in MIDDLE EAST ECONOMIC DIGEST, 24 ${ }^{\text {th }}$ October 1997

KHALAF, Sulayman

- (2001), "Globalisation and Heritage Revival in the Gulf; an

Anthropological Look at the Dubai Heritage Village", excerpt from a 
presentation given at the "Globalisation and the Gulf" conference at the University of Exeter, July 2001

- (2000), "Poetics and politics of newly invented traditions in the Gulf: camel racing in the United Arab Emirates", in ETHNOLOGY, Volume 39 Number 3, Summer 2000

- (1999), "Camel Racing in the Gulf: notes on the evolution of a traditional cultural sport", in ANTHROPOS, 1999

KHALDŪN, ‘Abd-ar-Rahman Abu Zayid ibn Muhammad ibn Muhammad ibn (1377), "The Muqaddimah: An Introduction to History", translated by ROSENTHAL, Franz [republished 1967 by Routledge and Kegan Paul, London]

(in Arabic) AL-KHALĪJ ARAB STUDIES (1991), "Gulf and Arab Security", November 1991

KHALIFA, Ali Muhammad (1979), “The United Arab Emirates: Unity in Fragmentation", Boulder, Westview Press

KHOURY, EM (1980), "The United Arab Emirates: It's Political System and Politics", Institute of Middle Eastern and North African Affairs, University of Michigan

KOSTINER, Joseph (ed.) (2000), "Middle East monarchies: the challenge of modernity", Colorado, Rienner

LEFTWICH (1993), "Governance, democracy and development in the Third World", in THIRD WORLD QUARTERLY, Volume 14 Number 3, 1993

LERNER, Daniel (1958, 1964), "The Passing of Traditional Society: Modernising the Middle East", Toronto, Free Press

LUCIANI, Giacomo (1987), "Allocation versus production states: a theoretical framework", in BEBLAWI, Hazem, and LUCIANI, Giacomo (eds.) (1987), "The rentier state", New York, Croom Helm

MALLETT, Robert L (2001), "Symposium on Shaykh Zāyid", in MIDDLE EAST POLICY, Volume 6 Number 4, June 1999

MANN, Clarence (1969), "Abu Dhabi" birth of an oil shaykhdom", Beirut, Khayats

MERZA, Ali (2001), "Economic Reforms in the Major Oil-Producing Countries", excerpt from a paper given at the "Globalisation and the Gulf" conference at the University of Exeter, July 2001

MIDDLE EAST ECONOMIC DIGEST, London

- EVERETT-HEATH, Tom (2002), "Dubai's financial future", Volume 26 Number $8,22^{\text {nd }}$ February 2002

- EVERETT-HEATH, Tom and DUTTA, A (2002), "Bridging the gap", Volume 46 Number $10,8^{\text {th }}$ March 2002 
- (1997), December 1997

- (1994), “UAE Special Report”, $1^{\text {st }}$ December 1994

- (1984), "Foreign firms reject investment proposal", in "MEED Special report: UAE"

$-(1978), 10^{\text {th }}$ February 1978

- (1977), Volume 22, $7^{\text {th }}$ July 1977

MOORE, Clement H (1970), "Politics in North Africa", Boston, Brown

AL-NUHAYYĀN, Shaykha Shamma bint Muhammad bin Khalid

- (2000), "Political and Social Security in the UAE", Dubai

- (2000), "Political and Social Security in the Arabian Gulf region and United Arab Emirates after the Second Gulf War: External and Internal Challenges", Research Centre of Slovak Foreign Policy Association, Studies on International Issues, Volume B05

NONNEMAN, Gerd (2001), "Rentiers and autocrats, monarchs and democrats, state and society: the Middle East between globalisation, human 'agency", and Europe", in INTERNATIONAL AFFAIRS, Volume 77 Number 1, January 2001

NORTON, AR (1999), "Associational life: civil society in authoritarian political systems", in TESSLER, Mark (ed.) (1999), "Area studies and social science: strategies for understanding Middle East politics", Indiana University Press

ONLEY, James

- (2003) "Britain's native agents in Arabia and Persia, 1758-1958", in COMPARATIVE STUDIES OF SOUTH ASIA, AFRICA AND THE MIDDLE EAST, Volume 33

- (2003) "The politics of protection in the Gulf: the Arab rulers and the British Resident in the Nineteenth Century", in NEW ARABIAN STUDIES, Volume 6

OVERTON, JL (1983), "Stability and change: Inter-Arab politics in the Arabian Peninsula and Gulf', $\mathrm{PhD}$ thesis, University of Maryland

PECK, Malcolm C (1986), "The United Arab Emirates: A Venture in Unity", Boulder Colorado, Westview Press

PETERSON, JE (1988), "The Arab Gulf states: steps towards political participation", in The WASHINGTON PAPERS, Number 131, New York, Praeger

POGGI, G (1978), "The development of the modern state", London, Hutchinson

PRADO, Alfred B (1996), "Saudi Arabia: post-war issues and US relations", CRS ISSUE BRIEF, Number 93113, December 1996 
PRATT, N (2001), "Conceptualising Globalisation: some Political Implications for the Arab World", excerpt from a presentation given at the "Globalisation and the Gulf" conference at the University of Exeter, July 2001

AL-QĀSIMĪ, Shaykh Fahim bin Sultān (1999), "Symposium on Shaykh Zãyid", MIDDLE EAST POLICY, Volume 6 Number 4, June 1999

AL-QĀSIMĪ, Shaykh Sultān bin Muhammad (1986), "The Myth of Arab Piracy in the Gulf', London, Croom Helm

RANDALL, V and THEOBALD, R (1998), "Political change and underdevelopment", London, Macmillan

(in Arabic) RĀSHID, Ali Muhammad (1989), "Political and Economic Agreements made between the Oman Coast Emirates and Britain (1806-1971)", UAE Writers' Union Publications

RICHARDS, Alan (2001), "Symposium on Shaykh Zāyid", in MIDDLE EAST POLICY, Volume 6 Number 4, June 1999

RICHARDS, Alan and WATERBURY, John (1996), "A political economy of the Middle East", Boulder, Westview Press

RIGGS, F (1991), "Bureaucratic links between administration and politics", in FARAZMAND, A (ed.) (1991), "Handbook of comparative and development public administration", New York, Marcel

RIZVI, SN Asad (1993), "From tents to high rise: economic development of the UAE", in MIDDLE EASTERN STUDIES, Frank Cass, Vohume 29 Number 4, October 1993

ROBERTSON, R (1992), "Globalisation: social theory and global culture", London, Sage

RUESCHEMEYER, D (1992), "Capitalist development and democracy", Cambridge, Polity Press

RUGH, WA (1997), "The United Arab Emirates: What are the sources of its stability?" in MIDDLE EAST POLICY, Volume 5 Number 3, September 1997

AL-SAYEGH, Fatma

-(1999), "Symposium on Shaykh Zāyid" taken from a conference convened by the Middle East Policy Council on $20^{\text {th }}$ April 1999 , in MIDDLE EAST POLICY, Volume 6 Number 4, June 1999 - (1998), "Merchants' role in a changing society: the case of Dubai, 1900-1990", in MIDDLE EASTERN STUDIES, Volume 34 Number 1, January 1998

- (in Arabic) (1997), "The UAE: from tribe to state", Al-Khalij Books, Dubai 
AL-SHAMSI, Fatima S

- (2001), "Symposium on Shaykh Zāyid", in MIDDLE EAST POLICY, Volume 6 Number 4, June 1999

- (1999), "Industrial Strategies and Change in the UAE during the 1980s", in ABDEKARIM, Abbas (1999), "Change and Development in the Gulf, London, Macmillan

SHARABI, Hisham B

- (1988), "Neopatriarchy: A Theory of Distorted Change in Arab Society", New York, Oxford University press

- (1966), "Nationalism and Revolution in the Arab World", Princeton, Van Nostrand

(in Arabic) SHARAF, Muhammad Yasir (1997), "UAE Society", Al-Mutanabi Books, Abu Dhabi

(in Arabic) SHARAH, Naji Sadiq (1995), "The UAE: Politics and Rulership", Al-Kitab al-Jamiy, UAE

STAUFFER, Thomas (2001), "Global Oil Markets and their Implications for Revenue Instability in the Gulf", excerpt from a presentation given at the "Globalisation and the Gulf" conference at the University of Exeter, July 2001

TESSLER, Mark (ed.) (1999), “Area studies and social science: strategies for understanding Middle East politics", Indiana University Press

THESIGER, Wilfred (1991), “Arabian Sands”, London, Penguin

(in Arabic) AL-TIKRITI, Walid (2003), "Afläj", Department of Antiquities and Tourism, Al-'Ayn

TODARO, M (1994), "Economic Development in the Third World", London, Longman

TOYE, J (1987), "Dilemmas of Development", Oxford, Blackwell

TRUED, Peter and GURWIN, Larry (1992), "False Profits", New York, Houghton Mifflin

WALLERSTEIN, I (1979), "The rise and future demise of the world capitalist system: concepts for comparative analysis", in WALLERSTEIN, I (ed.) (1979), "The capitalist world economy", Cambridge University Press

WEIGLE, MA and BUTTERFIELD, J (1992), "Civil society in reforming Communist regimes: the logic of emergence", in COMPARATIVE POLITICS, Volume 25 Number 1, October 1992 
WEITZMAN, Bruce Maddy (1999), "Why did Arab monarchies fall? An analysis of old and new explanations", in KOSTINER, Joseph (ed.), "Middle East monarchies: the challenge of modernity", Colorado, Rienner

WRIGGINS, Howard (ed.) (1992), "The Dynamics of regional politics: four systems on the Indian Ocean Rim", New York, Columbia University Press

YAMANI, Mai (2001), "Challenged by Example; Globalisation and the New Arab Awakening", excerpt from a presentation given at the "Globalisation and the Gulf" conference at the University of Exeter, July 2001

YAPP, ME (1996),"The Near East since the First World War: a History to 1995", London, Longman

YORKE, V (1980), "The Gulf in the 1980s", London, Royal Institute of International Affairs

ZABARAH, Muhammad 'Ahmad (1982), "Yemen: Traditionalism versus Modernity", New York, Praeger

\section{Secondary Sources (newspaper and magazine articles)}

Sources are English or dual English / Arabic unless stated otherwise

\section{AFRICA BUSINESS GUIDE, Cairo}

- AL-JABĪL, Muhammad (2002), "GCC: the emerging common market", December 2002

\section{APS REVIEW, New York}

- (1998), "UAE Profile: Dr. Muhammad Khalifa bin Kharbash" in "APS review gas market trends", June 1998

BBC MONITORING, London

- (2002), "Change in Bahrain Welcomed", $15^{\text {th }}$ February 2002

The DAILY TELEGRAPH, London

- KEEGAN, John (2002), "Bush faces long wait to build up enough forces against Baghdad", $5^{\text {th }}$ September 2002

- JOHNSTON, Philip (2001), "Fingers point at Iraqi leader as evidence grows", $1^{\text {st }}$ December 2001

- LOCKWOOD, Christopher (1996), "Warring Nation holds Key to Oil Riches of Central Asia", $11^{\text {th }}$ October 1996 
DAWN MAGAZINE, Karachi

- ABEIDOH, Rawhi (2000), "Arabs: a shrinking minority in the UAE", $28^{\text {th }}$ October 2000

The ECONOMIST, London

- (1981), London, 25 $5^{\text {th }}$ April 1981

EMIRATES TELEVISION, Abu Dhabi

- (2003), "Emirates stable and secure, says Muhammad", $17^{\text {th }}$ March 2003

The FINANCIAL TIMES, London

- FIELDS, Michael (1987), “Arabia keeps the faith", $10^{\text {th }}$ January, 1987

GULF NEWS, Dubai (articles from 1981-2003)

- KAWACH, Nadim (2003), "Call for Arab TV in English", $20^{\text {th }}$ January 2003

- AL-JANDALY, Bassma (2003), "Rail project may take six years", $14^{\text {th }}$ January 2003

- 'AHMAD, Ashfaq (2003), "Majority of expats suffer from some sort of depression", $11^{\text {th }}$ January 2003

- ZEITOUN, Doā (2002), "Direct Quote: safeguarding purity of Arabic", $22^{\text {nd }}$ December 2002

- BIBBO, Barbara (2002), "New contract rule to benefit nationals", $14^{\text {th }}$ December 2002

- (2002), "Dubai tops nation in urban population", $4^{\text {th }}$ December 2002

- KAWACH, Nadim (2002), "UAE deficit Dh7.8b lower than projected", $4^{\text {th }}$ December 2002

- ALI, Sayed (2002), "Ramadan Tournament gets big cash boost", $3^{\text {rd }}$ December 2002

- 'AHMAD, Ashfaq (2002), "Volunteers play key role in society", $29^{\text {th }}$ November 2002

- KAWACH, Nadim (2002), "UAE refutes report on oil sharing", $13^{\text {th }}$ October 2002

- ZEITŪN, Dō̄ (2002), "Theatre artists to gather in Sharjah", $13^{\text {th }}$ October 2002

- RAO, Sunil (2002), "UAE makes progress in achieving food security", $20^{\text {th }}$ January 2002 
- KAWACH, Nadim (2001), "TMF urges GCC to levy income tax", $16^{\text {th }}$ October 2001

- LANGLEY, Joanna (2000), "Mashreq Bank joins hand with NHR to promote Emiratisation", $3^{\text {rd }}$ September 2000

- (1998), "Emâr flies high with mega project", $19^{\text {th }}$ August 1998

- (1998), "Emār ups project outlay", $26^{\text {th }}$ February 1998

- (1997), "Emār to set up Dh700 million complex", 25 $5^{\text {th }}$ November 1997

- JOHNSON, ME (1997), "The lessons from Emär Properties Issue", $17^{\text {th }}$ May 1997

- JAML, Abu (1985) “Of Pearls and Pearl Kings", 5 "th April 1985

- AL-JUM'A SUPPLEMENT (1981), "The reason for the Iran connection", $21^{\text {st }}$ August 1981

HOBBY, G (2001), "The development of the Dubai Internet City", Dubai

\section{JANE'S DEFENCE WEEKLY}

- (1997), "Gulf States told to get tough over Offsets", $10^{\text {th }}$ December 1997

- BLANCHE, E (1997), "Offset Industry to gain from UAE programs", $29^{\text {th }}$ January 1997

JORDAN TIMES, Amman

- RANDA, Habib (2000), "Succession first for Arab 'republican monarchies' but maybe not last", $13^{\text {th }}$ June 2000

KHALEEJ TIMES, Dubai (articles from 1987-2003)

- MĀDAD, Sanā (2003), "Dubai charity telethon to support Iraqi people", $23^{\text {rd }}$ March 2003

- MUSSALLAM, NS (2002), "RCS projects to help disabled", $1^{\text {st }}$ December 2002

- FLEIHAN, Tarek (2002), "Informal association to raise marriage funds for nationals", $19^{\text {th }}$ October 2002

$-(2002)$, "Anti-smoking rally in Sharjah", $10^{\text {th }}$ October 2002

- IBRAHIM, ME (2002), "Dalmā Island to emerge as regional tourist spot", Dubai, $2^{\text {nd }}$ September 2002

- MĀDAD, Sanā and FLEIHAN, Tarek (2002), "Issue of teacher beating student may go to court", $29^{\mathrm{ll}_{\mathrm{t}}}$ May 2002 
- (2002), “National Panel set up for Palestinian Relief", 6" April 2002

- (2002), "UAE gets a clean chit", 6 th February 2002

- (2002), "UAE seeks ILO help on labour reforms", $16^{\text {th }}$ January 2002

- MĀDAD, Sanā (2002), "Ministry details proposal for workers" associations", $15^{\text {th }}$ January 2002

- RĀFAT, Hassan and RIZVI, Meraj (2002), "Schools asked to seek licence for new books", $15^{\text {th }}$ January 2002

- (2001), "Country's judiciary is independent: Dhahiri", $6^{\text {th }}$ December 2001

MĀDAD, Sanā (2001), "Welfare societies will need a federal licence", $27^{\text {th }}$ September 2001

- MANNAN, MA (2001), "Dubai Stands high in list of Best Skylines", $12^{\text {th }}$ May 2001

- AL-MUSHARRAKH, Zaikya (2000), "University Students take Al-Futtaim Trading Courses", $26^{\text {th }}$ July 2000

- RIZVI, Meraj (2000), "Only Nationals to be Captains of Fishing Vessels", $26^{\text {th }}$ July 2000

- (1998), "Dubai Investments Park excites investors", $25^{\text {th }}$ October 1998

- (1998), "Dubai Investments to lift returns, assets", $13^{\text {th }}$ May 1998

- (1987), "Folk art forum to be given federal status", $10^{\text {th }}$ October 1987

- ABU 'ĀTHIRA, Sa'id (1987), "Ship of the desert sails back", $24^{\text {th }}$ March 1987

\section{LE MONDE DIPLOMATIQUE, Paris}

- HIRST, David (2001), "The Emirs in the Internet era", February 2001

REUTERS, Abu Dhabi

- (2003), "Tanks back succession move in UAE's Ra"s al-Khaimah", $15^{\text {th }}$ June 2003

\section{AL-SHINDAGAH, Dubai}

- (1998) “By women for women", 20"th January 1998 
STAR MAGAZINE, Onirban, Bangladesh

- SALDAMANDO, Martin (2001), "Big news for a dogged freedom", $11^{\text {th }}$ November 2001

- SALDAMANDO, Martin (2001), "Human rights in the UAE", $23^{\text {rd }}$ September 2001

The TIMES, London

- McGRORY, Daniel (2002), “UAE seizes Al-Qaeda's Gulf leader”, $24^{\text {th }}$ December 2002

- THEODOULOU, M (2002), "Biggest man-made isles rise from the Gulf", $5^{\text {th }}$ January 2002

WAM, Abu Dhabi (Wikalat Anba al-Imarat: the UAE News Agency)

- (2003), "Elected Councils for Dubai", $2^{\text {nd }}$ April 2003

- (2002), "UAE to rebuild demolished Palestinian houses", $15^{\text {th }}$ January 2002

- (2001), "UAE paper calls for an international coalition against Israeli terror", United Arab Emirates News Agency, $21^{\text {st }}$ October 2001

$-(2001)$, "New avenues for UAE women", $17^{\text {th }}$ May 2001

$-(1977), 16^{\text {th }}$ November 1977

(in Arabic) AL-WASAT, Riyadh

- (1997), "UAE: youthful trend in UAE parliament", 22 2 January 1997

- (1994), number 147, $21^{\text {st }}$ November 1994

The WASHINGTON POST, Washington DC

- HOAGLAND, Jim (1991), "Across the Cultural Chasm: BCCI Viewed from East and West", $5^{\text {th }}$ August 1991

- MUGSON, Steven (1991), "British Judge Delays Plan to Dismantle BCCI", $31^{\text {st }}$ July 1991

- MUGSON, Steven (1991), "A Slam Heard 'Round the World: Closing of BCCI's Doors Leaves Unresolved Dilemmas", $23^{\text {rd }}$ July 1991 


\section{Other References}

ABERCROMBIE, Nicholas, HILL, Stephen, and TURNER, Bryan S (1994), "The Penguin Dictionary of Sociology", London, Penguin

BANNOCK, G, BAXTER, RE and DAVIS E (1992), "The Penguin Dictionary of Economics", London, Penguin

CALLAN, L and ROBISON, G (2000), "Oman and the United Arab Emirates", Hawthorn, Australia, Lonely Planet Publications

\section{CAMBRIDGE INTERNATIONAL DICTIONARY OF ENGLISH (2002)}

CLEMENTS, Frank A (1998), "United Arab Emirates", World Bibliographical Series, Volume 43, Oxford

ENCYCLOPAEDIA OF ISLAM NEW EDITION (1960), London

OXFORD ENGLISH DICTIONARY, (second edition)

POLSCI.COM (2001), "Political reference Almanac - UAE Political System", New York, Keynote Publishing

TRIDENT GUIDE (1996), "United Arab Emirates”, Abu Dhabi, Trident Press

\section{Websites}

The various Internet websites listed in the endnotes are correct to the author's knowledge as of May 2003 